ESCOLA DE COMUNICAÇÃO E ARTE

NADIA MOROZ LUCIANI

Iluminação Cênica:

a performatividade da luz como elo entre a cena e o espectador 


\title{
Iluminação Cênica:
}

\section{A performatividade da luz como elo entre a cena e o espectador}

\author{
Versão Corrigida (versão original disponível na Biblioteca da ECA/USP)
}

Tese apresentada ao PPGAC - ECA/USP

Programa de Pós-Graduação em Artes Cênicas

da Escola de Comunicação e Artes da

Universidade de São Paulo para a obtenção do

Título de Doutora em Artes.

Área de Concentração: Teoria e Prática do Teatro Linha de Pesquisa: Texto e Cena

Orientadora: Prof. ${ }^{a}$ Dr. ${ }^{a}$ Cibele Forjaz Simões

São Paulo

2020 
Autorizo a reprodução e divulgação total ou parcial deste trabalho, por qualquer meio convencional ou eletrônico, para fins de estudo e pesquisa, desde que citada a fonte.

Catalogação na Publicação

Serviço de Biblioteca e Documentação

Escola de Comunicação e Artes da Universidade de São Paulo

Dados inseridos pela autora

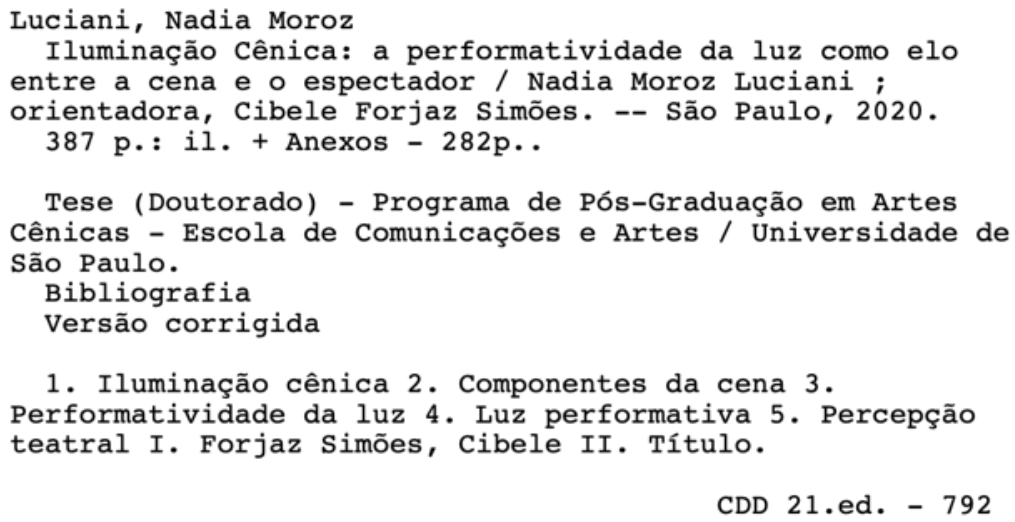

CDD 21.ed. - 792 
Este trabalho foi parcialmente realizado com o apoio do Programa Institucional de Internacionalização da Coordenação de Aperfeiçoamento de Pessoal de Nível Superior (CAPES-PrInt) do Brasil por meio do Programa de Doutorado Sanduíche no Exterior (PDSE) realizado no Centro de Estudos das Artes Contemporâneas (CEAC) da Universidade de Lille (UdL) na França sob a orientação da Prof. ${ }^{a}$ Dr. $^{a}$ Véronique Perruchon. 


\section{FOLHA DE APROVAÇÃO}

LUCIANI, Nadia Moroz. Iluminação Cênica: a performatividade da luz como elo entre a cena e o espectador. Tese (Doutorado) Escola de Comunicação e Artes, Universidade de São Paulo. São Paulo, 2020.

Aprovado em: 06 de julho de 2020.

\section{Banca Examinadora}

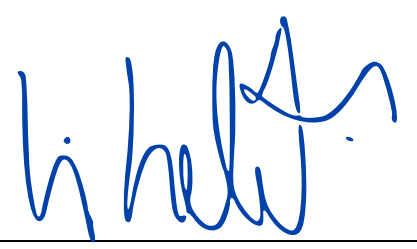

Prof. ${ }^{a}$ Dr. ${ }^{a}$ Cibele Forjaz Simões (presidente)

Universidade de São Paulo - USP

Prof. Dr. Eduardo Augusto da Silva Tudella

Universidade Federal da Bahia - UFBA

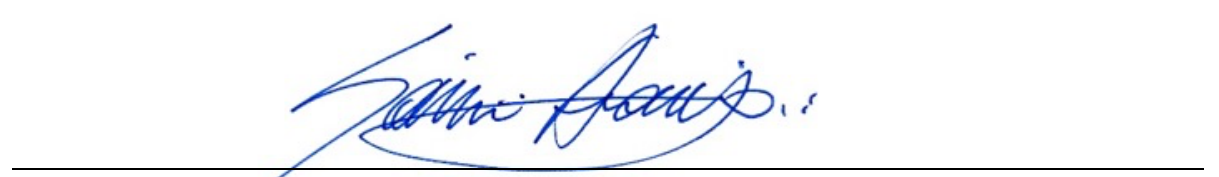

Prof. Dr. José Sávio Oliveira de Araújo

Universidade Federal do Rio Grande do Norte - UFRN

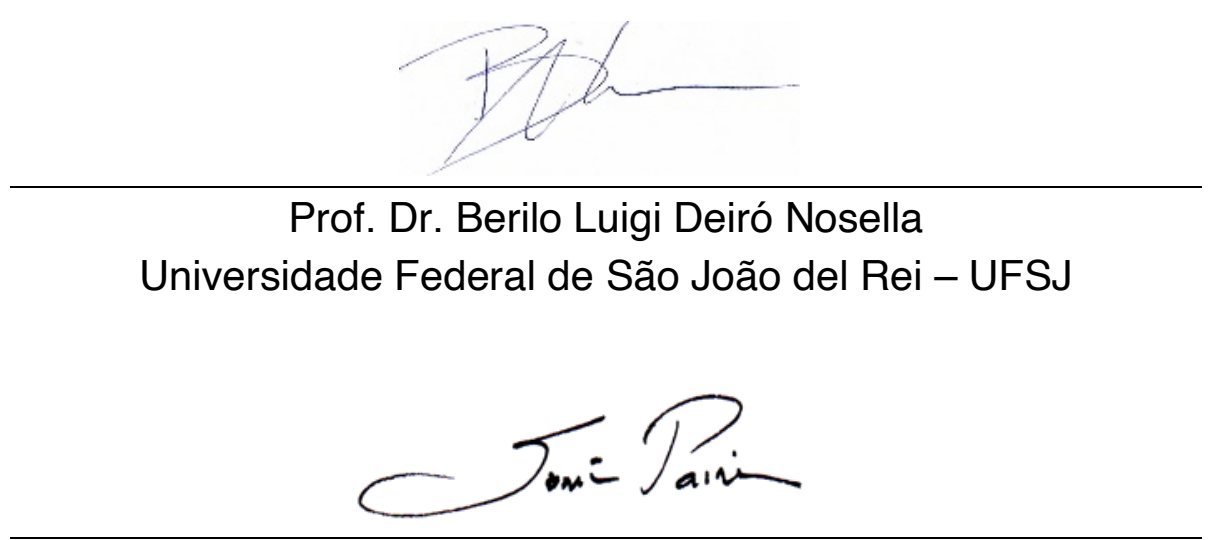

Prof. ${ }^{a}$ Dr. ${ }^{a}$ Sônia Maria Caldeira Paiva

Universidade de Brasília - UnB 


\section{AGRADECIMENTOS}

Eu dedico este trabalho e agradeço profundamente:

A todos que fizeram parte, direta ou indiretamente, da minha trajetória no teatro, por todas as trocas, ensinamentos e aprendizados acumulados a cada experiência profissional, acadêmica ou pessoal relacionada ao teatro e à luz.

Ao Aurélio de Simoni e Beto Bruel por terem me apresentado o mundo fantástico da luz e pela generosidade em compartilhar comigo sua paixão e amor pela arte.

Aos meus orientadores Zebba (até 2018) e Cibele pela paciência, dedicação e estímulo constantes. À Cibele, particularmente, por acreditar no meu trabalho, na minha pesquisa e por tanto fazer para a realização deste estudo.

A todos os iluminadores e pesquisadores que, ao longo dos últimos 30 anos, conviveram comigo e tanto me ensinaram nos palcos, nas mesas (redondas, de bar e de luz), nos debates formais e informais, nos seminários e encontros sobre iluminação. Agradeço ainda a generosidade dos que se esforçam para promover esses encontros e empenho dos que deles participam, estimulando a pesquisa em iluminação cênica e sua constante relação com a prática.

Ao Prof. Dr. Luiz Fernando Ramos pelas valiosas contribuições, principalmente no exame de qualificação, responsáveis pelos novos rumos da pesquisa.

À Véronique Perruchon pela oportunidade do doutorado sanduíche na UdL e pelo importante estímulo ao estudo acadêmico da iluminação cênica na França. Agradeço igualmente ao Sebastian Ambit por tê-la encontrado.

A todos os iluminadores e iluminadoras que aceitaram participar dessa pesquisa por meio das entrevistas e cujas preciosas colaborações e contribuições em muito cooperaram com o desenvolvimento da tese e de seus conceitos.

A todos os autores, mais ou menos afamados, mas todos fundamentais para que fosse possível organizar e fundamentar cientificamente as intuições oriundas da prática profissional e didática e que só puderam resultar num estudo doutoral por suas reflexões e publicações.

Ao Prof. Dr. Edélcio Mostaço por, com suas aulas, estimular o surgimento do embrião dessa pesquisa; ao querido orientador de mestrado Prof. Dr. José Ronaldo Faleiro, pelas orientações precisas da escrita acadêmica e ao antropólogo argentino e amigo Prof. Dr. Jorge Kulemeyer, pelo estímulo constante e pelas observações oportunas e espirituosas. 
À Lilian Fleury pelo TELAB e por, através dele, impulsionar meu regresso à universidade e, principalmente, pelo estímulo em regulamentar e seguir adiante com meus trabalhos de pesquisa e extensão com a criação do LABIC.

À Gisele Onuki pelos conhecimentos e estímulo nas atividades de extensão, primeiro como extensionista e depois como gestora e, finalmente, nas de internacionalização, dois aspectos do meio acadêmico nos quais mais acredito.

Ao projeto de extensão LABIC - Laboratório de lluminação Cênica, desde 2010 minha verdadeira fonte de inspiração e pesquisa.

A todos os alunos que, pelo interesse e dedicação, me inspiram, estimulam e ensinam a cada nova experiência e, especialmente, aos que passaram pelo LABIC, que eu não poderia deixar de nominar, um a um, na ordem da colaboração e participação no projeto e na minha vida: Henrique Moreno Rocha, Régis Waechter, Franciele Gonçalves, Tamyres Dieb de Lima, Matheus Brito Martins, Juliana Partyka, Bianca Pereira de Lima, Rafael Araújo, Rafael Pedretti, Edicésar Passos, Pedro Pacheco, Gabriela Valcanaia, Milena Sugyiama, Andressa Malaquias, Juliana Furtuoso, Taynara Siqueira, Paulo Rizotti, Vinícius Précoma, Vitor Hugo Von Holleben e Franco Wigg.

À Gabriela Valcanaia (Gabi), pelas trocas, apoio e parceria na etapa final de elaboração da tese e realização das entrevistas. Nas entrevistas agradeço também o apoio de Antônio Palermo na Itália e de Maria Clara Ferrer na França.

A todos os amigos pelo incentivo, parceria e ajuda, de uma forma ou de outra, para a conclusão dessa etapa sem desistir ou esmorecer, em especial a Rosana Roberta da Silva, Luciana Bueno e Celine Drummond, que me acolheu e apoiou na etapa de redação final da tese.

Ao meu irmão Vicente Moroz Luciani e sua querida família Sabine, Isabele e Vicentinho, pelo carinho a cada visita, em território nacional e internacional; à Ivone Pires, pela acolhida sempre, e aos meus pais Vicente Maceno Luciani (in memorian) e Irene Moroz Luciani, por eu saber que sempre acreditaram em mim, torceram e se orgulharam de minhas conquistas. À minha mãe, ainda, pela revisão atenta e dedicada.

Ao Neury, pelo apoio de sempre e, por fim, o agradecimento mais especial e fervoroso às minhas duas preciosas filhas, Giulia Luciani Gaio e Giovana Luciani Gaio, por toda compreensão, companheirismo, estímulo e amor incondicional que nos une, alicerça e impulsiona a ir cada vez mais longe. Amo vocês duas mais do que tudo!!!! 


\section{RESUMO}

LUCIANI, Nadia Moroz. Iluminação Cênica: a performatividade da luz como elo entre a cena e o espectador. Tese (Doutorado) Escola de Comunicação e Artes, Universidade de São Paulo. São Paulo, 2020.

Esta pesquisa busca comprovar, a partir de conceitos e investigações a respeito da arte, do teatro, da cenografia em seu conceito mais amplo e do design, a atuação performativa da iluminação cênica por meio de sua presença como materialidade poética que se realiza na relação que pode estabelecer com o espectador. Para tanto, permeia conceitos basilares das práticas teatrais dos séculos XX e XXI elaborados principalmente por Josette Féral, Richard Schechner e Hans-Thies Lehmann, além de, mais recentemente, Luiz Fernando Ramos e sua teoria da mimesis performativa, para compreender as noções do teatro cujo processo de criação coletiva, colaborativa ou participativa caracterizam a produção cênica contemporânea. Analisa a luz como agente performativo que afeta o espectador que se dedica à ela, sobre o que foram investigados diferentes conceitos e autores como presença cênica, recepção ativa, estética da recepção de Hans Robert Jauss, fenomenologia da percepção de Maurice Merleau-Ponty e affordance de James Jerome Gibson. Com isso, almeja explorar cientificamente os efeitos que a luz-matéria tem sobre a percepção humana, dedicando-se especialmente à luz para a cena em sua relação com o espectador teatral. Com o objetivo de verificar sua hipótese da performatividade da luz, a pesquisa busca fundamento, ainda, na análise de algumas criações de luz, tanto da autora quanto de outros iluminadores, cuja proposição em matéria de iluminação indica características performativas, e em uma relevante amostragem de entrevistas, realizadas ao final do processo de investigação, com profissionais da área no Brasil, na Itália e na França.

\section{Palavras chave:}

Iluminação Cênica; Componentes da Cena; Luz Ativa; Performatividade da Luz. 


\begin{abstract}
LUCIANI, Nadia Moroz. Lighting Design: the performativity of light as element of connection between the stage and the spectator. Thesis (Doctorate) Escola de Comunicação e Artes, Universidade de São Paulo. São Paulo, 2020.

This research aims to prove, based on concepts and investigations about art, theater, scenography in its broadest concept and design, the performative action of stage lights through its presence as a poetic materiality that takes place in the relationship that can establish with the spectator. To this end, basic concepts of theatrical practices of the $20^{\text {th }}$ and $21^{\text {st }}$ centuries developed mainly by Josette Féral, Richard Schechner and Hans-Thies Lehmann, as well as, more recently, Luiz Fernando Ramos and his performative mimesis theory, to understand notions of the theater whose collective, collaborative or participatory process of creation characterize contemporary theatre production. It analyzes the light as a performative agent that affects the viewer who is dedicated to it toward important concepts from different authors such as presence, active reception, Jauss' aesthetic of reception, Merleau-Ponty's phenomenology of perception and Gibson' concept of affordance. With this, it aims to scientifically understand the effects that light-matter produces on human perception, especially dedicated to light for the stage in its relationship with the theatrical spectator. On the goal of verifying its hypothesis of the performativity of light, the research also seeks a practical foundation in the analysis of some stage light creations, both by the author and other lighting designers, whose propositions of theatre lighting indicates performative characteristics, and in a relevant sample of interviews, conducted at the end of the investigation process, with theatre and lighting professionals in Brazil, Italy and France.
\end{abstract}

\title{
Key words:
}

Light Design; Scene Components; Active Light; Performativity of Light. 


\section{RESUMÉ}

LUCIANI, Nadia Moroz. Création Lumière : la performativité de la lumière comme lien entre la scène et le spectateur. Thèse (Doctorat) École Supérieur de Communication et Arts, Université de São Paulo. São Paulo, 2020.

Cette recherche vise à prouver, à partir de concepts et d'enquêtes sur l'art, le théâtre, la scénographie dans son concept le plus large, l'éclairage et le design, l'action performative de la lumière de spectacle par sa présence en tant que matérialité poétique qui prend place dans la relation qu'elle peut établir avec le spectateur. À cette fin, recherche dans les concepts de base des pratiques théâtrales des $20^{\mathrm{e}}$ et $21^{\mathrm{e}}$ siècles développés principalement par Josette Féral, Richard Schechner et Hans-Thies Lehmann, ainsi que, plus récemment, Luiz Fernando Ramos et sa théorie de la mimesis performative, pour comprendre les notions du théâtre dont le processus de création collective, collaborative ou participative caractérisent la production scénique contemporaine. Elle analyse la lumière comme un agent performatif qui affecte le spectateur qui lui est dédié, sur quoi ont été étudiés des différents concepts et auteurs tels que la présence scénique, la réception active, l'esthétique de la réception de Hans Robert Jauss, la phénoménologie de la perception de Maurice Merleau-Ponty et le concept d'affordance de James Jerome Gibson. De tout cela, elle vise à comprendre scientifiquement les effets que la lumière-matière a sur la perception humaine, se consacrant spécialement à la lumière pour la scène dans sa relation avec le spectateur théâtral. Dans le but de vérifier son hypothèse de la performativité de la lumière, la recherche cherche également un fondement dans l'analyse de certaines créations lumières, à la fois par l'auteur et d'autres par d'autres créateurs lumière, dont la proposition indique des caractéristiques performatives, et dans un échantillon pertinent d'entretiens, menés à l'issue de la recherche doctorale, avec des professionnels du domaine de l'éclairage et du théâtre au Brésil, en Italie et en France.

\section{Mots clés :}

Création Lumière ; Composants de la Scène ; Lumière Active ; Performativité de la Lumière. 


\section{SUMÁRIO}

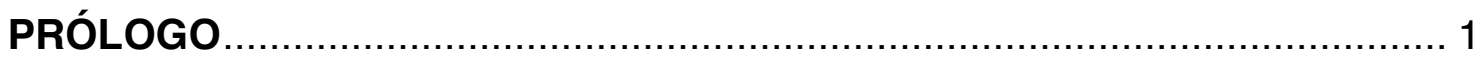

INTRODUÇÃO

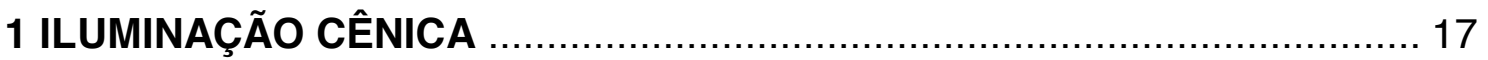

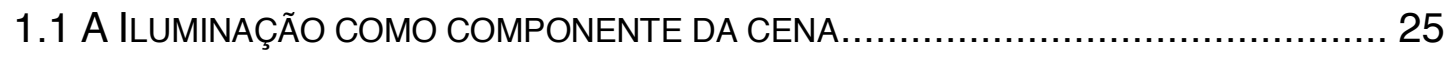

1.2 OS PROCESSOS COLABORATIVOS, O ESPECTADOR E A LUZ.......................... 33

1.3 PROCESSO CRIATIVO E FORMAÇÃO DO ILUMINADOR................................... 54

1.3.1 Funções e Variáveis da Luz......................................................... 74

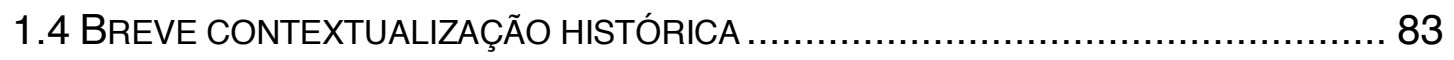

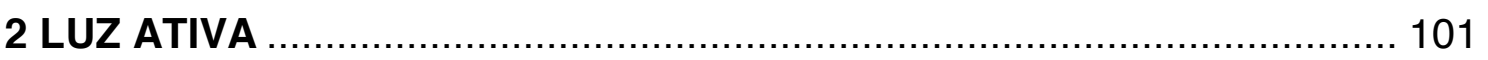

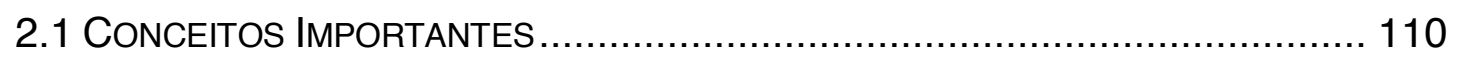

2.1.1 Conceito amplo de cenografia ................................................... 113

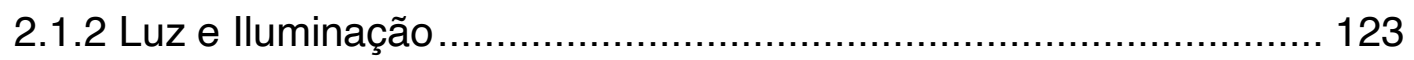

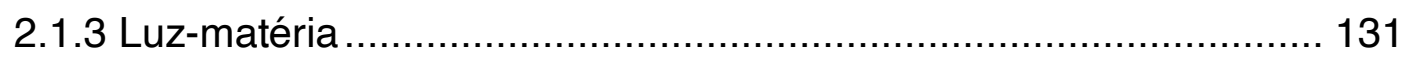

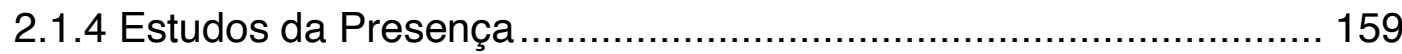

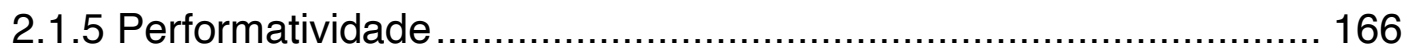

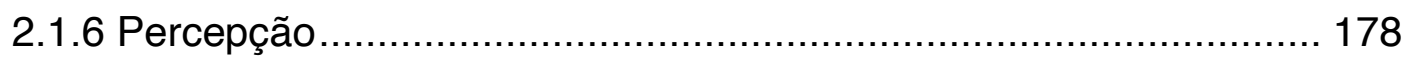

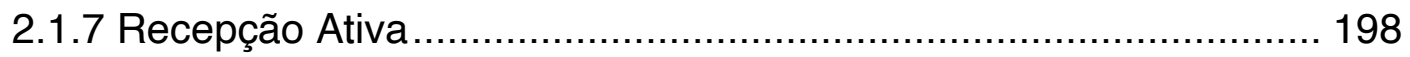

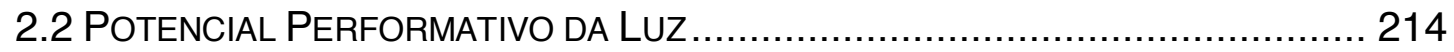

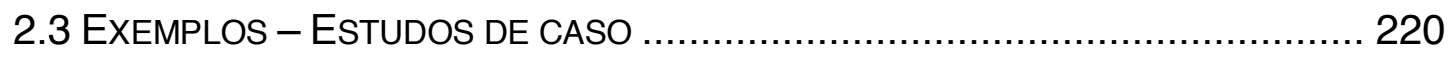

2.3.1 Cibele Forjaz e o Teatro Oficina …........................................... 222

2.3.2 Guilherme Bonfanti e o Teatro da Vertigem............................... 240

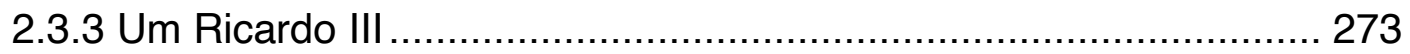

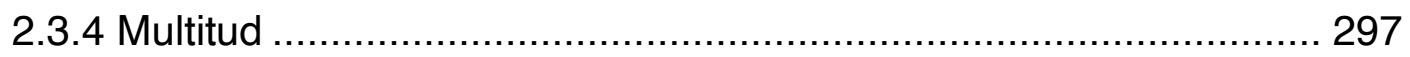


3.1 A LUZ COMO ELO ENTRE A CENA E O ESPECTADOR ................................... 324

3.2 CARACTERÍSTICAS E CONDIÇÕES DA PERFORMATIVIDADE DA LUZ.................. 331

3.2.1 lluminação e gravidade ........................................................... 342

3.3 A PERFORMATIVIDADE DA LUZ AINDA POR INVESTIGAR ............................. 345

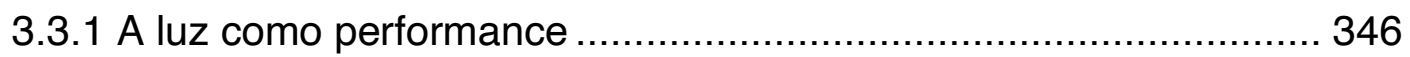

3.3.2 A luz concebida e a luz performada - os performers da luz .......... 350

3.3.3 A luz, o tempo, o ritmo e o movimento......................................... 357

3.3.4 A performatividade da cor ........................................................ 360

3.3.5 A comprovação da experiência do espectador .............................. 363

3.3.6 A performatividade do blecaute .................................................. 364

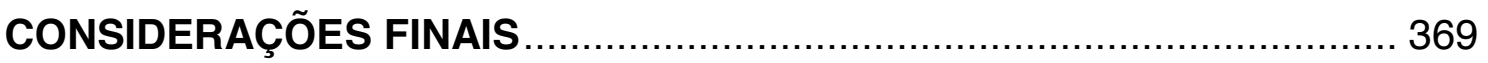

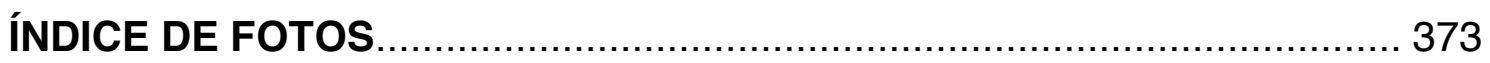

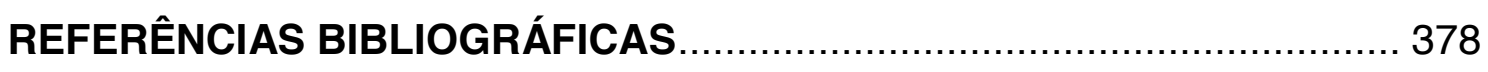

ANEXOS

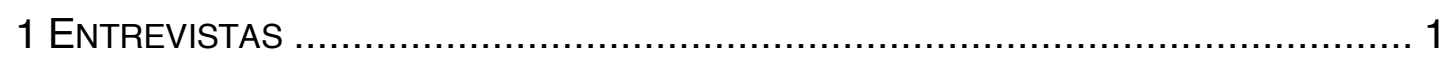

1.1 Questionário em Português ........................................................ 3

1.2 Questionário em Francês............................................................... 4

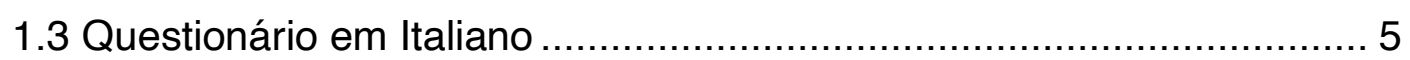

2 ILUMINADORES ENTREVISTADOS - BIOGRAFIAS ………............................... 6

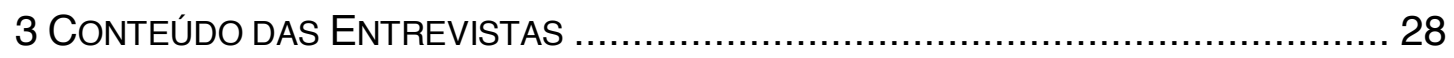

3.1 Alessandra Domingues - Iluminadora Paulistana.............................. 28

3.2 Aurélio de Simoni - lluminador Carioca ............................................. 37

3.3 Beto Bruel - lluminador Paranaense ................................................ 48

3.4 Christine Richier - lluminadora Francesa ....................................... 60

3.5 Christophe Forey - lluminador Francês ............................................. 61

3.6 Claudia de Bem - Iluminadora Gaúcha ............................................ 69

3.7 Cibele Forjaz - Iluminadora Paulistana.............................................. 75

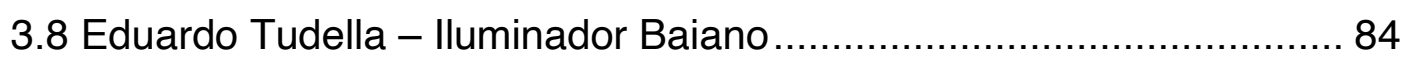

3.9 Elsa Revol - Iluminadora Francesa ................................................ 92

3.10 Eric Soyer - Cenógrafo e lluminador Francês ............................... 109 
3.11 Fabrizio Crisafulli - Iluminador e Diretor de Teatro Italiano 113

3.12 Gianni Staropoli - Iluminador Italiano ........................................... 117

3.13 Guilherme Bonfanti - Iluminador Paulista .................................... 121

3.14 Jorginho de Carvalho - lluminador Carioca ................................... 136

3.15 Lucas Amado - lluminador Paranaense ........................................ 142

3.16 Marisa Bentivegna - Iluminadora e Cenógrafa Paulista ................. 151

3.17 Nadja Naira - Iluminadora Curitibana ........................................... 164

3.18 Pasquale Mari - Iluminador e Diretor de Fotografia Italiano ........... 179

3.19 Paulo Cesar Medeiros - lluminador Carioca.................................. 181

3.20 Renato Machado - Iluminador Carioca.......................................... 184

3.21 Roberto Gill Camargo - Iluminador Paulista ................................. 196

3.22 Rodrigo Ziolkowski - lluminador Paranaense ............................... 205

3.23 Thierry Fratissier - Iluminador Francês......................................... 209

3.24 Wagner Corrêa - lluminador Paranaense...................................... 218

3.25 Wagner Pinto - lluminador Paulista............................................... 221

4 CONTEÚDOS ORIGINAIS DAS ENTREVISTAS EM FRANCÊS E ITALIANO ................. 234

5 Verdades E Mitos sobre a Performatividade da LUZ............................ 282 
"Don't forget, the most important is poetry.

Everything you make must be a poem on stage, that's the secret"

J.S. 


\section{PRÓLOGO}

Julho de 1989, o inverno castigava Curitiba quando a professora da disciplina de Linguagem da Dança (ninguém sabia dizer exatamente o que queria dizer esse título) do Curso de Comunicação Visual do Departamento de Artes da UFPR, Liane Essenfelder, nos levou para uma visita ao Teatro Guaíra e uma entrevista com o então cenógrafo e iluminador do Ballet Teatro Guaíra - BTG. Foi mágico adentrar esse templo do teatro de Curitiba, do qual até então eu só conhecia as áreas acessíveis ao público como espectadora, e conhecer suas entranhas, segredos e recintos exclusivos aos artistas que ali habitavam. A professora Liane, uma visionária do design cênico, talvez até sem muita consciência disso, foi a primeira a me apresentar Appia, Craig, Diaghilev e Svoboda e tantos outros, como mostram minhas anotações de aula, consultadas tantos anos mais tarde, à época da pesquisa de TCC e depois novamente na de mestrado. Foi nesse dia frio de julho, então, que eu conheci o querido e charmoso uruguaio que viria a se tornar um grande amigo, Carlos Kur, com quem tanto aprendi, neste dia e em todos os anos de convivência que viriam a seguir.

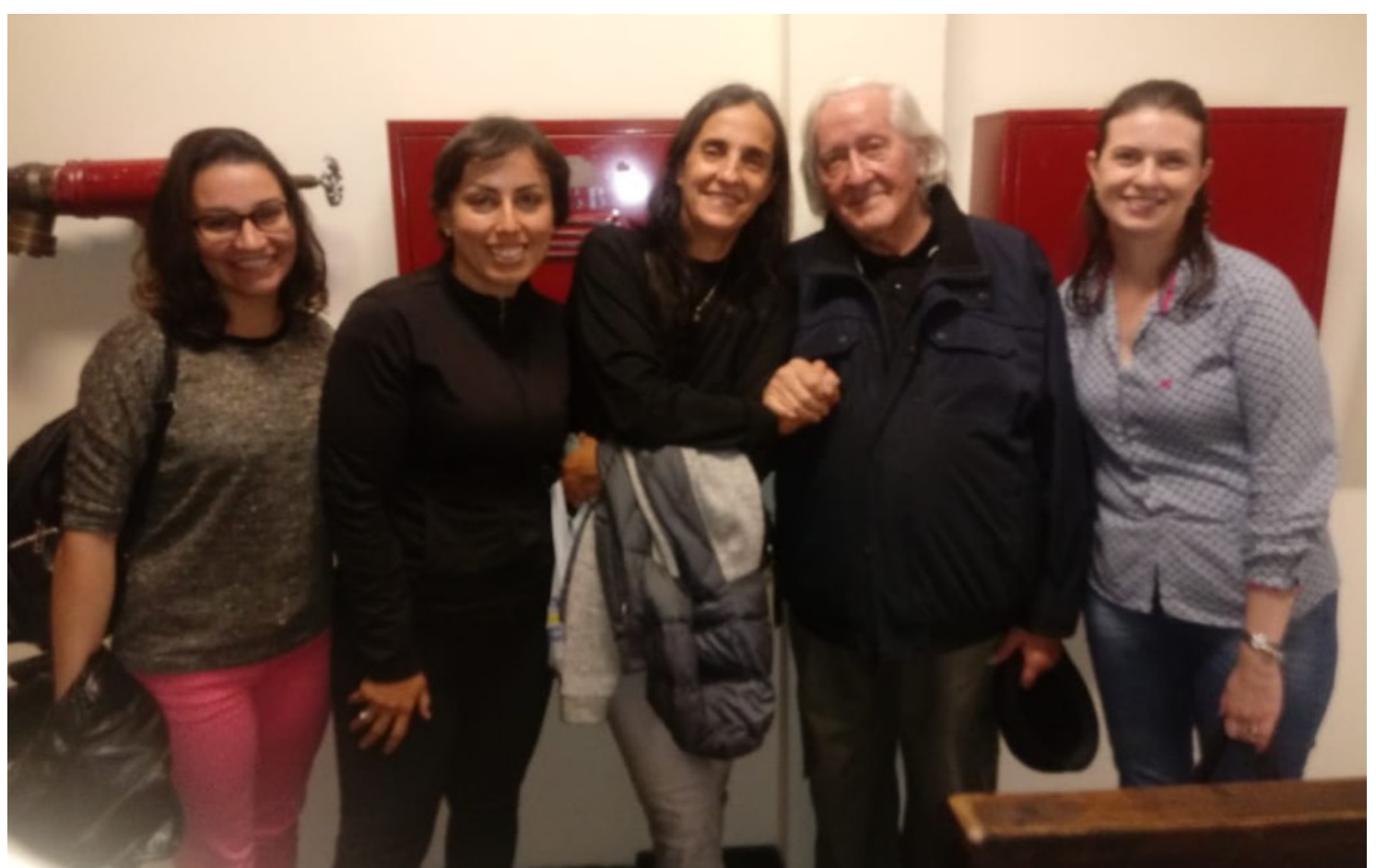

Figura 1 - Foto com Carlos Kur durante a Oficina de lluminação Cênica do LABIC realizada excepcionalmente no Mini Auditório do Teatro Guaíra em 2019. Foto acervo pessoal. 
Ao entrarmos no Teatro Guaíra, fomos imediatamente encaminhados à sala do Kur, onde funcionava a coordenação técnica do teatro, por um labirinto fantástico de corredores, coxias, estruturas cênicas e salas por cujas portas entreabertas podíamos vislumbrar, curiosa e fortuitamente, um pouquinho do mundo fantástico existente por trás dos bastidores do teatro. Logo ao entrar, maquetes, desenhos e relatos apaixonantes tornaram a experiência ainda mais surpreendente e encantadora. Antes disso, no entanto, ao passar pela porta de vidro da entrada do menor auditório do Teatro Guaíra, o Mini Auditório, onde mais tarde eu faria a luz para tantos espetáculos acadêmicos, amadores e profissionais, daria tantas aulas e teria tantas experiências, tão ou mais belas que a primeira, que relato a seguir.

Mesmo tendo passado rapidamente por esta porta, também conhecida pelo glamoroso título de "entrada dos artistas", eu pude ler, num pequeno cartaz improvisado e escrito à mão, as intrigantes palavras OFICINA DE LUZ. Provocada, principalmente como estudante de Comunicação Visual da UFPR, futura designer e egressa do curso de Desenho Industrial do CEFET-PR, onde tivera tantas aulas e ateliers práticos em marcenarias e oficinas, eu logo lembrei dos trabalhos feitos para o saudoso professor Toshiuki Sawada e tantas outras atividades práticas nas incríveis instalações da antiga Escola Técnica. Intuitiva e inadvertidamente, deduzi que deveria ser algo do gênero. Acreditando se tratar de algum atelier para criar e construir abajures e outros artefatos luminosos, para fins cênicos, é claro, eu me interessei e pensei em obter maiores informações a respeito assim que possível. Foi o que fiz.

Descobri, assim, que luz, no caso, significava iluminação para teatro, a realização de um projeto de luz criado para espetáculos cênicos, uma surpresa para mim. Apesar de muito frequentar o teatro como espectadora e já ter tido alguma experiência com produção de vídeo quando trabalhei como arte-finalista em algumas agências publicitárias, eu não tinha a menor ideia do que seria iluminação cênica. Admito que talvez nunca tenha conscientemente refletido, até então, sobre esta atividade, muito menos sobre a existência de profissionais específicos para sua concepção e realização. Curiosa, não me furtei, no entanto, 
movida principalmente pelo entusiasmo juvenil, a perguntar, num ímpeto de ousadia, se eu poderia participar daquela oficina. A pergunta foi feita, durante a entrevista, para o assistente do Carlos Kur na época, mais tarde o grande diretor Cleon Jacques que hoje dá nome a um teatro em Curitiba. Ele me explicou, gentilmente, que aquele curso sobre iluminação estava tendo início naquele mesmo dia e que as vagas limitadas eram dirigidas para funcionários da Fundação Cultural de Curitiba, mas que talvez não estivesses todas preenchidas. Bingo! Ele prontamente nos levou, a mim e mais dois colegas igualmente curiosos, Alexis Teixeira e Luciane Hilú, que viria a ser minha colega de TCC sobre Design Cênico, ela dedicada à cenografia e eu à iluminação até o Mini-Auditório. Seguimos novamente por aquele labirinto fantástico que eu depois passaria a conhecer tão bem, até o pequeno teatro onde já havia começado a primeira aula da tal Oficina de Luz. Alguns instantes depois, tendo sido aceitos fazer parte da turma já em andamento, eu seria introduzida, em um só momento, ao espaço sedutor de uma sala de espetáculo e, mesmo sem saber ao certo o que isso significava, no mundo do teatro.

Cleon abriu a porta do auditório e pudemos ver, sentado em uma cadeira no canto do proscênio do palco um senhor de cabelos brancos e ar simpático, falando pelos cotovelos, com um brilho indescritivel no olhar, para uma pequena plateia, cujos olhos e mentes atentos denunciavam o interesse e encantamento pelo assunto em questão. Ele aceitou que nos juntássemos ao grupo e logo fomos igualmente hipnotizados pelas palavras daquele senhor apaixonado pelo seu labor, palavras que viriam a transformar completamente a minha vida e determinar para sempre meu destino pessoal e profissional, em todos os sentidos. Seria no teatro que eu faria minha história, trabalho, pesquisa e até mesmo constituiria minha família.

O gentil senhor em questão era Aurélio de Simoni, grande personalidade do teatro e iluminador carioca, que estava em Curitiba a convite do Teatro Guaíra para "fazer a luz", como se diz coloquialmente do trabalho do iluminador, para a montagem do espetáculo $A$ Vida de Galileu, uma adaptação do texto original Galileu Galilei, de Bertolt Brecht. A peça seria a montagem do TCP - Teatro de 
Comédia do Paraná naquele ano, realizada com atores paranaenses e a direção do encenador, também carioca, Celso Nunes. Seguiram-se 15 dias intensos de 8 horas diárias de aula (que eu só pude acompanhar integralmente graças à greve da UFPR daquele ano, deflagrada oportunamente, para mim e meus colegas), além das demais horas que passamos juntos nos ensaios, visitas a outros teatro de Curitiba, almoços, jantares e espetáculos que vimos juntos. Durante esse período intenso de convivência, ele me ensinou a "ver a luz", mas não sem antes me advertir sobre o fato de que eu nunca mais veria um espetáculo da mesma forma, como simples espectadora, o que se revelou, em muito pouco tempo, uma verdade absoluta que transmito hoje a todos os meus alunos igualmente enfeitiçados pela iluminação.

Neste curto período que passei com o Aurélio, eu tive a oportunidade de assistir os ensaios da peça, uma montagem profissional com um elenco e equipe de criação formada pelos melhores profissionais do ramo, e acompanhar todo 0 processo criativo, tanto do próprio espetáculo e de cada um de seus componentes como cenário, figurino e encenação em geral, quanto, mais especificamente, da iluminação. Considerada como parte da oficina, acompanhamos também a montagem da luz, à qual Aurélio fez questão de incluir uma etapa de reconhecimento e manutenção dos equipamentos de iluminação do Guairinha, onde a peça faria sua temporada. Depois disso, pudemos acompanhar também os ensaios técnicos, o ensaio geral e assistir à estreia, uma experiência completa e inesquecível, com a qual eu tive a sorte de debutar em minha carreira no teatro. Todas essas experiência foram muito ricas, mas o que mais me marcou, durante todo esse tempo, foi poder conhecer e entender a paixão e o respeito que $\circ$ Aurélio tem pelo teatro, pela profissão e pela responsabilidade assumida por ele e todos os profissionais encarregados da realização da luz de um espetáculo, incluindo igualmente o iluminador, o operador de luz e os técnicos montadores. Ele não só me apresentou o mundo do teatro, como me contagiou com o seu amor pela arte da iluminação, compartilhando generosamente todo o seu conhecimento, adquirido em tantos anos de prática neste ofício mágico e na convivência com grandes nomes do teatro brasileiro. 
Além deste precioso, mas curto período de convivência com o Aurélio, eu tive a oportunidade de também conviver e trabalhar com o iluminador curitibano, hoje mundialmente conhecido, Beto Bruel, a quem Aurélio me apresentou pouco antes de voltar para o Rio. Aurélio não só me abriu as portas do teatro, como me permitiu entrar pela porta da frente, pois, por intermédio do Beto, eu só fui fazer teatro amador e estudantil depois de mais de dois anos trabalhando apenas com teatro profissional. Foram anos igualmente intensos, nos quais eu pude perceber no Beto uma igual paixão e respeito pela luz e pelo fazer teatral, e depois dos quais eu pude, finalmente, alçar meus próprios voos como iluminadora e professora de iluminação. Eu dei início a essas duas carreiras quase que ao mesmo tempo, com igual empenho e comprometimento, uma enriquecendo e impulsionando a outra na prática e na teoria, com pesquisas e criações simultâneas. Além da importância que tiveram em minha própria vida e formação, esses dois grande profissionais representam também, no Brasil, o início da profissionalização e do respeito pela profissão e pelo profissional responsável pela tarefa exclusiva de iluminar um espetáculo cênico.

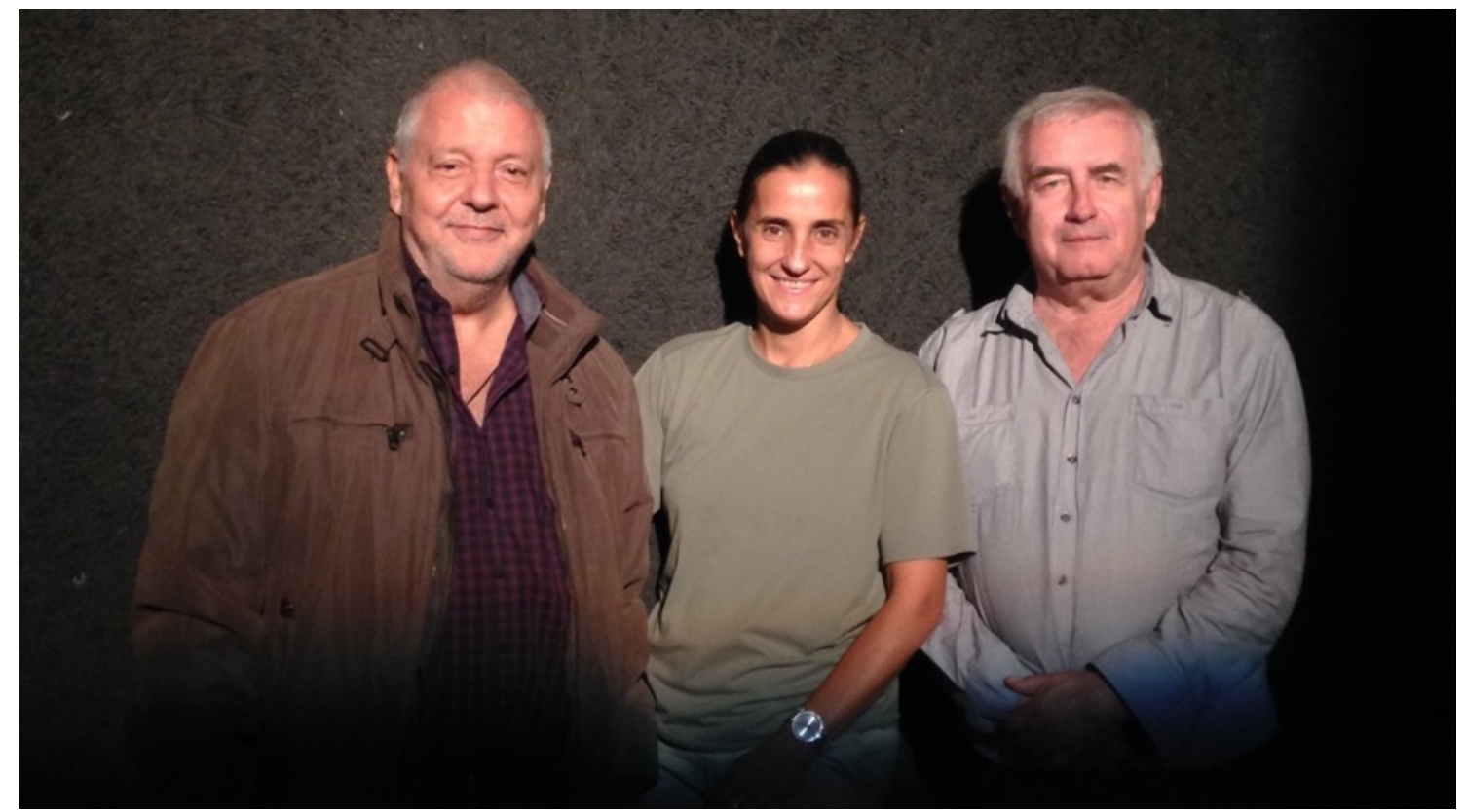

Figura 2 - Entre meus dois mestres, Aurélio de Simoni e Beto Bruel, em abril de 2017 no Espaço das Artes em São Luiz do Purunã no Paraná - Foto: Kraw Penas.

A respeito do que pude aprender com cada um deles, eu faço minhas as palavras de Jean Rosenthal (1972) a respeito de Stanley McCandless: "Eu sempre senti que McCandless era de fato o avô de todos nós [iluminadores]. Não 
porque não tenha havido nenhum outro antes dele, mas porque ele tinha uma atitude tão específica e organizada em relação à luz e determinou o mais importante: uma atitude que afirma que deve haver uma técnica e um método para organizar suas ideias"1 (ROSENTHAL, 1972, p. 16) não só para me referir a eles como também a Jorginho de Carvalho, reconhecido por seus pares como o primeiro iluminador brasileiro, mestre de Aurélio e de tantos outros iluminadores cariocas. Foi a partir destes profissionais da luz, pioneiros da arte e da técnica da iluminação cênica no Brasil, que a profissão adquiriu e tem hoje o reconhecimento como um dos elementos fundamentais do espetáculo teatral, minha profissão e paixão, na vida, no trabalho e na docência.

As atividades exercidas como artista da luz e como professora da arte e técnica da iluminação sempre foram, para mim, uma a inspiração da outra, alimentando-se e nutrindo-se mutuamente, a ponto de eu não poder distingui-las no meu cotidiano profissional. Instintivamente relacionando-as, tanto nos palcos quanto nas salas de aula, eu sempre usei minhas experiências práticas como material de ensino e, sempre que possível, incentivei meus alunos, tanto curriculares quanto das oficinas e cursos livres, a participarem dos ensaios e montagens de luz que realizei. Do mesmo modo, as pesquisas e reflexões feitas na preparação das aulas e as trocas constantes com os estudantes influenciaram e transformaram, inegavelmente, meu fazer artístico ao longo dos anos, como explicarei mais adiante. $\mathrm{O}$ mais importante resultado dessas experiências foi 0 desenvolvimento de uma abordagem pedagógica teórica da iluminação como elemento estrutural da cena, registrada em minha dissertação de mestrado, e em cujo percurso eu fui surpreendida pela descoberta de um possível potencial performativo da luz como componente ativo do espetáculo, tanto na concepção quanto na execução face a um público que a ele se dedica participativamente. É esse potencial performativo que eu busquei investigar na presente tese.

\footnotetext{
1 «I have always felt that McCandless was indeed the granddaddy of us all. Not because there were no others before him, but because he did have such a specific and orderly attitude toward lighting and he set up the most important thing : an attitude which demands that there must be a technique and a method for organizing your ideas » (tradução da autora).
} 


\section{INTRODUÇÃO}

Je suis un professionnel, pas un artiste, un professionnel qui exerce un art collectif ${ }^{2}$ Josef Svoboda

Assim como Svoboda, eu sou uma profissional, mas também uma artista, assim como ele também, aliás. Sou uma designer e uma iluminadora teatral ${ }^{3} \mathrm{e}$ foi como tal que eu me descobri no teatro. Ao contrário de muitos outros profissionais da luz que experimentam, antes, outras atividades como a atuação, a dança ou, mais corriqueiramente, a cenografia, foi como consequência da minha formação em design que eu iniciei minha carreira no teatro como iluminadora. Focando meus interesses na iluminação cênica como linguagem no teatro e, resistindo às resistências, tanto em um campo (teatro) quanto no outro (design), eu sempre busquei associá-los no entendimento e na sistematização de uma metodologia do processo criativo da luz.

Dito isso, fica evidente e importância da minha biografia para a trajetória dessa pesquisa e das razões que sempre me fizeram desejar, além de iluminar e criar luz, também compreendê-la, conhecer seu funcionamento, objetivos, desafios e funções no espetáculo. Como designer, eu sempre procurei entender

\footnotetext{
2 Eu sou um profissional, não um artista, um profissional que exerce uma arte coletiva (tradução da autora).

${ }^{3}$ Como designer de formação e lluminadora de profissão, me parece oportuno fazer aqui um aparte a respeito dos termos adotados para a denominação da profissão e do profissional encarregado da iluminação cênica no Brasil, onde persistem discussões sobre nominar a função como iluminador, criador de luz ou lighting designer, e também nos EUA e na França. Jean Rosenthal declara-se pioneira da iluminação como profissão nos EUA dos anos 30 , instituindo 0 termo lighting designer. Christine Richier descreve, na introdução de sua tese de doutorado sobre Josef Svoboda, o surgimento da profissão e do termo nos EUA no final dos anos 60, quando, segundo o depoimento de Svoboda, os teatros da Broadway estavam em atividade, mas não equipados, então havia a necessidade de alugar os equipamentos de empresas privadas, que instalavam conforme orientação recebida a cada espetáculo pelo diretor ou produtor, que não sabiam muito sobre a luz e a instalação elétrica do teatro. Surge assim a necessidade de um profissional especialmente dedicado à orientar essas montagens $\mathrm{e}$, consequentemente, a profissão de iluminador (RICHIER, 2019, anexo 1, p. 74-75). Na França, é feita a diferenciação entre éclairagiste, o profissional que, entre o final do século XIX e início do século XX tinha a função de clarear e cena, e créateur lumière, aquele que além de iluminar assumia também a responsabilidade criativa de uma importante parte do espetáculo, assim como a diferença entre éclairage (luz) e lumière (iluminação). Essa distinção se apresenta de forma semelhante, em língua inglesa, entre light (luz) e lighting (iluminação).
} 
o verdadeiro e relevante papel da luz no teatro. Mais do que clarear, ou seja, tornar o espetáculo visível, eu entendi muito cedo que era importante, também, o que a luz tinha a dizer, o que comunicava e como podia estabelecer a relação da cena com o espectador. Ou melhor, como criava o elo pelo qual o espetáculo podia se relacionar com o público, se tornando esse elo, permitindo o acesso e a compreensão do espetáculo pelo espectador.

Todas essas inquietações tiveram origem na graduação em Comunicação Visual, como era chamado o curso de Design Gráfico na época. As atividades profissionais e acadêmicas tiveram início ao mesmo tempo e eu me tornei professora de cenografia e iluminação na antes mesmo de poder me considerar uma iluminadora. A adaptação da metodologia da criação em comunicação visual para a criação em teatro pelo processo de design thinking permitia explicar o processo de criação das linguagens cênicas, de onde o termo design cênico. Apesar de não atuar como cenógrafa, as aulas de cenografia com base nos princípios do design ajudaram na elaboração do conceito de design cênico, hoje uma disciplina incorporada no currículo do curso de artes cênicas ${ }^{4}$.

Além da metodologia do projeto do design, outras disciplinas da formação do designer, indispensáveis tanto para a criação artística quanto para a comunicação, como semiótica, estética, composição e as teoria da cor, da forma, da comunicação e da informação estruturam o conceito de design cênico. $O$ ensino específico da iluminação, encontrava ainda fundamento na observação do trabalho e do processo de criação do iluminador Beto Bruel, de quem eu era assistente na época, e das equipes com as quais trabalhávamos. Mais tarde, esse conhecimento foi complementado, logicamente, pelo meu próprio processo de criação e pela maneira como eu mesma entendia a cenografia e a iluminação a partir de minhas experiências profissionais.

A investigação proposta nesta pesquisa se baseia, então, no conjunto das minhas experiências como pesquisadora, professora e iluminadora. Ao longo

\footnotetext{
${ }^{4}$ Novo currículo dos Cursos de Bacharelado em Artes Cênicas e Licenciatura em Teatro da Faculdade de Artes do Paraná - Campus de Curitiba II aprovado e instituído em 2010.
} 
dessa trajetória profissional e acadêmica, existem alguns temas importantes aos quais eu dediquei meu tempo e reflexão, seja em atividades pedagógicas, criativas ou de estudo e pesquisa. O primeiro dentre eles é o conceito de Performance Design, com o qual eu tive contato a partir da minha primeira participação na Quadrienal de Praga em 2007. Este conceito, difundido internacionalmente e que já possui sólidas vertentes teóricas no Brasil, principalmente no que diz respeito à relação entre o trabalho da equipe de criação em teatro (cenógrafo, figurinista, iluminador e sonoplasta) e as atividades do design. Ele faz referência também ao conceito amplo de cenografia, que Luciana Bueno descreve como "resposta narrativa e gráfica à dramaturgia" (BUENO, 2007, p. 12) e Josef Svoboda qualifica como "tradução espacial de uma ideia"5 (RICHIER, 2019, anexo 1, p. 27). Este conceito amplo de cenografia, abrange a "grafia da cena", ou seja, o conjunto de elementos significantes usados para grafar 6 no espaço uma ideia. Neste sentido, a cenografia representa o conjunto de linguagens que compõem a expressão gráfica da cena, a ambientação do espetáculo que Cristine Richier (2019) chama de visual cênico. Para ela, o visual cênico é um conceito diacrônico que entende o teatro como uma sucessão de imagens reveladas no espaço e no tempo da representação, percebidas de forma diferente por cada espectador (RICHIER, 2019, p. 19).

De modo que a cenografia representa, neste estudo, a totalidade sensorial da cena teatral, sem ater-se nem ao cenário, propriamente dito, nem somente aos seus elementos visuais, também conhecidos como visualidades ${ }^{7}$. A esse respeito, Jacques Aumont (2012) esclarece que a percepção do espaço nunca será apenas visual, considerando a incapacidade do sistema da visão de perceber, por exemplo, a distância e a verticalidade. Desta forma, o autor afirma que a noção de espaço está tão associado à experiência tátil e cinética quanto

\footnotetext{
5 « La Scénographie est la traduction spatiale d'une idée » (tradução da autora). Frase de Josef Svoboda, cenógrafo tcheco durante a entrevista concedida a Christine Richier e Djamila Salah em Paris em março de 1993, presente no Anexo 1 - Les Entretiens sur la Lumière, transcrição da entrevista em documento anexo à tese de doutorado Josef Svoboda, poète de l'immatériel. (RICHIER, 2019).

6 Entendendo grafia também em um sentido mais amplo, como escritura, tanto no plano (bidimensional) quanto no espaço (tridimensional).

7 Termo usado com frequência em pesquisas realizadas no Brasil por diferentes autores, a exemplo de Eduardo Tudella (2017) e Ismael Scheffler (2019).
} 
visual (AUMONT, 2012, p. 33). O conceito de sensorialidade admite, assim, que o espetáculo e seus elementos constituintes, indissociáveis na percepção do espectador, sejam acessíveis ao espectador por todos os seus sentidos e habilidades cognitivas. Mesmo que, segundo Lucia Santaella (2012), o sentido da visão seja o mais afetado no teatro, ele claramente não é o único. Lembranças e memórias desencadeadas por uma cena podem remeter a um cheiro de infância ou, ainda, alguma ação cênica pode, inesperadamente, causar no público frissons ou arrepiar sua pele pela emoção que provoca, representando outros meios sensoriais pelos quais até mesmo os elementos considerados apenas como visuais podem alcançar o espectador. Tanto odores quanto reações táteis representam estímulos a outros sentidos que não o visual na relação sensorial do observador com a cena, ou seja, nas sensações resultantes de sua percepção global do espetáculo.

Paralelamente aos estudos em performance design, outros temas correlatos permitem fundamentar a criação cênica em qualquer que seja qual a linguagem do espetáculo. A associação entre a criação no teatro e a metodologia do design gráfico é explicada por Osvaldo Gabrieli (2007 apud LUCIANI, 2014, p. 47), que define um bailarino como um ponto que se desloca no espaço e a distribuição dos corpos como uma configuração plástica. Disciplinas como as teorias da informação e da comunicação, a semiótica, a estética, ou ainda outras mais aplicadas como as teorias da cor e da forma, fundamentais para a criação no plano e no espaço, fundamentam o entendimento e emprego da iluminação cênica como linguagem. Cibele Forjaz (2013) reforça ainda mais esse entendimento em suas pesquisas da luz como elemento estrutural e estruturante do espetáculo, que Fabrizio Crisafulli (2019) chama também de estrutural e construtivo (structurel e constructif), adicionando as características poética e dramatúrgica da luz.

Foi também por meio de experiências e pesquisas internacionais que eu conheci o conceito de lighting design, uma forte contribuição para confirmar a relação que eu já julgava existir entre o teatro e o design, minhas duas áreas de interesse profissional e acadêmico. Ele permite, conforme muito bem explicado 
pelo professor Tudella (2012), entender a iluminação cênica como uma área de aplicação do design e, com isso, assimilar toda sua complexidade e engajamento ao aliar forma e função, artes e ofícios. O surgimento da Bauhaus, na primeira metade do século passado, permitiu a criação do design, que reconciliou arte e técnica (FLUSSER, 2007, p. 183-184) em uma atividade que requer tanto conhecimentos técnicos e tecnológicos quanto sensibilidade artística e criativa. O mesmo acontece com a iluminação cênica, entendida como uma área de criação artística que envolve o emprego de equipamentos e técnicas.

Outro aspecto bastante relevante e que exerce um papel importante em minhas pesquisas é o ensino da iluminação cênica, cujo processo de elaboração pedagógica me serviu tanto em aula quanto nas atividades profissionais e de difusão dos preceitos da iluminação cênica como design em eventos científicos e artísticos. A preparação das aulas, em conjunto com as atividades práticas em artes gráficas, cenografia e iluminação, foram sempre oportunidades de reflexão para uma compreensão mais profunda dessas atividades e da melhor forma de explica-las, o que resultou na minha dissertação de mestrado (LUCIANI, 2014). Além disso, não posso deixar de citar a constante troca com os alunos, estagiários, orientandos e bolsistas das atividades de ensino, extensão e pesquisa, constantes fontes de inspiração e cuja convivência mantém acesa a chama da investigação científica e o interesse pelo conhecimento. As trocas com colegas de profissão também merecem ser citadas, considerando principalmente os diversos e imprescindíveis encontros científicos da área promovidos no Brasill $^{8}$ e as tantas publicações recentes em língua portuguesa, com conteúdos técnicos e reflexões científicas de grande valor e qualidade 9 .

\footnotetext{
8 O destaque para o volume da realização deste tipo de evento científico no Brasil se deve à experiência vivida no período do doutorado sanduiche (PDSE) na França (2109-2020), no qual eu pude constatar a raridade de tais eventos e até mesmo da interação entre artistas e pesquisadores da área. Ter participado de alguns eventos científicos (Colloque Lumière Matière na UdL - França e UNIPD - Itália e II EASTAP Conference na ULisboa em Portugal) me fez perceber ainda como existe um grande distanciamento entre pesquisadores e artistas, cuja experiência é raramente compartilhada no meio acadêmico. Folgo em salientar, no entanto, que este cenário se encontra em processo de reavaliação e demonstra tendência, pelo interesse mútuo, a se transformar num futuro próximo.

9 Como, por exemplo, a valorosa tese recém publicada do Prof. Eduardo Tudella (2017) sobre a luz na gênese do espetáculo, a obra de pesquisa que estabelece o vínculo entre a iluminação
} 


\section{Organização da pesquisa e estrutura da tese}

Foi longo o caminho percorrido por este estudo desde a proposta inicial até $\mathrm{o}$ objeto final, a performatividade da luz como elo entre a cena e o espectador. O projeto original de pesquisa previa o estudo e a proposição de uma metodologia para o ensino da iluminação cênica para estudantes, acadêmicos ou livres, jovens profissionais e demais interessados na arte e no ofício da luz criada para a cena. A performatividade da luz constava no projeto apenas como parte do processo do entendimento da atuação da luz em um espetáculo cênico, mas não era, ainda, o tema principal da pesquisa. Em seguida, durante as orientações do doutorado e com base nas próprias pesquisas e incertezas a respeito do caminho a ser tomado pela pesquisa, o argumento final recebido do orientador na época, o professor José Batista Dal Farra Martins, foi muito enfático e irrefutável. Dar aulas já era um conhecimento adquirido, não havia o que investigar.

Concentrado, então, cada vez mais no aspecto artístico e menos no pedagógico da iluminação, o projeto foi se encaminhando mais claramente para o processo criativo e o desempenho da luz no espetáculo. Havia, no entanto, noções ainda muito difusas, conceitos fundamentais para a investigação que necessitavam ser mais aprofundados. Parecia inegável haver alguma relação entre a performatividade da luz e a performance, bem como parecia haver a obrigatoriedade de um agente humano, um performer, responsável por ela. Além disso, a recepção vinha se destacando como um elemento chave do fenômeno da performatividade da luz e parecia fundamental compreender melhor como acontecia essa nova relação do espectador com a cena por meio da luz. Esses

cênica e as artes plásticas de Valmir Perez (2012), a importante referência bibliográfica já tão explorada por estudantes, profissionais e pesquisadores da iluminação do Prof. Roberto Gill Camargo (2012), além de artigos em revistas científicas (algumas até com dossiês temáticos especialmente dedicados à iluminação), teses, dissertações e monografias. Com um caráter menos científico, mas também muito úteis, existem os sites, blogs e fóruns cibernéticos sobre a iluminação cênica, onde circulam informações, vídeos, textos e tutoriais, toda uma coletânea de materiais, dos mais técnicos aos mais conceituais. 
já eram os focos principais da investigação, mas ainda havia muitos caminhos possíveis e a escolha não parecia fácil.

Foi no exame de qualificação ${ }^{10}$, que se deu, finalmente, a definição dos novos rumos da pesquisa. Apesar da continuidade do tema da pesquisa ter sido aprovada e estimulada, as análises, observações e sugestões dos membros da banca, principalmente do professor Luiz Fernando Ramos ${ }^{11}$, reorientaram e estruturaram a investigação num sentido, de certa forma, bastante diverso ao original. Foi sugerido que o tema da performatividade da luz ${ }^{12}$ adquirisse definitivamente o protagonismo da investigação, mas com maior ênfase para o que efetivamente seria a performatividade da luz num panorama mais definido e preciso. Ficava cada vez mais evidente, a partir daquele momento, que, apesar de ter seu conceito estruturado a partir da noção de performatividade de Josette Féral (2015), parecia não haver dependência entre a suposta performatividade da luz e as práticas performativas. Mesmo considerando a performatividade do teatro como conceito basilar da pesquisa, então, foi possível desvincular as duas noções de performatividade (da luz e do teatro), para buscar compreender, efetivamente, o que é e de que forma a luz, como fenômeno físico, atua no espetáculo e na relação que estabelece entre a cena e o espectador, sendo ela mesma o agente performativo em estudo.

Nada além de uma forte intuição, a noção da luz no teatro como elemento atuante e autônomo carecia de embasamento científico para seu entendimento pleno, e cuja equiparação com outros elementos da cena, principalmente o ator, sofria a resistência de outros pesquisadores. Mais tarde ficou claro, no entanto,

\footnotetext{
10 Uma importante etapa do processo de doutoramento realizada no Brasil e cuja proposta é avaliar, orientar e eventualmente redefinir os caminhos da pesquisa e que eu descobri, com muita surpresa, não ser realizada em outros países como a França, por exemplo.

11 Professor do PPGAC da ECA-USP com quem eu participei do $1^{\circ}$ Seminário sobre lluminação do Teatro da Vertigem, organizado por Guilherme Bonfanti e Chico Turbiani. O evento, onde eu pude expor o embrião do conceito de performatividade da luz em uma mesa com minha orientadora Cibele Forjaz colaborou significativamente com esta pesquisa.

12 Tema investigado desde a pesquisa do mestrado e deixado de lado na dissertação, igualmente por sugestão da banca de qualificação, tendo sido objeto, inclusive, de alguns artigos publicados entre o mestrado e o doutorado, como é possível verificar nas referências, ao final da tese. $O$ termo empregado foi igualmente questionado à época dos estudos de mestrado e doutorado, principalmente pelo emprego de um termo ainda ambíguo e questionável, de certa forma, na própria teoria do teatro.
} 
que essa concepção era compartilhada por outros iluminadores e designers, a exemplo de Jorginho de Carvalho ${ }^{13}$ que declarou sentir, já nos idos de 1960 e 70, que "a lluminação interpretava a ação que estava sendo realizada em cada momento [...], precisava ser entendida como intérprete, tendo conceito e dramaturgia", mas que, infelizmente, acabou por ter que renunciar à sua intuição: "Pouco tempo depois, tive que refrear minha avidez em difundir essa ideia de luz como intérprete que, na época, era só um sentimento e não tinha muita gente interessada em debater essa ideia comigo" (CARVALHO, anexos, p. 140).

Com o propósito de fundamentar o conceito intuitivo, então, foram empregadas ferramentas científicas de pesquisa teórica e prática no métier da iluminação cênica. As referências e disciplinas do curso de doutoramento, bem como outras anteriores da graduação e do mestrado, permitiram a incursão por noções que aprimoraram, pouco a pouco, seu entendimento. Muitas teorias, dentre elas a da própria materialidade da luz, as teorias da percepção e da presença cênica, além da observação da prática profissional pessoal e de outros iluminadores, foram muito importantes para identificar e analisar o comportamento e a atuação da luz na cena. As experiências como criadora, num caso, ou espectadora, no outro (um pouco mais qualificada que um espectador comum, é inegável, mas igualmente observadora do fenômeno da luz no teatro) permitiram delinear e perceber cada vez melhor o conceito e o que realmente se pretendia comprovar como sendo a performatividade da luz, ou seja, o que efetivamente poderia levar uma luz a ser, ou não, performativa.

A proposta final de estrutura para a tese ficou estabelecida, então, em três partes. O primeiro capítulo apresenta a iluminação cênica como performance design, ou seja, como parte da cenografia em seu conceito mais amplo. 0 segundo é voltado à apresentação dos conceitos fundamentais à estruturação do tema com as análises dos estudos de caso selecionados. Por fim, o terceiro e último dedica-se à apresentação do conceito de luz performativa e do que se conclui como performatividade da luz.

\footnotetext{
${ }^{13} \mathrm{Em}$ entrevista realizada como parte desta pesquisa, disponível nos anexos, p. 136-141.
} 
É interessante esclarecer, antes que tenha início a leitura desta tese, o processo de elaboração, desconstrução e reconstrução percorrido pelo tema da performatividade da luz ao longo da pesquisa. Um tanto quanto desacreditado no início, exigiu o questionamento e a investigação profunda de cada hipótese e para ser possível, finalmente, compreendê-lo a ponto de poder apresentá-lo em bases mais sólidas, mesmo que não definitivas. Ficou igualmente claro, ao final do processo, como ele continua sendo um conceito em construção e constante evolução como o próprio teatro. Apesar de toda a pesquisa, ainda há muito para investigar, considerar e comprovar sobre a noção proposta de performatividade da luz como se apresenta aqui. No entanto, é com muita satisfação que dei por concluída esta etapa e trago a público os primeiros passos no entendimento da luz como ato performativo da cena contemporânea, não necessariamente restrita à performance ou ao teatro performativo, mas presente em todas as configurações cênicas nas quais se faz, emprestando termos empregados por diferentes autores, ativa, atuante, actante, performante ${ }^{14}$, ou seja, uma luz performativa que, assim como proposto por Schechner (2002 apud FÉRAL, 2009, p. 72), não é verdadeira ou falsa, certa ou errada, mas apenas acontece.

O entendimento da iluminação cênica apresentado no primeiro capítulo, foi desenvolvido ao longo dos anos da prática como docente e no exercício da profissão como artista, bem como sua relação com o processo de criação e os demais componentes do espetáculo. Seu conteúdo resulta de pesquisas teóricas dedicadas ao design cênico desde a graduação, acrescidos de novos estudos e exemplos de projetos de iluminação próprios contextualizados a cada etapa. $O$ capítulo se encerra com uma breve exposição da história recente da iluminação cênica como linguagem componente do espetáculo ${ }^{15}$.

\footnotetext{
14 Termos e conceitos empregados por diferentes profissionais, professores, pesquisadores e especialistas para designar a atuação da iluminação cênica.

15 Esta contextualização foi quase que exclusivamente focada nas transformações da iluminação cênica mais recentes, considerando que boa parte do referencial teórico recentemente produzido e disponível em língua portuguesa sobre iluminação cênica concentra-se ou ao menos versa sobre seu aspecto histórico, a exemplo das pesquisas acadêmicas de Hamilton Saraiva (USP), Cibele Forjaz (USP, Eduardo Tudella (UFBA) e Berilo Nosella (UFSJ), entre outros, além da própria história do teatro mundial traduzida em publicada no Brasil, onde é possível encontrar, efusivamente, alusões às transformações históricas das artes da cena vinculadas à iluminação cênica e à tecnologia teatral.
} 
O início do segundo capítulo é dedicado à noção de luz ativa, embrião desta pesquisa doutoral, com base no próprio autor do conceito, Adolphe Appia e demais pesquisadores que se dedicaram a ele. Em seguida, é apresentado o conjunto de conceitos importantes no sentido de aprofundar e encadear 0 entendimento da luz ativa ao ambiente atual da prática teatral e performativa contemporânea. Cada um dos conceitos é trabalhado com base em autores específicos de cada área e complementado por aplicações do assunto investigado em outras obras dedicadas aos estudos teatrais, conforme o caso, quando havia. Ao final da exposição destes conceitos, uma breve compilação dos argumentos apresentados introduz o potencial performativo da luz defendido. Por fim, foi feita a descrição da análise das hipóteses performativas encontradas em quatro diferentes estudos de caso. Primeiramente, na obra de dois iluminadores, Cibele Forjaz e Guilherme Bonfanti, e seu trabalho com as companhias brasileiras Teatro Oficina e Teatro da Vertigem, respectivamente. Em seguida, em dois projetos de iluminação específicos de dois espetáculos cênicos, a peça teatral Um Ricardo III e o espetáculo de dança Multitud, cujos projetos de iluminação apresentam, igualmente, características consideradas como performativas.

Por fim, o terceiro e último capítulo consolida o atual entendimento dos conceitos propostos, concluindo por apresentar, em tempo, alguns possíveis vieses de continuidade para este estudo, entendendo que nem todas as respostas foram dadas ou encontradas e vislumbrando que ainda há muito a explorar e compreender a respeito da luz performativa e da performatividade da luz no teatro contemporâneo. 


\section{ILUMINAÇÃO CÊNICA}

A luz é a experiência mais espetacular dos sentidos, uma aparição propriamente celebrada, adorada e implorada nas cerimônias religiosas antigas.

Rudolf Arhneim

A compreensão do projeto de criação em iluminação cênica, seja para o teatro, a dança, a música moderna ou clássica, o teatro infantil, a ópera ou até mesmo um desfile de moda, se baseia em alguns conceitos investigados tanto em atividades teóricas quanto práticas. O primeiro deles é o próprio conceito de iluminação cênica, que resulta em uma luz criada especialmente para a cena, cuja função vai muito além de iluminar ou de torna-la agradável aos olhos do espectador em seus preceitos estéticos. Christine Richier (2019) descreve, assertivamente, a iluminação cênica como a organização dramatúrgica e técnica de um conjunto de refletores no espaço e no tempo para construir uma partitura luminosa escrita para o olhar do espectador (RICHIER, 2019, p. 18). Não menos importantes dentro do contexto da pesquisa, estão o conceito amplo de cenografia e os conceitos de performance e performatividade, fundamentais para o entendimento da luz performativa, de alguma forma associável a um outro importante conceito, o de luz ativa, já preconizada por Appia (1923) e que vai de encontro a alguns de seus princípios e características, tanto quando empregada num tipo de teatro mais tradicional ou clássico, como prefere Féral (2015, p. 129), tributário do texto, da fala e do encenador, que detém o domínio do conjunto de mensagens ou informações a serem transmitidas a um espectador tido como passivo, quanto nas suas vertentes mais colaborativas e interativas.

Além desse entendimento da iluminação como linguagem cênica, sua estética e atuação poética, há ainda o conceito de luz-matéria, cuja presença e materialidade poética tem a capacidade de atrair e manter a atenção do espectador sobre a cena. A iluminação cênica também merece ser investigada em suas capacidades expressivas e sensoriais, fundamentais para sua atuação como fenômeno físico presente e materializado em cena, resultado da 
elaboração e da experiência sensorial e perceptiva de artistas e espectadores, compartilhado por ambos no momento presente da cena teatral.

Em cada processo de encenação de uma obra, a luz é parte determinante da (re)escritura do texto dramático por meio das linguagens empregadas. A iluminação cênica, como aspecto dinâmico e transformador de toda obra teatral, faz apelo à subjetividade do espectador, assim como acontece com os estímulos sonoros. Tanto os estímulos sonoros quanto luminosos são constantes durante toda a representação. O som e o silêncio, a iluminação ou a falta dela, seja informando ou apenas incitando a percepção do público, estão sempre presentes, o que constitui também sua concepção como linguagem. Desta forma, como um importante elemento do conjunto de linguagens, sensorialidades ou visualidades do espetáculo cênico, a iluminação recorre imperativamente à percepção humana, instaurando um estado de simbiose entre o público e a cena pelo ambiente que cria e as sensações que é capaz de provocar.

Ainda tratando do aspecto da iluminação cênica, faz-se necessário abordar o conceito de tecnologia teatral, definido e compreendido, principalmente, pela aceitação da atividade do iluminador teatral como a de um técnico apto apenas para dominar certas ferramentas tecnológicas e da ideia tácita dessa habilidade como sua única possível contribuição ao fazer teatral (TUDELLA, 2017, p. 27). No combate a situações recorrentes de questionamentos a respeito das características e habilidades dos profissionais da luz, é importante compreender qual o sentido dado, neste contexto, ao que se qualifica como tecnologia teatral. É comum haver divergências de entendimento entre iluminadores, operadores de luz e técnicos montadores quanto às suas atribuições no fazer teatral. Igualmente, alguns artistas responsáveis pelo projeto de iluminação de um espetáculo não se percebem como os autênticos criadores da luz, sentindo-se apenas a serviço dos desejos e orientações do encenador ou das rubricas do dramaturgo. Outra questão habitual diz respeito ao uso do termo lighting designer (PEREZ, 2012a) para designar a função criativa do iluminador, entre outras querelas. Tão importante 
quanto compreender as atribuições do iluminador, é assimilar o conceito de tecnologia teatral como um termo que não faz referência apenas às hitechnologies, ou seja, aos computadores, projetores de imagens, mesas computadorizadas ou aos sofisticados equipamentos de iluminação de última geração, mas principalmente ao uso que se faz deles no teatro para alcançar fins narrativos, dramáticos ou sensoriais junto ao espectador, entendendo que isso exige, do profissional da luz, iguais medidas de sensibilidade, criatividade e técnica ${ }^{16}$.

Entendendo tecnologia ${ }^{17}$ como uma forma de conhecimento que pode gerar um conjunto amplo e diversificado de instrumentos e ferramentas, ou seja, entendê-la como um conjunto de habilidades e produções humanas que favorecem e facilitam a relação do ser com o meio que habita, é importante ressaltar que a tecnologia teatral envolve também soluções físicas ou mecânicas, a exemplo de um sistema de roldanas usado para suspender um elemento do cenário, ou a escolha do tecido certo para causar um efeito específico na cena por refletir mais ou menos a luz que incide sobre ele ou para dar ao figurino a leveza adequada para criar o movimento desejado do ator ou bailarino. Ou ainda o uso de um pedaço de madeira específico, especialmente escolhido para que, ao ser batido contra a superfície interna do bastidor nas coxias, produza um som cujo timbre soe com as características expressivas exatas para marcar a entrada enfurecida de uma personagem em cena. No que diz respeito à iluminação cênica, também é importante considerar que uma vela ou candeeiro, tipos de fontes luminosas que poderiam ser qualificadas, ironicamente, como equipamentos low-tech, podem revelar-se muito mais adequadas a uma determinada cena do que um refletor de LED ou um moving-

\footnotetext{
16 Segundo o iluminador Aurélio de Simoni. estas são as três habilidades indispensáveis ao iluminador no exercício de seu ofício e arte.

17 entendimento de tecnologia abordado aqui não se restringe aos artefatos e instrumentos, mas é permeado pelas mediações materiais ou simbólicas como meio para favorecer, facilitar e contribuir para a melhoria das condições de vida da população. Essa acepção social de tecnologia, aplicada pelo Programa de Pós-Graduação em Tecnologia e Sociedade - PPGTE da Universidade Tecnológica Federal do Paraná - UTFPR, entre outros, abrange a teoria crítica da tecnologia como uma investigação científica da natureza do conhecimento tecnológico que permite uma noção mais abrangente que envolve, ciência, técnica e cultura como um conjunto de conhecimentos científicos ou empíricos e mediações sociais diretamente aplicáveis à produção de bens e serviços com impactos transformadores da sociedade.
} 
light, muitas vezes qualificados, em seu pedestal de sofisticação, como equipamentos hi-tech.

Josef Svoboda (apud RICHIER, 2019, p. 283) afirmava que se alguém quer fazer a luz de um espetáculo, precisa antes conhecer o material de que dispõe, conhecer as possibilidades de cada fonte luminosa e saber como explorar suas capacidades, como melhorar sua performance e encontrar novas formas de utilizá-las, com filtros coloridos, acessórios ou adaptações. Ele sentia necessidade de confiar no equipamento, principalmente em se tratando de equipamentos antigos e obsoletos, afirmando ser possível obter resultados interessantes de equipamentos seculares, como os músicos fazem com seus instrumentos. Para ele era inconcebível considerar somente os equipamentos mais modernos sem conhecer primeiro as fontes mais simples, mais primitivas.

No interstício entre arte e tecnologia, para além do aspecto informático ou material, Anna Barros (1999) analisa a obra de James Turrell como uma arte limítrofe entre o ambiente físico e o virtual. A partir da investigação intuitiva de diferentes experiências fenomenológicas com a luz, é estabelecido um intercâmbio entre artista e cientista, na qual o acesso às tecnologias de ponta faz despertar uma nova forma de entender a separação entre a teoria e a prática, a arte e a tecnologia em experimentos práticos com resultados artísticos. A arte desenvolvida a partir de bases científicas e tecnológicas é acrescida de aspectos poéticos próprios, permitindo unir os dois campos de conhecimento (BARROS, 1999, p. 25). Para Irwin e Turrell, dois artistas norte-americanos do grupo conhecido como Light and Space Art que fizeram do seu trabalho com o espaço e a luz material de pesquisa sobre a arte da percepção, também chamada de arte do fenômeno, a tecnologia não é algo que vem de fora do indivíduo, mas sim uma manifestação de seu próprio pensamento que pode permitir o acesso à arte por meio da percepção.

Já em 2007, Jean-Guy Lecat previa as transformações pelas quais a iluminação cênica passaria tanto por questões tecnológicas quanto ecológicas, com LEDs integrados aos cenários e figurinos, antecipando os atuais painéis de LED disponíveis no mercado, que ele chamou de "cicloramas auto iluminados": 
Hoje com o desaparecimento programado da lâmpada incandescente, entre outros, na Europa para em torno dos anos 2010, está nascendo uma revolução cultural na iluminação. $O$ aparecimento, nos anos 60 , dos diodos eletroluminescentes (LED - light emitting diode) e, há 10 anos, dos diodos eletroluminescentes orgânicos, vai transformar nossa concepção de iluminação (principalmente desde que uma luz de cor branca se tornou possível). Já adotados para a iluminação pública, a iluminação de monumentos, na agricultura e nos automóveis, os diodos não apresentam um rendimento luminoso muito bom, mas com uma vida útil de 50.000/100.000 horas e seu tamanho, eles apresentarão uma diversificação muito grande ${ }^{18}$ (LECAT, 2007, p. 32).

Josef Svoboda igualmente previa, ainda nos anos 50, a criação de equipamentos cuja prerrogativa principal seria a preocupação com questões ecológicas e de economia de energia: "Senhores, a luz fria... Nós voltaremos a ela, já está sendo estudada"19 (RICHIER, 2019, anexo 1, p. 130), além de questões ergonômicas e de rendimento luminoso.

O que nós realmente precisamos no teatro é reduzir o atulhamento das fontes de luz e aumentar sua eficácia. Vocês sabem, como eu, que aumentar a potência aumenta a produção de calor, que então é preciso dissipar. O ideal seria a luz "fria", se gastaria menos energia para uma eficácia luminosa muito mais importante. Isso deveria se tornar objeto de programas de pesquisa para os próximos anos: diminuir o tamanho das fontes luminosas aumentando sua potência20 (RICHIER, 2019, anexo 1, p. 130).

O incessante surgimento de novos equipamentos de controle da luz e fontes luminosas cada vez menores e mais potentes confirmam as previsões e desejos dos cenógrafos e iluminadores mais antigos, fazendo surgir uma nova geração de profissionais com suas estéticas já adaptadas às novas tecnologias. É impossível negar as virtudes ecológicas e luminosas do LED (light emitting diod), cujo baixo consumo de energia e extrema versatilidade permite equipar a

18 " Aujourd'hui avec la disparition programmée, de la lampe à incandescence, entre autre en Europe aux alentours de 2010, une révolution culturelle dans la lumière est en train de naître. L'apparition dans les années 60 de diodes-électroluminescentes (LED - light emitting diode) et depuis 10 ans des diodes-électroluminescentes-organiques va bouleverser notre conception d'éclairage (surtout depuis qu'une lumière de couleur blanche est devenue possible). Déjà adoptées pour l'éclairage publique, l'éclairage des monuments, en agriculture et dans les automobiles, les diodes n'ont pas nécessairement un rendement très performant mais avec une durée de vie de 50.000/100.000 heures et leur dimension, elles vont connaître une diversification très grande » (tradução da autora).

19 « Messieurs, la lumière froide... Mais on y reviendra, c'est déjà à l'étude » (tradução da autora). 20 «Ce dont nous avons vraiment besoin au théâtre, c'est de réduire l'encombrement des sources de lumière et d'augmenter leur efficacité. Or vous savez comme moi qu'augmenter la puissance augmente la production de chaleur, qu'il faut alors dissiper. L'idéal serait la lumière 'froide', on dépenserait moins d'énergie pour une efficacité lumineuse beaucoup plus importante. Cela devrait faire l'objet de programmes de recherche pour les années à venir : réduire la dimension des sources en augmentant leur puissance " (tradução da autora). 
maior parte dos equipamentos usados no teatro, desde reproduções dos tradicionais PC, elipsoidal, set light e PAR até os mais novos modelos de movinglight, com resultados cada vez mais satisfatórios. Apesar dos modos de produção, descarte e reciclagem do LED serem ainda bastante questionáveis, não há como evitar a substituição gradativa da iluminação com lâmpadas incandescentes nos teatros neste início de século. Christine Richier (2019, p. 308) explica os aspectos legais da proibição da fabricação das lâmpadas alógenas na Europa e das constantes petições e movimentos de iluminadores a favor da sua preservação, exclusivamente no universo do espetáculo cênico. Já desde o final do século XX aumentam as proibições para o uso urbano e doméstico das lâmpadas de tungstênio e isso não deverá tardar para chegar ao hemisfério sul e aos teatros. De modo a transformar completamente a linguagem e a estética da iluminação cênica, a exemplo da cada importante mudança tecnológica, da luz solar à da chama das velas, lamparinas a óleo e gás, do fogo à eletricidade e, finalmente, do filamento incandescente ao LED.

Paralelamente à invasão do LED, a robotização das fontes luminosas transforma a cena teatral contemporânea e cria novos paradigmas para a iluminação cênica. Os moving-lights, equipamentos capazes de se movimentar por controle remoto e modificar automaticamente as características de seu facho luminoso como cor, forma, difusão, abertura, direção e intensidade, conquistam cada vez mais os palcos. Originalmente usados em shows, concertos e espetáculos musicais, eles foram sendo aperfeiçoados, mais silenciosos e compactos, com uma luminosidade e temperatura de cor mais próximas às dos equipamentos convencionais e uso mais versátil e viável no teatro, na dança e até mesmo em óperas e concertos de música erudita. Possíveis de serem programados à distância e cujos fachos luminosos podem ser regulados sem que seja necessário chegar até o aparelho, eles permitem reduzir os riscos do trabalho em altura e o tempo de uso do espaço pela equipe de iluminação para a montagem e a afinação da luz. Em contrapartida, demandam um tempo muito maior de programação da mesa e de seus efeitos, etapa que hoje pode também ser realizada à distância, fora do teatro, com o uso de simuladores virtuais e programas computadorizados ligados às mesas de comando mais sofisticadas. 
Apesar das facilidades, os novos equipamentos apresentam fragilidades e tornam-se obsoletos muito rapidamente pelo lançamento constante de novos modelos e tecnologias cada vez mais avançadas. O aumento no tempo de programação, nem sempre previsto, é outro empecilho que favorece o uso de programações e efeitos padronizados, criados pelos próprios fabricantes e que resultam numa uniformização empobrecedora no uso de seus recursos e das possibilidades estético-poéticas. da luz (TUDELLA, 2017, p. 39).

Por outro lado, as recentes tecnologias, equipamentos e programas, com suas habilidades e recursos inovadores, vêm oferecendo à prática da iluminação cênica novas possibilidades de escritura dramática da luz na constituição da cena. Suas potencialidades gráficas e cinéticas de interação com os performers, a cena e o público permitem gerar imagens e resultados sensoriais cujas novas perspectivas e prerrogativas estéticas eram, até então, inimagináveis, reforçando e comprovando sua atuação como elemento constitutivo, construtivo e fundante da cena, inclusive de forma performativa. Após desenvolver sua pesquisa doutoral a respeito dessas novas tecnologias, a decorrente mudança de paradigmas na iluminação e a vocação dramatúrgica e até performativa dos novos recursos tecnológicos, o iluminador Renato Machado ${ }^{21}$ declarou:

\begin{abstract}
Eu acho que como a luz elétrica foi uma grande revolução tecnológica e que proporcionou novos caminhos para o teatro, o meu doutorado defende que estamos diante de uma nova grande revolução tecnológica, e que ela vai criar novos caminho para o teatro e já está criando. E essa revolução tecnológica é a digitalização dos processos e o computador como ferramenta de trabalho. Isso está gerando uma nova forma de construção da narrativa no teatro. [...] Isso tem levado a um novo paradigma da construção teatral e, na verdade, estamos diante de uma coisa muito poderosa, porque a luz não só interfere, de fato, na construção da narrativa, mas, como a Nadia diz, ela é atuante na cena... A associação entre projeção, iluminação, sonoplastia, cenografia e figurino com estrutura de tecnologia e a utilização do computador como ferramenta, estão nos levando para um novo status, uma coisa completamente diferente (MACHADO, anexos, p. 191).
\end{abstract}

Além dos aspectos e usos dramatúrgicos das ferramentas, é preciso considerar também a afinidade dos profissionais do teatro e da luz, como indivíduos, com essas tecnologias. Existe hoje uma nova geração de

${ }^{21}$ Em entrevista realizada como parte desta pesquisa, disponível nos anexos, p. 184-195. 
iluminadores que se adequam à classificação apresentada pela pesquisadora Luciane Hilu como "nativos digitais", indivíduos apresentados originalmente, em seus contextos social e profissional, aos novos meios digitais (HILU, 2016, p. 142). Apesar da abordagem direcionada para os meios digitais de comunicação, não é difícil associar os argumentos apresentados à relação dos jovens iluminadores com as tecnologias digitais.

\begin{abstract}
Para compreender um pouco mais sobre esses indivíduos, há que se pontuar que a tecnologia para eles não é mais só um instrumento, mas é uma extensão de si próprio. [...] O dispositivo passa a ser entendido como um artefato que se configura como uma verdadeira extensão do ser humano, lembrando que, a princípio, qualquer tecnologia ou invenção é uma extensão ou auto-amputação de nosso corpo (MCLUHAN, 1996 apud HILU, 2016, p. 142).
\end{abstract}

A respeito da relação ente usuários e produtos tecnológicos, Castells (2000 apud HILU, 2016, p. 153) afirma que, "diferente do que ocorreu em outras revoluções, na revolução tecnológica, usuários e criadores podem tornar-se a mesma coisa", ou seja, os usuários assumem o controle da tecnologia. Eles não são passivos diante dos conhecimentos necessários para operar e fazer uso dela, trocando informações, comentando, envolvendo-se, participando e propondo serviços (HILU, 2016, p. 153). Sem limitar-se ao emprego, esses indivíduos compartilham e reformulam suas ferramentas, tornando-se ativos como consumidores e criadores, usuários e produtores, numa relação semelhante à existente entre os jovens iluminadores e seus simuladores de imagem, consoles, interfaces e equipamentos motorizados.

O que parece fundamental acrescentar, no entanto, é que a tecnologia, em si, pouco importa nesse contexto, pois "o que realmente faz a diferença é o que as pessoas conseguem fazer com a tecnologia. $O$ que mais importa é a funcionalidade, a flexibilidade, a disponibilidade e a capacidade de criar [...] A tecnologia desaparece e surge somente o benefício da utilização do que se faz dela (HILU, 2016, p. 157). É inegável que novos tempos e novos paradigmas se anunciam na esfera da tecnologia aplicada às artes cênicas, e as boas novas visivelmente não se aplicam apenas à iluminação. 


\subsection{A lluminação como componente da cena}

O entendimento fundamental da iluminação como componente da cena parte do princípio de que a gênese de qualquer processo de criação da luz para um espetáculo deve se dar sempre conjuntamente com a elaboração da cena, a partir de um marco zero da criação específica daquela montagem, sem que haja uma criação antecipada de qualquer um dos demais elementos que irão compor a cena nem uma ideia pré-concebida do que será feito pelo próprio iluminador. Parece-me imprescindível que, como artista partícipe, ele possa se envolver com o processo desde seu início e que possa se deixar influenciar e contagiar por todas as ideias e concepções embrionárias do novo projeto. Acreditar, por já conhecer o texto ou já ter feito uma montagem semelhante, que sabe de antemão o que deverá ser feito e que tudo está sob controle e será uma tarefa fácil ou tranquila pode resultar em uma grande armadilha. É comum acontecer de um iluminador ser chamado para fazer um novo trabalho e o produtor ou $o$ próprio diretor do espetáculo the diga que vai ser simples, que para resolver 0 problema só será necessário fazer uma luz geral e alguns poucos focos, sem nenhum desafio ou complexidade, mas isso nunca é verdade e mesmo criar uma luz com poucos recursos ou apenas "algumas gerais e focos" certamente pode ser uma atividade tão complexa quanto a que é constituída por um grande conjunto de equipamentos sofisticados, se o resultado buscado for coerente com o espetáculo e trouxer em si a importância e relevância necessária para o que se apresenta ao espectador.

No contexto contemporâneo da criação da iluminação cênica resultante das práticas iniciadas no final do século XIX e perpetuadas ao longo do século $\mathrm{XX}$, para além de algumas convenções teatrais mantidas na comunicação com o espectador, como o uso de cores e intensidades de luz padrões, entende-se ser necessário ao iluminador da modernidade saber considerar, na totalidade, o complexo contexto de circunstâncias materiais e imateriais de cada projeto, para precipitar-se em direção ao novo espetáculo permitindo-se reconhecer e identificar os mínimos detalhes do trabalho ao qual vai dedicar seu tempo, 
criatividade e competência. Mesmo que seja a montagem de um texto conhecido ou já iluminado antes, é preciso entender todos os meandros da nova proposta e acompanhar o máximo possível de ensaios, principalmente os primeiros trabalhos de mesa entre toda a equipe de criação e elenco. É preciso compreender o que passa pela cabeça do diretor, do encenador e do dramaturgo, assim como dos atores, dançarinos, músicos ou performers, saber a razão de ser (e estar) de cada componente da cena, conhecer suas referências, o porque de ter sido criado e colocado em cena, qual a função e papel que deve desempenhar, seja sensorial ou representativamente, o que motivou sua concepção e seu uso.

No âmbito do design, se acredita, que um bom trabalho consiste em eliminar o que é dispensável ${ }^{22}$, ou seja, seguindo a mesma premissa, para se criar um bom cenário, é fundamental eliminar tudo o que não é necessário à cena. Pode-se concluir, então, que tudo que é posto em cena deve ter uma razão de ser, e que esta razão deva, ainda, ser compartilhada com todos os membros da equipe de criação. Importante característica dos processos colaborativos, esse entrosamento é fundamental para a criação de uma iluminação integrada à cena e ao espetáculo. A criação de um projeto de iluminação dentro do conceito de luz ativa, luz para a performance ou luz para a cena, que permite entender o conceito de luz performativa, subentende a participação, colaboração e integração do iluminador com o coletivo.

É comum que a curiosidade simplista de alunos, jovens diretores ou atores iniciantes os levem a imaginar que seja possível, e até perguntarem, em aula, como fazer um determinado efeito, ou qual seria a melhor iluminação para uma cena alegre, uma cena de amor ou tristeza, a luz de uma atmosfera desértica ou polar, um clima mais melancólico ou mais dramático. A estes questionamentos só é possível responder que não existem fórmulas mágicas, respostas fáceis ou soluções óbvias para nenhuma destas situações cênicas. Não se pode dizer que

\footnotetext{
22 Com base na famosa afirmação "Great design is eliminating all unnecessary details", bastante repercutida nos meios do design, criada pelo designer gráfico Minh D. Tran, radicado em Manchester - UK.
} 
uma cena melancólica será sempre azul ou que uma cena alegre será invariavelmente amarela e a romântica rosa. Nem que o calor será sempre âmbar e o frio lavanda. Como saber se é melhor usar luz frontal, lateral ou contraluz para uma cena sem vê-la, sem senti-la, sem conhecer a forma com que os seus elementos interagem com um ou outro tipo de iluminação? O que deve determinar a ambientação geral de uma cena é a sequencia de ações e situações que levam a esta determinada cena. Somente o sentimento, a construção, o caminho percorrido pelo ator, em conjunto com os demais componentes da cena, como som e figurino, mais as orientações do encenador, é que podem conduzir à sua configuração final e à escolha do tipo de luz adequada para ambientá-la, relacionando-a e vinculando-a intrinsecamente à complexa sucessão de acontecimentos da obra integral.

É preciso olhar para a cena, ver como ela se configura, entender como ela foi pensada pelo dramaturgo, encenador ou coreógrafo e, finalmente, pelo performer, o que ele sente e como reage, suas ações e subtextos. Entrar na cabeça e investigar o pensamento do diretor, invadir a mente do ator e se colocar no lugar do bailarino. Conhecer o cenário e o figurino, mesmo que eles ainda não estejam prontos. Saber porque e com que intenção, em um momento preciso, o ator levanta ou abaixa a cabeça, o bailarino se desloca pelo espaço, ou o músico levanta seu instrumento. É preciso observar como eles o fazem e tentar perceber o que sentem quando isso acontece. É importante descobrir o que o diretor tem em mente ou pretende quando diz a um ator para entrar ou sair de cena mais rápido ou mais lentamente, para parar em um determinado lugar do palco, olhar ou não para o público, interagir ou não com seu interlocutor em cena. Como confirmação desse procedimento que antecede a criação, vale lembrar o que disse, inúmeras vezes, o iluminador carioca Aurélio de Simoni: "Tudo informa luz!"23

\footnotetext{
${ }^{23}$ Algumas das vezes, inclusive, nas páginas 38 e 42 da entrevista realizada como parte desta pesquisa, disponível nos anexos, p. 37-47 e na entrevista recentemente concedida ao canal do YouTube "da ideia à luz" disponível em https://www.youtube.com/watch?v=ndTbWXy9x04 visitada em 26 de agosto de 2020.
} 
Para o cenógrafo Josef Svoboda, a luz está intimamente ligada ao cenário, sendo impossível pensá-los separadamente. "Eu não consigo imaginar fazer uma cenografia sem pensar na sua luz. Elas são interdependentes e estiveram sempre unidas em meu pensamento do espaço. Elas são indissociáveis"24 (RICHIER, 2019, anexo 1, p. 74). Ele afirmava que, como cenógrafo, tinha a sorte de fazer também a luz de seus espetáculos, associando as intenções e os resultados almejados em seus projetos com a luz necessária para alcançá-los. O depoimento de Marisa Bentivegna ${ }^{25}$ corrobora, igualmente, com a interdependência entre as duas linguagens, revelando como a questão do espaço nunca foi desvinculada dos seus processos de criação da luz: "O que eu observo, de uns anos para cá, é que a dupla cenário e figurino era assinada pela mesma pessoa de maneira muito comum, e hoje em dia, para mim, faz muito mais sentido ser uma cenógrafa-iluminadora, do que fazer cenário e figurino" (BENTIVEGNA, anexos, p. 162). Há situações, no entanto, que não é possível que um mesmo profissional seja responsável pelas duas linguagens, então é fundamental que haja entendimento e colaboração entre os dois, que o iluminador compreenda as necessidades do cenógrafo e vice-versa.

Sobre essa associação entre cenário e luz, enquanto Svoboda afirma que é necessário pensar a luz antes de escolher uma estrutura, uma superfície ou os materiais a serem usados no cenário (RICHIER, 2019, anexo 1, p. 75), Marisa declara que, para ela, "o espaço é superimportante e, em noventa por cento dos casos, a criação do espaço vem antes do que a criação da luz" (BENTIVEGNA, anexos, p. 162). Esses dois depoimentos de dois importantes profissionais da cena, só confirmam a assertiva de que tanto a maneira como a luz incide sobre os diferentes materiais, objetos e superfícies, quanto a estrutura e concepção do espaço que ela ocupa, são fundamentais para se construir a atmosfera ou clima do visual cênico de uma cena ou espetáculo.

\footnotetext{
24 « Je ne peux pas imaginer faire une scénographie sans en penser la lumière. Elles sont interdépendantes et ont toujours été liées dans ma pensée de l'espace. Elles sont indissociables » (tradução da autora).

${ }^{25}$ Em entrevista realizada como parte desta pesquisa, disponível nos anexos, p. 151-163.
} 
A iluminadora, professora e pesquisadora francesa Christine Richier desenvolveu, com base em uma série de entrevistas com o cenógrafo tcheco, que ela qualificou poeticamente de "fragmentos de uma discurso luminoso" 26 (RICHIER, 2019, p. 14), uma rica tese de doutorado que versa a respeito do seu entendimento sobre a iluminação cênica e sua relação com os demais componentes da cena. Por meio dessa pesquisa é possível concluir que, para Svoboda, o teatro é uma arte coletiva e que fazer teatro exige encontrar a conexão entre todos os seus elementos como meios de expressão artística, sem o que, segundo ele, o que se faz não é teatro. Svoboda pensava a luz em toda sua amplitude, como descreve Christine Richier na introdução de sua pesquisa: "Inicialmente intrigada pela maneira como ele trabalhava a materialidade do facho, sua textura, sua presença plástica no espaço, eu descobri igualmente no trabalho de Svoboda um senso agudo da cor, da composição mas, sobretudo, do ritmo"27 (RICHIER, 2019, p. 4). Isso somente confirma e demonstra toda a complexidade e importância da interação entre todas as linguagens formadoras do visual cênico no teatro.

Igualmente importante é a relação da luz com o som, cujos efeitos, paisagens ou composições sonoras apresentam, assim como a luz, um forte poder subjetivo de influência sobre a percepção do público. Marcello Amalfi apresenta, na concepção de seu conceito de macro-harmonia, a interconexão existente entre esses dois componentes da encenação, entre outros. Com base em seu processo pessoal de composição musical para o teatro, ele defende a macro-harmonia como um admissível campo, no qual cada membro da equipe de criação e o encenador podem estabelecer um diálogo criativo durante 0 processo de elaboração do espetáculo (AMALFI, 2015, p. 212). Por meio do conceito de imagem sonora e considerando a interferência mútua entre os diferentes componentes da cena, o autor explica a potencialidade de colaboração entre a música e a iluminação em um processo de montagem cênica

26 «... fragments d'un discours lumineux » (tradução da autora).

27 " D'abord intriguée par la façon dont il travaillait la matérialité du faisceau, sa texture, sa présence plastique dans l'espace, j'ai également découvert chez Svoboda un sens aigu de la couleur, de la composition, mais surtout du rythme » (tradução da autora). 
do Théâtre du Soleil. Ele afirma haver um intercâmbio na concretização da relação simbiótica das composições e improvisações musicais de Jean-Jacques Lemêtre com os demais elementos da encenação, a exemplo da iluminação como elemento que ele caracteriza como sendo de natureza extramusical (AMALFI, 2015, p. 104).

A partir desses pressupostos é possível concluir a importância da participação ativa e intensa do iluminador, assim como dos demais criadores, no processo criativo, para que seja possível propor um projeto de luz coeso e integrado ao espetáculo. O relato do iluminador francês Christophe Forey ${ }^{28}$ sobre seu processo de criação da luz para uma peça durantes os ensaios, enquanto o diretor trabalhava improvisações com o elenco, parece ser uma boa forma de ilustrar essa forma de participação no processo de construção do espetáculo visando este fim:

\begin{abstract}
As meninas já tinham montado a luz, os maquinistas o cenário e eu, que tinha uma base da luz pronta, experimentei alguns efeitos de luz diretamente nas cenas, durante os ensaios, de acordo com o espaço criado, que de repente era acentuado ou suavizado, criando essas áreas de jogo, ambientes mais escuros e assim a marcação da cena foi realizada diretamente neste espeço e com essa luz. [...] Depois do ensaio, efetivamente, no dia seguinte ou no próximo dia, eu via o ensaio e mudava algumas coisas com base no que tinha visto, mudava a direção ou eliminava alguns efeitos que não eram mais necessários e no próximo ensaio fazia a mesma coisa para uma próxima etapa. $\mathrm{O}$ importante é que os ensaios aconteciam com uma proposta de espaço e de luz e o diretor levava a luz em consideração, necessariamente. $\mathrm{Na}$ verdade, se você coloca uma luz para um diretor, ele trabalha com essa luz, se você não coloca nada, bem, ele trabalha com o que tem (FOREY, anexos, p. 67).
\end{abstract}

Com exemplos desse tipo, que infelizmente, como o próprio Christophe admitiu, não ocorrem com muita frequência, é possível perceber a importância de estabelecer, nas fases de criação e de ensaios, uma boa relação com 0 elenco e os demais artistas criadores do espetáculo. É somente quanto essa relação se estabelece, que pode surgir, efetivamente, a interação da luz com os demais componentes da cena. Não se defende aqui essa condição como aspecto indispensável para a criação da luz, pois a efetiva ação, existência ou interferência da luz na cena pode se dar mesmo que nem haja a presença ou

${ }^{28}$ Em entrevista realizada como parte desta pesquisa, disponível nos anexos, p. 61-68. 
colaboração de um profissional encarregado desta função, mas sim que a especialidade e o apreço com que a ela ele se dedica pode resultar na intensificação dos seus efeitos e decorrências na percepção do espectador.

O iluminador francês Thierry Fratissier ${ }^{29}$ relembrou que, mesmo que o iluminador participe intensamente do processo criativo, a iluminação, por questões práticas e financeiras de montagem, ainda é o último elemento a ser adicionado à cena. Isso faz com que a equipe de criação só tenha contato, materialmente, com a luz, pouco antes da estreia, sem muito tempo para reagir ou criar relações significativas com a luz.

.... luz, na maioria das vezes no sistema de produção de hoje, só chega realmente no fim da criação, ou seja, já existe o cenário, os figurinos, e até, é claro, o ator, tudo chega antes que a luz possa ser montada no palco. E aí todo o trabalho é modificado, todo o trabalho dos outros é modificado e, principalmente, o do diretor que, se estiver atento à luz, também saberá usá-la para extrair dela informações que transmitirá ao espectador. E então o espectador, obviamente, vê apenas o todo e a luz é, de uma certa maneira, o elo entre ele e esse todo. $O$ link entre tudo. É isso, eu quero dizer que se cortamos a luz, não há mais espetáculo, mas se iluminamos, tudo o que foi posto em cena desde o início pode aparecer e naturalmente que os atores, entre eles, se veem de forma diferente quando colocamos a luz, então atuam juntos de forma diferente, os figurinos vivem de forma diferente. $E$ nós, naturalmente, os levamos em consideração para escolher tanto as direções quanto as cores das luzes que devem funcionar com o figurino e a cenografia, nem se fala, porque obviamente é ela quem esculpe a luz, é isso, nosso trabalho é um trabalho que naturalmente leva em conta todo o trabalho, o conjunto (FRATISSIER, anexos, p. 212-213).

Uma situação ideal de criação, para Fratissier, acontece quando é possível ensaiar com luz, propor efeitos e interações no tempo real dos ensaios. Ele cita, inclusive, os benefícios de fazer a gravação da mesa durante os ensaios, a exemplo de suas experiências com a ópera e uma, em especial, durante os ensaios de uma montagem do diretor Claude Régy, quando ainda era assistente de Dominique Bruguière (FRATISSIER, anexos, p. 214-215). No entanto, tanto ele quanto o iluminador brasileiro Beto Bruel ${ }^{30}$ ressaltaram a flexibilidade da luz face aos demais componentes da cena, bem como a proximidade existente entre o iluminador e o diretor do espetáculo, sobretudo na

\footnotetext{
29 Em entrevista realizada como parte desta pesquisa, disponível nos anexos, p. 209-217.

${ }^{30} \mathrm{Em}$ entrevista realizada como parte desta pesquisa, disponível nos anexos, p. 48-59.
} 
fase final de construção do espetáculo, quando se chega ao palco. Beto Bruel comentou que: "É muito difícil você mudar o cenário inteiro, o figurino inteiro de uma peça, coisa que com a luz, podemos fazer, não é? Você pode mudar a posição do refletor, você pode mudar toda a programação da luz..." (BRUEL, anexos, p. 51), da mesma forma que Thierry Fratissier afirmou que: "é raro vermos um cenário ser transformado pouco antes da estreia, é raro ver figurinos serem questionados no dia anterior à estreia, mas não é nada raro rever a iluminação na véspera estreia, se não toda ela, pelo menos algumas cenas" (FRATISSIER, anexos, p. 214). Ambos destacaram, com isso, a relevante participação da luz na criação, flexível o suficiente para poder ser trabalhada e revista por muito mais tempo durante o processo criativo, algumas vezes até a estreia ou mesmo durante a temporada do espetáculo.

No entanto, é fundamental que o iluminador possa detectar, a cada novo processo e em suas diferentes etapas, quais dos estímulos percebidos ao longo dos ensaios e das trocas poderão inspirar a luz. É partir de então que poderá optar pelo tipo de refletor a ser usado para cada efeito, o melhor ângulo de incidência da luz para iluminar, com a cor escolhida, um ator, o cenário e os figurinos, bem como com que velocidade e intensidade cada feixe luminoso será acionado na mesa de comando a cada cena do roteiro elaborado. A exemplo do que repete Aurélio de Simoni ${ }^{31}$, tudo indica luz, e o iluminador deve estar atento a todo o conjunto de informações, seja qual for o tipo de espetáculo, sua linguagem ou processo de criação empregado.

31 Ver nota $n^{\circ} 23$ desta tese. 


\subsection{Os processos colaborativos, o espectador e a luz}

Algumas das transformações ocorridas na atividade teatral a partir da virada do século XIX para o século XX foram decisivas, tanto para os resultados quanto para os processos de elaboração e construção do espetáculo cênico. As inovações tecnológicas e a renovação do teatro como linguagem em sua relação com o público, bem como o surgimento da figura do encenador e a importância dada à recepção e à participação do espectador determinaram novas formas de conceber e de fazer teatro em todo mundo, do leste europeu às américas. Em muitas experiências, cada uma delas de uma forma específica, o público é deslocado de sua posição passiva para participar ativamente da cena, e sua emancipação (RANCIÈRE, 2012) provoca importantes transformações, diretas e indiretas, principalmente no trabalho do ator, mas também no processo geral de criação do espetáculo, envolvendo cada componente da encenação.

Muito recentemente, após um longo período (mais precisamente um século) de grandes transformações na prática teatral, transitando entre as artes visuais, com a performance, os happenings e os site specifics; as mídias eletrônicas, com a invasão da cena pelo cinema e o vídeo, e tantos outros formatos, novas circunstâncias promoveram alterações ainda mais profundas na relação estabelecida com o espectador. Pela implicação de distintas situações e imposições sanitárias ${ }^{32}$, os espetáculos à distância passaram a instituir novos

\footnotetext{
32 Uma dessas situações foi a realidade virtual que assolou a humanidade na segunda década do século XXI, período final da redação da presente pesquisa, cuja pandemia do Coronavírus impôs, pela propagação planetária da Nova Covid-19, o isolamento social compulsório no mundo todo, resultando em novas formas de aproximação digital e de relacionamento pessoal e profissional. $\mathrm{O}$ estado de home office, a prática do ensino à distância e as redes sociais criaram novos paradigmas de atuação e interação que chegaram às mais diversas formas de manifestações artísticas. Museus disponibilizaram suas exposições e acervos pela internet, companhias de teatro publicaram seus espetáculos e foram produzidos concertos e shows musicais especialmente para os meios virtuais. Dada a crise econômica, principalmente do meio artístico e cultural, uma das indústrias mais afetadas, abriram-se editais e programas de incentivo à cultura especialmente voltados para produções nos meios digitais, visando a realização de espetáculos inteiramente virtuais, cuja criação, concepção, ensaios e, inclusive, apresentação, precisavam ser realizados virtualmente. A nova realidade e os novos formatos artísticos, com a súbita obrigatoriedade da produção inteiramente realizada à distância, impuseram importantes reflexões e transformações na vida e na arte.
} 
paradigmas para a concepção dialógica da cena por meio virtuais. Peças de teatro, performances, show musicais e depoimentos de artistas no formato de lives "ao vivo" ou vídeos gravados, começaram a ser criados, ensaiados e apresentados pela internet, com designers, artistas, performers e espectadores isolados, cada um em seu ambiente físico, em casa em qualquer lugar da cidade, do país ou do mundo, mas reunidos em um mesmo ambiente virtual. A aproximação digital surge como alternativa em tempos de confinamento compulsório, demonstrando a potencialidade do contato à distância entre artista e público como alternativa surpreendentemente eficiente e viável para diferentes tipos de manifestação artística.

Voltando ao mundo não virtual das salas de espetáculo e das cenas compartilhadas presencialmente entre artistas e espectadores emancipados, não foram somente os atores e encenadores do século XX que passaram a se preocupar com o público. Essa inquietação, partilhada por toda equipe de criação, não se restringia ao momento das apresentações, mas concentrava-se igualmente, ou até mais intensamente, ao processo de concepção dos personagens, cenas, e componentes sensoriais do espetáculo. Os artistas passaram a criar ou a buscar criar uma conexão profunda com esse espectador, com quem passaram a se comunicar de maneira direta, profunda e participativa.

No caso específico da iluminação cênica, sua principal tarefa passa a ser, nesse contexto, a de favorecer essa conexão por meio do elo criado entre eles pela luz. Esta experiência compartilhada com o espectador é expressa na intenção e no desejo de se fazer presente por meio da luz, o que pode ser comprovado pelas declarações do iluminador italiano Gianni Staropoli33, para quem "o espetáculo ao vivo acontece no olhar de quem também está vivo" (STAROPOLI, anexos, p. 118, e do brasileiro Paulo Cesar Medeiros ${ }^{34}$ que confirmou que "Para perceber uma luz é preciso estar vivo e em conexão permanente" (MEDEIROS, anexos, p. 182). A experiência sensorial do teatro se

\footnotetext{
${ }_{33}$ Em entrevista realizada como parte desta pesquisa, disponível nos anexos, p. 117-120.

${ }^{34} \mathrm{Em}$ entrevista realizada como parte desta pesquisa, disponível nos anexos, p. 181-183.
} 
efetiva a partir da relação íntima da luz com a presença e a comunhão entre artistas e espectadores.

Na investigação sobre a prática da criação cênica relacionada ao público e seu contato com a cena por meio da luz, as entrevistas permitiram confirmar a preocupação dos iluminadores com o espectador, parte originalmente externa ao espetáculo, situado além da fronteira entre palco e plateia, mas que passou, nas práticas contemporâneas, a ser considerado como coautor da cena e a figurar como forte preocupação e inquietação de atores, diretores, cenógrafos e, principalmente, iluminadores. Além de Staropoli e Medeiros, a maioria dos iluminadores entrevistados ${ }^{35}$ revelaram se ocupar desse aspecto em seus processos criativos. Beto Bruel${ }^{36}$ (anexos, p. 57) destacou o poder exercido pela luz sobre o espectador, enquanto Aurélio de Simoni37 (anexos, p. 42) declarou que, para ele, a "razão do teatro está lá na plateia" e Cibele Forjaz ${ }^{38}$ (anexos, p. 76-77) lembrou o protagonismo dado aos espectadores nos espetáculos no Teatro Oficina. Nesse mesmo sentido, Pasquale Mari39 (anexos, p. 179) declarou que seu processo criativo "convocado pelo gesto do diretor, visa os espectadores, com os quais me identifico antes de qualquer coisa em qualquer contexto em que me encontre operando", Wagner Pinto 40 (anexos, p. 226) revelou que "o tempo todo eu só penso no espectador [...] Os atores estão no palco e eu na plateia, eu vejo os ensaios pela perspectiva do espectador... Eu crio para quem está na plateia, mesmo!" e Nadja Naira ${ }^{41}$ apresentou um eloquente relato de como se dá a sua preocupação, ao criar a luz dos espetáculos da companhia brasileira teatro, com o espectador:

É só o espectador que me interessa. Pense o que são o ator, o texto, a cenografia, a iluminação, a marcação, os efeitos, senão uma situação que está sendo criada naquele momento, por todos esses elementos, para que alguém se relacione com aquilo. Quem é esse alguém? Não é o ator, não é o técnico... É também, mas é principalmente aquela pessoa que está ali, que veio até esse lugar para ver, ouvir e estar

\footnotetext{
35 Ver entrevistas realizadas nos anexos, p. 28 a 233.

36 Em entrevista realizada como parte desta pesquisa, disponível nos anexos, p. 48-59.

37 Em entrevista realizada como parte desta pesquisa, disponível nos anexos, p. 37-47.

$38 \mathrm{Em}$ entrevista realizada como parte desta pesquisa, disponível nos anexos, p. 75-83.

$39 \mathrm{Em}$ entrevista realizada como parte desta pesquisa, disponível nos anexos, p. 178-180.

$40 \mathrm{Em}$ entrevista realizada como parte desta pesquisa, disponível nos anexos, p. 221-233.

$41 \mathrm{Em}$ entrevista realizada como parte desta pesquisa, disponível nos anexos, p. 164-178.
} 
nesse lugar. Então, o que eu penso quando eu crio é em como a pessoa que veio aqui vai ser afetada por isso, vai perceber isso e vai ver isso. É nela que eu penso, mas não é ceder também. Porque se você só pensa no espectador, você cria tudo para o deleite do espectador? Não! Você cria tudo porque o espectador vai entender? Não! Você cria tudo porque a demanda do espectador vai...? Não! Porque pode virar uma facilitação. Você faz tudo para agradar, para que seja bonito para o espectador, para que seja fácil ou didático? Não, não e não! Essas respostas são todas não. Não é para ele, é com ele. Talvez seja essa a questão, são essas as palavras: "Como eu consigo criar um espaço com ele, para que ele se sinta lá, vivo ativo, pertencente?" Não é só pertencente num sentido bom, ele pode se sentir incomodado, querer sair, não estar confortável em assistir a uma peça de três horas, a cadeira pode ser desconfortável, a temperatura pode incomodar, as palavras podem ser difíceis e ele precisa correr, essas coisas... (NAIRA, anexos, p. 172-173).

Num relato semelhante, o iluminador francês Thierry Fratissier ${ }^{42}$ também $^{2}$ atestou sua preocupação com o espectador, mas observou que, na sua opinião, nem tudo deve ser dado ao espectador, sob risco de não lhe oferecer nada de novo, inesperado ou surpreendente:

...para mim o que importa é o olhar de quem está na plateia, que pode ser o diretor, o meu olhar, obviamente, mas também o olhar do espectador [...] eu começo a pensar nele só quando já me sinto um tanto coerente em relação a tudo [...] à força de constatar que eu percebo muitas coisas no dia em que assisto à estreia e que já não posso fazer mais nada, então isso significa que talvez eu não pense o suficiente no espectador, (risos) visto que quando eu me encontro na posição de espectador, percebo muitas revelações, tanto sobre o trabalho dos atores quanto sobre o trabalho da luz [...] porque eu espero que o trabalho que fazemos juntos quando montamos um espetáculo traga algo de novo para o espectador, algo que possa surpreendê-lo. De alguma forma, alimentá-lo com o que ele não tenha sido alimentado antes. Parece muito pretensioso, mas ao mesmo tempo é um pouco nossa ambição. [...] Para mim, é importante que o espectador possa perceber coisas que ele não esperava. Então, se eu começar a lhe oferecer o que ele espera, é um pouco contraditório, é isso (FRATISSIER, anexos, p. 211).

Além da confirmação de artistas, profissionais e criadores da luz na cena, a participação e importância dada ao espectador na obra artística é também destacada em investigações científicas, a exemplo do destaque dado pelo artista visual norte americano Robert Irwin (1971 apud BARROS, 1999, p. 144) a respeito da dinâmica do fenômeno perceptivo das suas obras de arte. A arte do fenômeno, proposta resultante das reflexões e experiências desenvolvidas por ele e Turrell com o movimento Light and Space Art, surge da relação entre o ser

42 Em entrevista realizada como parte desta pesquisa, disponível nos anexos, p. 209-217. 
e a circunstância, tendo como princípio uma ação condicional em resposta a um conjunto específico de elementos num tempo e lugar determinados. Segundo Irwin, o artista eleva o processo de consciência perceptiva do público à importância que Ihe é reservada, na qual todos os sistemas lógicos são moldados instintivamente. Esse procedimento, assentado na impermanência, expõe uma arte em mutação perene dada à percepção do observador que, situado no âmago do trabalho, questiona, se relaciona e dá sentido à obra. Essa autonomia o torna responsável e representa, para Irwin, a implicação social dessa chamada "arte do fenômeno" ou "arte da percepção".

Relacionando a criação teatral com as artes visuais, notadamente no trabalho de Turrell com a luz, Oliver Wick (1990 apud BARROS, 1999, p. 107) cita a abertura para o diálogo gerado por sua obra, que, segundo ele, só vem a ser, efetivamente, pelos olhos do observador no ato da percepção, submetendo qualquer compreensão definitiva dessa arte, aberta e susceptível, assim, às impressões e percepções do espectador. As imagens de luz criadas por Turrell foram associadas ao Luminismo, uma escola americana cujos pintores tendiam a definir suas obras mais em termos de processo do que de produto, privilegiando, ao invés de julgar ou analisar, a visão e a maneira de ver e perceber o objeto artístico como trabalho dependente da participação do observador. Barros (1999, p. 139-140) avalia, a partir dos escritos de Irwin, a tensão existente, na criação artística, entre o saber estabelecido e as possíveis fissuras, incertezas e enganos desse saber. Se, por um lado, o lugar da criação encontra-se nos limites do conhecimento e suas investigações se estruturam em regras sobre como ocorre a percepção da arte, por outro, é para além dos seus limites que é possível revelar uma percepção não objetivada da obra artística, centrada na experiência do observador.

A importante pesquisa de Jean-Jacques Roubine (1998) expõe o amplo panorama das transformações e novas maneiras de ver e perceber o teatro na Europa no período entre os anos de 1880 e 1980. O que interessa destacar aqui, no entanto, é a atenção que passa a ser conferida a esse público e suas consequências para o fazer teatral. "Meyerhold gostaria de arrancar o 
espectador reduzido à sua não existência de voyeur pelo naturalismo para associá-lo ao trabalho do autor, do diretor e do intérprete e fazer dele o 'quarto criador' (ROUBINE, 1998, p. 37). A relação do público com o espetáculo, que Roubine classifica como uma das grandes preocupações do teatro moderno, transforma não apenas o trabalho do ator, mas também todo o trabalho de dramaturgia e encenação, afetando, além do elenco, a totalidade da equipe de criação, que começa a se envolver em igual medida com o cuidado dado ao espectador e à recepção teatral.

Até então, neste período e ambiente eurocêntrico, a maior importância e atenção dadas, em uma montagem cênica, concentravam-se na literatura e na dramaturgia do teatro, limitando-se, com maior ou menor êxito, a fazer viver a peça, colocar em cena tudo o que determinava o texto dramático em suas mais detalhadas orientações. Reconhecida como a Era do Dramaturgo, esse período foi marcado por grandes e históricas atuações de intérpretes que fizeram nome ao representar de maneira extraordinária personagens clássicos da história do teatro, como Hamlet ou Antígona. Em seguida, este período deu lugar à Era do Cenógrafo, na qual grandes pintores dedicaram-se à criação de imponentes cenários pictóricos que fizeram história por maravilhar e encantar o público da época, a exemplo dos Ballets Russos de Sergei Diaghilev. A essa época, seguiuse a chamada Era do Encenador, na qual toda a atividade teatral era conduzida por um novo artista, o diretor, cujo título francês metteur-en-scène designa bem sua função como aquele que "coloca em cena" e coordena todos os componentes do espetáculo numa organização harmônica e coesa de seus elementos plásticos, cênicos e dramatúrgicos (PERRUCHON, 2017, p. 226). Esse período, também conhecido como a vanguarda do teatro moderno, trouxe à cena grandes nomes que, por sua vez, determinaram distintas formas de ver e fazer teatro, como Artaud, Stanislavski, Meyerhold, Brecht, entre tantos outros. Ele representou, ainda, uma importante libertação dos textos clássicos, com o surgimento de uma encenação mais autoral e uma dramaturgia mais contemporânea e politizada. 
Marcello Amalfi (2015) dedica especial atenção à influência do surgimento do encenador no aspecto visual do espetáculo, destacando principalmente, em sua pesquisa, a diferença do ocorrido na realização artística teatral e musical a esse respeito:

De forma geral, no universo do teatro, ele [o aspecto cênico] ganhou uma nova ênfase, ampliando constantemente seus recursos expressivos com novas propostas, como a utilização da iluminação por Adolphe Appia (1862-1928), a dos cenários por André Antoine (18581943, ou a das imagens e projeções de filmes por Erwin Piscator (18931966). Já no universo da música de concerto, ele permaneceu estagnado. A luz continuou apresentando o mesmo caráter funcional, assim como os eventuais cenários. Os figurinos dos músicos, dos solistas e do maestro permaneceram replicando padrões tradicionais, enquanto que o posicionamento e a movimentação no palco ficaram limitados a um mesmo ritual de roteiro único, com pouca ou nenhuma ligação com a obra executada (AMALFI, 2015, p. 42).

Como consequência dos novos procedimentos no campo teatral, o final do século XX assistiu ao surgimento de diferentes formas de teatro como o pósdramático e o performativo, cujas formas de construção cênica, partilhadas com toda a equipe de criação, ainda sob a batuta do encenador, mas já não mais de forma tão ditatorial e contundente como autoridade inquestionável do processo, revelam novas maneiras de fazer e vivenciar a atividade teatral. Alguns encenadores e coletivos são exemplos representativos destes tipos de processo, como André Engel e Joël Pommerat, na França, e José Celso Martinez Corrêa e Antônio Araújo, no Brasil. À frente do Teatro Oficina e do Teatro da Vertigem, respectivamente, os dois encenadores coordenam a elaboração coletiva, colaborativa ou participativa, conforme o caso, de espetáculos teatrais potentes e intensos, que ilustram o fenômeno do trabalho de grupo e de novos processos de criação nos palcos brasileiros. Essa potência pode ser entendida como resultado da sensação de pertencimento destacada por Pamela Howard, que é gerada em toda a equipe pelo trabalho conjunto realizado desde a pesquisa: "quanto mais coletiva a pesquisa, mais a rede se espalha e mais colegas têm a sensação de pertencimento ao projeto (HOWARD, 2015, p. 115).

Apesar de serem procedimentos bastante semelhantes, a criação coletiva e o processo colaborativo apresentam diferenças fundamentais, como foi explicado por Cibele Forjaz (2015), que descreve a criação coletiva como uma 
prática teatral resultante de movimentos de grupos engajados e militantes cuja libertação da figura do diretor foi característica dos anos 70 no Brasil. Nesse tipo de organização teatral não existia uma regência absoluta, nem necessariamente uma distribuição clara de tarefas, todas realizadas pelo coletivo, geralmente grupos amadores oriundos de movimentos universitários. Como decorrência da organização, por vezes anárquica, de trabalhos realizados em workshops de criação, os espetáculos primavam pela elaboração conjunta da cena e por uma intensa participação do público. Não havia uma figura central que orientasse o trabalho ou seus resultados, definidos pelo coletivo, sempre que possível, ou sua maioria em caso de divergências de opinião.

Já no processo colaborativo, "a pesquisa cênica é realizada coletivamente, através de cenas criadas pelos atores, porém [...] a finalização do texto é realizada por um dramaturgo; a encenação cabe ao diretor; o desenho do cenário ao cenógrafo e assim por diante" (FORJAZ, 2015, p. 31). Neste tipo de formação, são preservadas as funções da equipe de criação, mas o conceito da escritura do texto e da encenação é elaborado em conjunto, por meio do trabalho realizado a partir de uma temática específica ou de uma obra, cuja reflexão se deseje levar a público. Esso objeto original de reflexão é, segundo ela, desconstruída e reconstruída cenicamente pelo coletivo:

Normalmente o procedimento de reconstrução parte de workshops
realizados pelos atores durante a primeira fase do processo de
trabalho. Esses workshops são cenas combinadas ou improvisadas
que pressupõem um conceito, uma proposta pessoal idealizada por um
ator que, nesse momento da criação, pode propor uma cenografia, uma
luz ou uma adaptação textual própria, urdidos da forma que o autor da
cena considerar importante para a plena comunicação de sua ideia
cênica. Em um segundo momento, o dramaturgo elou o encenador
realiza seu trabalho de criação, lançando mão da pesquisa realizada
por todos. [...] Em quase todos os casos, por mais que a finalização do
espetáculo dependa dos diferentes criadores, em suas funções
determinadas, o conceito do trabalho é coletivo (FORJAZ, 2015, p. 31).

Segundo o diretor Antônio Araújo, à frente do Teatro da Vertigem desde a sua criação, o conceito de coletivo empregado no seu trabalho diz respeito a um modo de fazer, à maneira como as diferentes funções se articulam na criação da obra cênica em um processo compartilhado, colaborativo e democrático do fazer artístico, sem a presença de um criador epicêntrico ao processo, mas por 
um conjunto de criadores que definem coletivamente os conceitos, práticas e materializações da obra (ARAÚJO, 2018, p. 13). Esse conceito diferencia-se do teatro dito coletivo, que pretendia uma diluição das funções artísticas e um acúmulo ou transitoriedade de atribuições em que a dramaturgia e a encenação coletivas, bem como a criação de cenários, luz e figurinos, realizada conjuntamente por todos os integrantes do grupo, substituem, respectivamente, a necessidade e a presença, durante o processo, do trabalho de um dramaturgo, encenador, cenógrafo, iluminador e figurinista43 (ARAÚJO, 2018, p. 14).

É possível identificar um processo semelhante, mas com características próprias, na descrição feita pelo diretor e iluminador Roberto Gill Camargo ${ }^{44}$ a respeito da criação no seu Grupo Katharsis: "A minha linha, usando um termo emprestado da biologia, é um trabalho coevolutivo, ou seja, de codependência entre as partes envolvidas, e que só anda se tiver esse entendimento, essa negociação entre as partes". Sobre o processo, ele explicou ainda que "você coloca um elemento, aí vem outro e coloca outra coisa e transforma o que veio antes. Isso é um ciclo, um processo possível pela transformabilidade, uma coevolução", cujos impactos e trocas promovem, sucessivamente, novas respostas e novos impactos (GILL CAMARGO, anexos, p. 198-199).

A criação cênica definida pelo professor Ênio Carvalho ${ }^{45}$ como um processo de provocação coletiva reflete o espírito do trabalho realizado com o seu grupo amador de teatro no Espaço da FALEC. Suas criações resultam de encontros nos quais são definidas, conjuntamente, as diretrizes e características do trabalho a ser desenvolvido, mesmo que cada artista tenha sua função

\footnotetext{
43 Apesar de todo os cargos serem aqui descritos aparentemente no gênero masculino, é importante destacar que eles se referem a funções e atividades profissionais que podem e são desempenhadas, igualmente, por artistas de qualquer gênero, considerando a mim, autora desta pesquisa, como uma iluminadora mulher que não relaciona, necessariamente, seu desempenho, qualidade e competência profissionais ao gênero, nem seu, nem de outros colegas de profissão. Richard Pilbrow (2008) destacou, na introdução de seu livro, aliás, com razão, que os melhores lighting designers são, normalmente, mulheres.

${ }^{44} \mathrm{Em}$ entrevista realizada como parte desta pesquisa, disponível nos anexos, p. 196-204.

45 Professor Ênio José Coimbra de Carvalho, diretor do grupo de teatro amador da FALEC Faculdade Leocádio Correia, da qual é fundador e diretor, também autor do livro História e formação do ator da Editora Ática, publicado em 1989.
} 
previamente determinada. Este tipo de processo é descrito por Antônio Araújo como "uma metodologia de criação em que todos os integrantes, a partir de suas funções artísticas específicas, têm igual espaço propositivo, produzindo uma obra cuja autoria é compartilhada por todos" (ARAÚJO, 2009, p. 48). Ele explica que, mais do que excluir a hierarquia e a soberania exercida pelo diretor, essa dinâmica de trabalho aponta para um "sistema de hierarquias momentâneas", que fluem de um polo da criação para outro no processo de autoria da obra.

Apesar de, neste tipo de trabalho coletivo, as funções de cada integrante do grupo serem normalmente estabelecidas previamente, como as de direção, atuação ou dramaturgia, por exemplo, uma possível mobilidade entre as funções em diferentes projetos não descaracterizam o processo colaborativo nem comprometem o trabalho. A horizontalidade do processo faz com que os criadores estejam, como Araújo explica, "em pé de igualdade na função autoral de cada membro, cuja atuação é potencializada" (ARAÚJO, 2009, p. 49). Ele esclarece, no entanto, que, ao contrário do que acontece nas criações coletivas, o artista responsável por uma determinada área tem a palavra final sobre ela, mesmo que ele exponha e discuta com o grupo sua criação, aceite sugestões e incorpore ideias dos demais participantes do processo. Guilherme Bonfanti ${ }^{46}$ descreve, como exemplo dessa horizontalidade, o processo de criação do Espetáculo Bom Retiro 958 metros:

...não existe um pré-projeto de nada, enquanto em um modelo mais tradicional o diretor e o cenógrafo se encontrariam antes, chegam a uma proposta de cenografia e quando começa o processo isso já está concebido. Aqui, nós temos uma porosidade muito grande, e eu incluo nisso os atores. Acho que quem menos interfere é a dramaturgia, que se preocupa mesmo com a palavra. Depois, nós sempre fazemos um texto do que foi encenado. O Duran (Antonio Duran), que é o nosso dramaturge, vem depois que a peça está em cartaz com um gravador e reescreve o texto como foi dito [...]. Nesse momento, entram rubricas inventadas por todas as áreas que não estavam no texto original, coisas de luz aparecem e viram rubrica. Tudo passa pela sala, sempre. Temos um percurso que é uma pesquisa teórica, que uma hora se mistura com uma pesquisa de campo, que gera material para a sala de ensaio. [...] É um trabalho que vai sendo construído junto e com um invadindo o trabalho do outro, claro, com respeito. Temos o que o Tó (Antônio Araújo) chama de hierarquias flutuantes na qual, em dados momentos, cada um de nós tem a palavra, digamos que a direção da coisa, então isso aqui está mais consolidado, [...], mas é bastante

${ }^{46} \mathrm{Em}$ entrevista realizada como parte desta pesquisa, disponível nos anexos, p. 116-130. 
normal nós interferimos na vida dos outros de maneira positiva (BONFANTI, anexos, p. 121-122).

Uma característica importante do processo colaborativo, indispensável para se alcançar os resultados almejados, é o tempo dedicado a cada criação. Como as diretrizes da montagem não são previamente dadas e, além de todos os elementos da encenação, o próprio texto a ser encenado, se houver, é fruto do trabalho coletivo, o desenvolvimento é lento, intenso e profundo. As inúmeras interferências e contribuições mútuas dilatam o período de ensaios e expandem as zonas de colaboração. Joël Pommerat ${ }^{47}$ explica, sobre o processo de construção da peça Contes et Légendes, que o resultado obtido só foi possível pelo tempo dedicado tanto à criação da temática (no início do processo só se tinha como definido que o novo espetáculo seria sobre crianças) quanto do texto e de todos os demais elementos da criação, inclusive personagens, marcações de cena, temas secundários, entre outros.

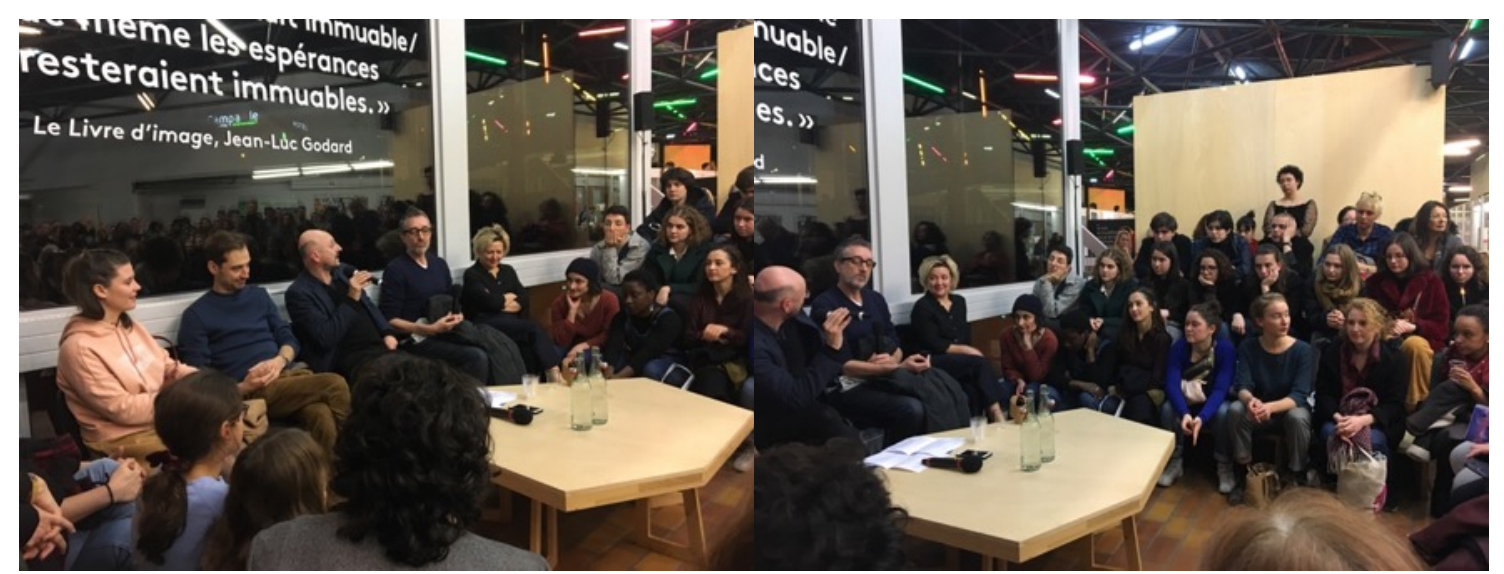

Figura 3 - Encontro com equipe de criação do espetáculo Contes et Légendes, de Joël Pommerat, no Teatro Nacional Naterre-Amandiers em janeiro de 2020. Fotos Nadia Luciani.

As atrizes do espetáculo (nas fotos acima, toda a primeira fila de pessoas sentadas à direita) explicaram ainda a importância de trabalhar conjuntamente com toda a equipe de criação e da presença constante nos ensaios dos figurinistas. Igualmente responsável pela pesquisa visual e a caracterização, o trabalho desta equipe foi fundamental para a criação das pessoas (como Pommerat prefere chamar os personagens) e situações dramáticas propostas.

47 Em conversa com a equipe de criação mediada pelo Prof. Dr. Christophe Triau, da Universidade Paris-Nanterre, realizada após a apresentação de sua mais recente criação, o espetáculo Contes et Légendes, no Teatro Nanterre-Amandiers na França no dia 18 de janeiro de 2020. 
Além de dois atores adultos, todo o elenco jovem, formado exclusivamente por mulheres, mesmo para os papéis masculinos, foi selecionado em ateliers de criação teatral, depois dos quais se seguiu mais de um ano de encontros e ensaios criativos até chegar à estreia do espetáculo.

O encenador acrescentou que tanto o texto, com a ampliação da temática para os clichês, dramas familiares, autoafirmações e construção de gênero da criança e do adolescente, quanto o surgimento dos robôs, elementos chave da versão final da dramaturgia da peça, foram consequência, principalmente, do trabalho realizado com a participação colaborativa da equipe de criação durante todo o processo. Como dramaturgo, Joël Pommerat declarou ainda, com convicção, que a escrita de seus textos acontece junto com os atores, da mesma forma que a encenação, que só pode ser realizada com a presença e a participação de toda a equipe de criação. Maria Clara Ferrer, pesquisadora que dedicou boa parte de sua investigação teatral ao trabalho de Pommerat, escreveu, a respeito do processo de criação e da participação de Eric Soyer, cenógrafo e iluminador da Companhia Louis Brouillard:

\begin{abstract}
Partindo de uma temática e um título, primeiro elemento que ele define ao iniciar um projeto, Pommerat desenvolve com os atores e colaboradores um minucioso trabalho de improvisação durante vários meses. [...] O que ele chama de "improvisação" são experimentações de relações espaço-temporais entre as presenças. Todos os colaboradores artísticos participam dessa dramaturgia in progress que consiste em explorar diferentes possibilidades de inscrição dos corpos em um dado espaço. [...] Pommerat se interessa pela maneira como as presenças são percebidas, Aos poucos as composições cênicas se definem e o texto elaborado e alterado cotidianamente vai se infiltrando na escrita cênica. [...] Isso exige uma estruturação prévia do espaço assim como de sua implementação luminosa. Ou seja, a cenografia aparece como uma condição sine qua non para qiue a dramaturgia possa se desenvolver, daí a importância da cúmplice relação que Pommerat desenvolveu com Eric Soyer (FERRER, 2015, p.58).
\end{abstract}

Segundo Araújo, a tensão produtiva desencadeada num processo criativo colaborativo gera um antagonismo positivo que "fortalece o próprio grupo e o conceito geral que este tem do trabalho" (ARAÚJO, 2009, p. 50). No entanto, apesar do regime democrático de decisões, existem momentos de subordinação, nos quais a distribuição dos personagens é definida pelo diretor, a redação final do texto pelo dramaturgo, o desenho dos cenários e dos figurinos pelo cenógrafo 
e pelo figurinista, respectivamente, os efeitos sonoros pelo sonoplasta ou compositor e o desenho da luz pelo iluminador. Da mesma forma, a construção de eventuais personagens ou "pessoas", como prefere Joël Pommerat, são definidas pelos próprios atores e performers, sempre em atuação conjunta com todos os demais integrantes e componentes da cena. Assim sendo, todas essas decisões são fruto de muita experimentação, amadurecimento e constantes negociações, considerando principalmente a rede de interdependência gerada entre as diferentes linguagens e a colaboração dialógica e participativa que se estabelece entre os artistas envolvidos.

Da mesma forma, entender a dramaturgia do espetáculo não como uma dramaturgia da escrita literária, mas como uma dramaturgia da escrita da cena, expande suas fronteiras para além do aspecto narrativo de um texto dramático, abarcando as demais expressões cênicas em dramaturgias próprias (dramaturgia da luz, do corpo, da voz, do espaço ou da imagem) relacionadas ao fenômeno teatral, em toda sua efemeridade e suscetibilidade às relações estabelecidas no instante presente da ação. Araújo chama de "dramaturgia em processo" este objeto em fluxo contínuo de transformação, que advém dos exercícios de improvisação, investigação, experimentação e construção coletiva da obra cênica (ARAÚJO, 2019, p. 16). Seguindo o mesmo método, surgem todos os outros elementos "in process" que caracterizam o processo colaborativo, mas sem, no entanto, destituir a responsabilidade do artista encarregado de cada função, criação ou atividade, a exemplo do iluminador, que apresenta e defende o conceito norteador e estruturador da luz que propõe para o trabalho em desenvolvimento, interagindo, sugerindo, acatando e incorporando sua criação ao conjunto da obra. Trabalhando com o diretor Joël Pommerat desde a criação da Companhia Louis Brouillard em 1997, o próprio cenógrafo e iluminador Eric Soyer ${ }^{48}$ explicou, sobre seu processo criativo:

...eu trabalho com pessoas que escrevem, então sempre começamos a partir de uma página em branco e é claro que os desejos do diretor, do encenador, do dramaturgo são fundamentais, especialmente em sua capacidade de despertar ou desencadear outros desejos nas pessoas ao seu redor, nos colaboradores. Depois, não se trata de

${ }^{48} \mathrm{Em}$ entrevista realizada como parte desta pesquisa, disponível nos anexos, p. 109-112. 
responder aos seus desejos, mas de criar um diálogo com eles, de poder, pelo desejo, estimular a criatividade e isso, isso também passa por zonas de atrito (SOYER, anexos, p. 109-110).

Roland Barthes apresenta o conceito de escritura múltipla como sendo um espaço onde se casam e se contestam escrituras variadas, das quais nenhuma é original (2004 apud ARAÚJO, 2018, p. 19) e na qual coabitam diferentes autores. Suas escrituras individuais são identificáveis nos atritos, como citado por Soyer, que geram em justaposição e contaminação mútuas. Como um dos autores que se manifestam por meio de sua arte e expressão cênicas, o iluminador participa do processo sendo o artista criador responsável pelo projeto de iluminação, cuja interação com os demais elementos da cena se evidencia a cada processo. Nos processos tradicionais de montagem cênica, principalmente os centrados na figura de um diretor ou encenador, é comum o iluminador ser chamado para compor a equipe ou realizar seu trabalho de criação quando todos os demais elementos, inclusive a marcação de cena, já se encontram em estágio adiantado de criação ou, como acontece muitas vezes, completamente definidos. O papel do iluminador, nesses casos, se limita a mostrar a criação dos demais artistas criadores, apenas destacando, evidenciando ou ocultando o que já está posto em cena.

O processo colaborativo, ao contrário, permite que a criação aconteça de forma totalmente distinta, possibilitando ao iluminador a oportunidade de propor marcações de cenas, elementos cenográficos e até mesmo soluções dramáticas complementares ao texto. A interação é mútua, o que faz com que a integração entre luz e cenário, luz e atuação, luz e som, entre outros, aconteça de forma mais orgânica e integrada. A relação estabelecida entre o iluminador e os demais artistas, como performers, cenógrafo, figurinista, sonoplasta, dramaturgo e encenador, resulta em um trabalho cuja colaboração favorece a criação individual da luz, mas sempre em um âmbito mais amplo, considerando sua participação como parte estrutural do todo que compõe o espetáculo. No entanto, essa perspectiva demanda e carece, muito possivelmente, de uma abordagem Faucautiana que reflita sobre a forma como as diferentes relações de poder, de 
fragilidades e submissões podem incidir sobre o processo criativo em diferentes realidades e contextos.

Apesar dos depoimentos reveladores sobre o entendimento da atuação possivelmente performativa de suas luzes em diferentes espetáculos cênicos, o iluminador carioca Renato Machado ${ }^{49}$ demonstrou reconhecer a importância do encenador e da coesão entre os membros da equipe de criação:

Eu trabalho para um encenador. Por mais que eu trabalhe com uma ferramenta poderosa, por mais que ela possa ter um nível de prioridade que a coloque acima de outras ferramentas, eu trabalho para um encenador e devo satisfação a ele. A minha função é usar a minha imaginação para criar um projeto que atenda a expectativa e a imaginação dele. O contato com o diretor é primordial, assim como com os desejos dele. Eu costumo dizer que, se você teve uma ideia incrível, sensacional para resolver um projeto de iluminação, mas o seu diretor não gostar da sua ideia, você vai jogá-la fora. É simples assim. Você vai pegar a sua ideia incrível e vai jogá-la fora porque ele não curtiu a sua ideia. E tem um outro contato, porque existe uma coisa importante que é a estrutura que o teatro tem em torno de uma equipe de criação. Esse contato e essas relações, eu acho que são superimportantes. Eu acho que, durante o processo de criação de uma peça, ter encontros regulares com os principais responsáveis por cada uma das disciplinas envolvidas na criação da peça, é fundamental. E para isso você faz uma reunião na qual está o diretor, o iluminador, o cenógrafo, figurinista, diretor musical, videografista, se for o caso, coreógrafa... Esses encontros, que definem efetivamente a estética que aquele espetáculo vai ter, são fundamentais (MACHADO, anexos, p. 186).

Entre a autoridade profissional e a maleabilidade criativa, o processo desierarquizado empregado por Ariane Mnouchkine nas montagens do Théâtre du Soleil representa, para Marcello Amalfi (2015), um fator bastante relevante do trabalho criativo do grupo. Segundo a diretora, necessitar da "última palavra" faz imaginar que exista um conflito permanente entre os criadores. "Eu penso, na verdade, que é um pouco lastimável que seja necessário haver uma 'ultima palavra"'50 (PICON-VALLIN, 1995 apud AMALFI, 2015, p. 109). Para ela, tudo na criação deve ocorrer durante o processo, sem nenhuma relação de poder, narcisismo ou prova de força. O importante é que todos estejam dispostos a

\footnotetext{
49 Em entrevista realizada como parte desta pesquisa, disponível nos anexos, p. 184-195.

50 « Je pense qu'en fait, s'il faut avoir le dernier mot, c'est un peu dommage » (tradução da autora).
} 
recomeçar, rever seus processos e aceitar as sugestões e interferências mútuas, a autonomia e condução da direção, sem imposição nem resistência.

A iluminadora Alessandra Domingues ${ }^{51}$ relatou como fronteiras difusas determinam as atribuições de cada integrante das companhias Mundana e Cia. Livre de Teatro das quais participa como artista criadora:

...no campo das ideias, todo mundo interfere muito no trabalho um do outro e acaba expandindo da própria coisa em si. Claro que a responsabilidade de fazer a luz era sempre minha, as decisões finais sobre qual tipo de equipamento, como essa luz ia acontecer, sempre foi minha. Claro que em conjunção e acordo com toda a equipe. O que eu sinto, principalmente na Mundana, é que existe essa quebra de hierarquia em todo projeto, então, apesar de eu ter a responsabilidade com a luz, as pessoas têm essa liberdade de propor coisas, assim como eu tenho de propor coisas. Isso é uma prática que me acompanha muito na minha carreira como iluminadora... Na minha trajetória, eu criei projetos ou mesmo luzes que eram lidas pelas pessoas como cenografia e não como iluminação (DOMINGUES, anexos, p. 29).

Da mesma forma, as experiências de Fabrício Crisafulli (2019), dramaturgo, encenador e iluminador italiano, com sua companhia, particularmente no que diz respeito à criação da luz na montagem do espetáculo II Pudore Bene in Vista revelam fortes características de processo colaborativo:

Os membros do grupo (não somente os atores e dançarinos, mas também, por exemplo, aqueles que se ocupam do som ou da técnica) são convidados a confrontar a situação proposta, confrontação que coloca em jogo, antes mesmo de suas respectivas formações específicas e suas capacidades técnicas, suas diferentes personalidades, a fim que as reações/proposições de cada um venham a suscitar variações da condição dada inicialmente, e que essa condição (que constitui o mundo embrionário do espetáculo) seja novamente proposta, por sua vez, modificada por essas mudanças nas relações. Em resumo, o que se cria, pouco a pouco, ao longo desses ensaios, é um "lugar", um ambiente feito de relações evolutivas. [...] Esse procedimento é igualmente decisivo quanto à determinação do papel da iluminação, que pode variar muito de um espetáculo para outro, mas que, em cada caso, se configura enquanto fator fortemente ligado ao conjunto das relações. Em outros termos, a luz não é compreendida com um elemento "projetado" sobre o espetáculo para determinar seu aspecto visual específico, mas como um componente do "lugar" onde acontecem as relações, integrado às ações, às durações, aos espaços, às formas, aos sons, às palavras, que, nessas relações, se definem pouco a pouco. Na relação com esses elementos, a luz se torna, ao mesmo tempo, causa e consequência. É por isso que sua concepção, mais do que se referir a parâmetros e a critérios prédeterminados, derivados de costumes teatrais e hábitos técnicos,

51 Em entrevista realizada como parte desta pesquisa, disponível nos anexos, p. 28-36. 
surge das relações inerentes ao processo criativo, o que implica, desde o início do trabalho, na sua atuação como elemento construtivo52 (CRISAFULLI, 2019, p. 213).

A importância do trabalho de criação da luz desenvolvido no Teatro da Vertigem, cuja experimentação e uso de materiais não convencionais jamais seria possível em outro tipo de processo, é destacada pelo iluminador Guilherme Bonfanti (2018). Sua atuação nos processos criativos do grupo é exemplo latente dos resultados performativos obtidos em um trabalho integrado entre a encenação teatral e a concepção da luz de maneira colaborativa. Segundo ele, tudo é compartilhado, discutido e decidido conjuntamente, da escolha e definição do espaço cênico até a marcação e distribuição das cenas. A iluminação resultante não se adequa ao espetáculo apenas como linguagem, mas também como implicação estética, cujas fontes luminosas são pesquisadas e trabalhadas artesanalmente para a construção e uso de equipamentos não convencionais na iluminação dos espetáculos da chamada Trilogia Bíblica do Vertigem, composta pelos espetáculos O Paraíso Perdido, montado em uma igreja, O Livro de Jó, realizado em um hospital e Apocalipse 1,11 cuja apresentação foi feita em um presídio. O iluminador destacou, da mesma forma que muitos dos iluminadores entrevistados nesta pesquisa ${ }^{53}$, a importância do trabalho continuado com o mesmo diretor ou o mesmo grupo, tanto para a formação profissional quanto

\footnotetext{
52 "Les membres du groupe (non seulement les acteurs et les danseurs, mais aussi, par exemple, ceux qui s'occupent du son ou de la technique) sont invités à se confronter à la situation proposée, cette confrontation mettant en jeu, avant même leurs formations spécifiques respectives et leurs capacités techniques, leurs différentes personnalités, afin que les réactions/propositions de chacun viennent susciter des variations de la condition donnée initialement, et que cette condition (qui constitue le monde embryonnaire du spectacle) se repropose à son tour, modifiée par ces changements, dans les relations. En somme, ce qui se crée peu à peu au cours des répétitions est un "lieu ", un environnement fait de rapports évolutifs. [...] Cette procédure est également décisive quant à la détermination du rôle de la lumière, qui peut varier beaucoup d'un spectacle à l'autre mais qui, dans chaque cas, se configure en tant que facteur fortement lié à l'ensemble des relations. En d'autres termes, la lumière n'est pas comprise comme un élément " projeté " sur le spectacle pour en déterminer l'aspect visuel spécifique, mais comme une composante du " lieu » où les relations se déroulent, intriquée aux actions, aux durées, aux espaces, aux formes, aux sons, aux paroles qui, dans ces relations, se définissent peu à peu. Par rapport à ces éléments, la lumière devient à la fois origine et conséquence. C'est pourquoi sa conception, plutôt que de se référer à des paramètres et à des critères prédéterminés, dérivants de coutumes théâtrales et d'habitudes techniques, jaillit des relations inhérentes au processus créatif, ce qui implique, dès le début du travail, sa mise en jeu comme élément constructif » (tradução da autora).

53 Outras opiniões podem ser verificadas nas respostas à pergunta número dois das entrevistas realizadas para esta tese, disponíveis nos anexos, p. 28-233.
} 
para o aprimoramento conceitual da criação em iluminação cênica e conclui que "a cena é meu disparador e tudo surge a partir dela e para ela. Trabalho a autonomia da criação, interfiro na cena, mas é ela que me motiva. Minha trajetória está completamente ligada ao Teatro da Vertigem, meu pensamento sobre a luz, as descobertas, erros e acertos. [...] O coletivo é o meu lugar." (BONFANTI, 2018, p. 28).

O processo colaborativo é, sem dúvida, o ambiente propício, quiçá ideal, para a proposição de uma luz ativa, participativa e atuante no espetáculo teatral. Tanto no teatro quanto em outras áreas, a atividade do design se tornou, com as mudanças de paradigmas característicos da segunda metade do século XX, interdisciplinar e colaborativa. Como atividade integrativa, o design se expande em um sistema abrangente cujo valor se encontra na oportunidade de contribuir, no espírito de colaboração. "O design baseia-se no ato de partilhar, é uma arte coletiva, com o são seus objetivos, não procura a satisfação furtiva do indivíduo, mas o gozo público do coletivo (DORMER, 1990 apud HILU, 2016, p. 231). Isso sugere, principalmente, a participação ativa do artista criador da luz em todo o processo criativo, interagindo com os diferentes componentes da cena.

Conhecer as cores e texturas do figurino, testar a maquiagem na luz ou experimentar diferentes ângulos e matizes sobre os elementos cenográficos durante o processo de criação e os ensaios pode alterar, ativar e potencializar mutuamente a expressividade de cada um desses componentes da cena. A contribuição deste criador, que Cibele Forjaz chama de iluminador-encenador (FORJAZ, 2018, p. 74), em todas as fases do processo confere ao seu trabalho uma participação ativa no resultado final da encenação, cuja luz poderá interagir, tanto física quanto conceitualmente, com os cenários, marcações de cena e a própria atuação dos performers, sugerindo, propondo e colaborando com a concepção geral do espetáculo e interferindo, radicalmente, na relação estabelecida como espectador.

A condução do processo criativo no Teatro Oficina, encabeçado pelo diretor, ator e dramaturgo José Celso Martinez Corrêa, concede à iluminação uma participação ativa tanto durante a criação quanto nas apresentações, 
segundo relato da iluminadora Cibele Forjaz junto ao Teatro Oficina ${ }^{54}$ cujo trabalho com o grupo revela-se como bom exemplo de iluminação performativa resultante de um método participativo de criação. As demandas e ações de Zé Celso como encenador e performer atuante na cena fazem romper todas as fronteiras entre ficção e realidade. Ele expõe, interage e contracena com a luz e seus operadores, induzindo a mesma conduta a todo elenco e equipe. A interatividade da luz, cuja criação é continuada durante todo o processo, é inegável. A criação da visualidade e da sonoridade no Teatro Oficina são procedimentos mais participativos do que a construção do texto, da dramaturgia, da encenação e da atuação, onde a interferência da direção é mais acentuada. A integração e a ação conjunta, no entanto, são consistentes e permanentes, mesclando os processos de criação e exibição durante os ensaios e as apresentações, quando os espectadores participam e integram a cena tão intensamente quanto os artistas.

Outro bom exemplo de trabalho colaborativo entre a luz e a equipe de criação teatral é o desenvolvido por Beto Bruel com o encenador e dramaturgo Felipe Hirsch desde 1998, ano de montagem do espetáculo Juventude, da Sutil Companhia de Teatro. A pesquisadora Silvia Fernandes compara o trabalho da Sutil com as companhias paulistanas do Teatro da Vertigem e da Companhia do Latão e destaca seu processo de estudo, pesquisa e construção artesanal da cena com "recursos cinematográficos e de estranhamento na dramaturgia e na atuação, além do emprego quase abusivo da intertextualidade" (FERNANDES, 2010, p. 18). A parceria se repetiu no ano 2000 com o espetáculo A Vida é Cheia de Som e Fúria e seguiu, a partir de então, com criações cujos componentes extremamente integrados resultaram sempre do trabalho colaborativo da equipe. A elaboração da luz em processos compartilhados de experimentação, além da inesgotável predisposição para realizar mudanças, ajustes e adequações fazem do trabalho de Beto Bruel um exemplo ímpar da interação entre as linguagens teatrais, característica indelével dos processos colaborativos de criação.

\footnotetext{
54 Abordado com maior atenção no estudo de caso especialmente dedicado ao trabalho de Cibele Forjaz com o Teatro Oficina entre os anos de 1991 e 2002 (Capítulo 2.3.1).
} 
A cenógrafa Daniela Thomas declarou, em um depoimento feito para o vídeo documentário À $L u z$ de Brue ${ }^{55}$, a importância da colaboração e participação intensa dos criadores no processo para se alcançar resultados coesos e expressivos, principalmente no que diz respeito à relação entre cenografia e iluminação. Segundo ela, a dedicação e colaboração do iluminador Beto Bruel não se restringe à criação de luz e aos temas relacionados à ela, pois sua vasta experiência e o respeito conquistado com os anos de atividade teatral resultam em contribuições muito mais relevantes e com um alcance muito maior para os resultados da construção cênica. As interferências da luz na configuração geral dos espetáculos, por vezes sutis e noutras incisivas, são resultado da colaboração na gênese da criação da encenação e na presença incansável do iluminador nos ensaios e montagens. Nessas oportunidades, suas contribuições chegam a intervir tanto a concepção do cenário quanto a marcação das cenas ou a atuação dos performers.

Podem ser citados muitos outros exemplos de iluminadores que realizam seus trabalhos de criação de forma participativa, em processos mais ou menos colaborativos, cuja concepção dramatúrgica e interação com a cena é fundamental para a atuação da luz no espetáculo. Cada vez mais, no teatro contemporâneo, é concedida ao iluminador a oportunidade de participar e contribuir com o processo criativo dos espetáculos, deixando de ser apenas o responsável por tornar o espetáculo visível ou dar-lhe atributos estéticos, o que pode limitar sua ação como potente componente cênico. Para Crisafulli,

\footnotetext{
...a luz se define, então, no seio do conjunto de relações que são estabelecidas durante a construção do espetáculo e sua concretização por meio de trocas mais ou menos estreitas com outras ações e com os textos. Estes, que geralmente são escritos ou retrabalhados durante os ensaios, são influenciados pela forma como a luz é concebida pouco a pouco, da mesma forma que ela também é afetada pelos textos ${ }^{56}$ (CRISAFULLI, 2019, p. 220).
}

55 Filme documentário À Luz de Bruel: a poética da luz em Beto Bruel, realizado pela Werner Produções em 2018 e dirigido pelas cineastas Téia Werner e Silvia Gabriela sobre o trabalho do iluminador paranaense Beto Bruel.

56 "La lumière se définit donc au sein de l'ensemble des relations qui s'établissent pendant la construction du spectacle et sa concrétisation à travers des échanges plus au moins étroits avec les autres actions et avec les textes. Ceux-ci, qui sont habituellement rédigés ou réélaborés 
Essa valorização e integração cada vez maior da luz no processo criativo evidencia o potencial performativo e as capacidades de atuação e interação da luz com a cena. Isso tem feito com que diretores, encenadores e dramaturgos não só estimem, como exijam e contem com a participação e colaboração do iluminador em todo o processo criativo, desde sua concepção até a apresentação do espetáculo ao público. Alguns profissionais contemporâneos e performativos, a exemplo da iluminadora paulistana Marisa Bentivegna ${ }^{57}$, representam uma nova maneira de fazer luz, cuja operação é realizada performativamente a cada apresentação, propondo, interagindo e atuando conjuntamente com os performers de maneira que o processo criativo nunca se dê como completamente concluído e seja reinventado a cada apresentação. Ela relatou, a respeito de uma cena do espetáculo Aldeotas:

O mais interessante é que a luz não teria que correr atrás das proposições dos atores, ela poderia propor. Então, por exemplo, tinha uma determinada cena que eles deveriam nadar em um açude e tinha uma determinada luz, que era um código para esse momento. E eu poderia propor essa cena e eles poderiam embarcar ou não, mas normalmente embarcavam, porque nós trabalhávamos com esse princípio da escuta, todos os intérpretes jogando juntos ali (BENTIVEGNA, anexos, p. 158).

Esta necessidade de interação da luz com a cena faz com que, algumas vezes, haja uma imposição de que o criador da luz seja, também, o operador, visando a simbiose, durante as apresentações, entre luz e a cena, eventualmente gerada nos ensaios e nos processos de construção da dramaturgia e da encenação. A estreita relação do espetáculo com o espectador, mediada pela luz, não pode ter origem em outra forma de construção cênica. Somente o processo colaborativo ou participativo de criação, do qual tanto o iluminador quanto o operador de luz possam participar intensa e ativamente, pode permitir a criação de uma iluminação que seja, efetivamente, além de iluminar e permitir que as cenas sejam vistas, parte integrante e constituinte do espetáculo.

pendant les répétitions, se ressentent de la manière dont peu à peu la lumière se construit, tout autant qu'elle-même est influencée par les textes " (tradução da autora).

${ }^{57} \mathrm{Em}$ entrevista realizada como parte desta pesquisa, disponível nos anexos, p. 151-163. 


\subsection{Processo criativo e formação do iluminador}

Instigado pela auto-indagação a respeito do momento exato em que a iluminação é chamada para participar da constituição do visual cênico ou da visualidade do espetáculo teatral, o professor, iluminador e pesquisador Eduardo Tudella (2017) desenvolveu uma extensa e preciosa pesquisa para identificar a presença da luz na gênese do espetáculo. Para ele, a visualidade no teatro está relacionada com a "atitude crítica que orienta o iluminador e confere postura estético-poética à sua contribuição para a práxis cênica" (TUDELLA, 2017, p. 25). A atividade que Tudella qualifica como práxis cênica representa a articulação regulada entre as partes de um todo para alcançar um determinado fim, conferindo expressividade, comunicação e experimentações sensoriais a um acontecimento espetacular, efetivado na relação artista-público. Ao incorporar organicamente qualidades visuais, a práxis cênica, como manifestação artística, estabelece associações entre a luz e a cena como "qualificação visual do termo dramaturgia" (TUDELLA, 2017, p. 23).

Ao considerar a presença da luz como uma exigência da cena, Tudella delineia diferentes formas de atuação, tanto do iluminador como artista componente da equipe de criação, quanto da luz como elemento componente do espetáculo. Entrelaçando-se de modo transversal com os diferentes aspectos da cena, podendo ser convocada ao longo do processo de criação ou como etapa final do mesmo processo, a iluminação pode estabelecer, ou não, uma ligação com o desígnio espetacular do teatro. Este segundo caso lembrado por Tudella, refere-se às situações, felizmente já não tão frequentes, nas quais o iluminador se depara com o espetáculo pronto, presumindo-se que só neste momento haverá o que iluminar (TUDELLA, 2017, p. 25). Interessa particularmente a este estudo, no entanto, investigar o processo de criação da luz para a cena somente no contexto interdisciplinar que ocorre, segundo Tudella, entre o que ele define como estado pré-cênico e a cena propriamente dita. Este contexto, que se apresenta principalmente, ou quase que exclusivamente, nos processos colaborativos, é o que permite a cooperação e participação integral do iluminador 
e da luz como agentes e componentes da criação. Sendo assim, fica considerado aqui, em consonância com as afirmações do autor, que "as relações entre a luz e os demais agentes do espetáculo promovem as instâncias visuais presentes já na ideia primeira da cena" (TUDELLA, 2017, p. 25).

\title{
Para o pesquisador Flávio Desgranges,
}

\begin{abstract}
Um espetáculo teatral traça uma longa e sinuosa trajetória até se concretizar enquanto ato propriamente artístico. [...] Esta sinuosa trajetória da concretização de um acontecimento artístico tem seu princípio gerador estabelecido nas opções investigativas dos artistas, nas associações mnemônicas e elaborações estéticas que estes instauram em seus processos criativos. As táticas e estratégias definidas nos processos de produção artística estabelecem condições marcantes e indeléveis para os moldes de recepção [...] criando condições para que a escrita cênica seja percebida como poética. Desde a gênese do espetáculo, durante o processo criativo, são gerados operadores estéticos [...] que podem mostrar-se potencialmente provocativos e fecundos (DESGRANGES, 2017, p. 22).
\end{abstract}

De modo a explicar a estreita relação que ocorre entre a gênese dos processos de criação artística do espetáculo e os efeitos estéticos provocados nos espectadores, ele explica o artifício da coerência investigativa que desencadeia os procedimentos experimentais e improvisacionais com o objetivo de promover um diálogo no contexto estético e histórico entre os artistas e o público, considerando sua relevância e as pertinências de seus interesses mútuos em bases éticas e estéticas precisas. Para o cenógrafo e iluminador Eric Soyer ${ }^{58}$, os iluminadores consideram todo o conjunto de informações e são, eles mesmos, os primeiros receptores dessas informações, ou seja, nas suas próprias palavras, ele diz se sentir como "a primeira cobaia sensível em relação ao que acontece em cena" (SOYER, anexos, p. 110).

Escrever sobre o processo criativo em iluminação cênica significa considerar o trabalho coletivo que caracteriza o teatro, cujo objeto de criação não existe no fragmento ou em cada uma de suas partes, mas somente no complexo conjunto do todo que o compõe. Esse processo é constituído por uma sucessão de atividades individuais e coletivas, da qual devem participar todos os membros

${ }^{58} \mathrm{Em}$ entrevista realizada como parte desta pesquisa, disponível nos anexos, p. 109-112. 
da equipe de criação, elenco e direção do espetáculo. É importante destacar que todas as etapas de realização do espetáculo são fundamentais para o processo de criação da luz, não se devendo negligenciar a participação em qualquer uma das fases de projeto, conversas e trabalhos dramatúrgicos dos quais seja possível participar. Da mesma forma, como já foi visto, a criação de cada componente do espetáculo pode trazer importantes informações para a iluminação que será colocada em cena e conhecer seu processo de concepção certamente resultará numa interconexão muito mais fluída entre cada duas linguagens, seja luz e cenário, luz e marcação de cena, luz e sonoplastia, entre outras. Segundo Cibele Forjaz:

Cada encenador ou, em última instância, espetáculo, desenvolve uma
forma própria de escrita da luz, que deve ser analisada de acordo com
o conjunto de elementos que constrói a encenação e a composição de
uma visualidade específica, da qual a iluminação é um fator
estruturante e, portanto, relacional. [...] Assim como a luz não existe
para os nossos olhos senão em relação com a matéria e sua reflexão,
mudando totalmente de acordo com o conjunto dos elementos que
compõem um determinado campo visual e sua percepção, a
iluminação cênica só pode ser criada, vista, lida, analisada e criticada
de acordo com a forma de escrita específica a que se propõe: como
um elemento articulador da visualidade da cena, em conjunto e em
relação com a concepção do espetáculo como um todo. (FORJAZ,
2013a, p. 330 )

A afirmação da iluminadora francesa Dominique Bruguière "todo cenário contém nele a sua luz"59 (BRUGUIÈRE, 2017, p. 65) pode ser complementada pela sugestão de que não só ele, mas todo espetáculo, quando é concebido, já contenha a sua luz, que está, de certa forma, presente na mente, nas ideias e no trabalho de cada componente da equipe de criação. Cabe ao iluminador, então, decifrar essas informações, ideias e fragmentos para transformá-los em um projeto de iluminação coeso e integrado. Essa habilidade, tanto de entendimento quanto de relação com a equipe não é algo dado nem fácil de conquistar. Ela requer altruísmo, generosidade e uma compreensão profunda dos propósitos de cada artista, isso sem contar a experiência e os conhecimentos técnicos e práticos que permitem vislumbrar os resultados, as

59 « Chaque décor porte en lui en lui sa lumière » (tradução da autora). 
propostas e as possibilidades de atuação e interação da luz com os demais elementos antes mesmo que se chegue ao palco.

Quando um encenador diz que quer uma geral azul, uma coreógrafa diz que quer um pino e um músico diz que não quer luz nele, é preciso entender o que existe por trás dessas expressões e desses desejos, pois talvez não seja a uma geral azul, um pino ou à falta de luz que eles estejam se referindo literalmente. Ao contrário, é preciso entender que o que eles podem estar fazendo, efetivamente, é fornecer importantes informações a respeito do clima da cena, do destaque necessário para um solo e do incômodo que a luz frontal pode representar para a leitura da partitura ou a visualização do maestro. Alguns iluminadores se queixam que certos diretores não precisam de iluminadores, mas de técnicos montadores, pois afirmam saber o que querem e como deverá ser a luz, mas na verdade eles não sabem. Ou não sabem com certeza ou o conhecimento necessário, apenas pensam que sabem ou imaginam um determinado resultado visual, mas que muito raramente corresponde efetivamente ao que desejam ou precisam para a cena. Eles apenas visualizam, imaginam aspectos da criação conjunta e, de fato, o que conseguem verbalizar ou expressar em palavras normalmente tem pouca ou nenhuma relação com o que imaginam e necessitam. Cabe ao iluminador, com muita sensibilidade e conhecimento técnico, decifrar essas informações e transformá-las no resultado sensorial e estético adequado ao espetáculo e, acreditem, desejado pelo diretor, coreógrafo ou maestro, como os do início deste parágrafo.

Dito isso, fica clara a importância da formação do iluminador e do preparo necessário para fazer da luz uma linguagem e um componente eficiente para o espetáculo, capaz de constituir, junto com os demais elementos, o visual cênico, atendendo ao objetivo de atrair e manter a atenção do espectador pelo tempo de duração do espetáculo, como muitas vezes destacado pelo iluminador carioca Aurélio de Simoni60 a respeito da complexidade e responsabilidade do projeto de iluminação para além de atributo estético visual da cena. Questões conceituais mas mantê-lo atento e concentrado no palco por 60 ou 120 minutos é muito mais complicado". 
envolvidas na criação e realização da iluminação cênica em seus aspectos expressivos se revelam tão importantes quanto conhecer os equipamentos de luz e as instalações cênicas e elétricas de teatros e salas de espetáculo.

Tanto a iluminação quanto a cenografia em seu conceito mais amplo, são linguagens, que utilizam outro tipo de vocabulário, mas que devem dizer o mesmo que a dramaturgia e as outras criações componentes do espetáculo. 0 iluminador precisa dominar a linguagem da iluminação cênica, entender como acontece o fenômeno da luz material e como ele se relaciona com a cena e com o espectador, envolvendo questões físicas, mentais, óticas, fisiológicas, psicológicas, compositivas, perceptivas e sensoriais. É preciso traduzir a peça e suas ideias, que o cenógrafo tcheco Josef Svoboda chama de "ideia fundamental”, em sua própria língua (RICHIER, 2019, p. 199), a linguagem da cenografia e da iluminação.

É por esse entendimento que se percebe a completude e adequação da formação em design na capacitação de artistas profissionais habilitados para o domínio de tais linguagens cênicas, a exemplo de importantes encenadores, cenógrafos e iluminadores brasileiros com este tipo de formação acadêmica, como Gerald Thomas, Luciana Bueno e Marisa Bentivegna, respectivamente, para nem citar designers estrangeiros com acesso a cursos de formação específica em lighting ou performance design. Eduardo Tudella (2012) reconhece o iluminador como designer da luz ou lighting designer, cuja expressão, segundo ele, revela a intimidade deste profissional com "habilidades e competências técnicas aliadas a pressupostos estéticos que criam a visualidade de um espetáculo (TUDELLA, 2012, p. 14). Descrita de modo simples, a função do lighting designer é entendida por ele como uma atividade criativa, um labor artístico que inclui tanto uma face estética quanto outra, de natureza técnica, que interagem dinamicamente. Percebe-se assim um cuidado ou, mais precisamente, uma preocupação com a formação e o preparo intelectual deste profissional, cuja atividade prática não se limita a conectar cabos, acender refletores e dominar ferramentas tecnológicas sofisticadas. É preciso também entender a complexidade e as exigências de um trabalho 
artístico e criativo que visa, antes de mais nada, a interação com a plateia, a comunicação e a expressão de ideias, conceitos, ações e intenções estéticas performativas.

Assim como, historicamente, surgiram diversas formas de preparo do ator e do performer, existem estratégias para o preparo do iluminador por meio da aquisição de certos conhecimentos, que visam capacitá-lo para alcançar melhores resultados junto ao espetáculo e ao público. Não se trata de negar o aspecto intuitivo, inspiracional ou empírico da criação artística, muito pelo contrário, mas de entender que o teatro tem, como um de seus objetivos, a comunicação e a comunhão entre palco e plateia, que só será possível se a cena for acessível, estética e informativamente, ao público.

Em seu estudo sobre a improvisação nas artes performativas, Gisela Biancalana (2011) realizou um interessante estudo sobre as diferentes técnicas e procedimentos metodológicos para o trabalho laboratorial dos performers como sistematização do trabalho do ator na era do encenador. Associando essas competências a questões técnico-expressivas, ela traça um panorama dos diferentes treinamentos do ator no desenvolvimento de uma corporeidade poética voltada para as necessidades da cena. Como exemplos, é possível citar os conceitos de "verdade cênica" ou "segunda natureza" de Stanislavski, os "jogos teatrais" de Viola Spolin, o "corpo subjétil" de Ferracini, a "restauração do comportamento" de Schechner, o "corpo santo" de Grotowski e a "biomecânica" de Meyerhold, que afirma, a respeito da preparação do ator, que toda arte é a organização de um material que depende de uma reserva de meios técnicos para sua realização. De modo que é possível perceber aqui, a existência, em toda atividade teatral, mesmo aquelas consideradas puramente artísticas e criativas, o cuidado e o rigor na aplicação de práticas e técnicas específicas para a sua realização. Isso fica mais claro ao se constatar as horas de treinamento, ensaios e prática laboral necessárias para o bom desempenho de atores, bailarinos e músicos instrumentistas. Arte e técnica são indissociáveis e fazem parte de um mesmo conjunto de trabalho e dedicação quando se almeja alcançar um bom resultado artístico expressivo. 
Ao estender essa preocupação com a formação para o campo dos demais componentes da cena e assumir que o iluminador necessita, igualmente, adquirir e desenvolver suas competências para a criação da luz, é preciso considerar que as técnicas e os procedimentos metodológicos para o trabalho com a iluminação em seu aspecto artístico e criativo vão muito além dos conhecimentos e experiências com refletores e softwares de iluminação. Assim como o ator, o iluminador precisa conhecer e dominar as técnicas necessárias para elaborar e realizar a expressão artística da luz, o que não se limita aos equipamentos e recursos tecnológicos, mas também à organização plástica do espaço cênico pela materialidade da luz que coloca em cena, considerando a realidade física e material do teatro em suas dimensões de espaço, textura, profundidade e substância (SPOLIN, 1992 apud BIANCALANA, 2011, p. 137).

O professor Eduardo Tudella destaca a importância do preparo técnico e intelectual do profissional encarregado da iluminação de um espetáculo cênico, alertando, no entanto, que "há um risco calculado quando se decide encarar a luz como um aspecto que contribui amplamente para o espetáculo, e não como uma exclusiva questão técnica, mecânica, superficial ou até externa" (TUDELLA, 2017, p. 17). O pesquisador argumenta que "o conjunto de habilidades e competências técnicas, imprescindível como requisito parcial na elaboração da luz para a práxis cênica, torna-se discutível quando transformado em objetivo final da formação e atuação do profissional/artista" (TUDELLA, 2017, p. 27), salientando que o artista, para poder assumir a responsabilidade de conceber e planejar a luz para um espetáculo cênico deve, além de conhecer e dominar os equipamentos com os quais vai trabalhar, estar preparado para apresentar ao diretor ou à equipe envolvida no processo o que chama de proposição estéticopoética.

Nesse sentido, é compreensível que se deva valorizar, assim como no preparo do performer, também a formação crítica e intelectual, técnica e criativa do iluminador como membro da equipe de criação do espetáculo, considerando que desenvolver habilidades compositivas seja indispensável tanto para esta quanto para todas as áreas criativas do fazer teatral. Isso conduz à histórica 
relação entre artes plásticas e design quando, na primeira metade do século XX, a Bauhaus buscou, pelas ideias de seu fundador Walter Gropius, reconciliar as duas áreas de conhecimento em uma atividade que pudesse servir para, segundo o filósofo Vilém Flusser, transformar o ser humano em um artista livre (FLUSSER, 2007, p. 184). Ele relembra a "separação brusca entre o mundo das artes e o mundo das técnicas e das máquinas, de modo que a cultura se dividiu em dois ramos estranhos entre si: o ramo científico, quantificável, e o ramo estético, qualificador" (FLUSSER, 2007, 183).

Assim como Flusser, o filósofo Mikel Dufrenne também se ocupou da reconciliação entre técnica e estética (DUFRENNE, 1981, p. 241) pelas vias do que chamou de fenomenologia dos objetos. Inspirado pela "gênese da tecnicidade", de Gilbert Simondon, ele relacionou o pensamento técnico e o estético numa análise fenomenológica dos objetos que considera o acordo do ser humano e do mundo como seu principal fundamento, "a hipótese geral que fazemos do sentido do devir da relação do homem (sic) ao mundo consiste em considerar como um sistema o conjunto formado pelo homem (sic) e o mundo" SIMONDON, 1969 apud DUFRENNE, 1981, p. 239). Para Dufrenne, o objeto (da criação) pode ser estético sem querer ou solicitar sua estetização "e, também, sem perder suas outras virtudes - encanto, funcionalidade, inteligibilidade" quando é estetizado e se exprime no sensível (DUFRENNE, 1981, p. 243).

Essa tendência do objeto técnico de se oferecer como estético deve atender, segundo o autor, a três condições. A primeira determina que ele deve ser encontrado e experimentado sempre, em uma experiência cada vez singular, como uma necessidade ${ }^{61}$. A segunda condição é de que "um sentido apareça no sensível, totalmente imanente a ele", sua essência singular, expressa pelo objeto quando ela se oferece à evidência. Por fim, a terceira diz respeito ao ser do mundo. Ela impõe que, se o objeto não propõe, por vocação, um mundo que lhe

\footnotetext{
61 Para Dufrenne há, no homem (ser-no-mundo), uma premente necessidade do belo, uma sede de beleza, que só é satisfeita pelo objeto estético no campo do sensível, quando a experiência estética revela sua relação mais profunda e estreita com o mundo (DUFRENNE, 1981, p. 25). Essa necessidade igualmente reside no sensível, em sua relação no mundo, no reino das formas, das cores ou dos sons (DUFRENNE, 1981, p. 248).
} 
seja próprio, ao menos que ele se ajuste ao mundo exterior, concentrando em si a força do mundo dado e a alma e do mundo vivido (DUFRENNE, 1981, p. 248250).

O surgimento da atividade do design se deu, então, como forma de reconectar o campo estético e o campo técnico ao exprimir o vínculo estreito estre arte e técnica, ressignificando o lugar no qual os pensamentos valorativo e científico caminham juntos, viabilizando um novo tipo de cultura. Josef Svoboda afirmava, a partir de sua experiência como cenógrafo e artista visual, nos cursos e oficinas que ministrava pelo mundo, que a cenografia é uma disciplina das artes plásticas ${ }^{62}$ (RICHIER, 2019, anexo 1, p. 42). Considerando, então, a reconciliação entre artes e ofícios, da filosofia à práxis, finalmente proposta pela Bauhaus, é possível concluir que, hoje, a iluminação, assim como os demais componentes do visual cênico, são disciplinas derivadas do design, entendida aqui como formação ideal para o iluminador designer da luz. O design para a cena ou para a performance, denominação internacional da cenografia, não significa fazer coisas extraordinárias ou espetaculosas ${ }^{63} \mathrm{com}_{\text {o objetivo exclusivo }}$ de encantar o público, mas sim realizar algo que possa revelar ideias, emoções, sentimentos e sensações. Nas palavras de Svoboda:

\begin{abstract}
Eu posso ser diferente em cada cenografia, mas no fundo eu continuo o mesmo, [...] eu sou fiel ao mesmo sistema de análise, à minha concepção, minha fé no fato de que cada peça é um universo, um mundo, ou um fragmento de mundo. É esse mundo que é preciso descobrir e traduzir. [...] É por isso que o teatro é tão vivo. Mas se você não tomar esse caminho, se você não buscar o principio essencial de uma obra, então você faz simplesmente um show. Fazer coisas na minha profissão, coisas fáceis, para surpreender a multidão, eu posso fazer, eu sei fazer coisas extraordinárias, [...] mas eu sempre recusei trabalhar assim, isso seria desacreditar, depreciar os meios que eu utilizo, eu não poderia mais fazer teatro, eu não poderia voltar ao teatro porque eu teria vergonha... É essência, é preciso ter consciência dessa dimensão para fazer seu caminho64 (RICHIER, 2019, anexo 1, p. 37).
\end{abstract}

\footnotetext{
62 «La Scénographie est une discipline, est une branche des arts plastiques » (tradução da autora).

63 'O termo 'espectaculoso' se refere aqui àqueles efeitos que abrem mão do direito de interagir positivamente na cena, permanecendo na operação mecânica de projetar sobre o espetáculo uma luz 'bonita"' (TUDELLA, 2017, p. 32).

64 « Je peux être différent dans chaque scénographie, mais au fond je reste le même. [...] je suis fidèle à ce système d'analyse, à ma conception, ma foi dans le fait que chaque pièce est un univers, un monde, ou un fragment de monde. C'est ce monde qu'il faut découvrir et traduire [...].
} 
Relatos de muitos dos iluminadores entrevistados para esta pesquisa ${ }^{65}$ confirmam essa assertiva ao afirmar que, se possível, preferem que o espectador não se dê conta racionalmente ou não "veja" a sua luz, mas perceba-a integrada ao conjunto da visualidade da encenação, a exemplo tanto do experiente iluminador Aurélio de Simoni66, ao revelar que: "Tem muita gente que chega para mim e diz: 'Aurélio, eu adorei a luz', e eu digo: 'Ah, que maravilha, que bom, mas você ouviu o texto? Você viu o cenário? Você viu que ator maravilhoso?"' (DE SIMONI, anexos, p. 45) quanto, igualmente, a queixa do jovem artista Lucas Amado67: "Eu nunca gosto quando alguém elogia uma luz minha e eu percebo que ela está indo além da obra" (AMADO, anexos, p. 144).

O projeto de iluminação inserido em um contexto criativo coletivo não deve almejar somente aplausos ou prêmios, ensejando ser percebido em destaque ou além do conjunto cênico, sobrepondo-se ou protagonizando a ação por meio de efeitos pirotécnicos, movimentos ou desenhos obtidos pelo uso, se inadequado, de sofisticados equipamentos, aparelhagens ou fumaça em excesso. Ao contrário, a iluminação deve ter um propósito maior, transmitir um conceito, estar alinhada com as diretrizes da encenação e compactuar com a cena em sua interação com o observador. Ela deve compor com os demais elementos do espetáculo para expressar uma ideia comum e transformá-la em imagem fluída e diluída no conjunto do que se apresenta ao espectador, que acaba por concluíla ao adicionar seu próprio olhar e repertório à experiência estética do teatro. 0 iluminador Wagner Pinto68 demonstrou compartilhar dessa opinião ao afirmar que "Quando você tem um projeto de luz que é maior, ou seja, que aparece mais que o espetáculo, alguma coisa está errada..." (PINTO, anexos, p. 223).

C'est pour ça que le théâtre est tellement vivant. Mais si vous ne prenez pas ce chemin-là, si vous ne cherchez pas le principe essentiel d'une œuvre, alors vous faites simplement un show. Faire des choses dans ma branche, des choses faciles, pour épater les foules, je peux le faire, je sais faire des choses extraordinaires, mais $j$ ai toujours refusé de travailler comme ça, ce serait discréditer, déprécier les moyens que j'utilise, je ne pourrais plus faire di théâtre, je ne pourrais plus y revenir parce que j'aurais honte... C'est essentiel, il faut prendre conscience de cette dimension pour faire son chemin » (tradução da autora).

65 Entrevistas disponíveis nos anexos, p. 28-233.

66 Em entrevista realizada como parte desta pesquisa, disponível nos anexos, p. 37-47.

67 Em entrevista realizada como parte desta pesquisa, disponível nos anexos, p. 142-150.

${ }^{68} \mathrm{Em}$ entrevista realizada como parte desta pesquisa, disponível nos anexos, p. 221-233. 
Com isso se evidencia, como abordado por Biancalana (2011), a importância do domínio técnico-expressivo do iluminador que pode, de certa forma, ser adquirido por meio da formação em design. Os conhecimentos teóricos, a exemplo das teorias da informação, da comunicação, da forma e da cor; dos estudos em semiótica, estética, ergonomia e percepção visual; além dos exercícios de composição da imagem no plano e no espaço e das práticas com o desenho gráfico podem subsidiar e embasar a criação da luz e garantir resultados mais efetivos. Segundo Svoboda, para criar o visual cênico "é preciso saber desenhar!" (RICHIER, 2019, anexo 1, p. 42). O conhecimento e a habilidade no contexto da criação teatral apresenta, assim, relação direta com os conceitos do design, considerando sua abordagem contemporânea como um processo integrativo, um sistema abrangente cujo valor está na oportunidade de contribuir (HILU, 2016, p. 231) e não reside no produto final, mas no ato de fazêlo. Não está no resultado, mas no processo (HILU, 2016, p. 228).

Conclui-se, assim, com que propriedade e pertinência os estudos e práticas do design podem fornecer ao iluminador as reservas técnicas (no sentido do domínio da linguagem e expressão gráficas) e os conhecimentos necessários para o desenvolvimento adequado de suas competências artísticas e compositivas, bem como para o emprego adequado dos recursos tecnológicos de que dispõe. Tanto numa esfera cultural e artística quanto social, o design é um campo para o qual convergem diferentes disciplinas, uma atividade projetual ou conceitual, um processo com resultados tangíveis, "um meio para adicionar valor às coisas produzidas pelo homem (sic) e também como um veículo para as mudanças sociais e políticas" (FONTOURA, 2002 apud HILU, 2016, p. 228).

A designer, professora e pesquisadora Luciane Hilu (2016) argumenta que diversos fatores "mudaram a forma de pensar o mundo e o design, que deixou de pensar os artefatos desconectados da sociedade para pensar a sociedade como um todo, adquirindo funções sociais e projetando soluções para um mundo real. Segundo ela:

O design pode ser entendido como uma atividade de resolução de problemas, interdisciplinar, que combina sensibilidade com habilidade e conhecimento nas áreas das artes, tecnologia, da ciência e da 
economia, se situando entre o homem ( $\mathrm{sic}$ ) e o mundo artificialmente proposto, Considera-se que o designer deve assegurar um equilíbrio entre estes diversos componentes de forma a atender aos ensejos sociológicos e culturais, artísticos, tecnológicos, científicos e mercadológicos que envolvem diferentes dimensões humanas" (HILU, 2016, p. 228).

Almejando atender às demandas da criação cênica e estabelecer um discurso coerente com a linguagem e tendências da cena contemporânea, o projeto de iluminação precisa ir além da criatividade e da concepção estética e formal, mas tornar-se mais amplo e complexo, incorporando conceitos e ideias, meios e processos, ferramentas e sistemas que viabilizem sua realização. Com essas características a iluminação demanda um profissional que foque sua atenção na geração de soluções e resolva problemas através da prática sistemática da crítica, seja um especialista que conceitua e articula ideias em experiências tangíveis" (HILU, 2016, p. 230). Entender que "o processo do design-entendido como prática reflectiva ou co-evolução de problema e solução no paradigma da emergência - corresponde nas suas fases e mecanismos a todo e qualquer processo criativo ou processo [...] em qualquer domínio que seja" (TSCHIMMEL, 2010 apud HILU, 2016, p. 252) é o que permite estender a abrangência da atuação do designer para o universo teatral. Segundo Hilu, o design é compreendido como um processo social sustentado no engajamento de uma ampla gama de perfis de indivíduos, cuja formulação de problemas comuns conduz a soluções coletivas de natureza integrativa.

A estratégia e visão globalizante de criação, característica das práticas do design, também conhecida como design thinking, ou pensamento em design, compreendido como um processo impregnado de conhecimento, no qual o agente produz e compartilha o conhecimento (HILU, 2016, p. 253-254). Como abordagem estrutural e ampla, Luciane Hilu afirma que esta mentalidade pode ser incorporada em variados tipos de equipes e/ou projetos, induzindo processos exploratórios e interativos que residem no centro de processos criativos. $O$ "design thinking é essencialmente um processo de inovação centrado no ser humano que enfatiza observação, colaboração, aprendizado e visualização de ideias" (LOCKWOOD, 2006 apud HILU, 2016, p. 255). Ele busca incrementar a criatividade nas tomadas de decisões por meio de hábitos sistêmicos, permitindo 
ao iluminador um entendimento holístico do processo relativo à concepção e execução da luz, desde a problemática surgida no processo de construção e elaboração do espetáculo até a recepção por parte do espectador. Isto posto, visto não haver, no Brasil, uma formação específica em iluminação cênica, a formação em design gráfico revela-se como a mais adequada para formar iluminadores, em detrimento da formação em licenciatura, interpretação e direção teatral, como é usual, tanto pelo teor do seu conjunto de disciplinas quanto pela abordagem empregada no processo e na metodologia da criação.

\begin{abstract}
Enquanto pensamento. o Design Thinking é estruturado em busca de um continuum de inovação envolvendo um grupo de indivíduos em colaboração e cocriação. Sua matriz mental é baseada na experimentação, deixando os participantes do processo abertos a novas possibilidades e dispostos a propor novas soluções. Combina empatia no contexto de um problema, de forma a colocar as pessoas no centro do desenvolvimento de um projeto. O design migra da posição de ser para as pessoas, para ser com as pessoas, e ainda ser pelas pessoas por si só, em um processo de criação gerado pelos próprios indivíduos que passam a ser ver como participantes ativos no processo de criação (HILU, 2016, p. 256).
\end{abstract}

A empatia, tida como a "capacidade de desenvolver conexão com as pessoas em um nível fundamental, a fim de proceder à ação centrada no ser humano" (HILU, 2016, p. 257), pode surgir no processo criativo teatral desde 0 momento em que é feito o convite para integrar a equipe de criação de um novo espetáculo, seja de maneira formal ou em uma simples conversa corriqueira. Nessa ou numa conversa posterior ao aceite, as linhas gerais da montagem são compartilhadas pelo diretor, pelo grupo ou qualquer outro membro que se coloque como proponente do projeto, ocupando a mente do iluminador até o início da sua efetiva realização.

Essa etapa, também conhecida como incubação, é, diferente de outras mais ativas e participativas, uma fase passiva, individual e, principalmente, inconsciente. Essa etapa constitui um dos momentos mais importantes do processo, pois é quando o artista se coloca em estado de alerta e passa a absorver e armazenar toda e qualquer informação, que possa ter alguma relação com o projeto, em seu repertório de "ferramentas" conceituais, seu banco de dados que será espontaneamente acessado durante o real processo de criação. 
O relato do iluminador Renato Machado ${ }^{69}$ revela a importância dessa fase no seu processo criativo: "Eu vou estrear uma peça no início deste ano com a PeQuod, uma montagem de Pinóquio, da qual nós já estamos falando desde meados do ano passado. Então, você já está envolvido com aquilo há mais tempo, o que te permite fazer um trabalho mais preciso" (MACHADO, anexos, p. 188). A intuição, a criatividade e a competência projetual do designer se aliam, então, para conceber um projeto de iluminação específico e adequado ao espetáculo ao qual se destina, considerando todas as suas particularidades, da concepção, profundamente engajada com a criação coletiva, à execução, com todo seu rigor técnico relativo ao equipamento, ferramentas e realização da luz durante as apresentações públicas.

Como alguns dos aspectos mais obscuros do processo criativo, a inspiração, a intuição e a criatividade, foram e são ainda profundamente investigados por sociólogos, psicólogos e psicanalistas, que exploram o tema e tentam explicar como se dão esses procedimentos na mente de artistas, designers e criadores em geral. Existem muitos entendimentos alegóricos sobre a criação, destituindo do processo de inspiração e criatividade qualquer traço de razão ou pensamento científico, reservando a ela, exclusivamente, o campo da intuição e do empirismo. Donis A. Dondis (2007), em uma obra dedicada a explorar o conceito de alfabetismo visual, na qual investiga uma maneira de "controlar os complexos meios visuais com alguma certeza de que, no resultado final, haverá um significado compartilhado" (DONDIS 2007, p. 29), busca esclarecer alguns desses entendimentos equivocados sobre a criatividade.

Talvez devido à flexibilidade e casualidade desse passo [...] a elaboração de manifestações visuais costuma ser associada a atividades não cerebrais. Uma série de esboços rápidos e ostensivamente indisciplinados certamente não sugere nenhum tipo de rigor intelectual. Afinal, o artista é visto como que se estivesse num estado hipnótico, "no mundo da lua", enquanto toma as suas decisões. $\mathrm{O}$ que é que realmente acontece? $\mathrm{Na}$ verdade, o artista, designer, artesão ou comunicador visual está envolvido num ponto crucial de tomada de decisões, num processo extremamente complexo de seleção e rejeição. [...] $O$ talento, o controle artístico do meio de expressão e a intuição costumam ser vistos de um modo um tanto confuso. [...] Nas questões visuais, a apreensão imediata de significado faz com que tudo pareça muito fácil para ser levado a sério

69 Em entrevista realizada como parte desta pesquisa, disponível nos anexos, p. 184-195. 
intelectualmente. E comete-se com o artista a injustiça de privá-lo de seu gênio especial. [...] Qualquer aventura visual, por mais simples, básica ou despretensiosa que seja, implica a criação de algo que ali não estava antes, e em tornar palpável o que ainda não existe (DONDIS, 2007, p. 135-136).

A autora complementa explicando que não considera a inspiração e a intuição como métodos irracionais do processo de criação do designer, para o qual são necessários, segundo ela, um planejamento cuidadoso, a constante indagação intelectual e o conhecimento técnico dos elementos e das técnicas do design para, através de suas estratégias compositivas, buscar e encontrar soluções visuais para os problemas de beleza e funcionalidade, de equilíbrio e reforço entre forma e conteúdo. Apesar de sugerir e valorizar o rigor técnico e o controle na criação, buscando esclarecer visões equivocadas, a autora desmistifica, mas estima, o talento e a capacidade criativa do designer artista, cuja inspiração e criatividade atuam de forma aliada à técnica na concepção e manifestação das intenções expressivas do objeto de sua criação.

A análise do processo criativo na arte e no design permite associações conceituais entre a intuição, a imaginação e a criatividade. Enquanto que a intuição tem relação com sensações, impressões e pressentimentos, um sextosentido que permite conexões empíricas, a imaginação permite o contato com uma reapresentação mental do ainda inexistente e a criatividade é mais relacionada à inteligência, ao talento, nato ou adquirido, e à capacidade inventiva dos indivíduos. A capacidade criativa é, muito frequentemente, associada também à capacidade ou predisposição para a observação, para um novo olhar sobre as coisas, mesmo as mais corriqueiras, um olhar atento e perceptivo, diferenciado a ponto de permitir uma flexibilidade cognitiva que, associada à imaginação, torna-se elemento fundamental para a criação. Albert Einstein, fazendo alusão ao uso da intuição e da inspiração, afirmou que a imaginação é mais importante que o conhecimento, pois enquanto o conhecimento é limitado, a imaginação abrange o mundo e estimula o progresso, dando luz à evolução ${ }^{70}$.

70 Conhecida e amplamente divulgada citação do físico e cientista alemão Albert Einstein publicada no livro "Sobre Religião Cósmica e Outras Opiniões e Aforismos" em 1931. 
Como artista plástica e investigadora sobre os processos criativos, Fayga Ostrower (1991) aborda a criatividade pelo viés da constituição do ser criativo como ser sensível, cultural e consciente, cujos caminhos intuitivos e inspirações conduzem à criação como formação e concepção de algo novo, de fenômenos relacionados de modo novo e compreendidos em termos novos. A autora associa o potencial criativo à sensibilidade que, "por se vincular, no ser consciente, a um fazer intencional e cultural em busca de conteúdos significativos, se transforma e torna-se, ela mesma, faculdade criadora" (OSTROWER, 1991, p. 17). O ato criativo se realiza, então, segundo a autora, no nível do sensível, com base em memórias, associações e simbologias inerentes ao ser criativo, que as ordena e configura dentro de um contexto específico como objeto, ação, ideia ou teoria (OSTROWER, 1991, p. 79).

Artistas, designers cênicos, cenógrafos e iluminadores têm muito a dizer sobre a criação no teatro, seus processos e sua relação com cada obra realizada $^{71}$, bem como sobre intuição, inspiração e criatividade, a exemplo dos depoimentos de Svoboda a respeito de sua sensibilidade para a arte, da influência que telas, esculturas e poemas tiveram sobre sua criação e sua maneira de conduzir seus processos criativos.

... quem não é atraído pelo teatro ou pela arte em geral, quem não sabe ler um poema ou uma peça com o coração, mas somente com o intelecto para acumular conhecimentos, não está no bom caminho. Eu nunca leio uma peça como intelectual, com um conhecimento préestabelecido. Eu a leio e pode me acontecer de chorar, eu não tenho vergonha de me sentir tocado. Eu serei arguto mais tarde, quando eu farei a análise, mas minha primeira leitura é a de uma boa dama (sic) que gosta de sentir emoções sensíveis quando vai ao teatro. É claro que eu tenho alguma experiência, ela tem seu peso, esse primeiro olhar não é absolutamente novo, mas é indispensável. É uma maneira de manter um rumo. De não me lançar em um deserto inacessível ao

\footnotetext{
${ }^{71} \mathrm{~A}$ realidade do confinamento e do isolamento social instaurados pela pandemia que assolou 0 planeta Terra na primeira metade do ano 2020 ocasionou uma supervalorização e utilização dos meios virtuais de comunicação entre as pessoas, com apresentações artísticas, vídeo-aulas, tutoriais e depoimentos de todo tipo, qualidade e conteúdo. Uma das suas mais frutíferas ações para o meio do teatro, do design cênico e da iluminação foi a avalanche de entrevistas de iluminadores e iluminadoras a respeito de sua trajetória profissional ou acadêmica e criações artísticas, como na série Lighting Studio, no canal do YouTube da SP Escola de Teatro, ou o canal Da ideia à Luz de Marcelo Santana e Wallace Rios, depoimentos e lives, como as iniciativas dos perfis no Instagram de César Pivetti e o Mulheres na Luz de Luana Melo Franco, material tanto efêmero exclusivo para os ouvintes e espectadores online quanto registrado e disponibilizado, na internet, para usos e proveitos futuros.
} 
espectador. As coisas ilegíveis para o espectador não têm impacto sobre ele ${ }^{72}$ (RICHIER, 2019, anexo 1, p. 78-79).

Valmir Perez dedicou boa parte de sua pesquisa, já publicada (PEREZ, 2012b), à inspiração da iluminação cênica em pinturas e obras de arte universais e Henk van de Geest, um iluminador holandês, ao abordar o questão da inspiração na criação da luz ${ }^{73}$ também relembrou a relação íntima da iluminação cênica com a observação da natureza, dos fenômenos físicos da luz natural e artificial e da luz nas obras de arte. A percepção da luz natural é igualmente relatada por Svoboda como importante fonte de inspiração para suas criações, a exemplo de obras criadas para Giorgio Strehler: "Não é fácil de conseguir climas atmosféricos verdadeiros no teatro, tem tudo o que a natureza cria, o sol, a atmosfera... [...] A luz passa através de um grande filtro, profundo e quase imaterial, é uma qualidade de difusão que não sabemos fazer no teatro", alertando, inclusive, para o cuidado com que essa inspiração deve ser tratada pelo iluminador: "Se inspirar com a luz natural pode ser maravilhoso [...], mas não se trata de reproduzir uma paisagem em todos os seus detalhes, eu retenho somente a qualidade da luz"74 (RICHIER, 2019, anexo 1, p. 83-84).

A designer e pesquisadora Raquel Rohenkohl qualifica a criatividade, simplesmente, como a capacidade de criar coisas novas (ROHENKOHL, 2012, p. 45), mas classificando-a em três tipos de expressão criativa: a criatividade

\footnotetext{
72 «... celui qui n'est pas attiré par le théâtre ou l'art en général, celui qui ne sait pas lire un poème ou une pièce avec le cœur, mais seulement avec l'intellect pour accumuler de connaissances, celui-là n'est pas sur le bon chemin. Je ne lis jamais une pièce en intellectuel, avec un savoir préétabli. Je la lis et il peut m'arriver de pleures, je n'ai pas honte de me sentir touché. Je serai malin plus tard, quand j'en ferai l'analyse, mais ma première lecture est celle d'une brave dame qui aime ressentir des émotions sensibles quand elle va au théâtre. Bien sûr j'ai une certaine expérience, elle a son poids, ce premier regard n'est pas absolument neuf, mais il est indispensable. C'est une manière de tenir un cap. De ne pas m'égarer dans un désert inaccessible au spectateur. Les choses illisibles pour le spectateur n'ont pas d'impact sur lui " (tradução da autora).

${ }^{73}$ Conferência Inspiration for Lighting no E-Scapes - Conferência Internacional de Design para a Performance, realizada na Praça das Artes da Fundação Theatro Municipal em São Paulo entre 10 e 14 de agosto de 2014.

74 «Ce n'est pas facile de réussir vraiment des ambiances atmosphériques au théâtre, il y a tout ce que crée la nature, le soleil, l'atmosphère... [...] La lumière passe à travers un grand filtre, profond et presqu'immatériel, c'est une qualité de diffusion que l'on ne sait pas faire au théâtre " "S'inspirer de la lumière naturelle peut être merveilleux [...] mais il ne s'agit pas de reproduire un paysage dans tous ses détails, je retiens seulement la qualité de la lumière " (tradução da autora).
} 
artística, a científica e a conceitual. Em seus estudos, a criatividade relacionada ao design é abordada no sentido conceitual, diferenciando-se tanto da criatividade puramente artística, que não apresenta um compromisso com a comunicação ou com a informação, nem uma preocupação com o receptor, espectador ou observador final, quanto da criatividade científica, exclusivamente comprometida com a investigação, experimentação e verificação de hipóteses científicas e tecnológicas.

Rohenkohl considera a capacidade criativa fundamental para a atividade do designer e alerta para a constante cobrança de originalidade e ineditismo na concepção de produtos ou obras. A originalidade, a fluência e a flexibilidade representam as três características cognitivas da pessoa criativa. Além dessas, Razeghi (2008 apud ROHENKOHL, 2012, p. 47) destaca ainda a especialidade de produzir soluções relevantes para problemas existentes, identificando os diferentes níveis da prática processual da criatividade no design como sendo preparação, incubação, iluminação e verificação, que podem ser relacionados às etapas projetuais da criação em iluminação cênica ${ }^{75}$, independente do tipo de processo criativo a que se refere.

A preparação teria início a partir do primeiro contato com a proposta e as conversas com o diretor, dramaturgo e equipe de criação. A incubação, como já citado anteriormente, refere-se ao período em que, de posse da temática e das proposições estético-poéticas do espetáculo, o designer passa a absorver referências, informações e ideias que poderão, ou não, serem usadas na criação final. Segundo Baxter (2000 apud ROHENKOHL, 2012, p. 48), é quando todas as informações essenciais para a criação são reunidas e processadas pelo inconsciente principalmente nos momentos em que o consciente não está em atividade. A fase da iluminação é a etapa da criação propriamente dita, na qual

\footnotetext{
$75 \mathrm{O}$ entendimento dessa associação entre os níveis criativos da prática processual do design para o processo criativo do teatro podem variar conforme o tipo de processo (colaborativo, coletivo, tradicional, textocentrista, entre outros), tipo de espetáculo cênico (teatro, dança, música, ópera, artes circenses, performance, entre outros) ou ainda formato teatral (dramático, pós-dramático, performativo, entre outros), mas seguem, invariavelmente, uma mesma estrutura.
} 
acontece a participação nos ensaios e o acompanhamento dos processos criativos dos demais membros da equipe de criação.

Por fim, a verificação, definida como a fase em que a ideia criativa é conscientemente examinada e aplicada, faz referência tanto ao ensaio técnico, quando a luz criada é testada, demonstrada e aprovada pelo diretor, encenador, coletivo ou equipe de criação, quanto à sua apresentação pública, seu objetivo final, quando ela é confrontada à percepção do espectador. Ainda parte da fase de verificação do processo criativo do design, estão as etapas de materialização da solução criada, revisão, retoque e aperfeiçoamento (ROHENKOHL, 2012, p. 51), facilmente associáveis à montagem, ensaio técnico e ajustes no projeto de iluminação do espetáculo.

O processo criativo fundamentado na visão holística do designer irá considerar tanto as demandas do encenador, o contexto do espetáculo e as necessidades dos performers em cena quanto as características cenográficas, as condições técnicas de montagem, os equipamentos disponíveis e as condições do teatro e do palco em questão, além, é claro, da importante preocupação com o espectador, a verdadeira razão de ser do teatro, a quem toda obra se destina, com suas características, grupo social e cultural a que pertence, seu repertório, ponto de vista e, até, possíveis expectativas em relação a um determinado trabalho. Colocar-se no lugar no espectador, tanto metafórica quanto fisicamente, na plateia, faz com que o iluminador nunca deixe de considerar o ponto de vista e a experiência sensorial daquele que efetivamente dará o real sentido à cena, anexando a ela suas próprias referências e emoções.

O artista ou performer em cena é, igualmente, ponto de atenção e preocupação no processo de criação em seus dois aspectos sensoriais, o físico e o emocional. Tanto a luz deve lhe conceder o clima e o ambiente para uma boa realização da cena, colocando-o no mesmo estado luminoso e perceptivo que o público, quanto não deve ofuscá-lo ou atrapalhar sua movimentação e deslocamento em cena. A luz ainda pode auxiliá-lo na orientação e localização relativas ao espaço e aos elementos cenográficos, presentes no palco ou imaginários, interagindo com eles e colaborando com sua atuação e 
desempenho cênico ou dramático. Desgranges explica que, num processo colaborativo, "as resoluções não são estabelecidas previamente e depois levadas para a cena, tomando o texto dramático como centro da produção em face do qual se definem as opções de encenação" (DESGRANGES, 2017, p. 31). A inspiração surge do processo, que se engendra de maneira cooperativa com a participação de todos os envolvidos, atuando conjuntamente durante o decorrer da pesquisa. Segundo o autor, "as opções cênicas não surgem como determinações vindas de fora, mas das entranhas das próprias investigações artísticas". Antônio Araújo explica, em um de seus depoimentos publicados, a criação no processo colaborativo, cuja perspectiva de compartilhamento permite a realização de uma atividade na qual "o ator traz elementos para a cenografia que, por sua vez, propõe sugestões para o iluminador, e este para o diretor, numa frequente contaminação" (ARAÚJO, 2018, p. 16).

O aspecto humano da criação cênica considera, sem exceção, todos os envolvidos: encenador, dramaturgo, performers e equipe de criação, montagem e execução. Todos indivíduos, com reservas, habilidades, limitações e sentimentos que demandam respeito e atenção. A catastrófica dicotomia entre arte e técnica dividiu a cultura ocidental, até o final do século XIX, em dois ramos distintos, o científico e o estético. Separando o inseparável: o mundo das artes e da técnica e das máquinas, gerou consequências igualmente desastrosas nas relações humanas, como a distinção entre artistas e técnicos. Não há um só domínio das artes que não exija rigor técnico para o alcance da excelência. É inconcebível o desempenho de qualquer atividade das artes da cena por um artista desprovido de domínio técnico. Todo profissional envolvido em uma realização cênica necessita tanto de habilidades técnicas e competência quanto de sensibilidade, sutileza e capacidade artística para desempenhar, como se espera, uma operação de luz, de som ou do maquinário cênico. Tão técnico e artista quanto qualquer ator, bailarino ou músico quando executam, com igual primor, a obra criada por um diretor, coreógrafo ou compositor, acrescentando a ela suas aptidões e habilidades técnicas, artísticas e criativas. 


\subsubsection{Funções e Variáveis da Luz}

Com o objetivo de atender a todas as demandas, das solicitações do encenador ou necessidades individuais e contexto específico dos diferentes componentes do espetáculo, até a recepção por parte do público, além das condições técnicas disponíveis, é preciso haver, por parte do iluminador, um entendimento global dos resultados a serem alcançados pelo projeto de iluminação, entendendo que, neste caso, não se trata apenas de clarear a cena ou torná-la bela, mas de interagir com o que acontece e chegar até o espectador. O processo do design, que "começa com a definição de um propósito e avança através de uma série de questões e respostas no sentido de uma solução" (BERNSTEIN, 1995 apud HILU, 2016, p. 228) e cuja metodologia representa "o caminho pelo qual se chega a um dado resultado" (HILU, 2016, p. 248) revelase como procedimento ideal para a criação da luz atingir esses resultados.

Luciane Hilu (2016) desenvolve o tema da criação com base no processo de design thinking que, apesar de não possuir natureza linear, apresenta etapas que se permeiam e se reconfiguram num processo interativo (HILU, 2016, p. 258). As diferentes etapas do processo criativo do design, segundo suas pesquisas, incluem a imersão, na qual é constatado o problema em questão; a análise e síntese; a ideação, que é a criação propriamente dita e a prototipação, quando as soluções são testadas e selecionadas. Para Fontoura (2002 apud HILU, 2016, p. 249), "o design faz uso da metodologia e de técnicas [...] no desenvolvimento prático de projetos e na solução de problemas projetuais. As metodologias, os métodos e as técnicas fazem parte do processo de design".

Relacionar o processo da criação do design e o de criação cênica forneceu a síntese necessária para a elaboração de uma metodologia de criação da luz. O entendimento do trabalho holístico do iluminador face ao espetáculo, suas proposições e o trabalho do restante da equipe de criação foi associado ao objetivo de formatar, originalmente com fins pedagógicos, uma abordagem estratégica da criação cênica. O resultado foi a elaboração de um procedimento 
metodológico empregado tanto em processos criativos profissionais quanto em aula, organizado em duas etapas chamadas de funções e variáveis da luz.

A primeira, relacionada à etapa do design de "identificação do problema", se destina ao entendimento das funções da luz no espetáculo, ou seja, aquilo que se espera dela, em todos os níveis, a sua ação cênica e tudo o que a equipe de criação, o elenco e o espectador demandam como efeito, resultado poético e sensorial ou ambiente cênico. Classificadas em três grupos principais, as funções da luz no espetáculo são:

- práticas

- semânticas

- estéticas

As funções práticas dizem respeito às funções primevas de visibilidade $\mathrm{e}$ condução da atenção do espectador pela área cênica ou de atuação. O professor Eduardo Tudella (2017) explorou longamente em sua pesquisa a questão da visibilidade, diferenciando-a da visualidade e relacionando-a diretamente com a capacidade humana de ver (TUDELLA, 2017, p. 42). Ainda sobre o aspecto da visibilidade, Aurélio de Simoni ${ }^{76}$ declarou que, para ele, uma das funções da luz é a de "mostrar o trabalho dos outros" (DE SIMONI, anexos, p. 38), enquanto que o iluminador e pesquisador Roberto Gill Camargo ${ }^{77}$ demonstrou reconhecer o poder da luz como "manipuladora do olhar" (GILL CAMARGO, anexos, p. 202), alertando para o cuidado que julga ser preciso ter com essa manipulação, que não deve ser esse o maior interesse do iluminador sob o risco de limitar o sentido e a interpretação da cena por parte do espectador (GILL CAMARGO, anexos, p. 199). Por outro lado, o reconhecido iluminador carioca Paulo Cesar Medeiros ${ }^{78}$ admitiu a condução do olhar do espectador como uma importante função da luz que, segundo ele, "respira, tem texturas, tem quentes e frios, muda de estado, de intensidade, direciona o olhar, dá valor a esse ou aquele elemento (MEDEIROS, anexos, p. 182). Além da visibilidade, ou seja, de permitir que o que está em cena seja visto, a luz, por meio desse acesso visual do espectador

\footnotetext{
76 Em entrevista realizada como parte desta pesquisa, disponível nos anexos, p. 37-47.

77 Em entrevista realizada como parte desta pesquisa, disponível nos anexos, p. 196-204.

${ }^{78} \mathrm{Em}$ entrevista realizada como parte desta pesquisa, disponível nos anexos, p. 181-183.
} 
ao espetáculo, permite que se estabeleça a visualidade, o que quer dizer a relação sensorial instaurada entre ambos.

As funções semânticas da luz se relacionam diretamente com a capacidade de representação simbólica da luz, ou seja, aquilo que ela pode significar ou representar em cena como objetos, situações, climas, efeitos, ausências ou presenças efêmeras substituídas por fachos de luz ou ambientes luminosos. Alguns autores contemporâneos dedicaram para de seus estudos à função simbólica da luz como Patrice Pavis (2005) e Roland Barthes (2007), mas foi principalmente por intermédio dos membros do Círculo de Praga que suas teorias se difundiram. Neste círculo surgiram importantes textos, reunidos na publicação constantemente reeditada de Jacó Guinburg (2006) como o título de Semiologia Teatral. Tadeusz Kowzan (2006) faz alusão a uma subconsciência semiológica em todos que se ocupam do espetáculo e afirma que "a arte do espetáculo é, entre todos os domínios da atividade humana, aquela onde o signo manifesta-se com maior riqueza, variedade e densidade" (KOWZAN, 2006, p. 97). Sobre outros dos textos inclusos na mesma publicação, Christine Richier destaca de que forma esses pesquisadores, a partir do conceito wagneriano de Gesamtkunstwerk, defendiam a ideia de uma arte teatral cujo centro e unidade impedia que fosse reduzida a um simples agrupamento de outras artes (RICHIER, 2019, p. 96). Jindrich Honzl (2006) a partir da visão de Zich da representação considerada como um conjunto de signos para afirmar que:

A partir do momento [...] que o palco não ficava limitado por sua
arquitetura, todos os outros fatores do fenômeno teatral precipitam-se
pela brecha assim aberta: a personagem, ligada até então à mímica do
homem (sic), à mensagem do autor (que até aqui era apenas uma fala)
e descobrimos surpresos que o espaço cênico não é necessariamente
um espaço, mas que o som pode igualmente representar um palco,
que a música pode ser o evento, o cenário é a mensagem (HONZL,
2006, p. 129).

No entanto, a semiologia teatral vem sendo recentemente bastante questionada para dar conta da complexidade do fenômeno teatral contemporâneo em suas vertentes performáticas e performativas. "Segundo Marvin Carlson, enquanto o teatro era considerado e entendido como meio de informação e comunicação, a semiótica bastava para explica-lo e justifica-lo. 
Porém, quando passa a ser experiência e compartilhamento, é preciso encontrar ferramentas no campo da percepção e da recepção que auxiliem sua análise e compreensão teórica" (LUCIANI, 2014, p. 180).

Por fim, as funções estéticas se relacionam aos aspecto da luz como expressão. Segundo a teoria proposta por Jauss (1978), em primeiro lugar, está a forma de expressão e vivência do artista em relação à obra de arte, sua poética, também entendida como procedimento, estilo ou técnica empregada, e poiética, relacionada ao fazer, à criação e à realização da obra propriamente ditas. Em seguida, é reativa à experiência do espectador no ato de percepção da obra e os efeitos provocados por ela. Por fim, faz alusão à identificação surgida entre a obra ou o artista e o observador, ou seja, as interferências e alterações mútuas provocadas em um pelo outro, nos dois sentidos.

A segunda etapa do processo de criação da luz, relativa à "busca de solução" do design, equivale às escolhas do iluminador na definição das características da luz que dará forma ao que ilumina. Esse é o cerne do processo criativo com base nos princípios do design, pautado nas decisões, ou seja, na escolha de uma solução gráfica de cor, tamanho, forma, posição, em detrimento de outra, considerando os objetivos e premissas da criação e dos resultados esperados. Para Donis A. Dondis,

\begin{abstract}
Uma mensagem é composta tendo em vista um objetivo: contar, expressar, explicar, dirigir, inspirar, afetar. $\mathrm{Na}$ busca de qualquer objetivo são feitas escolhas através das quais se pretende reforçar e intensificar as intenções expressivas. [...] Isso exige uma enorme habilidade. A composição é o meio interpretativo de tentar controlar a reinterpretação de uma mensagem visual por parte de quem a recebe. O significado se encontra tanto no olho do observador quanto no talento do criador. O resultado final de toda experiência visual, na natureza e, basicamente, no design, está na interação de polaridades duplas: primeiro, as forças do conteúdo (mensagem ou significado) e da forma (design, meio ou ordenação); em segundo lugar, o efeito recíproco de articulador (designer, artista ou artesão) e do receptor (público espectador). Em ambos os casos, um não pode se separar do outro. A forma é afetada pelo conteúdo; o conteúdo é afetado pela forma. A mensagem é emitida pelo criador e modificada pelo observador (DONDIS, 2007, p. 131-32).
\end{abstract}

Pamela Howard descreve o momento das escolhas pelas quais o designer toma as decisões que darão forma e significado ao seu trabalho, como a etapa 
da emoção da composição. Para ela, "escolhas são feitas e decisões são tomadas o tempo todo no processo de composição" (HOWARD, 2015, p. 150), é o momento instigante que ela chama de busca e caça. Ao conjunto das escolhas a serem feitas durante o processo de criação do projeto de iluminação para um espetáculo, foi dado o nome de variáveis da luz, a saber:

- equipamento

- posição

- cor

- movimento

Essas decisões, tomadas pelo iluminador no momento da criação, dizem respeito a cada um dos efeitos a ser usado, isoladamente ou em conjunto com outros, na construção das cenas. A primeira escolha é relativa ao equipamento de luz. Isso quer dizer tanto as fontes luminosas e refletores, que definirão a natureza ótica e física do facho luminoso de cada efeito, quanto o sistema de controle da luz, que revelará o aspecto geral da operação e dos movimentos da luz no placo. Tanto um quanto outro precisam ser escolhidos, precisa e adequadamente, para o tipo de projeto em desenvolvimento, não considerando, como já foi dito, nenhuma relação entre tecnologia e qualidade estético-poética da luz. Ao optar por equipamentos convencionais ou alternativos, luzes duras ou difusas, fachos fechados ou amplos, o iluminador irá definir o tipo de fonte luminosa mais adequado aos efeitos desejados, determinando a qualidade visual do que será apresentado ao público.

O material tradicional de iluminação teatral ainda em uso no Brasil, inclui refletores com lâmpadas incandescentes alógenas ${ }^{79}$ como o PC (com lente plano-convexa), diferentes modelos de PAR (Parabolic Aluminized Reflector), set lights e elipsoidais, além dos equipamentos motorizados com diferentes tipos de fontes luminosas e uma imensa gama de novos recursos com LED (Light Emitting Diod) nos mais variados formatos, já equipando, inclusive, refletores inspirados nos tradicionais com resultados bastante satisfatórios. A variedade de

79 Christine Richier anuncia, em seu estudo, o iminente momento em que as lâmpadas incandescentes serão definitivamente extintas do cenário teatral, independente dos apelos e protestos de toda classe de iluminadores do mundo todo (RICHIER, 2019, p. 308-309). 
opções, tanto de fontes luminosas quanto de acessórios e diferentes consoles e mesas de controle da luz analógicas e digitais, mais ou menos sofisticados, considerando ainda os simuladores e softwares de programação e interface, acabam por definir não só o uso como os aspectos estéticos e dramatúrgicos da luz. Esses aspectos, em consonância com a encenação, interferem, finalmente, tanto na linguagem quanto nas escolhas estética e dramatúrgicas da criação coletiva e cada um de seus componentes.

Depois de definido o material a ser utilizado, o iluminador precisa buscar o melhor lugar para posicionar cada refletor ou fonte luminosa, considerando as possibilidades e condições de instalação disponíveis na sala e o ângulo ideal de incidência da luz sobre o corpo ou objeto a ser iluminado, determinando a forma como ele será percebido pelo espectador. Para ilustrar a complexidade e importância desta decisão, ou seja, da escolha do melhor lugar onde posicionar o refletor, definindo o ângulo da luz determinado por essa escolha, vale citar a inveja que Josef Svoboda admitiu sentir dos pintores: "...tem uma coisa que eu invejo no pintor, é que ele pode fazer a luz vir de onde ele quiser, só depende dele, ele é independente..." 80 (RICHIER, 2019, anexo 1, p. 4). Além das questões estéticas e criativas, o iluminador ainda precisa atentar para as condições da instalação e dos recursos disponíveis em cada teatro ou local onde vai montar sua luz, dependendo do equipamento disponível, dos suportes e da equipe para realizar plenamente seu projeto criativo.

Outra importante escolha durante o processo de criação é a cor do facho luminoso, que resultará na impressão cromática do efeito de luz e da cena. $O$ primeiro catálogo de cores da iluminação cênica, descrito por Sebastiano Serlio em seu Tratado de Arquitetura ainda no século XVI, era composto por vermelho, âmbar, amarelo, azul e verde conforme a lista de substâncias que preenchiam os recipientes colocados à frente das velas para colorir a luz no teatro (RICHIER, 2019, p. 365). Hoje em dia, essa escolha é muito mais diversificada e pode dizer respeito tanto à temperatura de cor, uma sensação cromática provocada pela dépend que de lui. Il est indépendant... » (tradução da autora). 
aparência da luz emitida pela fonte luminosa que resulta na percepção de calor ou frio por parte do observador, quanto de um matiz, que fornece o atributo cromático ao ambiente, cena, cenários ou figurinos. Tanto a temperatura de cor quanto a cor do facho luminoso são alterados com o uso de filtros corretivos ou coloridos (gelatinas), disponíveis numa grande variedade por diferentes fabricantes, ou ainda com o uso de equipamentos de LED (light emitting diod), cujo facho luminoso é formado por emissores vermelhos, verdes e azuis (sistema $R G B)^{81}$ que compõem, quando combinados, todas as outras cores do espectro.

A noção mais importante a respeito do uso da cor no teatro é que ela "não tem existência material, mas é tão somente, uma sensação provocada pela ação da luz sobre o órgão da visão" (PEDROSA, 1012, p. 19). Ela é fruto da sensação provocada pela luz que, depois de atingir e ser refletida pelos objetos, sensibiliza o órgão da visão e é interpretada pelo cérebro a partir de referências perceptivas individuais próprias a cada indivíduo. O enfoque fenomenológico proposto por Johann Wolfgang Goethe (2011) sobre a percepção das cores se opõe ao materialismo científico das teorias de Newton. Em uma linguagem quase poética, o alemão afirmou a afinidade instantânea entre luz e cor, quando "qualquer luz moderada pode ser considerada colorida; ou melhor, na medida em que é vista, é lícito chama-la de colorida" (GOETHE, 2011, p. 122). Para ele, as cores proporcionam estados de ânimo esteticamente deduzidos do efeito sensível e moral das cores, classificadas em positivas, estimulantes vivazes e ativas na gama do amarelo, laranja e vermelho; e negativas, que provocam um sentimento de inquietação, ternura e nostalgia pela gama dos azuis e vermelho-azulados. Goethe afirma ainda, que "quando o artista se deixa levar pelo sentimento, algo colorido imediatamente se anuncia" (GOETHE, 2011, p. 155).

Por fim, a última escolha que o iluminador precisa fazer para determinar o aspecto geral de cada um e do conjunto de efeitos de luz de seu projeto de

81 Existem ainda versões mais modernas de equipamentos desenvolvidas com sistemas cromáticos mais complexos, como o RGBW (com emissores vermelhos, verdes, azuis e brancos), o RGBWA (com emissores vermelhos, verdes, azuis, brancos e âmbares) e os novos sistemas de 7 cores (com emissores vermelhos, verdes, azuis, brancos, âmbares, anis, congos e limas) difundidos pela ETC no Brasil, que garantem um índice de reprodução de cor (IRC) mais fiel e comparável ao da luz solar ou da lâmpada de filamento incandescente. 
iluminação é o movimento da luz, ou seja, as passagens de um aspecto luminoso para outro. Para Christine Richier a execução da transição de luz é mais importante do que o próprio conjunto de efeitos que compõem cada uma das cenas do projeto de iluminação de um espetáculo (RICHIER, 2015, p. 96).

O movimento da luz é determinado pelos aspectos da transição da luz como o momento, a intensidade e a velocidade do acender e apagar de cada um ou do conjunto de refletores ou efeitos usados em cada cena (cue), tanto em mesas computadorizadas quanto analógicas. As deixas de texto, som, marcação ou qualquer outra definida pela configuração geral do espetáculo e do projeto de luz definem o momento exato da mudança de luz. A velocidade, que pode variar de zero, em uma transição brusca, a qualquer outro tempo, determina como ocorre o movimento da luz, interferindo diretamente na percepção do espectador. O último aspecto do movimento é a intensidade, que pode variar de $0 \%$ (blackout) a $100 \%$ (full) e determina o grau de luminosidade que cada efeito terá em cada cena quando as luzes são acendidas (fade in), apagadas (fade out) ou trocadas (cross fade) manualmente ou automaticamente no tempo gravado no sistema operacional da console (mesa de luz).

Em relação direta com a atuação do operador da luz durante o espetáculo, o movimento da luz determina o ritmo e o envolvimento do espectador com o espetáculo. Para o iluminador Rodrigo Ziolkowski82, é a roteirização que "vai fazer com que essa luz pontue, respire, pause, acentue certos momentos do espetáculo" (ZIOLKOWSKI, anexos, p. 208). A forte relação entre a criação da luz e a operação chega ao ponto de alguns iluminadores não delegarem essa função, a exemplo da iluminadora Cibele Forjaz ${ }^{83}$ no Teatro Oficina: "eu sempre operei a luz, é sobre estar junto e ter esse aprofundamento da linguagem da luz como uma atuante na cena e na relação direta com a plateia" (FORJAZ, anexos, p. 76). Em outros casos, a luz é gravada em mesas digitais computadorizadas que permitem sua pré-programação detalhada, com todos os tempos e efeitos criados, e a operação é realizada por profissionais de confiança do iluminador,

\footnotetext{
82 Em entrevista realizada como parte desta pesquisa, disponível nos anexos, p. 205-208.

${ }^{83} \mathrm{Em}$ entrevista realizada como parte desta pesquisa, disponível nos anexos, p. 75-83.
} 
que os ensaia com cuidado para que a luz seja executada precisamente conforme o roteiro de luz.

A integralidade do processo de criação, com todas as suas etapas e metodologias, denota a complexidade do trabalho do iluminador e sua equipe, da concepção à montagem e execução da luz. Para o cenógrafo e iluminador Eric Soyer ${ }^{84}$, a iluminação cênica participa ativamente da cena teatral e, além das atmosferas e das arquiteturas, se escreve como uma partitura espaçotemporal, constituindo um elemento fundamental e ativo na relação entre a cena e o espectador:

...assim como na cozinha, vamos definir um sabor, definir as texturas de luz que vão nos ajudar. Em seguida, vamos definir uma palheta e, a partir desta palheta, vamos escrever uma partitura e cada espetáculo, de alguma forma, tem seu sabor, sua própria essência. Obviamente que na minha maneira de abordar as coisas, tem uma coisa que podemos encontrar por meio da totalidade do espetáculo e que chamamos de uma linguagem com as coisas reconhecíveis pela maneira que eu tenho de ver e também de dar a ver. Assim, cada espetáculo é, por assim dizer, uma experiência entre o que chamamos de dispositivo cênico e cenográfico e a composição da luz, a partitura (SOYER, anexos, p. 111).

${ }^{84}$ Em entrevista realizada como parte desta pesquisa, disponível nos anexos, p. 109-112. 


\subsection{Breve contextualização histórica}

Flávio Desgranges afirmou que "cada produção teatral contemporânea, queira ou não, se coloca como reflexão viva acerca da história do teatro" (DESGRANGES, 2017, p. 24). Segundo ele, o artista precisa ter clareza sobre os diálogos que trava com seus antecessores, percebendo de que modo a sua opção artística se relaciona com a realidade que o antecede, bem como com as proposições já desgastadas, além do jogo simbólico em curso e da perspicácia estratégica para confrontar o cenário conceitual, estético e técnico em vigor. Mesmo que em outro contexto, o autor corrobora com a evidente eminência de que o artista, qualquer que seja sua área de atuação, precisa estudar e se posicionar ante a dimensão história e estética de seu trabalho. Para Desgranges, "o fazer artístico atual não admite a ignorância ou a dissimulação do artista acerca de aspectos da história da arte e do contexto sociocultural que o cerca" (DESGRANGES, 2017, p. 24). Essa reflexão pode se aplicar tanto aos aspectos temáticos e conceituais do teatro, citados pelo autor, quanto às características estéticas e às práticas de montagem, entendendo a participação, influência e atuação de cada componente da cena na investigação e no posicionamento político, cultural e social das realizações artísticas.

Da mesma forma que o advento da luz elétrica e sua utilização no teatro a partir da segunda metade do século XIX, deu início a importantes transformações ocorridas na prática teatral (FORJAZ, 2013a, p. 13-14), as revoluções, ocorridas nas últimas décadas, a respeito da tecnologia teatral, da iluminação e dos recursos técnicos e midiáticos da cena, transbordaram os limites da simbologia e da linguagem narrativa para subverter, igualmente, o reverso desta relação: o espectador e sua maneira de ver, ou melhor, de sentir, experienciar e perceber o que lhe é dado, não mais à contemplação, mas à vivência e à experimentação. Historicamente, a iluminação cênica teve suas funções transformadas pelas novas práticas e teorias desenvolvidas por artistas, profissionais, estudiosos, autores, dramaturgos e encenadores, gente de teatro que pensa e constrói, a seu modo, a história. 
Desde o surgimento da luz elétrica como recurso cênico até meados do século XIX, o caráter de visibilidade (permitir que se veja) e de representação era preponderante na iluminação dos espetáculos de teatro e dança, na esteira de correntes artísticas como o realismo, o naturalismo ou o impressionismo, cada uma com suas características e expressões particulares. Ao final do século XIX e início do XX, a luz adquire uma função simbólica e afirma sua presença informativa e significativa na cena, até que, na metade do mesmo século, começa a atender a demandas dos espetáculos contemporâneos da época, revelando seu potencial para uma nova participação na construção e investigação da cena: sua função poética.

Neste trajeto, a iluminação, entre outros elementos, adquiriu status de signo e de linguagem, cuja função narrativa igualava-se à do texto, do cenário ou da representação dos atores. Por fim, a força imagética da cena atingiu novos patamares e a encenação sobrepujou a ilusão e a representação da realidade para exprimir emoções, sensações e impressões do encenador, que as criava e fazia materializar no palco em cada uma das linguagens empregadas. A partir da modernidade, no âmbito teatral, a própria característica narrativa do teatro é posta em xeque pelas experiências pós-dramáticas descritas por Lehmann (2007). As unidades de tempo e espaço são derrubadas e a narrativa, fragmentada, para dar lugar às sensações e interpretações possibilitadas pela encenação. O espectador assume a coautoria da cena e ganha liberdade para ver, perceber e assimilar o que é encenado como lhe aprouver, pois é na recepção que o espetáculo efetivamente se realiza. A expressividade da cena ganha terreno e a interpretação e participação do espectador se convertem em elementos constitutivos da representação.

Alain Badiou, em conversa com Elie During (2007), debateu sobre a materialidade da encenação e contrapôs o "plástico" ao "teatral", afirmando que o primeiro se dá quando há primazia do espaço sobre o tempo, enquanto que no segundo é imperativa a primazia do tempo sobre o espaço (BADIOU; DURING, 2007, p. 21). Isto determina a importância dada à ação no espaço/tempo e ao gesto, no chamado "teatro da operação", no qual a ideia do teatro, ou seja, seu 
objeto de exposição ou tema, são construídos durante a ação, estabelecendo uma relação entre o que se denomina como visível (encenação) e invisível (aquilo que se encontra entre a ideia e o ato). Este teatro da operação sucedeu, segundo Badiou, o teatro da representação, e pôs fim à era do encenador, o detentor da instrução e do conhecimento, aquele que gerencia ou orquestra o todo da representação teatral, dando lugar ao teatro da construção ou do processo, no qual a criação é compartilhada e a ação realizada no aqui/agora, imediato e coletivo, uma "mostração artificial do presente como ficção" (BADIOU; DURING, 2007, p. 24).

A respeito das mudanças, decorrentes desta transformação do teatro, ocorridas na prática e nos usos da iluminação como linguagem, é impossível dissociar as descobertas tecnológicas das mudanças estéticas da luz de teatro. Cristine Richier (2019) afirma que, talvez, seja difícil mensurar a influência das evoluções tecnológicas das fontes luminosas nas transformações estéticas da configuração do visual cênico e a maneira como elas se relacionam com cada período da história do teatro. Ela apresentou, em sua tese, um breve, poético e eficiente apanhado histórico dessa trajetória:

Depois do tempo das chamas, passamos do magnífico herói isolado em um foco de luz bem definido [...] ao anti-herói face à dificuldade de ser [...], errando em ambientes de contraluz azulados. Depois vimos a geometria das lâmpadas fluorescentes tubulares virem cenografiar o teatro e a dança dos anos 80 . Linhas brancas que seccionavam um espaço transformado em laboratório e a cena contemporânea ser banhada pela luz estranhamente colorida das lâmpadas de sódio e mercúrio emprestadas da iluminação urbana. Com a democratização do vídeo do século $\mathrm{XX}$, a projeção veio iluminar os corpos e atuar em novas interações com a cenografia e a encenação. Por fim, são os refletores de LED e os automatizados que vem hoje destronar os antigos equipamentos, com seus fachos móveis e suas cores saturadas, que renovam incessantemente a imagem para o olho supostamente atento e versátil dos espectadores do século XX|85 (RICHIER, 2019, p. 297).

\footnotetext{
85 «...après le temps des flammes nous sommes passés du héros magnifié, isolé dans un faisceau à bords nets [...] à l'anti-héros en proie à la difficulté d'être [...], errant dans les vagues de contre-jour bleutés. Puis on a vu la géométrie des tubes fluos venir scénographier le théâtre et la danse dans les années quatre-vingt, lignes blanches qui sectionnent un espace devenu laboratoire, et la dance contemporaine baigner dans la lumière bizarrement colorée des lampes au sodium ou au mercure, empruntées à l'éclairage urbain. Avec la démocratisation de la vidéo au tournant du $X X X^{e}$ siècle, la projection est venue éclairer les corps et jouer des nouvelles interactions avec la scénographie, enfin ce sont les projecteurs à LEDs et les automatiques qui
} 
Entender a atuação performativa da luz requer tanto a assimilação dos processos e funções da luz no teatro contemporâneo quanto relembra a gradual transformação que deu origem ao uso da luz como linguagem no espetáculo teatral. Cibele Forjaz destaca a conquista, pelo emprego da luz elétrica no teatro, a partir do século XIX, da escuridão e, com ela, do desenvolvimento do que chama de 'partitura do visível', transformando a iluminação teatral em linguagem (FORJAZ, 2008a, p. 152). Ao mesmo tempo, e pelo advento do mesmo recurso, a iluminação conquistou também o movimento, atributo que permite articular espaço e tempo no teatro e representa o alicerce do conceito de performatividade da luz. A respeito destas transformações, Fabrizio Crisafulli (2019) expõe seu entendimento da iluminação como poesia, ação e drama. Foi, segundo ele, por meio dessas transformações que a luz adquiriu suas novas qualidades e que, pela primeira vez, foi realmente possível a extinção total da luz, trazendo para o teatro a escuridão e toda sua expressividade. Da mesma forma, ocorreu o aumento de sua potência e a multiplicação e o enriquecimento de seus equipamentos, com grande impacto sobre a criação dramática por meio da luz. Ele conclui que, com isso, que "a luz adquiriu a possibilidade completamente nova de modelar o espaço e o tempo; de se tornar música, matéria inefável, substância cosmológica; de se materializar nos objetos e nos corpos; de se constituir como ação. De se erguer como estrutura, como linguagem teatral"86 (CRISAFULLI, 2019, p. 23).

Para Patrice Pavis, "situada na articulação do espaço e do tempo, a luz é um dos principais enunciadores da encenação, pois comenta toda a representação e até mesmo a constitui, marcando o seu percurso" (PAVIS, 1999, p. 202). Ao longo de todo o século $X X$, a arte foi redefinida, em suas diversas formas de manifestação, das artes plásticas à música e ao teatro, com base na experiência sensorial e não mais no seu aspecto formal e físico. E algumas

viennent aujourd'hui détrôner l'ancien parc, avec leurs faisceaux mobiles et leurs couleurs saturées qui renouvellent sans cesse l'image pour l'œil, supposé zappeur et versatile, des spectateurs du XXIe siècle " (tradução da autora).

86 "La lumière a acquis la possibilité totalement nouvelle de modeler l'espace et le temps ; de devenir "musique ", matière ineffable, substance cosmologique; de se matérialiser dans les objets et les corps ; de se constituer comme action. De s'ériger en structure, en langage théâtral » (tradução da autora). 
novas formas de teatro, a narrativa e as unidades de ação, tempo e espaço são questionadas em nome da experiência sensorial do espectador. A visualidade é preterida em detrimento do sentido e da experiência, abrindo espaço também para a participação do público, que recebe e complementa a obra. Com isso, a luz também se transforma, de narrativa a performativa, e adquire novas funções, passando a atuar, provocar sensações, contracenar e conduzir os espectadores na viagem de sentidos que os conectará ao espetáculo, cada um à sua maneira. Segundo observações em experiências próprias, a luz e o som se revelam, igualmente, como os dois componentes mais potentes da encenação poética, pois ambos possuem a capacidade de burlar a observação e a interpretação consciente do sentido da cena, ingressando diretamente no inconsciente do espectador por meio de sua percepção estética.

Com base no conceito de pós-dramático (LEHMANN, 2007), Cibele Forjaz demonstra como, por questionar a ideia de narratividade e unidade da ação dramática, a função da luz se transformou. Mesmo considerando a significação da luz no contexto da expressividade e recepção do teatro contemporâneo, no qual "a linguagem da luz é responsável por conduzir o percurso da narrativa, juntando pedaços, encadeando cenas, criando signos que tornam inteligíveis, aos olhos do espectador, essas viagens no espaço e no tempo" (FORJAZ, 2008b, p. 152), ela reafirma não apenas a multiplicidade e infinidade de interpretações possibilitadas pela linguagem da iluminação, mas também a participação do receptor na condição de sujeito coautor da obra e a qualidade polifônica da manifestação teatral e da luz, cuja sensação provocada no espectador tem mais valor do que qualquer sentido previamente atribuído a ela.

A iluminadora americana Jennifer Tripton ${ }^{87}$ qualifica a iluminação como "música para os olhos", afirmando que, assim como o estímulo musical, ela pode transportar o espectador de um lugar para outro, de um sentimento para outro, de um estado de espírito para outro. Ela explica ainda que a luz deve ser, na

${ }^{87}$ Em entrevista à crítica de teatro Linda Winer da Newsday para o programa Women in Theatre, disponível em https://www.youtube.com/watch?v=vvWEDMqHnqw, consultado em setembro de 2019. 
maior parte do tempo, imperceptível, e que sua ação subliminar no palco é efêmera, mesmo em sua natureza material. Segundo ela, a luz afeta a todos, indiscutivelmente, quando os refletores acendem e seus fachos luminosos direcionados encontram algum corpo ou objeto, num instante efêmero, para depois seguirem seu percurso para fora do palco. Ainda nos anos 30 do século passado, Jean Rosenthal declarou que os efeitos de luz usados até então eram ingênuos e pouco expressivos, reclamando que "as comédias são claras, os dramas neutros, o dia é amarelo e a noite azul" (ROSENTHAL, 1972 apud BOONE, 1997, p. 78) para depois revolucionar, como o seu trabalho, a arte da iluminação cênica nos EUA. O uso que ela fez da luz em espetáculos de dança e musicais da Broadway transformou a maneira de entender e perceber a iluminação, principalmente pela sua característica, peculiar na época, de criar uma atmosfera diferente para cada espetáculo. Essa prática a colocou em evidência e elevou a qualidade e importância do papel desempenhado pela iluminação nos palcos. No campo específico da dança, a dançarina e coreógrafa Loïe Fuller realizou relevantes investidas no uso expressivo da luz cênica. Segundo Martha West, "por meio de consideráveis tentativas e erros, Fuller descobriu que os figurinos e a luz eram tão parte da dança quanto o movimento em si"88 (WEST, 1996, p. 89). Historicamente, a luz foi sendo adaptada às novas práticas teatrais e cênicas, acompanhando as transformações estéticas e tecnológicas de cada período. Ao mesmo tempo, a luz foi adquirindo, também, propriedades dramatúrgicas e expressivas, que ampliaram sua participação na cena.

Ainda no campo da dança contemporânea, Fabrizio Crisafulli (2019) cita a composição de luz, som e cenário, feita pelo cenógrafo Robert Rauschenberg para a companhia de dança Trisha Brown, com o objetivo de criar um dispositivo de intenso valor cênico que participasse ativamente dos movimentos coreográficos e das dinâmicas espaciais:

Rauschenberg concebeu estruturas metálicas montadas sobre rodas, de alturas diferentes, sobre as quais estavam instalados much a part of dance as the movement it self » (tradução da autora). 
equipamentos sonoros e de iluminação, munidos de suas baterias elétricas. Essas estruturas eram movimentadas pelo próprios dançarinos, que podiam, assim, fazer variar, simultaneamente, ao longo da performance, a organização do espaço, a proveniência do som e a posição das luzes, das quais emanava uma série de luz difusa branca de grande intensidade, fazendo brilhar os figurinos claros dos dançarinos 89 (CRISAFULLI, 2019, p. 153-54).

A pesquisa e a arte sempre tiveram grande importância e participação na fusão entre os interesses acadêmicos e as atuações artísticas como iluminadora. Paralelamente ao trabalho profissional, as atividades de pesquisa, extensão e ensino da iluminação cênica permitiram e incentivaram o estabelecimento de uma importante relação entre a teoria e a prática. Com isso, foi curioso observar, no estágio atual da pesquisa sobre a performatividade da luz, como a própria história da iluminação se entrelaça com o que foi elaborado, na etapa da estratégia pedagógica apresentada anteriormente, como funções da luz. $\mathrm{Na}$ sistematização do procedimento metodológico de criação, elaborado para fins didáticos, as funções prática, simbólica e estética reverberaram entre as aulas e a atividade profissional desempenhada ao longo dos últimos 30 anos.

No princípio, as funções práticas da luz, entendidas como a capacidade de permitir a visibilidade do espetáculo e a condução do olhar do espectador, apresentam uma relação direta com as primeiras pesquisas, ainda na graduação, acerca do período da história da iluminação dos seus primórdios até o advento da luz elétrica. Neste período, o emprego da luz natural, depois do fogo com a vela, o óleo e, finalmente, o gás, tinham como principal função permitir que o espetáculo fosse visto, sem se ocupar, necessariamente, de outros aspectos, na maioria das vezes nem mesmo separando a área de atuação da sala onde estava o público.

Em seguida, as funções semânticas, despontadas principalmente a partir do advento do movimento na luz, quando se obteve a possibilidade de um maior

\footnotetext{
89 «Rauschenberg conçu des structures métalliques montées sur roues, de hauteurs différentes, sur lesquelles étaient installés des appareils sonores et d'éclairage ont, munis de leurs batteries d'alimentation. Ces structures étaient déplacées par les danseurs eux-mêmes, qui pouvaient ainsi faire varier simultanément, dans le courant de la performance, l'organisation de l'espace, la provenance du son et la place des lumières, lesquelles émanaient d'une série de diffuseurs à émission très intense et blanche, faisant briller les costumes clairs des danseurs " (tradução da autora).
} 
controle, resultando na representação simbólica na cena do espaço, tempo, clima, ritmo e intenção, têm relação com as pesquisas práticas com criação de luz para espetáculo teatrais e musicais e a análise simbólica da luz com base nos estudos da semiótica e das teorias da informação e da comunicação. É importante destacar que, na época, era prática teatral recorrente não incluir o iluminador no processo criativo desde o início. Isso fazia com que ele só fosse apresentado ao espetáculo num momento muito próximo à estreia, quando ele já se encontrava praticamente pronto, com todos os seus elementos e marcações definidos, restando ao iluminador somente a tarefa de mostrar ou intensificar as intenções já elaboradas pelos demais criadores do espetáculo como o diretor, o cenógrafo ou o sonoplasta. Neste contexto, as luzes criadas adquiriam um aspecto bastante simbólico, representando elementos reais ou imaginários elaborados na construção das cenas ou, muitas vezes, substituindo artifícios cenográficos que não podiam ser realizados por questões financeiras ou técnicas.

Em um terceiro e último estágio, finalmente, as funções estéticas dizem respeito diretamente ao estágio atual da pesquisa e da prática profissional, cuja estudo e produção artística consideram, principalmente, a expressão poética da luz no espetáculo, a experiência estética do espectador e a relação catártica estabelecida entre eles por meio da iluminação. É quando a representação e o aspecto ilustrativo da luz na cena dão lugar às sensações que a luz é capaz de provocar no espectador, sua capacidade de acessar a percepção do público e fazê-lo sentir, interagir e entregar-se à experiência real do espetáculo, associando-a às suas próprias vivências e realidades.

É possível constatar como essas diferentes etapas se relacionaram, curiosamente, com a trajetória criativa e com os projetos de criação nos diferentes períodos e nos quais o desempenho das luzes criadas tiveram, em diferentes momentos, ênfases mais expressivas em cada uma das três funções elaboradas teoricamente: prática, semântica e estética, evidenciando uma coerência conceitual entre as transformações da linguagem da iluminação cênica, a metodologia da criação e a prática cênica. Inicialmente, nos primeiros 
projetos, a maior preocupação estava em permitir ao espectador o contato visual necessário com a cena, mostrando e evidenciando o trabalho dos demais criadores, numa atuação restrita como instrumento de visibilidade. A luz deveria permitir que o espectador percebesse a intenção do encenador, definindo o lugar da ação, para onde sua atenção deveria estar exclusivamente voltada, priorizando a compreensão do texto e da narrativa a cada cena. Um dos melhores exemplos dessa fase está na luz da peça $A$ Menina que Pisou no Pão, com dramaturgia e direção de Eugênio Guielow, realizada em 1993, cuja luz pode "tanto conduzir o olhar do público por uma composição estática no espaço cênico quanto produzir movimento pelo acender e apagar as luzes para obter efeitos de orientação da visão do espectador" (LUCIANI, 2014, p. 88).

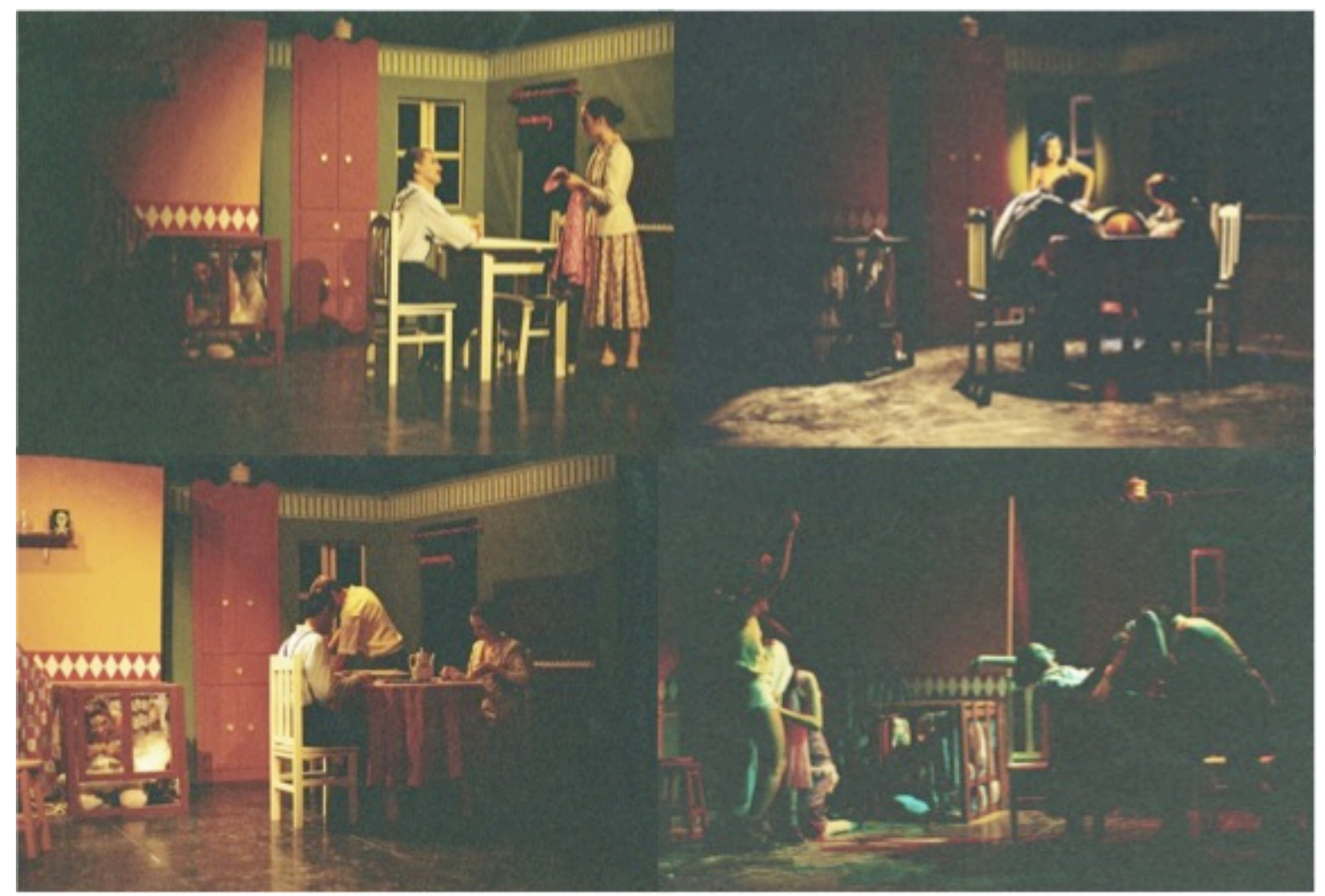

Figura 4 - Condução da atenção e do olhar do espectador pela luz no espetáculo A Menina que Pisou no Pão, no Mini auditório do Teatro Guaíra em Curitiba em 1993. Texto e direção de Eugenio Guielow. Luz Nadia Luciani. Fotos Chico Nogueira.

Neste espetáculo, eram as luzes gerais da direita e esquerda do palco, usadas alternadamente, que orientavam o olhar do espectador para onde acontecia a cena principal, mesmo que do outro lado ainda houvesse alguma ação secundária, nem sempre mais discreta, e que permanecia em uma suave contraluz (abaixo, nas duas fotos da esquerda). A iluminação também dava 
destaque para o aparecimento da fada na janela (foto superior da direta) e, com movimentos frenéticos e cores intensas, acentuava uma cena de loucura e delírio dos personagens (foto inferior da direita), cuja verdade narrativa, acompanhada de uma sonoplastia intensa e perturbadora, ficava em aberta para o público.

Pouco a pouco, à medida que aumentava o domínio sobre 0 funcionamento das fontes luminosas, dos equipamentos, da instalação e do controle da luz com seus efeitos e resultados na cena, foi-se intensificando o aspecto simbólico da iluminação, aquilo que ela podia representar e informar, semanticamente, ao espectador. Essa prática denotava uma via de mão única de informação e comunicação do espetáculo em direção ao espectador, sem que necessariamente houvesse ou se esperasse dele algum retorno. Esse modelo se enquadra no sistema clássico da comunicação, formado por um emissor (o criador, iluminador do espetáculo), um meio ou linguagem (a iluminação cênica) e um receptor (o público), no qual a eficácia é garantida pela transmissão da informação, independente de seus efeitos ou da alteração do comportamento que possa vir a provocar.

Paralelamente, estudos aprofundados da lógica ternária com base em importantes pesquisadores, foram permitindo explorar mais profundamente 0 recurso simbólico da luz. A iluminação evoluía, em meus projetos, como importante linguagem cênica, um sistema de signos cujos códigos poderiam ser percebidos e decifrados pelo espectador de acordo com seu próprio repertório. Eram construídos significados a partir de significantes próprios à linguagem da luz como forma, cor, intensidade e movimento, sempre relacionados e interligados ao espetáculo. Era explorada, a cada novo projeto, a transformação da cena por meio das diferentes propriedades da luz, já num primeiro esboço do entendimento da luz como matéria e de sua atuação performativa, a exemplo do uso da cor e do ângulo da luz na peça Otelo, as faces do ciúme, uma adaptação do texto original de Shakespeare pela dramaturga e encenadora Silvia Monteiro, realizada em 2009.

A encenação alternava cenas oriundas da trama shakespeariana com textos originais, escritos especialmente para a montagem, como falas de 
narradores, interpretados performativamente pelos próprios atores performers

do espetáculo, que permaneciam no palco durante toda a encenação,

observando as cenas, conduzindo a ação e compartilhando com o público seus

sentimentos e percepções sobre a narrativa.

Esta adaptação de Otelo buscou afastar o domínio do texto narrativo do plano ficcional para torná-lo real e presente para intérpretes e espectadores. Neste hiato limítrofe entre o real e o ficcional também ocorre uma subversão da noção de tempo e espaço na oposição entre personagens e narradores, que demonstram conhecimento prévio e externam sua opinião crítica sobre as falas e atitudes que ora narram e ora representam. Para diferenciar narração e ação "dramática" e evidenciar esta dupla atuação, a iluminação trabalhou dois diferentes ângulos de incidência da luz sobre o palco, cada um com uma temperatura de cor e matiz específicos, ambos com tonalidades "sujas" e colorações "desbotadas" da cor azul e rosa, representando, respectivamente, o presente crítico e o passado dramático. Este primeiro, em tom frio, iluminava, do chão, as cenas "narrativas", cujo incomum ângulo de incidência colaborava com a sensação de estranhamento e anti-naturalidade ao iluminar corpos e rostos já bastante deformados pela maquiagem carregada e igualmente pouco natural. $O$ segundo padrão de iluminação traz, num tom aquecido e angulação tradicional de $45^{\circ}$, comum às vistas e percepção humanas, mais naturalidade às cenas ditas "dramáticas", ou seja, aquelas que reproduzem algumas das cenas da versão original do texto, escolhidas cuidadosamente para contar, de forma bastante concisa, a história elaborada pelo escritor inglês (LUCIANI, 2012, p. 5).

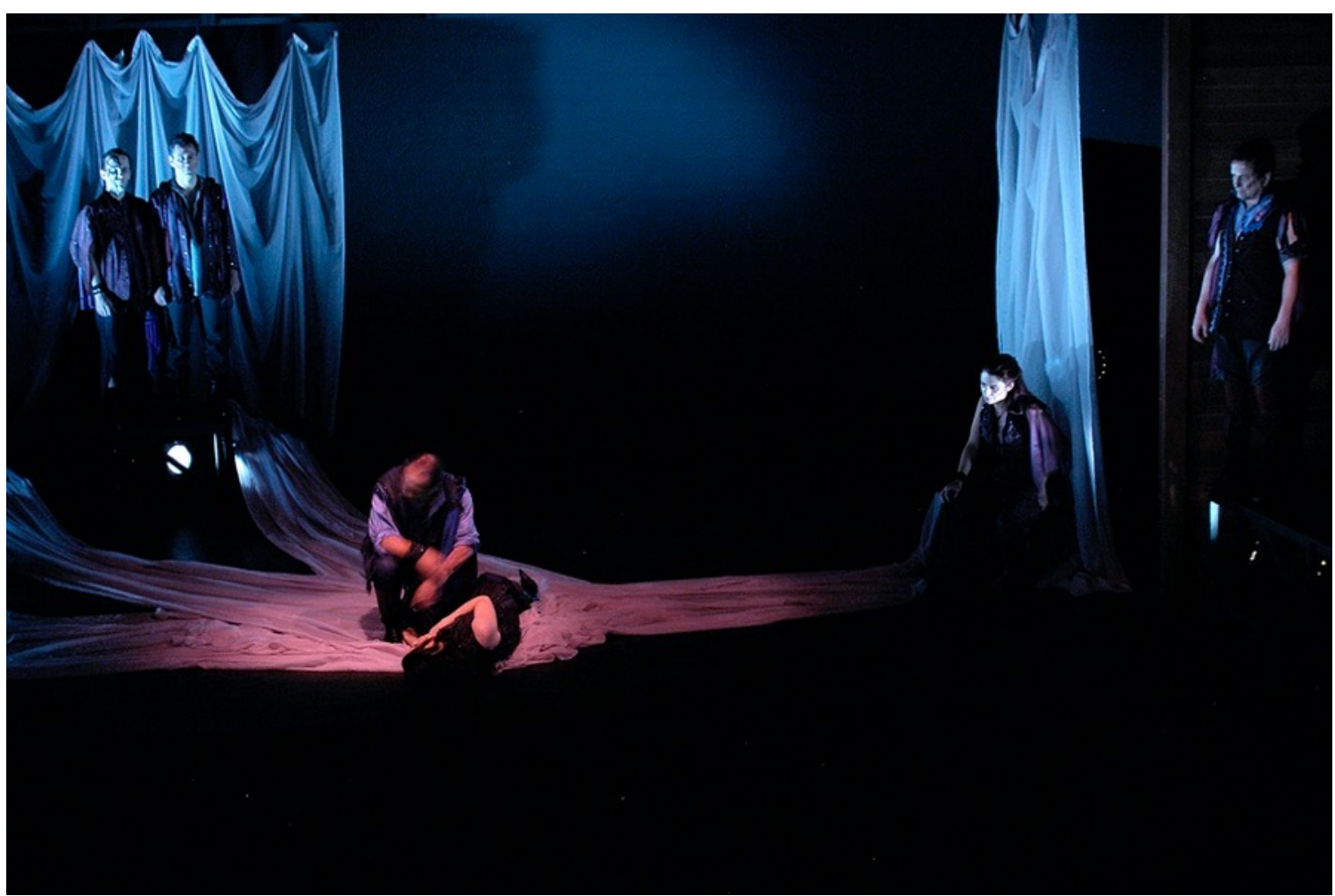

Figura 5 - Uso de cores quentes e frias na peça Otelo, as faces do ciúme, no Teatro Barracão EnCena em Curitiba em 2009. Texto de William Shakespeare, adaptação e direção de Silvia Monteiro. Luz Nadia Luciani. Foto Nicole Zattoni. 
Outro uso significativo da cor na definição da emoção pela visualidade da cena aconteceu no espetáculo Um trágico Acidente, com direção de George Sada, realizado em 2008, no qual a tragédia narrada pelo espetáculo era retratada em quatro distintos momentos cromáticos do espetáculo.

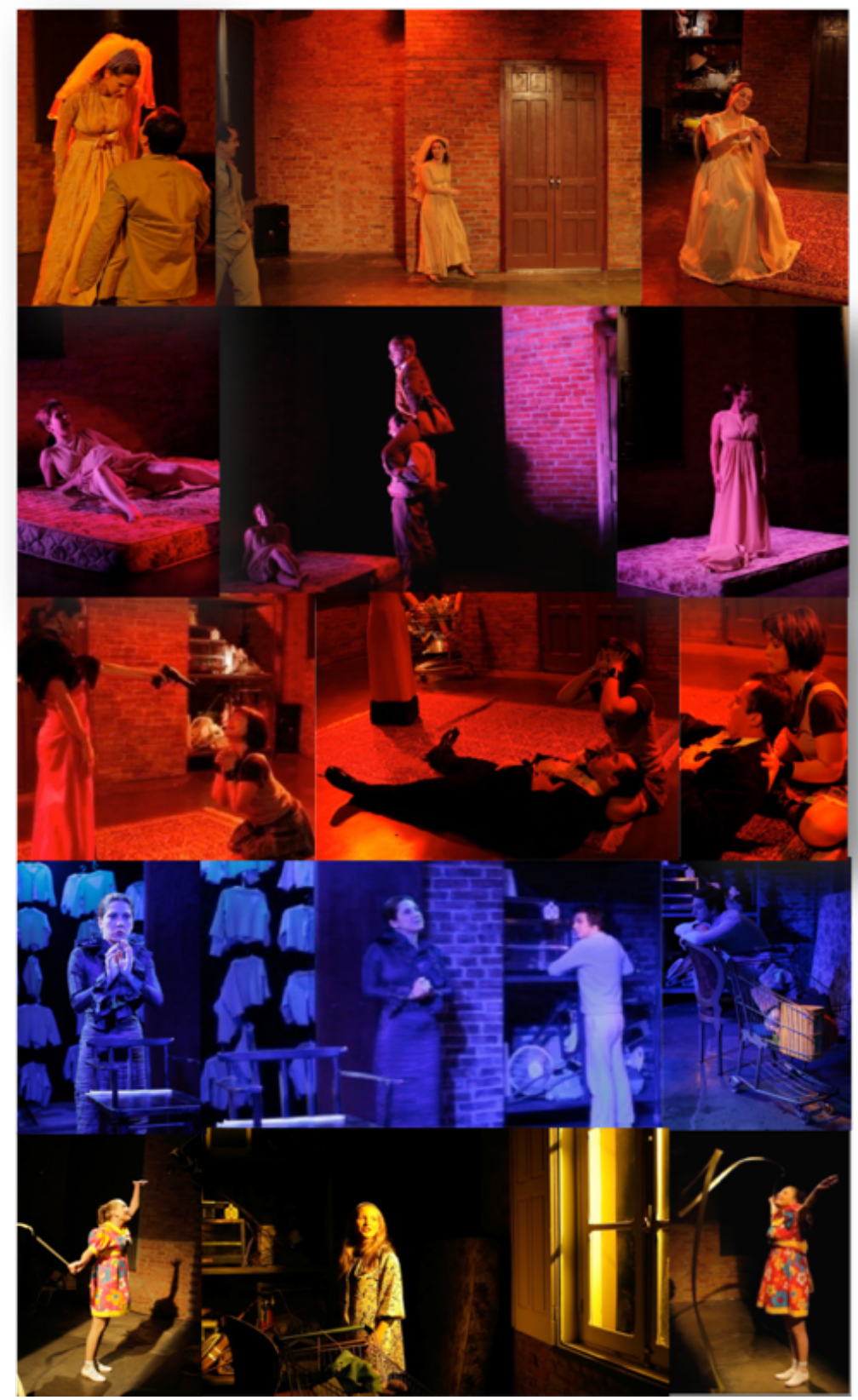

Figura 6 - Uso simbólico das cores âmbar, lavanda, vermelho, azul e amarelo na peça teatral Um Trágico Acidente, no Espaço Dois em Curitiba em 2008. Texto de Carlos Queiroz Telles e direção de George Sada. Luz Nadia Luciani. Fotos Daniel Sorentino.

O primeiro, de euforia, era representado com cores quentes entre o amarelo e o âmbar. O segundo, da transformação psicológica dos personagens, era iluminado com a profundidade dos tons lavanda. O seguinte, representativo do ápice trágico da peça, recebia uma forte coloração vermelha. Quase no final 
do espetáculo, o clima de melancolia e abandono era indicado pela cor azul. Por fim, uma réstia de esperança, onde já não restava mais nada, surgia com a luz amarela invadindo o palco todo, o mesmo amarelo que aparecia, ao longo da peça, em alguns poucos momentos de alegre luminosidade, no sentido figurativo e simbólico do sol exterior em contraponto com o peso e a escuridão do ambiente interno. A curiosidade a respeito desta luz é que a intensidade cromática percebidas nas imagens captadas pelas fotos não condizia com o resultado visual experimentado pelos espectadores, que se surpreendiam ao ver as imagens e não as identificar com o que tinha sido visto pessoalmente.

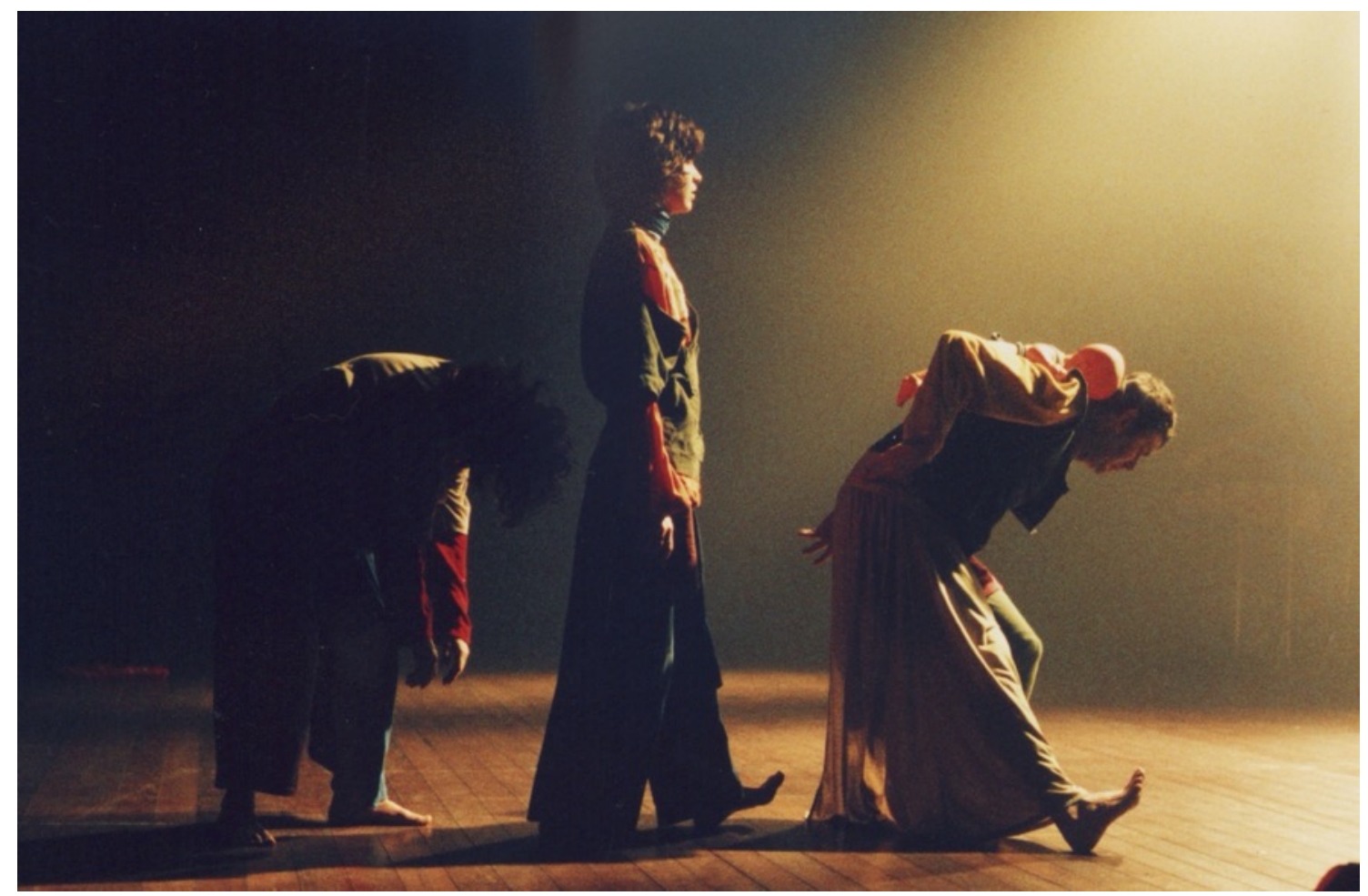

Figura 7 - Luz densa e material usada na peça Devorateme, apresentada na Casa Vermelha em Curitiba em 2002. Concepção e direção de Sueli Araújo. Luz Nadja Naira e Nadia Luciani. Foto Roberto Reitenbach.

Diferentes propriedades da luz como forma, cor, textura, volume, intensidade e movimento são recursos que podem ser exploradas visualmente na criação de ambientes e situações simbólicas pela materialização poética da luz com o uso da fumaça densa produzida pela queima do cloreto de amônia, uma prática controversa, por questões de toxicidade do produto, mas muito comum no teatro realizado no Brasil no final do século XX. A ausência de cenário na peça Devorateme, uma produção da Cia Senhas com direção de Sueli Araújo, 
permitiu o protagonismo visual da iluminação, que ambientava simbolicamente cada cena e momento dramático do espetáculo.

O movimento sempre teve, nos projetos desenvolvidos neste período, uma importância simbólica particular, principalmente por ser entendido como o recurso perceptivo mais potente da iluminação cênica. A intensa investigação e exploração dos possíveis significados, na recepção e percepção do espectador, de diferentes velocidades e intensidades nas transições de luz, fazia perceber como a alteração do ambiente luminoso das cenas de forma lenta ou brusca, com diferentes mudanças de abrangência e intensidade, podiam provocar diferentes efeitos perceptivos. Era interessante perceber como um blecaute brusco, por exemplo, podia interromper dramaticamente a cena e, consequentemente, o pensamento do espectador. Por outro lado, um blecaute lento podia instigar a criação de uma continuidade para a cena em sua imaginação. Era possível determinar, com o tempo da transição de luz, se a mudança do clima ou do lugar da ação seria notada ou aconteceria de maneira imperceptível para o público. Desta forma, pela duração e a ação conjunta com a respiração do performer ou o pensamento da personagem, a luz poderia favorecer a maneira como a cena iria afetar e interferir na experiência do espectador, imputando à operação da luz uma grande responsabilidade.

Todas essas descobertas e experiências pessoais no emprego dos recursos próprios à luz na cena conduziram a novas práticas, fortemente concentradas, por consequência, na experiência do espectador, mas sem negar, no entanto, a essência informativa e simbólica da iluminação. A percepção gradativa da materialidade poética da luz, ocorrida simultaneamente às primeiras intuições e observações a respeito da performatividade da luz, fizeram explorar cada vez mais as potencialidades ativas da iluminação em relação à percepção e à recepção do espectador aproveitando as novas tendências e proposições dos espetáculos iluminados. A forte carga psicológica e a importância dada pelos encenadores ao público ao espetáculo permitiam a realização de experiências conceituais e formais, buscando concentrar mais atenção ao que poderia ser implicitamente expresso pelos efeitos de luz criados. Gradativamente, foi 
diminuindo o interesse pela simbologia da luz para dedicar sua potencialidade expressiva à percepção, à recepção e às reações que a luz poderia provocar, a nível fenomenológico e sensorial, no espectador.

Inevitavelmente, a atenção dada à recepção resultou numa preocupação ainda maior com a operação da luz e sua sincronicidade com a cena. Já não bastava mais instruir o operador sobre o momento exato da mudança de luz, mas orientá-lo para atentar, quando possível ou necessário, para a reação do público ou o gesto do ator ao fazer a transição. Ficou claro que já não era mais possível criar a luz sem acompanhar a encenação ou assistindo os ensaios apenas depois das cenas já marcadas. Quando isso acontecia, faltavam informações importantes para a concepção da luz, cuja ação não poderia acontecer, nestas condições, associada à cena de maneira ideal. Também já não parecia mais possível passar a luz para um operador que não estivesse igualmente integrado ao trabalho, tendo visto tantos ensaios quanto, ou, como parecia cada vez mais óbvio, até mais ensaios do que o próprio criador da luz.

A importância da precisão na operação da luz para a percepção do espectador foi igualmente destacada pela iluminadora Marisa Bentivegna90:

...é um traquejo que os iluminadores e os operadores precisam ter, não só da coisa de resolver tecnicamente com rapidez, mas de pensar e respirar junto com quem está no palco. Não dá para você ficar jogando no celular porque a próxima cena é em cinco minutos e você só vai dar um go, você precisa estar respirando junto porque senão, não tem porque você estar lá. Agora eu sinto dessa maneira e escolher um operador para operar as minhas luzes também se tornou uma questão importante. (BENTIVEGNA, anexos, p. 160).

Com isso, fica clara a necessidade de uma integração total entre a operação da luz e a cena para a afecção do espectador. Alguns dos últimos trabalhos realizados neste período são bons exemplos dessa integração e simbiose, pois a iluminação criada para eles já não se concentrava em iluminar, clarear a cena, nem mesmo representar algo já posto, como reforço simbólico ou comunicativo, mas principalmente em interagir, reagir e atuar em unidade com os demais componentes da cena, humanos ou materiais, e o público.

\footnotetext{
90 Em entrevista realizada como parte desta pesquisa, disponível nos anexos, p. 151-163.
} 
Em muitos desses espetáculos, muito devido à proximidade com 0 público, a luz de plateia teve fundamental importância, a ponto de ser usada, como no espetáculo Huis Clos, representando Sartre (LUCIANI, 2019), tanto na entrada do público, como é normal, mas também em vários momentos do espetáculo, exigindo, na criação, uma atenção e cuidado incomuns. A escolha do tipo de refletor, a preocupação com o ângulo e a difusão da luz para não perturbar a visibilidade e o conforto do público e o tempo dos movimentos de entrada e saída desta luz foram alguns dos aspectos dos efeitos tornados tão específicos no espetáculo. Além disso, a luz de plateia também mereceu efeitos de integração com a cena, cujo acionamento em diversos momentos da peça colocava palco e plateia num mesmo ambiente sensorial.

Outro aspecto importante para o conceito geral da iluminação era o fato de que os atores, depois de entrarem em cena, um a um, não mais deixavam o palco. Mesmo $\mathrm{O}$ Criado, que na versão original ficava muito pouco em cena, nesta montagem, quando deixa o palco, é para colocar-se na plateia, diluindo ainda mais a distinção entre os dois espaços. Da plateia, continuava participando, percebia e reagia a tudo o que acontecia em cena, compartilhando suas percepções com os espectadores, integrando-os forçosamente à cena, sem opção de isenção ou fuga. Foi necessário, então, desenvolver luzes especiais para iluminar a plateia de forma distinta em diferentes momentos: na entrada do público, nas cenas em que o Criado interagia parcialmente com os espectadores, estando entre eles, e nos momentos em que se dirigia explicitamente à plateia, do palco. Também era importante, visto que o público seria iluminado durante a peça, que o ângulo de incidência da luz não atingisse diretamente os olhos dos espectadores nem os incomodasse e que, apesar da interação latente entre palco e plateia, esta segunda tivesse uma luz específica, que não invadisse a cena da mesma forma que a luz da cena a invadia durante quase todo o espetáculo (LUCIANI, 2019, p. 413).

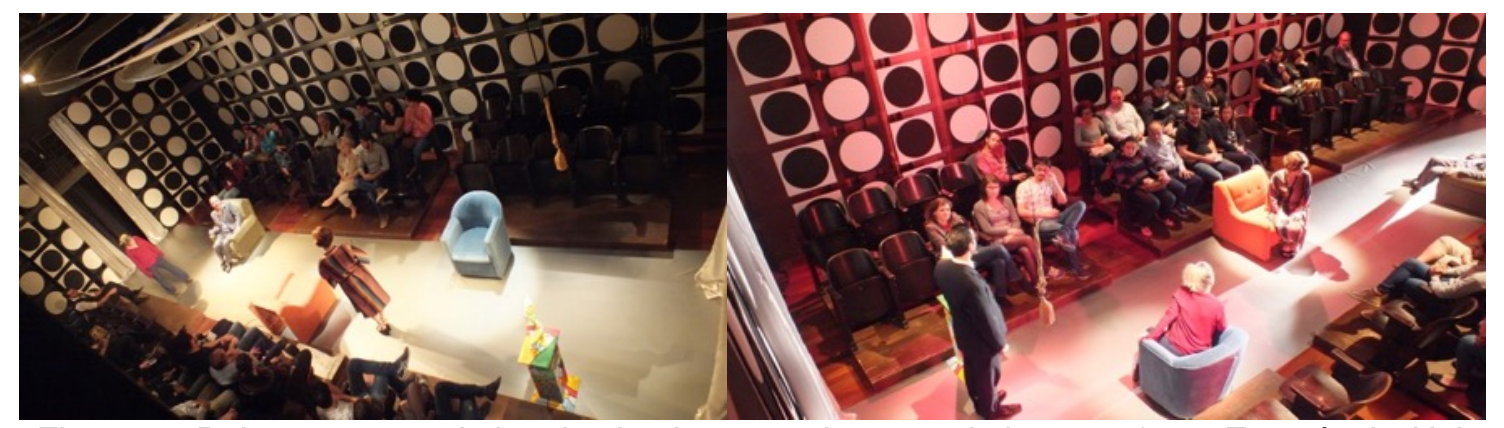

Figura 8 - Dois momentos da luz de plateia como elemento de integração no Espetáculo Huis Clos - Representando Sartre, no Espaço FALEC em Curitiba em 2017. Texto de Jean Paul Sartre, adaptação e direção de Ênio Carvalho. Luz e Fotos Nadia Luciani.

A direção precisa de Ênio Carvalho e a atuação conjunta da luz com os atores conferiram, segundo relatos da equipe e de espectadores, uma presença 
e participação ativa nas cenas. Muito da responsabilidade pela sensação de inclusão dos espectadores nas reflexões e conjecturas dos personagens foi creditada à luz por não fazer distinção entre os ambientes da cena e do público e pelos climas de tensão criados juntamente com a sonoplastia do espetáculo.

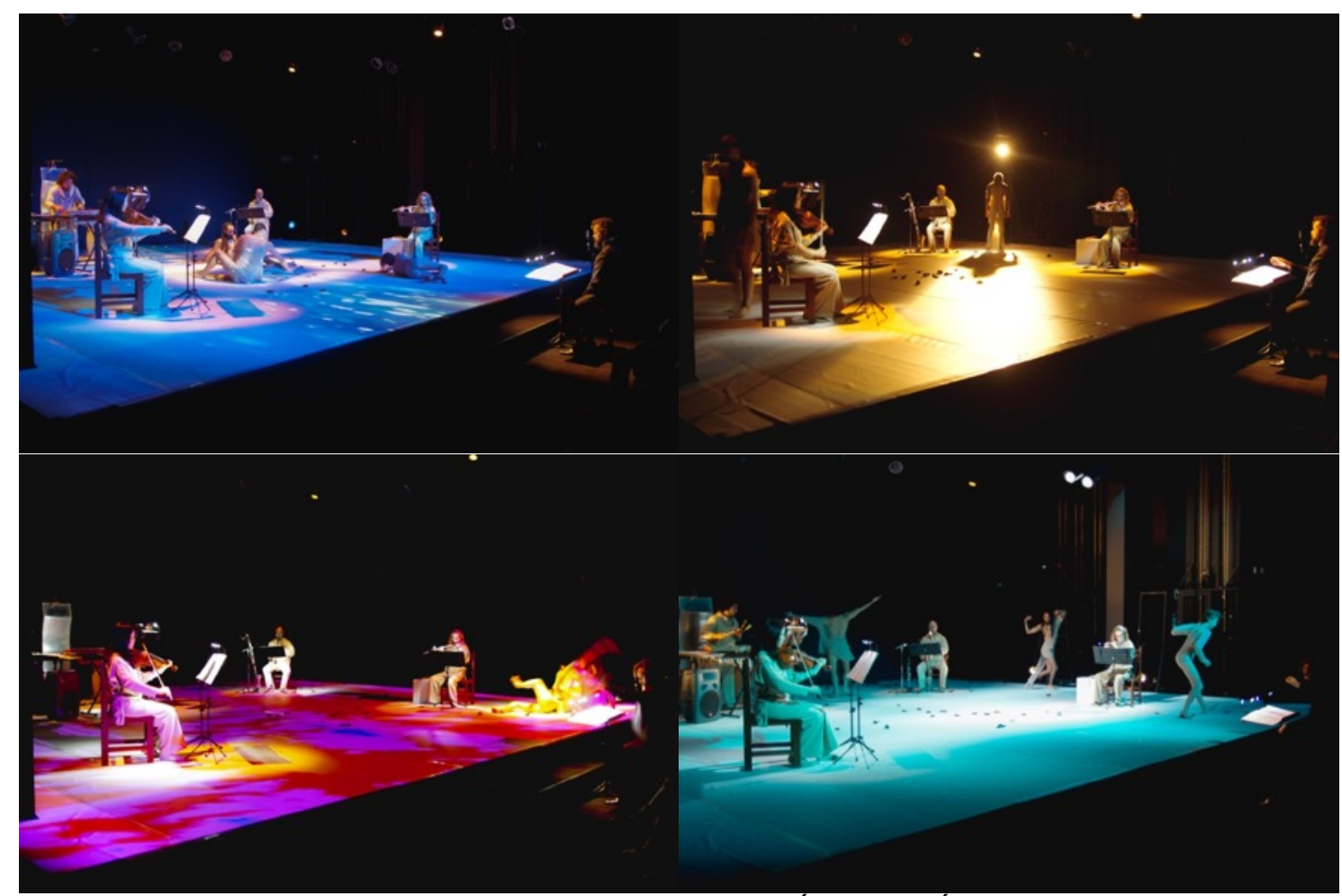

Figura 9 - Quatro momentos da luz do balé-concerto Águas de Éden e do Hades no Teatro José Maria Santos em Curitiba em 2018. Concepção geral e direção artística de Maurício Dottore. Luz Nadia Luciani. Fotos Gabriel Stocchero.

Outra importante experiência performativa, um pouco mais recente, foi a luz do balé-concerto Águas do Éden e do Hades, cuja criação musical e coreográfica ocorreu de forma inteiramente integrada à construção do espetáculo. As músicas, vertente nova da música erudita, foram compostas durante o processo, assim como a elaboração das coreografias e a criação da luz, dos figurinos, do cenário e das imagens projetadas.

A ideia de um balé-concerto ressalta a confluência das artes numa forma unitária. Neste raro gênero musical, músicos e bailarinos dividem o palco num espetáculo de impacto, com cenários e iluminação teatral: a própria dança, na forma de "poesia geral da ação", é parte da música. O balé-concerto Águas do Éden e do Hades se inspira no tema contemporâneo das águas, a partir dos rios míticos que atravessam o Éden judaico e o Hades grego. 91

91 Disponível em https://novacamerata.wordpress.com/bale-concerto/, consultado em 20 de novembro de 2018. 
Segundo o diretor artístico do espetáculo, Maurício Dottore, "quando você tem música tocando e o balé sendo dançado, a forma como o dançarino dança muda a música, e vice-versa" ${ }^{92}$, o que se estendia também, neste balé-concerto, para a iluminação e as projeções, que interagiam com os bailarinos e com a música, influenciando e sendo influenciados por eles, tanto no processo de criação quanto nas apresentações, onde a sincronia entre todos os elementos era fundamental para a percepção, envolvimento e entrega do público, iluminado, também, durante o concerto, no mesmo ambiente azul das águas místicas dos rios Eufrates, Hidequel, Ghion e Pison, nomes dados às quatro peças especialmente compostas para o espetáculo pelos compositores Mauricio Dottore, Indioney Rodrigues, Santiago Beis e Márcio Steuernagel. O cenário virtual das projeções foi criado por Alan Raffo e a visualidade do espetáculo se completava com os figurinos criados por Paulinho Maia.

Foram, principalmente, as reflexões geradas a partir dessas experiências que permitiram construir e delinear uma teoria que sustentasse conceitualmente o que é concebido como a atuação performativa ou o potencial performativo da luz. Com base na percepção de suas manifestações e no desejo de entendê-las melhor, teve início uma investigação, inicialmente intuitiva, dada a incerteza sobre por que caminhos seguir, de diversos conceitos que pudessem estruturar essa reflexão. O mais importante deles foi, certamente, a noção de luz ativa, preconizada por Adolphe Appia. Segundo Roubine (2003), num período de intensas transformações no uso da linguagem da luz no teatro, a primeira metade do século XX, Appia "toma consciência do poder sugestivo que emana da luz elétrica. Eis por que faz dela o próprio coração de seu modelo cenográfico" (ROUBINE. 2003, p. 160). O conceito de luz ativa continua a instigar e motivar pesquisadores do início do século XXI, a exemplo da diretora e iluminadora brasileira Cibele Forjaz (2013a) e do diretor e iluminador italiano Fabrizio Crisafulli (2019). 


\section{LUZ ATIVA}

Eu descobri que era um péssimo ator e sendo um péssimo ator eu fui fazer outras coisas no teatro e aí eu descobri que, mexendo na mesa de luz, a luz acendia no palco e eu podia ser um ator no palco através da luz. Jorginho de Carvalho

Muito antes do uso de conceitos como performance ou performatividade, Adolphe Appia já expunha suas ideias sobre uma luz ativa, formativa e criadora. Considerado um pioneiro na consciência do poder sugestivo da iluminação elétrica como essência do modelo cenográfico que propôs, ainda nos primórdios do século XX, Appia definia a iluminação do século XIX como helligkeit, em alemão, cujo significado pode representar uma luz geral, brilhante ou ambiente. Segundo Richard Pilbrow, "Appia achou essa luz lamentavelmente inadequada, propondo um novo tipo de luz: a gestaltendes lichit, uma 'luz reveladora da forma', em três dimensões, direcionável e móvel, que daria aos objetos seu aspecto, forma e significado naturais"93 (PILBROW, 2008, p. 3). As teorias de Appia foram consideradas por Max Keller como a metodologia da iluminação cênica, classificada em dois tipos de luz: a luz direcionada e a distribuída ${ }^{94}$ (KELLER, 2010, p. 289).

Segundo a pesquisadora alemã Birgit Wiens (2014), o novo espaço teatral proposto por Appia para a apresentação de Orfeu e Eurídice, de Dalcroze, em 1913, além de renunciar à boca de cena com sua divisão precisa da área de atuação e do público, também propôs abrir mão do obscurecimento da plateia, como era praticado em Beyreuth, no intuito de que espectadores e atuadores compartilhassem o mesmo espaço. Para ele, os dois espaços, palco e plateia, deveriam ser ligados tanto por sons, que se difundiam em um e outro meio, quanto pelos efeitos das "emanações da luz formadora, produtiva e criadora" (WIENS, 2014, p. 225).

\footnotetext{
93 « Appia found this pitifully inadequate and foretold a new kind of light : gestaltendes lichit, a 'form revealing light'. This three-dimensional, directional, moving light would give objects their natural roundness, shape and significance » (tradução da autora).

94 «...the methodology of light design as summed up by Adolphe Appia : directed and distributes light. " (tradução da autora).
} 
As reflexões de Appia sobre uma "nova maneira" de olhar no teatro se fundamentaram em boa parte em reflexões sistemáticas acerca da performatividade da luz. [...] Ele estava interessado em configurar a significação da imagem enquanto processo - como acontecimento estético no qual a visualidade será exibida de modo extensivo e dinâmico nas mudanças dos efeitos de luz e se desdobrará no olho de um observador que percebe ativamente (WIENS, 2014, p. 225).

O professor e pesquisador gaúcho Angelo Passos (2018) destaca a transformação ocorrida no pensamento de Appia em suas duas fases mais importantes: a primeira, cuja influência fundamental era decorrente da admiração que nutria pelo compositor alemão Richard Wagner, e a segunda, posterior ao encontro com Émile Jaques-Dalcroze, criador da Rítmica, um sistema de exercícios corporais relacionados à música e à interação mente-corpo. Tímido, gago e introspectivo, Appia, realizou poucas de suas idealizações cenográficas e espaciais, legando ao teatro contemporâneo, no entanto, uma vasta obra de escritos e reflexões teóricas que transformaram o ideário do cenário e da iluminação teatral a partir do século XX. Segundo Passos, Appia declarava, desde seus registros mais remotos, que havia duas reformas radicais imprescindíveis a serem feitas na encenação da sua época: o papel desempenhado pela iluminação, com a necessidade de criar uma atmosfera por meio da luz, e o uso do décor, nome dado por ele ao cenário, cuja função seria outra que a decorativa, visando a preparação do espaço para a ação do ator. Ele esclarece, ainda, que esta segunda poderia ser compensada, ou até mesmo descartada, pelo uso racional e eficiente da iluminação (PASSOS, 2018, p. 144).

Para Appia, cabe à iluminação vivificar o espaço cênico, colocando-o em movimento, o que significa libertá-lo da cópia do real. Ao associar a luz ao movimento, que ele considerava como a razão de ser e o aglutinador do teatro que almejava ver sobre os palcos, Appia detectou, nos princípios da encenação de Dalcroze, o ponto de partida para algo muito maior, a ideia transformadora existente por trás da Rítmica, na qual o ator assume papel preponderante na relação com os demais componentes da concepção espacial que criou, os chamados "espaços rítmicos", e com o público (PASSOS, 2018, p. 196). Nesses espaços rítmicos, Appia sugeriu o uso expressivo da luz como elemento 
cenográfico em espaços abertos, escadarias, volumes e diferentes níveis que, sem qualquer ornamentação, permitiam a movimentação livre do corpo do ator.

Passos destaca as semelhanças entre o pensamento de Adolphe Appia e Edward Gordon Craig, a respeito da visualidade e, no caso específico de Appia, também da sonoridade da cena (PASSOS, 2018, p. 161). Ambos defendiam a organização dos elementos da cena, mas enquanto Appia sempre considerou o corpo do ator como ponto focal de suas reflexões e proposições, Craig considerava cada vez menos o corpo humano em movimento, chegando a imaginar a cena sem ele. Para Craig, a maior preocupação estava no impacto visual global da coordenação equilibrada das relações espaciais entre objetos, movimento e luz. Mesmo considerando os diferentes pontos de vista, a luz expressa, nas reflexões de ambos, seu potencial de atuação, elevando o aspecto visual do espetáculo de mera cópia da realidade para a abstração do sentido profundo. Essa luz "viva" é elemento de fusão entre os aspectos visuais e os fatores temporais do espetáculo em expressão direta com o espectador (APPIA, 1921 apud FORJAZ, 2013a, p. 333).

A pesquisa do encenador e iluminador Fabrizio Crisafulli (2019) a respeito da luz ativa faz, igualmente, referência direta às ideias e experiências de Adolphe Appia, que:

... ao final do século XIX foi um dos primeiros a abordar - tanto em seus escritos quanto em suas criações - a questão da iluminação como uma questão artística do teatro. Para Appia, a luz ativa era uma luz cênica propriamente dita: iluminação expressiva e criadora de formas; iluminação como matéria poética e substância dramática. Ele opunha essa ideia às práticas mais comuns do teatro do seu tempo, nas quais a iluminação era compreendida essencialmente como "luz", como elemento técnico e funcional, secundário, completamente exterior em relação ao processo criativo95 (CRISAFULLI, 2019, p. 21).

\footnotetext{
95 "Le titre 'lumière active' est une référence directe à la pensée d'Adolphe Appia qui, à la fin du $X I X$ siècle, fut parmi les premiers à aborder - dans ses écrits comme dans ses créations - la question de la lumière en tant que question artistique du théâtre. Pour Appia, la lumière active était la lumière scénique 'proprement dite': lumière expressive et créatrice de formes ; lumière comme matière poétique et substance dramatique. II opposait cette idée aux pratiques plus communes du théâtre de son époque, où la lumière était comprise essentiellement comme 'éclairage', comme élément technique et fonctionnel, secondaire, voire tout à fait extérieur par rapport au processus créatif » (tradução da autora).
} 
Cibele Forjaz (2018) também ressalta a passagem do que pode ser considerado como uma luz passiva, que ela descreve como "lógica fotográfica do espaço e do tempo realistas" e que, para Denis Bablet, não intervém na cena nem desempenha qualquer papel ativo na construção do espetáculo, para uma luz ativa, que constrói novos espaços e tempos e confere vida e movimento à cena. Creditando igualmente a Appia a criação do conceito, ela o associa ao poder expressivo da iluminação e cita novamente Bablet, para quem a luz ativa é "um componente móvel e consciente na construção do espetáculo", e Roberto Gill Camargo, que caracteriza a luz como elemento "actante", para relacionar a transformação da função da luz no espetáculo à ideia de ação e movimento (FORJAZ, 2018, p. 73).

Neste mesmo texto, Forjaz traça um histórico do emprego da luz elétrica nos palcos, muito antes da criação da lâmpada de filamento por Thomas Edison em 1879, para a criação de efeitos que visavam surpreender e maravilhar o público. Da mesma forma, Louis Jouvet também antecipou o protagonismo e o potencial de atuação da luz em seu artigo sobre as contribuições da eletricidade para a encenação, de 1937: "graças às suas possibilidade múltiplas e ilimitadas de transformação", a luz "não está mais a serviço da ação, mas a ação é feita por ela, ela a suscita." ${ }^{66}$ (CHAOUCHE; VIALLETON, 2017, p. 1). No entanto, a mais importante inovação para a iluminação teatral a partir do fenômeno da energia elétrica, não estava na luminosidade nem na fixação da imagem, em contraponto com aquela da luz trêmula da chama, muito reclamada, aliás, por cenógrafos e espectadores amantes do ilusionismo criado por este tipo de fonte luminosa incidindo sobre os cenários pictóricos. O aporte mais relevante do emprego deste tipo de energia, mais do que da fonte luminosa, foi a possibilidade de controle da intensidade da luz, que, a partir de sua implantação, podia permitir variações de claro e escuro impossíveis até então. "Além de dar visibilidade, a iluminação cênica ganhou o poder de esconder [...] a luz elétrica inventou também o escuro no teatro", afirma Forjaz, que descreve a escuridão como o complemento da luz, a parte que faltava, o corte, o silêncio que dá sentido à service du jeu, le jeu est fait pour elle, elle le suscite » (tradução da autora). 
articulação da linguagem da iluminação, a possibilidade de acessar, além do visível, o invisível (FORJAZ, 2018, p. 73).

A luz ativa descrita por Appia transforma, então, a atuação da luz na cena, conferindo movimento à cenografia, vivificando a cena e permitindo uma relação concreta entre o ator e o espaço. Libertada da função de reproduzir a realidade, a luz passa a articular o que é visível em cena com os olhos do espectador, criando atmosferas, sensações e movimentos próprios à sua linguagem como elemento estrutural e estruturante do espetáculo (FORJAZ, 2018, p. 75). Indiscutivelmente, uma fusão entre arte e técnica, a iluminação passa por uma revolução estética que define seu novo potencial como articuladora da cena teatral. Ao mesmo tempo em que a eletricidade e a lâmpada elétrica adentram os teatros e palcos, surge um desejo de ruptura e de modificação das práticas tradicionais do teatro, calcadas em representações realistas da natureza, nas quais mesmo os novos efeitos tecnológicos não faziam mais do que mostrar a passagem do tempo e encantar olhares sedentos por inovações visuais. Wagner finalmente consegue, em 1876, extinguir a luz da plateia, revolucionando definitivamente a relação entre o espectador e a cena ${ }^{97}$. Simultaneamente, grandes efeitos ilusionistas, criados para as óperas do final do século XIX, deixam para trás a luz passiva, que tinha como finalidade apenas conferir visibilidade ao palco.

Em seu estudo sobre a dramaturgia da luz ativa, Fabrizio Crisafulli (2019) estabelece três diferentes modalidades da iluminação como elemento poético, ativo e construtivo da cena contemporânea, ligada à organização do espaço/tempo da ação, bem como ao sentido e estrutura da montagem cênica. Apesar da classificação precisa, mas cujos limites podem se tornar difusos conforme o emprego da luz em determinados espetáculos, seja mesclada entre os diferentes tipos, ele explica que todos podem adquirir uma conotação atuante, ou seja, todos podem aturar como o que ele chama, inspirado em Appia, de luz ativa. A primeira dessas modalidades diz respeito, claramente, à luz como

\footnotetext{
97 Passagem melhor detalhada ao final deste estudo, ao tratar da performatividade do blecaute como um aspecto da performatividade da luz ainda a ser investigada.
} 
instrumento de visibilidade, cuja função é a de iluminar os atores e a cena. Ele explica que este tipo de iluminação, por mais funcional, neutra e estável que seja, implica, na maioria das vezes, numa opção ligada a escolhas poéticas basilares da encenação, com efeitos ativos sobre a percepção do espectador. Como exemplo deste tipo de iluminação, ele cita Bertolt Brecht e o uso feito, por ele, da luz branca, homogênea e difusa em suas montagens.

O autor e diretor alemão, como se sabe, era partidário de uma luz homogênea, difusa, fixa e branca, anti-sugestiva e anti-ilusionista, à qual ele confiava a função de favorecer uma maior presença do ator, sua mais perfeita visibilidade e, simultaneamente, a mais profunda atenção crítica do espectador, sua mais adequada capacidade de julgamento. Para Brecht, a luz deveria ser um meio de impedir que o público se deixasse levar pela ilusão. Ele queria, então, que a cena fosse iluminada com uma luz clara e viva, e também que tal escolha permitisse ao espectador perceber seu vizinho, mantendo-se presente e consciente da ficção teatral98 (CRISAFULLI, 2019, p. 145).

A segunda modalidade definida por Crisafulli distingue a luz que "clareia" a cena da luz como imagem, esclarecendo que a luz da primeira modalidade também pode criar imagens em suas relações com a cenografia e os atores, modelando as formas corporais e arquiteturais e as ações, suas composições no espaço/tempo e contribuindo na definição da atmosfera de cada cena, a exemplo dos efeitos cinematográficos criados por Meyerhold em suas encenações. No entanto, a modalidade da luz como imagem, que se estende por um campo bastante vasto, apresenta uma grande influência da maior exploração do recurso da luz elétrica, da fotografia e do cinema. Ela está ligada à produção de imagens, formas e figuras criadas diretamente ou por reflexão, projeções fixas ou em movimento, silhuetas e fontes luminosas expostas à visão do público e novos materiais como o neon, a luminescência, o laser, os monitores, o holograma e o LED. Esse tipo de emprego da luz, segundo Crisafulli, "suscita um conjunto de questões e institui relações complexas entre diferentes meios, entre o material e

\footnotetext{
98 "L'auteur et metteur en scène allemand, comme on le sait, était partisan d'une lumière homogène, diffuse, fixe et blanche, anti-suggestive et anti-illusionniste, à laquelle il confiait la tâche de favoriser la plus grande présence de l'acteur, sa plus parfaite visibilité et, simultanément, la plus profonde attention critique du spectateur, sa capacité de jugement la plus adéquate. Pour Brecht, la lumière devait être un moyen d'empêcher que le publique s'abandonne à l'illusion. II voulait donc que la scène soit éclairée d'une lumière claire et vive, et aussi qu'un tel choix permette au spectateur d'apercevoir son voisin, de se maintenir présent à lui-même et conscient de la fiction théâtrale " (tradução da autora).
} 
o imaterial, o real e o virtual, a ação ao vivo e a ação gravada. Como exemplo da integração visual e dramatúrgica da ação, cenário, luz e projeção, o autor cita o trabalho conjunto de Meyerhold e Eisenstein, na Rússia, Reinhard e Piscator, na Alemanha e Radok e Svoboda, na Tchecoslováquia. Em ambos os casos, as fontes utilizadas como objetos luminosos se transformam em "elementos essenciais para a construção do espetáculo" (CRISAFULLI, 2019, p. 151).

Josef Svoboda também foi um entusiasta utilizador da projeção, que empregou em cenografias inovadoras e sem precedentes como fontes de luz móvel, chamadas, por ele, de luz em movimento. Ele percebia, na projeção de imagens em multi-telas, um potencial dramatúrgico, que constituiu, por si, a própria cenografia de diversas montagens do Laterna Magika99, em Praga (RICHIER, 2019, p. 325-332). Apesar disso, ele não conseguiu realizar, até o final de sua vida, o grande sonho da utilização de hologramas em seus cenários. "Eu sempre sonhei com um teatro de luz. Os atores entrariam em uma caixa vazia e se colocariam em torno de um holograma"100 (RICHIER, 2019, anexo 1, p. 15). Impedimentos técnicos, descobertos a partir de experiências nas quais o cenógrafo tcheco buscou trabalhar a iluminação sem suporte, criando um volume material de luz no espaço, impossibilitaram o uso desta técnica, que ele acreditava ter grande potencial de aplicação na criação de uma iluminação tridimensional (RICHIER, 2019, p. 300).

Por fim, a terceira modalidade de luz ativa apresentada por Crisafulli é a iluminação cuja escolha e definição do equipamento a ser usado é oriundo, da mesma forma que os demais elementos cênicos, das escolhas poéticas e dramatúrgicas fundamentais do espetáculo, ou seja, quando o próprio equipamento de luz assume um papel de destaque na encenação. Um bom exemplo desse tipo de uso do equipamento é quando as fontes luminosas são

\footnotetext{
99 Forma de espetáculo intermídia criado em 1958 pelo diretor A. Radok, baseado na interação entre os atores presentes e filmados, e nome da Companhia que desenvolveu esta forma, que Svoboda dirigiu de 1973 a 1989 (RICHIER, 2019, p. 2). « Forme de spectacle intermédia conçu en 1958 avec le metteur en scène $A$. Radok, reposant sur l'interaction de comédiens présents et filmés, et nom de la Cie qui a développé cette forme, que Svoboda a dirigé de 1973 à 1989 ” (tradução da autora).

100 « J'ai toujours rêvé d'un théâtre de lumière. Les comédiens entreraient dans une boîte vide et se mettraient à table autour d'un hologramme » (tradução da autora).
} 
colocadas às vistas do público, tendo um sentido ativo e dramatúrgico atribuído a elas. O uso de equipamentos alternativos ou não convencionais ao teatro, também é exemplo desta terceira modalidade, cuja fonte luminosa se torna objeto de cena. O autor classifica esse tipo de procedimento como um uso performativo do equipamento de luz, que passa a intervir diretamente na ação cênica, apresentando, como exemplo...

\begin{abstract}
...a artista nova-yorkina Laurie Anderson, que, desde o início dos anos setenta, tem sido uma das pesquisadoras mais ativas na exploração de todas as possíveis relações entre luz e objetos, corpos, som. Em seu trabalho, ela tende a relacionar equipamentos tradicionais e a alta tecnologia, construindo performances nas quais integra frequentemente luz, projeções de vídeo e monitores, com o cenário, a ação, os figurinos, os instrumentos musicais, chegando às vezes ao ponto de realizar uma espécie de eletrificação generalizada do corpo e dos objetos. Ou ainda a artista tcheca Jana Sterbak: sua Robe (1984) era uma roupa de malha metálica equipada com resistências elétricas que, ativadas por um sensor, acendiam cada vez que um espectador se aproximava. [...] Durante os anos 80 , em uma das performances mais conhecidas de Stelarc - um ciber-artista cipriota que vive na Austrália - seus olhos-laser realizavam uma inversão da relação visãoolho: ao invés de receberem a luz, eles emitiam. Ao longo das últimas décadas, foi realizada certa troca entre o teatro de pesquisa e esse tipo de experiências, que se aproximam do teatro. Elas se concretizaram em obras nas quais a luz e seus equipamentos se tornaram diretamente performativos. ${ }^{101}$ (CRISAFULLI, 2019, p. 155-156).
\end{abstract}

Desta forma, Crisafulli confere um caráter performativo ao uso dos equipamentos, mas desconsidera a atuação performativa da luz que eles emitem em contato com os corpos e objetos que iluminam. Ele tampouco analisa seus efeitos sobre o observador, ou seja, o fato de que o resultado da interação entre equipamento, luz e objeto modifica a maneira como eles são percebidos por um

101 «...l'artiste new-yorkaise Laurie Anderson qui, depuis le commencement des années soixante-dix, est une des plus actives expérimentatrices de tour les rapports possibles entre lumière et objets, corps, son. Dans ses travaux, elle tend à mettre en relation des instruments traditionnels et la haute technologie, construisant des performances dans lesquelles elle intègre fréquemment la lumière, des vidéo-projections et des moniteurs, avec le décor, l'action, les costumes, les instruments de musique, allant parfois jusqu'à réaliser une sorte d'électrification généralisée du corps et des choses. Ou encore l'artiste pragoise Jana Sterbak: sa Robe (1984) était un vêtement en maillage métallique équipée de résistances électriques qui, activées para un senseur, s'enflammaient à chaque fois qu'un spectateur s'approchait. [...] Durant les années quatre-vingt, dans une des performances bien connues de Stelarc - un cyber-artiste chypriote basé un Australie - ses yeux-laser réalisaient un renversement du rapport œil-vision : plutôt qu'ils ne recevaient la lumière, ils l'émettaient. Au cours des dernières décennies, un certain échange a eu lieu entre le théâtre de recherche et ce type d'expériences, qui du reste sont proches du théâtre. II s'est concrétisé en des travaux où la lumière et ses instruments sont devenus directement performatifs » (tradução da autora). 
espectador presente e ativo. Desconsiderar a participação do público, nestes casos, reduz a percepção do potencial performativo da luz, que efetivamente só acontece no olhar e na mente deste espectador dedicado ao que observa, aprecia e vivencia.

A iluminadora Marisa Bentivegna ${ }^{102}$, ao contrário, evidenciou a reação do público à luz em algumas das experiências realizadas em sua parceria com a diretora Cristiane Paoli Quito, cujo trabalho de improvisação junto à Companhia Nova Dança atribuía à luz uma função ativa com fortes resultados perceptivos sobre o espectador. Segundo ela,

\begin{abstract}
O público do Nova Dança sabia que os espetáculos eram sempre diferentes e voltavam. E aí começaram a perceber que a luz também era sempre diferente. Foi uma fase em que eu vi que nós estávamos formando um público que ia prestando atenção na luz. Então, eu ouvia de pessoas, que não eram críticos de teatro, mas pessoas amigas ou do público em geral: "Nossa, eu nunca tinha visto isso, nunca imaginei que tinha uma pessoa por trás" ... Eu não entendo como (risos), eu fui sentindo uma alegria de perceber os meus novos amigos percebendo qual a minha importância dentro do meu trabalho, é legal isso. E com a Quito tinha isso mesmo, de o público ver, rever e interagir, dizendo “...ontem foi melhor", “...hoje não teve aquela cena" e perceber que é realmente diferente a cada dia (BENTIVEGNA, anexos, p. 159).
\end{abstract}

Seu relato denota a maneira como uma luz ativa pode interferir na cena, interagindo com a atuação dos performers e provocando diferentes reações no espectador. Nesse mesmo sentido, o iluminador Rodrigo Ziolkowski103 destaca o momento em que o iluminador, depois de montada a luz, "senta na frente da mesa de iluminação e [...] começa a escrever uma dramaturgia com a luz" (ZIOLKOWSKI, anexos, p. 208) como sendo uma segunda etapa, ou seja, como parte integrante do processo de criação da luz.

102 Em entrevista realizada como parte desta pesquisa, disponível nos anexos, p. 151-163.

${ }^{103} \mathrm{Em}$ entrevista realizada como parte desta pesquisa, disponível nos anexos, p. 205-208. 


\subsection{Conceitos Importantes}

Para consolidar e formatar a intuição que veio a se tornar a proposta do conceito de performatividade da luz, foi preciso buscar, em pesquisas e conceitos já consagrados e publicados, as bases que pudessem auxiliar na compreensão do comportamento da luz ativa e seu potencial performativo. Um dos primeiros, e mais basilares, foi, sem dúvida, o conceito de luz ativa, de Adolphe Appia, já apresentado anteriormente, com seus fundamentos investigados por diferentes pesquisadores, dentre eles Cibele Forjaz, Angelo Passos e Fabrizio Crisafulli, usados neste estudo. Foi fundamental, também, entender e explorar o funcionamento operacional do processo de criação colaborativa, imprescindível para a realização da luz como ato performativo, com base nas práticas de grupos nacionais e internacionais e seus encenadores, a exemplo de Antônio Araújo, Joël Pommerat, entre outros.

Os conceitos de performance design e cenografia foram investigados a partir da publicação de Pamela Howard (2015), das pesquisas de Christine Richier (2019), Ismael Scheffler (2019) e Luciana Bueno (2007) e do entendimento da lluminação Cênica no teatro contemporâneo como aplicação dos conceitos do design. Atividade conhecida também como lighting design, foi estudada, principalmente, com base nas experiências artísticas pessoais, mas também a partir da interessante obra desenvolvida por Eduardo Tudella (2017), a publicação de Roberto Gill Camargo (2012), as pesquisas de Hamilton Saraiva (1990), Cibele Forjaz (2013) e Valmir Perez (2012) e os artigos e as entrevistas com importantes iluminadores/pesquisadores brasileiros e estrangeiros, atuantes nas universidades, escolas e teatros do mercado profissional da iluminação cênica. Essa investigação foi feita considerando tanto aspectos técnicos e processuais da criação de luz como linguagem cênica quanto uma abordagem da natureza e comportamento da luz como elemento físico e material, a luz-matéria, para o que foi fundamental a análise dos diferentes conteúdos apresentados no Colóquio Internacional Luz-Matéria (2019-2020) e a relevante publicação de Bernard Maitte (2015). 
Com o objetivo de aprofundar a análise da perspectiva imaterial e da ação performativa da iluminação na cena contemporânea, foi necessário explorar conceitos como o da própria performatividade, desenvolvido principalmente por Josette Féral (2015), Performance de Richard Schechner (2007) e pós-dramático de Hans-Thies Lehmann (2007), bem como os estudos de Edélcio Mostaço (2009) e, especialmente, a pesquisa sobre mimesis performativa de Luiz Fernando Ramos (2015). No que diz respeito à relação estabelecida entre o espectador e a luz e com o intuito de comprovar sua atuação performativa, temas como presença cênica, com base na pesquisa de Gisela Biancalana; percepção, pelos estudos de Lucia Santaella (2012) sobre a fenomenologia de MerleauPonty (1994) e do conceito de Affordance, do psicólogo norte-americano James Jerome Gibson (1986).

No intuito de compreender melhor como acontece a relação entre o palco e a plateia, foi necessário aprofundar os estudos sobre recepção ativa, estética da recepção de Hans Robert Jauss (1978) e ato de leitura de Wolfgang Iser (2007), chegando às formulações mais recentes dos estudos sobre o ato do espectador por Flávio Desgranges e Giuliana Simões (2017). Ainda sobre o espectador, foram importantes as análises das publicações de Paul Zumthor (2007) e Hans Ulrich Gumbrecht (2010), o conceito de espectador emancipado de Jacques Rancière (2012) e a noção de espectador cocriador da cena de Carmem Valdez (2009) desenvolvido a partir dos conceitos de Claude LéviStrauss, Hans-Thies Lehmann, Umberto Eco e Marco De Marinis.

Além desses, outros conceitos anteriores, ainda oriundos da formação em design, constituíram etapas importantes de estudo para que se chegar às reflexões que conduziram a esta pesquisa e à elaboração do conceito de luz performativa, a exemplo da percepção da arte, de Rudolf Arnheim; da semiótica e do signo teatral com Jindrich Honzl, Tadeusz Kowzan, Roland Barthes e Julia Kristeva; da estética, com Roberto Figurelli e Mikel Dufrenne; teoria e prática das cores com Israel Pedrosa, Goethe e Newton; criação e criatividade por Fayga Ostrower; o ato responsável de Mikhail Bakhtin e as valiosas publicações coletivas de Jacó Guinsburg, nem todas citadas ou usadas diretamente nesta 
pesquisa, mas que certamente fazem parte constituinte da gênese de todo 0 percurso empreendido antes e durante a escrita destas linhas ${ }^{104}$.

Assim sendo, os conceitos apresentados a seguir buscam introduzir os argumentos necessários para a conclusão final desta pesquisa, ou seja, o conceito da performatividade da luz. Apesar da tentativa de classificá-los e apresentá-los, cientificamente, de uma maneira mais sequencial, eles acabam sempre por se interconectar de alguma forma, relacionando-se no sentido final das contribuições para o desenvolvimento da investigação. Se explica, então, que apesar de estarem alocados em diferentes seções deste capítulo, algumas argumentações possam se repetir, sendo possível encontrar algumas passagens aparentemente mais prolixas ou dispensáveis, mas certamente proveitosas para o entendimento do que se apresenta.

Alguns outros conceitos detectados ao longo da pesquisa, tão importantes quanto os apresentados acima e a seguir, certamente a enriqueceriam e complementariam. No entanto, dada o volume já tão extensa, não figuram nas presentes páginas. Isso, no entanto, apenas denota a amplitude dos horizontes que esta pesquisa revela, deixando em aberto, para novas incursões teóricas e experimentos práticos, muitos dos possíveis caminhos vislumbrados. De modo que é preciso, num determinado momento, ater-se aos prazos e dar por concluído o processo de doutoramento, apresento o que segue, legando a novas pesquisas muitas das alternativas oriundas deste estudo e que revelam lacunas ainda por preencher, a exemplo do estudo sobre o tempo e o movimento da luz, a atuação do operador e seu impacto sobre a percepção do espectador, entre outros expostos com mais vagar ao final deste documento de tese.

104 No entanto, todas constam das referências bibliográficas desta tese para eventuais consultas, caso possam provocar a curiosidade ou o interesse do leitor. 


\subsubsection{Conceito amplo de cenografia}

Me parece importante, antes de abordar o tema da cenografia em seu conceito mais amplo, distinguir este termo das noções de cenário, espaço, ou, ainda, espaço cênico. Jean-Guy Lecat (2007) define espaço como, em primeiro lugar, um endereço, um local onde se vai para entrar em contato com uma representação, um espetáculo ou um acontecimento cênico. Ele acrescenta, ainda, que esse espaço não precisa, necessariamente, expressar nada, podendo até mesmo ser totalmente neutro, como nas tendências modernas e contemporâneas de espaços como a Cartucherie, próxima a Paris, sede do Théâtre de Soleil, ou a Performing Garage e o La MaMa, de Nova York. Segundo Lecat, o espaço é um local que recebe e reúne artistas e espectadores, devendo também proteger e abrigar dos ruídos, da chuva e dos perigos externos. "As paredes e o teto de um teatro não são indispensáveis ao espetáculo, o teatro de rua, por exemplo, sobrevive bem sem eles, mas favorizam a concentração e a relação público/espetáculo"105 (LECAT, 2007, p. 33). Ele acrescenta, ainda, que esse espaço deve ser neutro, mas não estéreo, para que favorize tanto a encenação quanto a concentração do público. "É preciso encontrar uma solução que faça sentir que a ação acontece em um mundo palpável e vivo, mas ao mesmo tempo que esta ação se sobressaia de um fundo que não lhe imponha nenhuma forma pré-definida"106 (LECAT, 2007, p. 8).

Uma possível relação entre o espaço e a cenografia é dada pela noção de espaço psicoplástico de Josef Svoboda, segundo quem a filosofia e a arquitetura se unem no teatro para, a partir do conjunto de componentes da cena e suas interações com o drama, construir uma dimensão psíquica do espetáculo, uma atmosfera dúbia entre concreta e impalpável (RICHIER, 2019, p. 203). Para

105 «Il faut donc trouver une solution qui fasse sentir que l'action se déroule dans un monde palpable et vinant, mais en même temps que cette action se détache sur un fond qui ne lui impose aucune forme prédéfinie " (tradução da autora).

106 "Les murs et le toit d'un théâtre ne sont pas indispensables au spectacle, le théâtre de rue par exemple s'en passe très bien, mais ils favorisent la concentration et la relation public/spectacle » (tradução da autora). 
Svoboda, o espaço psicoplástico é "um espaço capaz de se transformar com a ação dramática"107, ou seja, um espaço que é transformado e adaptado pela encenação, que o adequa a uma determinada representação ou ação cênica, dramática ou performática (RICHIER, 2019, p. 77). Segundo Richier, Svoboda afirma buscar uma ideia, não um cenário. Essa ideia, para ele, reside no segredo, na parte secreta da obra que cabe à cenografia revelar, trabalhando a partir de seu interior, e não da aparência ou do acabamento, para tornar visível o que há de invisível por trás de um texto ou tema. Para Svoboda, esta busca de um invisível a ser tornado visível caracteriza a função da cenografia, considerando, ainda, que o cenário se caracteriza pela representação de um lugar que pertence ao visível, mas que conduz ao invisível. Essa transição entre o visível e o invisível passa por um pensamento psicoplástico do espaço (RICHIER, 2019, p. 202).

Já para Pamela Howard (2015), o termo cenografia define a escrita ou o desenho geral do espaço cênico que, originário da raiz grega skino-grafika, designa não apenas um título ou uma função no quadro geral das atividades envolvidas em um processo de criação teatral, mas um conceito (HOWARD, 2105 , p. 259). Segundo ela, o vocabulário comum da cenografia como linguagem artística inclui volumes, espaços, cores, formas, escalas e materiais, não como conceitos abstratos, mas como caminhos práticos para decifrar o código dramático. Desta forma, o conceito de cenografia, definido como um trabalho colaborativo que expressa e desenvolve visualmente o espetáculo, se diferencia do ato de projetar cenários. Ele abarca em seu complexo, além do cenário, a totalidade do ambiente sonoro, luminoso e de caracterização do espaço e das personagens. A autora explica ainda que, como componente da criação teatral, a cenografia é aplicável em todos os lugares e em todos os espaços, do site specific ao teatro convencional, usados para performances, apresentações ou representações cênicas. O conceito defendido pela cenógrafa pressupõe, igualmente, uma relação de trabalho colaborativo entre equipe de criação, diretor e elenco, todos movidos por uma forte interação entre o encenador e os artistas visuais envolvidos (HOWARD, 2015, p. 259).

107 «...un espace capable de se transformer avec l'action dramatique » (tradução da autora). 
Para Howard a cenografia é muito mais do que uma tela de fundo para os atores, como foi frequentemente utilizada na dança. Mesmo assim, ela é uma manifestação cujo delicado e complexo processo de fazer o teatro funcionar, envolvendo o diretor, os atores, os artistas visuais e a equipe técnica, é sempre incompleta até o ator entrar no espaço de atuação e se envolver com a plateia. A cenografia exprime a visão de toda a equipe sobre o teatro, a música ou a dança, "uma obra que está sendo apresentada ao público como um trabalho em equipe" (HOWARD, 2015, p. 17). Entendida em seu caráter holístico, a criação cenográfica deve ser, para a cenógrafa, "uma síntese, sem emendas, entre todas as partes componentes de uma grande noite no teatro" (HOWARD, 2015, p. 18) elaborada colaborativamente por toda a equipe criativa envolvida em uma montagem cênica e destinada a um público que recebe, se envolve, identifica a intenção e reage a ela (HOWARD, 2015, p. 246).

\begin{abstract}
O entendimento da cenografia começa no potencial do espaço vazio. Em seguida, considera-se a palavra pronunciada em voz alta, o texto ou a música, que transforma um espaço vazio em um auditório. Das demandas do texto, o contexto da produção pode ser pesquisado para a seleção das formas, das cores ou dos objetos apropriados, que são reunidos em uma composição espacial e trazem vida e visão diferentes ao texto. Um espaço está morto até que os intérpretes o habitem, tornem-se elemento móvel do quadro cênico e contem a história que é aprimorada em sua utilização. $O$ espaço é moldado e alterado pelos atores com a evolução da representação. Assim, a colaboração entre os artistas teatrais se concentra por meio da visão do diretor, e isso anima o espaço e o adapta exatamente para satisfazer as necessidades da produção. Os espectadores são o elemento final que fecha o círculo, ocupando um espaço comum do edifício teatral e sendo a razão para a obra ser criada (HOWARD, 2015, p. 18).
\end{abstract}

A visão de Pamela Howard sobre o cenógrafo pode se estender a toda a equipe de criadores da cena como artistas capazes de entender e desenvolver as ideias do diretor, incorporando-as à visualidade da cena: conhecer o texto como o autor que o criou; ser sensível às necessidades do performer exposto ao público; e criar espaços imaginativos e apropriados à montagem em processo. De modo a conceber também a cenografia, em seu sentido mais amplo, como uma atividade não restrita à cena e à apresentação do espetáculo, mas como um processo complexo e abrangente, que se inicia com a proposta original do trabalho e não se finda com sua apresentação ao público, mas se perpetua pela experiência continuada do espectador em seu contato com a obra, tanto durante 
quanto após sua realização. A esse respeito, a importante pesquisa de Leonel Carneiro (2016), com base, em boa parte, nas investigações de Marie-Madeleine Mervant-Roux, não foi aprofundada nesta pesquisa, mas merece ser citada sugestão, se for do interesse do leitor.

Também conhecida internacionalmente como performance design, a cenografia abrange, então, todas as características sensoriais atribuídas ao espaço da ação cênica como cenário, iluminação, adereços e ambientação sonora de um espetáculo. Traduzido como grafia da cena ou representação gráfica de uma performance, encenação ou espetáculo cênico, ela define e determina a relação estabelecida entre as cenas e o espaço, desses com os personagens e o conjunto final resultante com o público espectador. Pamela Howard destaca, ainda, a íntima conexão entre a cenografia e a arquitetura, no entendimento do espaço e sua relação com a cena. A autora cita Appia como o primeiro arquiteto cênico do século $X X$, que trouxe abertura e frescor arquitetônico para os cenários pictóricos usados em sua época (HOWARD, 2015, p. 28). Béatrice Picon-Vallin também descreve a maneira como a cena contemporânea rompeu com a arte pictórica e voltou-se para a arquitetura com a cena arquitetônica de Craig, a cena construtivista ou a da Bauhaus, como resultado de pesquisas plásticas capazes de redefinir o espaço tridimensional no qual o performer precisa ter domínio sobre o movimento cênico para que sua atuação permita o controle das formas plásticas no espaço, que se torna fluído pela distribuição de cor e movimento pela atuação da luz (PICON-VALLIN, 2013, p. 123).

Em seu estudo doutoral sobre a obra de Josef Svoboda, a iluminadora e pesquisadora Cristine Richier também revela seu entendimento deste conceito amplo de cenografia ao descrever a iluminação como um dos componentes maiores da cenografia (RICHIER, 2019, p. 283). Pamela Howard, se referindo igualmente ao conceituado cenógrafo, relembra sua descrição de uma cena como uma potente imagem poética na qual, segundo ele, o corpo do ator, em síntese com a luz, o cenário e o figurino, transmite completamente um momento dramático: "as costas de um ator subindo uma grande escadaria, sozinho, no 
escuro, no palco de Édipo Rei, de Sófocles. Nos degraus, as dobras do seu casaco descartado capturavam a luz, falando de maneira eloquente a respeito da derrota" (URSINI URSIC, 1992 apud HOWARD, 2015, p. 218), revelando a importância do conjunto do visual cênico de uma encenação em seu contato direto com o espectador.

Em um outro interessante texto investigativo, Christine Richier (2015) se pergunta se é possível falar de imagem no teatro, argumentando que o que se vê num palco é sempre plural, mutável, diferente para cada espectador, que não assiste ao mesmo espetáculo quando sentado na primeira fila da plateia ou na última do primeiro balcão. Ela propõe, ainda, que o termo visual cênico seja mais apropriado para designar a distribuição de corpos e elementos cênicos em movimento e suas interações com a luz e o som.

A produção do visual cênico repousa sobre diversos componentes,
começando pelo lugar da representação, que desempenha um papel
importante com sua arquitetura, sua relação entre o palco e a plateia,
a cor de suas paredes ou da roupagem cênica. Ele é o invólucro de um
visual que se constrói no palco com o corpo dos artistas, sua presença,
suas expressões e deslocamentos, o cenário, as projeções, o figurino,
a maquiagem, os adereços, todos os elementos revelados,
transformados ou ocultados pela luz. E não vamos esquecer o universo
sonoro, outro meio poderoso de produção do visual ${ }^{108}$ (RICHIER, 2015,
p. 90).

Passível de ser associado ao conceito de visual cênico de Richier, a noção de imagem, apresentada pelo professor Tudella (2017), tem como base a abordagem do termo feita por diferentes pesquisadores do teatro, começando com Jean-Jacques Roubine, que se refere ao espetáculo como um conjunto de imagens em movimento e pondera, em seus estudos, que todo corpo, no teatro, é simultaneamente imagem e vice-versa (TUDELLA, 2017, p. 33). Sua investigação da práxis cênica como um conjunto de imagens, não só visuais, mas também mentais e sonoras, entre outras, cuja qualidade particular se deve

\footnotetext{
108 «La fabrique du visuel scénique repose sur de multiples composants, à commencer par le lieu de représentation, qui joue un rôle important avec son architecture, son rapport entre la scène et la salle, la couleur de ses murs ou celle des pendillons. II est l'écrin d'un visuel qui se construit sur scène avec le corps des interprètes, leur présence, leurs expressions et déplacements, la scénographie, les projections, le costume, le maquillage, les accessoires, autant d'éléments révélés, transformés ou effacés par la lumière. Et l'on n'oubliera pas l'univers sonore, autre puissant moyen de fabrique du visuel » (tradução da autora).
} 
à sua interação imediata com o espectador, o levou a considerar a cena como um discurso poético-visual. Para ele, "o discurso efetivado através da imagem encaminha para a apreensão da visualidade particular de um espetáculo" (TUDELLA, 2017, p. 34). Tanto um conceito quanto o outro subentendem a imagem no teatro como manifestação cuja ação transdisciplinar sobre a percepção do espectador permite as experiências estéticas e poéticas que se encontram na origem própria do conceito amplo de cenografia.

Fabrício Crisafulli colabora com o entendimento de imagem, visual cênico e cenografia por suas reflexões sobre as novas tecnologias em confronto com o teatro contemporâneo e as novas questões relacionadas à imagem eletrônica, imagem digital e todas as possibilidades ligadas ao seu emprego na cena, como a multimídia e a interatividade. Segundo ele, esses elementos constituem fatores bastante relevantes para o teatro a partir do século XX, com implicações vastas que ultrapassam o domínio da cenografia e alcançam a própria natureza da obra teatral, sua linguagem e esfera simbólica (CRISAFULLI, 2019, p. 192).

Pamela Howard também relaciona a cenografia com a tecnologia quando destaca que, em uma profissão onde tempo e dinheiro são sempre escassos, todos precisam se manter atualizados a respeito dos desenvolvimentos tecnológicos e das novas possibilidades em soluções das mais variadas. Mesmo contando com a expertise de profissionais especializados, é preciso conhecer e saber escolher e decidir 'se' e 'quando' uma nova ideia ou proposição pode ser utilizada. Ela também destaca que os conhecimentos acerca das evoluções tecnológicas em equipamentos de luz e som podem levar a uma linguagem cenográfica completamente diferente (HOWARD, 2015, p. 123). Por outro lado, Svoboda alerta que não se trata apenas de conhecer e usar a tecnologia, mas do uso que se faz dela:

No teatro, a minha diferença é que eu enriqueço a tecnologia, eu adapto, eu a transformo. E acontece o mesmo com o espaço teatral, [...] ele também é um instrumento que é preciso saber tocar, que é preciso saber usar. Espaço, volume, forma, luz, matéria, tecnologia, tudo isso forma uma orquestra sinfônica, existem muitos instrumentos para controlar no teatro, todos diferentes, mas que devem soar 
perfeitamente juntos ${ }^{109}$ (SVOBODA apud RICHIER, 2019, anexo 1, p. 40-1).

Esse tema ilustra a maneira como o mundo teatral assistiu à invasão da cena pelo vídeo, ao mesmo tempo que ocorria a evanescência e o esvaziamento material do palco pelo uso de imagens digitais e tecnológicas, muito como resultado da precariedade de recursos financeiros e estruturais na construção da cenografia contemporânea. Beatrice Picon-Vallin (2013) lembra a "efervescência teatral do primeiro terço do século XX e a cruzada por um teatro da visão, o teatro do encenador", que ocorreu simultaneamente ao desenvolvimento do cinema (PICON-VALLIN, 2013, p, 120). Ela cita Abel Gance, que afirmou que o cinema dotaria o ser houmano, que passaria a escutar com os olhos, de um sentido novo. Essa constatação prenuncia o que viria a acontecer com o teatro proposto por muitos encenadores que se serviram de imagens fílmicas para enriquecer e complementar suas composições cênicas na Europa e nos EUA,

Tendo entrado muito cedo na cena teatral, o filme, precedido pela projeção fixa, pode servir ao palco abrindo-o amplamente ao mundo (Meyerhold, Piscator), ou fazendo-o tender ao onírico, como desejava Artaud. Josef Svoboda, nos anos 1960, redescobre na cena, intensificada por seu pensamento de cenógrafo-técnicoexperimentador, a combinação da imagem fixa ou cinematográfica e da ação dramática (PICON-VALLIN, 2013, p. 122).

Segundo a pesquisadora, esse teatro de imagens é composto por elementos fílmicos que exercem funções espetaculares, igualmente narcísicas, introspectivas, intimistas e lúdicas que permitem ver o "não mostrável", alterando, complementando e perturbando a visão do espectador e ampliando, para um contexto totalizante, a ação que se desenrola no palco. Essas imagens, cênicas, em determinados contextos, atuam como corpos estranhos à cena para desconcertar, manipular e desestabilizar o público, interferindo na percepção do real e do teatro e criando variações sobre a aproximação e distanciamento entre cena e espectador. Ao mesmo tempo, belas imagens pictóricas podem

109 « Au théâtre, ma différence c'est que j'enrichi la technologie, j'adapte, je la transforme. Et c'est pareil avec l'espace théâtral, [...] il est aussi un instrument dont il faut savoir jouer, qu'il faut savoir utiliser. Espace, volume, forme, lumière, technologie, tout cela forme une orchestre symphonique, il y a beaucoup d'instruments à maîtriser au théâtre, tous différents mais qui doivent sonner juste. " (tradução da autora) 
ambientar e criar um teatro do pensamento de forma sensível, fazendo o espectador "ouvir o que lhe é dado a ver" (PICON-VALLIN, 2013, p. 133). Crisafulli aponta o americano Robert Wilson como um importante realizador do chamado teatro da imagem (CRISAFULLI, 2019, p. 184), creditando a ele uma sensibilidade pós-cinematográfica. Sobre o uso da projeção, ele destaca que Bob Wilson "tende à utilizar as projeções integrando-as com o cenário e as luzes, frequentemente projetando-as diretamente sobre os objetos e as arquiteturas cênicas, sempre subordinando-as a necessidades poéticas e compositivas precisas e prestando uma grande atenção à maneira como elas são percebidas"110 (CRISAFULLI, 2019, p. 190-91).

Ainda sobre a relação entre cenografia, iluminação e imagens virtuais, é preciso entender que a projeção de imagens também pode representar e ser utilizada como um tipo de fonte luminosa, cuja luz interfere e também pode atuar performativamente na cena. O ator ou performer que toca ou é tocado pela imagem, tem sua atuação influenciada por ela, alterando também a percepção do público da cena pela luminosidade e intervenção da imagem em movimento. Para Svoboda, "a projeção é uma forma de utilizar a luz, não é o cinema, não se trata de projetar um filme, mas de uma mudança da luz graças à película. Explorar a projeção como fonte de luz [...] para obter um efeito desejado [...] Isso é teatro!"111 (SVOBODA apud RICHIER, 2019, anexo 1, p. 40).

Mesmo que estática, a imagem projetada pode gerar no espectador a sensação de movimento e ação por meio da movimentação dos corpos sob a luz emitida pelo projetor, com suas formas e cores, a exemplo da imagem usada no espetáculo de teatro-dança O Voo do Poeta, de Pedro Pires com a Companhia G2 do Ballet Guaíra. Como única fonte luminosa usada na cena retratada na imagem abaixo, a luz projetada sobre os corpos das bailarinas e a textura das

\footnotetext{
110 « II tend à utiliser les projections en les intégrant dans le décor et les lumières, souvent en les envoyant directement sur les objets et les architectures scéniques, toujours en les subordonnant à des nécessités poétiques et compositionnelles précises, et en portant une grande attention à la manière dont elles sont perçues » (tradução da autora).

111 "La projection, c'est une façon d'utiliser la lumière, ce n'est pas du cinéma, il ne s'agit pas de projeter un film, mais d'une modification de la lumière grâce à la pellicule. Explorer la projection comme source de lumière [...] pour obtenir l'effet souhaité [...] Ça c'est du théâtre ! " (tradução da autora)
} 
flores afetava a percepção da cena, alterada pelo posicionamento das bailarinas e pela movimentação dos corpos em resposta à música envolvente e sensual, bem como à coreografia, com movimentos lentos e ritmados.

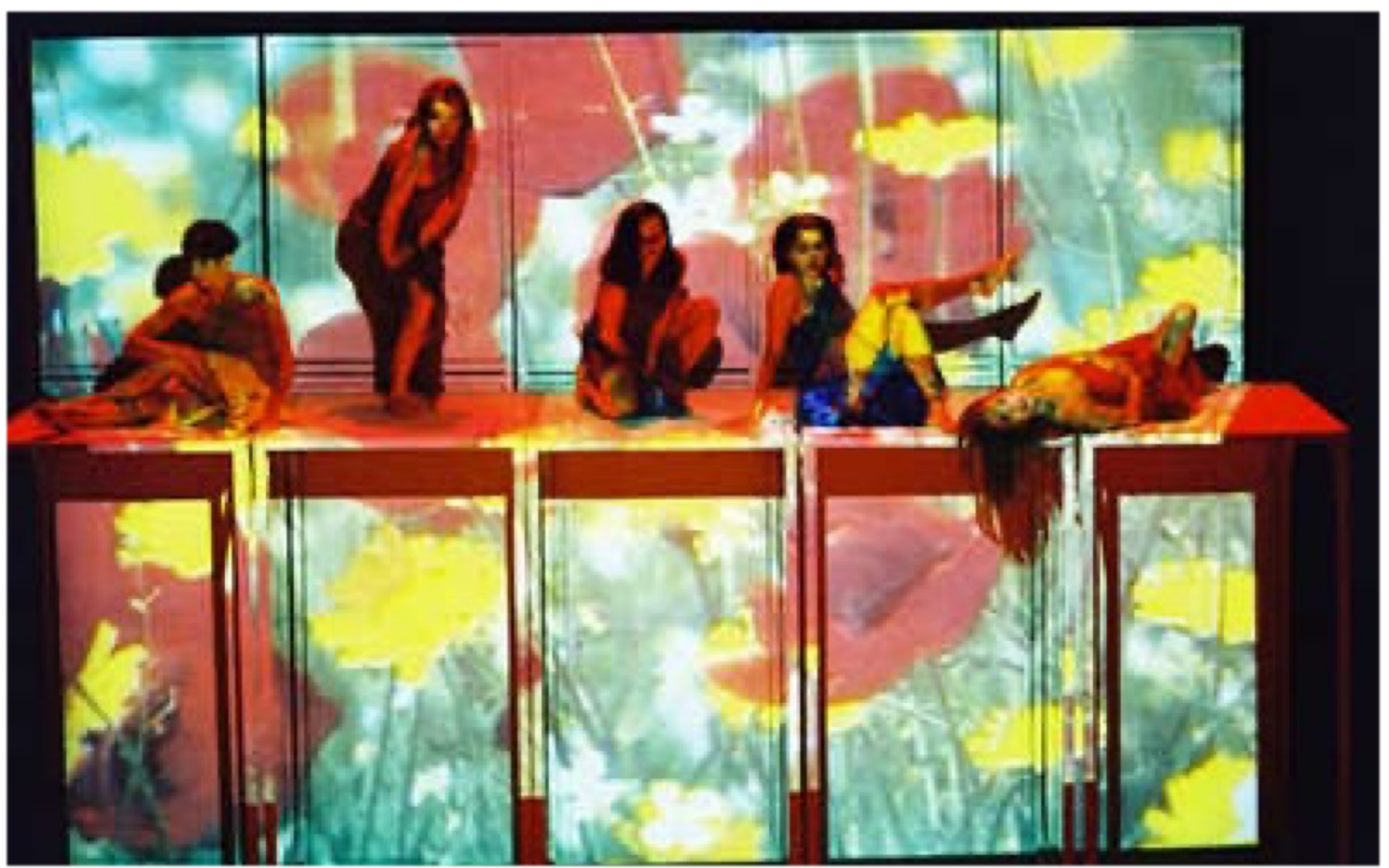

Figura 10 - Cena do espetáculo $O$ Voo do Poeta em que a projeção é usada como única fonte luminosa no Auditório Salvador de Ferrante do Teatro Guaíra em 2003. Coreografias e direção de Pedro Pires. Luz Nadia Luciani. Foto Sérgio Vieira.

A projeção usada como elemento cenográfico também foi empregada na peça Darwin, de Fábio Salvatti, em total interação com as cenas e com a atuação dos atores, por vezes contracenando com sua própria imagem e noutras atuando à frente da imagem projetada, cuja função variava entre ambientar e ilustrar as cenas (LUCIANI, 2018, p. 169).

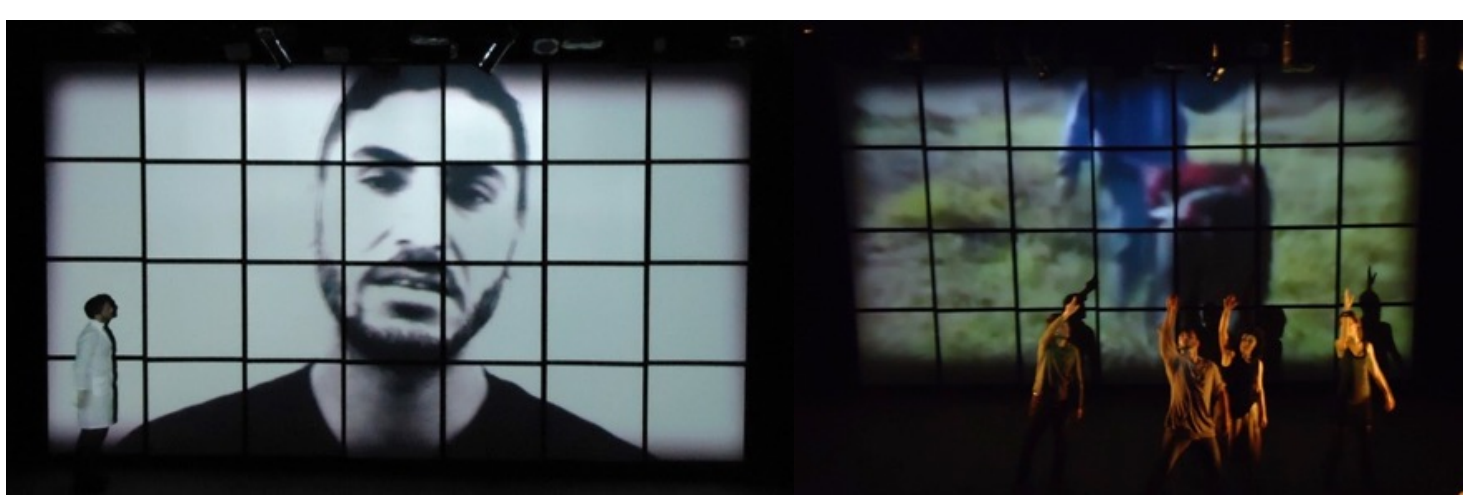

Figura 11 - Uso da projeção na peça Darwin, apresentada no TEUNI em Curitiba em 2012. Texto e direção de Fábio Salvatti. Luz Nadia Luciani. Fotos Rosana Roberta da Silva 
Neste espetáculo foram projetados, ao longo da peça, depoimentos dos atores a respeito da temática do espetáculo, a criação e evolução da espécie. Esses depoimentos reais, intercalados com as diferentes cenas ficcionais, mixavam ficção e realidade na interação dos atores em cena com suas próprias imagens projetadas, a exemplo da figura abaixo. Na figura da direita, a imagem em movimento projetada no cenário ao fundo do palco ambienta a coreografia dos atores, sem que haja, necessariamente, uma interação entre ambas para além da associação temática.

O movimento e a ação gerada pela projeção e pelo vídeo no teatro alterou o conceito e a prática da cenografia contemporânea, tanto em espetáculos teatrais quanto de música ou dança, passando de fases em que atuaram de forma meramente ilustrativa, substituindo os painéis pintados dos cenários pictóricos do final do século XIX, até a interação com a cena e a atuação dos performers, como feito por Svoboda no Laterna Magika, as encenações de Brecht e, mais recentemente, as de Robert Wilson. Ou ainda por seu simples uso como fonte luminosa capaz de alterar a percepção do espectador por meio da sua interferência na luminosidade e coloração dos objetos e corpos pela forma, cor e movimento das imagens que incidem sobre eles.

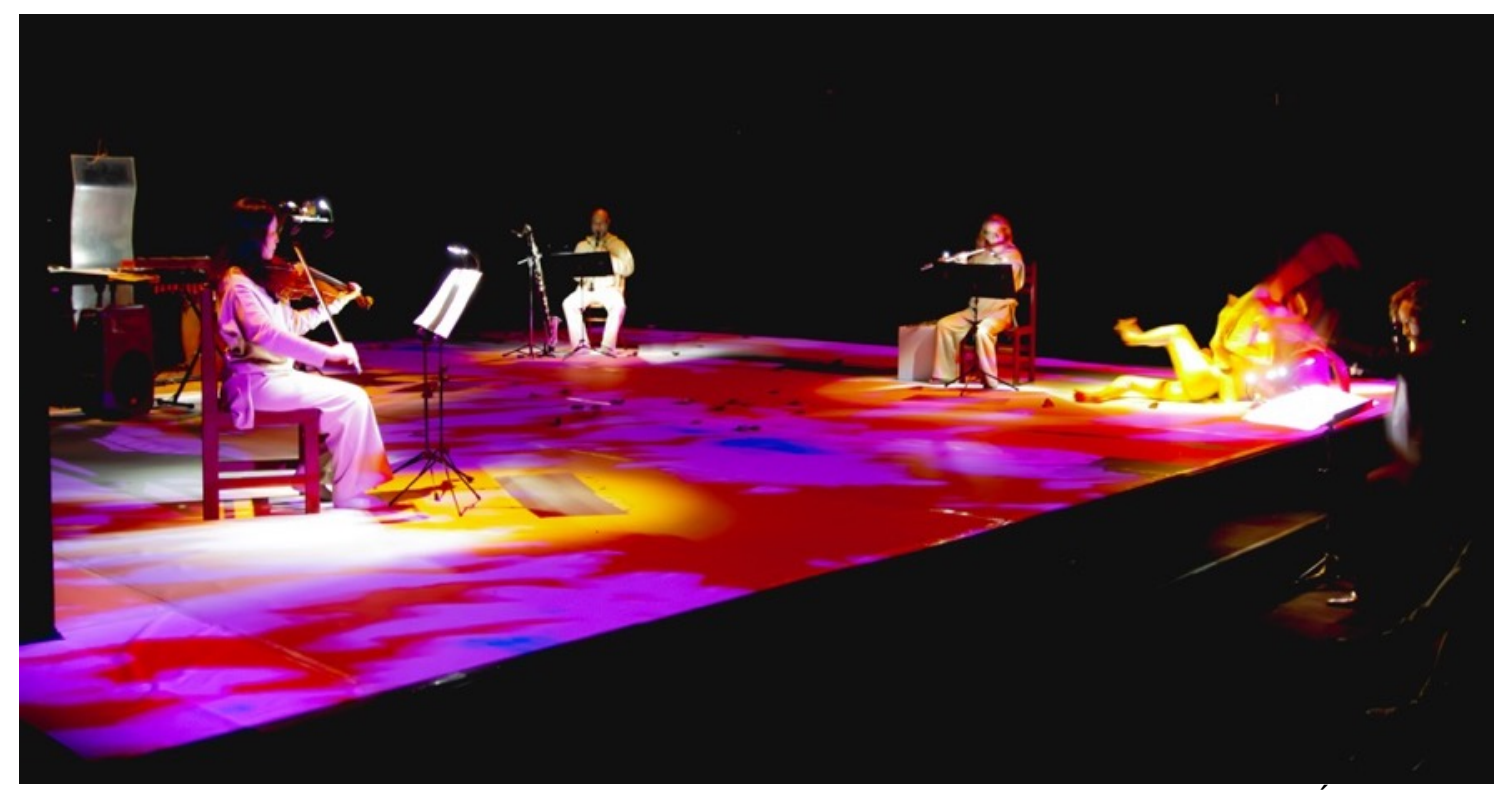

Figura 12 - Imagem projetada sobre cenário, músicos e bailarinos no espetáculo Águas do Éden e do Hades, apresentada no Teatro José Maria Santos em Curitiba em 2018. Concepção geral e direção artística de Maurício Dottore. Luz Nadia Luciani. Foto Gabriel Stocchero. 


\subsubsection{Luz e Iluminação}

Segundo depoimento do iluminador italiano Gianni Staropoli112, luz e iluminação são dois termos, em linguagem universal, de grande significado e beleza, duas definições que convergem, por natureza, para um mesmo ponto de origem e que transportam para as infinitas variações e sugestões oriundas de suas reflexões íntimas sobre a luz, eliminando distâncias siderais (STAROPOLI, anexos, p. 117). A luz e a iluminação podem ser compreendidas como dois aspectos distintos de um mesmo fenômeno que, apesar de ser normalmente associado a um estímulo visual, não está restrito ao sentido da visão. Para Arnheim (2012), a luz é uma das primeiras causas da percepção visual, precedendo todas as outras, "pois sem luz os olhos não podem observar nem formas, nem cor, nem espaço ou movimento" (ARNHEIM, 2012, p. 293). Ver a luz é a maneira mais óbvia de percebê-la, mas não é a única. A luz também pode acessar um observador por outros sentidos, desde que seja assimilada, igualmente, sua natureza material e imaterial.

A iluminação cênica, da maneira como é abordada neste estudo doutoral, se refere aos dois conceitos simultaneamente, pois assume esta dupla natureza da luz. O iluminador, encenador e dramaturgo Roberto Gill Camargo ${ }^{113}$ classificou a luz como matéria prima da iluminação (GILL CAMARGO, anexos, p. 198), ou seja, como fenômeno físico, a luz é um elemento material que, com forma e presença física, está ligado à visão e a iluminação, em seu aspecto imaterial e intangível, está ligado à percepção. Se, por um lado, há o projeto de concepção das luzes que iluminarão um espetáculo teatral ou cênico, entendido como iluminação em sua natureza imaterial, há, por outro, a luz, o fenômeno físico em si, a materialidade do feixe luminoso que ilumina a cena quando toca objetos e corpos, modificando, pela sua presença, a percepção do espectador. A esse conjunto foi dada, neste estudo, simplesmente, a qualidade de "luz".

\footnotetext{
112 Em entrevista realizada como parte desta pesquisa, disponível nos anexos, p. 117-120.

113 Em entrevista realizada como parte desta pesquisa, disponível nos anexos, p. 196-204.
} 
Desta forma, os dois conceitos se fundem e o termo "luz", de modo geral, se refere tanto à luz quanto à iluminação, no sentido amplo de objeto de estudo, paixão e atividade profissional, na teoria e na prática, nas salas de aula e nos palcos, como artista e mulher, nos últimos 30 anos de vida, trabalho e pesquisa da autora. No entanto, considerando os fins científicos a que se propõe este trabalho investigativo, foi preciso diferenciá-los de alguma forma. Rudolf Arnheim esclarece que:

\begin{abstract}
O termo "iluminação" não se explica por si. À primeira vista, pareceria que a iluminação deve estar envolvida toda vez que se vê algo, porque a menos que a luz incida num objeto, ela permanece invisível. Isto, contudo, é a maneira de raciocinar dos físicos. O psicólogo e o artista podem falar de iluminação somente se e quando a palavra serve para dar nome a um fenômeno que os olhos discernem diretamente (ARNHEIM, 2012, p. 297).
\end{abstract}

Os conceitos de luz, iluminação e iluminação cênica precisam, então, ser diferenciados para que seja possível, no enfoque da atividade artística investigada, entender a noção de "luz" empregada ao longo desta pesquisa. O primeiro conceito, entendido como simples fenômeno físico, diferencia-se do de iluminação como projeto concebido para iluminar algo, a exemplo, inclusive, de objetos, vitrines ou ambientes residenciais, comercias ou urbanos, entre outros. Por fim, iluminação cênica refere-se também a um projeto, mas, neste caso, criado especificamente para iluminar um acontecimento artístico, em todas as suas variantes possíveis, das artes visuais aos espetáculos cênicos e acontecimentos performativos. Muitas vezes entendido como sinônimo de iluminação, o termo luz foi adotado, neste estudo, principalmente pelo aspecto da materialidade poética do fenômeno físico da luz, explicada mais adiante, para que ela possa ser analisada e concebida como um elemento ativo na cena.

Talvez seja oportuno destacar, neste momento, a questão semântica tratada em trabalhos teóricos sobre iluminação cênica em língua francesa, que diferenciam os termos usados para a luz que clareia os ambientes ou cenas e a luz usada como linguagem cênica. O interessante desta distinção é que o termo luz, se relaciona, no teatro, ao termo éclairage, ou seja, a luz que clareia, enquanto que a iluminação cênica é que é designada como lumière, que seria a tradução literal de luz. Este paradoxo resulta numa certa complexidade 
encontrada no entendimento e na tradução de fontes e materiais de pesquisa em língua francesa, mas, ao mesmo tempo, num ótimo ponto de reflexão mais profunda sobre os dois conceitos.

Essa diferença é claramente expressa no estudo de Crisafulli a respeito das teorias de Adolphe Appia, que distingue o aspecto luminoso do estético ao designar lumière como a "iluminação expressiva e criadora de formas; iluminação como matéria poética e substância dramática"114 e éclairage como "elemento técnico e funcional, secundário, completamente exterior em relação ao processo criativo"115 (CRISAFULLI, 2019, p. 21). Nesses termos, parece que a mesma distinção é feita na prática da iluminação cênica na França, entre o fenômeno físico que clareia ou ilumina a cena, a luz (éclairage) e a iluminação (lumière) criada pelo lluminador (créateur lumière, diferente de éclairagiste) para provocar efeitos e resultados junto à cena, ao performer e ao espectador. Scott Palmer explica, igualmente, os termos usados na Inglaterra, de light, como "a substância material controlada para fins dramáticos, permitindo a visibilidade no espaço cênico e contribuindo para a experiência do público durante o evento ${ }^{116 "}$ (PALMER, 2013, p. xiii), associado ao conceito apresentado aqui como iluminação, e lighting que, "em contraste, se refere ao sistema técnico e aos processos empregados para criar a iluminação do palco"117 (PALMER, 2013, p. xiv), conceito mais relacionado ao que foi classificado aqui como de luz. A mesma distinção pode ser percebida nas palavras da pioneira da iluminação Jean Rosenthal ao afirmar que a "luz permanece indispensável para as pessoas verem aquilo sobre o que incide. A sua iluminação afeta tudo sobre o que a luz incide: como você vê, como se sente a respeito, e como ouve o que está escutando"118 (ROSENTHAL, 1972, p. 3). Rosenthal associa, igualmente, luz

\footnotetext{
114 «...lumière expressive et créatrice de formes ; lumière comme matière poétique et substance dramatique » (tradução da autora).

115 «...élément technique et fonctionnel, secondaire, voire tout à fait extérieur par rapport au processus créatif » (tradução da autora).

116 "...the material substance harnessed for dramatic use, enabling visibility in the stage space and contributing to an audience's experience of the event » (tradução da autora).

117 «...in contrast, refers to the technical systems and processes employed to create light on stage " (tradução da autora).

118 "... light remains primarily important in order for people to see what it falls upon. The lighting of it affects everything light falls upon: how you see what you see, how you feel about it, and how you hear what you are hearing " (tradução da autora).
} 
(light) ao fenômeno luminoso material, a luz física que clareia as coisas e permite que elas sejam vistas, e iluminação (lighting), como a luz criada para a cena teatral a partir de processos e conhecimentos técnico s e artísticos, a iluminação cênica como é de entendimento no âmbito teatral, performático e espetacular.

Assim sendo, é reforçada a retomada feita aqui, como conceito, da noção primária de luz, com o objetivo primordial de associar a iluminação em sua materialidade como fenômeno físico, a outros elementos materiais da cena, a exemplo dos corpos, gestos e movimentações do performers, objetos e elementos do cenário. O entendimento original de 'luz', empregada dos primórdios do teatro até o final do século XIX, considerando seus diferentes tipos de fontes luminosas, do fogo à luz elétrica, e usada apenas como mero instrumento de visibilidade, deu lugar ao conceito de 'iluminação', aquela concebida especialmente para a cena e, no trabalho de alguns artistas mais visionários, para cada espetáculo particular, a partir do simbolismo e do expressionismo, já no século XX. Finalmente, o que propõe-se, aqui, é o retorno ao conceito de luz, mas já num entendimento como acontecimento luminoso, mais ou menos elaborado, possivelmente improvisado ou ocasional, mas sempre relacionado a uma ação cênica, um fenômeno físico real, que se opõe a qualquer ilusionismo ou representação do real, uma tensão entre ficção e realidade, no contato da cena contemporânea com o espectador.

Além disso, ainda no contexto da cena contemporânea, é importante destacar a diferença, exposta pelo professor Eduardo Tudella ${ }^{119}$, entre a luz cênica (qualquer iluminação sem conexão com um conceito elaborado em acordo com a direção ou concepção de um espetáculo) e a luz para a cena (uma luz concebida com um propósito relacionado especialmente à cena que ilumina). Para Tudella, essa luz para a cena "define uma sucessão de imagens cênicas, incorporando qualidade expressiva, crítica, poética e plástica ao espetáculo" (TUDELLA, 2017, p. 519). Este conceito remete, mais adequadamente, à luz ativa de que trata este estudo, considerando sua interação com a cena, desde a 
elaboração, na gênese do espetáculo, até sua execução durante a apresentação ao público. Isso não impede, obviamente, que uma luz cênica (e não para a cena) exerça, também, em determinadas circunstâncias, uma atuação ou interferência performativa sobre o que ilumina e quem observa.

O que é apresentado neste estudo como luz ativa, então, se refere, principalmente, à luz que interage intencionalmente com a ação performática, tendo sido concebida especialmente para tal, ou seja, a luz para a cena, no conceito apresentado pelo Prof. Tudella. Para Sônia Paiva, a composição cênica tem início com a cenografia e o desenho do palco, se desenvolve com a localização e movimentação dos atores ou performers e se completa com o desenho da luz. Ela explica que mais do que qualquer outro elemento cênico, a iluminação é o que pode direcionar o olhar da plateia e controlar o que é e o que não é para ser visto pelo espectador (PAIVA, 2011, p. 51). É importante destacar que, neste conceito de luz cênica, apesar dela poder atuar como comunicação e informação, ela não age como elemento estrutural da ação cênica ou transformador da cena ou do espetáculo que ilumina ou ambienta. Ela pode, no entanto, se manifestar tanto num espetáculo teatral tradicional quanto numa cena performativa, sem ter sido criada especialmente para colaborar ou interagir com uma determinada ação, mas integrando, mesmo assim, a composição do visual cênico.

Com isso, entende-se que a interação estabelecida entre a luz e a cena pode ser voluntária, quando é resultado da criação do iluminador e da atuação do operador de luz junto ao performer em cena durante o espetáculo, ou involuntária, ocorrendo quando algo inesperado acontece, mas cujo efeito é percebido e assimilado igualmente pelo público. O espectador, em ambos os casos, elabora para si, a partir de sua percepção, um resultado sensorial efetivo e consistente, que desconsidera seu aspecto previsto ou imprevisto. Esse caso pode ser ilustrado com um acontecimento particular ocorrido em um espetáculo musical que eu iluminei no Teatro Paiol em Curitiba no ano de 2015. A cantora Cida Airam, apresentava, com banda e músicos convidados, o show de lançamento do seu primeiro $C D$, quando uma queda de energia desligou todos 
os equipamentos, tanto de luz quanto de som. Num momento de inspiração coletiva, todos os músicos continuaram a tocar "à capela" (sem amplificação) e a cantora seguiu cantando a música que mal começara.

Um aspecto particular e curioso deste teatro é que, dada a conservação da edificação pelo patrimônio histórico, não foi autorizado o fechamento das pequenas janelas existentes por toda a volta do edifício, que, permanentemente, permitem a entrada da luz do dia ou da iluminação urbana do entorno do teatro durante a noite. Essa interferência atrapalha, muitas vezes, a concepção da luz de muitos espetáculos e é objeto de frequentes reclamações de iluminadores locais e visitantes, que solicitam o fechamento das janelas. Neste episódio em especial, no entanto, este fato foi providencial e bem vindo, pois a claridade que entrava no teatro, filtrada pelo material translúcido azulado das janelas, rebatida ainda pelas paredes claras e levemente amareladas do teatro, permitiram luminosidade suficiente para que o público pudesse seguir vislumbrando os músicos e apreciando o show, independente do inegável desespero das equipes de iluminação e sonorização do espetáculo.

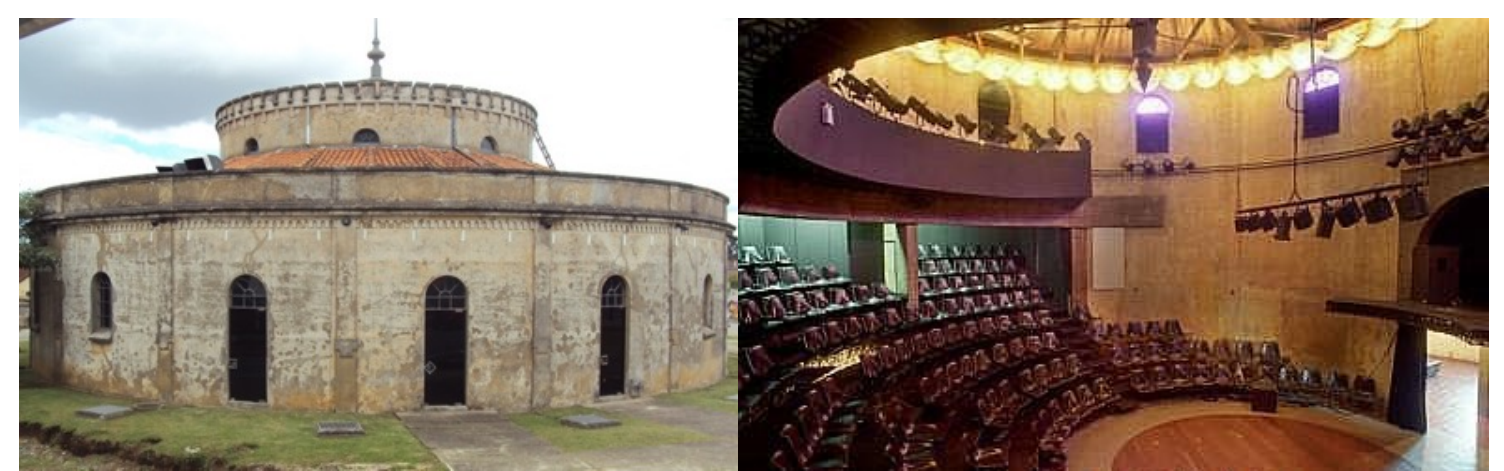

Figura 13 - Imagens externa e interna do Teatro Paiol em Curitiba nas quais é possível visualizar as janelas superiores que iluminavam o palco. Fotos Zig Koch e Eliane Costa.

Surpreendentemente, em uma sincronia mágica e inexplicável, no exato momento do final da música, próximo ao último acorde, quase simultâneo aos aplausos do público emocionado com a garra e presença cênica dos artistas durante aquele imprevisto técnico, a energia elétrica foi restabelecida e a luz voltou ao palco. O retorno da luz neste momento preciso trouxe consigo a dúvida sobre a real imprevisibilidade do ocorrido. Foi surpreendente o número de espectadores que questionaram e até mesmo elogiaram o "efeito" criativo e 
inovador, acreditando numa possível intencionalidade da aparente queda de energia com fins cênicos, o que permaneceu sendo comentado por amigos e artistas mais chegados ainda por algum tempo.

Poeticamente, pode-se dizer que esse tipo de fenômeno e seus efeitos podem acontecer tanto no teatro quanto na vida real, quando uma mudança de luminosidade, seja da luz natural ou da artificial, parece interagir sensorialmente com o momento ou a emoção sentida ou compartilhada com alguém. Alguns exemplos são banais, mas podem ajudar a entender o que quero dizer com fenômeno de luz "natural" que pode acontecer na vida real. Os postes de luz urbana possuem sensores fotoelétricos que os fazem acender e apagar ao anoitecer e amanhecer, respectivamente. Algumas vezes, quando isso acontece, é possível impressão que o fazem "propositalmente" quando alguém passa por eles, parecendo se relacionar, de alguma forma, a algo que foi dito ou pensado. Ou quando as nuvens no céu encobrem ou expõem a luz do sol, gradativamente, ou ainda quando o sol se põe por trás das montanhas ou da linha do horizonte, como belos efeitos de fade in ou out da luz cênica, operado conscientemente na mesa de comando por "alguém lá em cima".

Há um exemplo particular e emocionante deste fenômeno, uma passagem muito pessoal, mas que dentre muitos outros, parece ser o mais digno de ser citado. Foi quando, na missa de sétimo dia de falecimento do meu pai, no instante preciso em que o padre citou seu nome, ou quase, e a luz do astro rei inundou lenta e intensamente toda a igreja com uma estonteante luminosidade. Aquele efeito me fez sentir como se, naquele momento, o espírito do meu pai tomasse forma e viesse nos agraciar com sua presença, preenchendo o espaço por meio daquela luz, daquele calor e daquela materialidade física, quase palpável. Talvez eu não tenha sido a única a notar o acontecimento e o efeito provocado em mim, ou talvez sim, considerando minha condição de iluminadora, mas o que posso afirmar é que a luz, por um instante, transformou a cena e a percepção que eu tive dela, agindo de uma maneira que eu só posso qualificar como performativa. 
Do ponto de vista artístico, James Turrell, um dos mais relevantes artistas da luz na atualidade, define seu trabalho como o de um pintor, mas em terceira dimensão. Para ele, a luz não é algo que revela, mas a própria revelação, cujas possibilidades poéticas foram profundamente exploradas em suas obras. Turrell procurava neutralizar o espaço para permitir uma maior concentração do observador para a luz que o habita e suas qualidades físicas e perceptivas (BARROS, 1999, p. 102). Anna Barros define a percepção como arte, o artista como facilitador perceptivo e a luz como fenômeno capaz de enformar o espaço e deflagrar a percepção por suas qualidades de energia e materialidade desmaterializada (BARROS, 1999, p. 26). É inegável, então, sua capacidade de emocionar, envolver e sensibilizar, transformando e intensificando a experiência perceptiva por sua ação sobre a percepção humana. Para que esses fenômenos aconteçam, no entanto, é necessário haver uma sincronia e uma interação entre diversos fatores, fazendo com que, por vezes, pensemos ser impossível fazê-los de forma programada ou pré-estabelecida. A investigação profunda destes e de outros fenômenos, porém, a exemplo da natureza e comportamento da luz, da teoria e prática da cor, dos fenômenos fisiológico da visão e psicológico da percepção, dos estudos da presença e da recepção ativa, podem ajudar a entender como eles acontecem e usá-los como potente recurso cênico.

Cabe explicar, ainda, para o pleno entendimento deste trabalho de pesquisa que, na maior parte das abordagens, luz e iluminação se tornam quase que sinônimos, pois os dois aspectos da luz, material e imaterial, devem convergir para sua plena efetivação como ato performativo. São justamente aos aspectos físico e fenomenológico da iluminação, ou seja, a luz e seus efeitos sobre o espectador, respectivamente, que se refere a performatividade da luz como conceito e fenômeno cênico. É somente considerando seu aspecto físico em sua materialidade, associado à imaterialidade de sua ação sobre a percepção do espectador que é possível conceber a performatividade da luz presente e ativa na cena. 


\subsubsection{Luz-matéria}

Este capítulo pretende abordar o tema da luz-matéria, um conceito que prevê o entendimento da materialidade da luz como elemento e fenômeno físico que se manifesta na cena para, em interação com os demais componentes cênicos, agir sobre a percepção do espectador. A americana Jean Rosenthal, considerada por muitos pesquisadores como sendo a primeira iluminadora mulher da história da iluminação cênica nos EUA, declarou, em um de seus escritos, que "a luz é quase tátil para mim. Ela tem forma e dimensão. Ela tem um fim. Ela tem qualidade e é um corpo"120 (ROSENTHAL, 1972, p. 39).

A percepção do aspecto material da luz é recorrente nas reflexões teóricas ou na observação da própria autora desta pesquisa e de outros colegas de profissão, tanto que é comum ouvi-la, em palestras ou em sala de aula, dizer que a luz se materializa em cena. O que essa expressão, materializar-se, à qual Beto Bruel ${ }^{121}$ reagiu com alguma surpresa (anexos, p. 48), poderia significar, afinal? É possível considerar que a noção de materialização da luz signifique, basicamente, que ela se presentifica, ou seja, se torna presente quando colocada em cena, da mesma forma que qualquer outro elemento material, vivo e atuante. Mesmo quando ela não atinge nenhum objeto, pessoa ou elemento do cenário ou do palco, ou seja, quando parece "invisível", sua presença é real, bastando que algo a atravesse para que ela se revele em toda sua materialidade.

Este entendimento do aspecto material da luz é exemplificado pela iluminadora francesa Dominique Bruguière (2017) a partir de suas considerações a respeito da iluminação como luz e como matéria. Como luz, ela evoca mais facilmente a evanescência que o peso, enquanto que como matéria, suas impressões se modificam conforme a cor, a potência e até a textura com que se manifestam na cena.

120 " Light is quite tactile to me. It has shape and dimension. It has an edge. It has quality and is an entity. » (tradução da autora).

${ }^{121} \mathrm{Na}$ entrevista realizada como parte desta pesquisa, anexos, p. 48-59. 
As matérias luminosas são, para mim, da mesma ordem que os tecidos. Eu percebo sua transparência com uma lâmpada HMI em um refletor elipsoidal, enquanto que essa mesma lâmpada em um refletor Fresnel me dará a impressão de espessura. A sensação produzida por uma fonte única e potente, que desenhará com precisão os contornos e os relevos, terá uma essência diferente da produzida por uma série de refletores idênticos cujos fachos se fundem uns nos outros para criar camadas de cores, texturas fixas e suaves que podem adentrar as sombras sem alterá-las e se juntar discretamente a outras naturezas de luz. Em compensação, se os fachos se concentrarem em uma única direção, eles se transformam em uma substância quase palpável no ar, como se a luz de repente não tivesse mais necessidade de encontrar a matéria para ser vista. E conforme a luz seja difusa ou direcional, a cena e o que se conta nela não terão o mesmo "peso". Quando direcional, ela hierarquiza, define, esculpe. Ela marca cada objeto com uma sombra precisa e a fixa no espaço, ela conduz nosso olhar e nos leva a imaginar, quase que naturalmente, que existe algo além das paredes do teatro. É também ela que que faz o quadro, e seu movimento conduz o de nossa percepção. A luz difusa não escolhe 0 que nos mostra, nem conduz o olhar em uma direção definida. Ao invés de separar, ela engloba dissolvendo os limites e os contornos. Ela suaviza o relevo em lugar de salientá-lo. Quanto mais rica a diversidade de fontes, mais ela me dá a liberdade de inventar imagens sucessivas e, em uma única imagem, criar as camadas de transparências ou de colorações ou texturas que irão se misturar e se enriquecer mutuamente122 (BRUGUIÈRE, 2017, p. 49-50).

\section{Segundo Steiner (1986 apud GUMBRECHT, 2015, p. 84), "as artes estão}

maravilhosamente enraizadas na substância, no corpo humano, na pedra, no pigmento, na vibração das entranhas ou no peso do vento nos juncais". Para o autor, a boa arte e a boa literatura têm início na imanência, naquilo que a obra traz em si apesar, ou melhor, para além de seu aspecto externo, mas sem

122 «Les matières lumineuses sont pour moi de l'ordre des étoffes. Je perçois de la transparence avec une lampe HMl dans un projecteur à découpe, alors que cette lampe dans un projecteur à lentille Fresnel me donnera l'impression d'épaisseur. La sensation produite par une source unique et puissante, qui va dessiner avec précision les contours et les reliefs, sera d'essence différente de celle donnée par une série de projecteurs identiques dont les faisceaux se fondent les uns dans les autres pour créer de 'nappes' de couleurs, textures étales et douces qui peuvent entrer dans les ombres sans les altérer et s'allier discrètement avec les autres natures de lumière. En revanche, si ces faisceaux se concentrent dans une seule direction, ils vont se transformer en une substance presque palpable dans l'air, comme si la lumière n'avait soudain plus besoin de rencontrer de la matière pour se donner à voir. Et selon que la lumière est diffuse ou directionnelle, la scène et ce qui s'y raconte n'auront pas le même 'pois'. Lorsqu'elle est directionnelle, elle hiérarchise, définit, sculpte. Elle marque chaque objet d'une ombre précise et l'ancre dans l'espace, elle conduit notre regard et nous amène à imaginer, presque naturellement, qu'il y a un au-delà des murs du théâtre. C'est également elle qui fait le cadre, et son mouvement entraîne celui de notre perception. La lumière diffuse, elle, ne choisit pas ce qu'elle nous donne à voir, n'entraîne pas le regard dans une direction définie. Au lieu de séparer, elle englobe en dissolvant les limites et les contours, elle gomme le relief au lieu de creuser. Plus la diversité des sources est riche, plus elle me donne la liberté d'inventer des images successives et, dans une seule image, de créer des couches de transparences ou de teintes et de textures qui vont se mêler entre elles et s'enrichir mutuellement » (tradução da autora). 
desconsiderá-lo. Isso equivale a dizer, segundo ele, que é parte da experiência estética a tarefa e o privilégio de tornar presente "a relação entre a temporalidade e a eternidade, entre a matéria e o espírito, entre o homem (sic) e 'o outro'...” (STEINER, 1986 apud GUMBRECHT, 2015, p. 84).

$\mathrm{Na}$ imagem de mundo de Vilém Flusser, a ideia de mudança de estados da matéria dá origem a dois horizontes. No primeiro tudo que é visível é sólido ou material (horizonte do zero absoluto) e no segundo tudo que é invisível se apresenta num estado gasoso ou energético (horizonte da velocidade da luz). Ele apresenta a matéria como "um preenchimento transitório de formas atemporais" (FLUSSER, 2007, p. 24) que se manifesta na transformação dos corpos de um estado para outro. A oposição matéria-energia assume, assim, a conversão da matéria em energia e vice-versa. Desta forma, tudo é energia na ciência moderna e, sendo energia, é possibilidade de aglomerações casuais, ou seja, de formação da matéria (FLUSSER, 2007, p. 25). Assim sendo, é possível considerar que a luz, tanto como matéria quanto como energia, se expressa materialmente, mesmo que visível ou não, na relação física, material e energética que estabelece entre o palco e a plateia durante a apresentação de um espetáculo cênico.

Antes de tratar especificamente do aspecto material da luz no teatro, no entanto, parece importante citar uma abordagem mais recorrente na fala e nos escritos de pesquisadores, professores e iluminadores a respeito da sua imaterialidade. Nas entrevistas realizadas para esta pesquisa ${ }^{123}$, dos vinte e cinco profissionais entrevistados, dezoito relataram sua percepção da luz para a cena como sendo simultaneamente material e imaterial, sendo que quatro com ênfase em seu aspecto imaterial. Apesar de cinco deles atestarem 0 entendimento da luz apenas como material e de Pasquale Mari (anexos, p. 179) afirmar que ela não é nem uma coisa nem outra, o iluminador Jorginho de Carvalho (anexos, p. 136) foi categórico ao afirmar sua opinião sobre a imaterialidade, uma noção comum da luz como fenômeno sensorial que atinge performers e espectadores, afetando e influenciando suas ações e reações. $O$

${ }^{123}$ Disponíveis nos anexos, p. 28-233. 
jornalista Jean-Pierre Thibaudat (1991 apud RICHIER, 2019, p. 13) classifica a luz como impalpável ao ponderar que "o espectador não deve perceber nada. Sendo assim, como falar sobre o que não vemos? Se, por um lado, é possível discorrer à vontade sobre a arte concreta do figurino, o discurso sobre a luz é limitado. Como é possível nominar o impalpável, o fluído?"124 Christine Richier encontrou também na concepção do pesquisador cenográfico e teórico tcheco Vladimir Jindra, um dos fundadores da Quadrienal de Praga, esta noção da iluminação e da projeção como meios imateriais e impalpáveis da cena. Para ele, os meios fundamentais da cenografia: espaço, luz, movimento e reflexão, são imateriais (RICHIER, 2019, p. 15).

Segundo Richier, as manifestações cênicas dos meios imateriais como névoa, projeção, cortinas de luz, aparições, jogos de espelhos e fusões, entre outros, estariam num último grau na escala de imanência da fábrica do visual cênico. Acima deles estaria apenas a paisagem sonora, sem dúvida, segundo ela, o mais sutil dos seus meios imateriais. A pesquisadora relembra, no entanto, que é somente por meio de recursos materiais que é possível realizar o imaterial, ou seja, são equipamentos, cabos, materiais, sistemas elétricos e estruturas, além de horas de montagem. Jindra classifica os componentes cênicos em dois tipos: os tangíveis (materiais) e seus complementares impalpáveis (imateriais), que se manifestam, durante as apresentações, tanto para os atores quanto para o público, no que Richier nomeia como "um impalpável ambiental e ativo, dotado de uma capacidade instantânea de transformação"125 (RICHIER, 2019, p. 15).

São esses componentes materiais e imateriais os responsáveis, segundo Josef Svoboda, pela noção de movimento no teatro, que se dá pela renovação do visual cênico por meio da luz e das projeções. O controle destes meios está no centro de sua obra e resulta da busca da relação entre eles, a reflexão e a cinética, em interação com a dramaturgia, a matéria, o espaço e o tempo. Para

124 «...le spectateur ne doit y voir que du feu. Dès lors, comment parler de ce que l'on ne voit pas ? Si l'on peut disserter à loisir sur l'art concret du costume, le discours sur la lumière tourne court. Comment nommer l'impalpable, le fluide ? » (tradução da autora).

125 «...un impalpable environnement et agissant, doublé d'une capacité instantanée de transformation » (tradução da autora). 
Antonin Artaud, igualmente, o domínio do teatro não é psicológico, mas plástico e físico (PICON-VALLIN, 2013, p. 113), provocado por um de seus elementos mais expressivos e presentes, a luz! Invisível, ela precisa do espaço para se fazer presente e, mesmo não sendo vista, ela pode atuar e realizar o que se espera dela, no tempo e no espaço. Este é o paradoxo da materialidade e da imaterialidade da luz que, como onda ou matéria, é tão resultante da visão quanto da percepção.

Assim sendo, da mesma forma como existe o paradoxo da natureza da luz na ciência, há no teatro a ponderação sobre a natureza material e imaterial da luz e da iluminação. Para o iluminador Eric Soyer ${ }^{126}$, esse paradoxo revelase porque "a luz do palco é profundamente imaterial no sentido de que é uma onda, mas, apesar disso [...] é ela que desenha, revela ou oculta. Nesse sentido, podemos dizer que ela é profundamente material” (SOYER, anexos, p. 109). A iluminação, tanto como fenômeno físico quanto sensorial, apresenta-se em sua materialidade e revela-se na cena em seus dois aspectos, o visual e o perceptivo, a exemplo da diferenciação proposta por Tudella (2017, p. 42) entre visualidade e visibilidade.

A luz, cuja natureza corpuscular e ondulatória foi comprovada em diferentes experimentos físicos, é formada pelas ondas e partículas que constituem seu facho luminoso e, mesmo quando invisível, existe e preenche o espaço vazio do palco até que se interponha em seu percurso um objeto ou anteparo que a torne visível. Rodrigo Ziolkowski ${ }^{127}$ chamou a atenção para o que chamou de 'impermanência da luz", comparando-a com outros elementos físicos da cena, visto que "assim que o espetáculo encerra, você desliga o equipamento de iluminação e ela não existe mais. Talvez venha daí essa questão sobre a materialidade" (ZIOLKOWSKI, anexos, p. 205), enquanto que a iluminadora Elsa Revol128 opinou que, em princípio, a luz só pode existir se houver algo para recebê-la, alertando para o fato de que a própria luz não existe e só é vista

\footnotetext{
126 Em entrevista realizada como parte desta pesquisa, disponível nos anexos, p. 109-112. $127 \mathrm{Em}$ entrevista realizada como parte desta pesquisa, disponível nos anexos, p. 205-208. ${ }^{128} \mathrm{Em}$ entrevista realizada como parte desta pesquisa, disponível nos anexos, p. 92-108.
} 
quando atinge um corpo, um objeto ou um espaço e que seu aspecto imaterial revela-se quando ela é somente percebida e não vista (REVOL, anexos, p. 92).

No embate entre a materialidade e a imaterialidade da luz, parece oportuno retomar os conceitos de visibilidade e visualidade apresentados pelo professor Eduardo Tudella. Para ele, a visualidade está relacionada à postura crítica que orienta o iluminador e confere qualidade estética à sua contribuição para a práxis cênica (TUDELLA, 2017, p. 42) e é formada pelo conjunto de aspectos que delineia a qualidade visual de um espetáculo (TUDELLA, 2017, p. 36), configurando a porção imaterial da luz. A visibilidade, por outro lado, diz respeito à sensibilização do aparelho ótico humano resultante da incidência ou projeção de luz sobre um ambiente, corpo ou objeto, ou seja, seu aspecto material. Desse modo, entendemos que, na práxis cênica, os aspectos constitutivos da visibilidade, ou seja, seus aspectos materiais (as fontes de luz, os corpos sobre as quais elas incidem, os fachos luminosos e os resultados obtidos por este conjunto) contribuem para sua imaterialidade, a saber, a qualidade visual, ou visualidade, já indicada pela dramaturgia ou outro elemento que origine um espetáculo, como explica Tudella (2017, p. 42).

Assim sendo, a luz projetada sobre a cena promove a visibilidade, mas é o resultado de seus aspectos técnicos e físicos que resultarão nos efeitos estéticos e poéticos de tal ação, ou seja, a visualidade cênica. É sua porção material, sua qualidade física, que atua sobre a cena e sobre a percepção do espectador, é a luz materializada no palco que age, que performa, que interage e interfere na ação cênica e na recepção espetacular. Esse entendimento, no entanto, sempre foi analisado de uma maneira muito empírica e intuitiva, mais como uma percepção pessoal do que uma proposição conceitual. Era necessário investir numa investigação mais profunda para efetivamente comprová-lo. Essa oportunidade não demoraria a surgir.

Isso se deu quando da realização, na Universidade de Lille, de um colóquio inteiramente dedicado ao tema da luz-matéria, um conceito que se revelou fundamental para o entendimento da luz ativa que vinha sendo investigado. O Colóquio Lumière Matière, realizado em vocação binacional entre 
Lille na França e Pádua/Neneza na Itália nos anos de 2019 e 2020, respectivamente, foi organizado pelo grupo de pesquisa Lumière de Spectacle (LdS), dirigido por Véronique Perruchon no CEAC - Laboratório de Artes da Universidade de Lille, e por Cristina Grazioli, da Universidade de Pádua. Em suas duas etapas, a primeira de dois e a segunda de três dias, o tema foi intensamente explorado nas trocas entre estudantes, pesquisadores, professores, artistas e demais interessados em iluminação cênica e áreas afins.

Entremeado por apresentações artísticas e a apresentação randômica de um vídeo com obras de diversos iluminadores franceses, italianos, brasileiros e belgas, o colóquio, realizado inicialmente entre pesquisadores franco-italianos, ampliou sua abrangência internacional pela participação de um pesquisador e três pesquisadoras brasileiras, dentre elas a autora desta pesquisa. Essa participação brasileira se deveu, em parte, ao ciclo de conferências realizadas no Brasil no mesmo ano pela professora Véronique Perruchon ${ }^{129}$, criadora e coordenadora do LdS, cujo objetivo principal é o de incentivar uma cultura universitária da iluminação cênica a partir de sua dimensão prática, profissional e artística. Ele visa também a interação entre acadêmicos e praticantes do teatro e da iluminação, permitindo uma importante aproximação entre a teoria e a prática. Por esse aspecto, o evento representou uma quebra de paradigma de acontecimento científico na Europa, particularmente na França, país que ainda preserva ranços do intelectualismo oriundo do século das luzes que distancia, ainda hoje, a pesquisa científica teórica da prática em diversas áreas do conhecimento, principalmente nas artes.

Esse tipo de evento é muito comum no Brasil, com diversos exemplos organizados em universidades públicas e particulares, além de outras instituições de ensino do teatro por profissionais e estudiosos da área, alguns já

\footnotetext{
129 A proposição, pelo LABIC - Laboratório de lluminação Cênica da FAP/Unespar e o Luz Laboratório da UDESC, do projeto Lumière et Théâtre ao Institut Français da Embaixada da França no Brasil e Alianças Francesas de Curitiba e Florianópolis, com a participação das universidades brasileiras UNESPAR, UDESC, USP, USJR, UFOP e UFRN, permitiu a realização de um ciclo de palestras e lançamento do livro Noir, Lumière et Théâtralité pelas universidades envolvidas entre os dias 22 de agosto e 06 de setembro de 2020, culminando com a participação no evento A Luz em Cena, no CEART da UDESC em Florianópolis-SC.
} 
com mais de 10 edições realizadas ${ }^{130}$, mas que, até o momento, é muito raro na França. Por isso a importância de ressaltar o valor científico deste colóquio e do grupo de pesquisa LdS no CEAC da Universidade de Lille, que inovou ao reunir pesquisadores de importantes universidades da França ${ }^{131}$, da Itália ${ }^{132}$ e do Brasil ${ }^{133}$, performers, iluminadores, estudantes e doutorandos do programa de pós-graduação da UdL e demais interessados em torno do tema luz-matéria.

Buscando associar os aspectos físicos e cênicos da luz, o colóquio apresentou a luz-matéria, explorado pelos conferencistas convidados sob diferentes ângulos, da ciência à criação artística. Relacionado à física, à dramaturgia, à plasticidade, ao cinema e à teatralidade da luz, tanto no campo das artes da cena quanto em referências trazidas de outros campos científicos, as comunicações refletiram sobre a materialidade e a imaterialidade da luz na cena. Entre significação e metáfora, a iluminação cênica foi abordada em sua dimensão estética de maneira concreta e sensorial. Os estudos da dimensão material e da vocação imaterial da luz em relação com os campos físico, plástico e estético, permitiram uma maior aproximação e aprofundamento da pesquisa. A investigação do aspecto da materialidade da luz redirecionou decisivamente 0 entendimento e a conceituação da noção de performatividade da luz em desenvolvimento.

Para os organizadores do encontro, luz-matéria é uma associação de conceitos que não se finda em si mesma. No campo artístico, a luz se torna objeto de um enfoque ambíguo conforme a consideremos em sua materialidade, de um ponto de vista físico, ou em sua imaterialidade, na perspectiva da

\footnotetext{
130 A exemplo dos eventos Manhãs lluminadas, realizado em Curitiba entre 2004 e 2010 pela ABrIC-PR; A Luz em Cena, organizado pelo Luz Laboratório do CEAC - Centro de Artes da UDESC - Universidade do Estado de Santa Catarina, realizado desde 2007; Seminaluz, que realizou sua $12^{a}$ Edição em 2019 em Ipatinga-MG e Som \& Luz, organizado desde 2018 pela UFG, entre outros de igual importância.

131 Universidade de Lille (UdL), Sorbonne Nouvelle Paris 3, Paris-Diderot, Vincennes Saint-Denis Paris 8, Universidade de Artois, Universidade Paul Valérie (UPVM) e Universidade de Picardie Jules Verne.

132 Universidade de Pádua, Universidade Ca'Foscari, Universidades La Sapienza e Tor Vergata de Roma, Politécnico de Milão e Instituto per il teatro e il Melodrama de Venezia.

133 Universidade de São Paulo (USP), Universidade Federal de São João Del Rei (UFSJ), Universidade Estadual do Paraná (UNESPAR) e Universidade Estadual de Santa Catarina (UDESC).
} 
expressão e percepção artísticas. Essa ambiguidade faz lembrar a eterna dicotomia científica sobre a natureza corpuscular e ondulatória da luz (MAITTE, 2015). Numa reflexão crítica, quando a luz é considerada em seu aspecto material, ela se integra ao campo das artes visuais e é analisada em termos significantes por meio da iconologia, suscitando a maneira como ela ilumina um objeto real ou representada em uma pintura, na busca de seu significado. No entanto, essa mesma reflexão desperta, igualmente, o interesse na luz como fenômeno físico de construção do campo de visão, tanto na imagem plana quanto nas instalações performativas, a exemplo da obra de Olafur Eliasson e outros artistas da segunda metade do século XX como Bruno Munari ou Nicolas Schöffer. Já do ponto de vista da imaterialidade da luz, ela é analisada com os recursos da filosofia que emergem da observação da imagem, a exemplo de George Didi-Huberman (2007), que discorre a respeito da aparência e do visível, ou do crítico literário francês Max Milner (2005) na investigação do campo obscuro da representação do ser no mundo desde o mito da caverna de Platão.

A iluminação adquiriu, no atual contexto do teatro contemporâneo, uma crescente relevância por atuar em espetáculos sem cenários, com poucos figurinos, com uma ampliação na demanda de seu desempenho como linguagem e elemento estrutural da cena, incorporando inclusive a arte do vídeo. Ela se faz presente quando pontua um acontecimento dramático, uma mudança de cena, quando marca uma alteração de ritmo ou de intensidade, revelando a densidade ou entonação de uma ação ou espetáculo, mas também pode atuar de maneira sutil e imperceptível, agindo sobre a sensibilidade e percepção do espectador. Sua materialidade aparente faz dela um componente a ser levado em consideração na construção do aspecto visual do ambiente cênico, percebida, às vezes, apenas na chegada de uma nova atmosfera luminosa, mas que muitas vezes passa desapercebida, confrontando seus aspectos materiais e imateriais. Sua materialidade às vezes se perde em uma visão globalizada da cena que suprime sua densidade, mas mesmo que desapareça por trás da ação cênica ou se torne "invisível", a luz-matéria é, inegavelmente, uma realidade cênica e um componente primordial do espetáculo. Como parte constituinte da encenação, intencionalmente relacionada à dramaturgia, ela é principalmente ligada estética 
e plasticamente à realidade dramática da cena, percebida em suas variações informais, abstratas ou sensoriais, como onda ou partícula, visível ou invisível, material ou imaterial, conforme a circunstância.

O colóquio, além de toda a reflexão conceitual sobre o tema na fase da elaboração desta tese, trouxe, particularmente, cinco importantes contribuições para o entendimento do conceito de luz-matéria e para o enriquecimento desta pesquisa. As comunicações do professor emérito da UdL e físico francês Bernard Maitte, do iluminador de teatro e cinema italiano Pasquale Mari e do iluminador e doutorando da Universidade de Lille Victor Inisan, na primeira etapa do evento, e das pesquisadoras Yanna Kor, da Universidade Paul Valéry na França e Flavia Dalila D'Amico, da Universitá La Sapienza de Roma, na segunda. Comentadas a seguir, todas permitiram clarear e acrescentar importantes aspectos do fenômeno da luz como elemento material ativo da cena e sua relação com a presente pesquisa de doutorado.

\section{Luz e matéria na física contemporânea: uma mesma descrição}

Bernard Maitte (2015) explicou, pelos caminhos tortuosos da ciência e numa linguagem coloquial, acessível e até mesmo divertida, que luz, matéria e energia são a mesma coisa, têm a mesma descrição e se comportam da mesma forma. Com isso, segundo ele, o principal dualismo da física no que diz respeito à luz, sua natureza como onda e corpúsculo, se torna monismo na escala do infinitamente pequeno. Na história do pensamento científico, as noções de luz e matéria foram algumas vezes identificadas (a luz como corpúsculo), outras vezes diferenciadas (a luz como onda, energia que se propaga). Com o surgimento do conceito de fóton, que não é nem onda nem corpúsculo, e a evolução do pensamento sobre o átomo, o século XX inovou. Hoje, é entendido que a matéria é formada por átomos, eles mesmos constituídos por núcleos e elétrons, bem como pelo que os faz permanecerem juntos, o campo eletromagnético e seu quanta, o fóton. Com isso, Maitte comprovou que luz e matéria passam a estar 
juntas em uma mesma descrição e podem tanto se apresentar em uma delas quanto passar de uma forma à outra.

Em uma abordagem histórica da relação entre luz e matéria, Maitte partiu de Aristóteles e do seu entendimento da materialidade da cor, cuja existência, desde a pré-história, dependia dos pigmentos, ou seja, de impurezas. Desta forma, nas primeiras associações entre luz, matéria e cor, ainda no Século IV a. C., o branco era puro e a cor era sempre impura, visto que necessitava do pigmento. Por 2000 anos, o fundamento da teoria da cor e da cor na matéria foi a mistura dos pigmentos. Todas as cores eram possíveis e, no final, existia o preto, que era a mistura absoluta. O branco continuava sendo a pureza absoluta. Foi a partir do século XI, no Islã, que tiveram início as primeiras reflexões sobre o que é a luz, propriamente dita. Surgem duas teorias: a teoria corpuscular pequenas bolas que vinham do sol até nossos olhos e nos machucavam e, no século XIII, já no universo cristão, a teoria de que eram ondas que se propagavam no espaço. Por volta de 1666, Isaac Newton descobriu que algumas cores tinham um mesmo ângulo de refração e que as cores eram puras, ao contrário do que acreditava Aristóteles. Multiplicando suas experiências com o prisma (vermelho, verde e azul), ele decompôs a luz branca e descobriu que luz + luz $=$ branco. Poeticamente, Maitte relata:

\begin{abstract}
Newton renuncia aos estudos de filosofia e vai desenvolver as leis segundo as quais os planetas giram em torno do sol, as relaciona com a física do que se passa sobre a Terra e descobre a lei da gravidade universal, que explica todos os fenômenos físicos, que se integram num conjunto muito bonito e vasto e a luz se torna corpuscular. Seus estudos vão do infinitamente grande, os planetas, para o infinitamente pequeno, a luz. Mas a teoria corpuscular não consegue explicar as bolhas de sabão (MAITTE, 2015, p. 189).
\end{abstract}

No século XIX, havia um grande interesse pela teoria corpuscular da luz, teoria que explicava diversos fenômenos, como a propagação retilínea da luz, o fato da luz pegar fogo, o arco-íris, a refração e a reflexão da luz, tudo muito bem explicado, menos as bolhas de sabão, que Maitte destaca como tendo sido o grande desafio da ciência e o fenômeno que mais colocou à prova as diversas teorias e experiências a respeito da luz. 


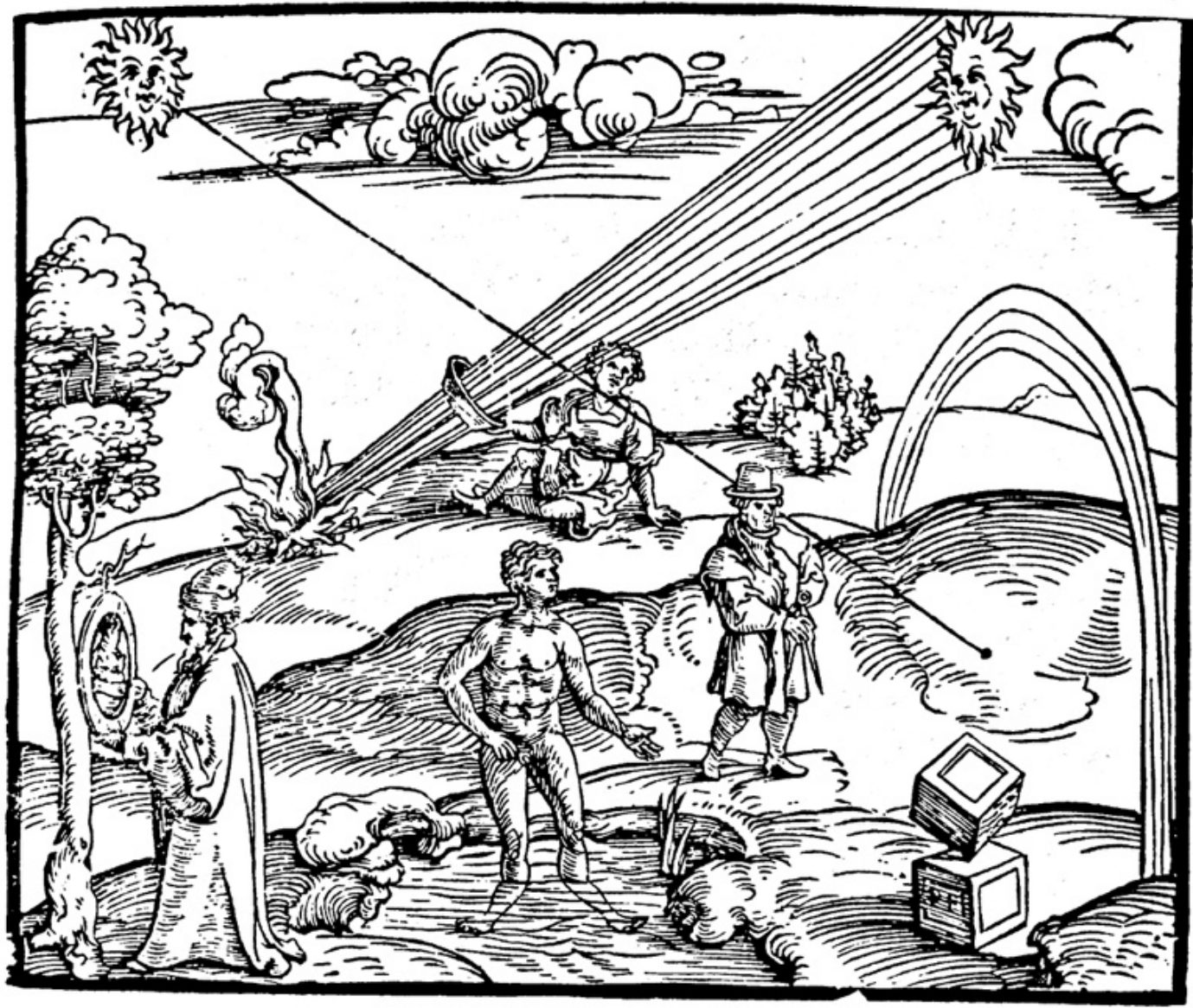

Figura 14 - Representação de Witelo (1535) que retrata diversos fenômenos de reflexão e refração que podem conduzir a uma teoria da luz. (MAITTE, 2015. p.55)

Quem deu início à solução para o problema das bolhas de sabão foi um professor e médico inglês chamado Thomas Young, que estudava a audição e a propagação do som. Ele se familiarizou com a propagação do som por ondas e tentou fazer o mesmo com a luz (o que explicaria as bolhas de sabão). Na água, as ondas se propagam, se separam e se contrariam. O mesmo, segundo ele, acontece com a luz, pois luz + luz pode resultar em obscuridade (quando passam por dois orifícios), mas corpúsculo + corpúsculo será sempre igual a corpúsculo. Com isso, ele refutou a teoria de Newton e declarou para a Sociedade Real Inglesa que a luz é ondulatória. Quinze anos mais tarde, na França, Fresnel observou o que acontecia quando a luz passava pelos cabelos ou quando a cidade era observada através de uma cortina com a luz difratada. Esse fenômeno, que não pode ser explicado por uma teoria corpuscular, confirmou a teoria ondulatória da luz, que, demonstrada pelos dois cientistas, permitiu 
explicar o que a teoria corpuscular explicava, mais a cor das asas da borboleta, as interferências da luz na água e, finalmente, as bolhas de sabão.

Em viagem pela Itália, Goethe afirmou que somente admirando as belas paisagens ensolaradas é que era possível admirar o esplendor das cores, confrontando o fato de Newton insistir em estudar a luz no escuro. A luz já era, nesta época, comprovadamente ondulatória, mas não se sabia ainda o que eram suas ondas. Experiências feitas na Dinamarca e na Alemanha no início do século XIX demonstraram que não era só a gravidade que interferia no movimento, mas também as vibrações. Na Inglaterra, Faraday fez experiências com imãs e correntes elétricas e descobriu o campo de propagação do magnetismo e da eletricidade. Maxwell conseguiu matematizar esse campo e descobriu que a eletricidade, o magnetismo e a luz se propagam na mesma velocidade, não vendo razão para diferenciá-los. Visto que os três têm as mesmas propriedades e velocidade, ele fez da luz um campo eletromagnético, o que consegue explicar, no início do século XX, diversos fenômenos físicos (MAITTE, 2014, p. 311).

As ondas eletromagnéticas operam com captadores diferentes, sendo que o olho humano é captador da luz, sensível apenas à porção visível do espectro eletromagnético, entre o violeta (0,7 mícron) e o vermelho (0,4 mícron). No final do século XIX, já se sabia que existem, na retina, quatro tipos de células fotossensíveis. As células captadoras em cones, sensíveis à luz em três tipos diferentes, azul, vermelho e verde, fazem a grande diversidade de cores às quais os olho é sensível. As células captadoras em bastonetes, que ficam principalmente na periferia da retina do olho, dão as diferenças de luminosidade. Luz e matéria estavam muito bem explicadas até a metade do século XIX. Toda luz, toda eletricidade, todo magnetismo, todo calor são ondas, ou seja, tudo contínuo, algo que se propaga continuamente. Toda física era, neste período, uma física do contínuo no espaço. Porém, no final do século XIX, foi construído um experimento no vácuo, no qual foi produzida a sombra de uma cruz em tubos de vidro por onde passava a eletricidade, um acontecimento que não podia ser explicado de outra forma que não pelo corpúsculo. 
Jean Perin demonstrou, em 1900, que essa corrente que atravessava o vácuo era formada por partículas, que ele chamou de elétrons, desviados pelo campo eletromagnético. Ele provou, assim, a existência, na matéria, de corpúsculos que são carregados negativamente e que têm massa mensurável por esse desvio. Finalmente, ficou comprovado que há corpúsculo na matéria e que, se havia corpúsculos negativos (os elétrons), haveria também corpúsculos positivos (os prótons, 6X mais maciços que os elétrons). Com isso, ele demonstrou que a matéria não era contínua, mas formada por átomos que continham um núcleo positivo com elétrons negativos em volta. A matéria se tornou descontínua e essa descontinuidade chegou também à luz.

Novas experiências demonstraram que quando se aquecia o ferro, ele se tornava preto, e quando a temperatura aumentava, ele ficava vermelho, depois amarelo, branco, finalmente azulado e se fundia. Ele tinha cores! Como se explicaria, então, que fosse possível obter cor pelo calor? A resposta é pela energia fornecida pelo ferro e seu comprimento de onda visível, uma energia infinita, conhecida na física como a "catástrofe do ultravioleta" (MAITTE, 2014, p. 329-331). Max Planck descobriu que o corpo aquecido não absorve nem emite ondas, mas energia, que Einstein afirmou não aumentar continuamente, mas em etapas, de forma descontínua. Aplicando essa teoria à luz, descobriu-se que, na luz, existem corpúsculos com energia, como os descobertos por Planck, o que ele chamou de efeito fotoelétrico e lhe rendeu o Prêmio Nobel 12 anos mais tarde, em 1918, por sua teoria quântica. A luz, alternadamente ondulatória e corpuscular, é tanto uma coisa quanto outra, conforme o fenômeno que se observa.

Em 1912, o físico Niels Bohr também refletiu sobre a relação entre luz e matéria. Ele conseguiu, visto que o átomo é constituído por partículas maciças prótons positivos e elétrons em volta, mais leves e negativos - reunir o modelo de Planck da luz e da matéria. Com isso, ele provou que um elétron, que é matéria e tem um nível de energia preciso, pode, ao ganhar energia, quando aquecido, ou perder, sob a forma de luz, por exemplo, passar de um nível de energia para outro. Ele provou, com isso, que as cores são, então, a passagem 
dos elétrons de um nível de energia para outro e, assim como os fenômenos de fluorescência e fosforescência, podem ser explicados pelo fenômeno da relação entre luz e matéria.

Maitte brincou com os conceitos da arte e da física ao argumentar que, com tudo isso, num conceito da estética clássica, a física não era bela, pois não era simétrica. Para ser bela, segundo Louis de Broglie, um físico francês que também tocava órgão, a matéria, que é formada somente por corpúsculos (prótons ou elétrons), deveria ser, assim como a luz, corpúsculo e onda. Isso fez com que ele propusesse sua tese de que a matéria deveria poder ser escrita tanto em onda quanto em partícula, como a luz, criando o que foi chamado, nos EUA, de Sinfonia Francesa. Com o objetivo de demonstrar que ele estava errado, os americanos Davisson e Germer decidem provar que os corpúsculos não podem se difratar. Ao contrário do que buscavam, eles acabam por descobrir, com suas experiências, a difração do elétron, provando a natureza ondulatória dos elétrons, pelo que De Broglie ganhou o Prêmio Nobel em 1929. Finalmente, luz e matéria são, ambas, onda e corpúsculo, tendo a mesma descrição, afirmação que deu nome à comunicação de Maitte no Colóquio.

Mas as descobertas da física, como era de se esperar, não acabaram aí, e Maitte continuou sua explicação sobre a relação entre luz e matéria até a física quântica. Ele esclareceu que luz e matéria não são onda $E$ corpúsculo nem onda OU corpúsculo, pois enquanto uma partícula pode ser localizada e contada, ou seja, é discreta em número e extensão, uma onda é contínua em número e extensão, e fótons e prótons são discretos em número e contínuos em extensão. Isso explica que luz e matéria não são nem onda nem corpúsculo, ou seja, o antigo dualismo da física (onda e corpúsculo) é substituído pelo monismo (quanta), significando que, na escala do infinitamente pequeno, matéria, energia e luz são a mesma coisa, descrita por algo que é discreto em número e contínuo em extensão: a partícula quântica (Maitte, 2014, p. 349). Para estabelecer uma relação entre luz e matéria, então, é preciso entender que "um átomo não é constituído apenas por prótons, nêutrons e elétrons, que têm massa, mas também pelo que os faz ficarem juntos, que é o campo eletromagnético, ou 
melhor dizendo, os quantas deste campo, chamados justamente de fótons (MAITTE, 2014, p. 349), que não têm massa, mas são tão materiais quanto os elétrons, que têm massa. Desta forma, cientificamente, a matéria não é só formada pelo que tem massa, mas também pelas partículas que fazem parte da matéria e que não têm massa, os fótons.

Com sua comunicação, Maitte coloca em xeque a materialidade e a imaterialidade, tanto da matéria quanto da luz. Maitte nos fez atravessar o amplo e rico panorama dos caminhos que ligam a arte à ciência, até concluir que, na física atual, é necessário abdicar da noção de substância e matéria e entender que a ciência é uma obra coletiva e em constante evolução. Como foi dito no início de sua comunicação, na física e na ciência não existem verdades, mas apenas pertinências, que devem ser colocadas constantemente à prova. É presumível, por consequência, que qualquer semelhança com a arte e com o teatro, em seus diversos contextos, possa não ser mera coincidência.

\section{A viagem da luz}

Pasquale Mari, que se auto intitula um "operário da luz", apresentou, na sequencia, um ponto de vista completamente oposto. Numa abordagem muito menos científica e mais poética, mas igualmente interessante, ele afirmou que a luz não é substância nem matéria, mas movimento. Em suas próprias palavras: "A luz é uma viagem!" Apesar de sua natureza poder ser traduzida como onda e matéria, lux e lúmen, claro e escuro, noite e dia, é preciso reconhecer, segundo ele, mesmo que sintaticamente, que a luz é movimento, que ela produz encanto e viaja livremente, enquanto se tenta fechá-la, analisá-la e condensá-la. Foram reproduzidas, a seguir, algumas de suas reflexões que podem auxiliar na reflexão sobre a ambígua materialidade e imaterialidade da luz no teatro e no cinema, ambas submetidas à percepção humana.

A palavra movimento o fez relacionar, em sua comunicação, a luz com o cinema, lembrando do falso movimento criado pelos 24 quadros por segundo 
diante de uma fonte de luz, uma ilusão de movimento provocado pela luz que é capaz de sincronizar-se com a vida real. Seu trabalho como realizador de uma imagem fixa e em movimento no cinema, o colocou na posição "de ver a luz, de ver a luz que viaja, de ter um encontro com a luz que viaja, com a luz que passa e que chamamos de imagem". Para ele, o enquadramento fotográfico, um quadro pictórico ou a boca de cena do teatro são oportunidades para "explorar a luz que viaja e forçá-la a ficar conosco por um instante".

Para Mari, a luz produz encanto, mas para isso é preciso restringir o movimento da luz a um campo visível. O olho, chamado a observar, se move sem controle entre o claro e o escuro, se aproxima da fonte de luz, segue em sua direção, indaga a sombra, descobre um novo detalhe, se fecha e recomeça do início. Em suma, por um certo período de tempo, o olho é prisioneiro da imagem, junto com a luz, absorvida e refletida pela superfície sobre a qual incide. Prisioneira nesse campo do visível, a luz não é fixa, mas se move continuamente, como um animal enjaulado, porém o faz mais sensivelmente, mais dramaticamente, mais calorosamente do que na experiência cotidiana do mundo, na qual tudo parece, infelizmente, escuro. E no fundo desta jaula, o movimento interno e a duração do que se vê, são chamados para o jogo. Como o cinema e o teatro, por exemplo, que têm a ver com o movimento e com o tempo, normalmente lentos, mas, que em última análise, tentam sincronizar e identificar a observação da luz, que passa com o tempo pessoal de cada observador. Observador que ele esclarece ser prisioneiro, no cinema e no teatro, no sentido mais dramático, visto que eles brincam com o que ele tem de mais precioso desde o início, sua expectativa, sua dor pelo que acaba, pela falta, pela confirmação de uma experiência e a súbita morte que surge com a palavra fim.

Para ele, o trabalho que nós, os operários da luz, fazemos, então, é interceptar essa luz de passagem, fazendo da cena uma armadilha, com o objetivo de convencê-la a brincar com o olho do espectador e, desta forma, dilatar o momento, ajudá-lo a esquecer seu tempo pessoal e aceitar interromper seu caminho para observar o tempo do outro, o tempo de um outro lugar que se forma em torno de todos os envolvidos e iguala seus passos. 
Para Mari, uma moldura é um limite do campo, que alude ao que está fora dele, ao movimento sugerido, ao sentido de relevo e profundidade na tridimensionalidade da matéria que emerge para interceptar a luz. Ele se pergunta, ao analisar uma imagem, se a figura retratada vai em direção à luz ou foge dela? Se a luz vem da direita ou da esquerda? Conclui dizendo que se é verdade que uma obra de arte chama a sua luz, seguramente ela também convida o observador a entreter-se com sua luz. A luz cênica é, para ele, uma luz que se entretém num espaço e entretém o observador pelas superfícies e volumes em cena, dentro do campo de ação, pelo seu poder maior ou menor de refletir a luz. No preto, a luz é engolida, no branco ela volta rápido em direção ao olho. E para que ela continue em jogo, há uma moldura em torno do quadro, uma moldura branca em torno de uma pintura ou uma moldura preta em torno do palco ou da tela de cinema. No cinema, essa moldura escura permite realizar o jogo de manipulação da luz que se realiza em três movimentos: a câmera, a imagem e o projetor, emoldurados pela superfície escura.

Em uma metáfora poética, ele disse que se a luz fosse água, a câmera seria um funil, que beberia toda a luz do mundo para os olhos e o projetor seria a bomba que joga a água comprimida com toda a força até a última gota, provocando belas nebulizações iridescentes. E o observador, na verdade, ficaria preso à tela durante o tempo necessário para que a luz presente em todos os quadros voltasse aos seus olhos, fazendo-os ficar por volta de uma hora e meia chorando e rindo diante do que é apenas uma história de luz em movimento. Ele complementa, dizendo sobre a magia da luz na arte, que ainda existem espectadores que conseguem se entreter por uma hora diante de um quadro de Vermeer ou até de uma pequena obra de Rembrandt de $40 \mathrm{~cm} X 40 \mathrm{~cm}$, observando a luz aprisionada se debater no interior da sua moldura.

Ele alerta que nós, iluminadores artistas que nos propomos a criar luz no teatro, sabemos que a luz deve atravessar o espaço, descrever a linha e desenhar a área. O facho de luz proposto intercepta o corpo que lhe atravessa, dialoga com a terceira dimensão, mas a profundidade continua incerta, a profundidade estabelece um contraponto com o momento em cena, segundo o 
movimento e o tempo que passa. Segundo Mari, quer seja ilusionista ou realista, a luz cênica observa precisamente a posição do espectador, chamando-o para testemunhar. Que represente a noite ou o dia, fechada ou aberta, o espectador convive, no espetáculo ao vivo, com a luz que foi pensada e criada para ele. É como ser convidado, por um tempo, para estar na casa ou no jardim de outra pessoa.

O que se representa quando se projeta luz para o teatro, segundo ele, é um modo de estar no mundo. Isso significa, do ponto de vista da luz, ocupar-se literalmente da atmosfera que existe por trás das pessoas, do espaço em que se respira, de iluminar essa atmosfera mais ou menos, de torná-la mais espessa, quase tangível, com potentes fachos de luz, ou simplesmente torná-la sutil, quase invisível, delegando a imagem da cena àquele que olha e escuta. Manter as pessoas juntas, perpetuar o fio de tensão e do envolvimento é, para ele, o trabalho incansável que nós, iluminadores, fazemos a partir da primeira luz que se acende ou se apaga até a última, que é aquela que permite, gentilmente, o retorno de todos ao mundo da experiência cotidiana. Desta forma, primeira luz, última luz, nascer ou pôr-do-sol, velar, dormir, atração, distração, são os valores em jogo para quem tem um refletor nas mãos e assume a responsabilidade de acendê-lo ou não. Isso sem mencionar o espaço que nos separa dos espectadores, um ator de outro ator, os atores do público. É preciso modular a luz como se modula o som, considerando sua viagem no espaço, por mais breve que seja, instantânea ou veloz. Para ele, quando se ilumina um palco não se deve esquecer a escuridão do céu, cuja luz das estrelas ilumina de longe nosso presente e nos encanta. É preciso ter consciência do sinal luminoso lançado no espaço por cada instrumento de luz, por menor que seja, e que ele deve ser organizado como o firmamento de um novo mundo que se cria. Aquele que trabalha com luz deve conseguir ver do mais distante ao mais próximo, ser míope e hipermetrope ao mesmo tempo, ter um olho nas partículas da luz e outro no conjunto do espetáculo teatral, um sobre o ator em cena e outro no fundo da plateia, no todo do edifício e do acontecimento que é o teatro. 
Para resumir, ele diz que, na qualidade de multiartista, quando pinta, propõe que a luz se transforme em matéria; quando esculpe, expõe a matéria à luz do mundo; quando é fotógrafo, deixa que a luz faça sua impressão, um traço de sua passagem que ele possa recordar; quando faz luz no espaço escuro do teatro, ele observa como ela viaja, onde repousa o facho e a matéria em que se transforma, dando a sensação de criar a realidade a partir do zero do invisível. A cena escura e o blecaute são, para ele, as condições em que fica mais evidente o gesto projetivo do iluminador, o ato de fazer luz.

Ele finalmente conclui dizendo que a atividade criativa de quem ilumina a cena performativa é construir um percurso da luz levando em conta a proveniência, o itinerário e a chegada, dados com os quais cada ser organiza sua viagem no mundo. Isso deve tornar visível e possível, por uma certa duração de tempo, o espaço necessário à ação cênica. Com um olho sempre atento à superfície e outro que percebe a profundidade, aquele que se ocupa da luz é destinado ao estrabismo, a observar a cena e, ao mesmo tempo, aquilo que não se vê, o fim do túnel, propondo ao passante uma suspensão, uma oportunidade de autoconhecimento, um tempo de reflexão. Esta é a missão de quem se ocupa, através da luz, de fazer da cena um lugar de trânsito, de movimento de emoções, as da ação, por um lado, e as do público, por outro, que chamamos teatro.

\section{A luminescência tóxica sobre a cena contemporânea}

A comunicação de Victor Inisan sobre o LED expôs a materialidade e a toxicidade dessa fonte luminosa que invadiu as cidades, teatros e até mesmo as casas das pessoas nas últimas décadas. Ele observou que se o LED, que não é uma lâmpada, mas um diodo emissor de luz, se parece ecológico pela economia no consumo de energia que representa, não o é nem de longe no processo de fabricação, ressaltando que o que faz acreditar nas suas vantagens como fonte luminosa pode ser um engano ou uma armadilha, semelhante ao que acontece com seu uso, seus conceitos e significados quando empregado na cena teatral. A toxicidade do LED e a violência dos efeitos provocados por ele nos seres 
humanos já são bastante conhecidas, tanto por retardar a produção de melatonina quanto por perturbar o sono de quem é exposto a ele, ao ponto de atingir células retinianas em crianças e deixá-las cegas.

Existe um paradoxo na materialidade do LED, cujo uso no teatro só foi possível a partir da descoberta do LED azul por Nakamura em 1992, e a recente criação, por ele mesmo, de um LED de alta performance que não use a cor azul. O resultado estético e visual oferecido pela materialidade da luz do LED nas artes cênicas é completamente novo. O diodo eletroluminescente produz uma luz que é menos direcionável e mais espacial do que a da lâmpada incandescente. Ele apresenta ainda melhor a textura e os volumes da pele. No entanto, novos equipamentos e tecnologias que empregam o LED como fonte luminosa, principalmente os inspirados em equipamentos tradicionais como o PC, e elipsoidal ou a PAR que conseguem reproduzir, minimamente, os efeitos clássicos, apresentam resultados luminosos muito diferentes. Sua luz, ao contrário da luz emitida pela lâmpada incandescente, concentrada apenas na pequena área de $2 \mathrm{~cm}$ de seu filamento, é distribuída em múltiplas fontes, agrupadas num conjunto que apresenta um resultado mais uniforme e dá a sensação de uma luz mais equalizada. Inisan citou, a esse respeito, a opinião do diretor Claude Régy, entusiasta utilizador do LED em seus espetáculos, justamente pela vantagem de funcionar sem que a fonte luminosa nem o facho de luz sejam percebidos pelo público.

A respeito do uso do LED no teatro, Victor destacou que, ao mesmo tempo que ele destrói um imaginário da luz tradicional do teatro, aquele da lâmpada incandescente quente, atraente e aconchegante, ele permite a realização de efeitos diferenciados pelo pouco calor emitido, que não aquece o ambiente e pode ser colocada mais próxima do palco e dos elementos do cenário, além da tão exaltada economia de energia. O LED apresenta, segundo ele, um paradoxo, pois, ao mesmo tempo que pode se aproximar fisicamente dos elementos no palco, podendo ser usado dentro do cenário e em peças do figurino, substitui um pouco a poesia solar da luz quente e bem definida por uma outra que é frequentemente fria e cujo facho luminoso é menos visível. Essa diferença 
resulta numa fricção que permite alguns usos dramatúrgicos do LED, visto que muitos iluminadores criam suas luzes levando em conta as características das fontes luminosas e dos equipamentos de que dispõem ou utilizam.

Inisan aborda essas propriedades dramatúrgicas do LED ao demonstrar que o tipo de luz escolhida pelo iluminador não tem relação apenas com o seu rendimento luminoso, mas também com o imaginário popular a respeito da fonte usada e com os resultados perceptivos deste imaginário sobre o espectador que, no caso do LED, remete ao poder frio, potente e impessoal, principalmente porque o LED cobre uma grande parte do espectro visível e é bastante nocivo e tóxico. Citando, inclusive, seus efeitos sobre diferentes tipos de seres vivos além do humano, ele alerta para as vítimas dos efeitos ilusórios do LED, que os fazem confundir a luz emitida com determinadas informações antes advindas da luz natural, custando-Ihes a vida.

Para exemplificar o uso do LED como luz tóxica, Inisan descreveu o espetáculo Richard III de Thomas Jolly, realizada em 2015. Composta, na grande maioria, por moving-lights que difundem a luz branca fria, carregada de azul, em fachos concentrados ou difusos, algumas vezes visíveis e em outras invisíveis, a luz apresentava "uma atmosfera glacial, sem repouso, uma atmosfera de medo e presságio da desgraça prestes a se abater sobre os personagens igualmente pálidos, exceto por Ricardo, que parecia imune a essa luz tóxica". Para Inisan, o poder, neste espetáculo, é a toxicidade, não sendo por acaso, então, a opção pelo LED com fonte luminosa. Ele conclui constatando que, imageticamente, o LED representa o futuro, as inovações tecnológicas, uma luz que pode se tornar invisível e permitir efeitos concentrados como o laser, mas que também pode destruir, arruinar e até mesmo matar. Seu uso na montagem de Jolly, expõe o lado pernicioso do exercício do poder, a cujo peso Ricardo III sucumbe, viciado e igualmente intoxicado pela luz. Acreditando reinar, ele foi vítima de um sistema biopolítico que o venceu. Para Inisan, o personagem principal da peça de Jolly não é Ricardo, mas a luz, cujo poder tóxico atinge tanto os que se submetem quanto os que se fartam dela, fazendo-os perder o sono e, por fim, a vida. 
Inisan associa, assim, a toxicidade material do LED, que ele descreve como uma luz mais fria e mais facilmente utilizável que as fontes luminosas tradicionais, e que acaba por se tornar, materialmente, uma luz que perturba, envenena, faz mal, ou seja, uma luz luminescente que altera e estraga o corpo do qual se aproxima, por seu uso no teatro e pelos efeitos que pode provocar, sensorial e perceptivamente, no espectador. Considerando o imaginário do LED, que vai, segundo ele, muito além dos domínios do teatro, ele afirma que essa fonte luminosa transporta o espectador para algo que ele já sabe ou sente a respeito da sua nocividade, interferindo na sua percepção da arte. Com isso, o uso da luz do LED, na construção de um imaginário teatral, se torna, também, um imaginário coletivo social, político, ecológico, um imaginário biológico diretamente ligado à percepção e à experiência do espectador com a materialidade da luz.

\section{Corporificar, espacializar, iluminar}

Na segunda etapa do Colóquio, realizada na Itália, a professora doutora e pesquisadora Yanna Kor (2019), da Universidade de Montpellier, apresentou uma analogia entre a expressão francesa que nomina o ato de encenar ou dirigir um espetáculo teatral, conhecido pelo termo mise-en-scène, e três outros conceitos, chamados de mettre-en-corps, mettre-en-espace e mettre-en-lumière. Esse terceiro termo, traduzido literalmente, apresenta a noção de "colocar na luz", podendo significar apenas o ato de "iluminar", dito de forma mais direta, ou, num entendimento mais complexo e profundo, "dirigir através da luz", ou seja, colocar conceitualmente "sob a luz", "colocar em luz", ou "em evidência narrativa ou dramatúrgica", da mesma forma e com a mesma intensidade com que um encenador "coloca" em cena os diferentes componentes da encenação.

A pesquisadora tratou principalmente, em sua fala, da relação da luzmatéria com as encenações da Alfred Jarry, cujo trabalho cênico dedica-se, em parte, à relação da máscara com a luz. Esta relação, para ele, define um tríptico entre máscara, luz e sombra, que revela a expressão dramática e dramatúrgica 
de seu trabalho. Ela destacou a importância das reflexões de Jarry sobre a iluminação cênica contidas no texto Da Inutilidade do Teatro ao Teatro, de certa forma negligenciado, segundo ela, nos estudos sobre o reconhecimento da crescente utilização e do poder da iluminação cênica, sobre o que pesquisadores dão mais atenção às publicações de Adolphe Appia e à análise das encenações de André Antoine ou das coreografias de Loïe Fuller. Os modelos teóricos e as suas reflexões de Yanna Kor a respeito do uso da luz nos espetáculos de Jarry tratam, simultaneamente, da materialidade da luz e das experiências de Jarry, nas quais a mimese facial do ator é substituída pelo jogo de luz e sombra criado sobre a máscara, transformando-a em tela de projeção, ou seja, numa parte componente do espaço cênico. Para Jarry, então, a encenação é transformada em um modelo estético de iluminação (mise-en-lumière), que é, ao mesmo tempo, corporal (mise-en-corps) e espacial (mise-en-espace).

Yanna Kor relembra o mantra da iluminação citado por Scott Palmer (2013, p. 142): "no teatro, se o ator não pode ser visto, também não pode ser ouvido"134, para evidenciar a presença material da luz, responsável por mostrar o corpo, o movimento e a expressão do ator. Para Jarry, colocar a máscara é como convidar o espectador ao diálogo, um diálogo metafórico que incita sua imaginação por meio da expressão criada pelo deslocamento da sombra sobre sua superfície. A máscara é, para ele, o objeto situado entre o animado e o inanimado, entre a vida e a morte, entre a presença e a ausência, entre o ator e a marionete. Tanto a máscara, para Jarry, quanto o corpo e o figurino, usados como tela de projeção de luz por Loïe Fuller, são analisados pela pesquisadora como partes integrantes de um mecanismo de projeção, do qual o espetador também se torna parte integrante. Colocar na luz (mettre-en-lumière), então, significa criar um espaço intermediário entre a máscara e o espectador, evocado pelo texto. A identidade da luz na máscara é criada, assim, pela sombra, que também é matéria, ou seja, é presença. A dimensão material exacerbada, da luz e da sombra, introduz um discurso sobre a essência do teatro, oriundo do teatro

134 «In the theater, if the actor cannot be seen, he cannot be heard » (tradução da autora). 
expressionista, no qual a luz deixa sua função passiva de iluminar, para adquirir outra ativa como iluminação cênica.

Ela conclui, finalmente, com uma indagação a respeito do dispositivo de projeção descrito por Jarry, formado pela tríade máscara-luz-espectador. Neste contexto, ela questiona quem seria o manipulador deste dispositivo, o performer que conduz a ação e que provoca seu resultado, buscando saber, ainda, se poderia haver algum elemento passivo neste conjunto. Adaptando esse dispositivo para um conceito mais amplo desta mesma tríade, composto pela luz, a cena e o espectador, é possível imaginá-la de forma que todos os seus elementos sejam ativos e constitutivos do resultado, que só é alcançado ao final do processo de recepção e percepção, concretizando-se na mente do receptor, o espectador teatral.

\section{Color Music: a sinestesia entre som e luz}

Mais uma vez, a materialidade da luz foi profundamente abordada na comunicação da pesquisadora Flavia Dalila D'Amico, cuja análise apresentada se concentra nas experiências do Quiet Ensamble, um grupo de pesquisa dedicado à observação do equilíbrio entre caos e controle, natureza e tecnologia, energia e matéria, na produção de resultados que surgem da relação entre o orgânico e o artificial de elementos mínimos e fantásticos como o movimento de uma mosca ou o som das árvores. A experiência apresentada demonstra a possível síntese entre som e luz em tempo real, com referências sonoras para imagens luminosas e cores em uma performance sinestésica e sensorial inusitada e surpreendente. Ela apresentou, como ponto de partida para essa experiência, o Optófono, teorizado e idealizado pelo dadaísta Raoul Hausmann entre 1921 e 1934 que, ao contrário de outros dispositivos criados como acompanhamentos luminosos para partituras musicais, foi concebido para transformar, pela utilização de técnicas de conversão elétrica, sinais luminosos em som e vice-versa. Segundo Hausmann, a eletricidade tem o poder de expandir a sensibilidade humana, o que o levou a criar, então, para pessoas não 
videntes, um dispositivo capaz de transformar o fenômeno da luz em variações de frequência sonora, estabelecendo uma sinestesia entre som e luz.

A experiência The Enlightenment ${ }^{135}$, do Quiet Ensamble que reúne cor, som e movimento, apresentada por D’Amico e demonstrada em vídeo durante o colóquio, expôs, além de uma interessante materialização da luz como fenômeno performativo, uma possível interação entre luz e som a partir de suas qualidades físicas e estéticas. As associações estabelecidas pela experiência foram capazes de produzir sensações ao dotar cada fonte luminosa de um som próprio e orquestrá-los na medida em que as luzes eram acionadas. Cada movimento de luz, realizado pelo acender das fontes luminosas, provocava sons correspondentes, criando um conjunto de efeitos luminosos, cromáticos e sonoros. A materialidade do instrumento consistia no agrupamento de diversas lâmpadas, como numa orquestra visual. Na velocidade e frequência das ondas luminosas e sonoras, a partitura dos instrumentos revelava o som, a cor e as vibrações luminosas em uma oitava musical realizada no espaço o no tempo.

A experiência é "um concerto de luz no qual cada lâmpada tem um som próprio, feito pela amplificação do ruído gerado pela energia elétrica que aciona cada lâmpada individualmente" cuja operação, realizada por meio de uma bobina de cobre usada para gerar o som oculto das luzes, gerava o som e o movimento visto e sentido pelo observador. Cada lâmpada captava, por meio de um sensor próprio, o som e o campo eletromagnético em torno do fluxo de energia irradiado por sua luz, tornando audível o som do "concerto invisível" das lâmpadas. Entre lâmpadas incandescentes, fluorescentes e estroboscópicas, a variedade e intensidade dos movimentos luminosos e sonoros resultavam numa experiência sensorial impressionante, uma verdadeira performance capaz de estimular a percepção e provocar sensações oriundas exclusivamente da materialidade expressiva da luz, da cor e do som, numa sinfonia particular e única.

135 Disponível em https://www.quietensemble.com, visitado em março de 2020. 


\section{A luz física e a materialidade da luz}

A rampa de baixa tensão criada por Josef Svoboda no final dos anos cinquenta é um bom exemplo de luz-matéria. Na descrição de Christine Richier: "A luz imaterial adquire, com o facho de baixa tensão, o status de matéria"136 (RICHIER, 2019, p. 437). Com esse equipamento, ele fez da luz materialidade cenográfica, dando às contraluzes uma presença arquitetural e dramática nunca conseguidas antes (RICHIER, 2019, p. 218). Fonte de luz singular, seu efeito era uma cortina de luz intensa e potente, cujos fachos extremamente concentrados e visíveis, graças ao conjunto formado por nove lâmpadas de $24 \mathrm{v}$ com espelho parabólico, forneciam ao espaço uma qualidade de luz inédita, que ocupava a altura da caixa cênica, dava ao palco uma profundidade singular e banhava o espeço com uma luminosidade uniforme e sólida. Uma marca registrada das cenografias de Svoboda, a rampa de baixa tensão passou a ser produzida e comercializada, levando seu nome à prática da iluminação nos teatros e salas de espetáculo por toda a Europa até os dias atuais (RICHIER, 2019, p. 301).

A obra do artista da luz James Turrell explora o fenômeno luminoso e extrapolar, a partir de experiências fenomenológicas, os limites da percepção. Pelo emprego da luz natural ou artificial que habita um determinado espaço, cênico ou plástico, o artista buscava criar uma atmosfera luminosa onde a visão pudesse penetrar conscientemente e cujas densidade, granulação material com resultados diversos, transparentes, translúcidos, opacos ou abertos à percepção eram gerados por diferenças na qualidade do ar (BARROS, 1999, p. 93). Com suas obras, Turrell busca atingir um estado de não pensar, no qual a luz se faz matéria, quase tangível, que habita o espaço. Ela é responsável pela atmosfera gerada, mutável e inconstante, susceptível à influência que afeta e se deixa afetar pela percepção do espaço por parte do observador.

Os conceitos investigados nesta pesquisa permitem considerar que a luz se materializa em cena, em manifestação visível ou invisível, material ou

\footnotetext{
136 "La lumière immatérielle acquiert avec le faisceau basse-tension le statut de matière " (tradução da autora).
} 
imaterial. Independente de ser ou não atravessada por um corpo, estar ou não visível, tocar ou não elementos do cenário, de acordo com a cena em que se insere, ela se faz presente ao revelar sua materialidade. A luz como fenômeno luminoso e elemento autônomo é capaz de afetar a cena e a percepção do espectador por meio da sua materialidade e presença poética. Analisar essa presença em trabalhos próprios e de outros artistas permitiu perceber o poder que ela exerce sobre a cena, ou seja, a potencialidade e vocação dessa luz física e material. Esse enfoque conduziu, então, à necessidade de aprofundar, com o objetivo de entende-la como fenômeno perceptivo, os conhecimentos a respeito dos estudos da presença, da percepção e da recepção ativa. 


\subsubsection{Estudos da Presença}

A respeito da presença, Merleau-Ponty escreve que "nossa primeira verdade - aquela que nada prejulga e não pode ser contestada - será que há presença, que "algo" lá está [...] perguntemo-nos, pois, o que é este "algo". [...] Este algo a que estamos presentes e aquilo que nos é presente são as coisas" (MERLEAU-PONTY, 2009, p. 157). O filósofo segue esclarecendo que as coisas, no sentido que há nelas, para além do que se vê ou toca, exibem um fundamento único para todas as suas "propriedades", das quais depende sua subsistência como coisa (algo) e emanam conjuntamente (MERLEAU-PONTY, 2009, p. 158). O visível, aquilo que toca, afeta ou atinge, está presente e se manifesta como algo que se doa à experiência do indivíduo (ser-no-mundo). O contrapondo deste algo, para o autor, é a possibilidade do nada, a abertura do mundo para que o algo exista, a partir da qual emana a experiência.

Uma inquietação das artes performativas emergentes na segunda metade do século passado, os estudos sobre a presença cênica se intensificaram na busca do entendimento das finalidades e das funções da arte a partir de novas investigações estéticas das relações entre a arte e a natureza e entre a arte e o ser humano. A pesquisadora Gisela Reis Biancalana (2011) investigou o aspecto improvisacional das artes performativas e a questão da presença do performer, qualificando-a como a "habilidade de estabelecer uma relação de troca com o público ao atrair sua atenção para a performance" (BIANCALANA, 2011, p. 130). Essa presença cênica como habilidade a ser estudada e desenvolvida pelo performer, tem como objetivo o domínio do seu ser/fazer cênico. Ao desenvolver essa capacidade, segundo a pesquisadora, ele deverá estar apto a fazer emergir uma corporeidade poética que revele plasticamente o invisível.

Parte de sua investigação concentra-se nos pressupostos conceituais das artes da cena e nas características da performatividade, para então debruçar-se especificamente sobre a presença em seu aspecto improvisacional. Num breve relato da história das artes da cena, ela explica o conceito da arte como técnica 
e domínio do fazer a partir da origem etimológica do termo em latim, ars que, por sua vez, vem do grego techne, significando, inicialmente, o campo da atividade humana ligada ao ofício do artista e seu lavoro. A exemplo de Vilém Flusser (2007), a autora transita pelos conceitos de artes liberais, artes servis (séc. II d.C.), artes úteis e belas artes (séc. XVI - séc. XVIII). Citando Kant a respeito da beleza estética e do juízo de gosto ligado às artes, ela finalmente aborda as transformações que revolucionaram a relação entre os conceitos de arte e técnica nos sécs. XIX e XX. A técnica, como forma de conhecimento, passou a ser chamada de "tecnologia" e a arte se tornou "produto da expressão criadora através da transfiguração do real em uma obra artística” (BIANCALANA, 2011, p. 127). A arte, aproximada das técnicas e da ciência, define novas linguagens e busca a autonomia pelas habilidades humanas do fazer artístico com técnicas e procedimentos metodológicos que orientam o trabalho laboral de artistas e performers, sistematizando o processo de criação e de formulação artística.

A pesquisadora relembra o surgimento, simultâneo ao advento da luz elétrica nos teatros, da figura do encenador, cuja preocupação com a preparação do ator resultou na elaboração de procedimentos para o treinamento corporal e vocal do performer da cena e no surgimento de diversas técnicas para desenvolver suas habilidades técnico-expressivas. A "intenção de produzir o belo" foi substituída pela "busca da expressão, da interpretação e da crítica social" e por formas de "reaproximação da ideia aristotélica de poética, da arte como trabalho e da produção de um conhecimento específico a ser transmitido", afastando-se ainda mais de uma qualidade empírica e "aurática" da interpretação e da criação teatral (BIANCALANA, 2011, p. 128) consideradas anteriormente.

Relativo à sistematização e treinamento no trabalho do ator, ela cita os manuscritos de Goethe sobre a técnica da fala, recitação, declamação, posturas do corpo, atuação conjunta e agrupamento de quadros estilizados (BERTHOLD, 2000 apud BIANCALANA, 2011, p. 128), além das técnicas, amplamente difundidas, de Stanislavski, Brecht, Barba, Ferracini, Schechner e Grotowski. 
performer, como em qualquer profissão, requer a aquisição de competências. Entre estas diversas competências residem as questões técnico-expressivas adquiridas em treinamentos laboratoriais e as questões voltadas para a presença pautada no desenvolvimento de uma corporeidade (corpo/voz) poética, voltada para as necessidades da cena (BIANCALANA, 2011, p. 132).

Em um viés mais substancialista e com o objetivo de apreender a experiência estética de maneira dissociada da hermenêutica e da assimilação cartesiana da obra artística, Hans Ulrich Gumbrecht (2010), ressalta a tensão entre a presença e o sentido na percepção da arte. O que não significa, segundo ele, renunciar aos conceitos e à compreensão da obra, visto que a interpretação e a busca do sentido constituem partes indissociáveis da existência humana, mas sim de resgatar a capacidade de se relacionar com o que se apresenta aos sentidos (capacidades sensoriais) de maneira desvinculada do sentido interpretativo ou conceitual. Na concepção de Gumbrecht, a presença refere-se "às coisas que, estando à nossa frente, ocupam espaço, são tangíveis aos nossos corpos e não são apreensíveis, exclusiva e necessariamente, por uma relação de sentido" (GUMBRECHT, 2010, p. 9), compreendendo o sentido como interpretação ou assimilação racional de um significante, ao contrário das capacidades sensoriais humanas acionadas face à presença das tais "coisas" presentes. A presença se relaciona, assim, com a experiência de modo não interpretativo, mas relativo àquilo que se produz no observador por meio dela, que o sentido ou significado atribuído, isoladamente, não consegue transmitir.

Ao confrontar o significante material ao significado espiritual e questionar o paradigma sujeito/objeto, o autor não busca eliminar o sentido em favor da presença, mas estabelecer uma cultura da presença que se distancia e se contrapõe à cultura exclusiva do sentido estabelecida pelas humanidades. Para ele, atribuir sentido a algo significa formar uma ideia do que seja esse algo em relação ao indivíduo, o que atenua seu impacto direto sobre seu corpo e seus sentidos. A produção da presença, ao contrário, se dá pela realização de eventos e processos nos quais ocorre o impacto dos objetos sobre os sentidos, ou seja, dos objetos presentes sobre o corpo humano. Entendendo esses objetos presentes como coisas-no-mundo, num conceito filosófico heideggeriano, que tende a substituir o paradigma sujeito-objeto pela noção de ser-no-mundo, o 
filósofo reafirma a substancialidade corpórea e as dimensões espaciais da existência humana (GUMBRECHT, 2010, p. 70). Com suas reflexões, Gumbrecht combate a tendência cultural moderna de evitar uma relação com o mundo fundada na simples presença, favorecendo uma oscilação entre os efeitos de sentido e os efeitos de presença provocados no observador pela experiência de estar-no-mundo. Segundo ele, "só os efeitos de presença apelam aos sentidos" (GUMBRECHT, 2010, p. 15), ou seja, permitem a verdadeira experiência sensorial.

Sua reflexão filosófica foi inspirada na teoria de Kittler sobre a "nova sensibilidade intelectual a todos os tipos de materialidades" (GUMBRECHT, 2010, p. 16). Relativa ao não-hermenêutico, essa teoria da década de 1980 desafia a tradição de interpretação e atribuição de sentido às coisas do mundo e propõe a reconfiguração das condições de produção de conhecimento com base na experiência real. Considerando todos os fenômenos e condições que contribuem para a produção de sentido, sem serem, no entanto, eles mesmos, sentido, como materialidades da comunicação e a experiência estética como uma combinação alternada entre as dimensões de presença e de sentido, a questão central do paradigma destas materialidades se encontra no interesse, na forma como a mídia e elas mesmas poderiam ter impacto sobre o sentido que transportam. Segundo Gumbrecht, é preciso que haja, na experiência estética, uma simultaneidade dos efeitos de presença e dos efeitos de sentido, cujas formas poéticas não sejam sujeitas exclusivamente ao sentido, mas se apresentem numa situação de tensão e oscilação entre ambos.

O autor detecta, assim, a contradição das materialidades da comunicação ao afirmar que os efeitos de sentido podem, de alguma forma e muito frequentemente, reduzir os momentos de presença, mesmo considerando sua indissociabilidade. A redenção se encontraria, então, nesse estado a ser atingido pelo paradoxo do êxtase da presença no mundo. Esse êxtase poderia ser alcançado, talvez, pelo isolamento de sentimentos antagônicos individuais, como a alegria e a tristeza, por exemplo, "concentrando-nos neles com nossos corpos e nossos pensamentos, deixando que esses sentimentos diminuam a distância 
entre nós (o sujeito) e o mundo (o objeto) até o ponto em que a distância possa transformar-se subitamente num estado não mediado de estar-no-mundo" (GUMBRECHT, 2010, p. 170). É fato que o meio mediático, apesar de alienar as coisas do mundo do presente do indivíduo (capaz de se concentrar mais num rosto projetado em uma tela do que no de alguém sentado à sua frente) tem, ao mesmo tempo, o potencial de lhe devolver algumas outras coisas, como reduzir distâncias e permitir experiências independente do lugar ocupado por seus corpos. No entanto, é fato, também, que qualquer experiência (como estar sentado a uma mesma mesa) não tem a ver só com comunicação ou com a simples "troca de informação", mas expõe conceitos importantes e úteis que permitem apontar o que é "irreversivelmente não conceitual" distanciando definitivamente, mesmo que sem dissociar, os efeitos de presença dos efeitos de sentido (GUMBRECHT, 2010, p. 173).

Ao demonstrar o momento em que o desejo, o anseio e a necessidade de dar sentido às coisas cedeu lugar à valorização complementar da presença e seus efeitos, destituindo os poderes reinantes da razão, Gumbrecht ressalta a revelação, na era moderna, da importância do papel do observador como elemento-chave da sua relação com o objeto. Por meio da redescoberta de seu corpo e dos sentidos como parte integral de sua observação do mundo (GUMBRECHT, 2010, p. 62), esse observador participa ativamente do ato de apropriação do meio pelos sentidos, experiência e percepção. É pelo desejo de estar em sintonia com as coisas do mundo, num processo de reconexão que permite ser sensível aos modos como o corpo se relaciona com um ambiente, que acontecem os momentos de presença. Nesses instantes, isolados dos ruídos tecnológicos e epistemológicos de seu tempo, o indivíduo permite-se ficar em sossego e total consciência de seu corpo e de si mesmo em contato com o mundo à sua volta. Segundo Dufrenne, "a obra de arte solicita o olhar e que a converte em objeto estético; olhar que se verifica constituinte ao se dedicar a ela para realizá-la, compreendendo sua expressão no que o autor qualifica como um sentido afetivo (DUFRENNE, 1981, p. 60). É esse estado de entrega e dedicação que o teatro dito performativo demanda do espectador ativo, ao qual se apresenta e cuja dedicação requer o compartilhamento de momentos de 
presença entre o sujeito (o espectador) e o objeto (a encenação e cada um de seus componentes cênicos), sem renunciar, no entanto, a todo e qualquer conceito, sentido, ou interpretação, mas permitindo-se experienciar e viver atentamente o instante proposto.

Estendendo os estudos da presença para além do trabalho do performer, ou seja, atingindo todos os aspectos sensoriais implicados na atuação performativa das artes da cena, entende-se, igualmente, a necessidade da qualidade e habilidade da luz para atrair a atenção do público e estabelecer com ele uma relação de troca. Para Joël Pommerat:

O ponto de partida da minha escrita cênica é a presença; não é a palavra que vai sair da boca do ator, mas é o impacto da presença de uma silhueta ou de um corpo antes mesmo que a primeira palavra seja pronunciada. É isso que me toca, e que faz com que, em seguida, eu me interesse ou não pelo que será dito. E essa presença no palco, ela só existe graças à luz (POMMERAT apud FERRER, 2015, p. 73).

Em uma aproximação dessas reflexões sobre a presença no contexto da iluminação cênica, fica evidente o entendimento de que a luz não apenas seja responsável por revelar a presença dos corpos em cena, mas que ela também possa, por sua própria presença, afetar e interferir na percepção do público, como defendeu a diretora e iluminadora teatral Cibele Forjaz ${ }^{137}$ em relação ao tipo de iluminação que realizou no Teatro Oficina:

\begin{abstract}
Eu acho que a luz participa da ação, quer seja com a interação da sua materialidade, vibração, foco e sua escrita, mas também na experiência de entrar em cena com lanternas ou pin-beams e ser uma parceira presencial na atuação e de maneira corpórea. [...], tem muitas formas de explicitar e atuar ao vivo, e faz parte da pesquisa do Oficina uma atuação que não é representativa ou que simboliza, mas que presentifica, atua junto e é ao vivo (FORJAZ, anexos, p. 79).
\end{abstract}

De modo que se faz necessário, igualmente, o desenvolvimento da capacidade que permita a efetivação da presença cênica da luz. O iluminador, como artista responsável pela criação de um dos elementos fundamentais do visual cênico, deve executar a construção, organização e elaboração da iluminação como expressão artística que requer, como qualquer outro componente da cena, a aquisição e o domínio de habilidades e competências

${ }^{137}$ Em entrevista realizada como parte desta pesquisa, disponível nos anexos, p. 75-83. 
específicas. Essas competências se estendem, ao contrário do lugar comum atribuído à atividade relacionada à iluminação, para muito além dos aspectos tecnológicos, incluindo questões técnico-expressivas da luz voltadas para a presença e pautadas no desenvolvimento de uma materialidade (forma/cor/movimento), porque não dizer, poética, passível de ser comparada à corporalidade poética do performer defendida por Biancalana, ambas igualmente voltadas para as necessidades da cena. Segundo o conceito heidggeriano de presença, mais associado à noção de existência do ser do que à presença corpórea de objetos, podemos vislumbrar ainda a iluminação como manifestação da presença das ideias da criação que se fazem presentes pela materialidade da luz. Segundo o filósofo, ao significar sua existência, seu espírito e consciência, o ser humano pode se manifestar, mesmo ausente fisicamente, ao se fazer presente através da existência de seu pensamento em ação.

Desta forma, é possível considerar a presença cênica da luz como manifestação da intenção do artista criador da luz, o iluminador, enquanto habilidade para atrair a atenção do espectador para a cena através de sua materialidade poética e para revelar, assim, o visível no invisível, fruir no espaço/tempo da performance, estabelecendo uma comunicação imediata e não objetiva ou conceitual com o público, característica principal e intrínseca da performatividade. É importante considerar, no entanto, alguns fatores circunstanciais que podem interferir na ação e na qualidade dessa presença como as características do local, as dimensões do espaço, os ruídos, imprevistos, as relações estabelecidas em cena e fora dela, a cultura, os contatos, as oportunidades, entre outros. Com base no domínio das técnicas e das condições do espaço cênico, então, o iluminador é capaz de elaborar o meio através do qual será estabelecida a relação de envolvimento entre a luz e aquele que a percebe ativamente. Com o objetivo de efetivamente entender como isso pode acontecer, então, foi necessário investigar melhor o próprio conceito de performatividade e a presumível independência entre a performatividade da luz e a performatividade do teatro ou do espetáculo propriamente dita. 


\subsubsection{Performatividade}

Dentre as referências e conceitos investigados ao longo da pesquisa, visando aproximar e esclarecer o entendimento da hipótese intuída sobre a performatividade da luz, o mais basilar foi, evidentemente, a própria noção de performatividade. O termo performativo, segundo Josette Féral (2015), é o mais adequado para designar a prática teatral fortemente influenciada pela performance a partir da primeira metade do século $X X$. É mais adequando também, segundo ela, que teatro pós-dramático, cuja conceito, apresentado pelo crítico e professor alemão Hans-Thies Lehmann (2007) o define como pura presentificação que elimina toda ideia de reprodução do real (FÉRAL, 2015, p.129. As teorias sobre o pós-dramático, juntamente com as de performance e performatividade, permitiram analisar e compreender as rupturas ocorridas na prática teatral a partir das vanguardas que caracterizaram o início do século passado. Mais tarde, ao aprofundar a investigação destes conceitos e das características de cada um, foi possível identificar e relacioná-los, no contexto cênico, dramático e espetacular das produções contemporâneas, com os diferentes componentes da cena, dentre eles a iluminação, mas não sem antes retomar a origem epistemológica dos conceitos que este estudo se propõe a pesquisar.

A performatividade é um conceito linguístico que remete à capacidade de certos enunciados de modificar a realidade e as práticas que designam. Em um conceito clássico, uma linguagem tem a função de descrever uma realidade, enquanto que, no conceito performativo, essa mesma linguagem teria a função de fazer surgir uma realidade. No plano epistemológico, a performatividade se distingue dos estudos tradicionais que consideram que o papel da linguagem é o de representar uma situação objetiva que teria um fim em si mesma (HACKING, 1983). Ao contrário desta concepção clássica, a orientação performativa, conforme apresentado por Latour (1984), convida a considerar a ação não só em seus princípios (dimensão ostensiva), mas em suas práticas (dimensão performativa). Ela considera que a realidade é uma construção que 
se fundamenta nas intervenções concretas e situadas, mediadas por instrumentos ou dispositivos usados.

Segundo Edélcio Mostaço, a noção de performance, com base nos estudos de Richard Schechner, pesquisador e fundador do programa dos estudos da performance nos EUA, é derivada do verbo homônimo em inglês, cujo significado mais corrente é o de fazer ou desempenhar (to perform). Schechner aponta essas atividades como os hábitos cotidianos automatizados e executados, muitas vezes, sem consciência ou reflexão sobre a perspectiva ou os modelos que os precedem (MOSTAÇO, 2009, p. 16). No entanto, com a influência de pensadores europeus, na maioria franceses, sobre o fazer teatral em meados do século $X X$, o termo passou a ser empregado para designar ações reais ou ficcionais como manifestação artística, inicialmente no domínio das artes plásticas. Com o nome de French Theory ou apenas Theory, os estudos desses teóricos franceses, a exemplo de Foucault, Derrida, Baudrillard, Guattary e Deleuze, entre outros, propunham uma revisão da performance art, que diferenciava-se da performance pelo caráter de "experiência corporal de natureza indivisa e voluntária do gesto na atitude e conduta do artista em uma situação extra cotidiana [...] perpetrando um ato inaugural" (MOSTAÇO, 2009, p. 21). Estes eventos buscavam, segundo o autor, a transgressão e a ruptura através do corpo do performer para, com sua originalidade, promover reviravoltas sociais, políticas e culturais nos indivíduos e meios alcançados.

A partir dos escritos do antropólogo Victor Turner, a atividade teatral e performática é relacionada às práticas rituais e aos jogos, definindo graus de personificação do ato performático em sua relação com a realidade cotidiana (FÉRAL, 2009, p. 60). Dentre eles, o jogo codificado ocorre diante de um sistema semiótico de referências, associado à linguagem falada e escrita por possuírem um vocabulário próprio e uma gramática que permitem a compreensão do que exprimem. Desta forma, esses jogos e performances seguem, segundo Schechner, um modelo de processo dividido em 10 etapas agrupadas em três categorias: a proto-performance, anterior à performance (treinamento, laboratório e ensaio); a performance em si (aquecimento, apresentação e 
desarme); e a pós-performance (resposta crítica, arquivamento e lembrança). Todas estas etapas, das que antecedem às que sucedem a apresentação, com seus significados, contextos e resultados, devem ser consideradas na atividade da performance, envolvendo tanto o trabalho e a expressão do ator quanto o de todos os performers envolvidos na encenação.

Com base nas teorias de Schechner, a performance pode ser tudo o que acontece em cena ou fora dela, ou seja, pode ser a ação e o espaço, em diferentes estruturas, tipos e formatos, na relação que estabelece com um público. O resultado do processo que ele chama de living, acting, performing, quando engajados num espetáculo, num jogo ou num ritual, implica em três operações principais: being, o ser/estar em cena, doing, o fazer e showing, o mostrar fazendo (FÉRAL, 2015, p. 117-118). A performatividade, diferente da performance, é um processo. Ela não tem, segundo Féral, um fim em si mesma, nem é uma realidade concreta ou acabada, mas é construção e reconstrução, mesmo que de ações ordinárias, quando impostadas como performance, diante de um público (FÉRAL, 2009, p. 66). Schechner acrescenta, ainda, que "não há limites 'teoréticos' para a performatividade" e que mesmo ações banais podem ser consideradas performance, através da imposição e realização de tais ações como ("as") performance (SCHECHNER, 2002 apud FÉRAL, 2009, p. 66), ou seja, pela consciência de quem as realiza e pela presença de quem as observa.

Austin e Searle encontram no fazer teatral o exemplo das situações que, dado seu caráter ficcional, caracterizam a performatividade como "atos 'falsos', destinados 'à ilusão', sem validade efetiva na construção da realidade através do que Searle chama de atos da fala" (MOSTAÇO, 2009, p. 30). Os dois pesquisadores desenvolveram, a partir da teoria dos atos da fala, o conceito de perlocução, declarando que o importante, na comunicação, seria se fazer entender, ou seja, produzir um efeito sobre o interlocutor. Para Austin, o ato perlocutório representa o efeito ou reação ao ato de pronunciar um enunciado em certas condições comunicativas com certas intenções, associadas ao seu significado, chamado de ato ilocutório. Os verbos performativos, na condição de atos da fala, devem estar ligados a contextos e condicionados a uma consciência 
livre e presente em toda a operação. Isso Ihes confere, segundo Jacques Derrida (1972), a capacidade de expandir sua ação para outras áreas, inclusive o teatro.

Enquanto que para Austin e Searle as enunciações performativas só podem acontecer na vida real, em situações reais (críveis) de enunciação e não se realizariam (fracassariam) na ficção, para Derrida o performativo está em qualquer processo de escritura, pois "a concretização da enunciação performativa é aleatória e 'parasitária', ela é instável, ambígua e jamais unívoca, cujo risco e possibilidade de fracasso não a invalidam na ficção" (FÉRAL, 2009, p. 72). Neste mesmo sentido, Schechner resume que, entendido como jogo, "o performativo não é 'verdadeiro' ou 'falso', 'certo' ou 'errado'. Ele acontece" (SCHECHNER, 2002 apud FÉRAL, 2009, p. 72). Se a performance diz respeito apenas aos atos reais, limitados ou não aos atos da fala, a performatividade pode abranger atos fictícios, desde que arraigados, no entanto, à realidade da experiência (MOSTAÇO, 2009, p. 30).

Em estudos anteriores, foi constatado que, a partir da modernidade, os aspectos narrativo e simbólico do teatro foram preteridos pelas experiências pósdramáticas e performativas. Desde o final do século XIX, quando a visualidade da cena adquiriu, através dos experimentos de Appia, Craig, Artaud e Jouvet, entre outros, forte caráter significativo e constitutivo da Obra de Arte Total preconizada por Wagner ${ }^{138}$, sua função simbólica foi sendo acentuada até tornar-se parte indissociável da expressividade do espetáculo dramático. Alguns anos mais tarde, com a conscientização do importante papel desempenhado pelo público no ato de recepção e percepção teatral, a representação cedeu espaço, pouco à pouco, à experiência compartilhada entre o performer e o espectador, e as ações performáticas, em interação crescente entre o palco e a plateia, dotaram o teatro de seu caráter performativo. Teatralidade e performatividade passaram a ser conceitos fortemente investigados para

138 Em seu livro A Mimesis Performativa, o professor Luiz Fernando Ramos dedica parte do segundo capítulo para apresentar argumentos que contestam a credibilidade do conceito de obra de arte total (gesamtkunstwerk) atribuído a Wagner, expondo críticas, principalmente de Nietzsche e Adorno, que atestam o protagonismo do ator e a destituição do caráter autônomo da música em suas óperas. Ver RAMOS, 2015. p. 52-57. 
explicar as diferenças existentes entre o teatro clássico, tradicionalmente textocêntrico e cuja condução concentra-se na regência de um diretor ou encenador, e o teatro performativo, normalmente fruto de processos coletivos, participativos ou colaborativos de criação dramatúrgica e cênica.

Segundo Féral (2015), a teatralidade é o resultado do trabalho poético do artista, um jogo de ilusões e aparências, cuja linguagem valoriza mais a ação do que a representação. Para ela, no entanto, performar é também entrar no jogo, engajar-se no processo de criação para evocar, antes mesmo da noção de teatralidade, a de performatividade.

Uma das principais características deste teatro é que ele coloca em jogo o processo sendo feito, processo esse que tem maior importância que a produção final. Mesmo que essa seja meticulosamente programada e ritmada, assim como na performance, o desenrolar da ação e a experiência que ela traz por parte do espectador são bem mais importantes do que o resultado final obtido. (FÉRAL, 2015, p. 130).

O performativo seria, então, o tipo de teatro dramático que apresenta uma noção de performatividade que é o centro do seu funcionamento e que, influenciado pelo conceito de performance, transforma o ator em performer e a representação em ação cênica, cujo foco é deslocado do texto para a imagem e a ação, fazendo apelo à receptividade espetacular do espectador (FÉRAL, 2015, p. 113-114). Desta forma, o termo performativo traduziria, melhor do que o sentido de pós-dramático, esse teatro que necessita de um evento ou ação cênica que seria, à sua maneira, a presentificação pura do teatro, apagando qualquer ideia de repetição do real (LEHMANN, 2007 apud FÉRAL, 2015, p. 129). O ato de fazer constitui o teatro e a ação cênica está centrada em seu agente, que faz uso dos recursos disponíveis (as articulações do corpo e da voz, por exemplo) para inscrever uma performatividade cuja ação se torna um pressuposto fundamental e a partir da qual uma nova realidade é instaurada e proposta ao espectador. Por natureza, a enunciação performativa é instável e ambígua, jamais unívoca, e, por isso, depende da interpretação do espectador durante o ato da recepção. A atenção do espectador é, então, colocada no gesto, na criação da forma e da presença, cuja estética revela-se como meio para 
estabelecer uma relação com o público, atraindo sua atenção para a cena e seus componentes.

Féral destaca ainda o sentido schechneriano da atuação do performer ao ampliá-lo para além do trabalho do ator, considerando também o dramaturgo, o encenador, o cenógrafo e a atitude consciente de todos os partícipes do jogo realizado no aqui/agora da realização cênica (FÉRAL, 2015, p. 93-94), dada à contemplação frente ao olhar que a aprecia. Este olhar, que Mostaço define como experiência singular e elementar de um indivíduo, vetorizada pelas tensões antagônicas e disjuntivas do eu e do outro, é a base da performatividade encontrada na realização teatral pelo seu caráter dramático e performático.

\begin{abstract}
...a teatralidade não está 'na coisa', mas no olhar do espectador; ela é um produto mental propiciado pelas percepções e, para emergir, não depende de um palco, atores ou cenografia, mas tão somente de uma operação de linguagem intermediando um sujeito e um objeto, para ficarmos na distinção clássica e que, não fortuitamente, remete também à metáfora objetual do próprio espetáculo minimal: algo a ser visto, alguém para ver. (MOSTAÇO, 2009, p. 38-39).
\end{abstract}

Assim como Mostaço afirma que a teatralidade não está no objeto ou na linguagem, mas na relação estabelecida com o receptor, Josette Féral argumenta que a performatividade somente apresenta seu potencial performativo (FÉRAL, 2009, p. 65-66) na recepção participativa do espectador.

A dualidade do mundo (afeto e dor, guerra e solidariedade, violência e virtuosidade) é apontada por Mostaço (2009, p. 36) como correspondente à dualidade do ser e o espetáculo o faz confrontar esta realidade de forma sensitiva e pungente. Os limites entre o real e o ficcional se tornam difusos, assim como a separação entre palco e plateia, cena e público, performer e observador. A experiência compartilhada revela semelhanças, ressalta diferenças, mas insere ambos num mesmo universo ficcional em que a realidade se faz presente na ação. O teatro segue para além das dicotomias de enfoque da performance na perspectiva das artes visuais, dado seu caráter cênico, cuja performatividade está na maneira de apresentar-se com consciência do que faz, ênfase e destaque para o que dá a ver. 
Os escritos de Féral permitem associar os conceitos de teatralidade e performatividade ao expor o que seria, para ela, o caráter primordial do teatro considerado performativo, um teatro que "acontece" em consonância com a ação cênica, ambas dadas à percepção e experiência do público. A teatralidade presente no ato performativo demanda, além da disponibilidade para a percepção, que haja um saber que complemente esta experiência. A teatralidade surge, segundo ela, deste saber do espectador, de que ele seja informado da intenção do teatro em sua direção. Este saber modifica seu olhar forçando-o a ver o espetacular e transformando em ficção o que poderia parecer realidade ou acontecimento. Este saber semiotiza o espaço em uma intenção que, instituída pelo ato performático, deve ser compartilhada entre aquele que contempla e aquele que desempenha (FÉRAL, 1988 apud ZUMTHOR, 2007, p. 41). Apesar de parecerem conceitos antagônicos, um impossibilitando ou rejeitando a realização do outro, é a teatralidade que permite, segundo Féral, a percepção do fazer performativo.

Na dicotomia entre o teatro "teatral" e o "performativo", quando do teatro se extrai o texto, o roteiro ou a instrução, o que resta, segundo Elie During, é:

...uma presença, e também uma ação, ou um encadeamento de atos
que se efetuam, que são performados, num dado lugar e num dado
tempo. Essa execução é mais importante que o produto, o resultado. o
fim. [...] Tratar-se-ia, então menos de encarnar a ideia formulada por
um enunciado ou uma instrução, mas antes de organizar localmente,
através de um jogo de diferenças, o lugar onde se desenvolveria esta
ideia, ou a verdade que ela encerra. (BADIOU; DURING, 2007. p. 26).

Para Badiou, o teatro é sempre uma mediação pública entre o artifício e a vida e o performer está no centro desta mediação, cuja dimensão coletiva é primordial, na forma de ato partilhado. Segundo ele, "a experiência performativa está na junção da ideia de participação, de construção de um novo coletivo e da importância da improvisação e do 'deixar-vir' fortuito” (BADIOU; DURING, 2007, p. 25).

Ainda sobre a experiência do espectador, Clóvis Massa afirma que, neste processo, mais importante do que um eventual sentido prévio elaborado pelo artista, é o que a obra provoca no receptor, afirmando que "o que acontece com 
ele é o que efetivamente resulta da ação cênica" (MASSA, 2010, p. 30). Nesse mesmo sentido, Zumthor alerta para a armadilha pragmática dos signos e seus interpretantes, que desconsideram o instante da percepção e seu contexto, concentrando-se nos fatos sociais e ignorando a experiência individual que, para ele, constitui a verdadeira origem do ritual coletivo (ZUMTHOR, 2008, p. 35-36). Para Zumthor, o que o poético tem de profundo encontra-se na capacidade de ser percebido e de gerar seus efeitos face à presença ativa de um corpo, um sujeito em sua plenitude de existir no espaço e no tempo que ouve, vê, respira e sente. Com isso, é possível estabelecer um paralelo entre o teatro performativo definido por Féral e a prática discursiva que Zumthor define como "poética" para concluir que a performance, como um modo vivo de comunicação poética, é a base do teatro dito performativo e da performatividade.

Uma terceira proposição de entendimento e denominação para as recentes formas das manifestações da cena contemporânea foi feita por Luiz Fernando Ramos (2015), em associação às diferentes noções da perspectiva mimética das novas formas de acontecimento artístico. A partir da investigação da ambiguidade que a transporta para além do conceito limitado de imitação do já existente, o autor apresenta a noção de mimesis performativa como opção aos conceitos de teatro pós-dramático e performativo para dar conta dessa produção cênica mais inventiva. Com seu conceito de mimesis performativa, Ramos propõe um modelo alternativo de análise e conceituação, para pensar as questões do teatro e das artes performativas hoje, que permite expandir, tanto o entendimento do espetáculo teatral como um todo, quanto de seus componentes cênicos, individualmente. Ao testar seu conceito em diferentes exemplos artísticos, ele vai além das questões específicas de gênero para investigar profundamente o sentido e a aplicabilidade das hipóteses levantadas em seu estudo sobre as perspectivas de uma cena estendida, que agrega diferentes linguagens em torno da postura antiteatral e antidramática, e que as caracteriza como performativas. Para tanto, o autor realiza... 
e plásticas, principalmente aquelas que se lançaram em obras performativas e que passaram a partilhar com a cena teatral $o$ compromisso com um espectador atento, mas, ao contrário da convenção teatral mais arraigada, recusam o dramático (RAMOS, 2015, p. 13).

Ao analisar a faceta espetacular da mimesis associada ao teatro e à afecção do espectador, Ramos explica que ela se define como ato performativo quando se opera a relação entre obra e observador que é, no caso específico de seu estudo, relativa à afecção operada no espectador, durante certo tempo, pelas materialidades cênicas que confrontam, simultaneamente, o apresentado e o ato da recepção (RAMOS, 2015, p. 19). Operar esse resgate da mimesis como antirepresentacão imitativa permite observar a forma como o conceito foi reciclado sem deixar de lado a representação, da mesma forma que o espetáculo antiteatral ou antidramático, mesmo negando as convenções do teatro, permanece espetacular e performativo (RAMOS, 2015. p. 23). O conceito de mimesis apresentado por ele pressupõe, essencialmente, a dependência de um espectador que a reconheça e por ela se deixe afetar. A exposição presencial a essa afecção é restrita a um tempo determinado, existindo sempre a intenção de afetá-lo de algum modo. Com isso, o autor estabelece a condição intrínseca do espetáculo, ou seja, a expressão de sua materialidade como superfície que se dá a ver e que, tempo-espacialmente indissociável do aqui e agora, se apresenta em duração e movimento "como poiesis de algo concreto, produção de visualidade e materialidade autônomas de qualquer referente anterior" (RAMOS, 2015, p. 24).

Seus estudos sobre a Poética de Aristóteles permitem observar a definição de mimesis como práxis, ou seja, como ação que permite o resultado positivo da poiesis que acaba por conceder ao teatro um caráter espetacular. Esse caráter espetacular estabelece a tensão entre a trama, seu aspecto literário e narrativo, e a encenação, materialidade sensorial que constitui o espetáculo. Desta forma, a trama narrativa e a encenação do espetáculo, mesmo que entendidas separadamente nos estudos mais recentes sobre a cena pósdramática ou performativa, jamais estarão, segundo o autor, completamente dissociadas, mantendo sempre um vínculo insuprimível (RAMOS, 2015, p. 27). 
Finalmente, ele situa nos escritos de Gordon Craig, ainda no inicio do século XX, a elaboração de uma "poética da cena" na qual a perspectiva espetacular se torna central e permite a composição de ações dramáticas que possibilitam encenar algo sem qualquer mediação literária (RAMOS, 2015, p. 30). Futuramente, diferentes encenadores como Robert Wilson e Gerald Thomas levarão a extremos esta cisão, até que, finalmente, surgem propostas para reconciliar cena e drama, realizando o que Ramos qualifica como "composições dramáticas não necessariamente mediadas pela literatura, mas articuladas como cenas" (RAMOS, 2015, p. 33-31), ou seja, poéticas simultaneamente narrativas e espetaculares, a exemplo das praticadas por Romeo Castelucci ou Antônio Araújo.

Destacando esse tipo de realização poética como característica dos processos criativos hegemonicamente colaborativos, cuja construção distanciase da literatura, mas guarda certo vínculo com uma trama consequente de ações dramáticas, ele observa um novo modo de operar a construção dramática. Nesta operação constitui-se "uma sintaxe de superfícies, tessitura de cores e imagens, apresentação de objetos não previamente identificados" na qual não há significação certa nem "mensagens estáveis", mas cuja percepção ocorre pelo "contato indiscriminado com as diversas materialidades que se alternam na composição física dos elementos, ou pelas massas sonora e visual que se apresentam como construções abstratas não narrativas" (RAMOS, 2015, p. 31).

Ao contrário da noção de teatralidade de Féral, apresentada como resultado do saber do espectador da intenção do teatro que permite a percepção do fazer performativo, visto que espetaculariza a realidade transformando-a em ficção, Ramos a declara incapaz de abarcar todas as complexas relações implícitas na representação espetacular. Ele destaca a ambiguidade do termo, que, por um lado, se refere à narratividade da trama e, por outro, à espetacularização da cena. Neste segundo aspecto, a tendência de exacerbação do teatral como recurso para combater o ilusionismo na primeira metade do século $\mathrm{XX}$ converge com a antiteatralidade que recusa o dramático como sua razão de ser, mas não rompe completamente com as narrativas 
ficcionais em sua construção dramatúrgica. O teatro performativo se confirma, assim, como campo de fricção latente entre a matéria sensorial bruta que se apresenta face à realidade do observador que a acolhe, entre a ficção e o real, cujo leitmotif passa a ser, efetivamente, a experiência do espectador.

Ramos desenha uma proximidade entre as artes visuais e o teatro ao definir o que chama de mimesis performativa pela situação, comum entre eles, de oferecer aos sentidos algo cuja leitura dependerá exclusivamente do público. Nas artes visuais, o observador que entra em uma sala onde há uma instalação ou qualquer outro objeto a ser contemplado, é colocado na situação de "ator ou agente produtor do sentido daquela obra" (RAMOS, 2015, p. 42). A presença e a duração são condicionantes indispensáveis do fenômeno espetacular, mas seu ato representacional, sempre mediado por atores, dificulta a autonomia de referentes, a exclusão do aspecto mimético ou outras formas de abstração ou negação da realidade. Segundo ele, a inexorável materialidade do teatro, que requisita uma presença em tempo real, mesmo que algumas vezes desmaterializada em imagens virtuais, impõe um aspecto mimético de sobreposição ou duplicação da vida (RAMOS, 2015, p. 40).

Por fim, Ramos credita sua noção de mimesis performativa a um movimento de fuga dos significados estáveis em direção ao vago a ao indeterminado, cuja transição do semântico para o sintático demanda uma disposição espaço-temporal para se impor. Segundo ele, "é nesse lugar e nesse tempo, partilhados entre obra e observador, que se trama uma sintaxe lúdica, um jogo de aproximações e distanciamentos, deslocamentos no espaço e no tempo que não constroem sentidos finais, mas constituem materialidades provisórias" (2015, p. 63). Num contexto de antimimetismo e antiteatralidade, Ramos propõe um novo modelo interpretativo, no qual sobrevive uma pulsão à mimesis e sua vocação performativa, atuando em formas mais abertas, cuja materialidade e presença se apresentam autônomas e livres de referências externas anteriores.

Antônio Araújo (2008) aprofunda a discussão sobre o tema, com o que chama de encenação performativa, ou seja, o trabalho de mise-en-scène de uma 
obra, na qual todos os elementos atuam, a exemplo da qualificação que ele atribui, igualmente, à equipe e ao próprio encenador, como performersencenadores (ARAÚJO, 2008, p. 254). Ele recorre a Renato Cohen (1989 apud ARAÚJO, 2008, p. 254) para explicar que o teatro performativo emancipa a atividade teatral do trabalho do ator, instaurando o discurso da mise-en-scène, na qual o performer se torna uma parte e não mais o todo, que é composto também pela luz, pelo som e por outros elementos tão importantes quanto ele. Araújo destaca que esse tipo de encenação busca negar a representação, chegando a caracterizar-se como uma não-encenação, se isentando da proposição de unificar, simbolizar ou interpretar um texto ou a própria realidade. A encenação performativa pretende, então, instaurar um acontecimento cujo objetivo principal é a produção da experiência capaz de provocar uma interferência no espectador a ponto de capacitá-lo para reagir e participar do processo que lhe é oferecido a ver e experienciar.

Finalmente, o autor e encenador conclui que a vocação da encenação performativa é deixar-se atravessar por sentidos, por linhas de força e heterogeneidades materiais, discursivas e de linguagens, numa produção de presenças. Essas presenças seriam pedaços de sentidos, postos em contato e em movimento, criando fricções entre a realidade e a ficção para "colocar diferentes fluxos de desejo e de sentido em conexão, deixando emergir as diversidades, habitando em heterotopias e, por fim, desestabilizar as cristalizações de unidade", participando de uma ação em um devir permanente (ARAÚJO, 2008, p. 257). Esta ação performativa aglutina todas as expressões materiais da cena, expondo o espectador a uma experiência compartilhada por todos os performers-encenadores envolvidos na ação, em cena ou fora dela, cujo processo performante se dá desde a elaboração até a exposição da obra, que nunca é considerada como acabada ou concluída, mas em constante processo, e cujo trabalho apresenta sempre um aspecto inesperado e fendido, propenso à interferência e incursão externa no ato da recepção. 


\subsubsection{Percepção}

Para Mikel Dufrenne (1981), o objeto estético é concreto, existe plenamente segundo uma necessidade intrínseca, definitiva, na glória do sensível, que se produz na convergência de quem sente e do sentido. A arte, no entanto, exprime o liame do ser com a natureza, considerando que a experiência artística original reconduz o pensamento e, talvez, a consciência, à origem. $\mathrm{O}$ sujeito é sensível à experiência estética, que responde à algumas de suas tendências e satisfaz algumas de suas necessidades por meio do objeto estético que, como obra de arte, só pode se realizar na percepção estética, na qual a estetização do objeto exige entrega e atitude. O sentido, então, segundo o autor, só se manifesta nessa experiência se todas as potências da consciência nela estiverem presentes (DUFRENNE, 1981, p. 26).

Segundo Anna Barros, a arte passou, a partir das tendências modernistas do século XX, "a ser a percepção e não mais o contexto ou os objetos presentes" (BARROS, 1999, p. 26). Pesquisas recentes sobre recepção e a experiência do espectador afirmam, igualmente, que as artes em geral, o teatro e a performance só se realizam ou se concluem na recepção, no contato e na percepção do observador ou espectador. Na verdade, a dúvida que surge é se não teria sido sempre assim, ou seja, se efetivamente, em algum momento, a realidade e o entendimento da arte e do teatro não tenha acontecido somente na percepção e na mente do espectador e que não tenha sido apenas o desejo dos artistas e encenadores o que os fazia crer, ansiar ou esperar que o público percebesse, visse ou compreendesse exatamente o que haviam imaginado ou planejado para suas obras artísticas.

Enfim, digressões à parte, o importante é que hoje está assimilado, por quase todos os meios artísticos, a consciência de que é na recepção, naquilo que o espectador pode ou consegue perceber e absorver da obra com seu próprio repertório, competências, habilidades e a partir da atenção que dedica ao que se lhe apresenta, que a obra ou o espetáculo cênico finalmente se 
concretiza. Ao analisar a percepção estética no campo das artes cênicas num contexto dramático e não performativo, Mikel Dufrenne a qualifica como uma percepção real, aquela que só quer ser percepção sem se deixar seduzir pela imaginação ou pelo intelecto reduzindo o objeto a determinações conceituais.

\begin{abstract}
A percepção estética opera a neutralização tanto do irreal, quanto do real: quando estou no teatro, o real - atores, cenário, sala - não é mais o verdadeiro real para mim, e o irreal - a estória que é representada diante de mim - não é verdadeiramente irreal, visto que, da mesma maneira, posso participar e por ela me deixar envolver sem ser enganado, mas o que é real e o que me "envolve", é justamente o "fenômeno" que a redução fenomenológica quer atingir: o objeto estético dado na presença e reduzido ao sensível como, por exemplo, a sonoridade da palavra ajustada aos gestos dos atores e aos encantos do cenário dos quais a atenção se empenha toda em preservar a pureza e a integridade, sem jamais evocar a dualidade do percebido e do real, isto é, a uma causa do seu aparecer, ao quadro como tela, à música como ruído de instrumentos, ao corpo do dançarino como organismo: ele não é outra coisa que o sensível em sua glória, do qual a forma que o ordena manifesta a plenitude e a necessidade, que traz em si e imediatamente entrega o sentido que o anima (DUFRENNE, 1981, p. 81).
\end{abstract}

Apesar de haver, no teatro performativo, uma maior interseção entre o real e o ficcional, a abordagem de Dufrenne permite avaliar a demanda de entrega e dedicação do sujeito ao objeto artístico no ato da recepção. Seria impossível falar de recepção sem abordar dois grandes autores clássicos sobre o tema da percepção nas artes, Rudolf Arnheim (2012) e Maurice Merleau-Ponty (1994). Por outro lado, foi na teoria de James J. Gibson (1986 apud SANTAELLA, 2012) que foram encontrados os fundamentos mais relevantes para comprovar os efeitos da luz ativa na cena sobre a percepção do espectador. Foi a noção de ecologia da percepção e o conceito de affordance que permitiram compreender a luz como elemento determinante do ambiente cênico e sua influência sobre a percepção humana.

Segundo Santaella (2012), o interesse pela questão da percepção se intensificou com a influência das novas práticas artísticas e midiáticas sobre as faculdades perceptivas e cognitivas humanas a partir da segunda metade do século XX. Com isso, surgiram inúmeras teorias da percepção, muitas das quais concentradas exclusivamente em considerar a visualidade, tendo em conta a predominância do sentido da visão nos processos da relação do ser humano 
com o ambiente e sua orientação no espaço. Em segundo plano está a relação auditiva e, por fim, numa porção muito menor, aquela desenvolvida pelo tato, o olfato e o paladar. A observação dessa dominância dos sentidos visual e auditivo resultou numa concentração dos estudos da percepção à visualidade e à relação entre o objeto percebido e o órgão da visão, em detrimento da estabelecida entre o que é percebido e a mente de quem percebe (SANTAELLA, 2012, p. 3). Segundo ela, mesmo as teorias de Arnheim, que muito se dedicou à percepção nas artes, são muito mais voltadas para o que ocorre no campo visual, sem observar os processos mentais ou cognitivos que regem a percepção.

O próprio autor admite o fato de sua obra mais significativa (ARNHEIM, 2012) ser limitada aos meio visuais e, dentre eles, principalmente à pintura, ao desenho e à escultura, apesar de comentar, embora com menos frequência, a fotografia e as artes da representação. Abordando temas relativos à percepção como equilíbrio, forma, espaço, luz, cor e movimento, Arnheim, mesmo que sem ser esse seu intuito primeiro, explora profundamente a relação do espectador com a cena. As forças perceptivas, entendidas tanto como forças psicológicas quanto físicas, explicam a busca e a necessidade humana pelo equilíbrio, estado de forças antagônicas agindo sobre um corpo e compensando-se mutuamente (ARNHEIM, 2012, p. 11) e pela harmonia, encontrada quando o conjunto de elementos de uma composição se ajustam num todo unificado (ARNHEIM, 2012, 338), relacionando a percepção com a satisfação plena do sentido da visão. No entanto, com o desenvolvimento de teorias mais holísticas, capazes de abordar os vários aspectos do processo perceptivo, surgiram novas possibilidades de enfoque das peculiaridades ontológicas, epistemológicas, psíquicas, corporais e ecológicas da percepção, mais adequadas ao contexto atual das relações entre o ser humano e seu meio.

Foi na fenomenologia da percepção de Merleau-Ponty e na ecologia da percepção de Gibson, além da semiótica da percepção de Pierce, que Santaella encontrou parte das respostas requeridas pelas novas questões a respeito da percepção, mas foram as duas primeiras teorias que mais atenderam a este momento específico da pesquisa sobre a relação perceptiva estabelecida entre 
a cena e o espectador por meio da luz. Numa retomada histórica das teorias da percepção, a autora relembra o conceito grego da percepção como um evento interior do observador, o questionamento do realismo ingênuo da veracidade da percepção pela lógica newtoniana e a diferenciação entre o mundo percebido e o mundo descrito pela física a partir da teoria da relatividade e da física quântica. O realismo direto, para o qual o mundo não é mais como parece ser, mas aquilo que é percebido, se torna uma tese ontológica, mas que não se sustentou ao reduzir o processo todo ao papel desempenhado pela mente ou pela consciência. Nas versões do materialismo, o que prevaleceu foi o dualismo entre matéria e mente, associando a percepção aos fatos físicos, de onde se originou o realismo indireto, que descreve a percepção como "ontológica, epistemológica e causativamente indireta" (SANTAELLA, 2012, p. 5).

Segundo Gibson, "nossos órgãos sensoriais, ou seja, nossos sentidos, são meios pelos quais se estabelece a ponte entre o que está no mundo lá fora [...] e o mundo que, na falta de um nome melhor, chamamos de mundo interior" (SANTAELLA, 2012, p. 6). Esse processo se dá apenas pela estimulação dos sentidos, o que não explica o que a percepção adiciona ao percebido e que não está lá fora, no mundo fenomênico e que não faz parte, portanto, da estimulação. É quando acontece o que é chamado de compreensão ou significado, tanto do que está lá fora quanto do que é produzido como efeito, sintetizados pela mente ou consciência. Na passagem dos órgãos sensoriais para o cérebro, algo se perde e algo se acrescenta e é aí que está, exatamente, a questão da percepção, está no que ocorre dentro do cérebro e não apenas no ato físico de perceber.

O nativismo e o empirismo tentaram resolver o paradoxo da contribuição da mente ao processo perceptivo, o primeiro alegando que a síntese mental é intuitiva ou inata, não pressupondo um aprendizado, e o segundo, afirmando que ela é resultante de experiências anteriores. Para os empiristas, os sentidos fornecem uma matéria bruta a ser suplementada pela mente, que constrói o mundo de acordo com um potencial que lhe é próprio, uma capacidade associativa inferencial. Uma teoria gestáltica atribuiu a síntese mental a uma organização sensorial, diferenciando sensação e percepção espontânea da 
forma, também conhecida como teoria do campo (GIBSON, 1986 apud SANTAELLA, 2012, p. 9). Para Gibson, o estímulo é essencialmente desestruturado e a mente é que constrói e elabora as formas. Para os gestaltistas, igualmente, a percepção é fruto de uma organização mental, na qual o todo é maior que a soma das partes, e em cuja estimulação sensória já ocorre uma síntese.

Em uma analogia desta teoria com a percepção teatral, o resultado será sempre maior do que a soma de todos os estímulos recebidos na experiência teatral. Segundo Gibson, há alguma coisa na percepção da qual a soma não dá conta, o que faz muito sentido na relação do espectador com o teatro, onde apenas o conjunto do que lhe é dado à percepção, e não suas partes isoladas, o afeta efetivamente. Complementando estas observações, Santaella destaca, ainda, que os gibsonianos acreditam que a percepção consiste em captar estruturas significativas na luz através de um processo de inferência determinada, de onde surgiu, justamente, sua teoria ecológica da percepção. Essa teoria, dentro dos parâmetros apresentados a seguir, ajudam no entendimento da concepção epistemológica da percepção que envolve um ambiente informativo e um percebedor ativo.

Antes de mergulhar na teoria gibsoniana, no entanto, com o objetivo de demonstrar sua complementariedade, Santaella perfaz uma apresentação sintética, por mais difícil que seja sintetizá-la, da fenomenologia da percepção de Merleau-Ponty, exposta brevemente a seguir. A partir de alguns antecedentes filosóficos, foi possível demonstrar, de maneira sucinta e eficaz, a contribuição de cada parte da teoria de Merleau-Ponty, concebida nos interstícios do corpo vivo com a pulsação do mundo, para a constituição do todo. Segundo Pardelha (2017 apud SANTAELLA, 2012, p. 17) a percepção para Merleau-Ponty é como uma abertura primordial a uma existência exterior, uma comunhão com o que as coisas nos revelam sobre si mesmas. É nesta comunhão que o mundo se mostra em sua materialidade a quem se encontra em potência de vê-lo no que ele revela, mas nunca por inteiro. 
Nos estudos clássicos da percepção, a sensação é o elemento primário que, ao contrário da experiência vivida, resulta na percepção como um conjunto de sensações destituídas de significado. Para Merleau-Ponty, no entanto, tudo o que é percebido está prenhe de ambiguidade e pertence a um contexto que Ihe dá forma, sendo, por isso, impossível decompor a percepção em sensações. Para ele, perceber não é recordar e não existem forças associativas que operam de modo autônomo. A experiência imanente acessa um passado que a envolve, sendo a percepção o primeiro acesso que temos às coisas e o fundamento de todo conhecimento. A reflexão fenomenológica esclarece as origens perceptivas da experiência real, ao considerar a natureza do sentir em sua comunicação vital com o mundo, aquilo que o torna presente. Isso se dá no campo fenomênico, um ambiente ambíguo, no qual acontece a reflexão de um indivíduo condicionado por sua situação concreta no mundo.

Considerando a percepção como um fenômeno psicofísico, o corpo vivo é incorporado em um sistema casual de estímulo e resposta, cuja estimulação de um órgão do sentido produz a percepção. O corpo se torna, então, o ponto de encontro entre passado, presente e futuro, considerado pela psicologia como um objeto afetivo, cujas sensações cinestésicas o habilitam a reconhecer sua localização espacial, posição e orientação. Retornando à questão da experiência, Merleau-Ponty busca a descrição fenomenológica do corpo na investigação da espacialidade. O ser é seu corpo e dele tem uma "imagem corporal" como intencionalidade encarnada, considerando a posição do corpo em relação aos objetos externos. Além disso, a consciência, o ser para a coisa por intermédio do corpo, é inseparável do mundo percebido. A espacialidade corporal, no entanto, só é revelada pelos projetos aos quais o indivíduo se engaja e que elucidam a sua existência espacial. O corpo habita o espaço e se projeta na direção de um mundo perceptivo, cujos sentidos são poderes individuais que o estruturam em uma experiência unificada. O sujeito e o mundo formam, assim, um todo organicamente relacionado. O corpo vivo, para Merleau-Ponty, é uma unidade sintética de poderes sensórios que é atraído pelo sensível e que só é experienciado na medida em que se percebe algo. Para não cair no dualismo entre sujeito e objeto, é preciso buscar na experiência a dialética na qual as 
coisas começam a existir. É criado, então, um fluxo primordial do que se torna significante quando ela atrai o corpo e quando a significância da coisa e do corpo existem conjuntamente, uma implicando a outra.

Quanto à expressão, Merleau-Ponty afirma que a intencionalidade genuína encontra-se exclusivamente no pensamento traduzido pela fala. No entanto, a fala não necessariamente pressupõe um pensamento anterior, do qual seria mera cópia, mas ela realiza o pensamento, ela é o pensamento do orador. Ele relaciona a fala, o orador e o discurso de forma a traduzir o encantamento pelo texto que não se chega a prever, mas pelo qual se é possuído. Só ao final desse encantamento é que é possível refletir sobre o discurso ou o texto. É preciso, para isso, estar atento ao silêncio primordial no qual toda fala se origina. A fala constitui um gesto genuíno, cuja comunicação e compreensão resulta de um ato de reciprocidade entre intenções. Há uma presença corporal primordial na qual expressão e compreensão se realizam pelo ser-no-mundo do falante, cuja intenção o ouvinte apreende pela modulação do seu próprio ser. Para Merleau-Ponty, a fala e o gesto só expressam o pensamento se o corpo já for esse pensamento. É pelo corpo que se compreende o outro e se percebe "coisas", sendo essa a maneira de se situar no mundo e de estruturar a experiência como subjetividade encarnada na qual mente, pensamento e corpo estão enraizados.

Todo saber, segundo Merleau-Ponty, se instala nos horizontes abertos pela percepção, sendo impossível separar o conhecimento da experiência perceptiva em que ele se origina. A sensação dessa experiência passa a ser a estrutura do ser-no-mundo, cujo sujeito é uma potência que co-nasce com um meio e se sincroniza com ele. A espacialidade vivida em uma experiência integrada é inseparável dos sentidos e da sensação. O sentir surge da coexistência com algo, da entrega, do abrir-se a esse algo antes de qualquer reflexão ou ato pessoal.

É fácil constatar na própria experiência que não há um ego pensante atrás dos nossos olhos e corpo quando contemplamos ao longe o azul profundo do mar unindo-se à luz azul do céu, ou quando nos aconchegamos no calor tépido de um corpo amado. Sentir é uma 
atividade anônima com final em aberto, anterior e pressuposta por nossa existência pessoal (SANTAELLA, 2012, p. 29).

Buscando capturar a gênese do espaço, o sujeito é descrito, fenomenologicamente, como uma subjetividade encarnada, sendo que o sujeito da experiência é o corpo fenomênico ligado ao mundo. O espaço oscila, então, entre ser parte do mundo ou ser um princípio da unificação entre o sujeito e a experiência. A percepção espacial revela que ser é estar situado e que vir-a-ser no mundo é o vir-a-ser de um ser que se orienta. A espacialidade primordial é inseparável do ser-no-mundo e a reflexão sempre encontra uma espacialidade já adquirida, indicativa de uma existência pré-pessoal do corpo como um eu natural, anônimo e generalizado. Já "o fundamento primordial das direções espaciais repousa na apreensão compreensiva e recíproca do corpo fenomênico com o mundo. Esse ancoramento do corpo no mundo e a dialética corpo-mundo anônimo são a fonte da objetividade." (SANTAELLA, 2012, p. 32). Considerando o envolvimento no mundo por meio do corpo, haverá sempre uma relação entre uma atitude corporal particular e a aparência dos objetos, chamada constância perceptiva. Essa constância das coisas, como da cor em variações de luminosidade, por exemplo, está fundada da consciência primordial do mundo como base de todas as experiências. É na medida em que a percepção é aberta ao mundo e às coisas, que se reconhece a constância das coisas. Esse ancoramento no mundo é, simultaneamente, finitude, incompletude e abertura, na constância do próprio corpo no mundo.

A percepção requer articulações formais e espaciais, a exemplo da profundidade, que se origina na espacialidade viva do corpo fenomênico, ou da luminosidade, que desempenha um importante papel no campo perceptivo. As coisas tem, então, uma unidade intersensorial sintética dos poderes sensórios do sujeito encarnado. Essa unidade sintética retoma, ou dá acabamento, a uma intenção alheia ou, ainda, inversamente, realiza, no exterior, suas potências perceptivas por um acasalamento de seu corpo com as coisas. A riqueza da percepção envolve uma ambiguidade fundamental, uma natureza com desfecho aberto e inseparável da objetividade das coisas. O mundo, assim como o teatro, não é um objeto acabado, ele tem fissuras, lacunas, subjetividades. O sentido 
das coisas não são significações oferecidas à inteligência, mas estruturas opacas, cujo sentido último permanece embaralhado. "Só quando vividos, por mim ou por sujeitos tais como eu, é que a coisa e o mundo existem, pois eles são o encadeamento das nossas perspectivas, ao mesmo tempo que transcendem todas as perspectivas, porque esse encadeamento é temporal e inacabado" (MERLEAU-PONTY, 1994 apud SANTAELLA, 2012, p. 33). É nessa ambiguidade e nas fissuras existentes no objeto observado que se encontra a performatividade, na relação entre o sujeito e o objeto, nos vazios que ele preenche por meio de sua percepção a apreensão do mundo.

Assim, a objetividade nasce na relação corpo-mundo e no poder primordial do sujeito encarnado de se ancorar no mundo pré-objetivo, pelo exercício de seus órgãos sensórios. As coisas se tornam reais quando são apreendidas como objetos intersensoriais. As coisas são inseparáveis de quem as percebe, pois nascem da sua apreensão do mundo, mas também objetivas e independentes. A identidade e a constância não são inertes, mas fruto de uma existência dinâmica resultante do convite e resposta das coisas à exploração perceptiva. Assim, a cor e a luz não são qualidades fixas, mas têm a ver com o olhar de quem percebe e com a resistência que oferecem à percepção. A objetividade emerge no habitat do eu natural e a apreensão do mundo não se reduz às coisas, mas também inclui o "Outro" e o "mundo cultural".

A percepção do Outro só pode acontecer em uma situação pré-reflexiva, na qual se revela o cogito (elemento puro, fundamento absoluto do conhecimento) para que a subjetividade se torne uma intersubjetividade. A consciência é perceptiva, ela é uma existência que se caracteriza pelo diálogo, fazendo dos outros e da cultura partes da imagem corporal já compreendidas antes de qualquer reflexão. O corpo é expressivo e, por sua presença no mundo, é o meio de comunicação entre o Eu e o Outro. A experiência se refaz continuamente no tempo e o Eu e o Outro se enredam nessa experiência ambígua e opaca. Para Merleau-Ponty, o sujeito é subjetividade encarnada que sente prazer nos interstícios orgânicos com o mundo e com os outros, sem nunca 
ter dele uma apreensão completa, abrindo espaço para outras subjetividades encarnadas num mundo social compartilhado.

Merleau-Ponty retorna ao cogito para buscar o direito relativo de estar no mundo. Apesar da existência pessoal do sujeito ser ambígua, inconstante, obscura e incerta, ele busca transcender essas condições pela reflexão pura para, pela consciência, alcançar a claridade e a verdade. No entanto, ele admite a ambiguidade, o erro e o engano como inerentes ao conhecimento que emerge da experiência perceptiva primordial, refletindo sobre as emoções verdadeiras e ilusórias numa esfera de ambiguidade. Em relação à linguagem, ele explica que a fala ultrapassa o pensamento que lhe funda e ultrapassa o pensamento que tenta entendê-la. Numa operação paradoxal, ela tenta expressar, por meio de palavras, significações dadas, uma intenção que transcende e fixa o sentido das palavras pela qual ela se traduz. Assim, a concordância do ser consigo e com outrem é dada pela fala resultante da expressão temporal e ilusória, visto que fundamentada em um momento de vida fugidio.

Há um enraizamento do pensamento na consciência perceptiva cuja espessura temporal e contingência não podem ser avaliadas. Não existe uma reflexão pura e o conhecimento, a certeza e a verdade revelam sua condição ambígua e opaca. Merleau-Ponty afirma que, não há, para o sujeito, separação entre o interior e o exterior. O mundo está todo dentro dele e ele está inteiro fora de si mesmo. O cogito compatível com a sua experiência vivida é a ambiguidade do sujeito de ser-no-mundo e ser-para-si numa relação existencial como ação e constante autotranscedência. Antes de ser objeto de seu próprio pensamento, o sujeito precisa existir e fazer existir o mundo à sua volta. O pensamento formal, então, está "fundado no pensamento intuitivo e é deste que brotam as certezas e as verdades. [...] Não há conhecimento absoluto, nem erro absoluto, porque nossa experiência da verdade é inseparável do nosso ser em situação". Assim, a concepção fenomenológica da verdade se afasta tanto do dogmatismo quanto do ceticismo. "Estar na verdade é estar no mundo" (SANTAELLA, 2012, p. 37).

A percepção é, por sua natureza, temporal, requerendo uma síntese corporal cuja espacialidade e motricidade acontecem no tempo. E ser-no-tempo 
é ser-no-mundo, o sujeito é o próprio tempo. Sem fluir de um lugar para outro, ele se constitui na sua relação viva com o mundo, numa síntese entre o passado, o presente e o futuro. O presente, para Merleau-Ponty, é um campo de presença que se abre para o passado e o futuro e conduz a uma inter-relação com essas dimensões temporais. Husserl (1994 apud SANTAELLA, 2012, p. 38) fala do fluxo de consciência, no qual cada experiência, cada percepção ou simples sensação é a ressonância de viver em continuidade. A experiência do tempo, então, é determinada por uma instantaneidade que tem lugar na consciência. Para Merleau-Ponty, o tempo é uma rede de intencionalidades que se sobrepõem e encontram seu centro no sujeito-corpo. O sujeito e o tempo constituem, assim, uma cadeia interconectada de campos de presença.

Desta forma, o eu afeta, é afetado e se auto afeta numa subjetividade que não está no tempo, mas que se confunde com a coesão de uma vida. Sujeito e objeto são momentos abstratos de uma totalidade concreta única, que é a presença, cujo corpo fenomênico e cognitivo é revelado pela experiência de estar (presente) no mundo. Na relação entre liberdade e engajamento, a presença significa que não existe casualidade na conexão do indivíduo com o corpo, o mundo e a sociedade. A liberdade, que nunca é absoluta, requer um poder sustentando pelo engajamento, uma entrega vivida na ambiguidade. A fenomenologia radical de Merleau-Ponty relaciona a subjetividade corporal do sujeito em troca dialética contínua com o mundo e com outras subjetividades encarnadas. Ele propõe um retorno à experiência concreta, contrária ao dualismo da objetividade e subjetividade, pela análise do corpo, do pensamento, do tempo, da intersubjetividade e da liberdade sustentada pelo engajamento. Ele apresenta uma consciência primitiva do sujeito, que encontra na percepção a sua operação mais imediata, mais embrionária, cuja consciência constitui uma rede de intenções significativas que se abre ao mundo e ao outro. E é, finalmente, da inerência primordial do ser-no-mundo que se abre caminho para a visão ecológica do ambiente vivido, da fenomenologia da percepção para a ecologia da percepção. 
Ainda sobre a fenomenologia da percepção, Anna Barros (1999) expõe, a partir da análise das obras e experiências de James Turrell e Robert Irwin, a arte como resultado da experiência que o observador "leva" consigo e na qual o artista assume a percepção como meio de trabalho artístico. Inspirado por SaintExupéry, Turrell explora a luz e o espaço para "criar uma arte cujo próprio meio é a experiência fenomenológica, principalmente pela visão, tendo a luz como material" (BARROS, 1999, p. 92). A autora explica ainda que os textos de Irwin

\begin{abstract}
são frutos da experiência ganha por meio de uma curiosidade que se estende por vários domínios do saber. É essa penetração em extratos da mente humana o que torna tão autêntica sua certeza do domínio da percepção sobre a cognição como fonte de conhecimento. Toda beleza e sofisticação desse logos nascente, pleno de tudo o que se definiu por humano, é o que Irwin deseja tornar consciente de uma arte que não oferece uma transformação, uma re-apresentação de algo, mas sim a experiência direta do que está acontecendo no processo "do fenômeno" (BARROS, 1999, p. 140).
\end{abstract}

Indo buscar respostas aos seus questionamentos a respeito da experiência artística, Irwin (1979 apud BARROS, 1999, p. 141) revela que "o verdadeiro departamento da arte é a natureza de nossas percepções de algo, esse algo que ocorre em cada um de nós e antes de qualquer coisa". Ele acrescenta, ainda, que o fenômeno artístico só se torna possível pela quebra da ideia de permanência, visto que é ao aceitar a impermanência que se abre a possibilidade para o fenômeno em si. Esse fenómeno, que pontua a arte do século XX, a exemplo da performance, é o que permite uma percepção nãoobjetiva da obra ou do fenômeno artístico.

Ferraz (2009 apud SANTAELLA, 2012, p. 42) afirma que a atividade perceptiva, segundo Merleau-Ponty, indica que o mundo não é alheio à subjetividade, mas um campo de eventos assimilados harmoniosamente pelos poderes do corpo. Essa assimilação ocorre a partir de um pacto estabelecido naturalmente entre o corpo e o mundo, no qual a percepção apreende significativamente os eventos que encontra. Santaella entende que esses argumentos insinuam o conceito de affordance, proposto por James J. Gibson, a partir de sua teoria da ecologia da percepção. Para desenvolvê-la, seu fundador elaborou, antes, uma teoria inédita dos sentidos como sistemas perceptivos ativos, contrariando a ideia tradicionalmente considerada do 
estímulo externo de sentidos passivos. Em sua teoria da percepção ecológica, o sistema perceptivo está em sintonia com as variações e as invariantes do ambiente, ativamente buscadas pela interação de um observador em movimento.

Numa evolução de sua visão psicofísica, Gibson define a percepção como função da habilidade de detectar informações, envolvendo um processo ativo de ressonância à informação. Ele afirma que os sistemas perceptivos, ao invés de serem estimulados, como se acreditava até então, ressoam a informação. Essa ressonância, que ele chama de informação ótica, realiza uma unidade na interface entre o animal (ser) com o ambiente (meio), considerado ecológico por ser concebido como relativo ao animal que nele habita. No conceito de ecologia da percepção, o ambiente não é apenas o que é percebido, mas é, sobretudo, uma fonte de estimulação. Para Gibson, os sentidos não são meros produtores de sensações, mas mecanismos ativos de busca e seleção de informações. A concepção ecológica e epistemológica da percepção de Gibson demonstra como o contato e a compatibilidade em ser percebedor e ambiente são possíveis, por envolver um percebedor ativo e um ambiente informativo ou estimulativo. Ao descrever fatores como movimento, forma e distância, Gibson demonstrou se preocupar menos com a maneira como as coisas aparecem do que com o que há para ser visto. A fenomenologia foi substituída, assim, pela descrição do ambiente como ponto de partida para a percepção, rompendo com a ideia de que a percepção está confinada ao presente instantâneo e incorporando os conceitos de evento e de sequencia de eventos como fatos perceptivos.

A ecologia da percepção é definida, então, como "uma realização epistêmica ativa, voltada à sobrevivência em um ambiente estruturado e dinâmico, ontologicamente relativo ao percebedor, na qual não existe separação possível entre mente e matéria, entre o percebedor e o mundo." (SANTAELLA, 2012, p. 49). O ponto de partida do conceito de ecologia da percepção está na reciprocidade dinâmica entre animal (ser) e meio (ambiente), cujo modo de vida (percepção e comportamento) está atrelado à ideia de entorno e ambiência. Para relacionar o ambiente com o percebedor, Gibson destina boa parte de seus 
estudos à luz, considerando que a informação disponível à percepção deve estar em um meio iluminado, além de descrito. Ele esclarece que não se trata apenas de uma luz que sirva para estimular os receptores, mas de uma luz cuja informação possa ativar todo o sistema, diferenciando, para isso, a ótica clássica da ótica ecológica. A ótica ecológica diz respeito, segundo ele, à informação disponível à percepção, atravessando a ótica física, a ótica geométrica e a ótica fisiológica, indo além delas. Ele distingue, ainda, três tipos de luz: a luz como energia física, a luz como estímulo para a visão e a luz como informação para a percepção.

A síntese de Gibson ainda prevê que o ambiente e o processo da percepção sejam descritos, introduzindo outra maneira de pensar sobre a percepção, com diferenças capitais no tratamento dado àquele que percebe e ao ambiente percebido. A ecologia perceptiva de Gibson apresenta uma visão completamente nova dos processos perceptivos, para a qual o animalobservador e o ambiente físico são recíprocos em um ecossistema integrado e cujos conceitos se articulam em uma lógica própria e particular, segundo a qual não existe uma distinção absoluta entre observador e mundo nem unidades naturais últimas; seus elementos não são contextualmente independentes nem existem cadeias lineares dos processo perceptivos; o espaço não tem precedência sobre o tempo e esse não se configura como uma série disjunta de instantes evanescentes; e conhecimento e vida não são processos intrínsecos ao animal-observador.

O primeiro ponto abordado por Santaella na conceitualização da teoria de Gibson é a distinção entre ambiente vital e espaço físico. Para ele, o ambiente é tanto aquilo que é percebido quanto fonte de estimulação necessária à percepção. No conceito clássico da física, o ambiente é dividido em matéria e energia, mas no nível das relações ecológicas, porém, ele é constituído por meios, substâncias, superfícies e layout de superfície. Os meios são basicamente os elementos que constituem o planeta: terra, água e ar, entendidos num conceito novo de percepção e ação. O mesmo meio em que o animal se move é também o meio para a luz, o som e o cheiro. O movimento do animal é 
guiado ou controlado por esses estímulos, informações sobre as coisas detectadas pelo animal para guiar e controlar sua locomoção. Ainda numa ordem ecológica, a atmosfera e a gravidade também são características do meio, além das porções de matéria em estado sólido ou semissólido, que não transmitem luz ou odor e que não permitem a locomoção, como a rochas, o solo, a areia, a madeira, os minerais, etc., chamadas substâncias.

As superfícies são as interfaces entre os estados da matéria (sólido, líquido e gasoso), como a terra-água no fundo de um lago, por exemplo, a águaar e a terra-ar, que Gibson chama de ground. Para completar o ambiente existem os layouts das superfícies e o fluxo reverberante da luz no meio, ou seja, o modo como a luz é absorvida e refletida nas superfícies, dependendo da composição das substâncias.

O ambiente, para um observador, consiste de substâncias, o meio e as superfícies. A gravidade, a luz, o calor, o som e as substâncias voláteis preenchem o meio de modo que o observador está imerso em um mar de energia física, um mar flutuante que passa por ciclos de mudança, especialmente de temperatura e iluminação (SANTAELLA, 2012, p. 53).

O ambiente é o entorno dos organismos, animais que percebem e agem, e ambos formam um par inseparável, pois um implica o outro. O princípio fundamental da investigação ecológica de Gibson é que o ambiente acolhe o animal e se oferece a ele. A ecologia trabalha com a noção de que o ambiente para um organismo vivo difere do ambiente para um objeto físico. Todo animal é, até certo ponto, um percebedor e um agente, pois percebe o mundo e age nele. O conceito de ambivalência indica que a informação atua na reciprocidade entre o que é envolvido e o que envolve, denotando como o ambiente circunda os animais a partir de uma propriedade ecológica relativa a criaturas que se movem. O conceito de ecossistema surge como o ambiente que permite a vida animada, cuja mobilidade, traço essencial do ser vivo, dá origem à dinâmica básica do ambiente, o evento.

A teoria gibsoniana entende o espaço vazio como superfície e o tempo vazio como evento, sendo as relações espaciais encarnadas em relações entre superfícies e relações temporais corporificadas em eventos particulares. $O$ 
animal em seu modo de vida não percebe o tempo, mas processos, mudanças, sequencias, então o fluxo dos eventos ecológicos difere da passagem do tempo linear newtoniana, pois os eventos podem ser percebidos e o tempo não. Os eventos fluem de modo heterogêneo e diferenciado, têm começo e fim, são fluídos e semielásticos e possuem uma estrutura sequencial.

Considerando a ênfase ecológica no ambiente constitutivo das condições nas quais a vida evolui, o conceito mais original e influente da ecologia da percepção é o conceito de affordance, impossível de traduzir, segundo Santaella, sem perder a sutileza do seu sentido: "a vida evolui de uma variedade de maneiras para tirar vantagem daquilo que o ambiente tem para oferecer." Para Gibson, a percepção é direta e os valores das coisas são percebidos imediata e diretamente. As affordances não são propriedade físicas abstratas, mas únicas para determinado animal e seus semelhantes, devendo ser medidas em sua relação com aquele animal. Isso define uma compatibilidade entre a vida e o ambiente, ou seja, o nicho ocupado pelo animal, que difere de habitat por se referir mais ao modo como ele vive do que ao lugar em que vive. Um nicho, então, é entendido como um conjunto de affordances específicas para um determinado animal.

A percepção implica em um ambiente significativo que se revela para um percebedor e as affordances representam os significados dos traços deste ambiente, ou seja, tudo o que ele oferece ao animal, incluindo objetos, perigo, alimentos, proteção, abrigo, suporte, aquecimento e tudo o mais que possa ser relacionado às formas vivas e esteja ontologicamente atado ao animal. Elas são fatos ecológicos pertencentes às funções do ambiente relacionadas ao animal, sendo, portanto, recíprocas a ele. Elas existem como oportunidades, e embora recíprocas, não são subjetivas ou contingentes aos humores ou necessidades do animal, que pode se dispor a fazer uso delas ou não. Elas se apresentam como um potencial para a interação do animal com o ambiente. É ele que age, mas só o faz por meio da utilização de uma affordance que, por sua vez, é indissociavelmente ligada a ele. As affordances têm sempre por referência o animal e suas capacidades, podendo ser usadas como melhor se the aprouver. 
O animal percebe o ambiente e detecta suas affordances no seu patamar mais fundamental. A sobrevivência, em seu nível mais elementar, depende da percepção das affordances. Os animais vivem em nichos ecológicos que são modos potencias de vida oferecidos pelo ambiente, ou seja, um conjunto de affordances, que podem ser positivas ou negativas. Ao mesmo tempo que o ambiente dá suporte à vida, ele também pode oferecer elementos potenciais para destruir a vida, ou seja, affordances em um ecossistema dinâmico de vida e morte.

Para Gibson, assim como para Merleau-Ponty, ambiente a animal, objeto e mente, sujeito e mundo, são interdependentes e indissociáveis, sua separação é inconcebível em todos os níveis. Numa análise associativa, o sujeito em relação com a ação cênica, seja como recebedor ou como agente, é inseparável do ato teatral performativo ao qual se dedica, cujo estímulo informativo ativa sua percepção em direção ao seu ambiente perceptivo. $O$ mundo social compartilhado de Merleau-Ponty pode se assemelhar à experiência do sujeito com a representação cênica, seus performers e os demais espectadores, sendo que ele só pode adquirir consciência do outro e do que observa se tiver plena consciência de si neste conjunto de relações que estabelece. Ele acrescenta ainda que o sujeito só pode se relacionar com o mundo se ele próprio fizer existir esse mundo a partir de si mesmo, localizando-o ao seu redor.

Ao analisar a classificação dos sentidos de Gibson como mecanismos ativos de busca de informação, sinto-me inclinada a associar esse conceito aos sentidos do espectador, cuja percepção advém do seu interesse e disposição ativa para estabelecer uma relação com o espetáculo. Os tipos de luz detectados por ele também permitem certa analogia com as funções da luz como instrumento de visibilidade e como elemento dado à percepção, incluindo tanto o fenômeno físico quanto o informativo da teoria gibsoniana. A relação reconhecida pela ecologia da percepção entre o ambiente e o percebedor pode perfeitamente ser adaptada à relação analisada neste estudo entre o teatro e o espectador, que percebe e age ativamente no ambiente teatral que o estimula. 
Finalmente, é o conceito de affordance que mais parece atender ao conceito do potencial performativo da luz como algo oferecido à percepção do espectador, visando estabelecer uma relação perceptiva e informativa entre ele e a cena. Parafraseando o conceito de Gibson, apresentado por Santaella, é possível demonstrar como o ambiente significativo do teatro se revela para 0 espectador e a luz atua como uma affordance cujos significados representam aquilo que ele oferece ao espectador, ou seja, seus aspectos físicos, materiais e emocionais, suas características e estímulos aos sentidos atentos e ativos. Ela pertence às funções da luz no espetáculo e está atada a ele e ao espectador, com quem se relaciona sensorialmente, sendo, portanto, recíproca a ele.

A luz cênica existe como uma oportunidade não subjetiva ou contingente às necessidades do espectador, que pode se dispor a fazer uso dela ou não. Ela se apresenta como um potencial elo para a interação do público com o espetáculo, considerando que se ele também age, só o faz por meio da iluminação. Lucas Amado ${ }^{139}$ relembrou, a esse respeito, uma impressão expressa por Waldo León, um fotógrafo, iluminador e artista visual Uruguaio, sobre a percepção da luz e da iluminação no teatro, entendida por ele como "a influência mais importante em nossa percepção visual do mundo" (AMADO, anexos, p. 142). A luz, como affordance da cena, vai ter sempre por referência as capacidades e características do público, que percebe e detecta informações e estímulos contidos na visualidade do espetáculo no seu patamar mais fundamental. Segundo o conceito de affordance, a iluminação seria um dos elementos que o espetáculo tem a oferecer para o público como forma de ativação e subsistência da relação estabelecida entre ambos.

Um possível exemplo da ação da luz sobre a percepção do espectador com base no conceito de affordance, ou seja, aquilo que o ambiente oferece à percepção, pode ser dado pelo efeito criado para a coreografia principal do espetáculo A Loucura de Bispo, dirigido por Octávio Nassur e coreografado por Patrícia Machado. A um momento dado e preciso, mais próximo do final do

\footnotetext{
139 Em entrevista realizada como parte desta pesquisa, disponível nos anexos, p. 142-150.
} 
espetáculo, uma música intensa e presente invadia a sala e o palco, este dominado também por um elemento cenográfico potente, elásticos tensionados, nos quais os bailarinos se enredavam com os movimentos de uma angustiante e violenta coreografia. Os elásticos eram agitados com tensão e intensidade crescentes, acompanhados igualmente pela música produzida ao vivo. $\mathrm{O}$ desafio foi descobrir como a luz poderia, com seus recursos, corresponder a toda essa força e energia expressos pela música e os movimentos dos bailarinos.

A resposta veio ainda na sala de ensaio, enquanto eu acompanhava o processo de criação das coreografias. Desde o primeiro contato com a coreografia em questão, eu imediatamente me dei conta de que o público teria que sentir, de forma mais visceral e experiencial, a manipulação imposta pelos bailarinos a esses elásticos, perceber sua vibração, acompanhar seu movimento intenso e aflito. Essa ação, como expressão da mente perturbada do personagem título do espetáculo, um artista alucinado por vozes, surtos de loucura e devaneios criativos, precisava ser compartilhada com o espectador.

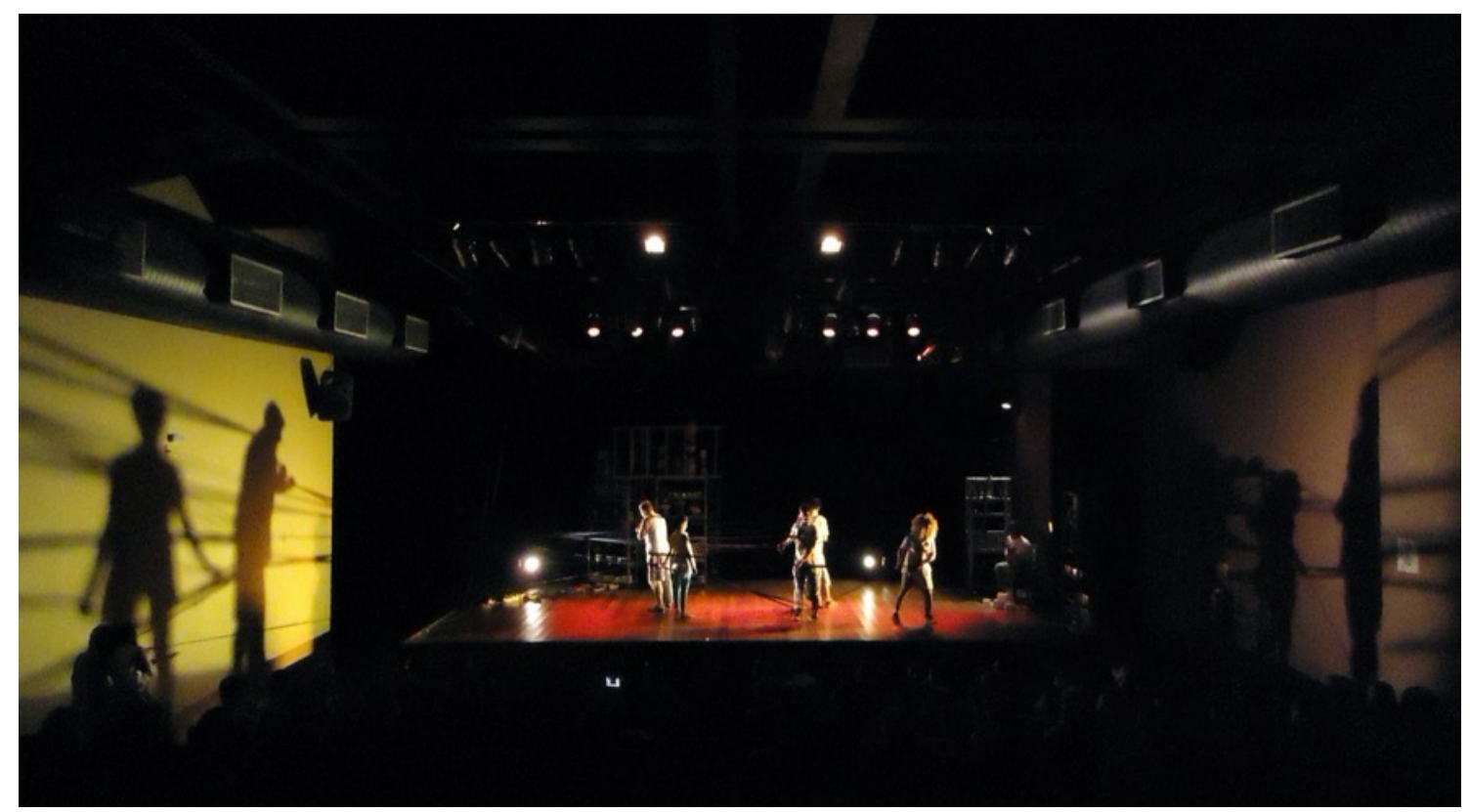

Figura 15 - Efeito de luz surround na plateia para o espetáculo A Loucura de Bispo apresentado no Teatro Londrina em Curitiba em 2014. Direção geral de Octávio Nassur. Luz e Foto Nadia Luciani.

O que me ocorreu, enfim, como possível solução, era projetar as sombras dos bailarinos e dos elásticos, ampliando a percepção do espectador deste movimento, mas onde eu poderia projetar essas sombras? Essa resposta eu não 
tinha como encontrar na sala de ensaio, teria que esperar para decidir sur place, o que aconteceu assim que eu entrei no teatro e vi as paredes claras do espaço destinado ao público, na plateia. Seria ali!

Foi, efetivamente, colocando dois refletores no chão no fundo do palco que eu consegui projetar as sombras dos bailarinos em movimento, como queria, nas paredes do teatro, ao longo de toda plateia até o final da sala. A ideia, inicialmente, não foi bem aceita pelo coreógrafo e pelos bailarinos, pois havia o risco de tropeçarem no equipamento e até mesmo se machucarem, isso sem contar o espaço considerável do já bem restrito palco que ocupavam. No entanto, numa justa equação entre custo e benefício, perdas e ganhos, todos acabaram cedendo face ao resultado obtido. O efeito consistia numa luz que, da mesma forma que o som, invadia igualmente palco e plateia, projetando imagens e afetando a percepção dos espectadores, contagiando o público com os movimentos enérgicos, além da vitalidade e intensidade do som e da cena. Esse efeito, que eu chamei de luz surround, envolvia os espectadores no mesmo clima e ambiente em que se encontravam os bailarinos, fazendo-os compartilhar da mesma tensão e percebendo, tanto por meio de seus sentidos mais latentes, a visão e a audição, mas também com todo o seu corpo, a pulsação da música e a contagiante emoção da cena recebida pelo público. 


\subsubsection{Recepção Ativa}

A experiência do espectador e as teorias da recepção tem sido tema recorrente e importante campo de estudo de autores, teóricos e estudiosos do teatro. Ainda no início do século XX, Edward Gordon Craig recusou a tradição mimética do século XIX para valorizar o vínculo que une o espectador ao espetáculo. Segundo Roubine, esse vínculo, para Craig, "é ainda mais forte na medida em que o segundo mobiliza a atividade de imaginação e devaneio do primeiro", cabendo à direção solicitar essa atividade, sem "saturá-la ou inibi-la com imagens excessivamente precisas" (ROUBINE, 2003, p. 161). A partir da metade do século passado, o espectador assume um relevante papel na construção e recepção do fazer teatral, levando seus criadores e realizadores a considerar, em sua concepção, a relação estabelecida entre ela, cada um de seus componentes e o público que os acolhe. A participação do espectador adquire uma ainda maior importância no processo de análise e entendimento de uma luz percebida como responsável por estabelecer a relação entre a cena e o espectador com sua atuação performativa.

Mostaço explica que a teoria da recepção trabalha sobre três eixos, articulados como ângulos, para dar conta da complexidade dos fenômenos artísticos, cada qual relacionado a uma área da produção e da fruição: a poiesis, a aisthesis e a catharsis (MOSTAÇO, 2017, p. 100). Em seus estudos sobre a estética da recepção e a experiência estética como função da atividade humana, Jauss (1978) apresenta a estética como...

...a atitude tornada possível pela arte e à qual nos leva tanto o gozo do belo quanto o prazer produzido pelos objetos trágicos ou cômicos, podemos aqui apresentar três conceitos chaves da tradição estética: poiesis, aisthesis e catharsis. Poiesis, entendida como "poder (savoirfaire) poiético", designa, então, um primeiro aspecto da experiência estética fundamental: o homem (sic) pode satisfazer, pela criação artística, a necessidade geral que ele tem de "se sentir parte do mundo e encontrar seu lugar no mundo": o homem (sic) "suprime do mundo exterior o que ele tem de estrangeiro e de frio", ele faz dele sua própria obra e alcança, com isso, um saber igualmente distinto do conhecimento científico, conceitual, e da práxis artesanal puramente reprodutora, limitada pela sua finalidade. Aisthesis designa um segundo aspecto da experiência estética fundamental: a obra de arte pode renovar a percepção das coisas, desencantada pelo cotidiano; a 
aisthesis permite, então, ao conhecimento intuitivo, seus direitos, contra o privilégio concedido tradicionalmente ao conhecimento conceitual. Enfim, catharsis designa um terceiro aspecto da experiência estética fundamental; durante e por meio da percepção da obra de arte, o homem ( sic) pode se libertar dos elos que o acorrentam aos interesses da vida prática e se disponibilizar, pela identificação estética, a adotar normas de comportamento social; ele pode também recuperar sua liberdade de julgamento estético (JAUSS, 1978, p. $131)^{140 .}$

A diretora, professora e pesquisadora Dodi Leal (2018) propõe, a fim de explorar aspectos receptivos das transgeneralidades, uma cartografia visual de gênero na performatividade em três categorias dialéticas, concomitantemente relacionadas às proposições de Jauss e suas reflexões a respeito da estética da recepção. Em seu decurso, Simões descreve a poiesis como parte da experiência do espectador, definindo-a como "atitude propositora do receptor ao se deparar com o objeto estético, ou seja, a sua manifestação na co-autoria da obra" (SIMÕES, 2010 apud LEAL, 2018, p. 59). Para ela, a aisthesis "representa o conhecimento sensível em detrimento do conceitual e relaciona-se ao efeito provocado pela obra de arte no receptor, ou seja, a mobilização causada pelo contato com a obra" (SIMÕES, 2010 apud LEAL, 2018, p. 61), enquanto que a catharsis "representa a concretização do processo de identificação que, por sua vez, possibilita a assimilação da experiência sensível como uma informação acerca do mundo" (SIMÕES, 2010 apud LEAL, 2018, p. 57).

A respeito da recepção estética, Pareyson (2001) introduz uma importante reflexão sobre a relação da obra de arte com o artista, o observador e a

\footnotetext{
140 «...l'attitude rendue possible par l'art et à laquelle nous ramènent aussi bien la jouissance du beau que le plaisir produit par les objets tragiques ou comiques, nous pouvons maintenant introduire ici les trois concepts clés de la tradition esthétique : poiesis, aisthesis et catharsis. Poiesis, compris comme "pouvoir (savoir-faire) poïétique", désigne alors un premier aspect de l'expérience esthétique fondamentale: l'homme peut satisfaire par la création artistique le besoin général qu'il éprouve de "se sentir de ce monde et chez lui dans ce monde": l'homme "dépouille le monde extérieur de ce qu'il a d'étranger et de froid", il en fait son œuvre propre, et atteint de la sorte a un savoir également distinct de la connaissance scientifique, conceptuelle, et de la praxis artisanale purement reproductrice, limitée par sa finalité. Aisthesis désigne un second aspect de l'expérience esthétique fondamentale : l'œuvre d'art peut renouveler la perception des choses, émoussée par l'habitude; l'aisthesis rend donc à la connaissance intuitive ses droits, contre le privilège accordé traditionnellement à la connaissance conceptuelle. Enfin, catharsis désigne un troisième aspect de l'expérience esthétique fondamentale; dans et par la perception de l'œuvre d'art, l'homme peut être dégagé des liens qui l'enchaînent aux intérêts de la vie pratique et disposé par l'identification esthétique à assumer des normes de comportement social ; il peut aussi recouvrer sa liberté de jugement esthétique » (tradução da autora).
} 
sociedade. Ao analisar forma, conteúdo e processo, ele propõe, ao invés de uma estética da expressão e da contemplação, uma estética da formatividade que distingue a estética e a poética que, tanto quanto a obra de arte, é parte da experiência estética (PAREYSON, 2001, p. 10). Segundo Pareyson, existem três definições tradicionais da arte: como fazer, como conhecimento e como expressão filosófica (PAREYSON, 2001, p. 24). A primeira prevaleceu na Antiguidade com seu aspecto exclusivamente executivo, fabril, manual; a terceira durante o Romantismo, cuja beleza da arte consistia na sua expressão, no sentimento e na contemplação; e a segunda, que persiste ao longo de todo o decurso do pensamento ocidental, afirma que a arte é interpretada como conhecimento, como linguagem e visão da realidade sensível em toda sua evidência, realidade metafísica superior ou realidade espiritual mais íntima, profunda e emblemática.

Ele afirma, com isso, que mesmo que a condição de expressão da arte seja aceita como tal, não é isso que a caracteriza em sua essência. Aliás, nem tampouco a de contemplação, que revela sua inadequação na exigência do fazer, realizar e executar que lhe é inerente. O autor defende que os conceitos da forma e da formatividade como os mais adequados para qualificar, atualmente, a arte e a atividade artística. Ao afirmar que...

Ela [a obra de arte] é um tal fazer que, enquanto faz, inventa o por fazer e o modo de fazer. A arte é uma atividade na qual [...] concebe-se executando, projeta-se fazendo, encontra-se a regra operando, já que a obra existe só quando é acabada, nem é pensável projetá-la antes de fazê-la [...]. A arte é, portanto, um fazer em que o aspecto realizativo é particularmente intensificado, unido a um aspecto inventivo. Nela a realização não é somente um "facere" [...], mas um acabar, [...] de modo que é uma invenção tão radical que dá lugar a uma obra absolutamente original e irrepetível, filosófica (PAREYSON, 2001, p. 26).

...ele permite compreender como a poética, objeto de estudo da estética, dedica-se a compreender as formas de expressão encontradas pelo artista para se manifestar, diferencia-se da estética, filosofia que compreende a relação perceptiva instaurada entre a obra acabada e o observador, no ato e resposta da experiência artística, que a modifica e transforma, num fazer permanente. 
Pareyson apresenta, neste viés, a questão da interpretação associada ao ato de recepção, alertando para a sua infinitude, ou seja, o fato de não haver interpretação definitiva nem processo de interpretação definitivamente acabado. Ele afirma que sempre haverá uma nova forma de ver e de interpretar a obra de arte relativa ao contexto ou às circunstâncias em que se insere sua apreciação, variando conforme o sujeito e o momento da contemplação, tornando-a infinita. O conceito filosófico da inexaurabilidade da obra de arte (PAREYSON, 2001, p. 228) revela a condição de infinidade do processo interpretativo, qualidade maior da obra de arte dialógica, cuja relação poética com o interlocutor perpetua-se infinitamente nas novas possibilidades de leitura e na busca eterna pelo recebedor de sua compreensão.

O tema da infinitude, abordado por Massa (2010) quanto à leitura do texto teatral, se estende à recepção dos elementos vivos da encenação. Ele associa as teorias de concretização de Ingarden (MASSA, 2010, p. 17-18), de recepção de Jauss (MASSA, 2010, p. 20), de efeito de Iser (MASSA, 2010, p. 28-29) e dos diferentes modelos de espectadores de De Marinis (MASSA, 2010, p. 32-34) para demonstrar como a percepção e a compreensão do espetáculo dependem intrinsicamente do estado, da capacidade e do horizonte de expectativa do espectador. A interferência exercida pelo espectador na interpretação da obra, conforme o contexto e as condições de recepção, revela sua participação como cocriador do espetáculo a partir da experiência teatral. Segundo ele, não existe, na obra, um sentido pré-determinado, considerando que ela só se constitui na consciência do espectador, durante o ato da recepção (MASSA, 2010, p. 28-29).

Zumthor (2007, p. 35) destaca a influência direta da postura e forma de recepção do leitor sobre as percepções e prazeres frente ao poético da obra, considerando que, segundo ele, a qualidade poética da expressão está em sua capacidade de provocar sentimentos, produzir efeitos e proporcionar prazer. $\mathrm{O}$ mesmo se pode dizer da qualidade poética do teatro, da luz ou de outras linguagens do espetáculo que, desde que afetados, influenciados e modificados pela forma e contexto de recepção e percepção a que seu público é exposto, produzem um determinado e diferenciado efeito sensorial e emotivo. 
Abordando mais especificamente a recepção no teatro performativo, as novas configurações da condição do espectador frente ao espetáculo acabam por deslocá-lo do seu lugar de conforto e passividade, confrontando-o aos espaços não convencionais de representação, obrigando-o a questionar e ressignificar os espaços em sua relação com a cena e com o público:

Essas novas configurações que tencionam e fragilizam as fronteiras das esferas do público e do privado nos permitem repensar o teatro e sua relação com a condição de expectação. Neste sentido, [...] é proposto um teatro no qual se estabelece um jogo com o espectador de forma a que este é deslocado de sua condição confortável e cotidiana para um terreno movediço e em permanente transformação (SANTOS in CARREIRA, 2009, p. 9).

Os processos de interferências mútuas de percepção do público face ao espetáculo coloca em questão a condição do espectador, por vezes em uma posição desconfortável e de desequilíbrio, ao fragilizar os limites entre ele e a cena. Esse procedimento de transformar o espectador em elemento funcional da cena é componente significativo de uma poética que toma espaços não convencionais para borrar "os limites dos territórios do público e do privado" (SANTOS, in CARREIRA, p. 10). Além disso, outro novo aspecto a ser considerado é "a potencialidade do funcionamento corporal dos espectadores como material dramatúrgico a ser descoberta pelos criadores da cena" (CARREIRA, 2009, p. 34). Carreira explica que se o espaço não convencional condiciona a produção e a recepção da cena, as operações corporais do público também impactam em suas linguagens, cuja poética permite uma construção cênica que explora as possibilidades expressivas das reações dos espectadores.

Ao estar submetido a uma condição de expectação que não permite conforto nem descanso, o público se transforma inevitavelmente em signo ativo da cena. A abordagem do espaço então não pertence somente aos artistas que a propuseram, ela se faz propriedade daqueles que se dispõem a criar tal situação desde o lugar criativo da recepção (CARREIRA, 2012, p. 34).

Em um outro viés, Dondis (2007), relaciona a questão da recepção à diferenciação entre ver, fato natural e fisiológico, e perceber, que pode, tanto ser intrínseco e espontâneo, quanto resultar de um processo de capacitação e aprendizado associado à habilidade para elaborar e interpretar informações visuais. Benjamin (2014) analisa a percepção da obra visual pelo público em 
relação com o prazer de ver e sentir da recepção explicitamente coletiva. Esse tipo de recepção é associado à crítica de novas formas de expressão, que são, segundo ele, a resposta da arte à demanda crescente de novidade desse público, cujo desejo mais intrínseco é o de ser atingido pelo sensível.

Marilena Chauí expõe, a partir da noção de obra fecunda de MerleauPonty, o conceito de leitura criativa, que acontece quando “...não vejo letras ou sinais sobre uma página, mas participo de uma aventura de significações na qual o escritor me invade arrastando-me do instituído para o instituinte, fazendo-me criador" (CHAUÍ, 2011). Carmen Valdez também propõe uma investida semelhante ao apresentar o conceito de espectador "bricoleur da cena" (VALDEZ, 2009), associando as noções de bricoleur de Lévi-Strauss; pósdramático de Lehmann; obra aberta de Umberto Eco e semiótica da recepção teatral de De Marinis. A pesquisadora reconhece uma proximidade entre a percepção teatral e o procedimento de bricolage, pela possibilidade do espectador elaborar conexões e ressignificações próprias para os elementos que encontra durante o processo de recepção.

Ao assumir o teatro pós-dramático como referência para se pensar o novo lugar do espectador, destacam-se particularmente, neste momento, os aspectos relacionados à construção de cena fragmentadas, sem o estabelecimento de uma narrativa linear e de significados previamente estruturados por seu autor. Este recorte parece estar diretamente relacionado à discussão de Eco acerca do que poderia ser assumido como "obra aberta". Segundo ele, uma "obra aberta" estaria diretamente vinculada ao reconhecimento de uma determinada "relação fruitiva com seus receptores". Obras que oferecem espaços vazios para interpretações diversas sem que haja uma intenção por parte do autor de que o entendimento da obra seja restrito às considerações que ele próprio oferece (VALDEZ, 2009, p. 6).

Nesse mesmo sentido, Roman Ingarden também reconhece, segundo Massa (2010, p. 19), a atividade cocriativa do espectador. A partir de estudos sobre a recepção literária, ele desenvolve sua teoria da concretização para investigar, igualmente, o processo de recepção do espetáculo teatral. Simões (2017, p. 365) descreve o efeito estético de uma obra de arte e os rastros do impacto desferido por ela para demonstrar como a experiência promovida pode tornar-se fecunda. Féral explica, igualmente, como o espectador ativo performa, ao entrar e sair da narrativa, navegando ao sabor das imagens oferecidas ao 
seu olhar, incitado a uma viagem no imaginário amplificada pelo que lhe é dado a ver e que, longe de buscar um sentido, deixa-se levar pela performatividade em ação (FÉRAL, 2015, p. 120).

Boa parte destes estudos teóricos sobre a recepção vinculados à revisão e ao redimensionamento do fazer teatral tem sua gênese na How to do Theory, de Iser, que afirma que são as teorias modernas que estabelecem a relação entre a arte, o observador e o contexto em que elas estão inseridas (MOSTAÇO, 2009, p. 29). O teatro estético ocidental é considerado como parte dos estudos performáticos que abarcam diversos outros níveis de atividades sociais. Neste sentido, Mostaço destaca a fusão, no performático, entre a eficácia (mais forte e presente em rituais ou representações sociais) e o entretenimento (característico das manifestações artísticas e culturais), em busca de uma transformação social e política. Esta cisão em uma manifestação teatral depende tanto do contexto e dos agentes da ação quanto das condições e estado da recepção, do olhar, da maneira como esta ação é vista, apreendida e compreendida pelo espectador e de sua entrega e disponibilidade para o evento. Mostaço explica ainda que, ao contrário do que se pensa, a experiência catártica do espectador face ao poético na experiência estética pode, nestas condições, ir "muito além das simples percepções e reações sensíveis provocadas pela obra artística" (MOSTAÇO, 2017, p. 100), resultando em efeitos transformadores e perenes.

Inspirado também pela noção de ato de leitura, Desgranges explica como o acaso, as circunstâncias do presente e o inesperado interferem nas bases do processo criativo colaborativo para possibilitar aos artistas que "escrevam o não pensado" e ofereçam aos espectadores o ensejo para que "leiam o não escrito", transbordando o processo criativo para o processo receptivo (DESGRANES, 2017, p. 32), enfatizando a necessidade de atuação do espectador no fato artístico. O público é colocado em estado de improvisação criativa durante o ato de leitura, elaborando associações inusitadas, tecendo um roteiro de leituras imprevisto, com rumos inesperados, tanto para a expectativa inicial dos artistas quanto para o espectador, que pode surpreender-se com o que consegue elaborar no curso de seu ato inventivo. Ele explica que, neste processo, "os 
espectadores são instados a se colocar em condições de efetivar uma leitura que se produza como ato artístico, se concretize como gesto criativo, engendrando o que podemos compreender como uma dramaturgia do espectador (DESGRANGES, 2017, p. 32).

Desgranges complementa que a participação integrada e em situação de igualdade das várias artes que compõem o espetáculo cênico em seus diferentes domínios linguísticos, promove, pela autonomia das distintas formas de linguagem, uma produção polifônica (ou mesmo cacofônica) que "enfatiza a necessária atuação do espectador no fato artístico, ressaltando o caráter singular de cada ato de leitura (DESGRANGES, 2017, p. 38). Isso explica, então, como a escritura cênica só se constitui como obra no momento em que é processada pelo espectador, determinando o caráter (co)autoral do processo. Segundo ele, o que se espera do espectador ativo é um "esforço artístico" para "que estranhe os sentidos comumente atribuídos a cada significante e que se disponha a empreender novas experiências, a inventar outro modo operativo, subvertendo os regimes consensuais". Para isso, ele precisa recusar a instantaneidade na percepção do que lhe é apresentado, dispondo-se a uma nova leitura e abrindo-se para novas possibilidades por meio das experiências sensoriais a que é submetido. Neste processo, o espectador é estimulado a elaborar um percurso próprio, no qual "o pensamento se coloca em diálogo com o não pensamento, o dito com o imprevisto, as relações concebidas racionalmente com as associações involuntárias” (DESGRANGES, 2017, p. 45).

No sentido da busca do envolvimento do espectador, é possível encontrar na investida ética, moral e estética do ato responsável de Bakhtin (2010), a significação e expressividade do fazer teatral. Foi com muito cuidado que as teorias de Bakhtin foram aplicadas à busca de uma verdade que justificasse a realização artística, encontrando, em si mesma, a motivação e razão de ser da cena contemporânea. Bakhtin explica que é inútil criar regras se não for possível convencer os homens a segui-las por sua própria vontade, o que pode ser traduzido, na representação teatral, às convenções, criadas como acordos tácitos entre artistas e espectadores, entre palco e plateia, que permitem o jogo 
cênico e a experiência como tradução da verdade, ou possibilidade de verdade, expressa pelo criador. Isso tudo só se torna possível como síntese do ato responsável do artista e o do observador, ambos engajados em uma única e real experiência ritual da representação da vida, em comunhão cujo conteúdosentido é o pensamento como juízo de validade universal que se origina em um e se realiza no outro, no ato de resposta do sujeito que permite reconhecer, na veracidade do devir, uma categoria original do agir-ato, uma atitude da consciência, na qual existe um sujeito moral sobre o qual é possível se apoiar. Schechner se apropria justamente destes conceitos para desenvolver o seu conceito de performance, onde performar é, a priori, o fazer responsável do teatro face a um público, que dele se serve para orientar sua existência e convívio em comunidade.

Marvin Carlson, compartilha a preocupação legítima investigada por Jill Dolan a respeito a capacidade do teatro de gerar uma comunidade engajada e comprometida. Segundo ele, o teatro e a performance "permanecem um local para o qual as pessoas viajam para ver e/ou experimentar alguma coisa juntas", para "se engajarem com o social em circunstâncias material e fisicamente incorporadas" (DOLAN, 1993 apud CARLSON, 2009, p. 223). Esta ampliação do âmbito da atividade teatral como ação social e cultural levam, segundo Mostaço, ao abandono do conceito tradicional de teatro textocêntrico e encenado, no sentido da constatação de um novo teatro performático que tudo abarca e tudo submete (MOSTAÇO, 2009, p. 24-25).

A compreensão deste novo teatro considera não só o momento da ação e o contexto em que se insere, mas sobretudo a realidade psicossocial e emocional dos envolvidos, agentes e espectadores, ambos partícipes. Sua temática aborda situações cotidianas, problemas sociais, questionamentos individuais e impõe à ação medos, posturas e realidades, solicitando o envolvimento de performers e público em iguais medida e profundidade. A real ação social, política, cultural e emocional desta atividade teatral encontra-se aquém e além do momento da ação, pois, assim sendo, tem início muito antes da concepção e elaboração do espetáculo, na experiência pessoal de cada 
agente, sua bagagem e repertório, e avança para muito após seu término, com reflexos e consequências individuais e coletivas provocadas em todos os envolvidos, ineditamente e com duração indeterminada. Segundo Biancalana:

\begin{abstract}
A plateia é ativa em sua própria forma de assimilar o que acontece no palco. O público também é ativo quando sua forma de recepção influencia o trabalho do performer, se não no que ele faz, ou seja, na ação realizada, através dos estímulos que envia a ele, influenciando seu modo de fazer [...] se o fenômeno cênico acontece a partir da relação de troca entre performer e espectador, quanto mais profunda for a troca, quanto mais qualidade se estabelecer nas relações, há uma implicação direta da atuação performativa, como uma espécie de estímulo. (BIANCALANA, 2011, p. 141)
\end{abstract}

A cena teatral é percebida, então, como uma cena aberta, não tendo um significado fechado que a anteceda ou mesmo presente durante a emissão. É somente na recepção que o espectador bricoleur acaba por definir, para si, individualmente, um sentido próprio para o que acaba de experenciar. Segundo Dufrenne, "o objeto estético significa certa relação do mundo com a subjetividade, uma dimensão do mundo [...] ele resume e exprime numa qualidade afetiva inexprimível a totalidade sintética do mundo" (DUFRENNE, 1981, p. 53). Para Kant, a noção de afeto remonta ao sentimento de prazer ou desprazer que impede chegar à reflexão e, hoje, remete ao componente emocional de uma experiência na dimensão subjetiva das emoções do espectador de maneira não analítica (AUMONT, 2012, p. 122).

Com base na "teoria do afetos", que atribui às escalas e padrões musicais a capacidade de produzir sentimentos específicos no ouvinte, Marcelo Amalfi (2015, p. 209) sustenta que uma pequena alteração na relação harmoniosa entre elementos simultâneos de natureza exclusivamente acústica, pode resultar em uma grande mudança do ponto de vista do conjunto sonoro, da escala e, também, de seu "afeto". Numa música, composta por elementos de naturezas diferentes, qualquer interferência ocorrida entre eles faz com que, mesmo que não haja qualquer alteração do ponto de vista sonoro, seja evidente a alteração do seu "afeto", ou seja, seu efeito sobre o ouvinte. Segundo ele, o mesmo pode acontecer em um conjunto de diversos elementos simultâneos de uma encenação, como a ação cênica, a luz, o cenário e as músicas, afirmando que "uma alteração em apenas um dos elementos pode resultar numa mudança 
significativa em todo o conjunto" (AMALFI, 2015, p. 210). Como exemplo, Amalfi apresenta uma situação na qual algumas características cênicas como a predominância cromática do cenário e da luz são mantidas em uma mesma ambientação sonora e que, pela simples transformação da imagem ou da ação cênica (nascimento ou morte, por exemplo), tem seu afeto alterado. No mesmo sentido, Eduardo Tudella ${ }^{141}$ usa o termo de origem latina compósita para explicar que "se você tirar um elemento daquilo ali, aquilo se transforma em outra coisa. Quando você tira um elemento e coloca outro, essa natureza que chamamos de espetáculo, de cena, será então uma arte compósita, criando uma outra realidade, uma nova natureza". Ele complementa ainda, sobre esse conjunto, que "em um espetáculo, a cor de um figurino, a textura de um cenário, a música que você vai usar, tudo tem uma contribuição que só aquele aspecto pode dar" (TUDELLA, anexos, p. 87).

Numa relação mais específica com a cenografia e cada um de seus componentes, Pamela Howard descreve os artistas visuais do espetáculo como os responsáveis pela visualização de todo o espaço usado em uma experiência teatral ou performativa, no qual "os espectadores são atores não falantes cuja participação ativa fecha o círculo cenográfico" (HOWARD, 2015, p. 252). Segundo ela, a natureza do espaço, a visibilidade, a audibilidade, o conforto e a segurança são condições prévias para o público, cuja maneira de ficarem sentados, em pé ou em deslocamento deve ser examinada para se encontrar a dinâmica mais forte entre os dois protagonistas do evento, o ator e o espectador. A autora acrescenta, ainda, que os espectadores têm um papel a desempenhar, tanto observando obras de arte quanto assistindo a uma produção cênica, pois preenchem as lacunas de indícios não precisos deixadas propositalmente pelos criadores interessados em sua participação ativa.

Com a ideia de "espaços rítmicos", criados para dar vazão aos ideais da cenografia como espaço criado, prioritariamente, ao uso pelos atores, Adolphe Appia pretendia também privilegiar o estímulo à capacidade de imaginação dos

${ }^{141}$ Em entrevista realizada como parte desta pesquisa, disponível nos anexos, p. 84-91. 
espectadores pelo que chamou de "envolvimento pleno no ato teatral". Segundo Passos (2018), por esse envolvimento, deve-se entender uma participação ativa do público, que constrói relações e preenche frestas. "O público, beneficiado por tal reforma, não deveria mais ser considerado como meros espectadores passivos, pois Appia acreditava que os experimentos que seguissem as linhas que sugeria, poderiam envolvê-los mais plenamente no ato teatral, a fim de experenciar diretamente uma ação vital e uma nova forma de arte excepcionalmente eficaz" (BEACHAM, 1985 apud PASSOS, 2018, p. 188).

Os espaços rítmicos desenhados por Appia para Dalcroze eram, no princípio, apenas a representação gráfica do desejo de uma arquitetura cênica que possibilitasse e estimulasse o jogo dos atores de uma forma mais complexa na relação como o espaço. Entretanto, no momento em que se tornaram possíveis - e viáveis -, com a inauguração, em 1912, do prédio que abrigaria as atividades de Dalcroze, passaram a ser a face concreta de um ideário que trazia em si uma definição alternativa de arte, a qual Appia abraçou inteiramente. A partir daí, tudo o que Appia escreveu foi baseado em uma mudança de atitude fundamental e irreversível, A arte não devia ser contemplada passivamente, mas ser algo em que se envolve ativamente. O teatro não era uma ilusão que se observa, mas um evento real que se experimentava (PASSOS, 2018, p. 189).

Mais recentemente, Jacques Rancière (2012) destacou a intenção da performance de tirar o espectador de sua atitude passiva, transformando-o em participante ativo de um mundo comum, criado para este fim. Ele questionou, no entanto, a oposição entre ativo e passivo que, no senso comum, considera passivo o espectador que apenas observa e escuta numa divisão do sensível que distribui, à priori, as posições e capacidades implícitas nos dois termos opostos. Desqualificar o espectador que "não faz nada" é desconsiderar sua capacidade de entendimento, construção de pensamento e reação ao que se lhe é dado à contemplação. A emancipação, segundo o autor,

...começa quando se questiona a oposição entre olhar e agir, quando se compreende que as evidências que assim estruturam as relações do dizer, do ver e do fazer pertencem à estrutura da dominação e da sujeição. Começa quando se compreende que olhar é também uma ação que confirma ou transforma essa distribuição das posições. $O$ espectador também age [...]. Ele observa, seleciona, compara, interpreta. Relaciona o que vê com muitas outras coisas que viu em outras cenas, em outros tipos de lugares. Compõe seu próprio poema com os elementos do poema que tem diante de si. Participa da performance refazendo-a à sua maneira, furtando-se, por exemplo, à energia vital que esta, supostamente, deve transmitir para transformá- 
la em pura imagem e associar essa pura imagem a uma história que leu ou sonhou, viveu ou inventou. Assim, são, ao mesmo tempo, espectadores distantes e intérpretes ativos do espetáculo que lhes é proposto (RANCIĖRE, 2012, p. 17).

A emancipação proposta por Rancière se opõe à identidade de causa e efeito que está no cerne da relação dominante que pretende impor ao espectador um única lógica, levando o artista a produzir apenas uma forma de consciência, uma intensidade de sentimento, uma energia para a ação. Existe uma distância, inerente a toda performance, entre a ação do artista e a sensação provocada no espectador. A partir dela se estabelece, desde que comprometidos, uma terceira coisa, estranha à ambos, sobre a qual nenhum deles tem domínio nem conhece o sentido e que afasta qualquer identidade de causa e efeito. Marvin Carlson (2009) cita os termos usados por Dolan para descrever o comprometimento dos que não mais observam ou contemplam, mas participam ativamente de uma atividade performativa de forma consciente e reflexiva. Segundo Carlson,

\begin{abstract}
...o "papel" que se espera da audiência muda de um processo hermenêutico passivo, de decodificação da articulação, incorporação ou desafio do material cultural particular do performer, para tornar-se algo muito mais ativo, entrando numa práxis, contexto no qual os sentidos não são comunicados, mas criados, questionados ou negociados. A "audiência" é convidada e se espera que opere como cocriadora de quaisquer sentidos e experiências que o evento gere (CARLSON, 2009, p. 223).
\end{abstract}

No entanto, tão importante quanto compreender essa nova postura ativa da audiência, é admitir, igualmente, a ocorrência da outra atitude descrita, da observação e contemplação. Esta conduta, evidentemente difere da postura cocriadora do espectador ativo, disposto e disponível para complementar a ação do performer com suas percepções e impressões. A esta poder-se-ia nominar, num sentido oposto à recepção ativa, de recepção contemplativa. Esse observador contemplativo seria, então, o espectador incapaz de produzir o que Rancière chama de terceira coisa inédita e desconhecida, ou seja, um espectador resistente e imune a qualquer efeito, reflexão ou sentido oriundo da ação proposta pelo espetáculo ou performance.

Ramos qualifica a vocação estética do artista na busca do olhar de um espectador como poiesis (RAMOS, 2015, p. 15) e se apoia em Kant para analisar 
a relação entre a arte e o púbico e o efeitos da obra artística sobre um observador ativo com base na estética da recepção. Segundo o autor, a relação aberta entre produtor e receptor gera as liberdades de cada um para reconhecer-se ou não, a partir da proposição de uma articulação das categorias racionais com os aspectos imprevistos da estética, qualificado como "o livre e harmonioso jogo entre a imaginação e o entendimento":

\begin{abstract}
O processo de recepção requer a liberdade do agente receptor em tomar ou não a obra que se lhe endereça como bela ou relevante, o que, de algum modo, retira da obra a prerrogativa da afetação e, ao contrário, a outorga alternativamente a quem a recebe. $O$ estético deixa de estar contido na produção da obra, como algo que traz já suas potências de afetação determinadas, e passa a ser um compartilhamento em que as latências poderão ou não se explicitar conforme seus destinatários possam, livremente, assimilá-las ou não. Assim, a grande obra não é a que afeta mais, mas a que afeta com menos intencionalidade. (RAMOS, 2015, p. 39).
\end{abstract}

Neste mesmo sentido, ainda sobre a estética da recepção, a teoria da formatividade de Pareyson defende o operar humano como uma atividade sempre pessoal de receptividade e atividade. Segundo ele, toda operação humana remete a um estímulo, uma proposta ou ponto de partida que revela a receptividade que se prolonga em atividade formativa (SILVA, 2013, p. 209). Em sua pesquisa sobre a formatividade, Íris da Silva (2013) demonstra como a filosofia consegue explicar e fundamentar a experiência com a arte pelo estímulo, oferecido ao olhar que se deseja fazer penetrante e profundo. Para Pareyson, "a matéria do teatro é composta não apenas da voz, do corpo ou das luzes, bastidores ou cenários, mas também da presença do público que olha e escuta" (SILVA, 2013, p. 195). Essa presença se institui em elementos sensíveis, a exemplo da divisão entre palco e plateia, cena e espectador, agente e recebedor.

Por meio do conceito filosófico de psicoplastia do espaço ${ }^{142}$, Josef Svoboda acreditava existirem denominadores comuns, capazes de se relacionar com o imaginário de cada espectador. Depois de dominar um determinado espaço por seus próprios conhecimentos e experiências, ele buscava transmitir ao público o espírito do espetáculo no qual trabalhava, criando atmosferas e

142 Além de Svoboda, que se apoderou do termo para definir as características do seu espaço cenográfico, o pintor e desenhista italiano Alberto Martini também nomeou uma série de suas obras, realizadas entre 1928 e 1934, de pinturas psicoplásticas (RICHIER, 2019, p. 203). 
climas no que chamava de "espaço psicoplástico". Essa psicoplastia do espaço era destinada ao público espectador, pensada para ele, e funcionava, algumas vezes, de forma fugidia e imprecisa, fugaz, visto a cenografia não ser, para Svoboda, uma ciência exata, mas uma ambiência que o envolve, assim como influencia e determina o que acontece em cena (RICHIER, 2019, p. 203). Existem espaços que geram calma, alegria de viver, e outros que levam à depressão. A cenografia é o que permite traçar, segundo o cenógrafo, no teatro, as grandes linhas de uma intenção. Num encontro entre filosofia e arquitetura, Svoboda "se vestia" do espaço, o que significa, segundo suas próprias palavras:

Quando eu me apodero de um espaço, é preciso que eu encontre seu ponto central, seu centro de gravidade, [...] meu centro de gravidade. Que é totalmente subjetivo, é claro... Porque é meu, está ligado à minha percepção do espaço, à compreensão que eu tenho dele, à atmosfera do momento, à luz e à minha maneira de ler tudo isso, minha cultura, minha formação... ${ }^{143}$ (RICHIER, 2019, anexo 1, p. 51).

Isso explica o que Svoboda entende por psicoplastia do instante, algo que está igualmente ligado aos humores, à percepção de um espaço que, segundo ele, é diferente segundo se ter comido bem, dormido bem, estar de bom ou mau humor. No entanto, essa percepção do espaço somente acontece se houver uma disponibilidade para a entrega necessária à percepção do conjunto de volumes, proporções, cores e luzes pensadas para estimular o imaginário e colocar o espaço em cena para o espectador (RICHIER, 2019, anexo 1, p. 106). A psicoplastia do espaço é, para Svoboda, um desafio, um elo entre o espaço e a emoção do personagem, um reflexo da situação do habitante deste espaço, de seus medos, sentimentos e sensações partilhados com o espectador. O espaço psicoplástico de Svoboda é um espaço que surge no imaginário do espectador a partir da sua recepção ativa, da percepção do conjunto de componentes da cena e suas interações com o drama, a narrativa ou a performance.

O espaço que Svoboda qualifica de psicoplástico é um espaço cujas características plásticas estão ligadas a uma dimensão psíquica, alguma coisa do espírito do drama, do invisível, dado a sentir pelo

143 «Quand je prends possession d'un espace, il faut que je trouve son point central, son centre de gravité, [...] mon centre de gravité. Qui est tout à fait subjectif bien sûr... Parce qu'il est le mien, il est lié à ma perception de l'espace, la compréhension que j'en ai, à l'atmosphère du moment, la lumière et ma façon de lire tout cela, ma culture, ma formation... " (tradução da autora). 
espectador. Pode-se pensar, aqui, na noção de atmosfera desenvolvida por Charles Dullin: "uma coisa ao mesmo tempo concreta e impalpável, precisa e difusa, potente e fugidia, que veste o drama como uma estratosfera indispensável"144 (DULLIN, 2011 apud RICHIER, 2019, p. 203).

O conceito de affordance, de Gibson (1986 apud SANTAELLA, 2012, p. 56-57) representa aquilo que o ambiente oferece à percepção, podendo ser associado à noção de espaço psicoplástico de Svoboda (apud RICHIER, 2019, anexo 1, p. 51), cuja dimensão psíquica amálgama o espaço e a cena, estimulando o imaginário do espectador. É possível conceber, assim, que o sentido final do espetáculo se dá pelo que é produzido como sensação pelo o conjunto da cena, que, finalmente, só se realiza na mente de cada espectador. Finalmente, fica evidente que é por meio da iluminação que isso ocorre, ou seja, pela luz constituída como uma affordance da cena, que permite o acesso do público ao espaço psicoplástico, cuja presença, segundo Svoboda, é sentida por ele: "É claro que o espectador não tinha necessariamente consciência dessa presença, ele não pensa dessa forma, não é sua obrigação fazer isso, mas ele sente, ele sente essa dimensão invisível"145 (RICHIER, 2019, anexo 1, p. 62).

A recepção ativa, ou criativa, como denominada por Nadiana de Carvalho (2014), resulta do caráter dialógico do teatro que se afasta do sentido puramente representativo para tornar-se expressão, valorizando a relação recíproca de trocas experienciais. Segundo a pesquisadora, o espectador, "por meio das suas interferências, interpretações diferenciadas e atos criativos [...] se torna participante ativo na construção do sentido da obra (CARVALHO, 2014, p. 76). Como condição para a revelação do visual cênico, a luz se torna, então, o meio de acesso do espectador à experiência sensorial que o espetáculo pode proporcionar e, consequentemente, sua contribuição como cocriador e partícipe.

\footnotetext{
144 "L'espace que Svoboda qualifie de psycoplastique est un espace dont les caractéristiques plastiques sont liées à une dimension psychique, quelque chose de l'esprit du drame, de l'invisible, donné à ressentir au spectateur. On peut ici penser à la notion d'atmosphère, développée par Charles Dullin : 'une chose à la fois concrète et impalpable, précise et floue, puissante et fuyante, qui habite le drame comme une indispensable stratosphère' " (tradução da autora).

145 « Bien sûr le spectateur n'avait pas forcément conscience de cette présence, il ne réfléchit pas de cette façon, ce n'est pas son devoir, mais il le ressent, il ressent une dimension invisible » (tradução da autora).
} 


\subsection{Potencial Performativo da Luz}

Estudos mais recentes sobre a genealogia do teatro visam priorizar as etapas que precedem a apresentação de um trabalho teatral em detrimento de antigos paradigmas de análise do espetáculo pronto, conforme ressaltado pela pesquisadora Silvia Fernandes (2017, p. 214). Segundo argumentos já expostos em capítulos precedentes, as investigações sobre os processos de criação cênica contemporâneos conduzem a um entendimento bastante amplo e contraditório do conceito de performatividade, prioritariamente desenvolvido no campo da performance, sobretudo nos estudos da pesquisadora Josette Féral (2015). A performance, a partir dos escritos de Schechner, é uma ação que pode ser explorada em diferentes domínios, inclusive o artístico, mas sempre em processo, admitindo que toda construção da realidade social traria em si um potencial performativo (FERNANDES, 2017, p. 217). Apesar da complexidade de analisar, neste contexto, a vocação performativa da luz no teatro, esta concepção do teatro contemporâneo como arte performativa da presença e os traços performativos detectados em sua linguagem permitem presumir e avançar numa possível concepção da iluminação cênica como componente ativo do espetáculo e da luz como ato performativo.

Uma observação atenta do comportamento e ação da luz tanto em projetos de iluminação próprios quanto em trabalhos criativos de outros colegas, permitiram vislumbrar e intuir o forte potencial performativo da iluminação cênica. A investigação dessa atuação performativa encontrou fundamentação em conceitos oriundos de diferentes áreas de conhecimento. Esses estudos permitiram diferentes entendimentos a respeito do fenômeno da luz na cena. As análises do espetáculo e do processo criativo conceituaram a iluminação como elemento estrutural e estruturante do espetáculo, da cena e do conjunto de ações desempenhadas pelos diferentes agentes e performers, associados a ambientações cenográficas sensoriais, principalmente as visuais e sonoras. Os estudos da presença, da percepção e da recepção revelaram que esta ação não é, nem pode ser, isolada ou fragmentada na recepção pelo espectador. Segundo 
a teoria da Gestalt, a percepção é fruto de uma organização mental que é maior do que a soma aritmética de suas partes, e cujo todo não pode ser segmentado no contato com o percebedor. De modo que se confirma, assim, a indissociabilidade do espetáculo, cujo conjunto de ações ou elementos cênicos são dados à percepção, como totalidade, pela luz, elemento aglutinante e revelador, responsável por estabelecer a relação entre a cena e o espectador.

A tese de Cibele Forjaz (2013) apresenta o conceito de "scriptura do visível" como modelo dessa organização estrutural do espetáculo por meio da iluminação, cuja função principal consiste, segundo ela, em "organizar a 'montagem-sonho' através da articulação do tempo e espaço [...] na prática do teatro expressionista" (FORJAZ, 2013a, p. 342-343). Nesse sentido, a luz se situa como meio entre a cena e a percepção do expectador, que exposto aos seus efeitos, é convidado a agir, igualmente, na formulação da ação cênica, num sentido duplo constante. Essa ação, que Appia, estimulado pelas novas possibilidades técnicas de seu tempo, chamou de luz ativa, se aplica, então, com base nos novos conceitos e práticas teatrais contemporâneas e pós-dramáticas como uma ação possivelmente performativa da luz no teatro.

No âmbito dos jogos relacionados por Schechner à atividade teatral, é possível perceber como o papel desempenhado pela iluminação situa-se na intermediação entre o que é dado pela cena e o que é apreendido pelo espectador, simultaneamente, pelo dar a ver, por sua atuação e pelas sensações que é capaz de provocar. Ainda considerando o conceito de performatividade, de Austin e os performances studies desenvolvidos por Schechner, emerge o entendimento de uma atuação da iluminação cênica que deixa de ser informativa ou simbólica para justificar, no fazer operante, sua expressão e manifestação como elemento performativo. Destarte, a partir da teoria dos atos da fala de Austin, a luz é percebida como ato perlocutório pelo desejo de produzir efeitos sobre o interlocutor, neste caso, o espectador teatral. Esse efeito, ocorrido no ato de recepção, surge da confrontação do que é dado a ver, pela luz que incide sobre a cena, à percepção do público. Desta forma, confirma-se que... 
...a iluminação é performativa porque é estrutural e estruturante do espetáculo, das cenas, das ações cênicas. Ela se explicita em cena, em ação, em atuação conjunta com os demais elementos e seu discurso compartilhado com o espectador, que interfere e constrói igualmente a ação, articulando tempo e espaço, ator e cenário, numa afetação mútua e constante (LUCIANI, 2018, p. 174).

No entanto, a observação desta atuação possivelmente entendida como performativa, apesar de percebida e analisada, com grande frequência, em manifestações, espetáculos e no trabalho de coletivos teatrais ditos pósdramáticos ou performativos, não chega a constituir uma constante. Desvinculase, assim, essa performatividade da luz da dependência de que a ação, o espetáculo ou o evento no qual ela se manifesta, apresente, necessariamente, qualquer característica performativa, manifestando-se, igualmente, em outros tipos de acontecimentos cênicos, performativos, teatrais ou dramáticos. Com isso, deu-se a continuidade da análise do que seria o potencial performativo e, a partir da observação e análise do comportamento da luz na cena, qual seriam as características que configuram uma possível ação ou ato performativo da luz no entendimento do próprio fenômeno luminoso, a própria luz-material como elemento em ação sobre a cena e a percepção do espetador. Finalmente, pelo curso da pesquisa, foi-se verificando que a luz, como linguagem autônoma e independente, mesmo que inter-relacionada às outras linguagens do espetáculo, participa, à sua maneira e por seus próprios meios, para o resultado final da cena na percepção do espectador, ou seja, ela pode ser considerada, por si só, performativa, independente do meio em que se encontra e age.

Segundo a pesquisadora Anna Barros, "a primeira das implicações de trabalhar com luz está além do controle de quem quer que seja, mesmo de um artista, e sua impregnação na psique humana é o que faz com que dificilmente ela possa ser isolada de suas implicações arquétipas." (BARROS, 2010, p. 161). Percebe-se, com isso, que a ação performativa da luz independe da performatividade do teatro ou da manifestação cênica na qual se insere. Em suma, a luz performativa, a luz que performa e dialoga com o espetáculo e o espectador, que age sobre e com a ação cênica, pode se apresentar em qualquer contexto, desde que espetacular e a um público atento, dedicado e igualmente ativo. Essa constatação redirecionou a pesquisa e ampliou seu 
universo de investigação e análise, permitindo vislumbrar um entendimento muito mais abrangente e, ao mesmo tempo, bem mais preciso, do seu objeto de estudo: a luz em sua natureza material e imaterial.

A presença cênica da luz está, então, na materialidade poética que revela o invisível no visível e que, por sua fruição no espaço e no tempo da cena, estabelece uma comunicação imediata com o espectador. É inegável a participação do iluminador e do operador de luz, sem eles não há iluminação e nem mesmo espetáculo visível, dirão alguns, mas essa dependência ';e percebida aqui como o que ocorre na relação entre o diretor ou o encenador com o trabalho do ator ou com a construção da cena. Depois de meses de trabalho, durante os quais elaboram, ensaiam e coordenam a colocação em cena (miseen-scène) de suas ideias e conceitos, finalmente, no momento da apresentação, quando tudo acontece, já não têm mais qualquer ingerência sobre o fazer. Ao contrário, a partir daquele instante, o que acontece em cena passa a estar concentrado exclusivamente na relação entre o performer e o público, sua presença cênica e a percepção do espectador, em interação no espaço comum que os abriga, sem outras interferências que não o próprio fenômeno teatral e seus efeitos.

De modo que o mesmo ocorre com a luz, a partir do momento em que o fader da mesa é acionado e o facho luminoso, isoladamente ou em conjunto, materializa-se no palco. Neste instante, já não há mais nada que possa ser feito, nem pelo iluminador nem pelo operador de luz. Não há mais controle, não há como querer ou desejar que o espectador veja, entenda ou sinta nada além do efeito que a luz projetada tem sobre o que ilumina e sobre sua percepção. Não se pode desejar nem mesmo que ele a veja ou perceba sua presença na cena. A partir desse instante o que ocorre está exclusivamente centrado entre a manifestação física da luz e a percepção do espectador, entre a luz-matéria em sua expressão material e imaterial e o indivíduo, com seu repertório, sensibilidade e disponibilidade. São essas condições que o farão ver e sentir o que Ihe for possível, nas condições dadas e na dimensão de sua entrega e engajamento com o espetáculo. 


\begin{abstract}
A luz performativa intensifica o atrito entre ficção e realidade, um facho luminoso pode não ser nada além de facho luminoso, mas que provoca emoções, percepções, identificações e reações no espectador. Não é um raio de sol, a luz que entra por uma porta ou uma janela, a representação do sonho ou da paixão, é apenas luz, frequência luminosas e cromáticas que interagem com a cena, no tempo da cena no espaço dado. Ela tem consequências, responsabilidades e atribuições relativas ao espetáculo e ao espectador, cujo resultado afeta e é afetado pela cena e sua interação com o público. É linguagem e expressão, ativa e atuante, age e reage no tempo e no espaço da ação (LUCIANI, 2018, p. 174-175).
\end{abstract}

Se a performance é considerada como um 'dar a ver' o espetacular, considerando, quando relativo ao corpo do ator, sua potência gestual e sofredora que expressa a dimensão ativa do acontecimento (BADIOU; DURING, 2007, p. 26), a potência expressiva da luz também pode ser tida como performance quando se dá a ver como acontecimento espetacular. O potencial performativo se encontra, então, tanto na concepção e na execução da luz quanto na sua expressão e ação cênica, mas é sua materialidade poética que, integrada à cena, efetivamente, resulta na efetiva relação estabelecida entre o espectador e a cena. É no espaço e no tempo das ações performativas de atores, dançarinos, músicos e demais artistas, numa relação direta e permanente com a cena e com o público, em seu caráter vivo e presente, que ela acontece como ato performativo.

Segundo Josette Féral, "os corpos são, acima de tudo, corpos-matéria marcados por intensidade energética e investimento no espaço" (FÉRAL, 2018, p. 138). Considerando que o jogo realizado nas estruturas cênicas, pelos corpos dos atores, é o que contribui para a performatividade, o conceito de corpomatéria de Féral permite compreender a luz-matéria como possível agente performativo que, assim como o corpo-matéria, é dado à percepção do espectador. A materialidade, a densidade e a presença da luz, assim como a dos corpos, são sentidas pelo público como portadoras de um discurso próprio, que se soma aos dos demais componentes da cena, do espaço e da narrativa. A fricção e o diálogo entre corpos e lugar são destacados por Féral como a gênese da força do impacto sobre o espectador. Da mesma forma, pode-se estender essa noção de percepção do espaço, de materialidade dos objetos, do 
ambiente e da luminosidade que o habita, para compreender a luz-matéria performativa como ponto de referência e de acesso do espectador à cena.

Afinal, dos elementos sensoriais da cena (principalmente os visuais), a iluminação, para além do corpo presente, emerge seu potencial performativo por sua luz, expressa como matéria, e pelo que revela ou oculta, destaca ou atenua, por sua atuação e interação com a cena e com o público. A luz se materializa no palco, transformando cada efeito, feixe e movimento de luz em presença. Desta forma, é possível afirmar que a luz performativa se define como a luz que surge, brota do coletivo e emana da ação, no espaço e tempo presente, sem códigos, enunciados ou instruções, num processo de desconstrução da realidade, dos signos, dos sentidos e da linguagem. Inspirada pela descrição de mimesis performativa de Luiz Fernando Ramos (2015) associada à atuação e desempenho da iluminação no teatro contemporâneo, performativo ou não, vislumbra-se, então, a vocação performativa da luz, merecedora de uma verificação prática em estudos de caso selecionados para, comprovados os argumentos teóricos colhidos, confirmar sua hipótese. 


\subsection{Exemplos - Estudos de caso}

Depois de assimilar, a partir dos conceitos investigados, o potencial performativo da luz como elemento ativo e propositivo da cena teatral, era necessário confrontar e confirmar as hipóteses teóricas com a prática e realidade da iluminação cênica. Isso foi realizado tanto em atividades profissionais quanto de ensino, considerando ainda a análise de espetáculos realizados ou assistidos antes e durante o período desta pesquisa doutoral. A contribuição do trabalho de outros iluminadores, encenadores e companhias de teatro, em alguns casos especialmente escolhidos para este fim, foi de extremo valor na investigação, pois permitiu verificar e constatar os conceitos e as conjecturas teóricas surgidas a cada etapa. Muitos dos aspectos do potencial performativo da luz foram sendo questionados e revistos ao longo do processo. Inicialmente mais estanque e atrelado a noções rígidas como a dependência de se manifestar apenas em performances ou espetáculos performativos, bem como o seu condicionamento à ação humana, a abrangência do conceito foi se ampliando até a compreensão, cada vez mais nítida, da manifestação e configuração da performatividade da luz na cena. A investigação científica em curso estimulou uma observação constante, em toda oportunidade, do comportamento e do desempenho da luz em qualquer manifestação, cênica ou não, como alterações da luz artificial em ambiente fechados ou fenômenos da natureza com seus efeitos sobre a percepção.

Concentrando-se na atividade teatral como escopo, foram selecionados alguns trabalhos, companhias e profissionais que pudessem permitir, por meio da análise de suas obras, identificar traços do conceito em desenvolvimento. As escolhas privilegiaram objetos de estudo cujas características se encaixavam nos preceitos que vinham sendo elencados como característicos da luz performativa. Alguns coletivos de teatro e encenadores brasileiros vêm sendo considerados como representativos de práticas que priorizam a intensa colaboração da equipe no processo criativo e a participação ativa do espectador. Nesse sentido, os trabalhos de Cibele Forjaz e Guilherme Bonfanti junto ao 
Teatro Oficina e ao Teatro da Vertigem, respectivamente, constituíram bons exemplos para análise na consolidação das teorias e hipóteses levantadas nesta pesquisa.

Além destes, foram analisados, ainda, dois outros espetáculos cênicos, uma peça de teatro e um espetáculo de dança, ambos apresentando características identificadas como representativas da hipótese da luz performativa proposta. O primeiro exemplo é o espetáculo teatral curitibano Um Ricardo III, com criação de luz da própria autora deste estudo e cujo processo de criação colaborativo e a execução precisa da luz motivaram sua análise. $O$ segundo, visto durante o período do doutorado sanduíche na França, foi o espetáculo de abertura do Festival NEXT, a performance Multitud, da coreógrafa Tamara Cubas, que permitiu confrontar com as pesquisas a experiência sensorial como espectadora, identificando traços notáveis da performatividade da luz apresentada.

Observar as particularidades de cada trabalho ou produção, investigar seus processos criativos e identificar a participação da luz durante o espetáculo, sua interação com o trabalho dos performers, o som, o cenário e os outros elementos componentes da cena, permitiu perceber de que forma a luz pode desempenhar um papel ativo e performativo, mesmo em espetáculos que não se enquadram numa proposta performática ou performativa. Perceber como sua criação está vinculada à concepção e à gênese do espetáculo e que sua atuação, em muitos casos, independe da natureza da encenação em que se manifesta, dá indícios de que, ao contrário, ela se associa mais intrinsecamente à ação e aos efeitos não objetivos ou informativos sobre a percepção do espectador, que interage e pode experienciar, intensamente, o que lhe é sensorialmente oferecido por meio da luz. 


\subsubsection{Cibele Forjaz e o Teatro Oficina}

\section{A Iluminação no Teat(r)o Oficina Uzina Uzona}

A análise do trabalho da iluminadora Cibele Forjaz, também professora, pesquisadora e orientadora desta tese, junto ao Teatro Oficina e, principalmente, ao diretor, ator, dramaturgo e encenador José Celso Martinez Corrêa, teve início a partir da oferta, pelo PPGAC, de um Simpósio sobre o Teatro Oficina: seis décadas de cena radical brasileira. O objetivo principal do simpósio foi o de preservar a memória deste importante grupo teatral brasileiro, mas, também, aprofundar e incrementar o debate e os estudos a respeito do que representaram os 60 anos de atividade do Teatro Oficina para a arte, a cultura brasileira e, principalmente, a cidade de São Paulo, ou mais exatamente, o bairro do Bixiga. O simpósio representou uma grande oportunidade de divulgação e compartilhamento sobre a atividade do grupo, cujo importante foco na relação do grupo com as práticas performativas do teatro contemporâneo e pósdramático. Apesar de abordarem muito pouco o tema específico da iluminação, as comunicações e depoimentos forma extremamente enriquecedores e úteis para esta pesquisa.

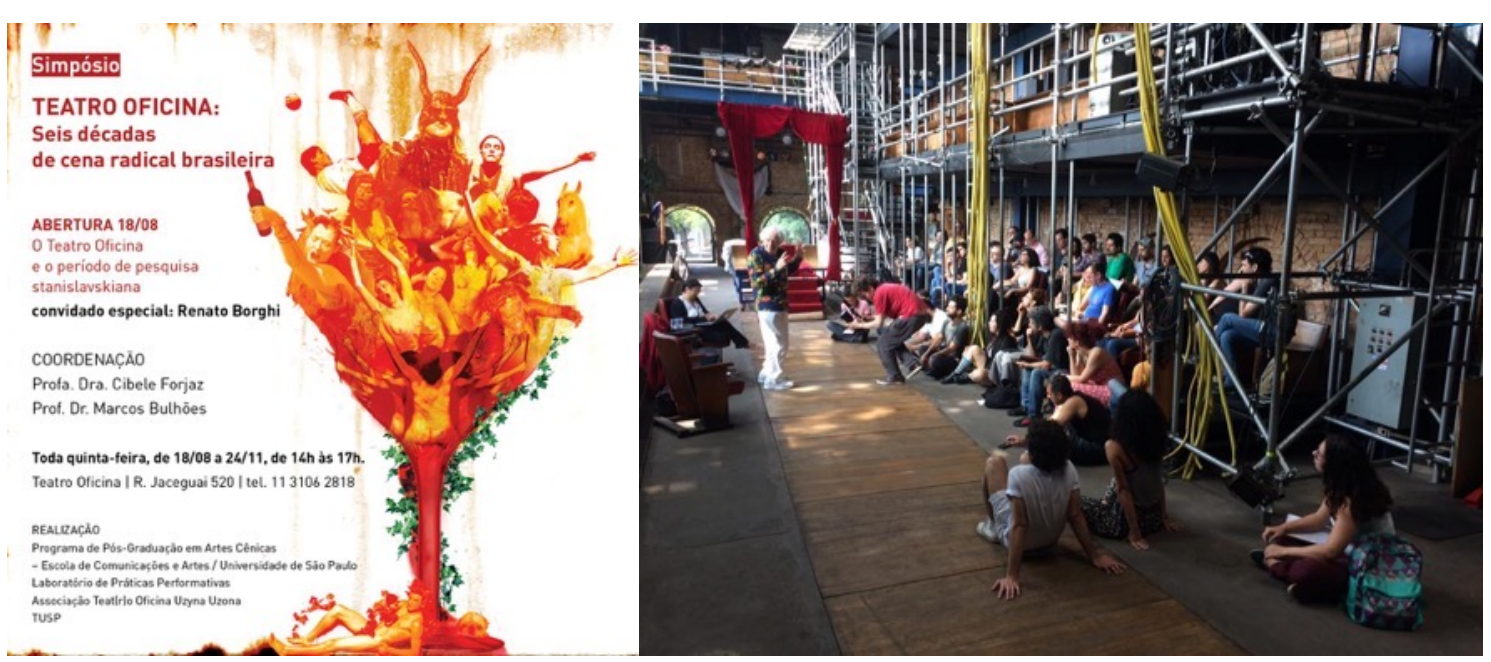

Figura 16 - Cartaz do Simpósio e conferência performativa de encerramento com Zé Celso no Teatro Oficina em São Paulo em 2016. Foto Marcos Bulhões.

Organizado em encontros semanais, no próprio espaço do Teatro Oficina, em São Paulo, o simpósio permitiu conhecer, a cada encontro, um pouco mais 
sobre as práticas realizadas pelo grupo de pontos de vista diversos, a partir da fala de atores, cenógrafos, músicos e colaboradores em geral que atuaram e passaram pelo Oficina. O depoimento da iluminadora Cibele Forjaz tanto permitiu confirmar muito do já sabido sobre o seu trabalho, quanto avançar na pesquisa de investigação a respeito da performatividade da luz. Além do simpósio e suas atividades, realizadas em diferentes formatos (palestras, debates, apresentações de pesquisas acadêmicas, vídeos, imagens e depoimentos), algumas publicações e textos serviram como referências para as reflexões, focadas principalmente sobre a obra da Cibele junto ao Oficina. Apesar da variedade de abordagens dos materiais pesquisados, era possível sentir, considerando pesquisas recentes, que este poderia ser um importante caminho para a investigação relativa à luz performativa e sua ação participativa, tanto no processo de criação quanto na realização durante o espetáculo. Um dos preceitos da noção em construção era sua concepção como resultado do processo participativo de criação da obra teatral e sua interação com o público, duas grandes características do trabalho realizado pelo Teatro Oficina.

Para entender o comportamento e a atuação da luz nos espetáculos do Teatro Oficina é importante, antes, conhecer um pouco da sua lógica de operação, das ideologias que regem um "teatro em devir permanente, um teatro penetrável, no qual o rito acontece ao entrar e cujo desafio surge no mesmo instante"146. A respeito das práticas teatrais do Oficina, Zé Celso explica seus conceitos e a estrutura fundamental na qual baseia seu trabalho que "se refere às pessoas, à cidade e ao cosmos. O luxo maior da vida é o encontro de pessoas e o teatro é o lugar do encontro". Para ele, o teatro é devir e atuar é comungar o corpo energético regido pela poesia, pela arte cênica. Assumidamente inspirado por Stanislavski, uma das suas mais importantes influências, o processo do Oficina é centrado no desejo (quero!) que conduz à ação, e no inconsciente, uma percepção do que só a arte pode transmitir. Estes são, para ele, "estados d'alma" que "atravessam as paredes e vão para o cosmos".

\footnotetext{
146 José Celso Martinez Correia na "Conferência performativa de encerramento" durante o Simpósio Teatro Oficina: seis décadas da cena radical brasileira no Teatro Oficina em São Paulo no dia 24 de novembro de 2016.
} 
Assim, a dramaturgia do Teatro Oficina configura-se como uma atuação em estado de permanência, pessoas compartilhando o aqui/agora de um teatro processual, vivendo o momento (teatro $=$ teat $(r)$ ) de festas folclóricas, desfiles patrióticos, atos singulares de apresentação e disponibilidade de corpos e ações. Para Cibele Forjaz ${ }^{147}$, "as montagens do Oficina incorporam todas as lutas, a história do Oficina, do bairro, da cidade". Essa dramaturgia se presentifica na figura de Zé Celso, o "Xamã do Teatro", como ele mesmo propõe, mas também o dramaturgo (em Cacilda!), o compositor (em Bacantes), o Pajé que administra energias, segundo Cibele, no exercício da pedagogia participativa, na qual todos falam e são ouvidos e cujos elementos fundamentais estruturantes são, nas palavras do próprio Zé Celso, "o conflito e a paixão pelo inimigo".

A diretora Johanna Albuquerque ${ }^{148}$ relembra o apontamento de Erika Fischer-Lichte para a virada performativa do teatro contemporâneo na Europa do pós-guerra, evidenciando uma analogia com o mesmo fenômeno, ocorrido num Brasil pós-ditadura, no Teatro Oficina pós-exílio, com importantes influências nacionais e internacionais, consagrando Zé Celso como "um diretor alquímico, catalizador de energias, capaz de vislumbrar o indivíduo no todo e propor um teatro de resistência". A dramaturgia e a encenação do Oficina sucumbiram a uma assimilação transgressiva, fundamentada na antropofagia de Oswald de Andrade, alimentando seus processos dos sistemas de Stanislavski, do teatro épico de Brecht, das influências de Artaud, Grotowski e, mais tarde, do Living Theatre e Los Lobos, que vieram ao Brasil para trabalhar com o Oficina. A relação estabelecida, nas montagens da década de 90 , entre teatro e performance, deu origem ao TE-ATO, um ato de doação na ação, de vida, de relação com o público, da extinção da separação entre espectador e ator na encenação performática que une ficção e realidade em um mesmo contexto.

\footnotetext{
147 Em depoimento realizado do debate sobre "A encenação no Teatro Oficina Uzyna Uzona" durante o Simpósio Teatro Oficina: seis décadas da cena radical brasileira no Teatro Oficina em São Paulo no dia 03 de novembro de 2016.

148 Em depoimento realizado do debate com o tema "TE-ATO: a Virada Performativa do Teatro Oficina, o encontro com o Living Theatre e Los Lobos e o estudo de caso de Gracias Señor e As Três Irmãs, no início da década de 1970 durante o Simpósio Teatro Oficina: seis décadas da cena radical brasileira no Teatro Oficina em São Paulo no dia 15 de setembro de 2016.
} 
A enunciação performativa no Oficina acontece tanto em suas práticas processuais quanto nos espetáculos levados a público, com verdade, intensidade e força. Assim como proposto por Schechner, o ato performativo do Teatro Oficina, como ação, não é "verdadeiro ou falso, certo ou errado, mas acontece" (SCHECHNER, 2002 apud FÉRAL, 2009, p. 72). Todos os aspectos da encenação praticada no Oficina apontam para uma tendência performativa, inclusas a exploração do espaço e a atuação da luz. A performatividade, nesse caso, não apresenta um fim em si mesma, nem é uma realidade concreta ou acabada, mas um processo, uma construção (FÉRAL, 2009, p. 66).

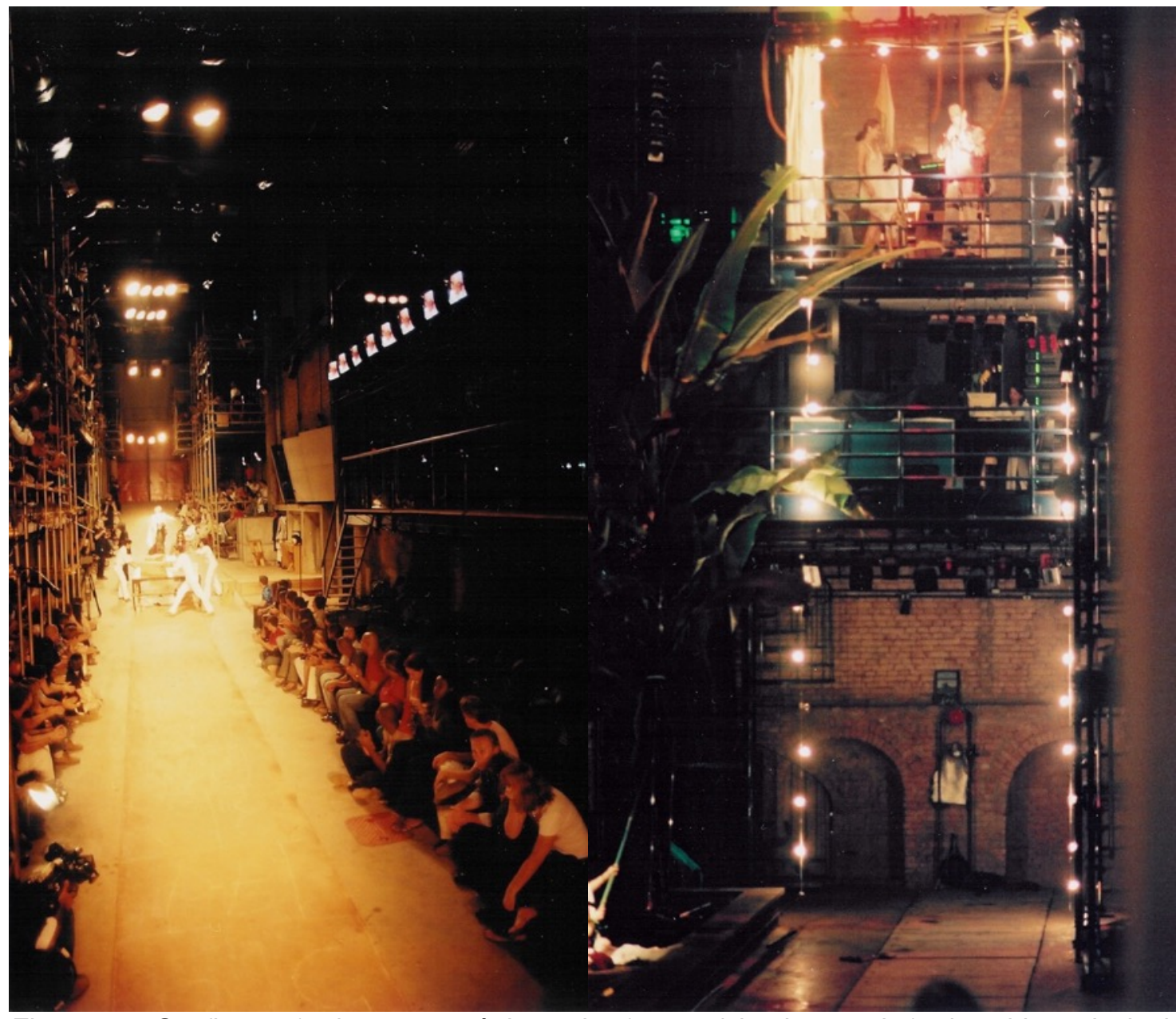

Figura 17 - Configuração do espaço cênico, relação cena/plateia e posição da cabine principal de operação de luz no Teatro Oficina. À esquerda cena de Cacilda. Texto e direção Zé Celso Martinez Corrêa. À direita cena de Bacantes. Texto de Eurípedes e direção de Zé Celso Martinez Corrêa. Luz Cibele Forjaz. Fotos Lenise Pinheiro.

No processo participativo característico do Oficina, eram os longos e ricos ensaios que geravam as demandas para a arquitetura da cena, surgida na relação com a cidade (recorte de cena e realidade que circunda o teatro) e 
preconizada pelo teto aberto, os janelões e os acessos secundários, que dão diretamente para o terreno baldio usado como estacionamento, todos empregados, alternadamente, em algumas montagens. Além do espaço urbano, a incorporação do público à cena também era fundamental para as concepções dramatúrgicas do Oficina. Essa relação é expressa tanto na disposição da plateia, que envolve toda a área de atuação, quanto na interação com o espectador, proposta na totalidade das encenações realizadas pelo coletivo. Osvaldo Gabrielli ${ }^{149}$ destaca a maneira como, no Oficina, era necessário fazer a matéria vir à tona, expondo toda sua brutalidade e evitando ao máximo o super manufaturado. Ele afirma que é na materialidade dos elementos brutos que se encontra a teatralidade. Da mesma forma, o cenógrafo explicou como a exposição do espaço cru, lugar de passagem e de ocupação pela multidão, faz entrever a fusão entre cenografia e arquitetura cênica, revelada pela linguagem ousada de Lina Bo Bardi na elaboração do edifício teatral e de seus cenários.

Outra apropriação do Teatro Oficina em seus espetáculos, com influência direta sobre a iluminação, é a exploração de novas tecnologias a caminho de um teatro dilatado/expandido e das tendências híbridas rumo à espetacularização. Marcelo Denny ${ }^{150}$ relembra Baudrillard e a constatação de que o teatro já nasceu multimeios, em um mundo de muitas telas. Ele propõe uma reflexão a respeito da natureza e dos métodos de uso da projeção e diferencia multimídia (projeção não problematizada) de intermídia (projeção problematizada por ela mesma), revelando a necessidade de integração do operador de imagens, que ele chama de performer, no espetáculo.

Seguindo em sua reflexão, Denny traçou um panorama das transformações históricas e aspectos renovadores do teatro no século XX, iniciando pelo Teatro Total de Richard Wagner, o trabalho com a imagem de Loïe

\footnotetext{
149 Diretor de arte e cenógrafo argentino, cujo depoimento foi realizado durante o debate sobre "Direção de Arte e Arquitetura" durante o Simpósio Teatro Oficina: seis décadas da cena radical brasileira no Teatro Oficina em São Paulo no dia 06 de outubro de 2016.

150 Professor e encenador em depoimento no debate sobre "Cena e Tecnologia: a iluminação e o vídeo no Teatro Oficina Uzyna Uzona", com Cibele Forjaz, Igor Marotti Dumont e Marcelo Denny durante o Simpósio Teatro Oficina: seis décadas da cena radical brasileira no Teatro Oficina em São Paulo no dia 27 de outubro de 2016.
} 
Fuller e a cineficação do teatro por Meyerhold, que ele classifica em cineficação interna, mais teatral, e externa, com o uso de projeções. Esse movimento permitiu, no palco, efeitos cinematográficos como a multiplicidade de pontos de vista, o close up, o plano detalhe, o corte, o movimento de câmera, o zoom e o foco, dando origem à atuação da luz e da imagem como montagem e edição da cena. A digressão histórica de Denny seguiu por Piscator e seus filmes documentais, os polyscreens, texturas e superfícies de Svoboda para o Laterna Magika, as experiências de Jacques Polieri, a recuperação do screen de boca de cena por Merce Cunningham, as videoinstalações do Studio Azurro, as manifestações do teatro digital do La Fura del Baus, The Wooster Group, Cristiane Jatahy, Bill Viola e, finalmente, o terreiro eletrônico do Teatro Oficina e a necessidade, apontada por Zé Celso, de "plugar o teatro", comparando a tecnologia à luz elétrica, cuja distinção e, ao mesmo tempo, forte relação entre o filme gravado e o vídeo produzido com transmissão ao vivo fez surgir, em seus espetáculos, um novo performer: o video maker.

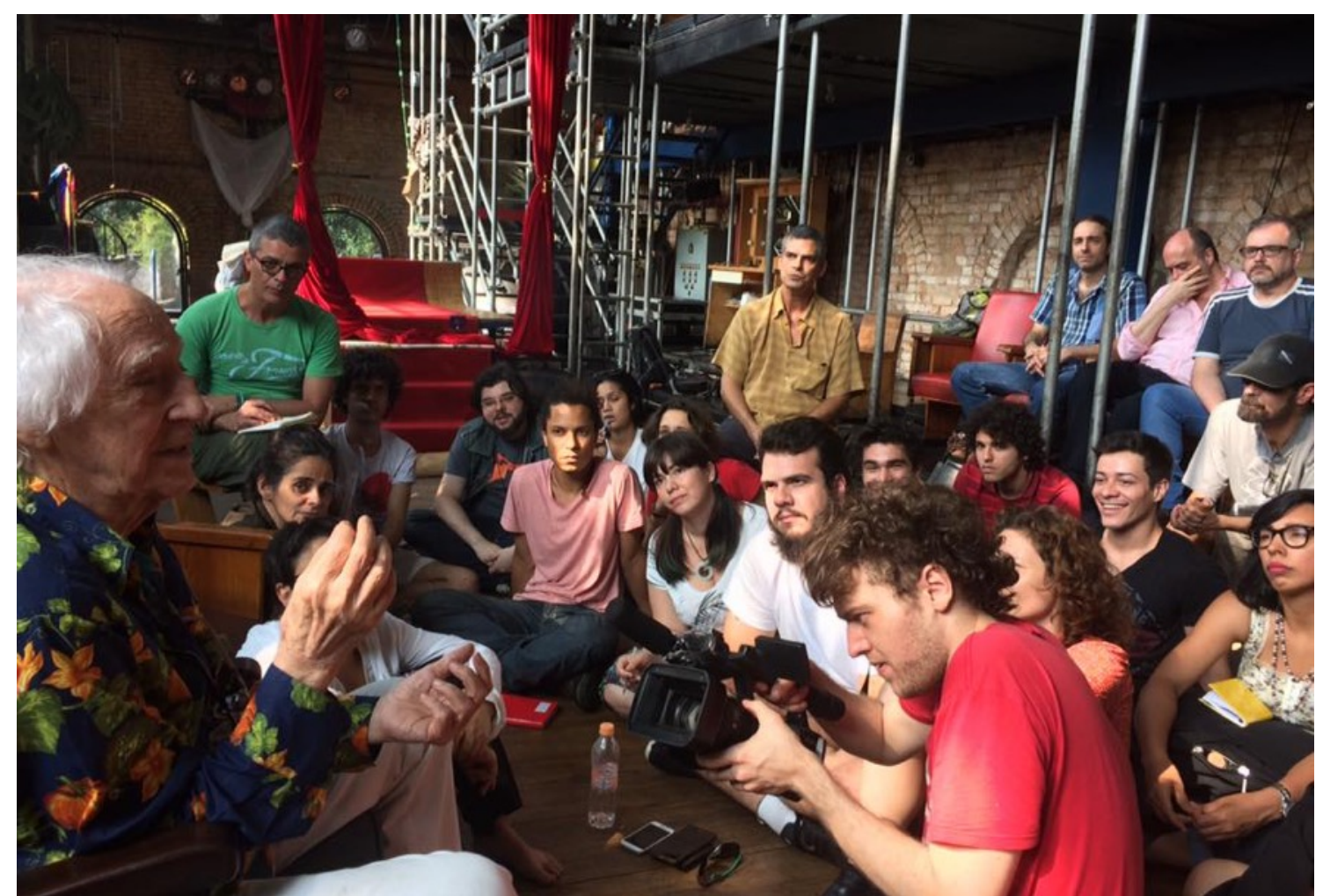

Figura 18 - O vídeomaker Igor Marotti durante o Simpósio Teatro Oficina: seis décadas da cena radical brasileira no Teatro Oficina em São Paulo. Foto Marcos Bulhões.

É oportuno destacar, a esse respeito, essa importante característica das montagens do Teatro Oficina, considerando a disposição e visibilidade do 
público espectador e partícipe. Um ambiente multimídia é permanentemente instalado, com diversas telas de projeção, de tamanhos variados, usados durante os espetáculos para projetar imagens captadas por esse performer, permanentemente em cena, e editadas ao vivo durante as apresentações. Esse trabalho revela-se não só performativo por si mesmo, quanto intensifica a performatividade dos atores em cena, criando novos planos, ângulos e pontos de vista para o espectador, que por vezes também é filmado e projetado nas múltiplas telas.

Luiz Fernando Ramos ${ }^{151}$ localiza as atividades e práticas do Teatro Oficina para além do pós-dramático ou do performativo, em uma dramaturgia particular e única. Segundo ele, Zé Celso passou, ainda nos anos 70, a escrever não mais como dramaturgo, mas como encenador, com rubricas tão significativas quanto os diálogos, edificando suas cenas num processo de escritura cênica original de exploração do espaço e do coro, recuperado por Zé Celso das tragédias gregas e inspirado em Brecht, cujo constante estado de improvisação trazia a responsabilidade de estabelecer uma relação direta com a plateia e cuja teatralidade desencadeava forte tensão entre texto e cena.

No que diz respeito à iluminação, Zé Celso fala da abrangência da palavra 'ator' e diz que a luz deve ser totalmente ligada ao corpo do ator, acompanhando qualquer sentimento mínimo seu. Para ele, a luz não deve ser conceitual, mas ter poesia, ela deve inspirar atores e espectadores, centrada sempre na atuação, no trabalho do ator. A encenação, para Zé Celso, é regida pela poesia e o mais importante é a imaginação poética do ator (e de toda a equipe envolvida no processo, bem entendido) ligada à vida. Considerando que seus espetáculos têm longa duração, alguns chegando a doze horas, ele mesmo afirma que, para participar, é necessário o ator viver para aquilo, entregar-se completamente e ter preparo físico para tal. Essa exigência do encenador em relação ao ator, considerando os depoimentos de outros artistas e da própria Cibele Forjaz, 
estende-se também à toda equipe, tanto durante o processo de criação do espetáculo quanto nas apresentações, e igualmente ao público, cujo engajamento, disponibilidade e entrega são fundamentais para que o rito aconteça a cada sessão. É nesse contexto que surge, no trabalho da Cibele, um possível "performer da luz", de quem, criador ou não, se exige uma participação ativa de interferência e condução do espetáculo por meio da linguagem da iluminação cênica, seguindo uma partitura pré-estabelecida ou a partir de improvisos gerados na comunhão com a atuação dos performers em cena e as reações do público.

Surge, assim, o ambiente para uma dramaturgia da luz diferenciada e com características nas quais é possível detectar...

...a potencialidade performativa da luz, na ação do criador/operador
que, em consonância com a narratividade da cena e dispondo de
recursos próprios à sua linguagem, constrói um discurso cênico de
ambientação, caracterização e composição do espaço e da imagem
com traços performativos, numa perspectiva estética, ou antes,
poética. Ela ajuda a vislumbrar um novo modo de fazer e de expressar
o futuro das artes cênicas, cuja revelação encontra-se na experiência
que proporciona e nas sensações que provoca no espectador co-
criador da cena, a partir de processos criativos múltiplos e
participativos, cuja experiência, acima da demonstração ou exposição,
encontra na vivência sua maior expressão e realização (LUCIANI,
2012a, p. 100).

A performatividade, segundo Josette Féral, acontece quando o ator é chamado a fazer (doing), a estar presente, a assumir os riscos, ou seja, "afirmar a performatividade do processo". Nesse momento, "a atenção do espectador se coloca na execução do gesto, na criação da forma, na dissolução dos signos e em sua reconstrução permanente", quando se instaura uma estética da presença (FÉRAL, 2015, p. 131). Essa presença, comum a todos os performers envolvidos na realidade cênica praticada no Teatro Oficina, não é nem estanque nem necessariamente pré-determinada por um roteiro ou partitura, mas resultante de um processo, no qual se constrói uma estrutura a ser seguida durante as apresentações, flexível e susceptível a todo tipo de imprevisto, adaptação ou improviso, desde que integrado ao conceito e compartilhamento proposto. A presença constante do dramaturgo e encenador Zé Celso em cena permite a 
condução e integração de todos os elementos componentes da cena, sob seu olhar atento e participação intensa.

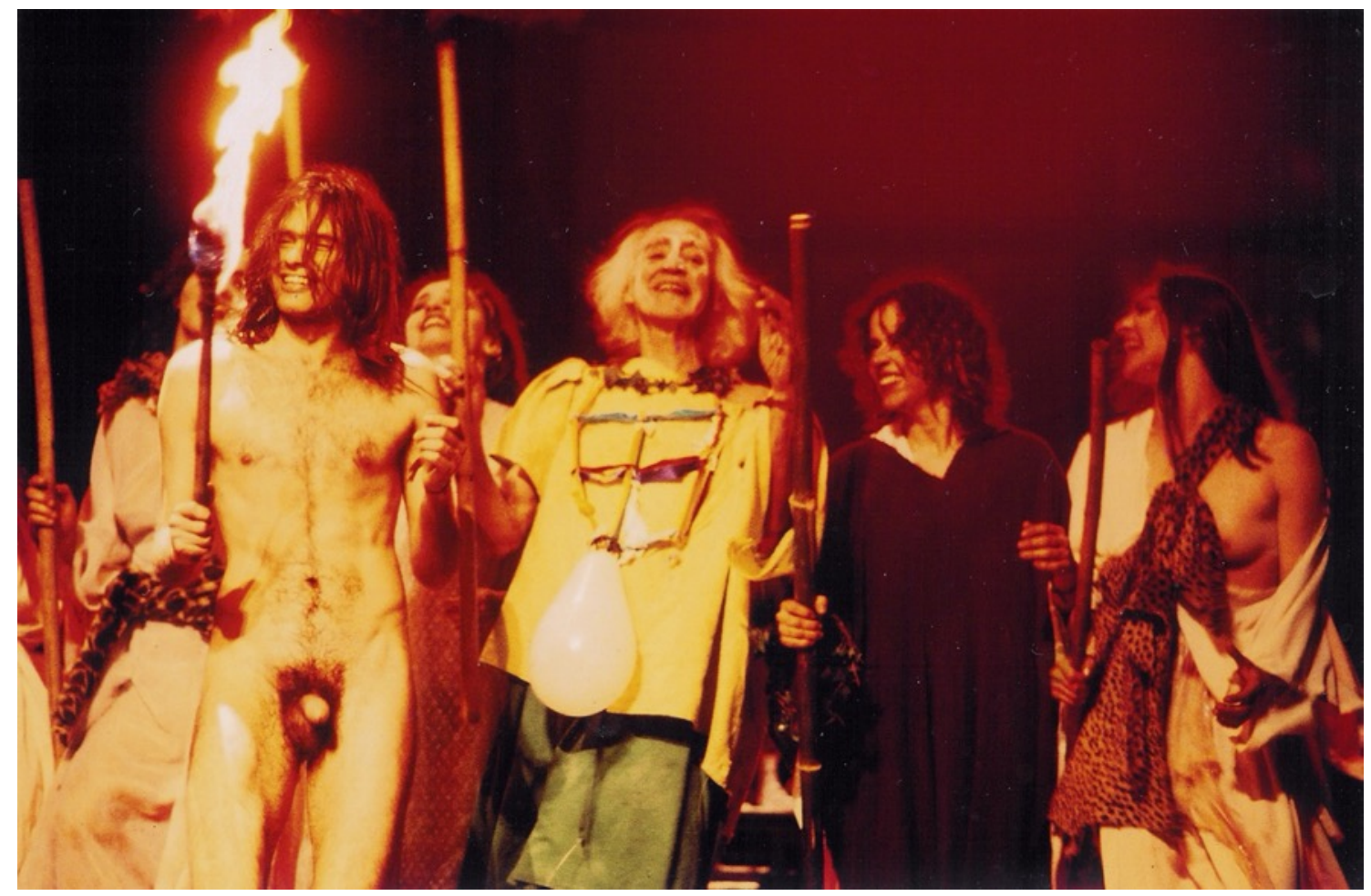

Figura 19 - Zé Celso em cena no espetáculo Bacantes. Texto de Eurípedes e direção de Zé Celso Martinez Corrêa. Luz Cibele Forjaz. Foto Lenise Pinheiro.

Abordando a questão da iluminação e sua atuação performativa por meio da operação durante os espetáculos do Oficina, normalmente realizada por ela mesma, Cibele Forjaz ${ }^{152}$ fala de uma luz diretora e encenadora, uma luz associável ao conceito definido por Patrice Pavis como "luz enunciadora da encenação" (PAVIS, 1999, p. 202). Ela explica essa função da luz como sendo o "jeito de fazer uma luz básica que dê conta de contar a história e entender seus conflitos". Esta acepção de uma suposta função narrativa da luz, que pode parecer paradoxal e contrária à hipótese de uma luz performativa, na verdade a comprova, pois demonstra a total interação do processo de criação e operação da luz com o processo de elaboração e operacionalização da encenação em todos os seus aspectos práticos, cênicos e técnicos. Cibele destaca, ainda, a importância da plateia, que ela assume como "personagem principal das peças

152 Em depoimento no debate sobre "Cena e Tecnologia: a iluminação e o vídeo no Teatro Oficina Uzyna Uzona" durante o Simpósio Teatro Oficina: seis décadas da cena radical brasileira no Teatro Oficina em São Paulo no dia 27 de outubro de 2016. 
do Zé", elemento fundamental da política do aqui/agora no Oficina. Para acontecer essa integração da plateia ao espetáculo, o envolvimento com a luz é fundamental, sendo necessário haver total entendimento do que é público na história, distinguir as cenas públicas das privadas, o interno do externo, e apropriar-se da arquitetura, iluminando o espaço cênico e a plateia, com o que ela chama de "geral do aqui/agora" e que o próprio Zé Celso classifica como "quebra-barato", por sua propensão a retirar o espectador de zona de conforto e inseri-lo na ação.

A iluminação também deve, segundo Cibele Forjaz, permitir aos atores e espectadores o "jogo de entrar e sair da história", considerando que o desenho da luz define, para isso, planos abertos e fechados, focos precisos e luzes gerais amplas. No caso do público, a constância da luz de plateia é indicativa de sua participação e permite a interação dos atores com os espectadores: "de repente, as luzes da plateia se acendem, todos os presentes se olham e temos um ator diante de um público; nesse momento, todos podem ser ou não ser Hamlet" (FORJAZ, 2008b, p. 154), mas o movimento de luz na cena, porém, pode criar respiros e variações na intensidade dessas participações, como é o caso dos pequenos canhões de luz, operados manualmente por atores espalhadas pelo palco, que direcionam a iluminação e o olhar do espectador em movimentos precisos durante o espetáculo: "um pin-beam (pequeno foco móvel) ilumina de perto um solilóquio, e estamos dentro da cabeça de Hamlet” (FORJAZ, 2008b, p. 154). Cibele chama os operadores desses pequenos canhões de "atores da luz", permitindo uma analogia, dada sua presença na cena e atuação performativa, com os "performers da imagem" citados por Marcelo Denny.

A luz, para Cibele Forjaz, deve contar a história, editar a cena e articular tempo e espaço, mas cumprir com todas as demandas da encenação complexa do teatro de Zé Celso nem sempre é fácil com os poucos recursos disponíveis. Poucos equipamentos e instalação precária resultam em soluções criativas e no aproveitamento de todo e qualquer material que se apresente, tecnológico ou humano. A precariedade é outra característica marcante do trabalho com iluminação no Teatro Oficina. Zé Celso destaca a importância de trabalhar na 
precariedade radical, sob o risco de não se produzir arte. Essa é uma das heranças da participação de Lina Bo Bardi no Oficina, considerando a "brutalidade da matéria que precisa ser trazida à tona"153, o que acaba por se tornar uma grande especialidade do trabalho no Oficina, com a exploração de recursos simples para a criação de efeitos precisos e bem empregados. Cibele cita vários exemplos, em diferentes montagens, dessa luz "precária" e eficiente, como a sombra de Hamlet que se agiganta pelo movimento manual de descida da set light que ilumina o ator, os canhões seguidores feitos com pin-beams ou loko-lights e operados manualmente, as paredes do teatro iluminados com Colortrans de $300 \mathrm{~W}$ reaproveitadas, gerais feitas com panelões de iluminação urbana com lâmpadas de vapor de sódio e riders básicos de iluminação, como é o caso da luz de Ham-Let ${ }^{154}$, realizada apenas com a geral do público, a geral da pista (2 Elipsoidais), cinco focos, e quatro pin-beams para os canhões, mas cujo roteiro preciso de operação do canhões e a movimentação desses poucos recursos dava conta da complexidade dramatúrgica do espetáculo de quase cinco horas de duração.

Num claro exemplo de ação da luz, Cibele Forjaz descreve a experiência de sua estreia como iluminadora do Oficina numa primeira leitura pública do processo de criação de Ham-Let ${ }^{155}$, que a companhia havia começado a ensaiar apenas dois dias antes, sem que ela tivesse participado destes ensaios ${ }^{156}$. A primeira ação da atuação performativa da luz se deu quando Zé Celso, logo no início da leitura, "grita, do meio da escuridão da plateia: 'Luz! Luz aqui'."157 para fazer acender, de improviso, sem que aquilo tivesse sido planejado, a contraluz da aparição do vulto do Fantasma do Rei, neste caso, a luz "de serviço" do fundo da plateia do próprio teatro. Em seguida, nas palavras de Cibele:

\footnotetext{
153 Expressão usada por Osvaldo Gabrielli para definir a valorização da arquitetura cênica e as diretrizes da direção de arte do Oficina no debate sobre Direção de Arte e Arquitetura durante o Simpósio Teatro Oficina: seis décadas da cena radical brasileira no dia 06 de outubro de 2016. 154 Montagem de Ham-Let, de Shakespeare, pelo Teatro Oficina Uzyna Uzona, estreada em 1993.

155 Em 1991, no SESC São José dos Campos.

156 No texto "A Linguagem da Luz Encenadora no Teatro Oficina Uzyna Uzona: estudos de caso da luz em Ham-Let e Cacilda!" do volume anexo ao Livro de Ouro do Teatro Oficina A Bigorna Extraordinária, não editado.

157 Ibidem.
} 
Peguei um refletor plano-convexo, uma extensão e corri até a tomada mais próxima. Com o refletor quente nas mãos segui Zé Celso por toda a parte, iluminando a plateia sempre que ele se dirigia aos 'vivos' ali presentes. Esse foi o começo de uma parceria de 12 anos com o encenador José Celso Martinez Corrêa (FORJAZ, 2013b, p. 13).

A iluminação de Ham-Let é descrita por Cibele como uma luz diretora, cuja função é conduzir o espetáculo articulando tempo e espaço, de desenho simples, mas cujo movimento é "complexo, rápido e preciso", evidenciando a importância do movimento como característica da performatividade da luz, uma das principais propriedades da luz que atua, interage e interfere na cena. É neste contexto que nascem dois importantes conceitos de Cibele Forjaz a respeito da iluminação: o de luz estrutural, criadora do espaço que revela "as várias camadas de significação imbricadas na encenação" e o de editora da cena ${ }^{158}$ pelas várias esferas existentes entre o palco e a plateia:

(i) o político-público; (ii) o privado-teatral, ou seja, a 'trama de teatros' que acompanha as peripécias do príncipe Hamlet em luta contra o seu tio, Rei Claudius; (iii) a esfera interior, onde a subjetividade ganha primeiro plano e a encenação entra "dentro" da cabeça de Hamlet [...] e as "cenas de aparição", que pedem a invenção de um universo paralelo (FORJAZ, 2013b, p. 14).

A principal luz da peça, reveladora, em grande parte, de seu caráter performativo, é a luz geral, que além de poder iluminar integralmente o palco, também permite dividi-lo em partes, conforme as necessidade da encenação, e desvenda a arquitetura do teatro com suas paredes, corredores e áreas de circulação, teto, jardim, fonte, porta de entrada, beco, entradas e saídas, expondo a estrutura de ferro e colocando o público e a pista em um mesmo plano, mesclando ficção e realidade, expondo a política do aqui/agora, mesclando o público e o privado, provocando "quebras" e "estranhamentos" cênicos e sendo, ao longo da apresentação, por vezes, o Palácio Elsinore, na Dinamarca, e noutras, o próprio Teatro Oficina, no Brasil.

Segundo Cibele, a lógica do movimento da luz neste espetáculo veio do seu profundo conhecimento do espetáculo, das marcações de cena e da movimentação no espaço, revelando mais uma importante possível

158 Aprofundados e desenvolvidos em seu mestrado e doutorado realizados no PPGAC-ECAUSP e concluídos em 2008 e 2013 , respectivamente. 
característica da luz performativa e da atuação do performer da luz, o operador que executa os movimentos da luz. É imprescindível, para que aconteça a performatividade da luz, ou seja, para a participação ativa da luz na cena e no espetáculo, bem como sua interação com os atores (e também com o público, em muitos casos), que tanto o iluminador quanto o operador tenham pleno conhecimento das cenas e suas motivações, do pensamento da personagem aos estímulos que conduzem às ações e movimentações no palco, das orientações do diretor e do encenador a respeito da construção das cenas e subsídios da encenação, das concepções do cenário, da sonoplastia e outros elementos cênicos, da totalidade da montagem, enfim, em todos os seus detalhes, para dar conta, inclusive, de "acompanhar a respiração dos atores nas reviravoltas surpreendentes das personagens de Shakespeare", como destaca a iluminadora de Ham-Let ${ }^{159}$.

A movimentação da luz na peça Ham-Let demonstra com clareza a atuação performativa da luz no embate proposto por esta encenação entre o teatro e a realidade, como, por exemplo, na quebra da luz geral, inclusa a área destinada ao público, como elemento de estranhamento e revelação; os focos, usados como "porta para dentro da subjetividade, que pode abrir a cena para diferentes pontos de vista que, por sua vez, levam a mundos diversos"; a luz focada no rostos dos atores em marcação livre ${ }^{160}$, que permitiam a "inteiração e passagem rápida (e clara) entre o plano da subjetividade e o aqui/agora"; a concretude das imagens simbólicas geradas pelas luzes "fechadas" em partes do corpo ou objetos da cena, demonstrando a capacidade de criar efeitos de zoom e plano detalhe, oriundos do cinema, na luz cênica. No caso da operação de luz da peça Ham-Let, Cibele optou por assumi-la, considerando a complexidade dos movimentos, a interatividade entre a mesa e seus "atores da luz" e a edição, que fazia "ao vivo", dos vários tempos e espaços propostos no

\footnotetext{
159 No período em que integrou a equipe do Teatro Oficina (1991 a 2002), além da função de iluminadora, Cibele Forjaz também atuou como assistente de direção de Zé Celso.

160 Feitos com os pequenos canhões de pin-beams operados por atores de dentro da cena, conforme descrição feita pela Cibele em depoimento realizado do debate sobre Cena e Tecnologia: a iluminação e o vídeo no Teatro Oficina Uzyna Uzona durante o Simpósio Teatro Oficina: seis décadas da cena radical brasileira no dia 27 de outubro de 2016.
} 
espetáculo: interno/externo; público/privado; real/ficcional, metafórico/explícito, presente/passado, em sua máxima performativa. Um dos princípios da performatividade, que Féral descreve como "aceitar o perigo do desafio do que pode ou não dar certo" (FÉRAL, 2009, p. 72), é marcada pelo código da ação através do qual o valor do risco e o fracasso tornam-se constitutivos desse tipo de ato performativo que, no caso do trabalho da Cibele com o Oficina, constitui o que pode ser perfeitamente qualificável como a performatividade da luz.

Outra importante experiência de Cibele Forjaz como iluminadora no Teatro Oficina foi a iluminação da peça Cacilda!, um espetáculo, nas palavras de Luiz Fernando Ramos ${ }^{161}$, "em constante transformação, uma história sem fim, referência na história do grupo", tanto pela dramaturgia quanto pela encenação, assim descrita por Cibele:

Cacilda! mistura a biografia da atriz Cacilda Becker, com as personagens e cenas das peças que ela representou, à vida teatral de Zé Celso e suas referências. Através desta justaposição de representações, o autor/encenador reconta, à sua maneira, a história do teatro brasileiro. Essa superposição de significados, tempos, personagens e tramas é de tal monta, que o excesso de significação faz do espetáculo um grande poema épico cênico, misturando assim, os gêneros lírico, épico e dramático. São várias histórias sobrepostas, assim como muitas camadas diferentes de significação, de modo que a narrativa explode em um jogo teatral onde as quebras e as transformações viram a regra de um meta-teatro delirante. Imagens oníricas e mitológicas contracenam com personalidades do teatro brasileiro e com as memórias do Teatro Oficina e de Zé Celso e estas, por sua vez, multiplicam-se em personagens de peças do repertório de Cacilda (FORJAZ, 2013b, p. 14).

Apesar de Cibele falar em narrativa, significação, representação e gêneros lírico, épico e dramático, esta sobreposição de linguagens cênicas e estéticas teatrais não poderiam resultar em nada mais performativo, uma "encenação, dentro da obra do Zé dos anos 90, que tem uma estrutura explicitamente pós-dramática" (FORJAZ, 2008b, p. 162). Cacilda! é um espetáculo composto de cenas tão distintas entre si quanto todas as vidas, peças e personagens do mito Cacilda Becker, realizado num espaço multidirecional com mais de 25 atores em cena. Coube à luz, então, estruturar o espetáculo,

${ }_{161} \mathrm{Na}$ apresentação da pesquisa "Dramaturgia de José Celso Martinez Corrêa. Estudo de caso de Cacilda?' durante o Simpósio Teatro Oficina: seis décadas da cena radical brasileira no Teatro Oficina em São Paulo no dia 11 de novembro de 2016. 
conduzir a atenção do espectador, editar as imagens e separar os diferentes planos das cenas simultâneas, determinando o que é fundo e o que é forma, 0 que é ação principal e o que é comentário critico, metáfora, sonho ou delírio.

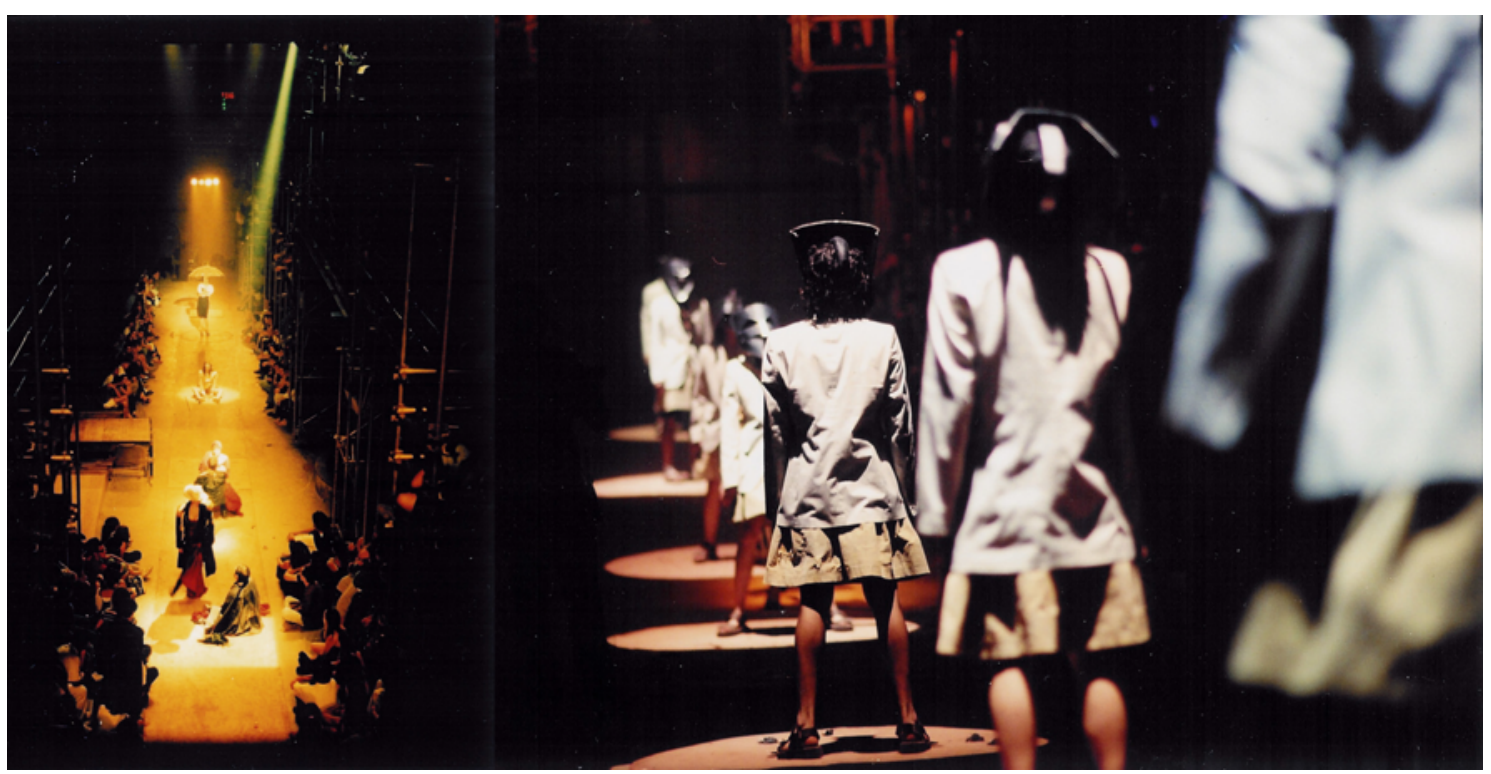

Figura 20 - Cenas do Espetáculo Cacilda!, à esquerda cena da chegada de Godot e à direita cena da invocação. Texto e direção Zé Celso Martinez Corrêa. Luz Cibele Forjaz. Fotos Lenise Pinheiro.

Da mesma forma que o texto original, a luz adquire características simbólicas, realistas, ilusionistas ou expressionistas, em linguagem lírica ou épica, com forte inclinação à teatralidade, conforme exigências da encenação, e cuja performatividade latente encontra-se justamente na capacidade de migração de uma linguagem à outra, acompanhando cada passo, cada novo cenário, cada movimento dos atores pelo espaço e a atuação pontual em cada cena:

Quando começa o primeiro ato vemos a última cena de Esperando Godot. A luz é teatral, construída em ângulos perfeitos de 45 graus (como Ziembinski costumava usar) com fresnéis visíveis em um pequeno teatrinho com rodas estacionado no meio da pista; a representação termina, a luz de serviço do grande teatro acende, interrupção, café e respiro; de repente Cacilda tem um aneurisma, o teatro todo se tinge de vermelho, não de refletores, mas de panelões de rua com lâmpadas de sódio, pintados por gelatina vermelha, totalmente monocromático, um único risco de luz incandescente suspende Cacilda no tempo, começa uma "viagem fantástica" rumo à morte; Cacildinha-criança brinca de amarelinha em um contraluz quente que remete ao início dos tempos; os faróis da Barca do Céu e do Inferno banham de azul o vermelho, como sirenes de ambulância, dividindo o Teatro Oficina em dois; Cacilda-Dama das Camélias surge envolvida por um foco de canhão que a persegue; Cacilda-Godot é levada para a UTI, em coma, morre não morre; instauram-se os três 
planos de Vestido de Noiva; um plástico transparente de 50 metros atravessa o teatro em uma grande diagonal, os panelões vermelhos se apagam e o sangue derrama pela artéria de plástico inundando a pista (FORJAZ, 2008b, p. 165).

A simbologia exacerbada das luzes que invadem cada cena, em total sincronia com a intencionalidade que as gera e move, confere à luz uma performatividade explícita, que se lança ao público e o insere no contexto de forma irrefutável. Segundo Cibele, o segundo ato, assumidamente pósdramático, "mistura ainda mais diversos tempos e espaços, ficções e realidades, pós-moderno com tropicalismo, delírios de consciência com cenas de teatro realista, viagem de ácido com simbolismo, pico com Pop, anos 60 com século XXI, Zé Celso com Cacilda Becker" (FORJAZ, 2008b, p. 168), tudo isso acompanhado por luzes psicodélicas, contrastantes, imagens do inconsciente e recortes de luz para cenas específicas destacadas do todo alucinado. A um dado momento da encenação, Gerald Thomas e Ziembinski interferem na luz, e Zé Celso, invadindo a cena, declara, como Cacilda: "Todos os teatros são meus teatros!". "A iluminação, inspirada por essa frase, multiplica luzes e linguagens em diferentes planos de ação, no teatro dentro do teatro e na relação direta com a plateia" (FORJAZ, 2008b, p. 170).

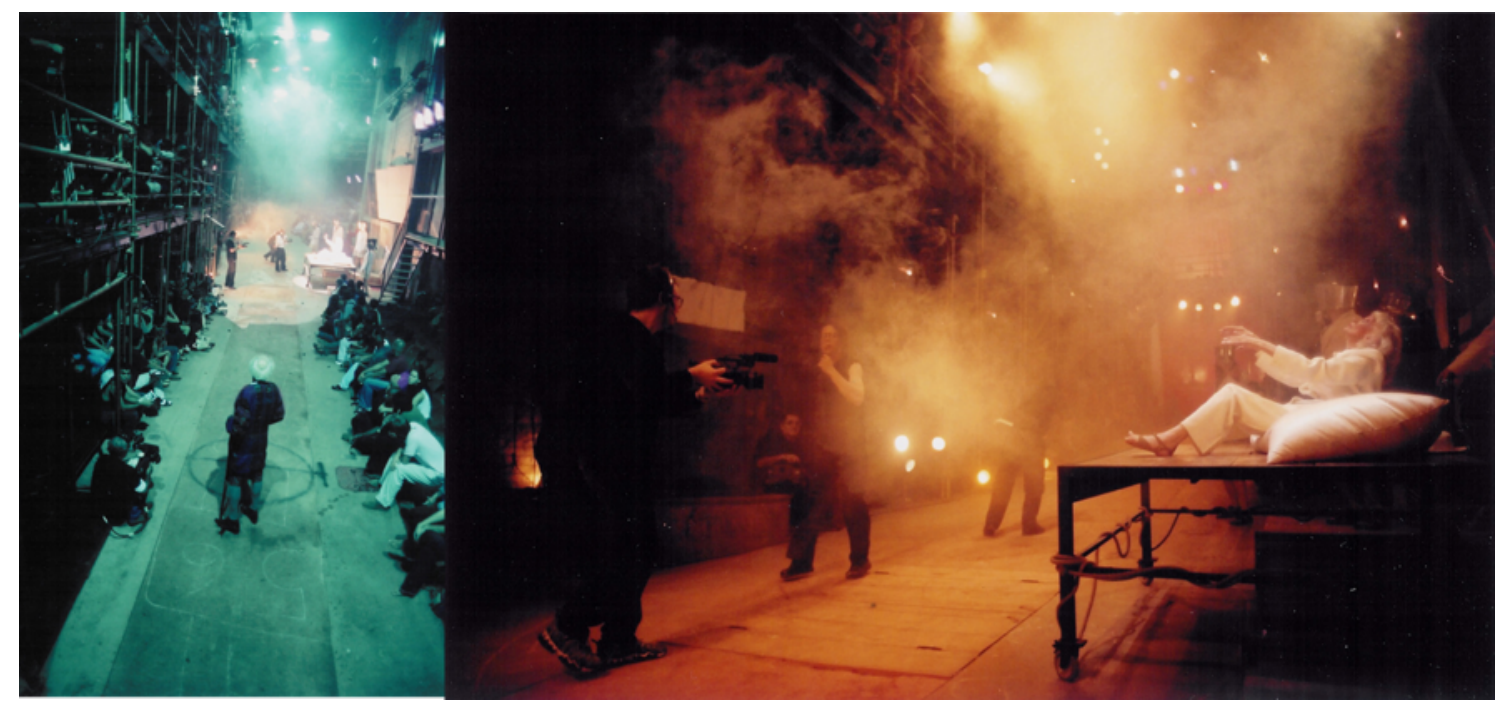

Figura 21 - Cenas da missa no Espetáculo Cacilda!. Texto e direção Zé Celso Martinez Corrêa. Luz Cibele Forjaz. Fotos Lenise Pinheiro.

Cibele conclui que "a linguagem da luz no Teatro Oficina tem a função de editar a ação cênica, articulando imagens no espaço e no tempo e criando uma partitura do visível que contracena com o texto e as demais linguagens da 
encenação"162 e destaca a importância do movimento da luz para transformar a percepção do espaço e do tempo da ação, provocar a fricção entre atores e espectadores, ficção e realidade, inserir o público na ação ou mergulhá-lo na subjetividade das atmosferas oníricas pelo simples "acender ou apagar de uma lâmpada". E acrescenta, ainda, a propriedade que identifica na iluminação, a partir destes projetos, de interromper o fluxo "natural" da vida, criando uma fissura no tempo e, portanto, conduzindo à destruição da "realidade", ou da "ilusão da realidade", ou seja, à destruição da ideia da arte como mimese e à inclusão da plateia como fator fundamental do espetáculo. Essa é, a meu ver, a interferência mais performativa atribuída à iluminação cênica, conferindo-lhe uma capacidade de atuação e transformação na percepção da cena, cuja ação sobre o espectador depende fundamentalmente de sua atuação e interação ao vivo, just in time, no momento da ação cênica íntegra, composta e integrada.

Desta forma, fica comprovada, no trabalho de Cibele Forjaz junto ao Teatro Oficina, a performatividade da luz enquanto fenômeno físico autônomo e atuante. Sua atuação como um elemento intimamente relacionado à ação cênica e à recepção, revela sua função performativa em ação conjunta com todos os demais componentes e na percepção do espectador, partícipe igualmente atuante na encenação. A importância do trabalho e da influência da iluminadora no Teatro Oficina ficou expresso no depoimento do iluminador Guilherme Bonfanti ${ }^{163}$ que, em 2019, fez a luz para uma remontagem do espetáculo Roda Viva. Ele se deparou com a forte herança da prática participativa de criação do grupo e os hábitos adquirido no processo de construção da luz desenvolvido entre a Cibele e o Zé Celso, que perduraram ainda por muitos anos, mesmo depois da sua saída:

... o que aconteceu quando eu cheguei, foi o encontro com uma estrutura muito blocada, enquanto luz na cena. Existia um fantasma que me rondava lá dentro que era a Cibele Forjaz (risos). Ela ficou muitos anos ali dentro e o que se faz hoje no Oficina é o que ela descobriu e isso foi continuado... O sistema RGB, o vapor, a luz que

162 No texto "A Linguagem da Luz Encenadora no Teatro Oficina Uzyna Uzona: estudos de caso da luz em Ham-Let e Cacilda!" do volume anexo ao Livro de Ouro do Teatro Oficina A Bigorna Extraordinária, não editado.

163 Em entrevista realizada como parte desta pesquisa, disponível nos anexos, p. 121-135. 
ilumina o todo e não distingue palco e plateia... O Zé (Celso) tem essa relação e a presença da plateia é muito forte o tempo todo. $\mathrm{O}$ que eu encontrei foram duas pessoas que trabalhavam na equipe, com uma série de demandas para mim, às quais eu tinha que cumprir. Tinha um check list: plateia tem que ser iluminada, a árvore tem que ser iluminada, o coreto tem que ser iluminado, o fundo tem que ser iluminado, a arquitetura tem que ser iluminada. Eu fiquei louco com isso, porque isso significava que eu, como criador, tinha que atender uma série de questões que já estavam postas ali e eu entrei achando que aquilo era o terreno da liberdade e da transgressão (BONFANTI, anexos, p. 123).

Finalmente, cabe esclarecer que a análise do trabalho da Cibele com o Oficina, feita, a princípio, como resultado da disciplina cursada no programa de doutoramento da USP, não teve o objetivo de estabelecer definitivamente as características ou colocar um ponto final na questão da luz performativa, mas proporcionar um aprofundamento e a continuidade nas investigações e estudos para identificar, exatamente, em quais destes aspectos se encontram as principais características da performatividade da luz, cujos preceitos se evidenciavam cada vez mais e que, certamente, revelavam sua força e intensidade a cada nova análise. Estudos de caso como este, realizados com o Teatro Oficina e suas práticas performativas, foram de extrema importância para o andamento e avanço da investigação que objetivava a consolidação do conceito de performatividade da luz. 


\subsubsection{Guilherme Bonfanti e o Teatro da Vertigem}

\section{O processo de criação e o uso de equipamentos não convencionais} nos espetáculos do Teatro da Vertigem - Trilogia Bíblica: O Paraíso Perdido I O Livro de Jó I Apocalipse 1,11 - BR-3 - Bom Retiro 958 Metros

Ao contrário do trabalho realizado por Cibele Forjaz com o Teatro Oficina, cujos roteiros de luz eram imprecisos e adaptáveis à cada apresentação ou situação, o trabalho do Guilherme Bonfanti segue uma rígida partitura cênica, na qual o desempenho da luz é cuidadosamente planejado, marcado e realizado a cada apresentação. Nem por isso deixa de ser performativo e profundamente integrado à ação cênica, justamente pela intensa participação na elaboração, concepção e idealização dos espetáculos e da encenação como um todo, desde a escolha e arranjo do espaço cênico até a montagem da luz e a gravação das cenas feitas com rigor e preciosismo técnico e estético.

Em uma experiência de criação realizada com o espetáculo Roda Viva em 2019, Guilherme Bonfanti ${ }^{164}$ constatou as diferenças conceituais entre 0 processo de criação e operação da luz de Cibele Forjaz, enraizados nas práticas do grupo em ambas as etapas, e seu próprio, desenvolvido junto ao Teatro da Vertigem, com condições de trabalho distintas, tanto técnicas quanto relativas à autonomia na criação. "Eu trabalhava com uma mesa Live onde não tem cue, não tem roteiro e onde o ator pisa, uma luz acende, ele vai para lá a luz acende. Ai eu pensei: Como assim? A luz não tem projeto? Não tem desenho? A luz não é proposta?" (BONFANTI, anexos, p. 124). Ele explica ainda que, aos poucos, foi conseguindo fazer tudo estar pré-gravado e só ajustar tempos com a luz abrindo e fechando, mudando planos. Apesar das diferenças, o rico processo e a experiência foi positiva para ambos. "O Zé não conhecia o meu processo e eu entrei ali numa precariedade técnica absoluta para um teatro gigantesco com uma pista imensa que tem que ser iluminada..." (BONFANTI, anexos, p. 125).

\footnotetext{
${ }^{164} \mathrm{Em}$ entrevista realizada como parte desta pesquisa, disponível nos anexos, p. 121-135
} 
Numa mescla de sua própria prática criativa colaborativa e os hábitos préestabelecidos no processo participativo do Oficina, o iluminador, conclui que...

... foi bastante difícil levar uma ideia de luz que fosse diferente da dele, mas eu consegui levar minha pesquisa com os movings, com os LEDs e consegui levar uma ideia de luz pré-organizada e também que é uma pessoa só que opera e não duas ou três, consegui fazer com que tivesse um desenho e que ele fizesse parte da encenação, como mais um elemento de comunicação com quem está na plateia e que atendia todas as demandas de iluminar a plateia, iluminar árvore, isso e aquilo (BONFANTI, anexos, p. 125).

A maior característica dos espetáculos realizados pelo Teatro da Vertigem e que afeta profundamente o trabalho realizado pelo iluminador Guilherme Bonfanti no grupo é o processo colaborativo de criação. Antônio Araújo define o processo colaborativo como uma "metodologia de criação em que todos os integrantes, a partir de suas funções artísticas específicas têm igual espaço propositivo, produzindo uma obra cuja autoria é compartilhada por todos" (ARAÚJO, 2018, p. 14). Num trabalho que estimula não só a criação material de cada componente cênico, mas, principalmente, a reflexão crítica sobre as escolhas estéticas e os posicionamentos ideológicos, cada participante do processo criativo colaborativo se converte em um artista-pesquisador que deve articular sua linguagem artística com o grupo, propondo e acatando interferências dialógicas entre linguagens e transitando, incessantemente, das partes ao todo e do todo às partes. Cada componente da equipe de criação elabora, individual e conjuntamente, a obra cênica total que será levada a público (ARAÚJO, 2018, p. 15). No caso específico do Teatro da Vertigem, o espaço de criação e proposição autoral ocupado pelo iluminador Guilherme Bonfanti é o que permitirá a participação ativa da luz no espetáculo.

Guilherme Bonfanti declara, em alguns de seus escritos publicados, o despreparo e a inexperiência com que deu início à sua participação no Teatro da Vertigem desde a sua origem. Trazendo na bagagem uma experiência restrita à caixa cênica tradicional à italiana e aos equipamentos convencionais de luz, além de processos criativos, também convencionais e centrados na figura do diretor, dramaturgo ou encenador, ele precisou reaprender seu ofício e rever, ao ingressar no Vertigem, seus conceitos a respeito da iluminação cênica. 
Considerando o percurso traçado especificamente por essa pesquisa e os materiais e pesquisas já produzidas a respeito, a abordagem sobre o trabalho de Guilherme Bonfanti junto à companhia do Teatro da Vertigem se restringirá, apesar da grandiosa contribuição de toda a produção do grupo para o teatro brasileiro, aos primeiros espetáculos produzidos pela companhia, os que constituem a Trilogia Bíblica, e dois outros, também bastante representativos do conceito defendido nesta tese.

O primeiro espetáculo do grupo, O Paraíso Perdido, apresentado na igreja Santa Ifigênia no ano de 1992 em São Paulo, cidade sede do Vertigem, deu início às atividades do grupo, à trilogia e, também, efetivamente, segundo Guilherme Bonfanti, à sua carreira de como designer de luz (BONFANTI, 2011, p. 110), nestes termos, apesar dele já ter realizado outros trabalhos de iluminação para shows e espetáculos de dança e teatro. O segundo espetáculo, O Livro de Jó, realizado no hospital desativado Umberto Primo, três anos depois, representou a continuidade da elaboração do processo criativo descoberto no primeiro trabalho. Apocalipse 1,11, cuja montagem foi realizada no ano de 1999, no presídio desativado do Hipódromo, também em São Paulo, encerrou o primeiro ciclo de trabalho do grupo (TURBIANI, 2012, p. 35). Em 2006, aconteceu a estreia $B R-3$, espetáculo montado e apresentado no leito do Rio Tietê, um grande rio bastante poluído da capital paulista, marcando a retomada do grupo depois de concluída a trilogia, seis anos depois. Mais seis anos se passaram, nos quais foram realizadas diversas produções, entre uma montagem e outra, depois do que houve a estreia da peça Bom Retiro 958 metros, cuja ocupação de diversas ruas do bairro Bom Retiro em São Paulo, além do interior de um shopping center e de um antigo teatro desativado, confirmam a característica do grupo de utilizar espaços não convencionais, também conhecidos pelo conceito de site specific. O termo, empregado, a partir dos anos 60 , para qualificar obras de arte realizadas em um lugar ou espaço específico ${ }^{165}$,

$165 \mathrm{O}$ conceito de site specific se refere a obras artísticas e intervenções em espaços urbanos ou naturais em intensa relação com o meio, também conhecidas como environmental art. Estas obras configuram uma situação espacial específica considerando as características e não podendo acontecer em outro espaço que não o local escolhido para sua realização. Quando empregado no teatro, refere-se à realização de peças ou espetáculos cênicos pensadas e 
foi sendo usado pelo Teatro da Vertigem desde seu primeiro espetáculo e é uma das mais importantes características de toda sua produção cênica.

Existe um movimento de provocação, aventura e pesquisa constantes na criação dramatúrgica e de todos os demais elementos envolvidos na elaboração dos espetáculos da companhia e da configuração política, estética e crítica do site specific, na qual a ocupação do espaço público se pretende o resultado de um processo problematizado de criação. "Há uma dimensão estética envolvida em todo o trabalho artístico que se deseja crítico", escreve o dramaturgo Antonio Duran (2018, p. 46) a respeito do pensar e do como fazer enquanto arte crítica e arte de resistência. Segundo ele, a dramaturgia do espaço, da encenação, do texto e da iluminação é resultado de "um pensamento crítico em processo", que colaboram mutuamente na construção de obras densas e profundas, cuja temática se relaciona tanto com o espaço quanto com o imaginário e a experiência vivida pelo espectador. Essas experimentações coletivas em espaços públicos são destacadas por Silvia Fernandes como características dos trabalhos do Teatro da Vertigem, que ela considera como "teatro processuais, gestados na imperfeição" (FERNANDES, 2017, p. 222).

Um dos aspectos mais importantes do teatro realizado pelo Teatro da Vertigem, com impacto direto no trabalho criativo de Guilherme Bonfanti e na luz performativa que ele realiza em cada um dos espetáculos analisados, diz respeito à ressignificação do lugar e ao papel desempenhado pelo público em suas encenações. Guilherme ${ }^{166}$ declarou sobre o espaço usado para a montagem da peça Apocalipse 1,11 no Festival de Curitiba em 2000: "é um presídio e tem um elemento ficcional acontecendo, a luz cria uma atmosfera e é óbvio que ela não está só iluminando a cena, mas ressignificando o espaço também, porque a função dele muda" (BONFANTI, anexos, p. 130). Além da transformação radical dos códigos da cena empregados pelo grupo, essa prática revolucionou as formas de recepção e impôs novas realidades para a condição

realizadas especificamente para e/ou em um local em relação intensamente dialógica com o espaço e suas características, história, contexto e/ou carga energética. (seria necessário buscar alguma referência mais precisa ou citar alguém?)

${ }^{166}$ Em entrevista realizada como parte desta pesquisa, disponível nos anexos, p. 121-135. 
do espectador, confrontado com situações reais e experiências perturbadoras e limítrofes, deslocando-o de sua posição passiva e confortável para um terreno instável, incômodo e perturbador, como acontece com o observador de segunda ordem, descrito por Gumbrecht como "um observador condenado, mais do que privilegiado, a observar a si mesmo no ato da observação" (GUMBRECHT, 2010, p. 62). Desgranges destaca a forma como esse espectador "se vê lançado em terreno previamente demarcado e explorado, mas não esgotado, pelos artistas [...] e se sente provocado a partir em busca exploratória pessoal, a partir de seus interesses, anseios e desejos" (DESGRANGES, 2017, p. 27). Sendo assim, o aspecto político e estético da ocupação do espaço interfere fortemente no resultado luminoso e no uso da luz como elemento performativo e atuante, responsável por estabelecer uma relação crítica do público com a cena a partir de sua experiência estética.

A análise das criações de Guilherme Bonfanti para o Teatro da Vertigem foi feita, neste trabalho, numa relação estreita com cada uma das características do que vem sendo elaborado como a noção de performatividade de luz. $O$ Paraíso Perdido é considerado, principalmente, como o primeiro trabalho da companhia no que diz respeito ao trabalho realizado num processo colaborativo de criação teatral, com intensa participação do iluminador e sua equipe. A análise da luz da peça O Livro de Jó considera, especialmente, o uso performativo de materiais e equipamentos alternativos em profunda relação com 0 meio/ambiente do espetáculo. O projeto de iluminação de Apocalipse 1,11 tem sua análise centrada, sobretudo, na experiência e participação do espectador e, sobre o espetáculo $B R-3$, o aspecto investigado tem relação direta com a escolha e o uso de um espaço urbano não convencional para a montagem do espetáculo e a relação estabelecida, no processo de criação, entre a iluminação e este espaço. Por fim, a análise da luz de Bom Retiro, 958 metros conduz a pesquisa por diferentes lugares, explorando a relação do espetáculo com a cidade, a sociedade e os ambientes díspares selecionados para as cenas. Segundo Desgranges, a motivação axial do trabalho do artista é "a produção de uma subjetividade que enriqueça de modo contínuo a sua relação com o mundo" (GUATARRI, 1992 apud DESGRANGES, 2017, p. 26), transferindo essa 
produção para o espaço coletivo. Esse é o espírito que envolve e caracteriza o trabalho realizado por Guilherme Bonfanti e a atuação performativa da luz criada por ele para as encenações aqui comentadas do Teatro da Vertigem.

Retomando o surgimento do grupo, foi em 1991 que teve início a pesquisa, a partir da mecânica clássica aplicada ao movimento expressivo do ator, que resultou no repertório de treinamento que deu origem à montagem do primeiro espetáculo da companhia, estreado no ano seguinte. Bonfanti já era integrante do grupo desde esse primeiro movimento e, como tal, participava da maioria dos encontros, inclusos os processos de treinamento e preparação de ator. Além do trabalho metodológico de elaboração dramatúrgica dos espetáculos, Bonfanti sempre colaborou, principalmente, com a concepção cênica dos espetáculos, tendo importância capital na escolha e definição dos espaços a serem ocupados a cada montagem, considerando suas características físicas, espaciais e técnicas para a iluminação, inclusive, e ainda com mais ênfase, nas situações de adaptação das peças para novos espaços. Essas adaptações, a exemplo de O Paraíso Perdido, cuja atividade durou cerca 12 anos com diferentes temporadas em São Paulo e apresentações em festivais no Brasil e no exterior, conduziram ao que Guilherme chama de "projeto aberto", ou seja, um projeto que poder ser revisto e modificado indefinidamente, tanto em seu conceito quanto nas soluções técnicas encontradas conforme se apresentavam novas condições, espaços e situações.

Partindo de pesquisas imagéticas, que permitissem relacionar a luz com as diferentes arquiteturas às quais as montagens do grupo eram propostas, Bonfanti lançou mão, principalmente, de sua intuição para vivenciar os espaços e explorar ao máximo suas potencialidades. Sobre os benefícios deste processo para seu próprio aprendizado, o iluminador ${ }^{167}$ admite:

... se olhamos do ponto de vista acadêmico ou do desenvolvimento da linguagem, o trabalho do Vertigem é muito mais rico e me possibilita muito mais coisas, porque me coloca em situações que me obrigam a dar saltos para poder conseguir vencer essas situações que aparecem. Nos outros trabalhos, é um ou outro me coloca em uma situação como essa, mas a maioria não, são trabalhos com soluções mais simples e

167 Em entrevista realizada como parte desta pesquisa, disponível nos anexos, p. 121-135. 
mais óbvias, no sentido de não ter grandes invenções (BONFANTI, anexos, p. 122).

A definição do tipo de equipamento e da presença discreta da luz, que permitiria a criação das atmosferas trabalhadas para as cenas, representaram suas primeiras inquietações a origem das reflexões de um trabalho que, apesar de coletivo e colaborativo, tinha, para ele, muito de pessoal e solitário, nos desafios e incertezas que o acompanhavam a cada trabalho. Intuitivamente, ele percebia a importância do aspecto sensorial que os espaços ocupados pelo grupo deveriam proporcionar ao espectador. Era fundamental, para ele, definir um caminho estético da luz que favorecesse a experiência proposta ao público pela encenação. Guilherme conta que, desde o primeiro espetáculo do grupo, as soluções, resultantes de incansáveis experimentações e referências estéticas, foram surgindo e se consolidando como procedimentos que viriam a ser usados, também, em todas as demais montagens. Sua escola foi o processo de tentativa e erro, entre acertos e incertezas, assim como a aprendizagem decorrente de cada trabalho, que o habilitou, progressivamente, para a continuidade do seu desenvolvimento profissional.

Guilherme Bonfanti ressalta a característica principal do trabalho colaborativo do Teatro da Vertigem como um importante disparador para a criação da luz. Ele explica que somente nesse tipo de processo é possível acompanhar os ensaios, experimentar novas fontes luminosas que interajam com os atores e as cenas de maneira integrada e coerente com a ação cênica e descobrir, a cada experiência, novas formas de iluminar, de migrar do todo para as partes e vice-versa, resinificando os espaços e conduzindo o olhar e 0 deslocamento físico do público. As características dos espetáculos e dos espaços arquitetônicos ou urbanos utilizados impunham novos desafios na descoberta de materiais e na construção artesanal de equipamentos alternativos, como lanternas, instrumentos hospitalares, postes de luz, entre outros explorados com maestria por Bonfanti e suas equipes a cada montagem. As soluções encontradas para resolver cada desafio, surgiam naturalmente e se tronavam procedimentos assimilados como procedimentos para os desenhos de luz dos próximos espetáculos do grupo. Com projetos em constante 
transformação, como alguns espetáculos, que tiveram longas trajetórias, 0 processo de experimentação e pesquisa de campo também foi se consolidando como processo fundamental para as criações de luz no Teatro da Vertigem.

Para realizar a iluminação de O Paraíso Perdido, Guilherme Bonfanti precisou absorver toda a carga imagética e conceitual do processo desenvolvido pelo grupo no campo dramatúrgico, ligado à fé e à religiosidade, e espacial, relacionado ao templo sagrado, integrando-se, de forma intensa e consistente, ao método, à temática e à ocupação do espaço, desenvolvidos pelo coletivo na elaboração do espetáculo.

O processo de elaboração de $O$ Paraíso Perdido começou no final de 1991 e se estendeu até novembro de 1992. No espetáculo, a companhia trata de questões metafísicas, como a perda de contato com plano divino, a nostalgia do paraíso e a busca de uma religação com o sagrado. Para tanto, inspira-se em relatos mesopotâmicos da criação, na gênesis bíblica e em textos apócrifos do livros de Adão e Eva e na obra de John Milton, Paraíso Perdido, poema que deu origem ao projeto (ARAÚJO et al., 2018, p. 315).

Ao entrar na igreja Santa Ifigênia, local escolhido para a montagem de 0 Paraíso Perdido, Guilherme percebeu que tudo o que havia aprendido sobre iluminação até então o ajudaria muito pouco (BONFANTI, 2015, p. 9). O conhecimento ligado à tradição do palco à italiana, com a estrutura da luz fixa no teto com varas e circuitos elétricos destinados a acomodar e esconder os equipamentos de luz do olhar do público, não teria muita serventia naquele templo, no qual ele não poderia usar ou expor os equipamentos tradicionais. Além disso, era importante valorizar, sem interferir, a arquitetura e as características do local, principalmente os vitrais. Foi preciso estudar e entender essa arquitetura com seus nichos, alturas e ângulos numa pesquisa, que ele classifica como empírica, do espaço e suas potencialidades. A prática de ficar observando o lugar por um tempo, deixando-se absorver por sua atmosfera, é descrita por Bonfanti como um processo de imersão e absorção das características e energias fornecidas pelo lugar ocupado a cada encenação:

Meu trabalho sempre foi contaminado pelo espaço e minha presença nele. Fico por muito tempo olhando a cena e o espaço, pensando nas possibilidades que ele me dá, sem saber que luz vou fazer, mas num processo de assimilação da atmosfera que ele tem, e a partir desta 
vivência e de um convívio com os ensaios vou construindo meu projeto (BONFANTI, 2012, p. 258).

De forma semelhante, o cenógrafo e iluminador tcheco Josef Svoboda também relata, a respeito da sua relação com o espaço:

É o espaço vazio do palco que me fascina mais. Eu o vejo a cada vez de forma diferente [...] Quando eu chego num teatro que eu não conheço, eu peço ao diretor técnico para deixar a cortina aberta depois do ensaio, me sento na orquestra e olho o espaço. É um momento formidável. Não acredite que eu penso [...] eu só olho, olho para o buraco. Da forma mais banal. Quem sabe haja algo a dizer sobre essa mania, mas eu não consigo me desvencilhar dela. Eu tenho a impressão de que se eu não o fizer, não vai funcionar...168 (SVOBODA apud RICHIER, 2019, anexo 1, p. 77)

As inquietações de Guilherme a respeito do ambiente e de sua integração com a encenação da peça, tiveram início quando ainda não havia nem texto nem dramaturgia definida para o espetáculo.

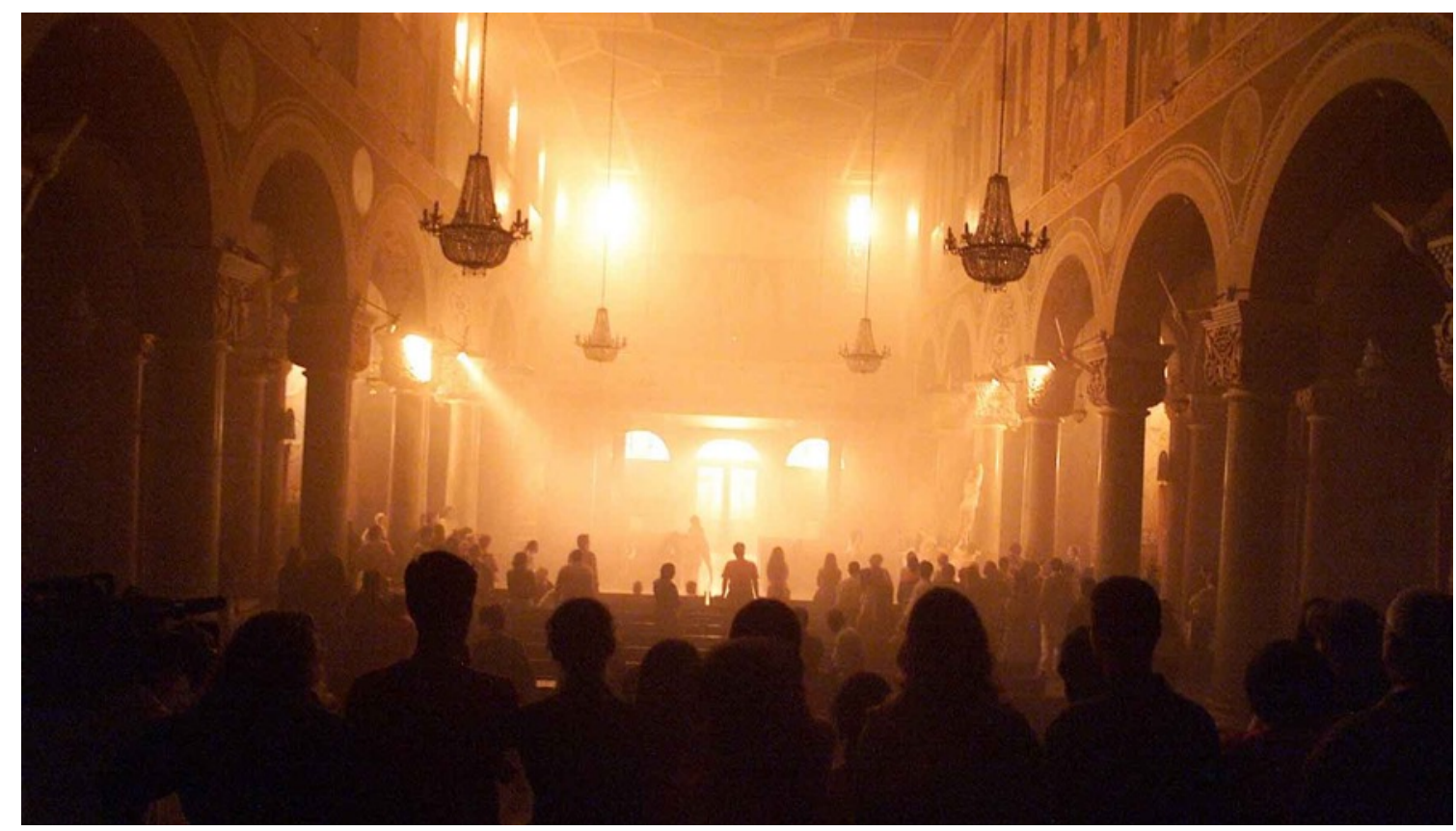

Figura 22 - Ambientação quente criada com fumaça e baixas intensidades da luz branca na Igreja Santa Ifigênia para o espetáculo O Paraíso Perdido. Roteiro de Antônio Araújo e Sérgio de Carvalho. Concepção e direção geral de Antônio Araújo. Luz Guilherme Bonfanti. Foto Otávio Valle.

168 "C'est l'espace vide de la scène qui me fascine le plus. Je le vois chaque fois différemment [...] Quand j'arrive dans un théâtre que je ne connais pas, je demande au chef plateau de laisser le rideau de scène ouvert après les répétitions, Puis je m'assieds à l'orchestre, et je regarde l'espace. C'est un moment formidable. Ne croyez pas que je pense [...] je regarde, je regarde le trou. Tout à fait prosaïquement. Peut-être y aurait-il à dire sur cette manie, en tout cas je n'arrive pas à m'en débarrasser. J'ai l'impression que si je ne le fais pas, ça ne marchera pas... » (tradução da autora). 
Considerando a ocupação do espaço como site specific, ele relata que "olhava para a igreja e achava que o público não podia entrar e ver refletores, os técnicos ou qualquer estrutura teatral. $O$ espectador tinha que vivenciar uma experiência, mesmo sabendo que era teatro" (BONFANTI, 2015, p. 9). Foi assim que surgiu uma característica estética importante para essa e outras luzes de Bonfanti para o Vertigem: todo equipamento ou artefato luminoso que fosse visível tinha que fazer sentido, dialogar, interagir e mimetizar-se naquele espaço. É quase como se fosse feita uma transposição do conceito para o universo da iluminação, buscando fazer uso somente de equipamentos, fontes e efeitos luminosos próprios ao ambiente ou local determinado para a encenação. Do contrário, todo equipamento tradicional, quando usado, deveria ser camuflado e escondido em nichos, frestas, colunas, no altar, nos confessionários, entre outros. A luz passaria a ter, assim, a sua especificidade relacionada à cena e à experiência do espectador.

Guilherme destaca que foi a arquitetura do espaço e a temática do espetáculo que conduziram às escolhas técnicas e estéticas da iluminação. $O$ desenho da luz de $O$ Paraíso Perdido, criado com inspiração nas ilustrações de Gustave Doré, foi criado com luz predominantemente sem cor, cujos fachos luminosos cortavam a igreja vindos de muito alto, ampliando a dimensão e a grandiosidade do sagrado que emana do templo religioso. O uso da fumaça e da luz branca (sem filtro), inspiradas no trabalho de Gerald Thomas, permitia, pela grande variedade de intensidades, a criação de diferentes colorações da luz, cuja temperatura tendia para tonalidades mais ou menos quentes, resultando num ambiente majestoso e impressionante, em contraste com as tonalidades mais frias, a exemplo das lanternas usadas no braço do anjo caído, que "colocava-o em outro plano, criando uma diferença estética entre sua figura e as demais personagens" (BONFANTI, 2015, p. 12).

Das ambientações gerais, Guilherme migra para a iluminação pontual de zonas espaciais, revelando parcialmente o espaço, na intenção de ressignificálo, conduzindo o olhar do espectador, num efeito que ele nomina como "revelação controlada", ou seja, uma "desconstrução da lógica do espaço" para 
fins dramatúrgicos e narrativos (BONFANTI, 2015, p. 11). Além de ocultar as fontes luminosas das vistas do público, Bonfanti também busca encontrar ou criar os materiais e as luminosidades adequadas para cada momento cênico. Numa persistente pesquisa prática, ele experimenta diferentes recursos com 0 objetivo de alcançar os efeitos e resultados desejados, cujo impacto estético corresponda ao imaginado por ele e por toda a equipe de criação.

Em seu estudo sobre a luz ativa, Fabrício Crisafulli (2019) atribui um uso performativo aos equipamentos e fontes luminosas alternativos. Ao classificar a luz ativa em diferentes modalidades, ele consagra a última delas a esse tipo de recurso. Segundo Crisafulli, uma dessas modalidades diz respeito às fontes luminosas usadas como objetos e elementos específicos e essenciais à construção do espetáculo. Em seu uso teatral, essa modalidade adquire destaque quando a importância dada a um equipamento ou fonte luminosa é oriunda das motivações ligadas às escolhas poéticas fundamentais da peça. Resulta dessa importância, também, a definição da posição das fontes luminosas no espaço e sua relação com a ação, não só dos performers, mas também dos cenários e objetos cênicos, cujo uso é elaborado no contexto da encenação, de forma a atribuir ao próprio equipamento um papel dramatúrgico (CRISAFULLI, 2019, p. 152). A exemplo do que é feito por Bonfanti em seu processo criativo, Crisafulli destaca, principalmente, o uso de equipamento alternativos e objetos luminosos não teatrais como característica do teatro que ele chama de teatro de pesquisa, no qual a busca por novas fontes e recursos resulta de investigações dramatúrgicas ligadas à essência de cada trabalho. Ao se apropriar das características arquitetônicas e emocionais de um determinado espaço, normalmente parte do cotidiano ou do imaginário de uma cidade e seus habitantes, o Teatro da Vertigem se apropria do conceito de site specific, no qual Bonfanti consegue estabelecer uma profunda relação entre os objetos luminosos que emprega e a cena.

Em um importante estudo sobre o emprego de equipamentos não convencionais no teatro, o professor, iluminador e pesquisador Francisco Turbiani (2012) ressalta o valor investigativo da experimentação de fontes 
luminosas diferentes e desconhecidas, nem sempre podendo prever seus resultados estéticos. Essa busca, realizada por um artista investigador ou iluminador pesquisador, como ele chama, tem o objetivo de descobrir novos usos para equipamentos luminosos preexistentes. O processo de criação artesanal decorrente desta busca, conduz a resultados únicos e exclusivos, muitas vezes com alto potencial performativo, pois que diretamente vinculados à cena e à concepção do espetáculo em questão, mas cujo contraste é imprevisível e sujeito tanto a bons quanto maus resultados.

O iluminador, ao trabalhar com equipamentos luminosos não-teatrais,
sejam lâmpadas desenvolvidas para o uso doméstico, industrial ou
comercial, ou mesmo refletores criados a partir de restos de sucata,
lida com algo novo, cujo resultado não pode ser antecipado com total
precisão. É somente através da avaliação de seus experimentos
práticos que apreende conhecimento sobre esses materiais e seus
possíveis usos na cena (TURBIANI, 2012, p.13).

O uso de equipamentos alternativos é, segundo Bonfanti, um dos principais responsáveis pela interação entre a iluminação e a visualidade dos espetáculos do Teatro da Vertigem (BONFANTI, 2018, p. 26). A busca da coesão e mimetização das fontes e dos equipamentos luminosos utilizados em cada um dos seus trabalhos com o grupo era fator fundamental e estrutural da criação dos projetos de iluminação.

O segundo trabalho realizado pelo grupo, O Livro de Jó, baseado na passagem bíblica homônima, narra a história do protagonista Jó, homem abençoado com riquezas, filhos e prosperidade. Devido a uma aposta entre Deus e Satanás, Jó terá sua fé testada (TURBIANI, 2012, p. 35) e sucumbirá à peste, substituída, nessa montagem, pela AIDS, o que justifica o uso de um ambiente hospitalar como site specific para a peça.

Espetáculo realizado a partir da adaptação de Luís Albert de Abreu do
texto bíblico homônimo do Antigo Testamento. O Livro de Jó foi
desenvolvido com a perspectiva de aprofundar elementos vivenciados
anteriormente, mantendo um processo criativo a partir dos
depoimentos pessoais dos atores. A dramaturgia mais formalizada de
Abreu trouxe ao grupo o universo da palavra. A exploração do
movimento coral abre espaço para a construção de personagens e as
experimentações corporais sobre as leis da física transformam-se em
treinamento de estados internos do ator. Foi a partir de determinadas
constatações/inquietações do grupo que surgiu a ideia de encenar o
texto bíblico em um hospital, espaço por excelência do pathos, do 
sofrimento, é uma espécie de lugar-tabu, lugar-purgatório que se elegeu para o enfrentamento da morte para a constatação inapelável da fragilidade humana (ARAÚJO et al., 2018, p. 316).

Segundo Turbiani (2012, p. 35), “a decisão de realizar o espetáculo dentro de um hospital desativado determina radicalmente a natureza da experiência cênica proposta e é fundamental para a compreensão das escolhas feitas pelo desenho de luz". Quando o grupo toma este tipo de decisão, muitas vezes abre mão de possibilidades e facilidades cenotécnicas e arquitetônicas em nome de significações subjetivas simbólicas, históricas e institucionais de espaços não convencionais, mas cuja relação dialógica com a temática e construção do espetáculo potencializa as questões propostas pela encenação e justificam a escolha por expor o público à concretude arquitetônica e ao imaginário do lugar escolhido.

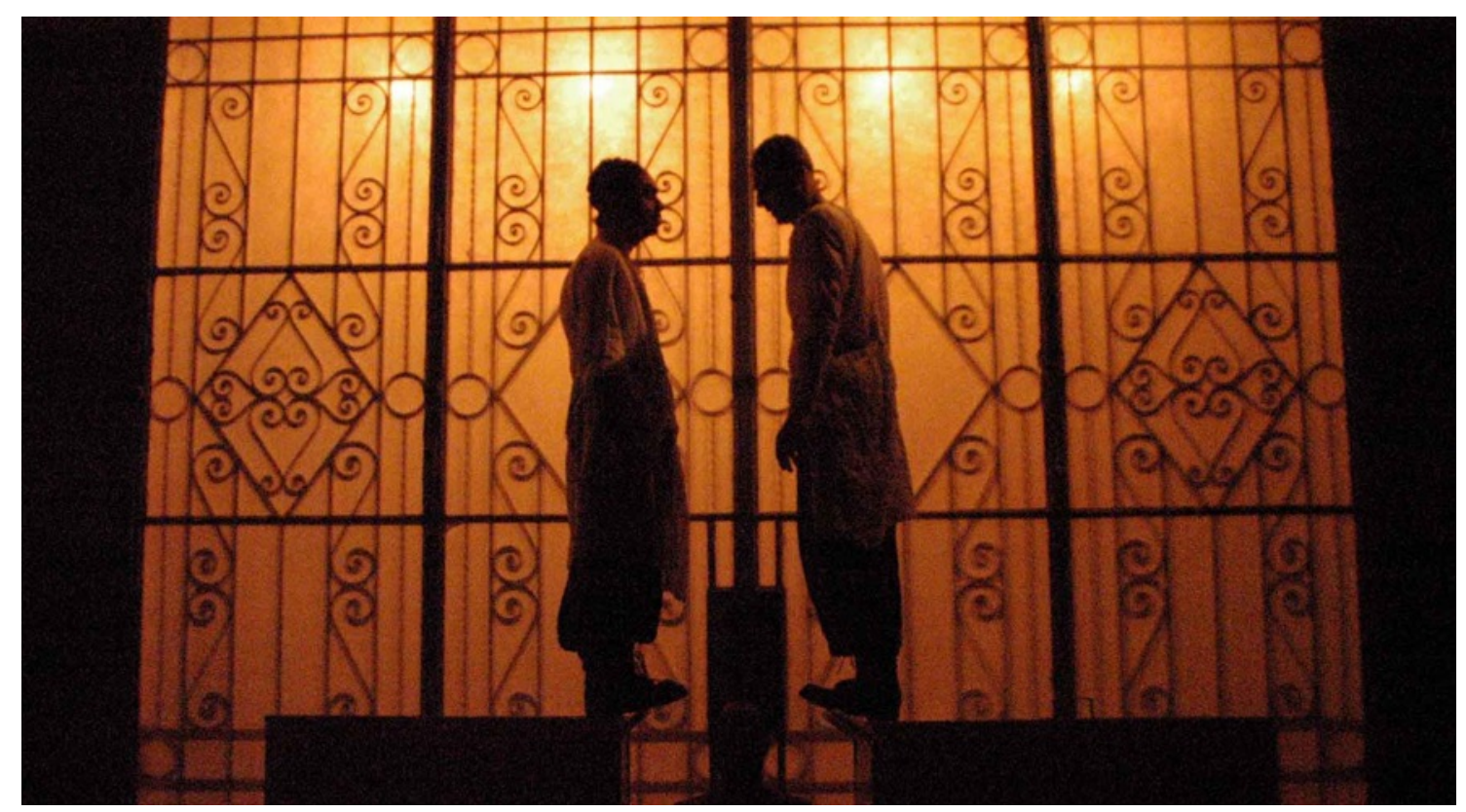

Figura 23 - Exploração da arquitetura e configuração do espaço para efeito de silhueta em cena do espetáculo $O$ Livro de Jó. Dramaturgia de Luís Alberto de Abreu. Concepção e direção geral de Antônio Araújo. Luz Guilherme Bonfanti. Foto Claudia Calabri.

Estes parâmetros acabam por impor, igualmente, à toda a equipe de criação, um mesmo rigor conceitual na busca da verossimilhança entre a realidade do espectador e a situação abordada pelo espetáculo. Bonfanti revela que, nestas circunstâncias, as fontes luminosas visíveis no ambiente hospitalar do espaço compartilhado igualmente por cenas e espectadores, não poderiam ser outras que não os equipamentos hospitalares, naturais àquele ambiente. Era 
importante, conceitualmente, que performers e espectadores sentissem a atmosfera do espaço sem que sua teatralidade fosse denunciada ou evidenciada por equipamentos de luz visíveis pelo público. Segundo ele, "a partir do momento em que Jó percebe e reconhece a sua doença, ele adentra o universo da AIDS" e precisa, assim, ser absorvido e envolvido pela arquitetura hospitalar. O mesmo deve acontecer com o espectador, possibilitando que ele "entre" na cena, sentindo-se parte dela e compartilhando-a com os atores.

Essa forte preocupação, despontada no processo criativo de $O$ Livro de Jó, acabou por determinar, segundo ele, uma estética constante em todos os trabalhos seguintes do grupo, cuja ambientação e marcação das cenas seria sempre acompanhada por maneiras específicas de iluminar, pela exploração da arquitetura local e pelo uso de fontes luminosas cuidadosamente escolhidas ou criadas para permitir a interação da luz com o espaço e as ações cênicas dos performers. Somente a participação constante nos ensaios e o profundo conhecimento das características, intenções e configurações da encenação, no todo e em cada uma de suas partes, poderia permitir tal engajamento, integração e atuação performativa dessa luz que, segundo o próprio Guilherme, não somente ilumina o espaço com "se torna o próprio espaço".

Para o iluminador, "os materiais acabam sendo uma 'imposição' do espaço, uma necessidade de dialogar com cada arquitetura e, a cada uma delas, responder com diferentes materiais/equipamentos" (BONFANTI, 2015, p. 6). A tentativa de aproveitar as experiências realizadas na igreja Santa Ifigênia no hospital Humberto Primo revelaram, para Guilherme, que não existem fórmulas prontas e que nada é dado no tipo de trabalho desenvolvido com o Vertigem. Segundo ele, é preciso sair da zona de conforto e buscar, a cada vez e a cada experiência com um novo espaço, diferentes fontes luminosas e soluções originais adaptadas à atual situação. Bonfanti afirma que "é esse encontro com o novo, com uma realidade desconhecida, com a falta de preparo técnico para enfrentar as situações que se apresentam, que vai resultar em um projeto exitoso" (BONFANTI, 2015, p. 12). 
O Livro de Jó tinha um primeiro segmento que se passava no deserto, onde os personagens eram apresentados e a cena se desenvolvia até o momento em que Jó era banhado em sangue e se reconhecia doente, Propus para a cena um iluminação com muita fumaça, tentando repetir algo que havia "dado certo": fachos, atmosfera onírica, distorção da arquitetura. Errado: Antônio Araújo imediatamente me alertou para a importância de que pudéssemos ver o espaço e entender que aquela ação se passava em um hospital. O público não poderia perder aqueles elementos de vista em nenhum momento. $\mathrm{O}$ espaço deveria estar presente desde o início e sem camuflagem. Começava ali um duro aprendizado: o que eu poderia trazer do espetáculo anterior para aquele? Procedimentos sim, mas não os resultados estéticos alcançados (BONFANTI, 2015, p. 12-13).

Uma das características fundamentais da performatividade, segundo Féral (2015) encontra-se no caráter de novo e de irrepetível. Quando relacionado com a atuação do ator ou do performer, essa afirmação se refere à originalidade e ao improviso presentes na performance. No entanto, no que diz respeito à criação da luz performativa, ou talvez, da criação performativa da luz, é possível considerar, como caráter de novo, cada uma das novas experiências criativas do iluminador, na condição do artista que elabora, assim como o ator, por meio do exercício, do ensaio, da repetição e da experimentação, seus recursos luminosos cênicos e performativos.

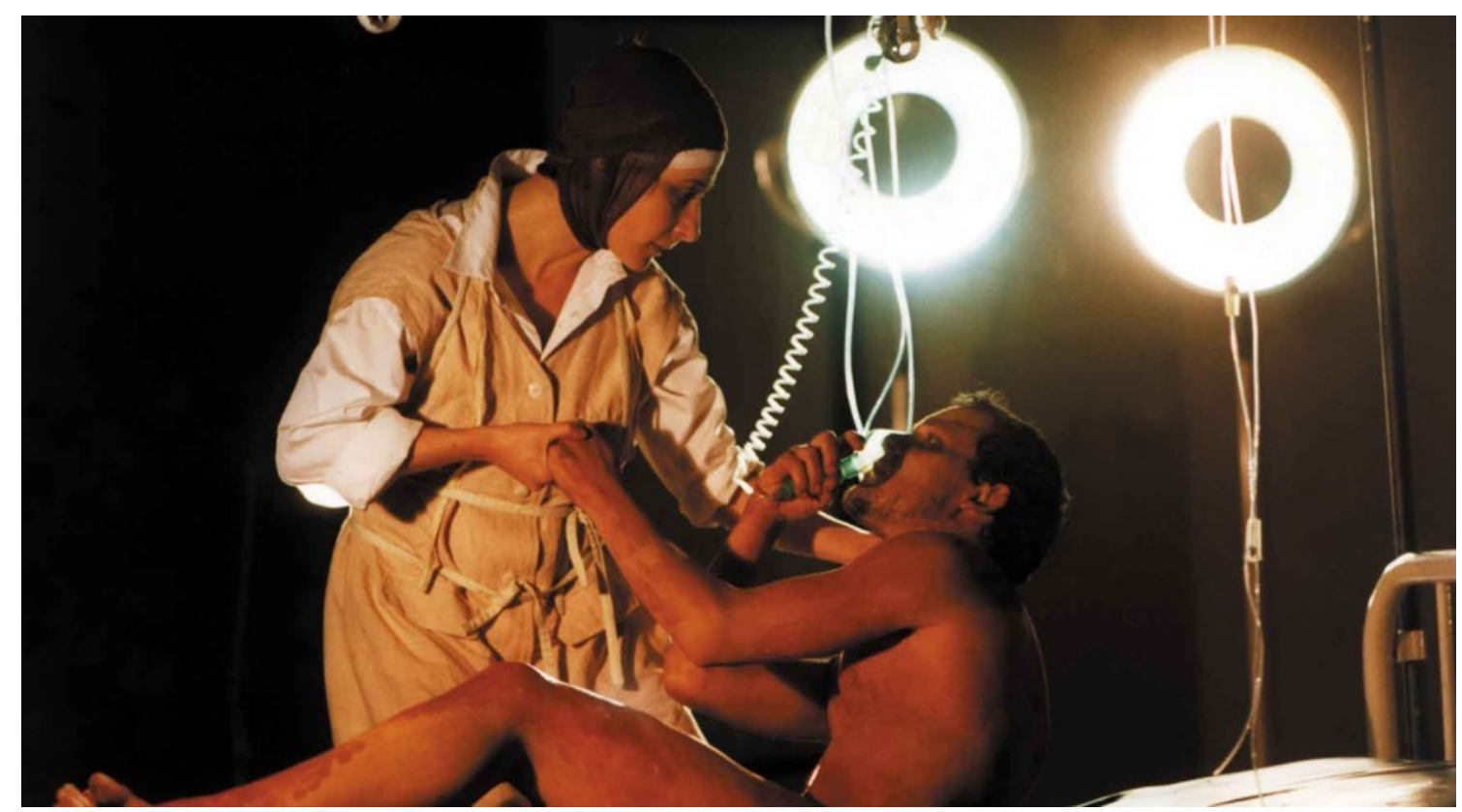

Figura 24 - Uso de equipamentos luminosos hospitalares para iluminar e ambientar as cenas de O Livro de Jó. Dramaturgia de Luís Alberto de Abreu. Concepção e direção geral de Antônio Araújo. Luz Guilherme Bonfanti. Foto Eduardo Knapp.

Ao transformar equipamentos hospitalares luminotécnicos, descobertos no ambiente hospitalar, em refletores cênicos, Guilherme fazia com que, ao 
mesmo tempo em que iluminassem, eles e seus efeitos também interagissem visualmente com os performers e com as cenas. Foram utilizados negatoscópios, olhos cirúrgicos, luminárias flexíveis, entre outros materiais encontrados abandonados no porão do hospital desativado. Alguns equipamentos foram usados na sua forma e com a fonte luminosa (lâmpada ou outro tipo de luz) original, enquanto outros tiveram que ser transformados e adaptados para corresponder ao efeito desejado. Foram feitas trocas de lâmpada para aumentar ou diminuir a luminosidade, para direcionar ou difundir o facho luminoso e para atender melhor às necessidades das cenas. "Tudo se dava de maneira muito simples: as cenas iam transcorrendo, e eu ia distribuindo equipamentos pelos corredores, iluminando a cena, avaliando os resultados obtidos. Foram três meses de correria e muito trabalho, trocando lâmpadas, fios, soquetes e adequando as luminárias às necessidades do trabalho" (BONFANTI, 2015, p. 13). Segundo o iluminador, aparelhos normalmente utilizados para ver radiografias, iluminar intensamente partes do corpo ou realizar procedimentos cirúrgicos passam a iluminar a cena e a exercer a função de refletores (BONFANTI, 2002 apud TURBIANI, 2012, p. 42-43)

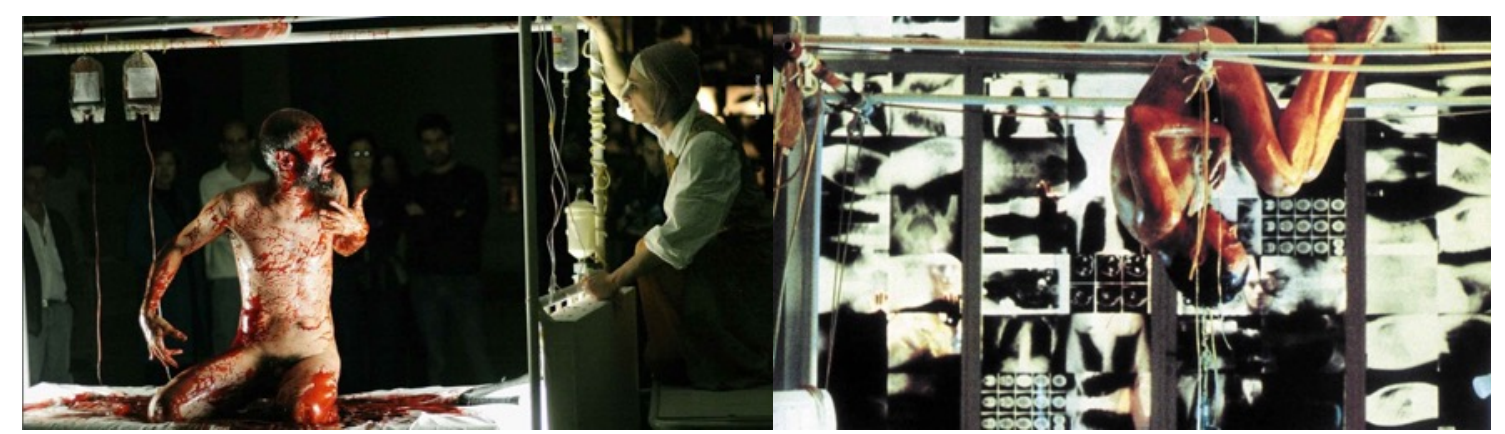

Figura 25 - Uso do negatoscópio nas laterais da maca e de radiografias reais iluminadas pela contraluz na cena da condenação em O Livro de Jó. Dramaturgia de Luís Alberto de Abreu. Concepção e direção geral de Antônio Araújo. Luz Guilherme Bonfanti. Fotos de Guto Muniz e Lenise Pinheiro.

Turbiani ressalta que "na luz criada por Bonfanti para O Livro de Jó, os equipamentos utilizados eram, em sua maioria, não teatrais. Alguns refletores de teatro até eram utilizados, porém sempre buscando que somente seu efeito luminoso fosse visível pelo público através de janelas ou portas, mas nunca o refletor em si” (TURBIANI, 2012, p. 39). Com o objetivo de não criar ruídos visuais com equipamentos tradicionais, Bonfanti utilizou ainda lâmpadas 
comumente usadas na iluminação arquitetônica como lâmpadas dicroicas, PAR 30 ou fluorescente tubulares adaptadas e instaladas discretamente, algumas ocultas e outras às vistas do público, mas sem que isso representasse um contraste com o aspecto visual geral do espetáculo. Além disso, como explica Turbiani, a luminosidade produzida por essas lâmpadas resultava, pelo seu índice de reprodução de cor (IRC), numa atmosfera fria, impessoal e asséptica que conferia, tanto aos performers quanto aos espectadores, uma mesma aparência pálida e doentia.

As soluções luminosas encontradas pelo iluminador, no entanto, tanto as tradicionais quanto as alternativas, nunca eram definitivas, pois a adaptação da luz para novos espaços representava, sempre, a necessidade e oportunidade de redimensionamento dos materiais e efeitos. A cena final do espetáculo, quando Jó caminha ao encontro de Deus, por exemplo, feita na primeira montagem com muita fumaça e uma bateria de 24 PAR64 adaptadas em uma luminária cirúrgica, cujo efeito o fazia desaparecer no excesso de luz, foi substituída, numa remontagem, por um refletor $\mathrm{HMI}$ de 5000W, cuja luz intensa dispensava o uso da fumaça. Ocupar novos espaços também permitia descobrir novos materiais, como as luminárias flexíveis, encontradas em um hospital chileno no qual o espetáculo foi apresentado, que substituíram as dicroicas com cano de cinefoil, usadas em diversas cenas, que eram bastante difíceis de fazer e instalar.

Além da materialidade performativa da luz, representada por todos esses artefatos luminosos, a operação da luz do espetáculo, realizada de forma sutil, sem que o público tenha contato visual ou consciência da presença do operador de luz, contribuía para a condução orgânica dos espectadores pelos corredores e salas do hospital adaptado para a encenação. "A movimentação do público pelo hospital e a via-crúcis de Jó são guiadas, passo a passo, pela luz. No fim, sem sabermos se em redenção ou maldição extrema, Jó se encaminha para a luz e é engolido por ela" (FORJAZ, 2010 apud TURBIANI, 2012, p. 48). A luz criada por Guilherme Bonfanti para a peça, segundo Turbiani, consegue traduzir os principais conceitos propostos pela obra. Ela cria uma ambientação favorável à participação do espectador que, envolvido pela cena, não percebe 
racionalmente as mudanças de luminosidade, sendo simplesmente conduzido pelo acender e apagar das luzes numa "experiência físico-sensorial na qual os limites do real e do ficcional se tornam turvos" (TURBIABI, 2012, p. 48).

A realização do terceiro espetáculo da Trilogia Bíblica representou a consolidação de muitos procedimentos descobertos durante a criação da luz das duas peças precedentes. Apocalipse 1,11 permitiu a aplicação de conceitos e práticas dramatúrgicas recorrentes como a exploração do espaço, a interação direta com o público e a exploração de uma temática atual e pungente.

No segundo semestre de 1998 o Teatro da Vertigem deu início a seu próximo projeto, a criação de Apocalipse 1,11 a partir do texto bíblico $O$ Apocalipse de João. $O$ final do milênio parecia indicar o fim dos tempos e o início de uma nova era, o terror da aniquilação total e a utopia de uma nova civilização. Daí o interesse em investigar essa zona de tensão, em que atos terroristas, crimes em massa, guerras étnicas estão na ordem do dia. A violência gratuita lança o grupo na região do absolutamente incompreensível e do confronto com a questão do Mal. A crença no fim dos tempos parece dizer respeito não apenas à ansiedade provocada por uma data no calendário, mas à nossa própria condição individual. À percepção subjetiva da passagem do tempo, do envelhecimento e da morte que cada um de nós vivencia, mistura-se um sentimento coletivo, uma consciência universal sobre o confronto com a transitoriedade. Um final de milênio parece nada mais fazer do que intensificar e ampliar essas percepções, quando o Teatro da Vertigem entra em choque turbulento com o imaginário da prisão (ARAÚJO et al., 2018, p. 317).

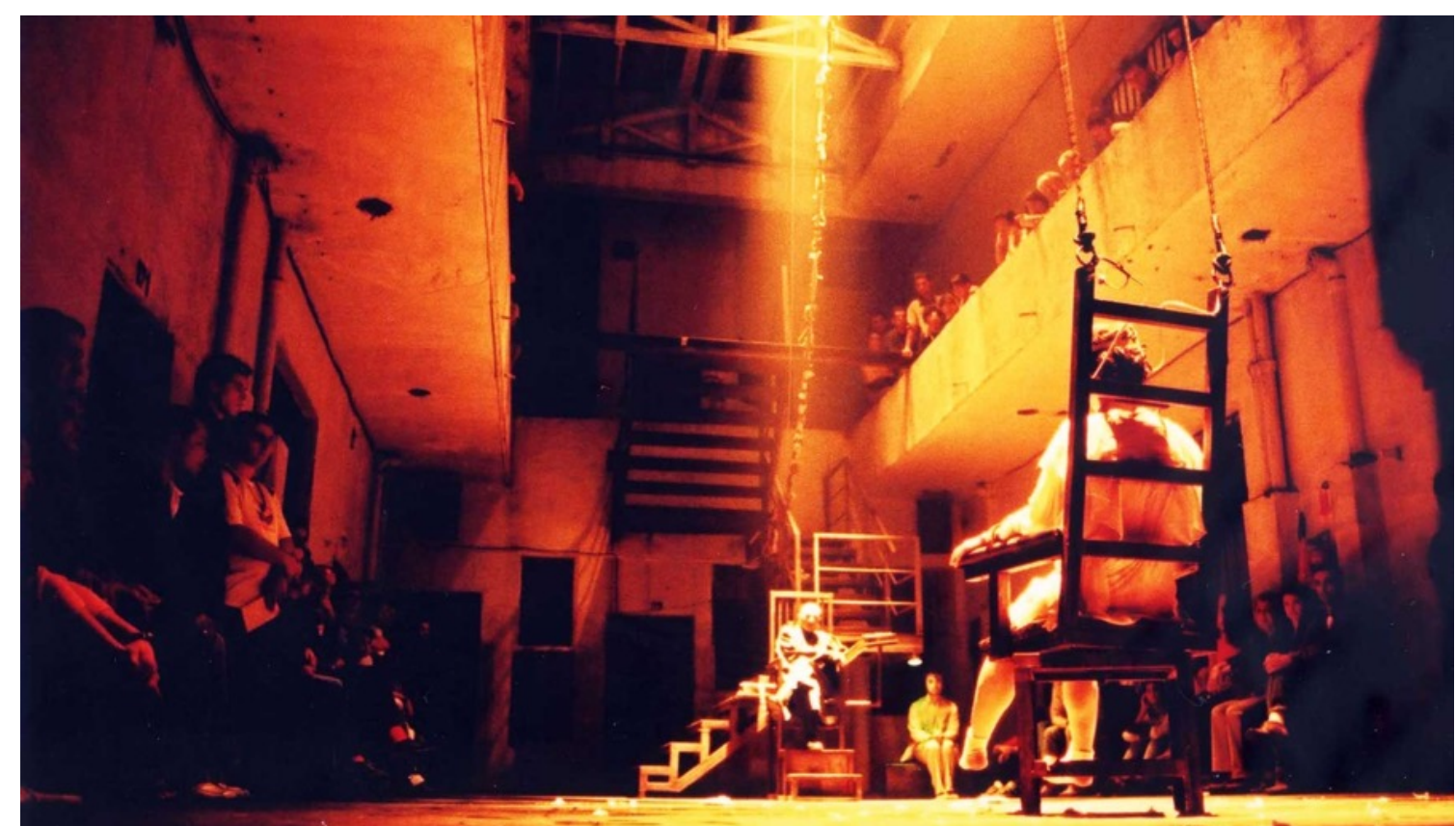

Figura 26 - Relação próxima entre a cena e o público favorece a interação e a atuação performativa da luz no espetáculo Apocalipse 1,11. Dramaturgia de Fernando Bonassi. Concepção e direção de Antônio Araújo. Luz Guilherme Bonfanti. Foto Edouard Fraipont. 
No que diz respeito à iluminação, práticas como a utilização de fontes alternativas, camuflagem dos equipamentos tradicionais, não visualização, pelo público, dos materiais, da instalação e do operador de luz, entre outras, foram repetidas por Guilherme e sua equipe. Foi criado, para a realização do projeto de luz do Apocalipse 1,11, um grupo de trabalho multidisciplinar, procedimento que se revelou essencial, pelo caráter experimental e investigativo do trabalho, exercitado nas pesquisas de campo. O processo foi iniciado com visitas a locais relacionados com a nova temática como motéis de alta rotatividade, boates decadentes, tribunais e delegacias, de onde surgiu a fundamentação conceitual do projeto de iluminação. Exercícios e experimentos luminosos com diferentes materiais e fontes eram testados nos ensaios com os atores e o restante da equipe de criação, ao mesmo tempo que eram propostos, pelas equipes correspondentes, adereços, figurinos e elementos cenográficos.

O espetáculo $B R-3$ foi produzido exatamente seis anos depois da conclusão da trilogia bíblica e da consequente consagração da companhia, firmando o processo criativo colaborativo exercitado pelo grupo nas três primeiras realizações como uma de suas mais importantes características. Desde o primeiro encontro para a montagem deste novo projeto, realizado para definir seu tema, o iluminador e a luz já estavam presentem no processo. A criação conceitual de $B R-3$ foi resultado de um longo processo de pesquisa teórica e seminários com a participação do escritor Bernardo de Carvalho, escolhido pela companhia para fazer a dramaturgia, resultante do processo colaborativo do grupo, como é sua prática usual. Definidos os lugares a serem retratados pela encenação: Brasília, Brasilândia e Brasiléia, teve início o processo de pesquisa, realizado inicialmente em São Paulo, com duração de um ano e meio e a participação de geógrafos, sociólogos, urbanistas, críticos de arte, arquitetos, juristas, teólogos, entre outros. $\mathrm{O}$ objetivo desses encontros era entender os espaços analisados e traçar a cartografia das afinidades e similitudes, para definir o fio condutor do espetáculo. do país, e por isso mesmo endógeno e umbilical. Tal parábola - que pode ser pensada tanto como curva quanto como narração alegórica - 
se inicia no quase litoral, passa pelo Planalto Central e se embrenha nos seringais da selva amazônica. Esse "percurso para dentro", esse movimento centrípedo, percorre desde uma quase fronteira litorânea a uma fronteira continental (Brasil-Bolívia). Materializa uma cartografia tripartida periferia-centro-periferia. Daí tal investigação colocar o grupo diante dos paradoxos e dos limites do que é percebido como centro e periferia. Se São Paulo é um dos principais polos urbanos do país e uma das áreas mais populosas do mundo, Brasilândia faz parte do conjunto de seus bairros periféricos. Se do ponto de vista cultural a cidade tem a melhor infraestrutura do país, é, paradoxalmente, a campeã nacional em moradias precárias. Brasilândia/São Paulo é, a um só tempo, centro e periferia. Por outro lado, se Brasília é a capital do Brasil, o centro do poder político nacional, por outro, é uma cidade ainda em busca de si própria, da construção de sua identidade, satélite de si mesma e de sua grandiloquente arquitetura, utopia artificialmente forjada de um Brasil moderno em contraste com a realidade arraigada de um Brasil arcaico. Se, quinhentos anos depois, já não podemos descobrir um Brasil, que ao menos possamos descobrir um certo Brasil. Mais que um mapeamento ou reconhecimento de um caráter, identidade ou país, esperamos que tal jornada sirva como norte, como farol, como bússola para a criação e recriação - de identidades e territórios (ARAÚJO et al., 2018, p. 318-319).

Guilherme descreve a encenação de BR-3 como sendo "um dos trabalhos mais complexos da companhia: do início até a estreia foram exatos três anos de preparação, sempre tendo a luz presente e atuante" (BONFANTI, 2011, p. 112). Já no início da pesquisa teórica ele definiu uma equipe de colaboradores voluntários, estagiários e aprendizes, como se tornou comum em suas criações, nas quais o trabalho em equipe e o processo de aprendizagem são bastante valorizados. A pesquisa de campo foi uma etapa muito significativa do processo, na qual Guilherme pode conhecer os lugares a serem retratados pela dramaturgia do espetáculo, sua luminosidade e atmosfera. Do convívio estabelecido, no período de um ano, com o bairro paulista da Brasilândia, onde Guilherme realizou também uma oficina de luz, surgiu o conceito de precariedade, que norteou boa parte do processo de criação da luz. A precariedade, para Bonfanti, "passa por materiais, estrutura, condições financeiras, preparo técnico e natureza dos espaços ocupados nos espetáculos" (BONFANTI, 2015, p. 6). Intercaladas com a experiência no bairro da Brasilândia, foram realizadas visitas às duas outras cidades do projeto, Brasiléia e Brasília, das quais não interessava a Guilherme...

... reproduzir uma cópia fotográfica, mas sim poder olhar para essa realidade e transformá-la em linguagem de luz, luz para teatro, feito na cidade, não em um palco. [...] Meu foco e interesse estavam voltados 
para conhecer esses lugares que não habito, Brasília e Brasiléia, uma vez que já estava trabalhando em Brasilândia. Desses fins de tarde, vendo o pôr-do-sol no eixo monumental em Brasília, da ida ao Vale do Amanhecer, da visita ao congresso, do céu com sua visibilidade absurda, muito azul e branco, do caminhar sem destino certo, surgiu a luminosidade de Brasília. No Acre, tínhamos a floresta e o desmatamento como um dos elementos mais fortes. Desta convivência surgiu o verde como símbolo do Acre. No meio disso tudo, a fé, presente nos crentes evangélicos da Brasilândia, nas comunidades místicas de Brasília e no Santo Daime, no Acre (BONFANTI, 2011, p. 112-113).

No início da fase que ele chama de construção dramatúrgica da luz, mais do que já ter em mente um projeto de luz definido, eram as inquietações com a realidade do país, a impotência e a consciência das dimensões e diferenças existentes que ocupavam seus pensamentos. Incorporando, neste momento, o grupo de estagiários que participaria do processo de criação e montagem, Guilherme iniciou um processo de workshops com o restante da equipe criativa, fez registros fotográficos, em vídeos e textos e realizou reuniões, discussões e experimentos práticos com fogo, carbureto, LEDs, lasers, espelhos, sombras e outros materiais. Em seguida, algumas dessas experiências foram empregadas nos ensaios, que aconteciam paralelamente a esse processo.

Guilherme destaca como fundamental para os resultados alcançados a abertura, concedida pelo diretor Antônio Araújo, para a participação da equipe de iluminação desde o início do processo de elaboração do roteiro da peça, realizado com o elenco, o diretor e o dramaturgo. Com isso, as experiências com equipamentos e fontes luminosas passaram a acontecer de maneira diretamente associada às cenas em desenvolvimento, porém ainda na sala de ensaio e não no espaço onde efetivamente seria realizado e espetáculo. "Isso nos trouxe alguns problemas, pois nosso olhar já tem que se materializar em algum espaço, temos que iluminar uma cena. [...] Em compensação, objetivou a pesquisa e a direcionou. A vivência na sala de ensaio nos trouxe uma intimidade com o roteiro e um conhecimento mais aprofundado das cenas." (BONFANTI, 2011, p. 114). Para resolver essa dificuldade de visualização do espaço real da cena, a equipe de iluminação realizou uma visita ao local, já definido, da apresentação do espetáculo. As impressões e sensações provocadas na equipe pelo primeiro 
passeio pelo rio Tietê, realizado propositalmente no período noturno, foram relatadas por Guilherme:

Tudo o que choca na visita diurna, aqui toma outra dimensão. O rio vira poético; sim, é isso mesmo, navegar em suas águas fedorentas e borbulhantes traz o mistério de navegar em outro rio qualquer. $\mathrm{Na}$ medida em que o barco desliza tomamos contato com uma cidade que não conhecemos, observada por uma perspectiva nunca experimentada até então. $O$ rumor dos carros em alguns pontos fica bem distante, a luminosidade é variável, de uma penumbra quase sem luz, a uma penumbra clara. Tudo num tom de amarelo, um sépia do vapor de sódio. A mistura da escuridão das águas com o vapor de sódio cria uma atmosfera de mistério. Os carros que passam sem parar criam um outro rio, é um movimento constante de faróis de veículos. Variam suas luminosidades e cores, suas alturas (caminhões, carros de passeio). Existem alguns pontos de observação em que a sensação é de água corrente, em forma de luz. Os reflexos da cidade nas águas criam imagens distorcidas, alongadas e algumas absolutamente definidas. Os postes com o vapor de sódio são linhas que se repetem ao longo do rio. Alternam-se com estas linhas desenhos brancos/azulados, verdes de neons, prédios se projetam na água reproduzindo imagens das margens. Ao passar embaixo dos viadutos temos um outro universo. Silêncio e escuridão se aliam à monumentalidade de algumas linhas que cruzam o céu, linhas de concreto. Umas claras, outras escuras, negras. Ainda embaixo dos viadutos temos nichos que revelam outro mundo, são nichos, planos, buracos. Neles há sinais de vida, alguém recentemente habitou este lugar, ou ainda habita (BONFANTI, 2011, p. 115).

Apesar de ainda não estar exatamente concentrado na definição do projeto de iluminação propriamente dito, o iluminador sentia que havia um certo delírio de sua parte, um pensamento muito grandioso, que ia além das condições de produção do espetáculo. Neste momento, ele percebe com que elementos da iluminação existente no local, a atuação da luz que irá criar deverá dialogar. Essa relação, a ser estabelecida entre esses dois fenômenos luminosos, é um dos caráteres performativos mais intensos da iluminação do espetáculo $B R-3$, pois além de contracenar com os atores e os espectadores, ela estabelece uma forte relação com o entorno, que Schechner chama de environment e que envolve todos os partícipes, voluntários ou não, da encenação.

A luz urbana presente nesse entorno não só teve que ser considerada, quanto explorada na criação da luz do espetáculo. Efeitos como a iluminação de vapor metálico e misto da iluminação pública, as luzes dos veículos, em constante movimento, as lâmpadas que iluminam as embarcações, os leitos do rio e as atividades de limpeza e manutenção, "silhuetados pelos postes das 
ruas", como descreve Guilherme, os viadutos e as fogueiras feitas por seus moradores com seus reflexos, formas, imagens e movimentos projetados nas águas do rio são alguns desses elementos com os quais a equipe teve lidar e interagir. Bonfanti conclui que o ambiente urbano está dado e é nele que serão construídas as imagens do espetáculo "a cidade é nosso pano de fundo, nosso cenário, e já vem iluminado, cuidemos na cena.” (2011, p. 118).

A permeabilidade e as fronteiras difusas entre as diversas áreas de criação do espetáculo, como a própria direção de cena, a dramaturgia, a atuação, os figurinos e a sonoplastia é um outro aspecto característico do desempenho performativo a ser exercido pela iluminação. A influência mútua e transversal entre os artistas e suas criações se prolonga para além do trabalho de pesquisa e avança para a fase de definição das cenas que compõem o espetáculo, resultando num período muito intenso e de muita criatividade, segundo Guilherme. Com essas definições, a luz finalmente começa a ganhar forma, através de ideias que se consolidam em atividades práticas de criação de novos equipamentos, experiências e pesquisas sobre materiais, eletricidade e diferentes tipos de lâmpadas que poderiam ser usadas na construção artesanal de novos artefatos luminosos. Alguns conceitos nortearam os próximos passos da criação, revelando a preocupação da equipe em relacionar fortemente os efeitos de luz com as ações cênicas, determinando sua atuação performativa durante o espetáculo.

O mais importante argumento era dado pela inter-relação entre os três Brasis retratados no espetáculo: Brasilândia, que nasce da destruição, mas é delírio expressionista; Brasília, que nasce destruindo e Brasiléia. A partir deles, cores e formas vão se definindo na relação com os lugares, personagens e situações, a exemplo da sombra da Helienai, que a acompanha; o laser vermelho para Wanda; os reflexos para Douglas; a necessidade de destaque para algumas cenas; o acompanhamento de determinadas trajetórias e assim por diante. Sem se deixar levar pelo belo e pelos efeitos gratuitos, Guilherme procura elaborar um repertório de possibilidades, analisando o que dialoga com a direção de arte e com o texto, pensando sempre no que é essencial para criar a atmosfera de 
cada cena. Foram mais oito meses de montagem e instalações para adaptar as ideias elaboradas à realidade do rio e da cidade. O espetáculo, cujo início acontecia numa embarcação que recebia o público e acompanhava a saga dos personagens pelas águas turvas da aventura, impressionava e surpreendia, a cada apresentação, tanto espectadores quanto artistas envolvidos no processo.

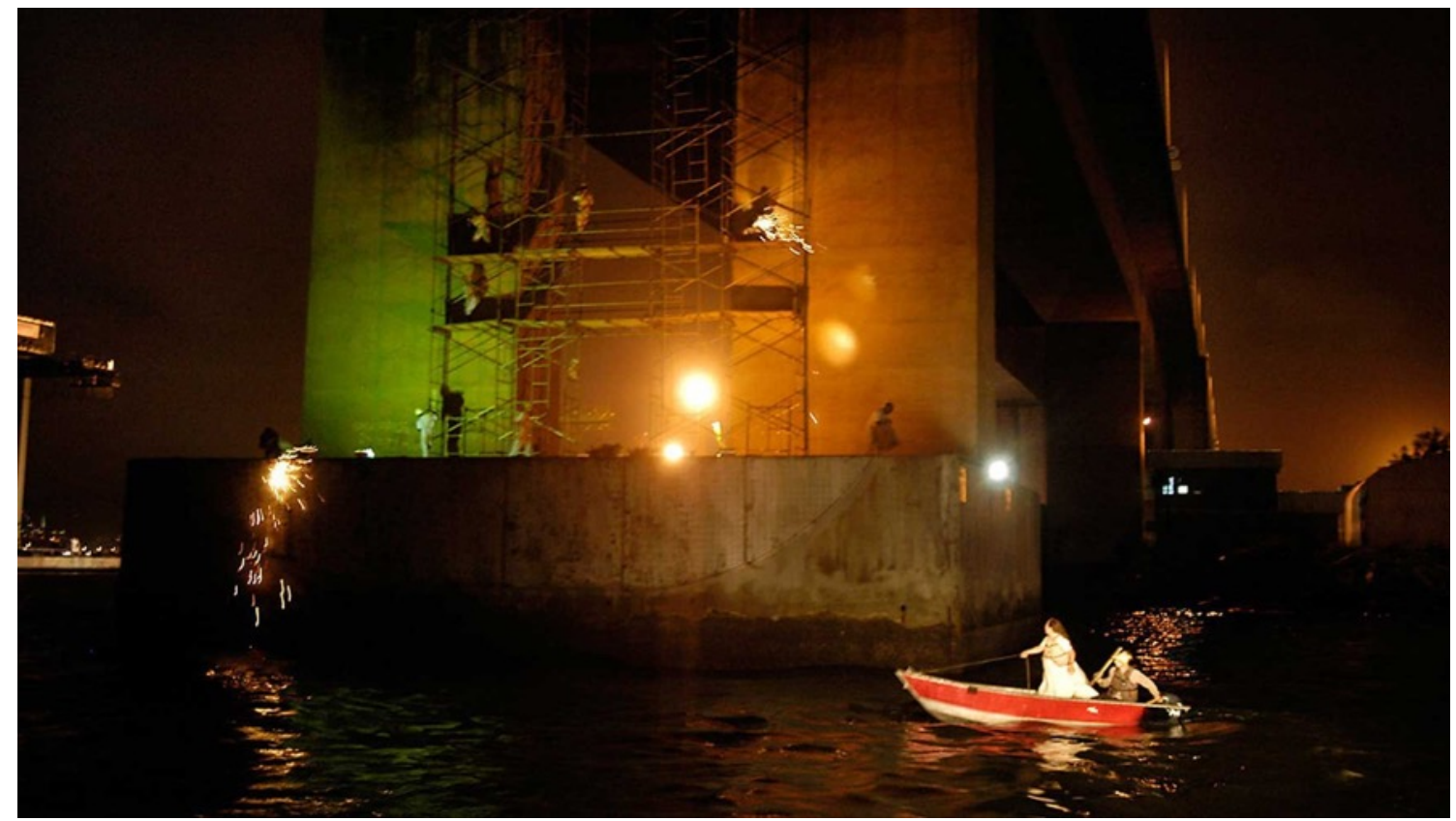

Figura 27 - Interação da cena com o entorno na remontagem da peça BR-3 no Rio de Janeiro durante o Festiva RioEncena, lâmpadas de vapor metálico e destaque dos personagens em movimento. Dramaturgia de Bernardo de Carvalho. Concepção e direção geral de Antônio Araújo. Luz Guilherme Bonfanti. Foto RioEncena.

Ao final do período de criação das quatro primeiras peças, entre 1991 e 2006, Bonfanti relata ter encontrado o método de trabalho que se tornou "um procedimento que consolidaria uma maneira de pensar e atuar nos processos de criação de luz da companhia" (BONFANTI, 2011, p. 110). Alguns elementos são destacados por ele como elementos constitutivos deste processo, cujos princípios e características são: construção artesanal dos equipamentos e materiais luminosos, procedimento de experimentação e testes, observação do funcionamento e do contraste entre a luz natural e a luz artificial e uma extensa pesquisa teórica e prática de campo e dos materiais a cada nova situação.

Outro ponto importante destacado por Bonfanti (2011, p. 111) é a construção de uma dramaturgia da luz, cuja pretensão, segundo ele, está na busca da criação de uma linguagem autônoma para a iluminação, com base 
numa verossimilhança no uso de artefatos luminotécnicos específicos, na noção de risco, característica dos trabalhos do grupo, da instabilidade dos processos, da condução da ação e do olhar e da luz como elemento ativo da cena.

Essa função dramatúrgica da luz, também citada, entre outros, pela iluminadora Nadja Naira169 a respeito de suas criações para a companhia brasileira de teatro (NAIRA, anexos, p. 178), tem seu surgimento, segundo a iluminadora e pesquisadora francesa Christine Richier (2019), nas últimas décadas do século XX, com o surgimento, na França, de uma primeira geração de iluminadores como André Diot e Jean Kalman. Ela destaca que, apesar do termo 'dramaturgia da luz' começar a ser empregado por artistas e teóricos e não se ter, na época, uma noção exata do que contemplava, ele certamente "elevava o profissional da iluminação ao mesmo nível do cenógrafo e do diretor na equipe artística da produção de um espetáculo, mais do que o associar à equipe técnica como no restante da Europa"170 (RICHIER, 2019, p. 2). Guilherme Bonfanti conquistou, com seu trabalho e intensa participação criativa, desde o surgimento da companhia, esse lugar de capital importância no grupo e em cada um de seus processos criativos.

O último espetáculo do Teatro da Vertigem a ser analisado nesta pesquisa é a peça Bom Retiro, 958 metros, um espetáculo que invade as ruas do bairro paulistano do Bom Retiro em um percurso de 958 metros de distância percorridos pelo público. A encenação retrata, em relação dieta com a cidade e o espaço urbano, o trabalho, as angústias e a situação de vida de imigrantes legais e ilegais que o habitam em diálogo com temas como a moda e a sociedade de consumo.

O trabalho tem como ponto de partida o desejo de fazer do espaço urbano um campo de experimentação artística. O que se compartilha com o público é uma criação dramatúrgica e cênica resultante da experiência de imersão do grupo no bairro do Bom Retiro. Na fase de preparação, deram-se os primeiros estudos teóricos o foram realizados três ciclos de palestras abertas ao público. Em um segundo momento

\footnotetext{
169 Em entrevista realizada como parte desta pesquisa, disponível nos anexos, p. 164-178. 170 «... hissait le praticien de la lumière aux côtés du scénographe et du metteur en scène dans l'équipe artistique de la production d'un spectacle, plutôt que de l'attacher à l'équipe technique comme dans le reste de l'Europe » (tradução da autora).
} 
foram realizadas as visitas de reconhecimento e as derivas, bem como as entrevistas e o trabalho prático, com improvisações e workshops, que compuseram a etapa da pesquisa de campo. Tal percurso foi revelando e, simultaneamente, delineando os principais eixos de investigação do trabalho: a moda, a imigração, o consumo e as relações de trabalho no contexto do bairro que se destaca por exercer, ao longo de sua história, o papel de significativa porta de entrada da cidade. Trata-se de uma área geográfica que, além de ser lugar de passagem, singulariza-se pela combinação e pela tensão entre as diferentes etnias que aí permanecem e coabitam, sobretudo judeus, coreanos e bolivianos. À medida que se intensifica a vivência do grupo no bairro e a experiência ganha expressão em forma de material cênico, tal fricção produz esboços de personagens, imagens $e$ situações que criam o substrato dramatúrgico a ser desenvolvido na confecção do texto. No espetáculo, que é ao mesmo tempo, intervenção e deambulação cênica, o público se desloca pelo bairro e o grupo partilha com ele um pouco de suas descobertas e incertezas (ARAÚJO et al., 2018, p. 324).

Em artigos publicados depois da criação da iluminação da peça Bom Retiro 958 metros, Guilherme Bonfanti relatou algumas das suas inquietações, nada surpreendentes, por começar um novo projeto da companhia. Ele escreveu sobre semelhanças e pontos em comum relativos à iluminação, especificamente, entre esse novo projeto e outros realizados anteriormente, destacando a proximidade, relativa às circunstâncias de ocupação da cidade, com BR-3. No entanto, segundo ele, há uma diferença crucial que separa os dois: enquanto em $B R$-3 o espaço urbano e suas luzes agem como pano de fundo, como cenário para as cenas vistas pela janela do barco no qual se encontram os espectadores, em Bom Retiro estes mesmos espectadores caminham por esse cenário, ou seja, pelas ruas do bairro onde se encontram, juntos com os performers, "dentro" do espaço cênico.

Paul Zumthor (2014 apud DESGRANGES, 2017, p. 49) defende a noção de performance como uma abertura para que o entorno possa se tornar atuante no processo de criação e recepção da obra. Segundo ele, a composição formada pela totalidade dos elementos que compõem a experiência artística é que revela o caráter performativo do espetáculo, ampliando a potência estética do acontecimento teatral. Este caráter performativo faz com que a substância presente seja integrada ao momento da experiência criativa, que insere $o$ ato ficcional no entorno real do mundo que o circunda. Nesta montagem, todos estão "em cena" e não há, segundo Guilherme, como esconder ou camuflar os 
equipamentos. "O que mais me inquietou no projeto Bom Retiro, 958 metros foi a questão 'rua'. Pensar um projeto de luz para o shopping ou para o Taib'171 estava dentro de experiências, que de certa forma, nó já tínhamos vivido, o 'site specific', mas até então em edifícios fechados" (BONFANTI, 2012, p. 256). Silvia Fernandes descreve a "experiência imersiva a que o espectador é submetido, sensorial e corporalmente. O resultado é que o centro de força se desloca para uma dramaturgia que se constrói na fricção aguda da cena performativa com o ambiente implicado na travessia" (FERNANDES, 2017, p. 223).

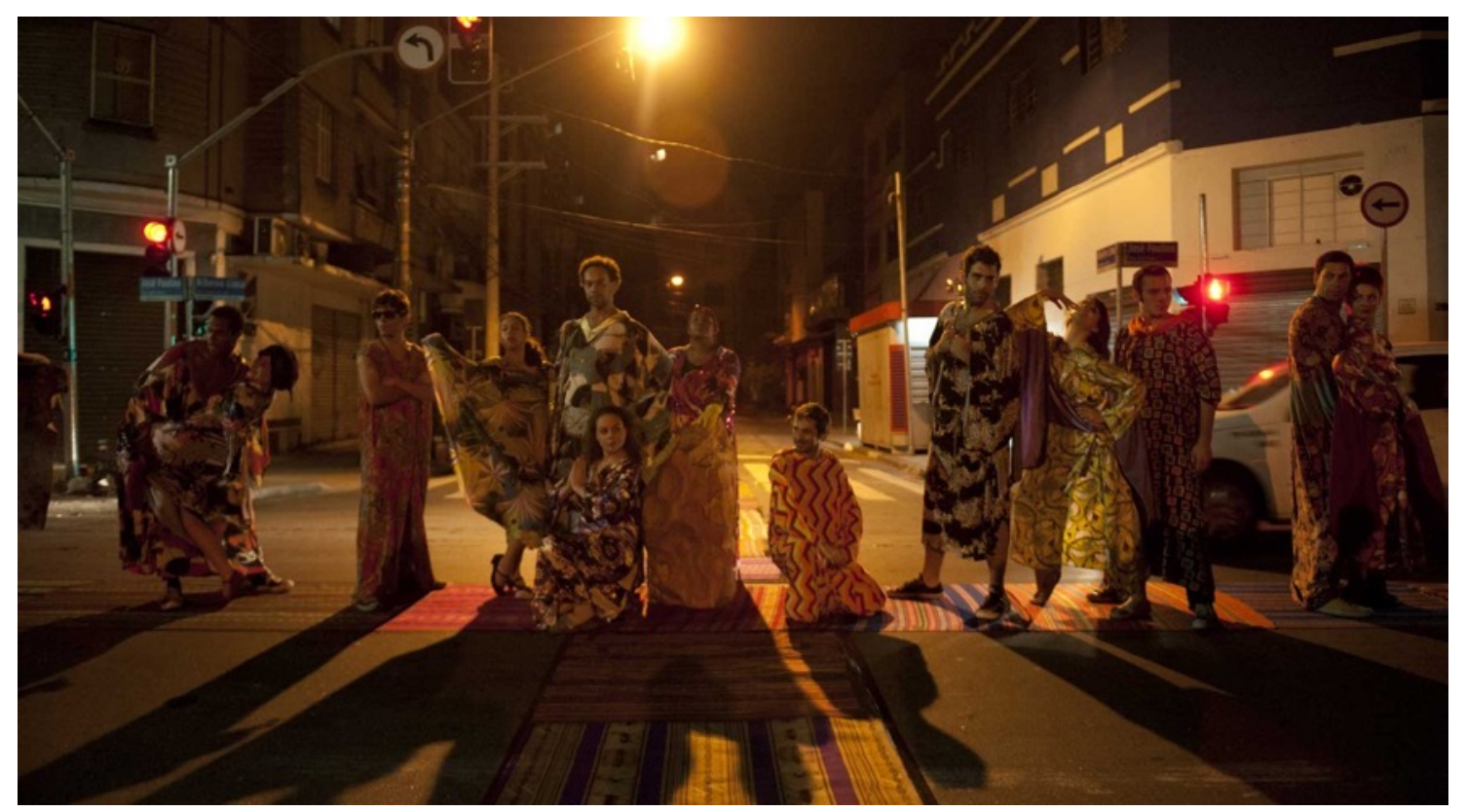

Figura 28 - Cena do desfile de moda na José Paulino da peça Bom Retiro 958 metros. Dramaturgia de Joca Reiners Terron. Concepção e direção geral de Antônio Araújo. Luz Guilherme Bonfanti. Foto Flavio Morbach Portella.

Além de dialogar e interagir com a luz urbana, o iluminador relata ter sentido a necessidade de fazer uso, de interferir e de explorar esses recursos como fonte luminosa e de efeito para as cenas. Esse desejo de intervenção, no entanto, apresentou dificuldades completamente diferentes das encontradas até então em seu trabalho, pois, para poder utilizá-los, seria necessário, também, poder controlá-los. Foi importante, ainda, pensar a luz da rua de maneira totalmente diferente de como se pensa a luz no teatro, quando a decisão sobre

171 O TAIB - Teatro de Arte Israelita Brasileiro, localizado no subsolo de um prédio no bairro Bom Retiro em São Paulo, foi ícone do teatro paulistano nas décadas de 60 e 70 . Em declínio a partir dos anos 80, foi finalmente fechado no começo dos anos 2000. Com suas estruturas minimamente preservadas, voltou à atividade por volta de 2003 e hoje estão sendo criadas campanhas para restaurar e trazer o espaço novamente para a efervescência cultural da cidade. 
a posição do refletor para se conseguir o ângulo ideal de incidência da luz sobre o que se pretende iluminar é parte integrante do processo de criação. Tarefas óbvias como conduzir o olhar do público ou concentrar a luz e a atenção do espectador em determinado objeto ou personagem se tornaram grandes desafios nesse novo contexto. Essas dificuldades de diálogo com o ambiente urbano, que não se restringiam ao trabalho com a luz, mas atingiam toda a equipe, consumiram boa parte do processo de ambientação e ajuste ao entorno da criação dramatúrgica. Os atritos, o confronto e as negociações necessárias ao processo de ressignificação da cidade, exigiam de todos uma entrega e imersão profunda nas conjunturas e realidades do lugar e do tempo que deveriam compartilhar, em diferentes camadas, com os demais artistas, os habitantes, os espectadores e os transeuntes ${ }^{172}$.

Durante os ensaios, realizados nas ruas do bairro durante a noite, Guilherme percebia atmosferas, contrastes, escuridão, risco, tensão, medo, solidão. Muito já estava dado no ambiente noturno da cidade semiadormecida, na qual trabalhadores, errantes e um pequeno tráfego noturno indicavam o ambiente com o qual o espetáculo teria que conviver e provocavam na equipe o desejo e a necessidade de entrar e controlar esse ambiente. Era preciso, também, controlar sua luz, direcionar, conduzir os efeitos e luminosidades colocando-os a serviço da encenação. Com a definição dos espaços escolhidos para cada cena, Guilherme pode começar a refletir mais objetivamente sobre as particularidades da luz já existente que poderia empregar e das que teria que elaborar para complementar o quadro. Para a cena da rua por onde o espetáculo caminha, já havia "uma configuração de postes que, de certa forma, ajudava muito, mas a questão é que tudo estava aceso ao mesmo tempo. Como conseguir, então, desvendar a rua aos poucos, como terminar uma cena e abrir a luz de outra?" se questionou Guilherme (2012, p. 257).

\footnotetext{
172 Considerando que a companhia do Teatro da Vertigem assinou um termo de responsabilidade com a Prefeitura e a Secretaria de Trânsito da Cidade de São Paulo assumindo, como condição para a autorização da realização do espetáculo no espaço urbano do bairro, que não haveria interrupção, reorientação, desvio ou interdição, durante as apresentações, do fluxo de pedestres e veículos nas vias e locais implicados na montagem.
} 
Tentando evitar efeitos mirabolantes e teatrais, o iluminador buscava, na observação da rua e de seus elementos postos, luzes que pudessem compor com as cenas que vinham sendo criadas, com a coisificação das personagens, com as máquinas, os manequins, as vitrines, aquela produção de moda falsa, simulacro do chique e do sofisticado. Apesar de perceber ser impossível e até desnecessário, naquele cenário urbano, esconder ou disfarçar fontes luminosas, ainda existia o desafio de mostrar as cenas realizadas na penumbra e que mal podiam ser vistas pelo público (NESPOLI, 2015 apud RAMOS, 2019, p. 54). No entanto, os experimentos com fontes de luz móveis e direcionáveis revelaram uma discrepância muito grande com o conceito geral da encenação e sua relação com o espaço. Observando e vivenciando o ambiente das ruas durante os ensaios noturnos, Guilherme finalmente se deu conta que a solução para a iluminação da peça estava ali, pronta para ser usada.
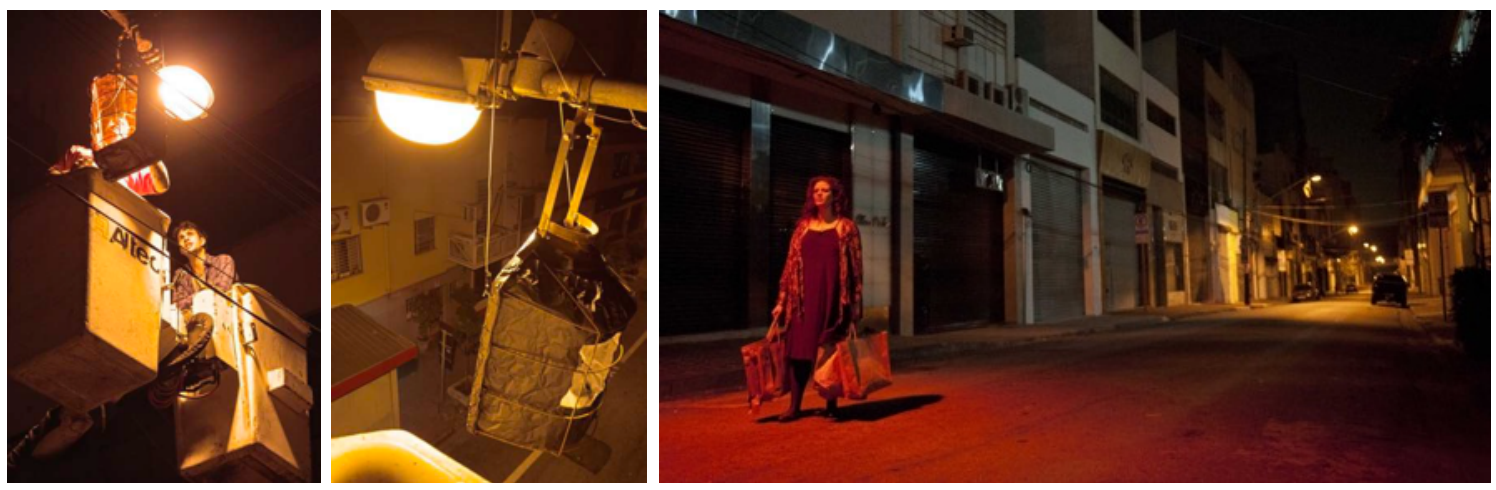

Figura 29 - Instalação e uso da traquitana para controle da iluminação dos postes de iluminação pública na peça Bom Retiro, 958 metros. Dramaturgia de Joca Reiners Terron. Concepção e direção geral de Antônio Araújo. Luz Guilherme Bonfanti. Fotos Guilherme Bonfanti e João Maria.

Depois de definir que "a luz da rua seria dos postes. Nada de foco, nada de seguidor nos atores que caminham pelo espaço. A luz da cena é a luz da cidade, e o teatro se apropria de um elemento que é de uso urbano e passa a ser luz de cena, a serviço da dramaturgia da luz" (BONFANTI, 2012, p. 258), ele deu início às suas experiência de adaptação e uso dos próprios postes de luz urbana com suas lâmpadas de vapor de sódio de 400 watts. Com o objetivo de explorar os postes como refletores e base para a luz de todas as cenas externas do espetáculo, foram realizadas pesquisas sobre as possibilidades de controle dessa luz. Era importante poder acender e apagar os postes, mas fazer isso não é tarefa fácil, principalmente por eles serem equipados com lâmpadas de 
descarga. Além disso, havia algumas exigências específicas para determinadas cenas que precisavam ser minimamente atendidas, como a troca de cor ou a concentração da luz em uma área um pouco mais restrita, isso sem considerar a própria condução das cenas pelo percurso definido para o espetáculo.

A partir desses problemas relativos ao controle da luz de boa parte dos 27 postes existentes no percurso a ser iluminado, a equipe de iluminação deu início ao processo de pesquisas para resolvê-los. Considerando a impossibilidade de interromper o fornecimento de energia dos postes e o tempo necessário para que elas pudessem ser acendidas novamente, o único caminho possível foi desenvolver um recurso mecânico, que ficou conhecido como "traquitana", para acender e apagar as luzes dos postes de rua. $O$ aparato deveria atuar como um dimmerizador mecânico da intensidade luminosa da lâmpada pelo abrir e fechar de "abas", a exemplo dos shutters usados para graduar a luminosidade dos refletores HMI. Dotado de um mecanismo operado manual e individualmente pelos "operadores de poste", como Guilherme passou a chamar cada um dos profissionais responsáveis pela operação, o artefato criado cobria e descobria a lâmpada do poste ao ser içado por uma engrenagem de roldanas e cabos de aço. Adicionados ao corpo dessas traquitanas de controle de intensidade, o iluminador ainda se serviu de filtros para alterar a cor da luz emitida e recortes para limitar a abrangência do facho luminoso. Concretizava-se, assim, o mais importante recurso de integração entre a encenação e o ambiente urbano pela mediação da luz potencialmente performativa que passaria a atuar, pela sua configuração e movimento, tanto sobre as cenas quanto sobre a percepção dos espectadores.

O recente estudo de Lúcia Galvão Ramos (2019) a respeito do potencial performativo da luz em contextos urbanos, associa a obra da artista plástica Eleonora Fabião e o trabalho criação de Guilherme Bonfanti para o espetáculo Bom Retiro, 958 metros com o objetivo de investigar a atuação da iluminação na expressão artística e na percepção do observador nos dois contextos. Com foco na relação estabelecida entre olho humano, luz e espaço, além do entendimento da arte como experiência compartilhada entre obra e espectador, a pesquisadora 
investiga a relação com o ambiente por meio da luz, em obras que estabelecem, segundo ela, "fissuras na tessitura da experiência urbana". Destacando o protagonismo do projeto de iluminação de Bonfanti na linguagem do espetáculo Bom Retiro, ela dá especial atenção às táticas e operações de ação direta do iluminador sobre a cidade (RAMOS, 2019, p. 50-55).

Lúcia Ramos destaca a questão do deslocamento como um ponto central desta e outras encenações do Vertigem, cujo público é impulsionado a algum tipo de percurso físico (RAMOS, 2019, p. 52). Neste caso, a iluminação e o uso das traquitanas, que iam acendendo e apagando a luz dos postes, é que direcionavam os espectadores pelas ruas do bairro. Segundo ela, a luz, como elemento potencial de articulação do espaço urbano, realiza grande efeito sobre o público espectador: "Ruas inteiras foram apagadas e coloridas e isso gerou um efeito extremamente potente, e o fato de que a manipulação dos contrarregras acontecia de maneira explícita ao público e no aqui e agora, também teve um enorme impacto na recepção do espetáculo" (RAMOS, 2019, p. 55).

O caráter espacial e transitório do espetáculo já era indicado na
retirada do ingresso, quando os espectadores recebiam um mapa do
bairro com o circuito a ser realizado. O espetáculo se iniciava em frente
a um centro comercial e logo ocupava seus corredores internos e lojas.
Depois o público ia sendo conduzido pelos muros da estrada de ferro,
pelas ruas vazias das quais observava as cenas nas vitrines e
marquises das lojas, até chegar em frente ao Instituto Cultural Israelita
Brasileiro para adentrar as ruínas do Teatro de Arte Israelita Brasileiro.
Ao final, a peça era encerrada na calçada em frente do teatro, a poucos
metros do ponto de partida (RAMOS, 2019, p. 53).

Segundo o resultado da série de entrevistas ${ }^{173}$ sobre a recepção do espetáculo Bom Retiro, 958 metros (RAMOS, 2019, p. 50), o uso da luz dos postes de rua o aspecto mais impactante da iluminação para o público. Além deles, Bonfanti usou ainda, em seu projeto de iluminação, alguns refletores convencionais de teatro, moving-lights, projeções mapeadas e de imagens sobre os atores e as fachadas, diversos materiais de LED, lâmpadas fluorescentes, lanternas, fogo, carcaças de velhos refletores com lâmpadas adaptadas, piscapiscas, entre outros, de acordo com a dramaturgia da luz, criada a partir da

\footnotetext{
173 Pesquisa realizada para a tese de doutorado de Elizabeth Néspoli em 2015 na ECA-USP.
} 
necessidade e do aspecto sensorial que elaborava para cada cena, de acordo com o relato feito após o ensaio corrido de março de 2012.

Tínhamos uma luz, um desenho, uma dramaturgia de luz neste corrido, pois tínhamos uma sequencia de feitos, a luz estava dialogando diretamente com as propostas da direção, com o espaço, com os atores e com a música, a operação de efeitos, ou cenas, tinha uma dinâmica que auxiliava na narrativa, havia um diálogo com o tempo e o espaço. Ajudava a produzir sensações em quem assistia, e criava uma relação de reconhecimento e ressignificação do espaço, em alguns momentos dificultando o deslocamento e provocando um estranhamento na relação com o espaço, ou seja, o incomodo colocava as pessoas em um constante estado de alerta, o que provocava reações absolutamente subjetivas em relação ao que se via. Cada cena tinha um tratamento e cada personagem uma situação diferenciada de contraste e cor (BONFANTI, 2013, p. 21).

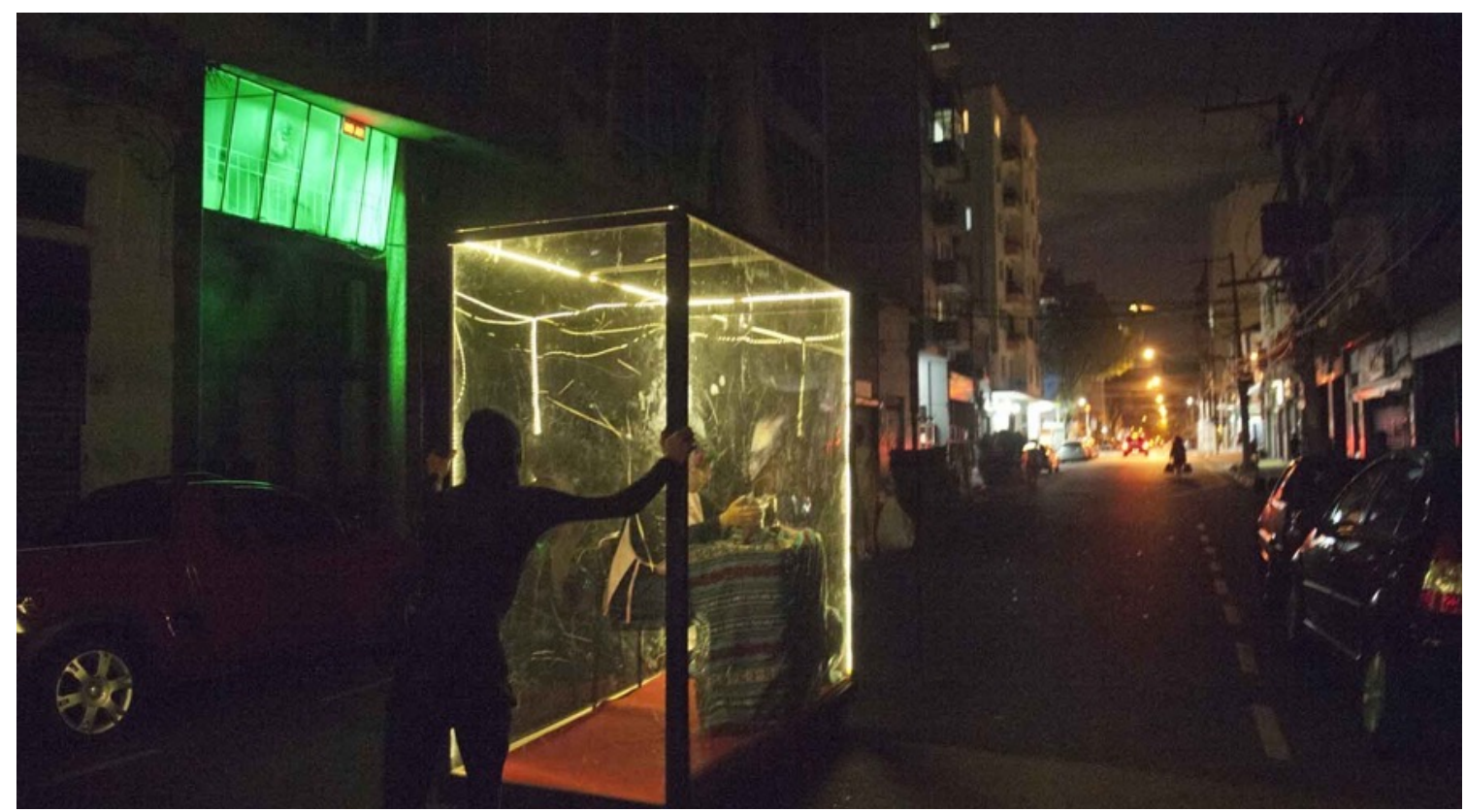

Figura 30 - Cena em deslocamento pelas ruas do bairro paulistano na peça Bom Retiro, 958 metros. Dramaturgia de Joca Reiners Terron. Concepção e direção geral de Antônio Araújo. Luz Guilherme Bonfanti. Foto Nelson Kao.

Além destes exemplos, a efetiva realização do potencial performativo da luz criada por Bonfanti, em atuação conjunta com as luzes da cidade oriundas da iluminação pública, lojas, semáforos e outras interferências da luz urbana no espetáculo e vice versa, também pôde ser constatada nos trechos dos depoimentos de espectadores selecionados por Ramos (2019, p. 56-58), nos quais são relatados efeitos de luz cuja previsibilidade e intencionalidade é questionada pelos entrevistados, a exemplo do efeito produzido pela luz do semáforo que colore alternadamente de vermelho e verde atores $\mathrm{e}$ espectadores; da luz dos postes que piscavam, apagavam ou tinham suas 
intensidades diminuídas; o eclipse gerado por uma luz que se apaga; ou o fato de fazer, através do efeito de luz, a cidade "atuar". Ramos conclui que "o projeto de iluminação desenvolvido por Guilherme Bonfanti conseguiu penetrar no tecido da cidade e, com isso, conduzir o público pelo percurso proposto de maneira sutil, mas muito precisa, e colocando-se como parte fundamental para o sucesso da proposta de encenação do espetáculo" (RAMOS, 2019, p. 60). A partir dos relatos, é possível perceber que os efeitos e recursos empregados funcionam como agentes capazes de ressignificar e potencializar as experiências do cotidiano, reposicionando os espectadores em relação ao espaço público da cidade e acionando sua capacidade imaginativa de atuação no espaço.

Cada um dos espetáculos do teatro da Vertigem apresenta um aspecto do que é possível entender como potencial performativo da luz no trabalho do iluminador Guilherme Bonfanti. No entanto, é importante ressaltar que essa separação não pretende assinalar que as características destacadas para cada análise são exclusivas do trabalho em questão. Muito pelo contrário, todas elas fazem parte, conjuntamente, do repertório, do processo criativo e da natureza da produção cênica do Teatro da Vertigem, tendo se tornado, tanto na prática quanto nas profusas investigações acadêmicas e publicações realizadas sobre o grupo, sua referência e assinatura. 


\subsubsection{Um Ricardo III}

\section{A performatividade da luz-matéria como elo entre a cena e o}

espectador na peça Um Ricardo III

O entendimento da performatividade da luz acontece a partir da tomada de consciência da participação e importância da iluminação em um evento cênico. Ela é, mesmo quando não percebida conscientemente, o resultado da percepção de artistas e espectadores quanto à ação e integração da luz com os demais componentes do espetáculo, o que a faz atuar, performar, agir desde o processo de criação até apresentações a público.

Existe uma preocupação crescente e uma tomada de consciência da existência, pertinência e importância da iluminação para a cena e a relação estabelecida por ela entre a equipe de criação, considerando os diversos componentes do espetáculo, e o público, ou seja, entre a cena e o espectador, tanto no espetáculo performativo, mas não apenas nele. A luz performativa pode se manifestar em todo tipo de acontecimento ou espetáculo cênico, a exemplo da peça de teatro Um Ricardo III, um espetáculo que poderia ser classificado como pós-dramático ou performativo, por diversas razões, mas não necessariamente. A materialidade poética da sua luz, no entanto, age sobre a cena e o espectador de uma maneira inegavelmente performativa.

A equipe de criação do espetáculo, formada pelo diretor Rafael Camargo, ao centro da foto abaixo com as atrizes Pagú Leal e Chiris Gomes, e a iluminadora Nadia Luciani, entre os atores Zeca Cenovicz e Bruno Rodrigues, foi responsável por toda a concepção do espetáculo, desde a adaptação do texto até a criação do visual cênico, com a participação de todos os membros em todas as etapas do processo. À exceção da iluminação, todas as demais linguagens do espetáculo foram resultado do processo de criação colaborativa, como a sonoplastia, o cenário e o figurino. À direita da foto estão o assistente e operador de luz Rafael Araújo e o fotógrafo Chico Nogueira e, em baixo, a professora Liana 
de Camargo Leão, especialista em Shakespeare da Universidade Federal do Paraná, cercada pelo produtor Dimas Bueno e seu assistente Thiozer Nunes.
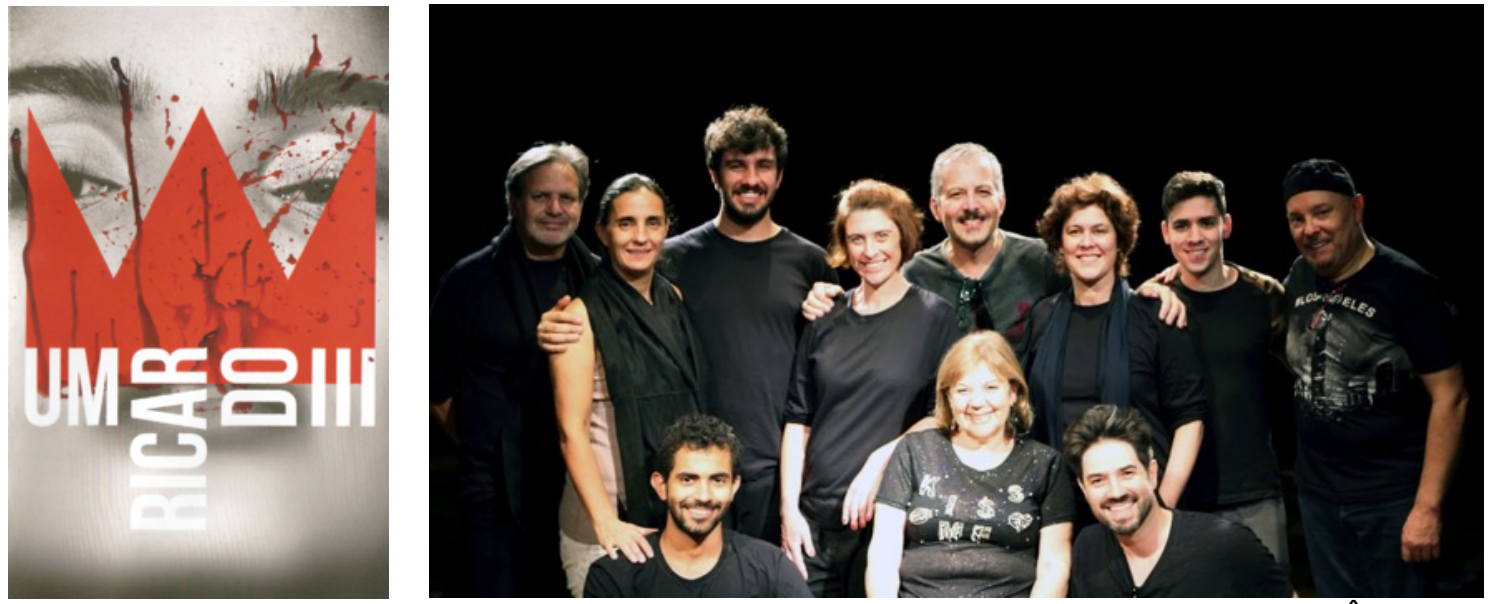

Figura 31 - Cartaz e equipe do espetáculo Um Ricardo III, apresentado no Teatro Ênio Carvalho em Curitiba em 2018. Cartaz Álvaro Gusso. Foto Chico Nogueira.

A peça Um Ricardo III foi encenada a partir de uma modificação radical da obra original do dramaturgo inglês William Shakespeare, a começar pela redução significativa do texto para menos de 50 minutos de espetáculo e pela linguagem adotada, atual e acessível, facilitando a compreensão da complexa trama shakespeariana. Seguida pela diminuição drástica do número e a distribuição irregular e inconstante dos personagens entre os quatro atores, inclusive a do próprio personagem título, Ricardo III, interpretado por todos os performers em diferentes momentos do espetáculo.
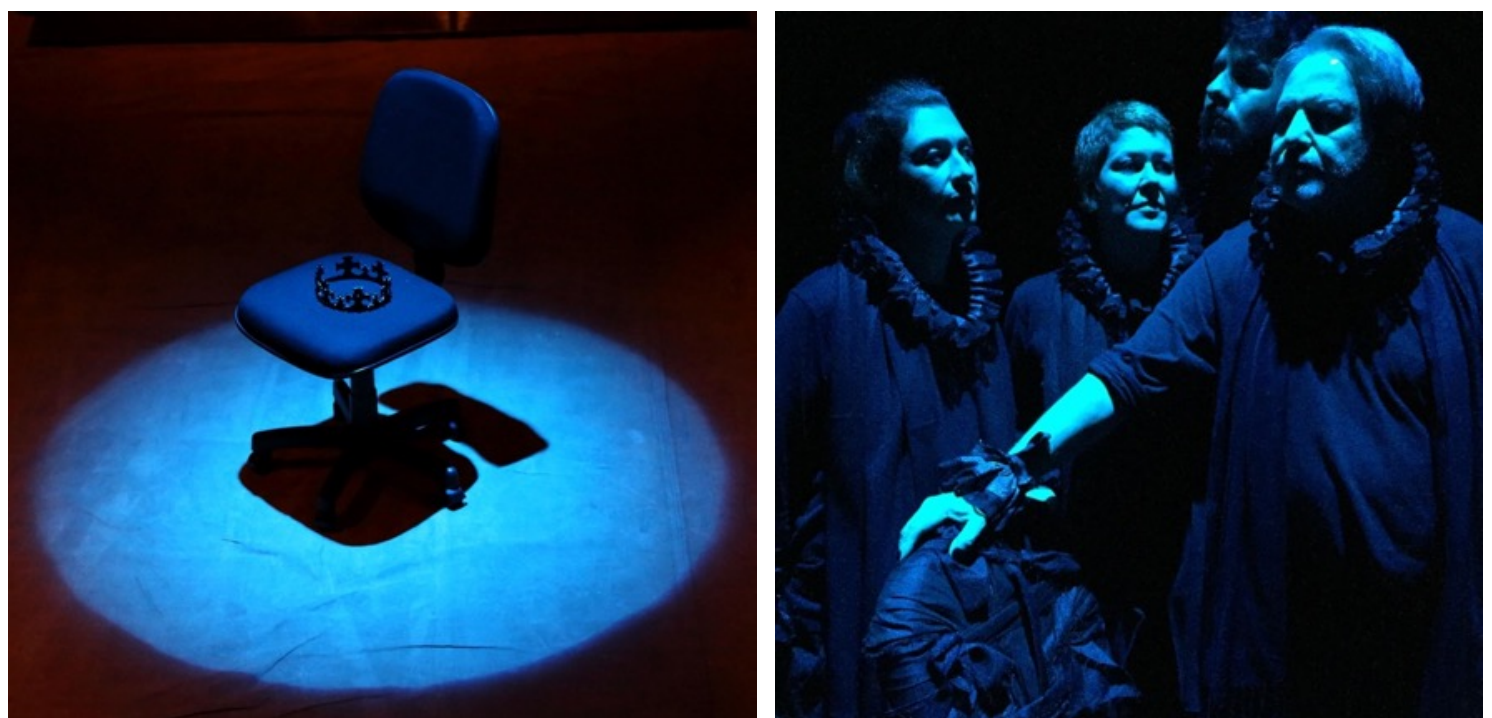

Figura 32 - Elemento principal do cenário, o trono de Ricardo III, ainda não finalizado, e os quatro atores do espetáculo na peça Um Ricardo III, texto de William Shakespeare. Adaptação e direção de Rafael Camargo. Luz Nadia Luciani.. Fotos Nadia Luciani e Chico Nogueira. 
As diferenças em relação a outras montagens mais tradicionais, incluíram ainda a transformação do espaço, completamente adaptado para integrar atores e espectadores em um mesmo ambiente e fazê-los partilhar e acompanhar a difícil e sangrenta intriga em busca do poder. O resultado obtido só foi possível graças ao processo colaborativo de criação, partilhado por toda a equipe. Iniciado com o entendimento e a decupagem do texto dramático, a ocupação do espaço veio em seguida e, por fim, a idealização do figurino e da sonoplastia, inteiramente realizada pelos próprios atores com instrumentos especialmente escolhidos para os efeitos desejados: um didjeridu (instrumento de sopro aborígene feito de madeira) e dois sinos tibetanos (instrumento de som intenso e constante muito usado para a meditação).

O número original de personagens foi reduzido das mais de seis dezenas do texto original para menos de dez. Por ordem de participação na peça, os primeiros personagens foram os fantasmas do Príncipe Eduardo; do Rei Henrique VI; de Hastings; de Anne, mulher de Ricardo III; de Buckingham e do Duque de Clarence, seu irmão mais velho, que o assombram antes da sua morte. Já com isso é possível perceber a inversão temporal feita na montagem, que começa por uma das cenas finais do texto original. Depois desta cena, a peça retoma a ordem original do texto para explicar essa morte trágica e assombrada e os atores passam a alternar personagens shakespearianos e narradores, criados durante a adaptação com o objetivo de localizar o público em relação à trama, explicando o contexto das cenas e as passagens de umas às outras com um certo olhar externo e crítico sobre os fatos. Suas falas também conectavam as diferentes cenas fragmentadas do texto original com textos criados colaborativamente para o mesmo fim. Essas transições entre narradores e personagens, muitas vezes situadas entre duas frases ditas por um mesmo ator, cada uma em uma iluminação diferente e específica, requeriam mudanças de luz precisas, algumas vezes bruscas, e que demandavam uma total atenção e cuidado por parte do operador de luz, considerando inclusive possíveis erros ou improvisos por parte dos atores. Outras vezes, cenas inteiras eram dedicadas a essas narrações sequenciadas, a exemplo da segunda cena do espetáculo, cuja 
luz iluminava todos os atores da mesma forma, com luzes a pino brancas, que mal revelavam seus corpos, e uma luz fechada nos seus rostos:

BRUNO: Convém lembrar que Ricardo III é uma das peças históricas de William Shakespeare e narra um pedaço da história da Inglaterra: está em pleno vigor a Guerra das Rosas, que durou trinta anos e colocou em conflito político e armado os dois ramos da dinastia Plantageneta: a Casa Real de York representada pela rosa branca e a Casa Real de Lancaster, representada pela rosa vermelha. Os yorkistas e os lancastrianos formavam duas linhagens igualmente descendentes de Eduardo III.

ZECA: Essa peça oferece uma visão rica dos bastidores políticos, por extensão, de todos os tempos e de todas as culturas, naquilo que esses bastidores têm de mais corriqueiro: as alianças que se fazem e desfazem conforme os interesses mais prementes; as promessas e traições políticas; o ser político como um ator que se vale de objetos de cena e de personagens coadjuvantes para cativar o seu público.

CHIRIS: No entanto, há de se atentar para o fato de que, ao romancear a ascensão e queda de Ricardo III para o palco, Shakespeare retratou Ricardo, Duque de Gloucester, exagerando-Ihe as características físicas de feiura, aleijão e sua maldade pessoal.

PAGU: Na verdade, sabe-se que Ricardo agiu de acordo com os costumes da época - decapitam-se os inimigos que podem vir a trazer dores de cabeça na arena política e, para garantir a coroa para si, matam-se herdeiros a sua frente na linha sucessória.

TODOS (um de cada vez): Voltemos ao começo. (mudança de luz)

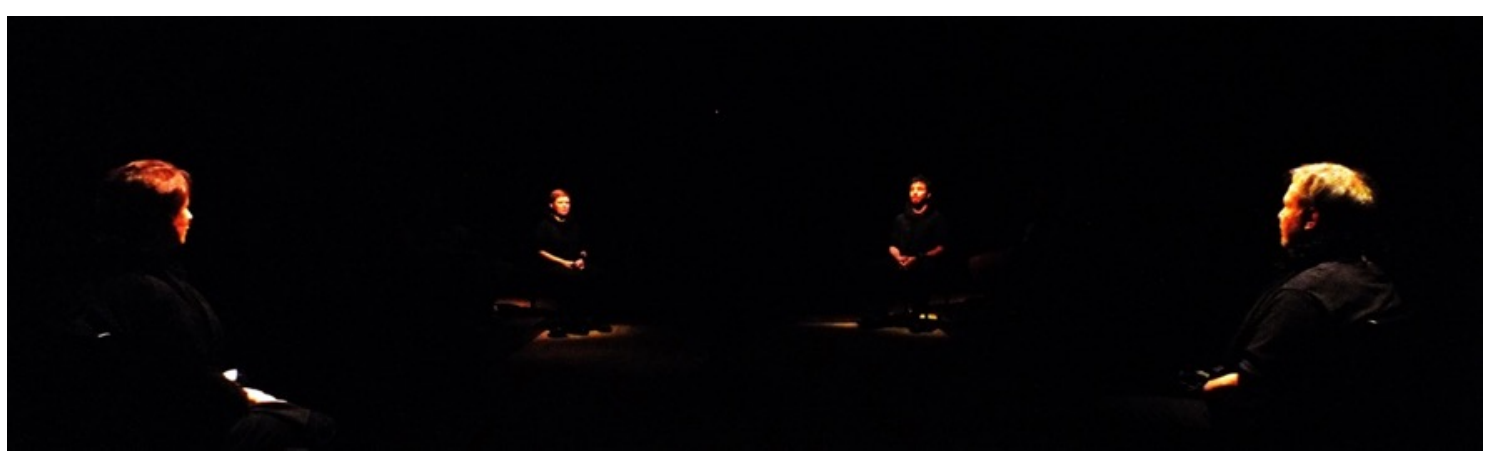

Figura 33 - Atores iluminados como narradores da peça Um Ricardo III. Texto de William Shakespeare. Adaptação e direção de Rafael Camargo. Luz e Foto Nadia Luciani.

A principal função da luz branca dos narradores era diferenciar os dois tipos de texto, os narrativos e os dramático, cuja luz era feita em colorações quentes e frias, conforme o desenrolar da trama. A diferenciação das luzes e seus movimentos exerciam uma função estrutural, segundo o conceito apresentado por Cibele Forjaz: "o que faz a ligação entre as várias partes do texto [...] é justamente o apagar e acender das luzes, que especializam os fragmentos que compões a peça” (FORJAZ, 2013a, p. 64). Foram inseridos textos complementares com o objetivo de esclarecer melhor o espetáculo, que 
se tornou extremamente denso quando reduzido e concentrado. Todas as adaptações, porém, foram feitas respeitando as ideias originais do autor e muitos textos foram mantidos, mesmo com a adaptação e modernização da linguagem.

Depois da cena inicial dos fantasmas e da primeira apresentação dos narradores, os próximos personagens inseridos na cena foram, além do próprio Ricardo III, as Rainhas Margareth e Elizabeth; a Duquesa de York, sua mãe e o Conde de Richmond, vencedor da batalha contra Ricardo III e futuro Rei Henrique VII da Inglaterra. A maior parte das cenas eram diálogos entre apenas dois personagens, todos com Ricardo III ao centro e seu interlocutor em um dos quatro cantos do palco, quase na área destinada ao público.

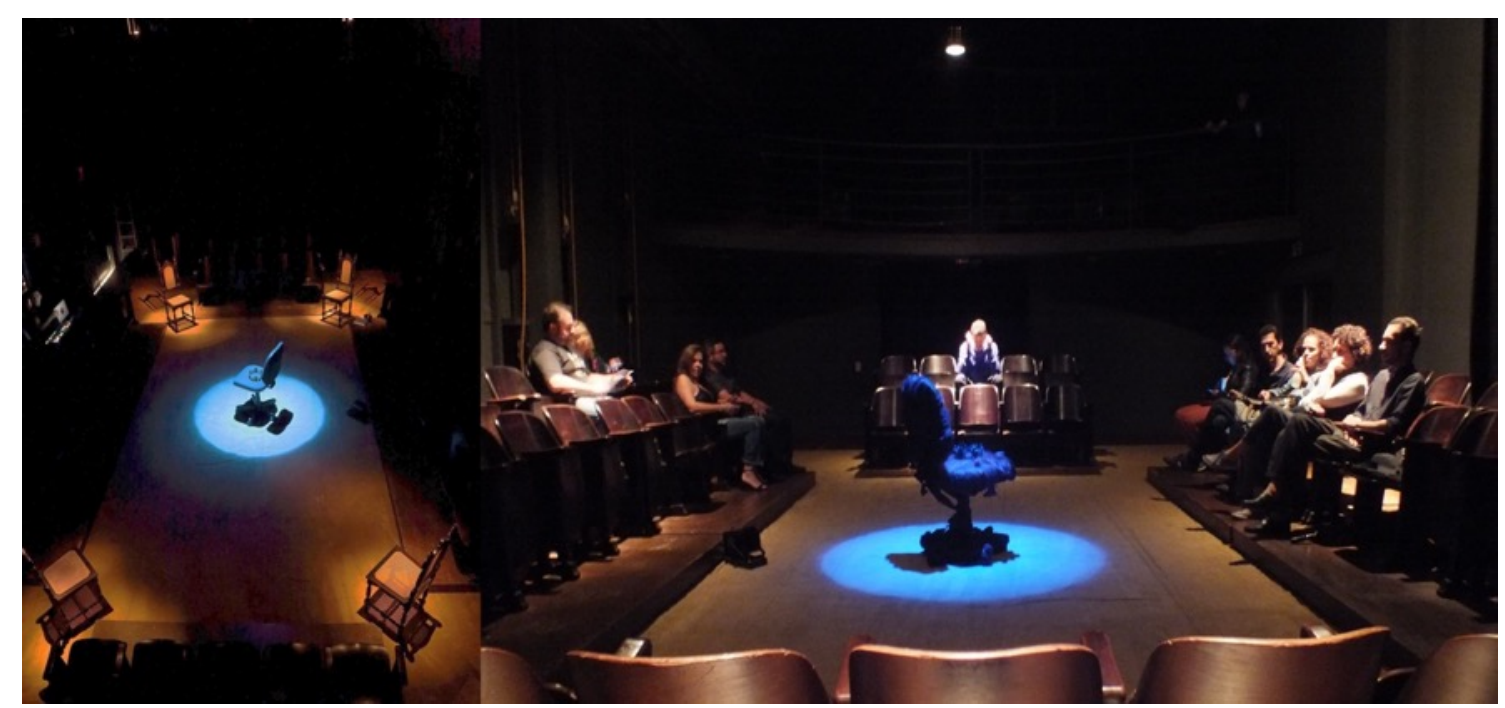

Figura 34 - Espaço cênico com as luzes dos elementos do cenário e a configuração da plateia com a luz de entrada do público na sala. Fotos Nadia Luciani e Chico Nogueira.

O espaço da representação foi determinado pelo posicionamento da plateia, que o cercava por todos os lados, como em um teatro de arena. As cadeiras a serem ocupadas pelos atores durante quase toda a peça, estavam localizadas praticamente entre os espectadores, resultando numa proximidade tão incômoda para uns quanto para os outros e, ainda mais, para a luz, cuja importante decisão estava entre iluminar igualmente cena e plateia, colocando em evidência também os espectadores, sob o risco de desviar a atenção de quem estivesse sentado no lado oposto da plateia, ou usar uma luz completamente fechada e fragmentada, que poderia comprometer a unidade cênica e a percepção da proximidade física, criada propositalmente entre ambos. 
Os diferentes personagens, interpretados pelos diferentes atores, tinham, cada um, um gestual e um comportamento característicos, adotados por todos os atores quando os interpretavam. A atuação dos atores era, igualmente, muito precisa e bem marcada pela encenação, também concebida colaborativamente. $\mathrm{O}$ processo de criação colaborativo favoreceu a improvisação e a criação, pelos próprios atores, das movimentações de seus personagens, o que facilitou sua assimilação e reprodução durante as apresentações. O mesmo acontece com o operador de luz, que por acompanhar o processo desde o início, conhecia profundamente a maneira como cada gestual foi criado e suas intenções, o que permitiu que a operação da luz fosse realizada de forma muito mais orgânica e sincronizada com a cena. Assim, a performance da luz e a simultaneidade entre os componentes, sobretudo os associados à atuação dos atores, o ritmo e as movimentações cênicas, eram orquestradas de tal maneira que um não podia acontecer sem o outro. Eles eram absolutamente conectados e interdependentes, revelando o fundamento primordial da encenação, que exigia também, do público, uma total atenção e concentração, sob o risco de perder o fio da história narrada. Em parte com este objetivo, mas também por causa da proximidade do público, a luz do espetáculo tinha o nível de intensidade mantido no mais baixo possível, para garantir a visibilidade, durante a maior parte da duração da peça. A luz baixa exigia do espectador uma atenção maior e, ao mesmo tempo, orientava seu olhar exclusivamente para o lugar da ação, que neste espetáculo era, ainda, muito restrita e contida, por determinação do tipo de encenação que representa uma marca das encenações do diretor Rafael Camargo.

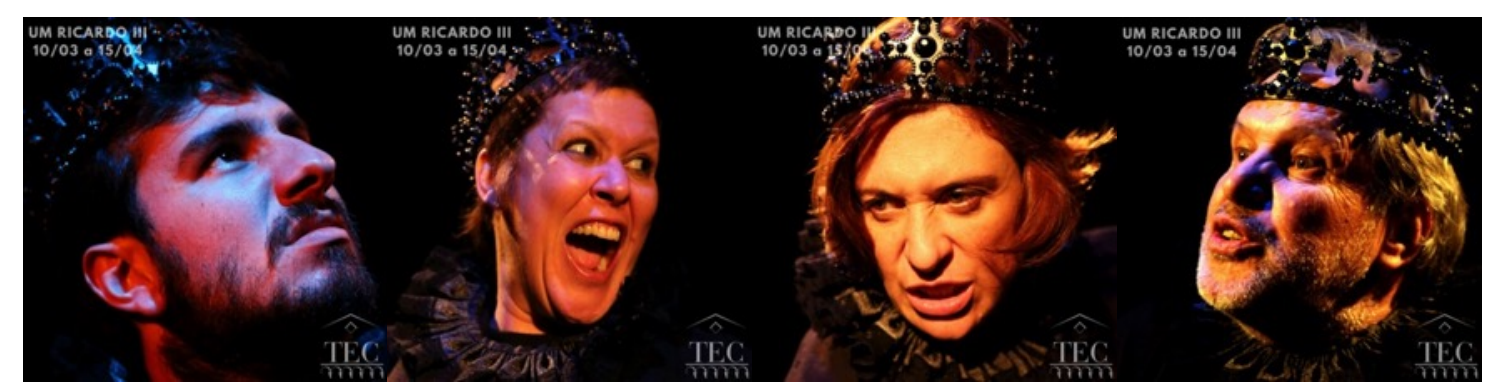

Figura 35 - Os quatro atores do espetáculo no papel de Ricardo III. Fotos Chico Nogueira.

Os quatro atores tinham figurinos exatamente iguais, composto por peças neutras e negras, e todos interpretavam, além de diferentes personagens 
e dos narradores, o de Ricardo III, alternadamente. Para isso, cada um dirigiase, no momento preciso, ao centro do palco, onde estava o elemento cenográfico representativo do trono. A coroa, também negra, era o adereço alusivo ao reinado de Ricardo III, usado por todos após a cena da coroação. A iluminação, única linguagem assinada por um profissional externo ao elenco, também contou, para sua criação, com a colaboração de toda a equipe, incluso o assistente e operador da luz, que acompanhou todo o processo de criação, com o objetivo principal de assegurar a performance da luz e o jogo cênico integrado e orgânico durante as apresentações do espetáculo ao público. A delimitação dos espaços, a determinação da linguagem e a definição da forma, foram os principais aspectos da iluminação, que tinha como objetivo principal favorecer a experiência compartilhada entre espectadores e intérpretes em torno da narrativa fragmentada e revelar, pela emoção e expressão estética, a história desconstruída e transformada de Ricardo III.

A estrutura da luz criada, modesta e bastante reduzida, exprime a objetividade da concepção da iluminação e evidencia tanto a simplicidade do espaço quanto da movimentação cênica, contida e limitada, característica da encenação, que valoriza a intensidade da interpretação e estimula a interação entre os atores e deles e com os demais componentes da cena e com o espectador. A grande proximidade com o público trazia o desafio de iluminar a cena sem ofuscar ou atrapalhar a visão e a percepção que os espectadores tinham dela. O palco era raramente todo iluminado, em parte por essa proximidade, mas também por razões poéticas relativas à criação da luz. Intensidades muito baixas, diferentes tipos de refletores, ângulos precisamente definidos e poucas cores foram os recursos materiais usados para favorecer a apreensão do espetáculo pelo público; sua visão e compreensão do texto, extremamente intricado e rápido; a complexa diferenciação entre narradores e personagens, alguns compartilhados por todos os atores e o acompanhamento da marcação cênica, modesta mas significativa. O) maior desafio do projeto de iluminação deste espetáculo foi traduzir a sua concepção cênica, bastante peculiar, para forma, cor e movimentos de luz. 
Por ter sido realizada em um teatro privado a acessível, nós tivemos o privilégio, nesta montagem, de ensaiar desde o início no espaço definitivo onde seriam feitas as apresentações. Esse fator permitiu experimentações muito mais eficientes da relação dos performers com o espaço e com a luz, montada com tempo suficiente para permitir uma concepção muito mais elaborada e vários ensaios antes da estreia. Tanto para a montagem quanto para os primeiros ensaios com luz, a mesa foi colocada na plateia, no lugar a ser ocupado pelo público, uma posição privilegiada para que eu, tendo o mesmo ponto de vista dos espectadores, pudesse confirmar os bons posicionamentos dos refletores e ângulos da luz sobre a cena e os atores. É muito comum, em vários teatros, que o ponto de vista da cabine ou do lugar onde a mesa de luz é instalada seja muito diferente da visão que o público terá do espetáculo, o que invariavelmente causa um resultado muito diferente do esperado no que diz respeito à iluminação, mas principalmente no caso deste espetáculo, devido à extrema proximidade entre o público e a cena.

Quando fomos gravar as primeiras cenas da luz, surgiu uma inesperada tensão entre o diretor e eu, comprometendo temporariamente a comunicação e a definição e gravação das cenas, principalmente no relacionado às intensidades das luzes. Ele me pedia, o tempo todo, para baixar mais a luz e eu respondia ser impossível, pois quase já não via mais os atores. Isso se explicou, enfim, pela dilatação das minhas pupilas e saturação da retina pela tela do computador (mesmo com sua intensidade no nível mais baixo para não incomodar os atores) e da suave luz de serviço e dos LEDs da mesa. Normalmente, essas luzes não incomodam tanto, sempre tem um pouco de luz na cabine, mas, nesse caso, a intensidade da luz da cena já era tão baixa, que mesmo esse pequeno ruído luminosos era fatal para a percepção da luminosidade ideal da cena por mim ou pelo operador de luz. A mesa foi gravada, mesmo sem que se chegasse a um entendimento ou consenso sobre as intensidades com o diretor.

Por fim, quando a mesa finalmente subiu para o primeiro balcão, onde ela ficaria durante as apresentações, para permitir uma boa visualização da cena e da plateia por parte do operador, eu entendi o que havia acontecido e fui eu, 
então que, sentada na plateia, pedi para o meu assistente e operador da luz regravar todas as cenas baixando mais e mais a intensidade dos efeitos. Eu devo acrescentar o detalhe de que a luz deste espetáculo, muito raramente, passava dos $30 \%$ e $40 \%$ ou, em casos muito precisos, chegava, no máximo, a $50 \%$ de intensidade. O espetáculo era realmente bastante escuro, um pouco como metáfora para a própria história negra e obscura de Ricardo III, como se a vida, o palco, a luz, as emoções e a encenação fossem uma só coisa. O ideal, é claro, seria que o operador de luz pudesse ficar próximo ao palco, para sentir melhor as cenas e as reações da plateia e poder realizar, assim, uma operação de luz mais precisa e integrada ao espetáculo. No entanto, era claro que, da mesma forma como a luz da mesa e da tela do computador me impediam de perceber a real luminosidade das cenas nos ensaios, certamente atrapalhariam e perturbariam muito a visão e a percepção que os espectadores teriam do espetáculo. De modo, que a mesa foi deslocada da plateia para o balcão, como mostram as fotos abaixo.
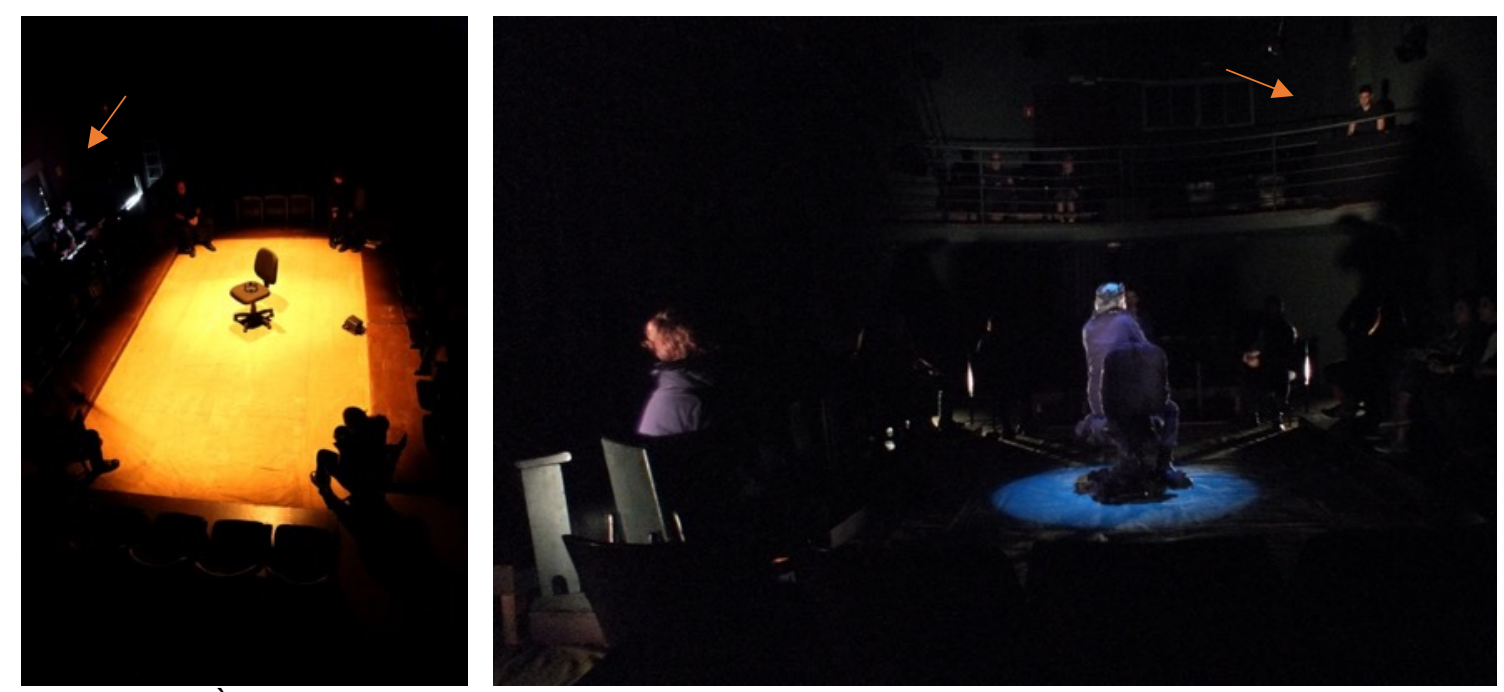

Figura 36 - À esquerda vemos a mesa de luz localizada na plateia, ainda durante a montagem e os ensaios, e à direita a posição final do operador de luz, no primeiro balcão do teatro, não utilizado para este espetáculo. Cenas de Um Ricardo III. Texto de William Shakespeare. Adaptação e direção de Rafael Camargo. Luz e Fotos Nadia Luciani.

Depois da luz concebida, definida e pré-gravada, começamos os ensaios técnicos de luz, nos quais podíamos acertar rigorosamente os tempos das transições e ajustar, mais precisamente, a composição das cenas e as intensidades, acrescentando efeitos sutis, mas que faziam toda a diferença no conjunto, como $10 \%$ ou $15 \%$ de luz no rosto de um ator ou um leve contraluz que 
ajudava a dar volume e compunha melhor o visual cênico. Ao final do processo, os fachos de luz coloridos atravessavam, restringiam, invadiam e inundavam o palco conforme era exigido ou solicitado pela ação, pelas emoções e pela intensidade do jogo dos atores. A operação da luz, precisa e pontual, atuava colaborativamente com eles em suas ações interconectadas e interdependentes, acompanhando a transição, a sonoridade e a evolução das cenas. A total concentração e contato, tanto visual quanto sensorial, mas, principalmente, ininterrupto e constante, entre a cabine, o palco e a plateia era fundamental para esse resultado. Outra característica performativa percebida na luz era a tensão e o risco representado pela exigência de tamanha precisão, considerando que tanto um engano seu poderia comprometer o trabalho do ator quanto o contrário. A imprevisibilidade do teatro, vivo, efêmero e irreversível, no qual o inesperado sempre pode vir de encontro ao pré-estabelecido e surpreender performers da cena e dos bastidores, podem gerar situações inesperadas que demandam presteza e capacidade de improviso de ambos os lados. É quando a luz performativa se associa à performance do operador enquanto agente que a materializa em cena, dois possíveis aspectos diferentes da performatividade da luz investigada neste estudo doutoral.

No momento da entrada do público, as quatro áreas da plateia, dispostas ao redor do palco, eram sutilmente iluminadas. No centro, somente a cadeira com a coroa real, isolada em um pino de luz azul intenso, referência cromática constante no texto original de Shakespeare. Público instalado e pronto, o que era identificado visualmente pelos atores e pelo operador, um efeito sonoro fazia baixar toda a luz de plateia até uma suave penumbra para a entrada dos atores, que precisavam instalar suas cadeiras, quase no escuro, na posição prédeterminada. As luzes afinadas em cada cadeira para iluminar cada um dos performers em vários ângulos diferentes e também, em um efeito específico, apenas fechada em seus rostos, fazia com que a colocação exata da cadeira na marca devesse demandar atenção especial de todos, sob risco de prejudicar a performance da luz durante praticamente todo o espetáculo. Cada cadeira tinha, afinados sobre si, um grande número de efeitos, como a luz a pino branca usada para os narradores, a luz fechada no rosto, o contraluz azul escuro, usado 
principalmente para a cena dos fantasmas que assombram o rei na cena da batalha e outros efeitos especiais para as cenas dos demais personagens interpretados alternadamente pelos quatro atores.

Depois da entrada dos atores, a luz descia até o blecaute total antes do início do espetáculo. Esse blecaute, como é bastante comum na linguagem teatral, tinha como objetivo transportar a plateia para um ponto ou grau zero, o lugar de partida antes do qual nada existe, metaforicamente, sem referências ou alusões externas ou precedentes ao que se vai vivenciar naquele momento preciso da união entre palco e plateia, da comunhão, que só o teatro permite, entre a cena e o espectador. Neste estágio de suspensão criado pelo blecaute, soavam, em analogia aos três sinais de Molière, sons profundos executados pelas próprias atrizes com dois sinos tibetanos, reforçando a indução ao silêncio, já imposto pela escuridão, e indispensável para o início do espetáculo. A encenação começava com as primeiras falas, alternadas entre os quatro atores, numa inversão da ordem original da peça. lluminados um a um, individualmente, por uma contraluz azul intenso e uma leve nuance de luz frontal fechada em seus rostos, eles assombram o Rei Ricardo III com incisivas adaptações dos textos de alguns dos fantasmas dos personagens assassinados por Ricardo em sua sede de poder e desejo de subir ao trono:

BRUNO/FANTASMA DO PRÍNCIPE EDUARDO: Amanhã, deixa que eu me sente pesado sobre a tua alma. Pensa em como tu me apunhalaste, no auge da minha juventude, depois desespera e morre. É o príncipe Eduardo quem clama. (mudança de luz)

ZECA/FANTASMA DE HENRIQUE VI: Quando eu era mortal, o meu corpo ungido foi por ti furado e perfurado de modo fatal muitas vezes. Pensa na torre e pensa em mim; desespera e morre, é o Rei Henrique VI quem ordena, desespera e morre. (mudança de luz)

CHIRIZ/FASTASMA DE HASTINGS: Sanguinário e culpado, acorda com culpa e em batalha sangrenta, termina teus dias. Pensa em Lorde Hastings; desespera e morre. (mudança de luz)

PAGÚ/FANTASMA DE ANNE: Ricardo, tua esposa, aquela Anne desgraçada, tua esposa que nunca dormiu uma hora calma contigo, vem agora perturbar-te o sono. Amanhã, durante a batalha, pensa em mim e deixa cair a tua espada sem fio; desespera e morre. (mudança de luz)

ZECA/FANTASMA DE BUCKINGHAM: Fui o primeiro a te ajudar em teu caminho até a coroa, e o último a sentir a tua tirania, na batalha, pensa em Buckingham e morre no terror da tua culpa. Sonha com feitos sangrentos e morte; já desmaiando, desespera; ao desesperar, dá teu último suspiro. (mudança de luz) 
BRUNO/FANTASMA DE CLARENCE: Amanhã, deixa que eu me sente pesado em tua alma, eu que fui afogado para morrer em vinho podre, o pobre Clarence, pela traição em pessoa eu fui traído e morto. Amanhã, durante a batalha, deixa cair tua espada sem fio; desespera e morre! Acorda desse pesadelo, Ricardo! (mudança de luz)

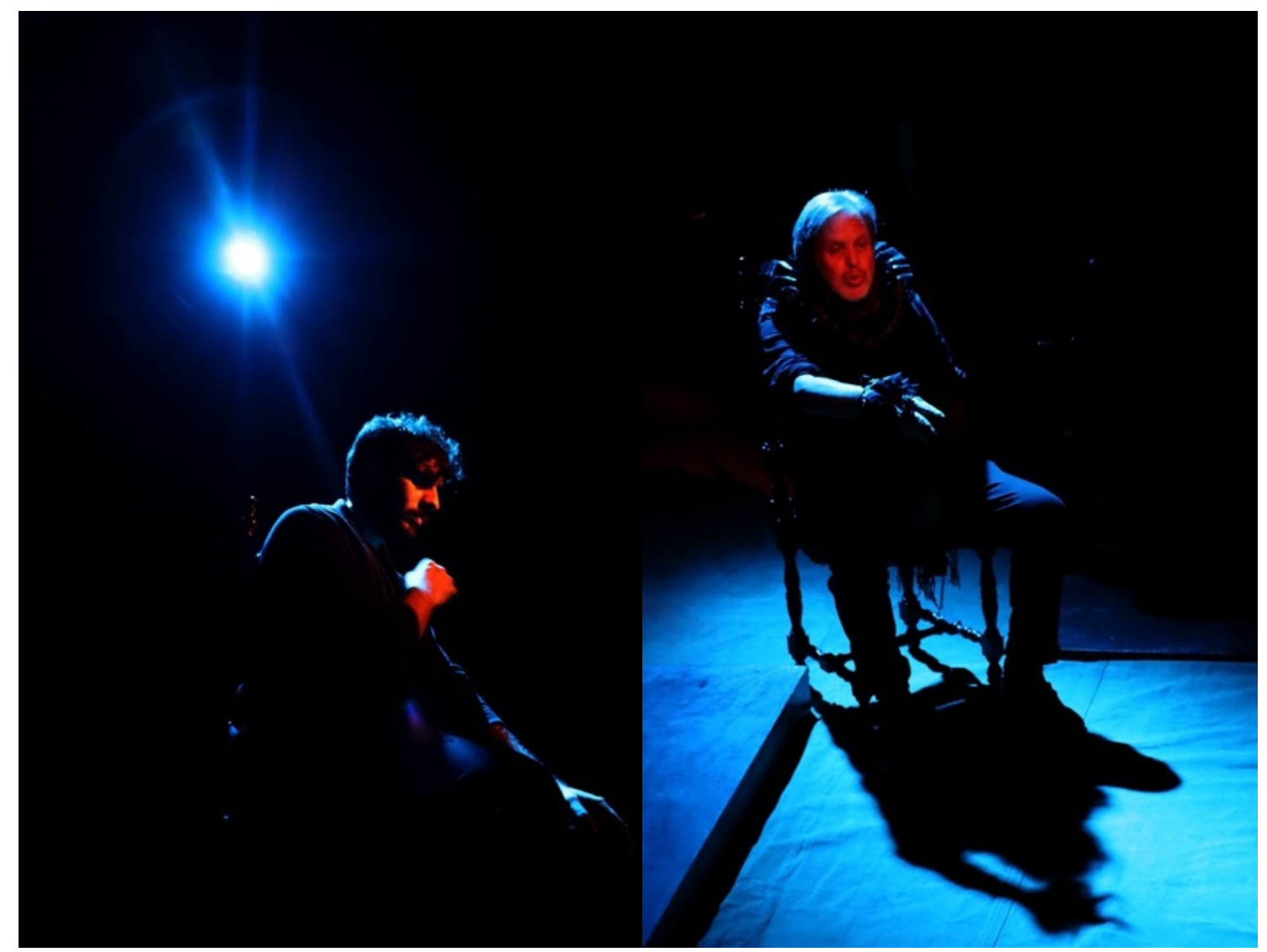

Figura 37 - Bruno Rodrigues e Zeca Cenovicz na cena dos fantasmas do Príncipe Eduardo e de Buckingham, respectivamente. Um Ricardo III. Texto de William Shakespeare. Adaptação coletiva e direção de Rafael Camargo. Luz Nadia Luciani. Fotos Chico Nogueira.

A cena dos fantasmas, concluída com o despertar de Ricardo III de seu pesadelo, é seguida pela primeira cena do texto original, o grande discurso de abertura de Ricardo, ainda como Duque de Gloucester. Na transição das cenas, uma das atrizes se desloca para a cadeira localizada no centro do palco, lugar para onde convergem todos os atores a cada vez que declamam e interpretam textos do protagonista da peça. Estes deslocamentos dos atores até o centro eram alguns dos raros momentos do espetáculo em que o palco era todo iluminado por dois corredores de luz quente e difusa, diagonais à cena. Essa temperatura de cor também era usada na maioria das cenas do protagonista antes de sua ascensão ao trono, o apogeu da trama, quando tudo se tornava mais azulado e frio. Esses corredores de luz ligavam cada uma das duas 
cadeiras localizadas nos extremos diagonais do palco e era por onde os atores se deslocavam até o centro, depois do que a luz fechava novamente sobre o personagem, usando como deixa precisa algum gesto ou fala. O objetivo desses movimentos de luz era mostrar, também, a transformação dos narradores em personagem, além de acompanhar a trajetória e concentrar, novamente, da maneira mais imperceptível possível, a atenção do público sobre ele e, eventualmente, seu interlocutor ou interlocutores, dependendo da cena, que permaneciam sentados em suas cadeiras nas extremidades do palco.

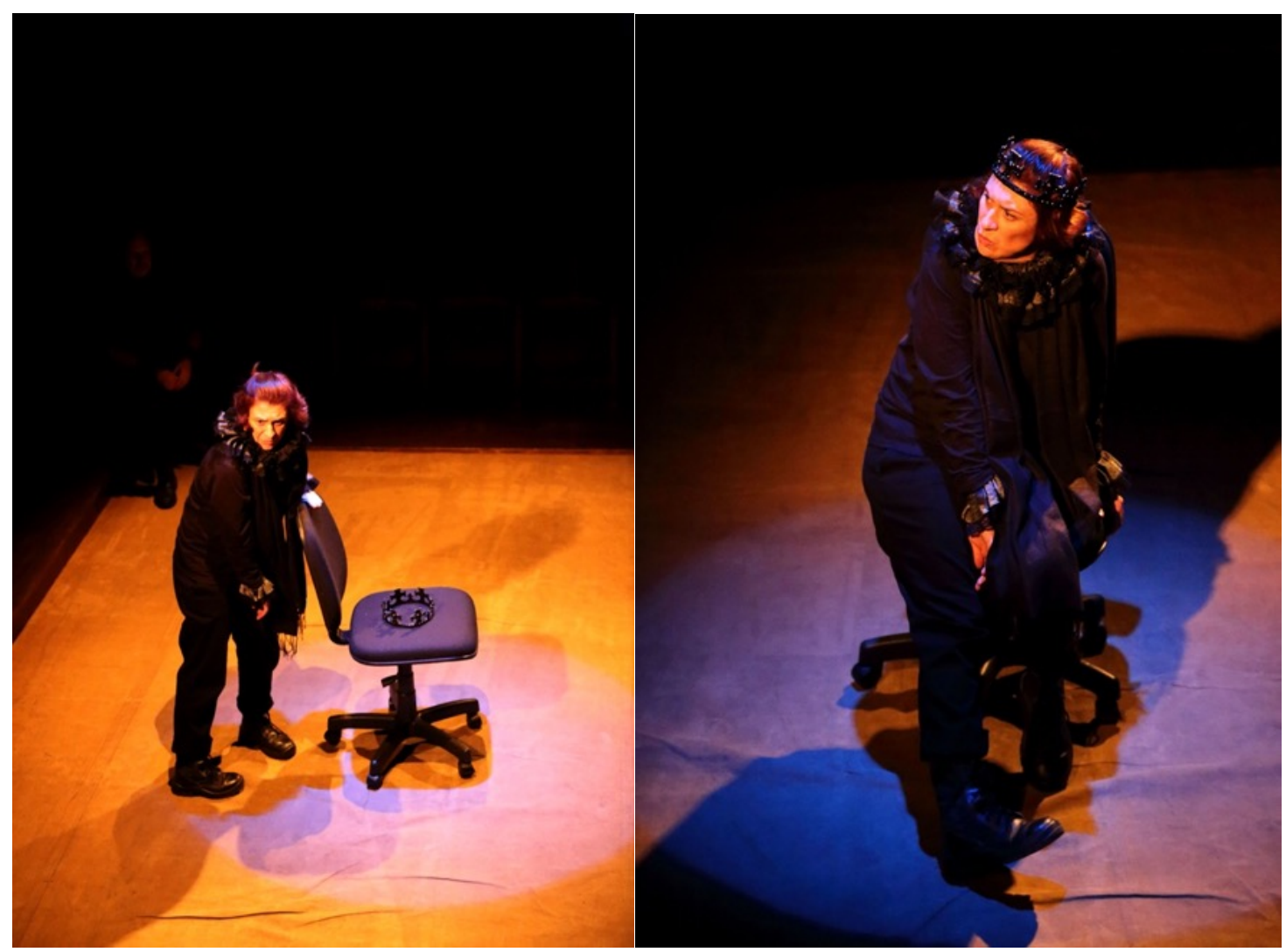

Figura 38 - Pagú Leal, em seu deslocamento como Ricardo III até o centro do palco e depois que a luz se fecha sobre ela. Um Ricardo III. Texto de William Shakespeare. Adaptação coletiva e direção de Rafael Camargo. Luz Nadia Luciani. Fotos Chico Nogueira.

A relação estabelecida, entre cena e público, pela própria estruturação do espaço, era reforçada pela luz e colocava os espectadores praticamente dentro da cena, de onde eles podiam perceber a ansiedade e os menores e mais sutis movimentos e expressões dos atores. Era essa proximidade que favorecia, em grande parte, a atuação performativa da luz. Nesse sentido, um importante momento da peça a ser destacada é a cena do cortejo de Eduardo III, na qual Ricardo destila todo seu veneno e revela sua verdadeira personalidade a um 
público exposto a sua crueldade e frieza. Antes da cena, a atriz Pagú Leal anuncia, como narradora, a entrada de sua personagem Lady Anne, desencadeando novamente, em sintonia com o operador, a mudança de luz de um estado para o outro e dando início à cena, sem que houvesse nenhuma movimentação física da atriz. Com a aproximação do ator que representa Ricardo para o centro do palco, fechando a luz nele em seguida, tem início o diálogo duro e insensível, no qual Ricardo dá provas de seu caráter e corteja a recém enlutada Lady Anne, enquanto esta revela toda sua ira, emoções e sentimentos destacados pela luz soturna e misteriosa que os ilumina, fechada em cada um dos dois performers:

PAGU: Entra Lady Anne acompanhando o corpo de seu marido Henrique VI (mudança de luz)

PAGU/ANNE: Parem, larguem um pouco a vossa honorável carga, se é que se pode encontrar a honra envolta em mortalha em um cortejo fúnebre, enquanto eu por momento pranteio, como pessoa devidamente enlutada, a queda prematura dos virtuosos Lancaster. Ah, amaldiçoada seja a mão que furou vossa carne; amaldiçoado o coração que teve coragem de cometer tal ato; amaldiçoado o sangue que tirou o sangue daqui.

BRUNO/RICARDO - avança para o centro: Parados, vocês que carregam o corpo. Podem descansar a sua carga.

PAGU/ANNE: Que praticante de magia negra conjura esse demônio para que venha interromper atos de devoção e misericórdia?

BRUNO/RICARDO: Canalhas! Larguem o corpo ou juro por São Paulo que também vira corpo aquele que me desobedecer! Cachorro de maus modos, me obedece enquanto eu Ihe der ordens! Ergue a tua alabarda mais alto que meu peito, ou juro por São Paulo que te ponho no chão a golpes e te chuto daqui a pontapés, miserável, por tua impertinência.

PAGU/ANNE: Mas, como? Vocês estão tremendo? Todos com medo? Ai de mim, eu não os censuro, vocês são mortais, e olhos mortais não aguentam encarar o diabo. Xô, fora, tu aí, pavoroso embaixador do inferno.

BRUNO/RICARDO: Minha doce santa, por piedade, não seja maledicente, não pronuncie calúnias, não rogue pragas.

PAGU/ANNE: Demônio sujo, pelo amor de Deus, fora daqui, e não nos atormentes, pois transformaste a terra, este mundo feliz, em teu inferno particular, repleto de gritos lancinantes e berros blasfemos.

BRUNO/RICARDO: Lady Anne, você não conhece as regras da caridade que transforma o mal em bem, as pragas em bênçãos.

PAGU/ANNE: Canalha, tu não conheces as leis de Deus, nem reconheces as leis dos homens. Nem mesmo a mais selvagem das feras desconhece um mínimo de piedade.

BRUNO/RICARDO: Mas eu desconheço e, portanto, não sou nenhuma fera.

PAGU/ANNE: Ah, que maravilha quando os diabos falam verdade! BRUNO/RICARDO: Mais maravilhoso assim é quando anjos ficam assim tão irados. 
PAGU/ANNE: Permita-me, infecção contagiosa em forma de homem, que eu acuse tua pessoa amaldiçoada, provando em detalhes que és culpado destes sabidos crimes.

BRUNO/RICARDO: Mulher mais linda do que as palavras podem descrevê-la, me dê uma folga e escute com paciência o meu pedido de desculpas.

PAGU/ANNE: Homem mais podre do que os corações podem imaginar-te, tu não tens como desculpar-te verdadeiramente, a não ser que te enforques.

BRUNO/RICARDO: Não matei seu marido.

PAGU/ANNE: Ora, mas então ele está vivo?

BRUNO/RICARDO: Não, ele está morto: assassinado pela mão de Eduardo.

PAGU/ANNE: Mentes do fundo de tua garganta fétida. A Rainha Margareth viu teu punhal assassino fumegando no sangue dele.

BRUNO/RICARDO: Fui provocado pela língua difamatória daquela mulher, que jogou a culpa dos dois nos meus ombros inocentes. A tua beleza que não me dava paz nos meus sonhos, pedindo que eu levasse a cabo a morte de todo mundo para que eu pudesse viver uma hora que fosse na doçura do teu peito.

PAGU/ANNE: cospe em Ricardo

BRUNO/RICARDO: Porque cospes em mim?

PAGU/ANNE: Se minha saliva fosse veneno mortal, pelo teu bem.

BRUNO/RICARDO: Jamais saiu veneno de tão doce lugar.

PAGU/ANNE: Jamais escorreu veneno em tão nojento sapo. Fora da minha vista! Tu infectas os meus olhos.

BRUNO/RICARDO: Os teus olhos, minha doce dama, já infectaram os meus.

PAGU/ANNE: Queria que meus olhos fossem basíliscos que matam só de olhar

BRUNO/RICARDO: Queria que fossem, para que eu pudesse morrer de uma vez, pois agora eles já estão me matando de uma morte em vida. Peça para eu me matar e eu o farei.

PAGU/ANNE: Já pedi.

BRUNO/RICARDO: Você fez isso quando estava furiosa, tomada pela raiva. Fale de novo, e enquanto estiver falando, esta minha mão, que pelo teu amor matou o teu amor, irá pelo teu amor matar um amor ainda mais verdadeiro: dessas duas mortes você será cúmplice.

PAGU/ANNE: Eu queria poder ver dentro do teu coração.

BRUNO/RICARDO: Ele se revela nas minhas palavras.

PAGU/ANNE: Temo que coração e palavras sejam falsos.

BRUNO/RICARDO: Então nenhum homem foi verdadeiro.

PAGU/ANNE: Vamos, vamos, guarde a tua espada, não é preciso de que te mates.

BRUNO/RICARDO: Então me diga que estou consigo reconciliado.

PAGU/ANNE: Isso tu só vais ficar sabendo mais adiante.

BRUNO/RICARDO: Mas posso ter esperanças?

PAGU/ANNE: Todos os homens, espero eu, vivem de esperança. (mudança de luz)

O momento em que Anne se deixa enganar e cede, finalmente à sedução

de Ricardo, é marcado por uma sutil e precisa, mudança da luz, que se torna mais aquecida e revela um pouco mais, pelo ângulo e tonalidade, dos rostos dos dois atores, enredados pelo diálogo e pelas articulações maquiavélicas de 
Ricardo para chegar ao trono. Pela configuração da sala em arena, a movimentação dos atores, quando no centro do palco, precisava contemplar diversos ângulos, o que fazia com a que a luz devesse prever, sempre, todos os diferentes pontos de vista possíveis para os observadores.

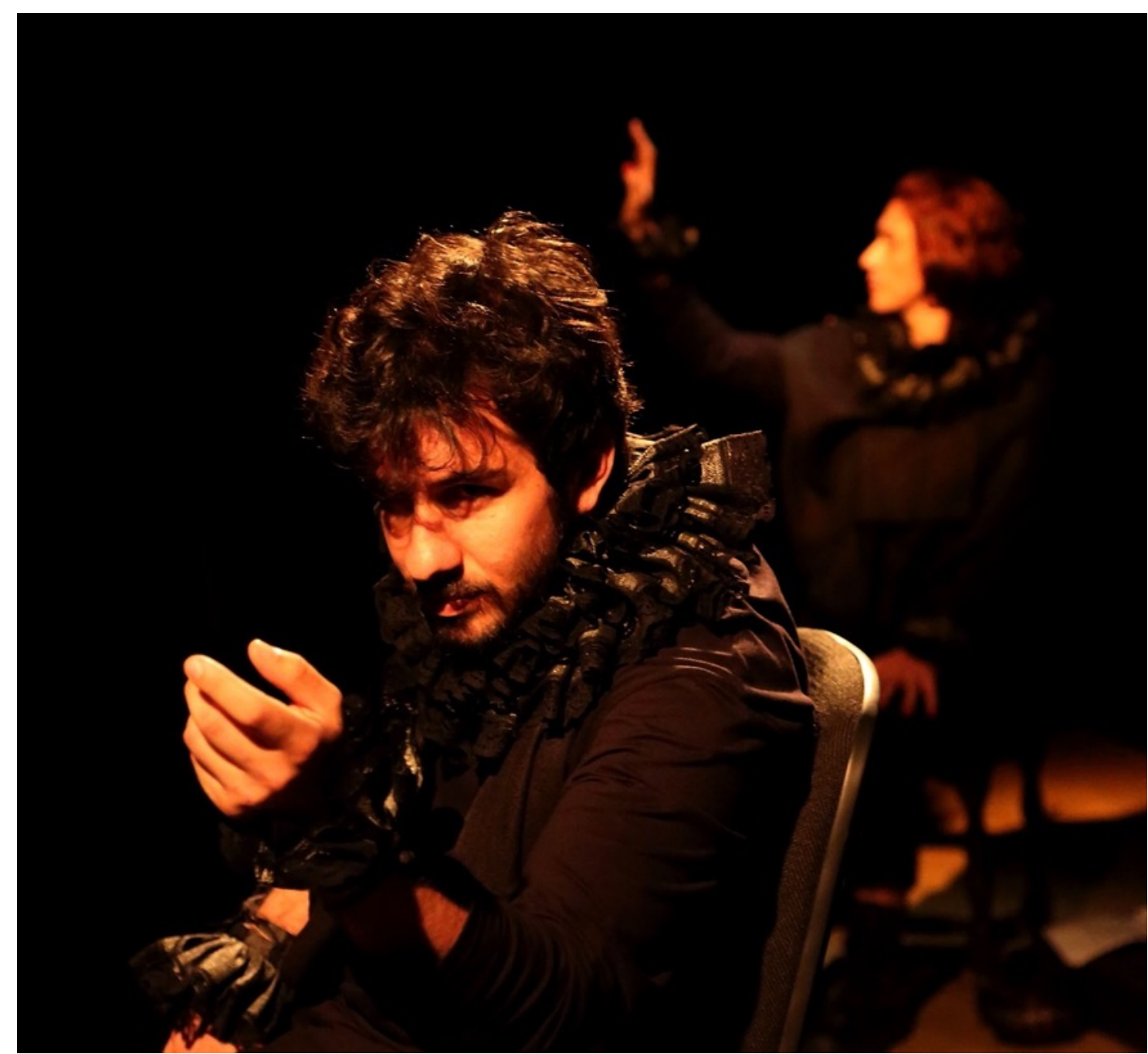

Figura 39 - Cena em que Ricardo, num interessante jogo cênico, mesmo de costas, seduz e convence a viúva de Henrique VI a desposá-lo. Um Ricardo III. Texto de William Shakespeare. Adaptação coletiva e direção de Rafael Camargo. Luz Nadia Luciani. Foto Chico Nogueira.

O mesmo acontecia com o direcionamento, atenção e olhar dos atores, a exemplo desta cena, em que o diálogo acontece com o ator de costas para sua interlocutora, unidos pela interpretação e diálogo precisos dos atores e pela iluminação que os isolava, cada um em sua luz concentrada, criando o universo paralelo em que ambos se encontravam:

BRUNO/RICARDO: Conceda-me usar este anel.

PAGU/ANNE: Receber não é dar. 
BRUNO/RICARDO: Olha como o meu anel abraça o teu dedo; é exatamente assim que o teu peito inclui o meu pobre coração.

PAGU/ANNE: De todo o meu coração; e muito me alegra, também, ver que você se tornou assim penitente.

BRUNO/RICARDO: Despeça-se de mim.

PAGU/ANNE: É mais do que você merece. Mas, já que você me ensina como agradá-lo, imagine que eu já me despedi. (mudança de luz)

BRUNO/RICARDO: Senhores, levem o corpo... (mudança de luz)

$\mathrm{Na}$ sequencia, acontecem duas cenas nas quais Ricardo, interpretado alternadamente por dois outros atores, continua a descortinar, com palavras e expressões frias e cruéis, seus estratagemas. Essas falas eram igualmente intercaladas com novos textos narrativos, inseridos para elucidar as passagens retiradas do texto original, como: "As intrigas políticas e palacianas ocorrem em vários níveis entre os yorkistas e os lancastreanos. Falsidade, traição, conspiração, ódio, morte.", acompanhados pelas respectivas mudanças de luz que indicavam a alternância entre os textos narrativos e dramáticos. Uma nova mudança de luz, motivada pelo anúncio de Ricardo III: "Lá vem a velha bruxa Margareth", faz acender o foco colorido que insere a personagem no ambiente em que já se encontra o Rei. Na deixa final do texto de Ricardo III, a luz muda novamente e transforma o ambiente tenso do embate entre Ricardo e Margareth para a neutralidade da cena narrativa. A atriz Pagú Leal anuncia, então, a próxima cena, sob o conjunto de luzes (a pino e fechada no seu rosto) característico dos narradores: "Rei Eduardo IV, doente, a Rainha Elizabeth e seu secto." A luz se transforma precisamente após seu texto, antes do início da cena.

Dada a proximidade entre o público e a cena, a relação estabelecida chegava próximo ao invasivo, gerando comoção e empatia, em alguns casos, ou desconforto e repulsa, em outras cenas, pelos personagens odiosos e seus textos, principalmente os do próprio protagonista, a exemplo de cena na qual Ricardo, enquanto Eduardo IV proclama a paz e a amizade entre seus Lordes, revela o ápice de sua falsidade e dissimulação, declarando-se aliado e fiel ao Rei e sua corte antes de anunciar, sarcasticamente, a morte do seu irmão Clarence, negando sua própria responsabilidade no caso. Numa montagem tradicional, esta cena, uma grande audiência do Rei, naturalmente repleta de partícipes, deveria ter uma iluminação clara e ampla. No entanto, dadas as características da luz criada para este projeto, com padrões mais sombrios, 0 
resultado foi o uso de luzes concentradas nos personagens, criando micro ambientes individuais para cada um, unidos da mente do espectador, como frames ou closes cinematográficos quando a câmera passa de uma ator para o outro durante um diálogo, permitindo ao público focar nos rostos, nas expressões e nas intenções dos personagens, aguçando sua percepção e assimilação da cena. A iluminação feita para o Rei moribundo, por exemplo, cujo facho luminoso vinha do chão, dava destaque para sua aparência sofrida e projetava sua sombra na parede, revelando ainda sua majestade e soberania, já perto do fim.

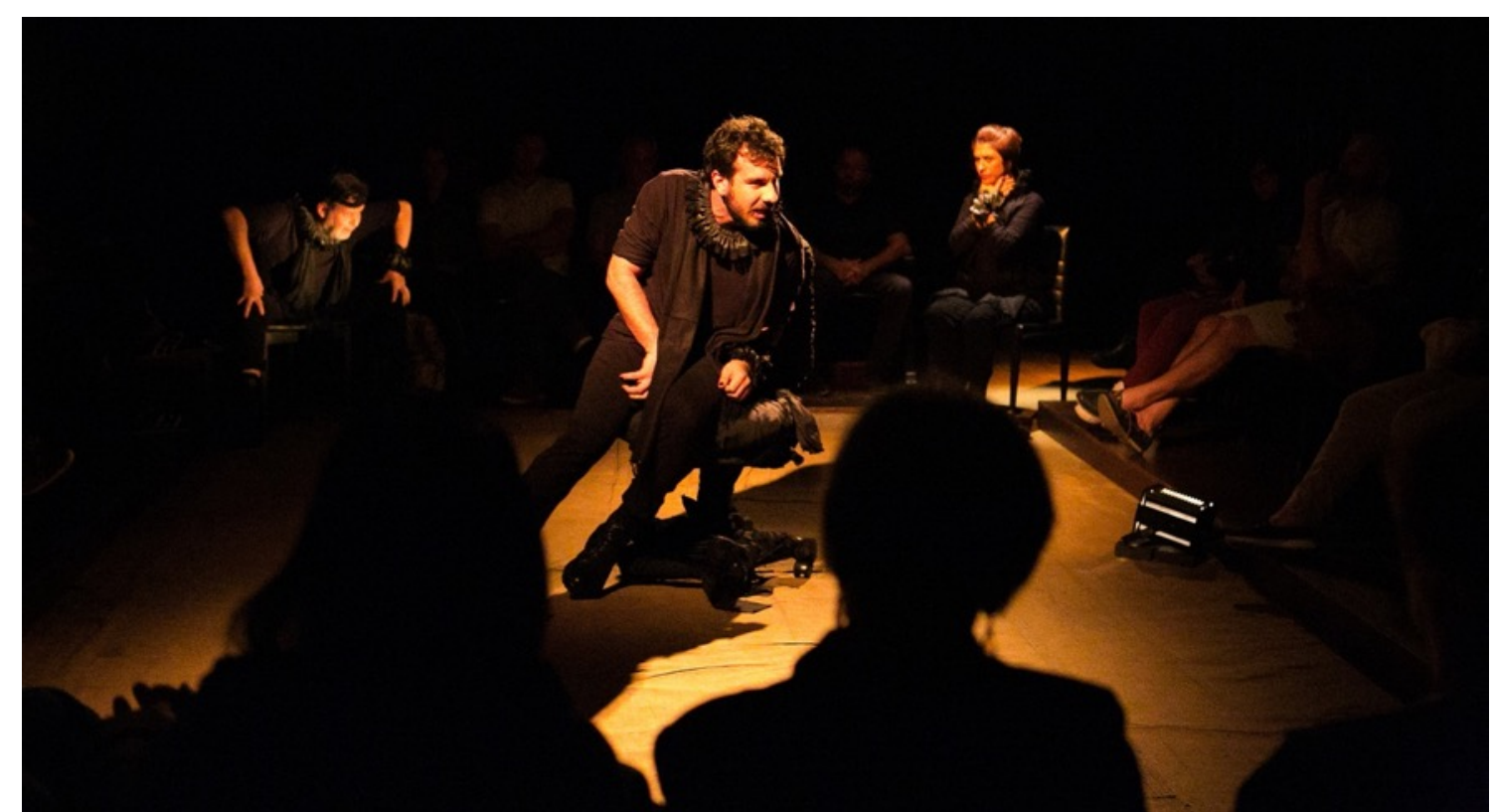

Figura 40 - Cena que que Ricardo anuncia a morte do irmão Clarence para o Rei Eduardo IV e sua corte. Um Ricardo III. Texto de William Shakespeare. Adaptação coletiva e direção de Rafael Camargo. Luz Nadia Luciani. Foto Chico Nogueira.

Ao final dessa mesma cena, num dos momentos de transição bem marcada entre personagem e narrador, o próprio ator que interpreta o rei transforma-se, junto com a luz que o ilumina, para anunciar sua morte. A passagem de um estado luminoso para o outro foi realizado em total sincronia entre o ator e o operador de luz, no tempo de uma respiração profunda, na qual o ator abandona a posição corporal e expressão do personagem monarca e assume a nova postura de narrador para declarar: "O rei morre."

Entre tantas outras intrigas, mortes e crimes, o Duque de Gloucester chega ao trono e se torna Ricardo III, numa cena que demonstra, mais uma vez, seu grande poder de manipulação e perversidade: 
CHIRIS: Assim, Eduardo e seu irmão são trancafiados na Torre de Londres e cruelmente assassinados a mando de Ricardo. Para que não restassem duvidas da legitimidade do seu direito à coroa, nosso herói tirano encena, com seus aliados, uma aclamação publica. Ricardo III é o usurpador do trono da Inglaterra (mudança de luz) PAGU/SECTO: PAGU/SECTO: Faça isso meu bom lorde os seus cidadãos assim lhe pedem, não rejeite, poderoso lorde, este amor ofertado.

ZECA/RICARDO III: O amor que vocês têm por mim, merece o meu muito obrigado, mas não sou merecedor de tão alta petição. Por que os senhores iriam querer amontoar essa carga sobre os meus ombros? Não sou adequado para ser governante ou majestade. Não me interpretem mal: não posso e não quero ceder a esse pedido.

PAGU/SECTO: Ah, senhor, faça-os felizes; aceite esse legitimo pedido de todos; sejas rei!

BRUNO/CHIRIS/PAGU/SECTO: Sejas rei! Sejas rei!

ZECA/RICARDO III: Vocês querem me por a força em um mundo de preocupações. São as circunstâncias que ditam a minha conduta. Não sou feito de pedra, sou permeável aos seus bondosos pedidos, embora contra a minha consciência e a minha alma. Já que é do agrado de vocês, pois são os senhores que estão querendo isso... eu aceito. (mudança de luz)

Na cena da coroação, uma das mais claras e luminosas do espetáculo, o palco era invadido pela luz de chão, vinda por traz dos atores e do público em um tom de azul claro, levemente esverdeado, em contraste com o azul escuro super fechado vindo de cima, ao mesmo tempo em que o som gutural do didjeridu preenchia o ambiente. A intensidade da música, acompanhada pelas palmas vigorosas, aumenta gradativamente até o momento em que a coroa é definitivamente instalada em sua cabeça. O silêncio e a mudança brusca da luz transformam a cena e permitem o relaxamento do público após os momentos tensos que o precedem.

Outra importante cena narrativa, que tende a incitar os espectadores a desejar a derrocada de Ricardo III, é a cena em que são feitos os relatos das atrocidades cometidas por ele para chegar ao trono, acompanhados pela luz de cada um dos narradores por vez, conduzindo freneticamente a atenção do público de um para o outro:

BRUNO: Mulheres, mães que perderam seus filhos, avós que perderam seus netos, esposas que perderam seus maridos, todos assassinados pelo sanguinário Ricardo III. A Duquesa de York, mãe de Ricardo, a velha Rainha Margareth e a Rainha Elizabeth. (mudança de luz)

BRUNO/ELIZABETH: Ah, meus pobres Príncipes! Ah, meus filhos queridos, minhas flores que não podem mais desabrochar, doces botões semiabertos! Se as suas cordiais almas ainda pairam no ar e 
não se fixaram em seu destino perpetuo, adejem ao redor de mim com suas asas etéreas e escutem os lamentos de sua mãe. (mudança de luz)

PAGU+CHIRIS/DUQUESA: Vida morta, visão cega, fantasma vivo de uma pobre mortal; quadro do infortúnio maior vergonha do mundo; quando por direito deveria estar na cova, foi usurpada pela vida; breve resumo e registro de odiosos dias: Descansa teu cansaço no legitimo solo da Inglaterra, que, de modo ilegítimo, embebedou-se de sangue inocente. (mudança de luz)

ZECA/MARGARETH: Se as dores antigas são as mais reverenciadas, reconheçam a minha como soberana e permitam que minha desgraça encare com firmeza a dor mais dolorida. Se a tristeza admite companhia, repensem seus pesares ao reconsiderar os meus. Eu tinha um Eduardo, até que um Ricardo o matou; eu tinha um marido até que um Ricardo o matou; vocês tinham um Eduardo até que um Ricardo o matou; vocês tinham um Ricardo até que um Ricardo o matou. (mudança de luz)

CHIRIS+PAGU/DUQUESA: Eu também tinha um Ricardo, e tu o mataste; e eu também tinha um Routland, que tu ajudaste a matar.

BRUNO/ELIZABETH: Minha cara senhora, hábil praticante de rogar pragas, fique um pouco mais e me ensine a amaldiçoar os meus inimigos. Você previu que tempo viria em que eu não teria como prescindir de sua ajuda para amaldiçoar aquela aranha inchada, aquele sapo imundo e corcunda.

ZECA/MARGARETH: As tuas dores saberão afiá-las, e elas serão contundentes como as minhas. (mudança de luz)

A continuidade dessa cena, a exemplo de muitas outras transições semelhantes, se dá precisamente sincronizada com o final do texto do ator Zeca Cenovicz, quando se apagam os quatro focos dos personagens que participaram da cena anterior e entram as quatro luzes a pino nos quatro atores, agora como narradores. Imediatamente depois, saem três deles e entra a luz no rosto da atriz Pagú Leal para que ela anuncie, como narradora, a próxima cena: “Agora, o ardiloso plano de Ricardo para fortalecer o seu reinado era casar-se com a sua sobrinha, filha da Rainha Elizabeth, irmã dos sobrinhos que ele covardemente matou", na qual o Rei Ricardo III, mais uma vez, em uma adaptação do texto original, dá provas de seu caráter ignóbil, vagamente perceptível pelas iluminação tênue do corredor de luz que o leva ao trono e das igualmente suaves luzes que o iluminam, em seguida, no centro da cena:

ZECA/REI RICARDO III: Minha querida cunhada Elizabeth, (Zeca chega no trono - mudança de luz) ... o que está feito, não pode ser agora remediado. Os homens às vezes agem impensadamente, coisa que mais tarde, traz oportunidades de arrependimento. Se tomei o reino de seus filhos, para remediar, quero dá-lo à sua filha. Se matei os frutos do seu ventre, para aumentar sua prole encarrego-me de gerar uma prole do seu sangue com sua filha. "Avó" é nome também 
carregado de amor e não fica muito atrás do adorado título de "mãe". (mudança de luz)

Quase no final do espetáculo, um pouco antes da batalha final, a atriz Pagú Leal anuncia o que virá: "Depois de sua sanguinária ascensão ao trono, Ricardo enfrentará e será derrotado pelo exército de Richmond e seus aliados." A luz sobre a atriz muda, então, do pino e foco da narradora para o foco colorido do personagem de Richmond, que profere seu discurso:

PAGU/RICHIMOND: Companheiros de armas e meus caríssimos amigos feridos sob o jugo da tirania: até este ponto país adentro, nós marchamos sempre em frente e sem obstáculos, e agora recebemos de nosso pai algumas palavras de grande conforto e muito incentivo. O porco-bravo desgraçado, sanguinário, usurpador que arruinou suas colheitas de verão e seus frutíferos vinhedos, que costuma abeberarse no sangue dos senhores como se este fosse lavagem e faz gamela os seus peitos eviscerados... esse porco imundo está nesse mesmo instante no centro desta ilha; acabemos com ele! (mudança de luz)

A luz muda novamente para o centro do palco, onde está o Rei Ricardo III, já no clima da batalha, com o cruzado âmbar e o pino azul intenso:

ZECA/RICARDO III: Pensem naqueles com quem vocês entrarão em combate: uma raça de vagabundos, patifes e desertores; uma escória de gente que nos chega da França e campônios calhordas sem eira nem beira, que o país deles empanturrado vomita para cá, e em busca eles vem de aventuras sem futuro e destruição certa. Mil corações batem, grandiosos, dentro do meu peito. Avante! Vamos para cima do inimigo! (mudança de luz)

A luz muda novamente e três dos atores indicam a transição de cena com o som crescente do didjeridu e dos dois sinos tibetanos. A luz também sobe, lentamente, até que a sala seja completamente iluminada por uma luminosidade azul esverdeada, fria e, principalmente, cruel. O que desencadeia o início do movimento progressivo da luz forma, justa e precisamente, as palavras do Rei: "Avante! Vamos para cima do inimigo!" Junto com as outras luzes já em cena, a geral azul intensa, usada pela primeira vez no espetáculo na sua intensidade máxima de $100 \%$, domina a cena e dá o tom do final do drama sanguinário. Quase derrotado, o Rei profere sua última súplica:

ZECA/REI RICARDO III: Um cavalo! Um cavalo! Meu reino por um cavalo! Apostei minha vida em um lance, então aceito o que marcarem os dados. Um cavalo! Meu reino por um cavalo. (mudança de luz) 


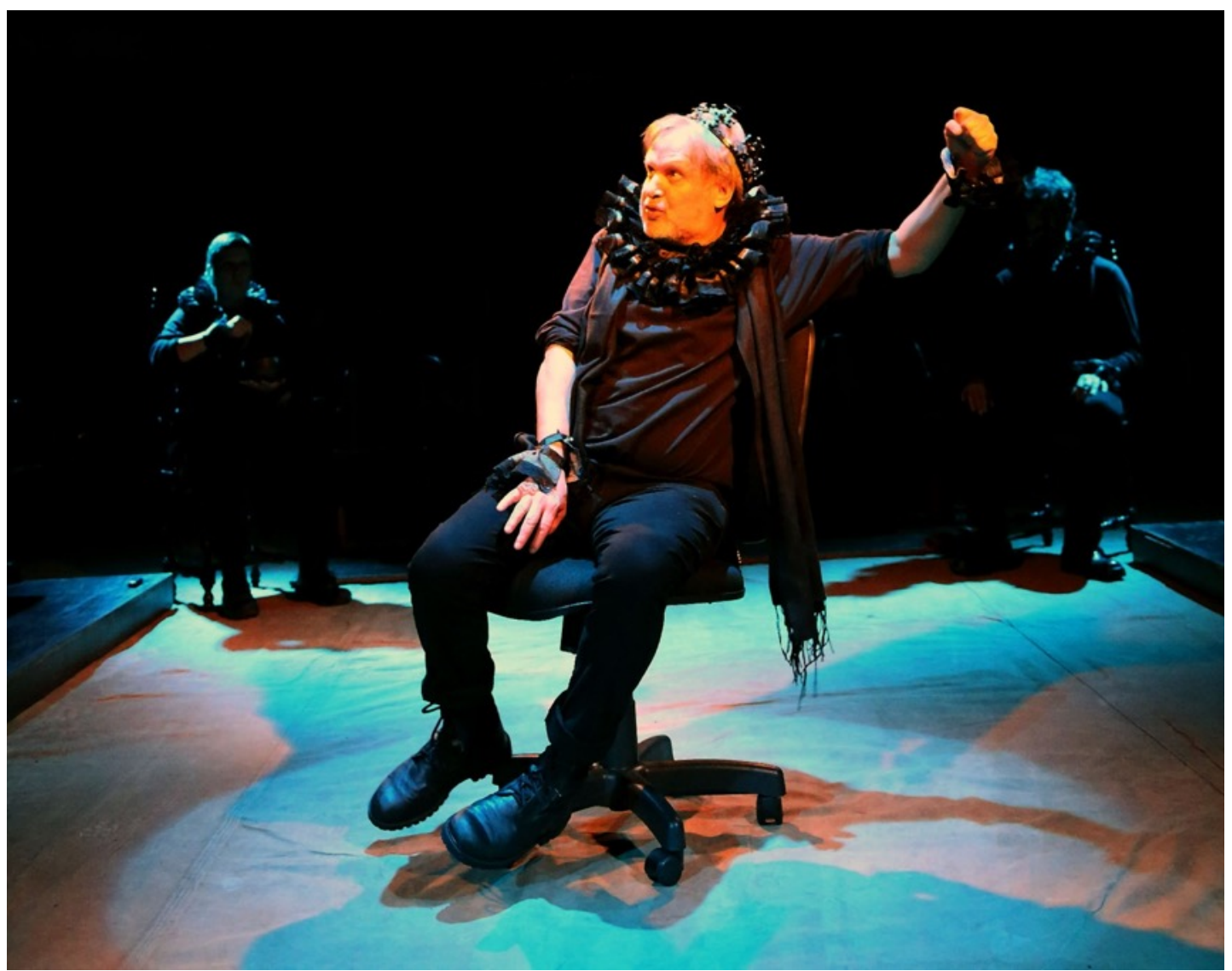

Figura 41 - O Rei Ricardo III em sua batalha final, enquanto os atores ao fundo tocam os instrumentos que ambientam a cena. Um Ricardo III. Texto de William Shakespeare.

Adaptação coletiva e direção de Rafael Camargo. Luz Nadia Luciani. Foto Chico Nogueira.

Finalmente, tudo se acalma, a luz muda novamente, apagam-se todos os outros efeitos, ficando só a geral azul e o pino do trono com o rei quase morto ao centro. A cena de batalha dá lugar ao clima azul denso e pesado do final do espetáculo, quando Richmond proclama a sentença final de Ricardo III:

BRUNO/RICHMOND: Louvado seja Deus e louvados sejam os vossos braços fortes, meus vitoriosos amigos! Ganhamos o dia: o cão sanguinário está morto! Agora estanca-se a grande ferida civil e faz-se renascer a paz; queira Deus que ela tenha vida longa. (mudança de luz)

A luz se dissipa, lentamente, até restar somente o pino azul do trono, presente desde o coroamento do Rei Ricardo III, quase tão sólido e material quanto o próprio trono e o poder do Rei, cuja face, corpo, figurino e coroa assumem a coloração azulada de seu poder frio e bárbaro. Num último suspiro, a frase irônica sai de sua boca quase imperceptivelmente, quebrando levemente o clima dramático da cena e provocando risos nervosos na plateia: "Ah, Richmond, que saco..." No entanto, o tempo e a desgraça não estão a seu favor. 
A coroa cai de sua cabeça e permanece inerte no chão, como registro de sua derrocada e da queda de seu reinado.

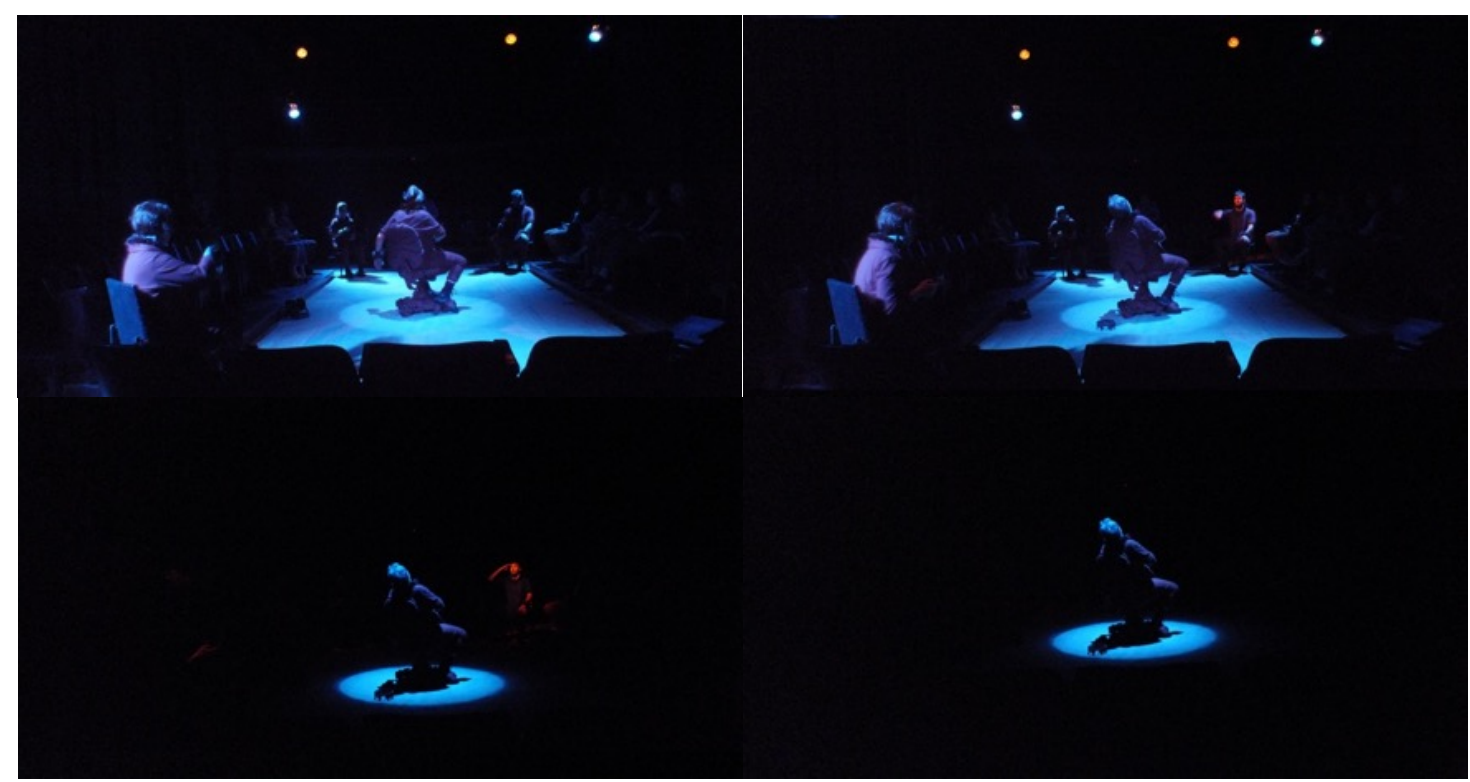

Figura 42 - Sequencia de movimentos de luz até o texto de Richmond, ao fundo, e o último suspiro de Ricardo III, vencido em uma sanguinária batalha. Um Ricardo III. Texto de William Shakespeare. Adaptação coletiva e direção de Rafael Camargo. Luz Nadia Luciani.

Fotos Chico Nogueira.

Esse pino azul, quase material, de uma cor intensa e uma saturação que parece brincar com os olhos do público, é apagado muito lentamente até o blecaute completo. É a mesma luz do início do espetáculo, mas que se extingue tão devagar, num escurecimento longo, com duração de mais ou menos 30', muito mais lento do que estamos acostumados no teatro, a ponto de causar certo desconforto e impaciência nos espectadores. Inicialmente gravado na mesa de luz, esse movimento acabou tendo que ser feito na mão, pois percebemos ser importante, para fazê-lo, sentir a reação do público, saber quando parecia que já tinha quase acabado para fazê-lo durar um pouco mais, entender até que ponto os espectadores ainda estavam apegados à cena e quanto ainda eles suportariam a tensão de saber que o Rei ainda vivia, que ainda havia nele alguma energia e que dali ainda poderia emergir alguma ação maldosa. 0 movimento tinha que ser feito manualmente, considerando a sensibilidade do operador para perceber a emoção do público e suas reações a cada apresentação. Esse blecaute progressivo, que culminava no desaparecimento da luz e, consequentemente, do personagem, tinha como propósito causar um efeito angustiante sobre o espectador, que torcia pela morte de Ricardo III depois 
de todas as atrocidades cometidas por ele, mas que presenciava, ao mesmo tempo, a resistência à morte e ao fim de seu sofrimento, o último suspiro de sua existência nefasta, pela luz que parecia não se extinguir nunca. A duração deste blecaute era como a obstinação de um reinado que tanto revelou da natureza humana perversa e que resistia em encontrar seu fim.
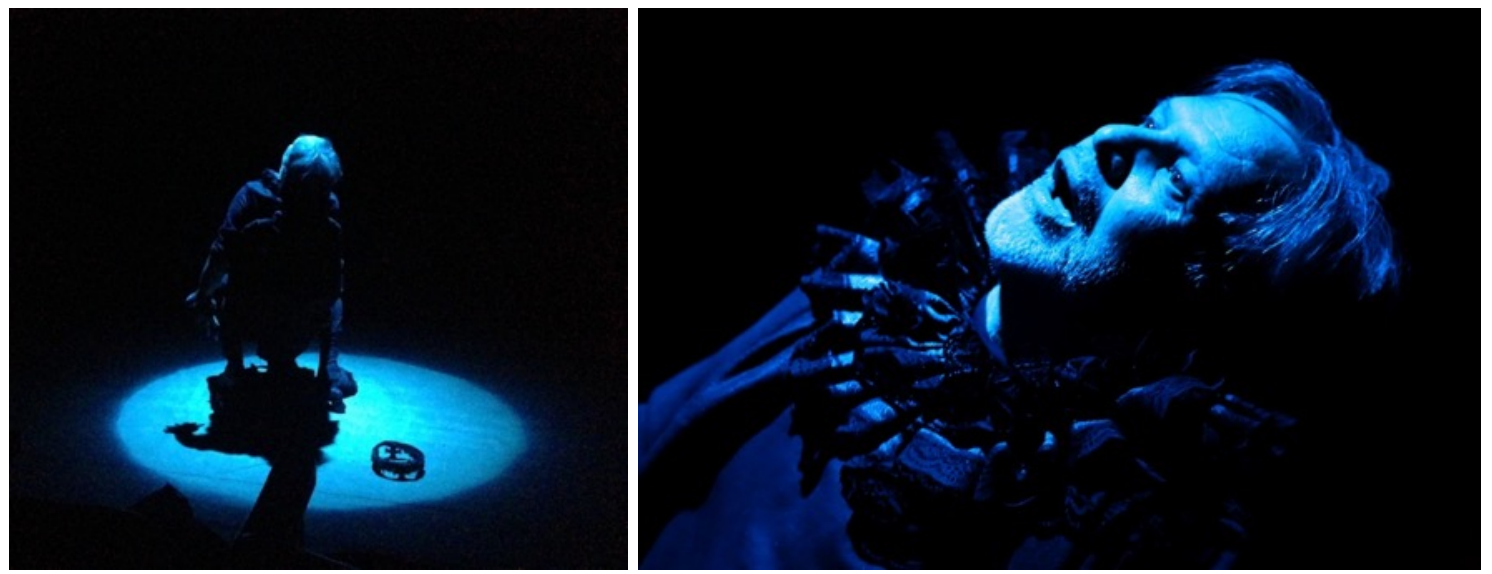

Figura 43 - A materialidade poética da luz no final do espetáculo Um Ricardo III, Um Ricardo III. texto de William Shakespeare. Adaptação coletiva e direção de Rafael Camargo. Luz Nadia Luciani. Fotos Nadia Luciani e Chico Nogueira.

Esse efeito de luz demonstrou, ainda, uma possível dramaturgia do blecaute, aqui tão material quanto a luz, e cuja velocidade, duração e maneira de ocupar a cena, ao mesmo tempo que a luz a abandona, podem provocar no espectador diferentes reações e sensações. Sua materialidade poética e sua presença cênica revelam, uma muito provável, performatividade do blecaute, a ser possivelmente investigada num futuro próximo.

Finalmente, para concluir este estudo de caso, a análise da luz-matéria performativa no espetáculo Um Ricardo III considera os aspectos específicos da luz aplicados à esta encenação particular, que integrados ao seu conjunto como parte estrutural da montagem, elemento editor e condutor narrativo, condiz com o espetáculo e estabelece o elo entre a cena e o espectador. A luz criada para esta peça expõe, como linguagem, uma expressão da paixão e da ira, apresentadas pelos atores e estendidas à interação entre o público e a cena, tornando-se um elemento ativo do espetáculo, um componente performativo do teatro e de sua magia. 


\subsubsection{Multitud}

\section{Abertura do Festival NEXT - França-Bélgica - Nov/Dez de 2019}

No dia 14 de novembro de 2019, ainda durante meu estágio de pesquisa do doutorado sanduiche na França, eu fui agraciada com o espetáculo de abertura do festival binacional NEXT, apresentado em Courtrai, na Bélgica. Multitud é mais que um espetáculo, é uma experiência sensorial à qual são submetidos, simultaneamente, performers e espectadores, num espaço-tempo presente, real, intenso e instigante do qual não se pode escapar. Espetáculo da coreógrafa uruguaia Tamara Cubas, já montado e apresentado no Brasil, segundo ela mesma, em duas circunstâncias. Uma delas foi durante 0 FestDança Curitiba, um festival nacional de dança organizado, em 2004, pelo bailarino Wanderley Lopes em parceria com o Centro Cultural Teatro Guaíra, cujo objetivo era convidar bailarinos locais para integrar, temporariamente, as companhias convidadas, participando dos espetáculos apresentados. No Brasil, foram principalmente performers, bailarinos, dançarinos e outros artistas da cena que responderam à chamada, ao contrário do que aconteceu nesta montagem na Bélgica. Além da incrível experiência de assistir e presenciar um grande acontecimento artístico, eu tive a grata surpresa, com este espetáculo, de me deparar, no momento em que desenvolvo minha investigação a respeito, com uma iluminação performativa no seu mais alto grau. A participação, influência e interação da luz com o espetáculo não poderia ser mais potente, instigante, comunicativa e, enfim, performativa.

Foi justamente por estar em pleno processo de amadurecimento e consolidação da minha pesquisa, bastante enriquecida por essa experiência, aliás, e mais precisamente por sentir toda a influência que a luz deste espetáculo tinha sobre mim e as pessoas ao meu redor, que eu pude constatar sua potencialidade performativa. Uma luz que propõe pontos de vista, maneiras de olhar, ângulos e formas, cores e sensações, impressões sobre o que é mostrado e proposto também pela ambientação, pelos performers, pelo som, pelo conjunto 
da cena e, inclusive, pela plateia, que é perceptivelmente afetada pelo que acontece em cena e, naturalmente, compartilha, expressa, voluntária ou involuntariamente, essa afetação aos que estão próximos. É inevitável perceber o efeito que o que acontece em cena tem sobre as pessoas ao seu lado, pois a luminosidade que emana do palco faz com que toda a plateia fique iluminada, ao ponto de que todos conseguem se ver e se perceber, visual e emocionalmente. Não raro, eu me surpreendi buscando identificar a reação das pessoas próximas, sentindo que essas reações e percepções eram tão parte do espetáculo quanto o que nos era mostrado no palco.

A luz, presente, era profundamente propositora do olhar, reveladora de tensões que, pelo ritmo e intensidade dos movimentos e transformações que propunha, acompanhava a cena e as ações, os jogos propostos e realizados pelos performers, intensificando ou abrandando o compasso dos movimentos, juntamente com o som, insistente e incisivo, quase perturbador, em vários momentos (ao ponto de duas senhoras ao meu lado cobrirem os ouvidos com as mãos), assim como a luz que, quase ao final do espetáculo, atinge plenamente e agride os olhos dos espectadores na plateia. Pulsando, respirando, interagindo e influenciando a ação cênica, a luz atuava e afetava a cena, conforme a expressão corporal dos performers e, à medida que os movimentos coletivos faziam deslocar a massa de pessoas, preenchendo o palco ao som de músicas, ruídos e interferências sonoras contundentes.

Logo ao entrar no espaço em que aconteceria o espetáculo, um grande galpão de exposições preparado à italiana, com a área do palco delimitada por equipamentos de luz e uma grande arquibancada instalada à frente dela, já era possível se dar conta da materialidade da luz. Na plateia, fomos recebidos por uma potente bateria de 6 set lights de $1000 \mathrm{~W}$ voltadas para nós. Usada como iluminação para a entrada do público, ela me fez me questionar, ainda mais uma vez, porque nós, iluminadores do mundo todo, continuamos a fazer esse tipo de luz de plateia, visto que, quando temos a oportunidade de estar no papel do público, sentimos o quanto ela é ruim, agressiva e perniciosa para a experiência do espectador. Enfim, há que se admitir que, em alguns casos, a intenção pode 
ser exatamente a de incomodar, cegar o público, ofuscar o olho do espectador com objetivos sensoriais precisos. Devo admitir, finalmente, que talvez tenha sido este o caso, pois eu pude perceber alguns efeitos desta luz em mim mesma e nas pessoas à minha volta. Uma senhora, que estava ao meu lado, me confessou que pensava que aquela luz tinha, como propósito, nos inquerir, nos colocar na posição de réus. Ela disse que se sentia angustiada como se estivesse sendo interrogada em um tribunal ou em uma sessão de tortura. Eu acabei por lhe confessar que a mim, particularmente, ela tinha apenas a capacidade de irritar, mas isso pode se dever à minha condição de profissional da luz, nem um pouco acostumada a estar deste lado do refletor, muito menos dessa forma tão agressiva. Enfim, a questão, afinal, é que, com isso, a experiência com a luz tinha início desde aquele momento, quando a incômoda luminosidade, perturbadora e presente, desde a entrada na sala, forçava as pessoas a colocarem a mão no rosto para conseguir ver quem chegava, se reconheciam algum conhecido a quem estavam esperando e para quem guardavam o lugar ao seu lado. Ou apenas para tentar vislumbrar um pouco do palco vazio e inerte, completamente oculto por essa luz que nos cegava.

Um pouco antes de começar o espetáculo, como era de se esperar por ser a noite de abertura do festival, um distinto senhor veio a público agradecer, em francês, flamengo e, com um pouco mais de dificuldade, inglês, os apoiadores, patrocinadores e colaboradores do festival. Ele nos trouxe ainda algumas importantes informações a respeito do espetáculo: "o elenco, formado por 64 pessoas desconhecidas e escolhidas entre voluntários, se reuniu apenas 1 semana antes da apresentação, quando do início do trabalho. Essas pessoas, vindas de diferentes lugares e realidades, não eram todos atores ou performers e nem mesmo se conheciam, mas entrariam em cena para compartilhar aquele espaço e aquele momento conosco, apresentando sua performance cheia de improvisações. Luz e som os acompanhariam nas marcações e nos improvisos." Eu descobri, mais tarde, que os "64 participante locais da Bélgica e da França" descritos no programa vieram, também, de outras partes do mundo, inclusive duas brasileiras, e que "em todas as suas diferenças, os dançarinos concretizam uma coisa magnífica com a qual a sociedade ainda tem tanta dificuldade: se 
compreender sem compreender a língua do outro". Esse fato ficou ainda mais curioso quando eu fui conversar com a coreógrafa depois do espetáculo e pude deduzir que sua comunicação com o elenco havia acontecido também sem muitas palavras, visto que aparentemente ela não falava inglês, francês ou flamengo. Nesta conversa, eu descobri ainda que a equipe de criação do espetáculo, formada por ela mesma, seus iluminadores, Leticia Skrycky e Sebastián Alíes e os músicos Francisco Lapet e Martin Crauciun, compunham uma equipe permanente que viajava com o espetáculo e chegava em cada local, igualmente, na semana da montagem, para executar o rider e o mapa de luz permanente, realizado, a cada vez, com as condições técnicas locais.

Em uma pesquisa posterior, eu descobri que Leticia Skrycky ${ }^{174}$ é uma iluminadora uruguaia formada em Design Cênico na Escola Municipal de Arte Dramática de Montevidéu, cujas especialidades, apesar de iluminar também teatro, são a dança contemporânea e as artes visuais. Em 2008 iniciou, em colaboração com Sebastián Alíes, um trabalho de investigação sobre iluminação cênica e instalações para as quais forma utilizadas as linguagens de vídeo, som e luz. Sebastián Alíes ${ }^{175}$ é um jovem designer gráfico, artista visual, video jockey e pesquisador de técnicas visuais, no âmbito da criação de imagens e interação de tecnologias e linguagens cênicas contemporâneas de som e luz.

Terminados os agradecimentos e as apresentações, somos lentamente libertados da incômoda luz das set lights que nos cegam para que possamos ver o palco à nossa frente, já preenchido em parte pelos equipamentos de luz, os únicos elementos presentes em cena, ainda dormentes, lentamente revelados por uma nova bateria de 6 set lights, mas desta vez voltados para a cena, como luz de ribalta (luzes posicionadas à frente o palco italiano, no chão, voltadas para o palco). Além de mostrar os demais refletores espalhados pelo palco, ela revela também o imenso galpão vazio, com suas paredes pintadas de preto e com toda a estrutura aparente de portas, encanamentos e ferragens. Com o revelar da cena, foi possível sentir novamente a presença e a materialidade da luz do 
espetáculo, cujo equipamento estava todo em cena, visível e imposto ao público, mesmo que ainda apagado. Não existia um só refletor suspenso, todos estavam na altura da caixa cênica, interagindo com os atores, dividindo e compartilhando o campo de visão e a percepção que tínhamos do palco.

Tanto eu quanto outras pessoas na plateia, segundo conversas durante o coquetel oferecido após o espetáculo, puderam sentir essa presença e, ao menos para mim, foi instigante, inclusive, imaginar quando, como e porque acenderiam as diferentes baterias de refletores, como as lâmpadas PAR 64 instaladas em tripés na altura da cabeça dos performers, completamente voltadas para nós, como canhões ameaçadores, prontos para dispararem a qualquer momento e nos cegar com sua luz implacável. Ao final do espetáculo, conversando com uma das performers brasileiras, eu pude perceber que essa curiosidade e expectativa era também compartilhada por eles, pois foi a primeira coisa que ela me perguntou sobre minha experiência como espectadora, depois de eu relatar meu prazer em ver o espetáculo. Além da bateria de contraluz com 12 lâmpadas PAR64, havia ainda 20 tubos fluorescentes verticais nas laterais do palco, 6 maxibruts com 8 lâmpadas cada, também nas laterais e nos quatro cantos do palco, e 6 set lights na ribalta, todos ligados individualmente, para que o iluminador pudesse jogar e interagir com a cena como fosse necessário a cada momento da improvisação e atuação da luz. Em conversa com a coreógrafa depois do espetáculo, eu descobri que a partitura proposta e seguida pelos 64 participantes voluntários, a cada montagem, ou seja, o plano de luz e som, eram fixos, permanentemente montados pela mesma equipe, sempre a uma semana da estreia.

Com o início do espetáculo, o espaço amplo a vazio do palco, preenchido apenas pelos refletores à sua volta, foi sendo pouco a pouco preenchido por pessoas que entravam em cena, vindos de trás da plateia, pelos dois lados. Ocupando os espaços vazios do palco, cada performer entreva em cena no seu próprio ritmo, estilo e comportamento particular, parecendo não se importar com os demais à sua volta, mas atentos, olhando fixamente os espectadores. Nós, na plateia, íamos percebendo, gradativamente, a diversidade com a qual 
teríamos que lidar durante o espetáculo. Surgiam pessoas tão diferentes, vestidos e agindo, visivelmente, cada um a seu modo, com suas próprias características, movimentos, expressões e humores. Eram pessoas de todas as idades, etnias, tribos e estilos, o que dava uma sensação de pluralidade e de infinitas possibilidades de identificação entre o público e o elenco. Era possível nos sentirmos, todos, indistintamente representados. Estávamos todos em cena, todos os gêneros, todas as idades, todas as idiossincrasias humanas expostas ali, diante de nós, e com isso éramos livres para nos identificarmos e condescender com um, com dois, com mais, com todos.

Em minha conversa com a coreógrafa depois do espetáculo, eu vim a saber, inclusive, que essa foi a primeira vez, depois dos seis anos em turnê pelo mundo todo, que quase a metade do seu elenco era formado por pessoas idosas. Isso também impressionava durante a entrada dos performers, quando podíamos notar que alguns, inclusive, tinham dificuldade de locomoção. Esse detalhe representava, aliás, mais um fator de identificação do palco com a plateia, considerando a similaridade etária existente entre o elenco e o público, majoritariamente constituído por pessoas idosas.

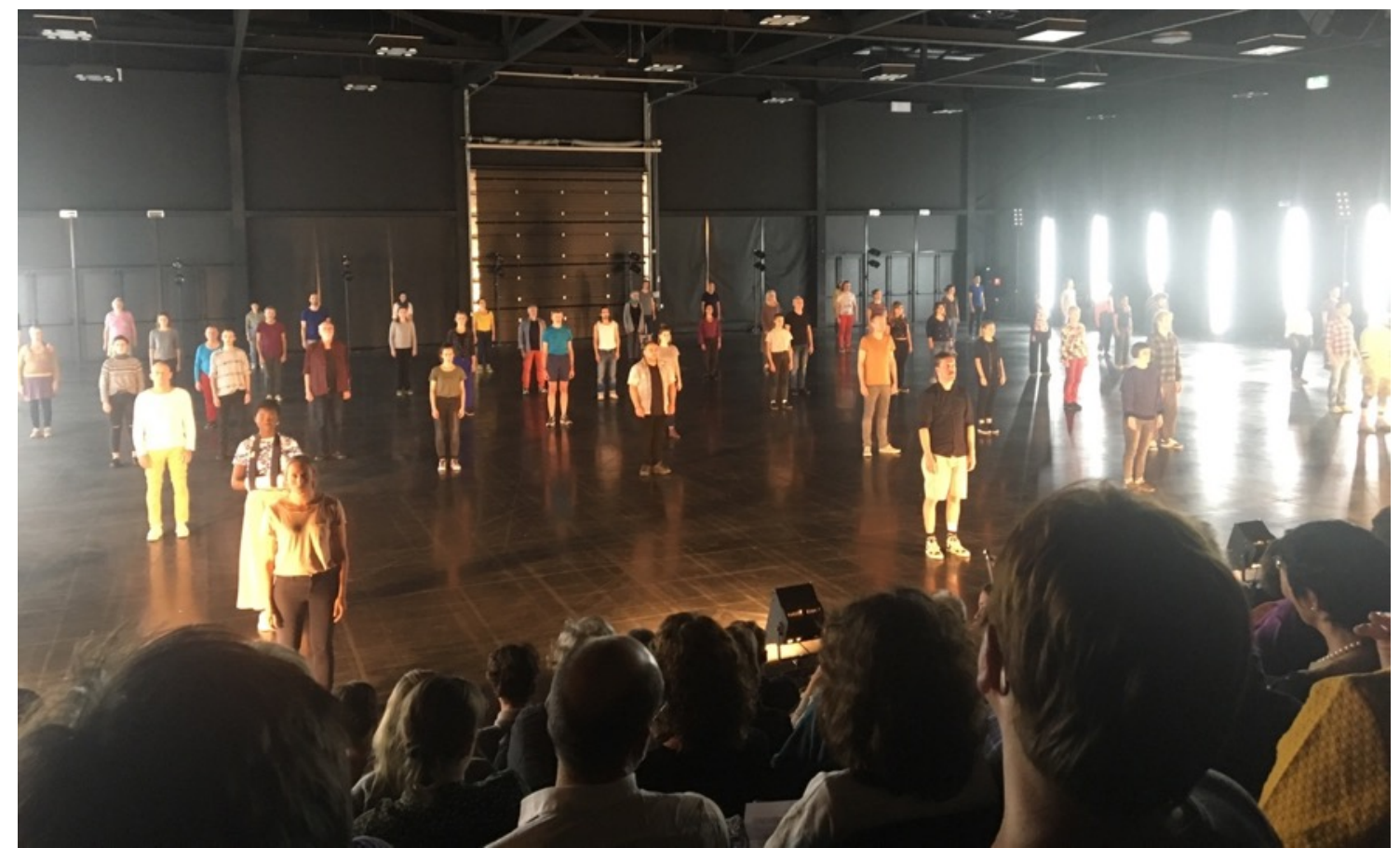

Figura 44 - Performers distribuídos pelo espaço ao início do espetáculo Multitud, coreografia de Tamara Cubas. Luz Leticia Skrycky e Sebastián Alíes. Foto Nadia Luciani. 
Essas entradas se repetiram por 64 vezes. Sessenta e quatro pessoas ocuparam o espaço antes vazio, ao mesmo tempo que, por sua vez, eram acesas, também lenta e gradualmente, as luminárias fluorescentes verticais nas laterais do palco. Uma a uma, alternadamente, sempre as mais próximas aos performers que entravam, elas iam igualmente entrando em cena. Essas luzes, ao mesmo tempo que permitiam que víssemos, analisássemos e explorássemos cada personalidade que adentrava a cena, com todas as suas diferenças e particularidades, também nos cegavam um pouco, dotando o palco de um certo ar etéreo. O que se percebia naquela diversidade era uma total consideração às características individuais, potencialidades e limitações de cada performer que chegava. A impressão que tínhamos era que não havia limite, condição ou exigência para estar ali, só o desejo.

Depois do espetáculo, eu vim a saber que nem todos, ou bem poucos dentre eles, eram dançarinos ou mesmo atores, pois a inscrição para o processo de seleção havia sido aberta a todo tipo de gente. A diversidade se tornava tão evidente, a medida que os performers iam surgindo e ocupando seus lugares, que era como se eles soubessem que tinham pleno direito a eles, com a postura, a atitude e a determinação de quem conhece e tem certeza do lugar que ocupa. Toda esta entrada acontecia no silêncio e, por não ser tão sensível ao som quanto sou à luz, eu não saberia dizer exatamente quando o som passou a fazer parte da cena, mas afirmo que, quando o fez, foi em total comunhão com a luz e a encenação. E assim foi em todo o restante do espetáculo, a partir do momento em que me dei conta da sua presença sonora. Eu imagino que minha sensibilidade ao som seja como eu gostaria que fosse a dos espectadores em geral à luz, sentindo seus efeitos sem dar-se conta, necessariamente, do acender e apagar das lâmpadas.

Tanto nesse início, quanto todas as cenas que viriam a seguir, tinham o tempo exato de nos cansar, nos exaurir e fatigar pela repetição de uma mesma ação, mas ao longo do espetáculo, com o passar de cada fase, cada jogo, vamos nos dando conta que elas tinham o tempo exato, também, de nos fazer entrar o jogo, de fazer parte das cenas desde onde estávamos, em nosso posto de 
espectador. Era o tempo necessário para nos permitir absorver todos os seus detalhes, compreender o jogo proposto, as relações estabelecidas, nos deixar absorver pelo que acontecia em cena e ser invadidos pela experiência compartilhada com os performers. Pouco a pouco, vamos aprendendo a perceber que cada performer tem seu ritmo, seu estilo e seu tempo. A repetição vai despertando no espectador uma empatia e uma identificação com um ou outro performer, quase como se fossem personagens, aparentemente reais, de nosso cotidiano, ou do deles mesmos. Podemos, com o longo tempo que nos é dado, observar detalhes, repousar nosso olhar sobre uma ou outra figura, sobre a maneira como o palco é ocupado, na individualidade ou no conjunto, no micro e no macro universo que se constrói aos poucos diante dos nossos olhos. Buscamos aquele performer que havíamos percebido antes, queríamos saber onde estava, como estava lidando com o jogo, como estava se saído dadas as características que já havíamos detectados. A relação e o engajamento criado com o público era inevitável e latente.

Depois dessa primeira cena de entrada/apresentação dos performers, começam a ser propostos os primeiros jogos. Neste início, a relação entre eles era pequena ou até mesmo nula. Há um primeiro momento em que todos ficam estáticos, olhando para os espectadores, indiferentes e parecendo ignorar completamente a presença dos outros corpos em cena. Lentamente, eles começam a circular pelo palco, ainda se ignorando ou nem mesmo se dando conta das outras pessoas que circulavam igualmente pelo palco. Eles caiam, levantavam e movimentavam-se sozinhos, como que alheios a qualquer existência ou manifestação à sua volta. Pouco a pouco, a atitude vai mudando, ao mesmo tempo em que a movimentação ia se intensificando. Alguns começavam a perceber seus companheiros, se olhavam, se notavam, mas ainda sem estabelecer nenhum tipo de relação. Aos poucos, percebia-se o surgimento de alguma emoção, de algum reconhecimento da presença do outro e de algumas aproximações, na tentativa de ajudar o outro, buscando evitar suas quedas e se amparando mutuamente em alguns momentos. Começava a surgir uma espécie de compaixão entre eles. Criavam-se relações, cumplicidades, olhares e interações, despertando nos espectadores os mesmos sentimentos. 
Havia também, ao longo de todo o espetáculo, um processo de identificação, de escolha de um ou mais performers, que acabavam sendo seguidos, ou perseguidos, pelo nosso olhar. Por curiosidade ou empatia, queríamos saber como ele daria continuidade à cena, como se comportaria no próximo jogo, como se relacionaria com seus parceiros, quais seriam suas atitudes e reações ao que era proposto a cada cena.

A luz do espetáculo era bastante simples, porém muito expressiva. Era clara a existência de uma partitura de luz pré-estabelecida, mas percebia-se também uma grande liberdade de improviso, tanto nas cenas quanto no seu acompanhamento pela luz e pelo som, sobretudo na duração variável, conforme a entrada no jogo e o engajamento dos performers. Tudo em cena parecia acontecer no seu tempo, o que fazia com que o espetáculo não tivesse uma duração fixa, dependendo integralmente da entrega e concretização do jogo por parte dos participantes, intimamente acompanhados nesta ação performativa, improvisada e imprevisível, pela luz e pelo som.

Da mesma forma, era perceptível que havia uma partitura préestabelecida do jogo, com uma notável oportunidade de expressão individual e de improvisação por parte de todo o elenco. Havia um total respeito ao ritmo, às individualidades, competências, capacidades ou limitações de todos os participantes, que entravam e se juntavam aos jogos propostos em seu próprio tempo, com suas personalidades e seu comportamento. Cada indivíduo se sobressaía, ao mesmo tempo que uma coletividade era estabelecida entre todo o conjunto de performers. Da mesma forma, a exemplo do que acontecia no palco, surgia na plateia um sentimento de respeito às diferenças, de desejo de compaixão, de aceitação do outro, de suas características, potencialidades e limitações. Cada espectador se permitia, pela duração das cenas, eleger e observar um ou outro performer, segui-lo com o olhar, compartilhar sua emoção, sue cansaço, seu esgotamento ou sua angústia. Colocar-se em seu lugar.

As cenas e os jogos seguiam-se uns aos outros, sem uma lógica aparente, mas mantendo um ritmo crescente de energia e intensidade dos movimentos, bem como ampliando gradativamente a relação estabelecida entre os performers 
em duplas, trios ou grupos maiores. Cada nova cena propunha diferentes relações entre eles, inicialmente ignorando-se, depois acolhendo-se, solidarizando-se, e, finalmente, pisoteando-se, andando uns por cima dos outros. Eles se relacionavam pelo olhar, pelo toque, pelo gesto, pelo movimento e também pela indiferença, rudeza e agressividade. As ações eram acompanhadas pelo som com todas suas variações de timbres, ritmos e volumes e pela luz, capaz de externar materialmente as emoções expressas com a frieza das lâmpadas tubulares ou o calor das incandescentes, pela alta ou baixa intensidade de luz, pelo ângulo que chapava ou esculpia, revelava ou ocultava os corpos, pelas penumbras ou pelas luzes agressivas que surpreendiam, cegavam, agrediam quem ousasse enfrentá-las.

A materialidade poética revelada pela iluminação deste espetáculo reafirmava sua presença e cumplicidade com o público ao lhe permitir o acesso, a relação e a identificação com a cena. Nos sentíamos próximos, partícipes, atuantes e autorizados a responder a essa luz propositora que, por sua presença material, expunha a cena, sugeria coisas, insinuava e mostrava um possível caminho de interação com o espetáculo. Ela sugeria o movimento, permitia lapsos de tempo, promovia uma alteração do espaço, e alterava nossas impressões sobre a cena. Eu conseguia reconhecer, nela, todos os traços performativos com os quais eu vinha me deparado em minha pesquisa, desde a presença no palco, a materialidade poética intrinsicamente ligada à cena e com a capacidade de atrair e manter a atenção do público, até a interação com cada elemento componente da cena e a influência sobre a percepção de performers e espectadores.

Uma cena particularmente instigante e angustiante propunha uma perseguição invasiva e crescente a um dos performers, que era manipulado e remexido por uma multidão enfurecida, que o perseguia e agredia, segurando-o somente pelas roupas, sem tocá-lo diretamente. Uma agressividade velada, indireta e pungente, à qual ele resistia como podia, sustentando, por sua vez, uma insistente, incômoda e permanente relação visual com a plateia. Seu olhar fixo, suplicante e implacável implorava por ajuda e não deixava de focar, de 
maneira potente e firme, os olhos dos espectadores. Ao final de cena, uma ira incontrolável assola a todos, que gritam, berram, urram assustadoramente, voltados de frente para o público. A cena intimidadora e agressiva tem fim com uma movimentação aleatória pelo palco, na qual os performers parecem se organizar sozinhos, em tribos, duplas ou grupos maiores em ritmos e ações diferentes de cada performer ou grupo.

Essa cena vai se transformando até que se estabelece um novo jogo, cujo movimento diagonal permite o surgimento de relações entre os performers, com cruzamentos do palco mais ou menos rápidos, dependendo das condições físicas de cada um, mas sempre oriundos de um contato visual, uma identificação mútua, que leva à movimentação repetida, na qual os performers se lançam diagonalmente de um canto ao outro do palco, em duplas, uns em direção aos outros. O jogo é estabelecido lentamente e exposto para a plateia. Ao mesmo tempo que concentrados em sua ação, há um nítido desejo de compartilhamento por parte dos performers em relação ao público, uma disposição para mostrar o jogo, expor suas regras e estimular a participação do espectador, que acompanha as movimentações, torce, vibra, cansa e tenta imaginar o que está por vir, que relações serão estabelecidas, quais serão desfeitas, quem será o próximo, quem sucumbirá, quem aceitará e quem rejeitará o jogo proposto.

A cena seguinte, marcada por uma corrida frenética em torno do palco, foi desencadeada progressivamente a partir de uma caminhada, também circular, entremeada por ações individuais ou em duplas, nas quais era possível perceber a total liberdade de cada performer em se juntar ou não ao novo jogo proposto, explorando, ao seu prazer, o tempo de que dispõe para fazê-lo. O tempo parece parar ou não ter a menor importância, sem exigir nenhum respeito ou devoção por parte dos performers. Eles se permitem deixar envolver pelas novas proposições em seu próprio ritmo, fazendo com que o espetáculo pareça não ter limite ou hora para acabar. A lentidão e repetição de cada cena tinha o tempo exato de nos extenuar, assim como fazia com seus participantes. Se em alguns momentos tínhamos a impressão de nos entediar, logo em seguida nos 
percebíamos concentrados em alguma ação ou distraídos por algum personagem específico que conseguíamos identificar, sob nossa própria iniciativa, conta e risco, cuja ação, de alguma forma, nos cativava ou capturava.

Esta corrida, cuja intensidade aumentava incansável e gradativamente, é acompanhada por um acender e apagar randômico e igualmente crescente, das luzes tubulares nas laterais do palco. Esse movimento sugere, ou impõe aos performers um aumento na intensidade da corrida, ao ponto de não sabermos quem impulsiona quem, se é o operador da luz que força o ritmo dos performers ou se é o contrário que acontece.

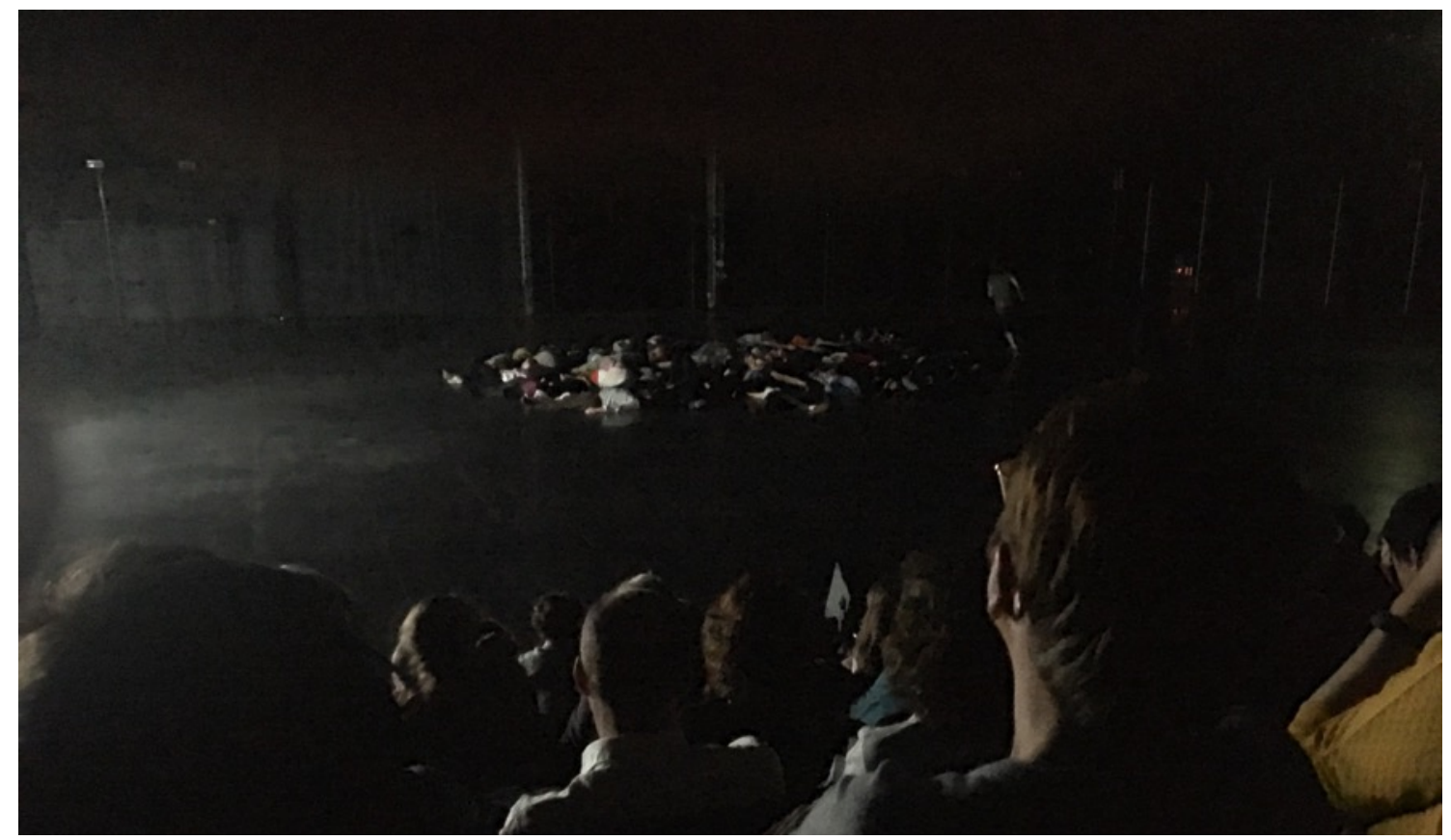

Figura 45 - Massa de corpos iluminados pela luz randômica das lâmpadas florescentes verticais ao redor do palco no final da cena da corrida do espetáculo Multitud, coreografia de

Tamara Cubas. Luz Leticia Skrycky e Sebastián Alíes. Foto Nadia Luciani.

Essa luz sequenciada, composta com outras fontes luminosas no início da cena, fica gradativamente só e ao final, quando todos caem, exaustos, no centro do palco, só ela se movimenta, iluminando a massa humana estática, à qual fornece uma falsa sensação de movimento. $O$ mundo parece entrar em suspensão o todos parecem mortos, exceto pela luz, que continua a girar e resulta em um efeito surpreendente e fascinante (ilusionista), como se os corpos estivessem girando em seu próprio eixo, movimentando-se para a esquerda, sem, no entanto, saírem do lugar. A impressão que temos é que os corpos giram, 
que o mundo gira, que a exaustão dos corpos nos leva para um estado de alucinação em que a realidade é desvirtuada e transformada em algo que nos escapa.

Lentamente um riso nervoso acomete alguns dos performers, que passam a contagiar os demais e logo estão todos rindo, gargalhando, contorcendo-se em espasmos de risadas descontroladas. A luz muda lenta e imperceptivelmente e as luzes tubulares são substituídas pelos dois maxibruts laterais ao centro da cena. Os corpos se movem, iluminados somente por essas duas fontes luminosas potentes que espalham sua luz por todo o ambiente e nos cegam, novamente, de forma indireta, pela grande quantidade de luz emitida.

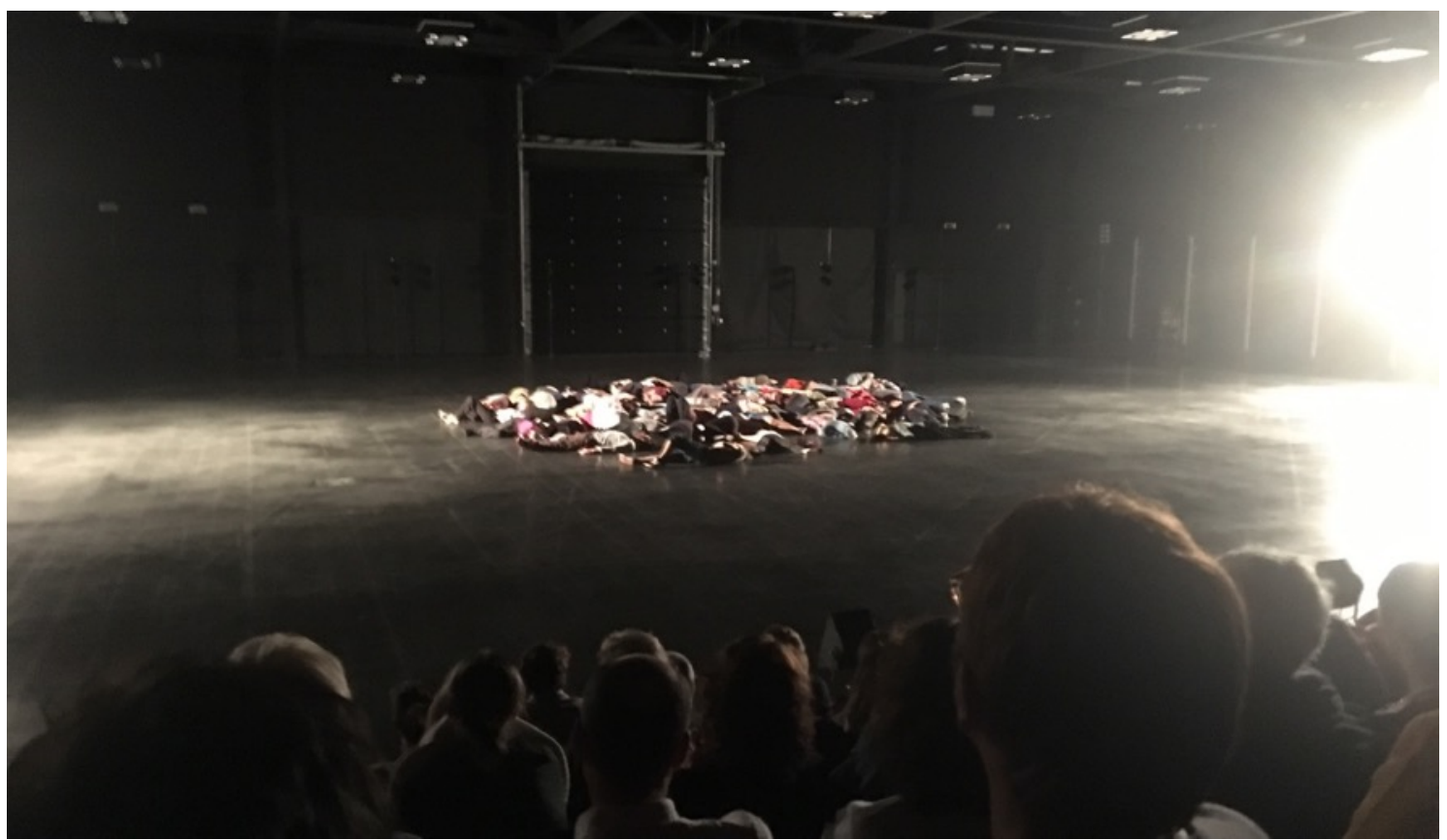

Figura 46 - Cena invadida pela luz intensa dos dois maxibruts laterais sobre os corpos exaustos ao final da cena enérgica da corrida em torno do palco no espetáculo Multitud, coreografia de Tamara Cubas. Luz Leticia Skrycky e Sebastián Alíes. Foto Nadia Luciani.

Essa sequencia de cenas extremamente enérgicas e cativantes não permitem que o público desvie seu olhar ou se desligue do palco. Depois de exaustos, exauridos por acompanhar uma corrida interminável, sufocados por um longo silêncio, os espectadores se veem surpreendidos pelo rir, gargalhar, movimentar-se como se não pudessem conter as reações a algo extremamente hilário compartilhado pelos performers. O riso contagiante alcança e constrange a plateia, que não consegue se decidir entre juntar-se ao riso ou reagir com 
estranhamento a essa inesperada ação cênica. Mais uma vez, a cena prolongase de forma incômoda e perturbadora, até que se inicia, muito gradativamente, um novo jogo. Demoramos para nos dar conta de que os performers começam a apropriar-se das roupas, dos acessórios, das características e emoções uns dos outros. As reações a esse troca-troca em cena são as mais diversas e surpreendentes. Há os que aceitam, os que rejeitam, os que se destituem facilmente de seus bens e os que se apegam, que resistem, agridem, reagem agressivamente ao jogo. $E$ há os desapegados... $E$ os solidários... $E$ os isolados... Mais uma vez percebemos, no palco, o respeito às individualidades, capacidades e limitações de cada um e sentimos, na plateia, as reações do público, a maneira como ele é afetado pelo que acontece em cena, pela manifestação sensorial e pelo estímulo à reflexão oferecidos pelo que nos é dado pela cena, pelo que compartilhamos e presenciamos.

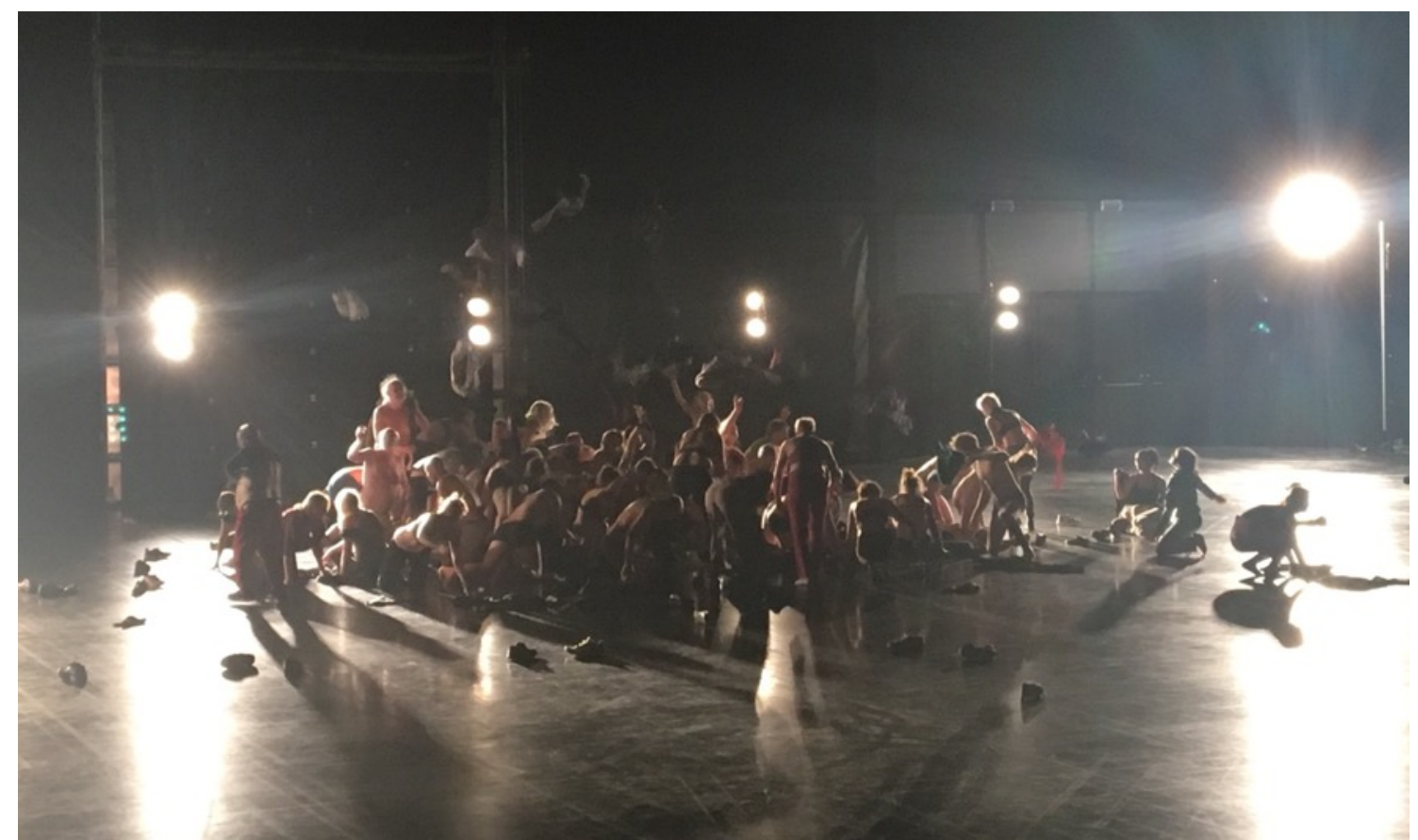

Figura 47 - Troca-troca de acessórios, roupas e emoções entre os performers num dos momentos intensos do espetáculo Multitud, coreografia de Tamara Cubas. Luz Leticia Skrycky e Sebastián Alíes. Foto Nadia Luciani.

Ao final desta ação, os ânimos se acalmam, a música chama para uma ambiente mais tranquilo, a luz muda e os performers começam a deslocar-se lentamente, cada um a seu tempo, para a direita do palco, onde todos deitam, já parcialmente despidos, alguns mais do que outros, iluminados apenas pela luz de apenas um maxibrut vinda da lateral direita. Os corpos começam a se mover 
lentamente em direção ao fundo do palco, acompanhados pela luz que muda do maxibrut da direita para o do canto ao fundo do palco. Os performers movimentam-se rastejantes, como animais de diferentes formas, deslizando uns por cima dos outros, numa coreografia lenta e envolvente, definindo desenhos e contornos, avançando gradativamente para a esquerda pelo fundo do palco, alguns corpos nus ou semidespidos que chocam, constrangem, sensibilizam ou penalizam os espectadores. Eles deslocando-se muito lentamente, hipnoticamente, sensualmente até, pelo espaço, quando, súbita e bruscamente, as lâmpadas PAR 64 do fundo do palco se acendem, num susto, de frente para a plateia, acompanhadas de um efeito sonoro estridente e agressivo.

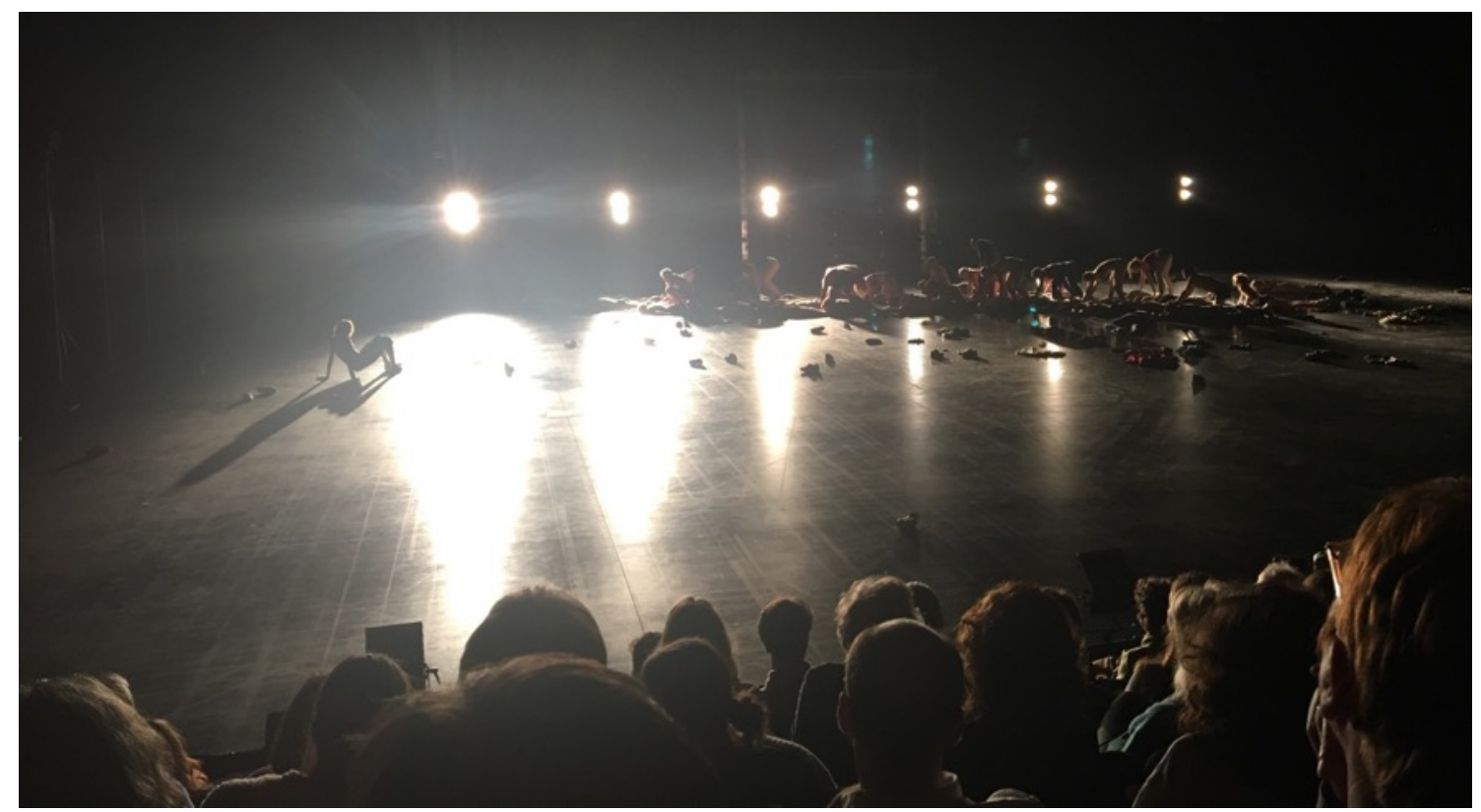

Figura 48 - Movimentação do corpos à luz das lâmpadas PAR que cegavam o público e atribuíam uma atmosfera imprecisa e mágica à cena no espetáculo Multitud, coreografia de Tamara Cubas. Luz Leticia Skrycky e Sebastián Alíes. Foto Nadia Luciani.

Foi como acordar de um sonho, ou de um pesadelo, e ser confrontado com a realidade daqueles corpos que, esculpidos por aquela contraluz, cuja materialidade poética conferia forma e cor aos seres e corpos que se moviam quase que coreograficamente, caminhando uns sobre os outros, sobrepondo-se, machucando-se, solidarizando-se e ajudando-se mutuamente para atingir seu destino, aparentemente inatingível. Não era possível ter certeza de como essa movimentação era feita, mas havia uma circulação de corpos que fazia a massa avançar continuamente, sem interrupção, como se a quantidade de pessoas fosse infinita e o caminho interminável. 
Pouco a pouco, lentamente, quando o grupo alcançava o limite esquerdo do palco, todos iam se desvencilhando, um a um, da massa humana para colocar-se em linha, na boca de cena, imóveis de frente para o público, dandose a ver e encarando a plateia, mostrando-se em toda sua nudez, integridade e comprometimento. A luz geral invade o palco e não se tem mais nada a esconder, insinuar ou modificar na cena ou na vida, da mesma forma que se encontram os performers, totalmente transformados pelo que foi vivido ali.

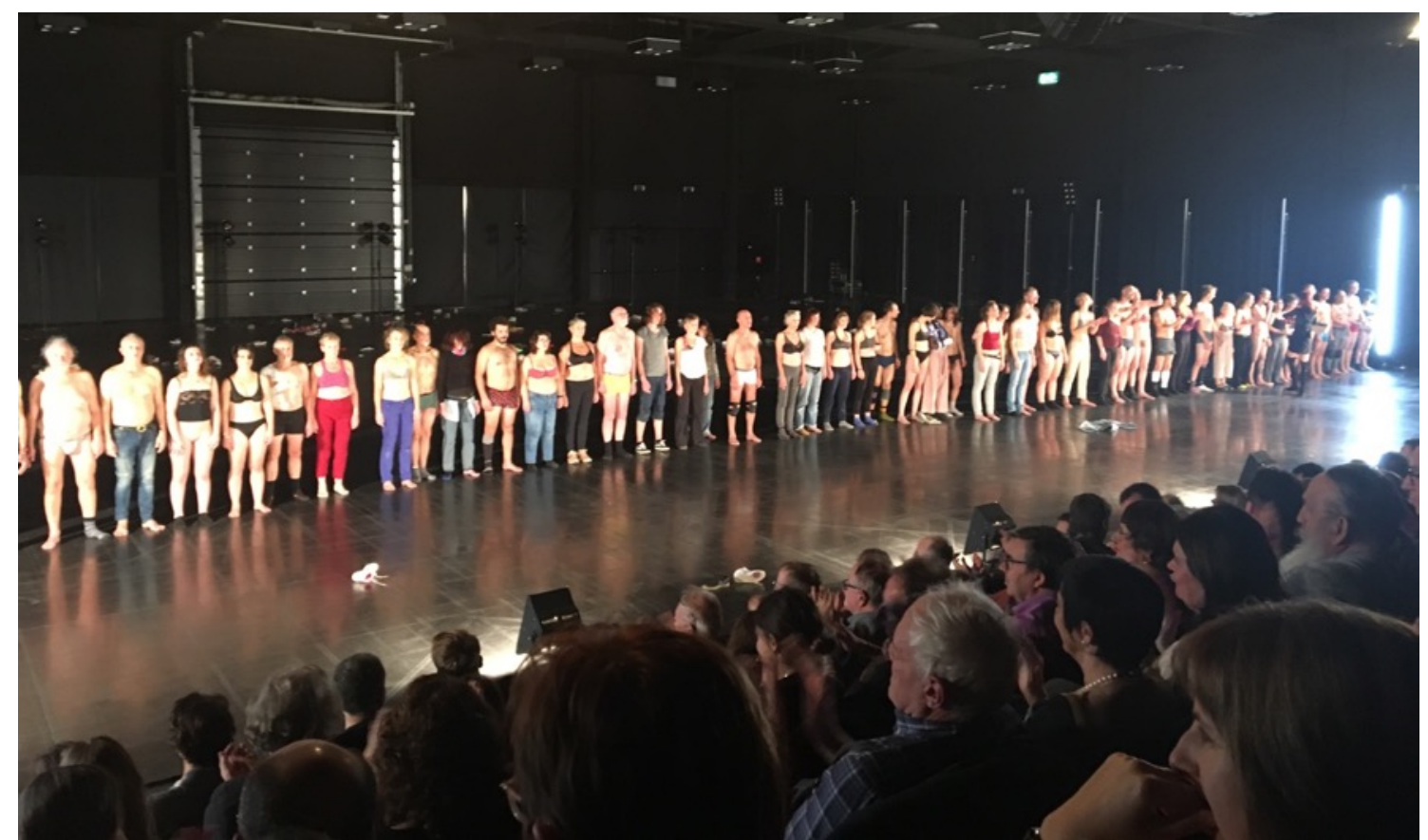

Figura 49 - Final do espetáculo Multitud, quando o elenco de 64 pessoas se alinha na boca de cena para confrontar o público aturdido e tão exausto quanto ele próprio. Coreografia de Tamara Cubas. Luz Leticia Skrycky e Sebastián Alíes. Foto Nadia Luciani.

Finalmente nos encontrávamos, todos, tanto no palco quanto na plateia, igualmente exaustos, destruídos, descabelados, desnudados e descontruídos, desprovidos de nossas crenças, preconceitos, energia, vestes e alma, completamente devastados, mas também aliviados e nutridos, cada um a seu modo, pela experiência desde espetáculo avassalador. 


\section{PERFORMATIVIDADE DA LUZ}

I always say, or have said in the past, that ninetynine and forty-four-hundredths of the audience does not pay any attention to the lighting, but one hundred percent is affected by it. 176 Jennifer Tripton

A performatividade da luz também pode ser considerada como um fenômeno que acompanha a história da iluminação para a cena desde os seus primórdios, como a luz natural usada em rituais sagrados ou nas encenações do período clássico. Mesmo sem que houvesse alguém especialmente responsável por ela, como acontece hoje nas montagens cênicas, é possível presumir que a luz já tinha propensão para desempenhar importantes papeis e interferir na percepção dos partícipes de atividades dessa natureza como um elemento que afeta e é afetada pelas ações que a acompanham, que intervém na sensação provocada pelos seus estímulos luminosos, que modifica as formas e configurações de objetos e corpos, que interage com a percepção humana determinando seus efeitos sobre os sentidos. Quando acionada, a luz performa e age sobre aquilo que ilumina, interferindo, como afirmaram Jean Rosenthal e Jennifer Tripton, na maneira como as coisas são vistas, atuando sobre o que é percebido e afetando quem observa ativamente.

O iluminador Max Keller, na apresentação do Light Fantastic, afirma que a luz cria uma nova realidade no palco e Christine Richier cita os estudos e reflexões de diversos iluminadores e teóricos do teatro a respeito da ação da iluminação na cena, principalmente a partir das publicações da ala teatral do Círculo de Praga. Segundo Otakar Zich e sua teoria da dramaturgia, a luz cria as qualidades dinâmicas da cena:

A luz no teatro não se contenta de conferir à cena suas qualidades atmosféricas e líricas, ela é também capaz de seguir o ritmo da ação, ela participa do seu desenvolvimento no tempo, de sua progressão

176 "Eu sempre digo, ou disse no passado, que noventa-e-nove vírgula quarenta-e-quatro (por cento) da plateia não presta nenhuma atenção à luz, mas cem por cento é afetada por ela" (tradução da autora). 
dramática, dos seus pontos culminantes e mudanças súbitas ou progressivas $^{177}$ (RICHIER, 2019, p. 295).

A performatividade, descrita como a capacidade de modificar a realidade e as práticas que designa, difere da linguagem em sua função de descrição ou representação da realidade para fazer surgir, devir uma realidade. A luz performativa, então, enquanto linguagem cênica, faz advir, no teatro, uma realidade ou se torna, ela mesma, essa realidade. Ela já não busca representar um efeito natural ou imitar uma ambiência ou luminosidade, mas ela se torna a luz e a luminosidade do ambiente que ilumina, sendo ela mesma a luz da realidade cênica posta, permanecendo, no entanto, em sua essência, como fenômeno físico de natureza material, cuja imaterialidade consiste na criação imagética que provoca na mente do espectador. Para Turrell, "a luz não é tanto algo que revela, como é ela mesma a revelação" (TURRELL, 1985 apud BARROS, 1999, p. 97). A orientação performativa considera a ação em suas práticas, cuja realidade se fundamenta nas intervenções concretas mediadas por instrumentos usados para este fim. A luz para a cena, assim, não tem uma existência em si, isoladamente, mas encontra sua razão de ser no contexto em que se encontra, na conjunção de elementos na qual intervém concretamente para construir a realidade que será percebida pelo espectador.

Não se trata de negar a luz como linguagem, mas de compreende-la em sua atuação e performance cênica. Isso não significa que a iluminação deixa de comunicar ou informar, que ela passou de um estágio para outro, que "evoluiu" de uma função para outra, mas sim que surgiram novas formas de entendimento e participação da luz na cena. É importante entender que a iluminação será sempre uma linguagem, mas, de forma geral, enquanto uma luz realista tende a representar a realidade da cena e a luz dramática tende a descrever essa realidade, a luz performativa faz surgir uma nova realidade, se tornando a própria realidade da cena e dos atores, performers que tampouco representam uma

177 « La lumière au théâtre ne se contente pas de conférer à la scène ses qualités atmosphériques et lyriques, elle est aussi capable de suivre le rythme de l'action, elle participe de son développement dans le temps, de sa progression dramatique, de ses points culminants et changements soudans ou progressifs " (tradução da autora). 
realidade, mas a vivenciam a partir de seus próprios meios e referências. Os conceitos semióticos e performativos da luz podem parecer contraditórios, e o signo pode parecer se opor ao conceito de performativo, mas, na verdade, não se trata de negar o signo teatral, mas entender que ele pode se modificar, pode deixar de apenar representar para efetivamente se transformar naquilo que enuncia, assim como o ator deixa de apenas representar um personagem, mas permite o devir desse personagem com base em suas próprias experiências, emoções e sentimentos, sem precisar se afastar de seu próprio ser para estar no lugar de outro.

Neste mesmo sentido, um feixe de luz amarela que projeta a imagem recortada de uma janela no chão do palco não deixará nunca de ser um refletor com gelatina e gobo para ser ou representar a luz do sol que atravessa uma janela e invade um ambiente. Essa leitura, que é gerada na mente do iluminador e pode vir a ser decodificada pelo observador, será sempre uma construção imagética do que se pretende mostrar. O observador, por sua vez, mesmo que por algum instante, venha a esquecer ou perder a noção do fenômeno físico da luz e a consciência da existência do refletor, nem por isso acreditará ver efetivamente a luz do sol no palco, dentro do teatro. Essa luz, em seu conceito performativo, pode transmitir, de acordo com a presença que imprime à cena e sua materialidade poética, a emoção, o sentimento e a percepção real do ambiente preenchido por essa luz ou pela lembrança que tem da luz do sol. É essa sensação, oferecida ao público, que pode remeter a algo já vivido, a uma experiência anterior do espectador, e que conduz à percepção de um sentimento comum, compartilhado entre a cena e o público, resultando em uma experiência conjunta, condicionada à entrega e dedicação de ambos, o elo estabelecido pela luz entre o espetáculo e o espectador.

Fabrizio Crisafulli (2019) destaca que uma das ideias principais do seu trabalho como iluminador sempre foi a de que:

... a luz pode exercer na cena um papel comparável ao que é realizado no mundo pela luz natural. Não se trata aqui, absolutamente, de imitar essa luz natural, mas de garantir que a luz se torne, em geral, a até mesmo em suas variações mais abstratas, substância vital, elemento essencial, primário, gerador, se libertando de toda função ilustrativa, 
sem visar nem o efeito nem o ornamento destinado a "servir" ao espetáculo, papeis subalternos aos quais o uso habitual a limitam frequentemente aos últimos dias dos ensaios e que não corrobora com o poder que o teatro tem de entrar em ressonância com a realidade ${ }^{178}$ (CRISAFULLI, 2019. p.209).

Essa comparação da luz teatral com a luz natural e seus efeitos sobre a percepção humana denota, de uma forma justa, o conceito de luz performativa, cujo efeito sobre a sensibilidade do espectador a qualifica como elemento de ligação entre a cena e o público, que a acessa tanto pelo sentido da visão quanto por todas as suas faculdades sensoriais e perceptivas. É, então, no espaço/tempo da ação, em relação com a percepção do espectador durante a recepção, que acontece a performatividade da luz, no conjunto estabelecido entre cena e público, no efeito gerado pelo fenômeno físico da luz sobre a percepção do espectador como resultado da iluminação criada especificamente para cada cena com o objetivo de interagir e atuar em conexão com todos os seus componentes ativos.

Para Turrell, não se trata da luz ou do seu registro, daquilo que ela mostra ou revela, mas da sua própria realidade. Ao propor uma experiência com a luz, ele se preocupa mais com questões de percepção do que de visão, imagens ou entendimento de histórias que ela possa representar (BARROS, 1999, p. 97). A luz performativa, se torna, assim, a realidade que ela revela, ou melhor, a realidade que advém dela, que ela se torna. A luz performativa surge como a experiência primeira do espectador em contato com o espetáculo, anterior a qualquer outra consciência ou preconcepção. Ao analisar a obra de Turrell, Schenker descreve o que pode traduzir a luz performativa como experiência proporcionada para o espectador teatral, ou seja, um acontecimento visual que "faz ver o que faz você ver e não o que há para ser visto":

\footnotetext{
178 «...la lumière peut remplir sur la scène un rôle assez comparable à celui que joue dans le monde la lumière naturelle. II n'est nullement question ici s'imiter cette lumière naturelle, mais de faire en sorte que la lumière devienne en général, et même dans ses déclinaisons les plus abstraites, substance vitale, élément essentiel, primaire, générateur, s'affranchissant de toute fonction illustrative, ne visant ni à l'effet ni à l'ornement destinés à 'seconder' le spectacle, rôles subalternes dans lesquels l'usage habituel la cantonne fréquemment lors des dernier jours des répétitions, et qui ne corrobore guère le pouvoir qu'a le théâtre d'entrer en résonance avec la réalité » (tradução da autora).
} 
Não existe nada ali: nada além da luz que tudo gera. O que percebemos não é o mundo, nem um significado, nem uma história, mas sim o instante antes deles serem gerados. Isso é percepção no seu estado primevo: o sentido que nós fazemos de algo antes de se tornar conhecido, e enquanto permanece puramente sensorial (SCHENKER, 1991 apud BARROS, 1999, p. 99).

Segundo Josette Féral (2015, p. 125), os espetáculos performativos instalam situações nas quais é primordial a inter-relação entre o performer, os objetos e os corpos, o que permite entender essa relação entre as diferentes linguagens do espetáculo como importante característica do seu caráter performativo. Dadas as suas propriedades performáticas de atuação e interação com a cena e com os demais componentes do espetáculo, bem como sua ação sobre a percepção do público, a luz pode ser entendida como performativa independente do contexto cênico, dramático ou performativo, considerando que é na recepção ativa e na percepção do espectador que, tanto a luz quanto o espetáculo, se realizam efetivamente. Essa luz apresenta, assim como o teatro descrito por Féral, a noção de performatividade que está no centro do seu funcionamento e atuação perante um espectador ativo e que traduz, melhor que o conceito de luz ativa, empregado por Appia no início do século passado, para designar a iluminação que, atuante e interativa, promove a conexão entre a cena e o espectador. O tipo de iluminação que passa a ser chamada de performativa, constitui parte integrante e indissociável da cena e, situada na gênese de processos colaborativos de criação cênica, atua como elemento estrutural e estruturante do espetáculo, configurando seu caráter improvisacional, participativo e interativo, tanto com a cena quanto com o espectador, expresso pela presença de sua materialidade poética.

Desta forma, ao corresponder esteticamente à ação cênica, a luz performativa revela seu caráter variável, original e ajustado a cada reprodução, mesmo que pré-concebida e ensaiada (repetida). No prefácio do livro sobre performatividade (MOSTAÇO, 2009, p. 8), Teixeira Coelho afirma que embora uma partitura, um guia, um roteiro possa preexistir a este processo (obra de cultura 'orquestral' de reunião e interação entre pessoas), o resultado, ao qual se dá o nome de obra de cultura, só acontecerá pela interação performática dos participantes do conjunto. Para Mostaço, o conceito de simulação, ficção ou 
experimento, simultâneos ao agir em tempo real, na presença do outro, está no núcleo da performatividade. A ênfase se encontra tanto sobre o modo como as ações são realizadas quanto recebidas, assimiladas e transformadas pela experiência. Para Féral, a performatividade acompanha o surgimento de significados múltiplos, oscilando entre o reconhecimento e a ambiguidade, de modo que a iluminação pode surgir, performativamente, como a fluidez, a instabilidade e a abertura do campo de possibilidades da relação que revela a poética da luz em sua expressão (per)formativa (FERRAL, 2009, p. 74). Isso estabelece o que pode ser entendido como a performatividade da luz em sua função poética, sua expressividade capaz de atingir e influenciar igualmente a cena e o público. Os conceitos intrínsecos da performatividade - ambiguidade, fluxo e instabilidade - são, assim, transpostos para a atuação da luz durante o ato cênico como ato performativo.

O conceito de mimesis performativa de Luiz Fernando Ramos (2015) traz um novo entendimento para as formas performativas do acontecimento artístico, notadamente no campo teatral e cênico. Para além de imitação do já existente, Ramos apresenta a mimesis como uma nova forma de representação antificcional, antiteatral e antidramática, desprovida de sentido e referência prévios, mas profundamente comprometida com a relação estabelecida com 0 espectador, facilmente adaptável ao estudo e compreensão dos demais componentes do espetáculo, dentre eles a iluminação. A mimesis, para Ramos, revela seu potencial performativo ao estabelecer uma relação com o espectador que pretende afetar. Seu conceito depende, então, de um espectador ativo que a reconheça e se deixe afetar pela exposição presencial a ela em um determinado espaço e tempo.

A poiesis, como condição intrínseca do espetáculo, se apresenta, em duração e movimento, como a produção da visualidade e da materialidade autônomas na constituição do espetáculo. No conceito de mimesis performativa, há uma inversão da perspectiva habitual da construção cênica, normalmente submetida a uma funcionalidade narrativa ou a um sentido dramatúrgico prévio. A ideia de "dramaturgia da cena", conceito amplamente estendido para outros 
campos da encenação como dramaturgia da voz, do corpo, do som ou da luz, desloca a construção dos componentes da cena da subordinação a uma funcionalidade narrativa de construção de sentido ou de percurso previamente definido para uma autonomia material liberta de referências anteriores. Com isso, Ramos (2015. p.24) permite entender a cena e, consequentemente, cada um de seus elementos, a exemplo da iluminação, como matéria substantiva que constitui o ato concreto da encenação que a materializa ou produz, de fato, e a dramaturgia como matéria secundária que se submete para concretizá-la.

A definição da mimesis como ação, concede ao teatro um caráter espetacular, estabelecendo a tensão entre seu aspecto narrativo e a encenação, mas sem dissocia-las. As novas composições dramáticas, não necessariamente mediadas pela literatura, são articuladas como cenas e estabelecem poéticas narrativas e espetaculares, normalmente resultantes de trabalhos realizados por meio de processos colaborativos de criação. Nesse contexto, Ramos explica que não há interpretação ou significação certa, mas a recepção ocorre pelo contato gerado entre a materialidade da cena e a percepção do espectador. Segundo o autor, os aspectos performativos dos seus elementos compositivos, aquilo que efetivamente se concretiza como fenômeno físico e material, a exemplo da luz, tornam-se fontes primordiais de relacionamento com o receptor. A luz se transforma, assim, em estímulo preponderante para que o espectador "reconstrua por si alguma integridade naquela obra indiscernível pela via racional" (RAMOS, 2015, p. 31). Ramos define o que chama de mimesis performativa pela situação de oferecer aos sentidos do espectador algo que dependerá exclusivamente de sua predisposição e dedicação ao que observa. Neste caso, a presença e a duração são condicionantes indispensáveis do fenômeno espetacular, cuja materialidade se impõe como realidade a este espectador ativo.

Ainda em sua análise das formas miméticas e antimiméticas de representação teatral, Ramos permite, a partir do conceito de mimesis performativa, uma analogia entre a utilização de corpos e da figura humana com a luz nos processos artísticos performativos. Ele destaca a intenção da arte em 
enfrentar e superar o preconceito existente contra o teatro considerado uma arte menor ou menos nobre pelo seu caráter imitativo ou mimético. Destacando a impossibilidade do teatro de desvencilhar-se dessa categorização reducionista pela sua dificuldade intrínseca de lidar com a materialidade do mundo e dos homens que nele vivem, ele permite associar corpo e luz na transição do teatro em direção ao performativo. Considerando que encenar um drama é duplicar o mundo diante do mundo, o caráter de imitação da vida e a necessidade do suporte humano inerentes ao teatro, ele é qualificado como o ato espúrio de substituir o existente por algo semelhante, mas diferente, pois que o sucede e repete (RAMOS, 2015. p. 49). É nessa "condição inexorável de ocupar espaço e tempo com matéria", seja o corpo do ator ou um feixe luminoso, para narrar ou representar o que quer que seja que se encontra a estreita relação do teatro com a mimesis.

Comparativamente, a relação entre corpo e representação pode ser associada à da luz com a iluminação cênica, cujas versões realista, naturalista ou ilusionista primavam por uma imitação da natureza na qual a luz se limita a expressar o dia e a noite, representar os astros celestes e até mesmo "encarnar" os raios de sol filtrados por uma janela ou pelas copas das árvores. Segundo Ramos, "isto talvez explique a dificuldade que os artistas modernos do teatro tiveram para suplantar as limitações de uma representação figurativa e realista e se lançar nos campos da abstração e da arte concreta, que já não buscava referentes no mundo a reproduzir, mas sim instaurar novas realidades" (RAMOS, 2015. p.49). Da mesma forma que Ramos aborda os corpos de atores, bailarinos ou performers como matéria bruta que fala por si e já não ocupa o lugar de um personagem (RAMOS, 2015. p.51), a luz performativa tampouco teria, nesta condição, qualquer função narrativa. Ele descreve esse percurso como um processo de emancipação das artes performativas que, liberta da função dramática, "passam a significar algo por si mesmo, no imediato da fruição espetacular" (RAMOS, 2015, p. 52)

É importante lembrar ainda a diferença já esclarecida entre iluminação, um projeto de concepção das luzes de um espetáculo ou ação cênica, e luz, o 
fenômeno físico que tem ação sobre o observador. Além disso, a luz ainda pode ser classificada como luz cênica, uma luz ambiente que localiza a ação, ou luz para a cena, aquela criada com um propósito ou fim específico. Ambas podem ser criadas a partir de um projeto de iluminação com propostas dramáticas ou performativas que, além de permitir a visibilidade, podem ainda estar relacionadas à representação de signos, podendo significar ambientes e coisas, como um palácio, um raio de sol, uma porta ou janela, ou à percepção humana e às sensações geradas no espectador no momento da ação cênica ou performativa, na sua interação com o performer ou com os elementos em cena e cuja relação indissociável é marcada pela atuação conjunta de ambos. É nesse segundo contexto e no efeito gerado por ele sobre a percepção do espectador que reside sua ação performativa, sua performatividade.

Luiz Fernando Ramos (2017) entende mimesis como um artifício produzido para tentar provocar efeitos que "algo anterior, real ou imaginário, existente ou presumível", provocaria se estivesse presente. Para isso acontecer, é necessário que haja um receptor, alguém disponível para perceber, sem o qual a mimesis não existiria. Segundo o pesquisador, ela é uma "produção intencional, realizada por um agente que visa afetar um outro e que depende, para que os efeitos pretendidos se efetuem, da assunção de sua presença e da disposição de jogar deste que a recepciona". O mais importante, no entanto, está na noção de que a mimesis, mais do que algo preexistente que se torna reconhecido pelo receptor, seja um inexistente que ganha existência pela obra do efeito criado. $O$ autor esclarece que são as artes, intencionalmente destacadas como técnicas, e o talento, entendido como engenhosidade e competência do agente, o artista produtor, que produzem essa existência e que com ela surge também uma "potência de afecção sobre eventuais receptores" (RAMOS 2017, p. 342).

Quando Ramos (2017, p. 343) se refere à produção de uma obra que visa atingir um receptor, ponderando que ela possa ser apenas uma ideia (como obra de arte conceitual) ou um ruído (a música eletroacústica, por exemplo), entendese que, considerada em sua reflexão, ela também pode ser uma luz, um efeito 
luminoso ou um facho da luz-matéria que afeta um outro, disposto e disponível para participar e perceber sensorialmente o ato performativo que se faz presente.

Quando um artista visual realiza uma performance, mesmo sem nenhum pretensão de estar representando alguma coisa além daquela ação, ou, talvez, apenas enunciando um conceito, uma presença ou uma ausência qualquer, ele estará, inexoravelmente, sublinhando este algo na malha da realidade que $o$ acolhe, apresentando-o, e assim realizando a poiesis (produção) de uma mimesis (RAMOS, 2017, p. 342-343).

Segundo Féral, o ato de fazer é o que caracteriza o teatro, e a ação cênica está centrada em seu agente, que faz uso dos seus recursos para inscrever uma performatividade que instaura uma nova realidade proposta ao espectador. Essa enunciação performativa, instável e ambígua, depende da participação do espectador, cuja atenção é colocada na presença, cuja estética se torna o meio que estabelece uma relação com o público, atraindo sua atenção para a cena e seus componentes. Essa é a função e o desempenho da luz performativa, cuja ação e interação com a cena instaura, por sua presença e materialização poética uma nova realidade dada à recepção do espectador.

Derrida chama de finalização performativa ${ }^{179}$ o momento de passagem à ação ${ }^{180}$ de um discurso teológico ou confissão (DERRIDA, 1993, p. 21), o que parece perfeito para designar a passagem de uma ideia de luminosidade à luz que se materializa no palco como ato perlocutório que visa afetar e ser afetada pela cena que ilumina e pela percepção de que quem observa. De modo que performativo parece ser, então, o termo mais adequado para designar esse ato ou essa luz que Appia qualificou como ativa e que, independente do contexto em que se apresente, se enquadra no conceito de performatividade, cuja ação cênica está centrada em sua materialidade como componente da cena que, fazendo uso de seus atributos ou recursos (as articulações de forma, cor e movimento, por exemplo) como pressuposto fundamental a partir do qual uma nova realidade é instaurada e proposta ao espectador.

O início desta pesquisa previa, entre outros interesses, a investigação da prática da iluminação cênica em espetáculos contemporâneos a partir da recusa

179 « accomplissement performatif » (tradução da autora).
180 « passage à l'acte » (tradução da autora). 
da representação, da simbologia e da previsibilidade em função de uma atuação mais participativa da luz na cena e do iluminador no processo criativo, na concepção coletiva do espetáculo e na atenção dada ao público, tanto no que diz respeito ao processo de criação quanto ao de recepção da obra teatral. Com o intento de explorar as práticas performativas e o próprio conceito de performatividade, buscava-se entender melhor suas peculiaridades, variações e características para encontrar um possível caminho para a aceitação do que vinha sendo sugerido como uma atuação performativa da luz ou de seus agentes, o iluminador e o operador de luz, este último entendido, no início do processo, como uma espécie de "performer da luz". Nesta versão, este suposto agente utilizaria os recursos materiais disponíveis e sua presença física ou remota, para materializar a luz, cuja ação sobre a cena seria primordial para sua constituição, tanto no palco quanto na recepção ativa do espectador. Finalmente, com as investigações a respeito, principalmente, dos conceitos de luz-matéria e de performatividade, a noção de agente ampliou-se para a assimilação do próprio fenômeno da luz como agente performativo.

Mostaço designa a mimesis como a reprodução de objetos reais por meio de uma não realidade em uma dimensão não performativa, cujos resultados mentais e corporais palpáveis são associados à experiência catártica (MOSTAÇO, 2017, p. 113-114). Na busca por encontrar, na cena contemporânea, uma definição mais adequada para a operação poética que visa atingir um receptor, considerando toda forma performativa em condição espetacular, cuja característica principal dependeria de um espectador em tempo real, Ramos propõe, então, a noção de mimesis performativa (RAMOS, 2017, p. 345). Com a mesma intenção de busca de uma nomenclatura apropriada e no intuito de assimilar, também a luz, como um artifício produzido para referenciar realidades e provocar efeitos e reações catárticas na percepção de outrem é que foram propostas, como resultado desta pesquisa, as noções de "luz performativa" como o agente, e de "performatividade da luz" como o efeito causado por ela. 


\subsection{A Luz como elo entre a cena e o espectador}

O teatro contemporâneo focaliza grande parte da sua atenção na relação estabelecida com o público e a maneira como se estabelece esta relação. A qualidade e a intensidade das interações, os meios, linguagens e experiências compartilhados resultam de diferentes processos, métodos e práticas teatrais. Os estudos da estética e as teorias da percepção buscam refletir a respeito desses processos para entender seus mecanismos e apresentar as melhores maneiras de alcançar a interação desejada entre a obra artística e o observador, entre teatro e público, entre cena e espectador. Segundo Roubine, Appia considerava a luz como o único meio para alcançar, como foi realizado mais tarde pelos simbolistas, a utilização do imaginário do espectador como parte integrante da encenação ou de seus prolongamentos (ROUBINE, 2003, p. 161).

Segundo Bourriaud (2009), a produção artística vivenciou, na segunda metade do século XX, o tempo de uma estética que ele chama de relacional e cujo foco se encontra na convivência e interação nas manifestações de arte que geram, por meio de novas formas de práticas artísticas, uma sensibilidade coletiva como forma de estar no mundo e constituir um campo de trocas subjetivas. A obra de arte é entendida por ele como um princípio dinâmico entre autor, obra e observador, que consiste exatamente na razão de ser da obra e sua realização. Conceitos como originalidade, autoria ou privacidade são renegadas a um segundo plano em detrimento da ligação da arte com a esfera das relações humanas e seu contexto social, visando uma rede colaborativa de interação e produção de subjetividades.

Considerando especificamente o campo das artes cênicas e seu aspecto proeminentemente visual, a iluminação se torna o meio mais óbvio, evidente e fácil de acesso à cena pelo espectador. Admitindo que o sentido da visão represente $75 \%$ da percepção humana (SANTAELLA, 2012, p. 1), é possível concluir que é por este meio que o público acessa mais rapidamente as informações e sensações expressas em um espetáculo teatral, mesmo que não 
fique restrito a ele. Desta forma, a iluminação, em seu primeiro aspecto sensorial ligado ao espetáculo, ou seja, seu uso como instrumento de visibilidade, já desempenha importante papel na relação estabelecida estre cena e espectador. É por meio de seus estímulos, configurados por seu aspecto visual e elementos plásticos como forma, cor e intensidade, que ele chega ao espectador e cativa, pela presença que impõe à cena, sua atenção e interesse. Quando colocada em cena (mise-en-lumière) ${ }^{181}$, além de atrair a atenção, orientar a leitura e auxiliar no entendimento do espetáculo, funções das quais jamais será destituída, a iluminação também age sobre tudo o que está/acontece no palco e sobre a percepção do espectador, interligando ambos em uma experiência sensorial que evidencia seu caráter atuante e performativo.

James Turrell, em suas obras, explora profundamente a relação entre a luz e o observador, aquele que, mais do que ver, vivencia uma experiência com a luz. O artista associa a experiência da luz com o tempo no que chama de dedicação à obra. Ele demanda de seu público que transpasse os limites da percepção, para o que o elemento tempo é fundamental. Segundo o artista, é preciso que o observador deixe seu sistema visual habituar-se à percepção da luz, o que significa dedicação ao que se olha, a obra ou o espetáculo que se dá a ver, sem o que não é possível alcançar o mesmo resultado perceptivo. Foi, então, na fenomenologia e na ecologia da percepção que foi possível comprovar as intuições a respeito da potencialidade performativa da luz como elo entre a cena e o espectador. Tanto o fenômeno perceptivo descrito por Merleau-Ponty quanto, e principalmente, os conceitos de ambiente vital e de affordance de Gibson revelaram-se fundamentais para o entendimento e aprofundamento dos estudos sobre a relação estabelecida entre o teatro e o espectador por meio do fenômeno da luz ativa, da luz performativa.

Para Merleau-Ponty, perceber o mundo em sua materialidade só é possível para quem se encontra em potência de vê-lo no que ele revela por meio

\footnotetext{
181 Mesclando aqui os conceitos de mise-en-scène e mise-en-lumière para descrever os atos de encenar e iluminar um espetáculo, respectivamente, este segundo usado nas teorias e estudos sobre iluminação Cênica em língua francesa, a exemplo das teses das pesquisadoras Christine Richier (2019) e Yanna Kor (2019) e do livro de Dominique Bruguière (2017).
} 
da abertura primordial a uma existência exterior por meio da percepção, que ele descreve como uma comunhão com o que as coisas nos revelam sobre si mesmas. Entender a dedicação de um espectador ao fazer teatral como o caminho para percebê-lo, considerando as fissuras e ambiguidades às quais é exposto, permitem assumir a luz como meio para inseri-lo no contexto que dá forma a este mundo, que é o da cena. Neste campo fenomênico, as origens perceptivas da experiência real do espectador estão no sentimento gerado em sua comunicação vital com o espetáculo, ou seja, na luz que o torna real. Incorporado no sistema de estímulo e resposta gerado pela cena, a estimulação pela luz do sentido da visão produz a percepção, cujo objeto afetivo permite o encontro entre passado, presente e futuro e cujas sensações cinestésicas o habilitam a reconhecer o meio e o ambiente em que se encontra. A sensação provocada por essa experiência lhe permite a interagir (ser-no-mundo) como potência que co-nasce com a experiência teatral e cria a sincronia entre seu mundo e o da cena. A espacialidade vivida em uma experiência integrada é inseparável dos sentidos e da sensação. O sentir surge da coexistência com a cena, da entrega, do abrir-se a ela antes de qualquer reflexão ou ato pessoal.

Merleau-Ponty afirma que a luz, como uma das articulações formais e espaciais necessárias à percepção, desempenha um importante papel no campo perceptivo. Ela ajuda a estabelecer a unidade intersensorial sintética dos poderes do espectador para dar acabamento à intenção oculta na cena ou, inversamente, realizar suas potências perceptivas em sua relação com a cena. A riqueza da percepção teatral envolve uma ambiguidade fundamental, uma natureza com final aberto, cujo sentido não está em significações oferecidas à inteligência, mas em estruturas opacas, nos vazios a serem preenchidos pela percepção que o espectador tem da cena. É essa ambiguidade que revela a performatividade do teatro e, consequentemente, do elo que unifica cena e espectador, na relação estabelecida entre ambos e na maneira como a luz permite que ele perceba e apreenda o que visualiza e sente.

O espetáculo se torna real para o espectador quando ele o apreende, por meio da luz, como um fenômeno intersensorial. Para se relacionar, ou seja, 
estabelecer sua relação com o espetáculo teatral, à cuja experiência é submetido, o espectador precisa, antes, existir e fazer existir esse mundo à sua volta, do qual brotam as certezas e as verdades de ser-no-mundo. Não existe casualidade na conexão do espectador com o espetáculo. Sua liberdade requer um poder sustentando pelo engajamento, pela entrega vivida na ambiguidade de um campo de eventos, assimilados harmoniosamente pelos poderes do corpo a partir de um pacto estabelecido naturalmente entre ele e o meio. Desta forma, o espectador é convidado a experimentar o espetáculo pela mediação da luz. Esse raciocínio conduz, naturalmente, para o conceito de affordance proposto Gibson.

Para o psicólogo americano James Jerome Gibson, a relação entre o indivíduo e o mundo se dá por meio da estimulação dos sentidos, uma espécie de ponte entre o mundo exterior e o mundo interior, a cuja experiência se acrescenta o que a percepção adiciona ao que é percebido, ou seja, a sua compreensão. Considerando a contribuição da mente ao processo perceptivo, ocorre o que Gibson chama de síntese crítica, quando algo se perde e algo se acrescenta aos estímulos sensoriais do percebedor (SANTAELLA, 2012, p. 6). A percepção seria, então, resultante tanto dos estímulos quanto de experiências anteriores, que permite assimilar o que é percebido por meio de uma capacidade associativa a partir da matéria bruta fornecido pelos sentidos. Assim, ocorre uma organização sensorial dos elementos componentes da cena pelos sentidos, cujo resultado da percepção total é maior que a soma de suas partes. Somente o conjunto do que é dado à percepção afeta, efetivamente, o espectador, considerando a interação entre essas partes. A teoria ecológica da percepção de Gibson permite explicar, então, como a percepção consiste em captar as estruturas significativas da luz através de um processo de inferência determinado por essas relações e interações entre os componentes da cena, a luz e o espectador, entendidos aqui como o ambiente informativo e o percebedor ativo descritos pelo autor (SANTAELLA, 2012, p. 48).

A realização epistêmica ativa da ecologia da percepção de Gibson voltada ao teatro se encontra, então, na relação dinâmica criada entre o espectador (animal percebedor) e o espetáculo (ambiente), não havendo separação possível 
entre ambos. De acordo com essa teoria, "o animal entende o mundo porque as coisas também falam" (SANTAELLA, 2012, p. 142). Em uma analogia da teoria gibsoniana com a experiência teatral, o espetáculo seria o mundo que acolhe 0 espectador porque existe, entre ambos, uma reciprocidade de entendimento. $A$ luz, para o autor, é o elemento que relaciona o ambiente e o percebedor, adquirindo, no meio cênico, a função de, além de expor o conjunto do que é dado à percepção, somar-se ao todo para estimular os receptores e ativar o sistema perceptivo do espectador. Boa parte dos estudos de Gibson são destinados à luz, que ele classifica como energia física, estímulo para a visão e fonte de informação para a percepção, diferente da visualidade permitida pela luz. No ambiente vital descrito por Gibson, não existe separação entre mente e matéria, mas o meio, entendido num conceito de percepção e ação ecológicas, é tanto o lugar onde o percebedor opera quanto onde se propagam a luz, o som e o cheiro. A percepção do espectador é guiada por esses estímulos, que são informações detectadas por ele para guiar e controlar sua ação. Esse é o entorno dos que percebem e agem, espectadores e performers, em um conjunto inseparável, no qual um implica o outro.

O princípio essencial da percepção ecológica de Gibson é que o ambiente acolhe $\mathrm{o}$ indivíduo e se oferece a ele como percebedor ativo que age e o transforma de acordo com suas habilidades e competências. Segundo o conceito de evento de Gibson, o espectador, em contato com a obra teatral, não percebe o tempo, mas apenas os processos, as mudanças, as sequencias e o fluxo dos eventos, que diferem da passagem do tempo regular, em uma estrutura sequencial. Os eventos podem ser percebidos, mas o tempo não, fazendo emergir tudo o que o espetáculo tem a oferecer ao espectador, segundo o conceito de affordance. As affordances, únicas e especiais para cada indivíduo, expressam a compatibilidade existente entre elas e o percebedor, cujo conjunto define o nicho, a lacuna a ser preenchida pelo entendimento do espectador, resultante da relação estabelecida entre ele e o que o espetáculo lhe oferece, incluindo objetos, sensações, informações e percepções ontologicamente ligados e recíprocos a ele. As affordances são as oportunidades de interação do 
espetáculo com o espectador, que age sobre a cena por meio da utilização de uma das affordances indissociavelmente ligada a ele, a iluminação.

A ação performativa da luz opera, então, na medida em que ela se manifesta fisicamente segundo normativas pré-estabelecidas ou improvisações que acompanham a representação cênica e são dadas à contemplação a fim de provocar sensações e reações frente ao olhar que as aprecia, se dedica e reage a elas. A iluminadora Nadja Naira ${ }^{182}$ relata, sobre o seu trabalho com a companhia brasileira de teatro e o ator, diretor e dramaturgo Marcio Abreu:

... ele fica doente, porque ele quer desfazer a lógica (do teatro), quer tirar o público da passividade, quer estimular o público a agir e reagir, pensar porque que as pessoas estão sentadas ali, porque elas estão há tanto tempo ali e que elas precisam se deslocar de um espaço para o outro, que elas são plateia e que devem reagir como plateia, que elas não são passivas e que não precisam aceitar essa forma. Claro, isso é objeto de criação, também, e nesse sentido a luz é potente pra caralho! Porque ela pode abrir esse espaço, fechar esse espaço, borrar esse espaço. Somos nós, luz, que conseguimos separar palco e plateia, somos nós que conseguimos juntar palco e plateia. A cenografia também consegue, se você traz um tapete vermelho que começa na plateia e avança no palco, você borra uma fronteira. Acho que essa ideia de abrir, borrar fronteira, perder a limitação, não criar muros... é o que fazemos na companhia. [...] Você sempre vai encontrar essa questão do espaço, da relação com a plateia, quem é a plateia e o que ela está fazendo aqui, qual o papel dela nessa peça, se ela é juíza, ou cúmplice, minha amiga no meio da ação ou não (NAIRA, anexos, p. 171).

A luz busca, então, a partir do entendimento e da relação pretendida como o público, colaborar, por meios de seus efeitos e de sua atuação performativa, para estabelecer essa relação, intervir nas reações do espetador, nas emoções e na geração de um sentimento de empatia ou estranhamento diante do espetáculo, da cena ou dos personagens. Esse sentimento gerado é o que irá promover, induzir e viabilizar a adesão do espectador, agindo para influir sobre sua percepção e provocar seu prazer em contato com a obra (MOSTAÇO, 2017, p. 111).

A classificação da empatia em diferentes modos de manifestação de Jauss (1978 apud MOSTAÇO, 2017, p. 110-111) explica as diferentes formas de

182 Em entrevista realizada como parte desta pesquisa, disponível nos anexos, p. 164-178. 
operação da catarse e seus efeitos sobre o público, permitindo conceber as diferentes formas por meios das quais a luz estabelece o meio empático que favorece a criação do elo entre o espetáculo e o espectador. Conforme sua configuração e atuação performativa, a luz insere o espectador no jogo da cena e permite experimentar as sensações e prazeres resultantes do estreitamento dos vínculos criados (empatia associativa); expor as qualidades positivas dos personagens, seus atos e condutas (empatia admirativa); a identificação com o drama, ao intensificar um ambiente de dor, clausura e sofrimento, ou com a comédia, pelo clima leve e descontraído que venha a propor (empatia catártica); criar uma atmosfera de identificação com a vida real de personagens comuns e imperfeitos (empatia simpatética) ou causar estranhamento, negação e recusa ao expor cenas de formas agressivas e embrutecidas, provocando reflexões críticas à situação apresentada (empatia irônica).

A luz performativa, como affordance, constitui, então, o estímulo sensorial do espetáculo para o espectador, de cuja entrega e dedicação dependerá, da forma mais fundamental e elementar, a sua percepção. Assim como na relação sujeito/mundo (Merleau-Ponty) e animal/ambiente (Gibson), o espectador e a cena são indissociáveis e interdependentes, cabendo à performatividade da luz estabelecer o elo que viabiliza o acesso mútuo e as inter-relações entre ambos. 


\subsection{Características e condições da performatividade da luz}

Um bom caminho para o entendimento do que poderia ser uma iluminação ou um conjunto de efeitos ou luzes performativas, talvez possa ser o de perceber quando uma luz não se enquadra no conceito de performativa. Uma iluminação que objetiva a atuação apenas como instrumento de visibilidade, que tem como função exclusiva permitir que a cena seja vista pelo público, mesmo que ela delimite quadros, cenas ou coreografias pelo acender e apagar das luzes e traga algumas características físicas como cor e abrangência do facho luminoso, pode até ser considerada como uma forma de expor a cena para o espectador, mas não de maneira performativa. É possível afirmar que toda luz performa, mesmo que não intencionalmente, mas que nem toda luz é, necessariamente, performativa, no contexto teatral, dentro do conceito defendido nesta tese. Para que ela possa ser considerada nestes termos, é preciso que haja uma intencionalidade, que haja uma participação no processo criativo, uma interação com a cena e, principalmente, que haja uma preocupação com o espectador a respeito do que the é oferecido à percepção. Segundo Ramos (2017, p. 343), "o que diferencia a mimesis da pura realidade não é uma qualidade ontológica, mas a intencionalidade na relação com o receptor". É essa mesma intencionalidade que pode fazer da luz cênica uma luz performativa, essa intenção de afetar, interferir, alterar e atuar sobre aquilo que ilumina e que se dá a ver com o objetivo de gerar efeitos e reações na percepção de quem observa atentamente.

Essa intencionalidade tem relação direta com o processo colaborativo de criação, pois para que seja possível impor uma intenção na luz, é necessário conhecer a intenção das outras linguagens que compõem a cena, conhecer a genealogia de cada cena e a concepção dos demais artistas e elementos que a compõem. Uma das condições essenciais para a criação e a realização de uma luz performativa está na gestação do espetáculo cênico por meio de um processo colaborativo, cuja participação ativa de todos os artistas criadores da cena interagem e interferem mutuamente na construção da cenas que, no momento da apresentação ao público e da interação com os espectadores, finalmente se 
concretiza como obra artística. É preciso, também, relembrar o conceito amplo de cenografia como composição integral da cena, na qual cada um de seus componentes é indispensável à atuação do outro, considerando sua interação e afecção sobre os espectadores no momento da recepção.

A pesquisa de Marcello Amalfi (2015) a respeito da macro-harmonia da música no teatro faz entender a realização teatral como uma polifonia cênica, no sentido da composição de muitas vozes, cada uma representada por um dos elementos constituintes da cena. Para ele, existe uma horizontalidade, expressa pela evolução individual de cada elemento, que toma a frente da realização cênica, mesmo que ainda haja uma verticalidade presente na simultaneidade na evolução conjunta destes mesmos elementos (AMALFI, 2015, p. 206). Amalfi acredita em uma vibração coletiva que, estabelecida entre esses elementos, provoca uma influência mútua se contrapondo individualmente em sua horizontalidade, "como um violino que dialoga com uma flauta em uma sinfonia" (AMALFI, 2015, p. 207).

Destas analogias surgiu a noção de macro-harmonia, desenvolvida a partir do emprego da harmonia na análise da prática da composição musical no teatro. O maestro e compositor Marcelo Amalfi considerou a questão natural das relações entre elementos contrários independente do sistema onde figuram para constatar como a mudança de um elemento da encenação afeta todos os demais. Em seu significado metafísico, a harmonia representa a unificação de contrários, dos quais se origina como acordo de elementos discordantes (FUBINI, 2008 apud AMALFI, 2015, p. 208). Para Amalfi, os componentes da encenação passam a ser integrantes da estrutura da música composta, que "extrapola os tradicionais componentes acústicos (as notas, ruídos, etc.), e abarca também os demais elementos aos quais ela é naturalmente associada em cena (os gestos, a luz, o cenário, texto, trama, intenção dos personagens, etc.), fazendo com que haja uma ampliação das relações harmônicas sobre as quais está constituída" (AMALFI, 2015, p. 211). Essa interferência recíproca entre todos os elementos da composição cênica, na qual a variação ou a alteração de um elemento influencia diretamente a constituição e, 
principalmente, a atuação dos demais, implica diretamente no conceito da performatividade da luz no conjunto de linguagens que compõem a cena teatral.

A ação performativa da luz só ocorre pela presença cênica da luz, que, segundo Elsa Revol'183, só existe quando algo a atravessa (REVOL, anexos, p. 92). Thierry Fratissier ${ }^{184}$ afirma, igualmente, que a luz, ao contrário do trabalho do ator, do cenário, dos figurinos ou do som, não existe se não houver o que iluminar:

\begin{abstract}
... a luz não pode trabalhar sozinha, sendo que um ator sozinho pode produzir um espetáculo, assim como um cenógrafo pode produzir um objeto cenográfico, [...] Obviamente isso não vai representar um espetáculo, mas pelo menos há algo de tangível. E o mesmo acontece com o figurino, o mesmo acontece com o som. [...], se não tivermos uma cenografia, quero dizer, um chão, ou até mais que isso, se não tivermos um ator, dançarino, cantor, ou outro personagem para iluminar, se não houver a encenação que o acompanha, nós não podemos fazer nada. Então, naturalmente, somos obrigados a fazer a luz com tudo o que compõe o próprio espetáculo [...] é óbvio que o resultado da luz vai criar uma interação (FRATISSIER, anexos, p. 212).
\end{abstract}

A luz, ao se materializar sobre aquilo que ilumina, se faz presente e atuante em cena, no conceito de luz-matéria, imprescindível para a vocação performativa da luz. Somente a luz materializada na cena pode permitir ao espectador, tanto a visibilidade quanto a visualidade necessárias para estabelecer seu vínculo com o que lhe é dado à observação e percepção estética. Para Gumbrecht (2010), o conceito de presença se refere a uma relação espacial com o mundo e seus objetos. A experiência do que ele define como presença é associável à materialidade da luz como fenômeno físico, que se expõe aos sentidos do observador no teatro ou fora dele. A luz-matéria estaria, então, inserida no contexto das materialidades da comunicação, descritas por Gumbrecht, e da materialidade poética inspirada na corporeidade apresentada por Biancalana, cuja presença se encontra na corporificação ou substancialização de algo que é dado à percepção do observador.

A luz física e material considera o fenômeno luminoso em si e seus efeitos sobre a cena e o espectador. Ela é considerada, então, como elemento

183 Em entrevista realizada como parte desta pesquisa, disponível nos anexos, p. 92-108.

${ }^{184}$ Em entrevista realizada como parte desta pesquisa, disponível nos anexos, p. 209-217. 
autônomo e seus resultados não têm, necessariamente, relação com a intenção ou interação voluntária, mas com sua presença e as reações que é capaz de provocar em cada espectador. A acepção da luz como elemento material, que age sobre a cena e o processo de recepção, não descarta seu entendimento como fator imaterial em sua ação sobre a percepção dos performers e espectadores, nem a intencionalidade do criador ou a habilidade do operador de luz. De forma integrada, é na dupla natureza material e da imaterial da luz que se encontra seu potencial performativo. A respeito da natureza da iluminação cênica, Marc Boucher esclarece, que Josef Svoboda, "mesmo reconhecendo seu status 'imaterial', ele a considera como o elemento fundamental da cenografia a e trata com um material"185 (BOUCHER, 2015 apud RICHIER, 2019, p. 31). Considerando o conceito de mise-en-lumière, assimilado como "colocar na luz", a iluminação é adicionada à cena tanto pela ação humana, oriunda da intenção do iluminador ou da execução pelo operador, quanto pode iluminar o espaço, os corpos e objetos cênicos por vias próprias, como fenômeno natural, em um espetáculo ao ar livre, por exemplo, ou por ações involuntárias de uma luz rebatida ou um reflexo não programado de luz. Seja qual for a situação, no entanto, sua ação sob a percepção humana independe da forma como ela é feita, mas sim de como é posta, como está em cena, uma luz que não é verdadeira ou falsa, certa ou errada, mas "acontece", de acordo com o conceito de performativo de Schechner (2002 apud FÉRAL, 2009, p. 72). Ela é performativa na medida da capacidade de influenciar e modificar a cena e a percepção do espectador por meio de sua materialidade e presença poética.

Dos vinte e três iluminadores entrevistados nesta pesquisa, apenas quatro revelaram ter uma percepção de uma só natureza da luz no teatro em sua materialidade. Todos os demais expressaram o consenso do entendimento da dupla condição da luz, que se mostra, simultaneamente, material e imaterial em sua aplicação no teatro. Imaterial pela maneira como afeta e produz efeitos sensoriais na percepção do espectador, juntamente com as sensações sonoras. E material, como fenômeno físico, cuja presença age em interação com os

185 « tout en connaissant son statut 'immatériel', il la considère comme l'élément fondamental de la scénographie et la traite comme un matériau » (tradução da autora). 
demais componentes do visual cênico sobre os quais incide. A exemplo da dupla natureza física da luz como onda e partícula, a iluminação cênica revela, igualmente, em sua atuação como materialidade poética da cena, seu duplo caráter material e imaterial. Essa concepção foi filosoficamente exemplificada pela iluminadora e pesquisadora Claudia de $\mathrm{Bem}^{186}$ :

Eu considero a luz as duas coisas. Tenho uma relação da luz com o olhar. Essa é a minha maior relação. Eu acho que a luz me conduz e me ensina a olhar as coisas. Acho que é uma dialética entre o que eu estou vendo e o que eu não estou vendo. Essa duplicidade está sempre junto. O primeiro conceito de luz é que ela torna as coisas visíveis. Aprendemos assim, mas ao mesmo tempo, para mim, luz é muito mais do que isso. É a maneira como eu vejo o mundo e como eu vejo as coisas. Como eu torno as coisas visíveis (DE BEM, anexos, $p$. $68)$.

Bem como de uma forma mais teorizada pela professora, diretora e iluminadora teatral, além de orientadora desta pesquisa, Cibele Forjaz ${ }^{187}$,:

... a luz tem uma existência material, concreta que atua sobre os corpos, é vibração, atinge o olho e cria impulsos elétricos, frequência de ondas que viram imagem no cérebro e tem toda uma interação com o material e o concreto, mas na cena ela também pode ser um canal de comunicação entre o que é material e o que é imaterial. Isso ocorre principalmente na medida em que a luz atua no visível, não necessariamente de modo conceitual, mas pode provocar a imaginação e a participação ativa da plateia e, nesse sentido, ela é imaterial... É relação e propicia a projeção da subjetividade da plateia, da imaginação, da abertura para o que não é dito e é sentido, mas que não poderia ser explicado (FORJAZ, anexos, p. 75).

Ou numa versão um pouco controversa, mas muito inspirada, do iluminador e diretor teatral Fabrizio Crisafulli188, ao explicar que:

Embora, do ponto de vista físico, possamos dizer que a luz é um elemento imaterial, do ponto de vista artístico, eu tendo a considerá-la como matéria. É como algo que tem sua própria substância, que pode ser modelado e que pode receber formas e configurações, capazes de fazer a própria luz se tornar um elemento "concreto", capaz de "presença". Eu nasci nas encostas do Etna e, desde criança, observando os fluxos de lava à noite, tive essa percepção da luz como matéria e forma, e isso acho que me influenciou bastante no desenvolvimento dessa ideia. Comparado à dualidade materialimaterial, há outro aspecto que me interessa, que diz respeito à relação da luz com a cena, objetos, atores: é sua capacidade de dar a esses elementos materialidade ou imaterialidade, dependendo de como ela

186 Em entrevista realizada como parte desta pesquisa, disponível nos anexos, p. 69-74.

187 Em entrevista realizada como parte desta pesquisa, disponível nos anexos, p. 75-83.

188 Em entrevista realizada como parte desta pesquisa, disponível nos anexos, p. 113-116. 
é usada. Em particular, dependendo se é luz difusa ou concentrada e como sua energia é regulada. É evidente que uma luz direta e dura, que cria sombras claras, torna a coisa iluminada mais "material" do que uma luz suave e difusa; e que existe um nível de intensidade de luz abaixo do qual tudo parece diáfano, imaterial e que, ao elevar a intensidade, tudo adquire concretude e materialidade. Costumo usar essas diferenças em sentido dramatúrgico e poético. Algumas vezes, por exemplo, usei variações muito lentas da intensidade da luz, apenas para explorar os diferentes graus da relação material-imaterial, que podem ser experimentados como tais no nível perceptivo, mas que também podem se tornar significativos no nível dramatúrgico (CRISAFULLI, anexos, p. 113).

Dentre os iluminadores que percebem a dupla natureza da luz, quatro deles consideram muito mais importante, no teatro, o seu aspecto imaterial, a exemplo da opinião poética do iluminador italiano Gianni Staropoli189. Ele afirmou que, em sua criação, pensa e sente o imaterial, qualificado por ele como a substância mais preciosa da luz, que se torna material quando se manifesta apenas em sua força mais tangível, aquela que existe só para clarear, para permitir que a cena seja vista e acessada pelo espectador. Para ele, a questão da materialidade ou imaterialidade da luz não resulta de uma equação superficial, mas de um conjunto de percepções subjetivas:

A luz cênica é sem dúvida uma luz projetada e construída, que se torna concreta. No momento em que a construímos, nós a tornamos viva e ativa, esquecendo, por sorte, a sua natureza artificial e efêmera. E é também por essa simples razão, na minha opinião, que ela pode se tornar material e imaterial ao mesmo tempo. Deixa-se moldar precisamente por ser matéria metamórfica da construção do espaço cênico (STAROPOLI, anexo, p.117).

\section{O iluminador francês Thierry Fratissier ${ }^{190}$ sintetizou essa percepção} afirmando que a luz é:

... material por que temos que compor com um feixe, com cores, com um projetor, etc. Mas o resultado e a ação da luz no palco são imateriais. Então, obviamente, temos que passar pelas duas concepções da luz. [...] finalmente, o que mais nos interessa é o lado imaterial da luz, [...] a matéria com a qual trabalhamos e a dimensão imaterial da luz, é mais a ação da luz no espetáculo, [...] se estamos lidando com iniciados da iluminação, eles analisarão o lado material da luz [...] Na maioria das vezes, eu ouso esperar que não tenhamos que lidar com espectadores muito iniciados no trabalho de construção da luz; portanto, neste caso, é obviamente o lado imaterial da luz que eles percebem primeiramente (FRETISSIER, p. 209).

189 Em entrevista realizada como parte desta pesquisa, disponível nos anexos, p. 117-120.

190 Em entrevista realizada como parte desta pesquisa, disponível nos anexos, p. 209-217. 
Finalmente, o poeta da luz Pasquale Mari191 acredita que "a resposta para a questão de saber se a luz do palco é material ou imaterial deveria ser: nem uma nem a outra" (MARI, anexos, p. 179). Ainda para ele, porém, "se não considerarmos a luz, entre outras coisas, na construção do fato cênico, se não Ihe dermos o status de material, quantificável, manipulável, com um peso físico na composição da imagem, se torna impossível analisar sua dinâmica na criação de nossa experiência como espectador" (MARI, anexos, p. 179). Nesse sentido, como elemento material e imaterial da cena teatral, a luz pode ser associada aos conceitos de visível e invisível como na obra homônima inacabada de MerleauPonty (2009). Segundo este estudo, o visível estaria no plano do sensível, do "algo" resultante da experiência confrontada com a possibilidade do "nada", que não é "nada mais (nem nada menos) que o invisível" (MERLEAU-PONTY, 2009, p. 232). Esse nada invisível associável à luz imaterial, é justamente a abertura proporcionada pelo algo visível e material da luz física que se propaga e se manifesta em cena, afetando tudo o que toca materialmente, como os objetos, corpos e elementos cênicos sobre os quais incide, e atinge imaterialmente, como a percepção de performers em cena e espectadores no ato de recepção ativa do espetáculo.

Para além do seu aspecto material ou imaterial, a luz da cena, como ato performativo em relação direta com a cena e com o espectador, não prevê erros ou enganos (DERRIDA, 1972 apud FÉRAL, 2009, p. 72), mesmo considerando uma luz previamente concebida, eliminando toda possibilidade de efeitos inexatos, seja na concepção ou na realização durante o espetáculo. A luz percebida pelo espectador será a luz da cena, e, para ele, não haverá outra. Se um movimento de luz deixa de ser realizado ou o operador de luz erra a operação ou o tempo de uma mudança de luz, se o ator erra o texto e ambos improvisam, e maneira como isso é feito é a verdade para aqueles espectadores no espaço/tempo em que acontece. Se um espectador se distrai com outra luminosidade, ruído ou acontecimento indesejado no momento de um efeito e não o vê, a sua verdade será o espetáculo sem aquele efeito, o que mudará,

191 Em entrevista realizada como parte desta pesquisa, disponível nos anexos, p. 179-180. 
mas não anulará sua percepção da totalidade do que lhe é apresentado. Visto desta forma, pode-se dizer que a luz performativa considera, também, a possibilidade de improvisos, adaptações e eventuais erros, que se tornam acertos naquela situação e devem ser assimilados como tal, mesmo que não voltem a acontecer numa próxima apresentação.

Há uma verdade a respeito do caráter efêmero e improvisacional do teatro destacado por Chacra (1991 apud BIANCALANA, 2011, p. 138), para quem "a vida da representação teatral é uma realização irreversível por 'ser em determinado momento'. Este fenômeno da vida e do teatro, mesmo quando ambos são programados, não prescinde do imprevisível". Sendo assim, a improvisação, como elemento constituinte do teatro, inclui a preparação dos atores, os laboratórios de criação e a interação durante a cena. Apesar dela limitá-la, em sua teoria, à improvisação realizada entre os atores e/ou o público, seu entendimento é facilmente aplicável à interação existente entre os performers e os demais componentes cênicos e entre esses individualmente, inclusive no que diz respeito à preparação e exercício de um possível performer da luz na figura do operador como propositor e reator aos fenômenos e acontecimentos cênicos. Biancalana (2011, p. 140) acrescenta ainda que os processos improvisacionais não se limitam a situações performáticas ou performativas, flutuando desde o espetáculo mais formalizado e ensaiado ao que se cria durante a performance.

Desgranges (2017) destaca o estado de alerta de artistas e espectadores em processos de criação teatral por um coletivo em trabalho conjunto de criação, abertos ao imprevisto e ao improviso, atentos ao inesperado de qualquer coisa que possa ocorrer como erros, enganos ou acontecimentos poéticos, previstos ou não, predispondo ambos a um ciclo de ações e reações mútuas e dialógicas, deixando-se atravessar pelo processo em curso. Acompanhando esse raciocínio, mesmo no teatro elaborado e ensaiado parece haver um estímulo e uma disposição para surpreender o espectador através da arte, do desejo de satisfazer, surpreender ou convencer. Isso acontece por meio da linguagem cênica ativa, no instante em que o pré-estabelecido confronta-se com o novo no 
momento presente da representação. $O$ público não é receptor passivo, ele reage à performance e provoca nela um efeito como resultado direto no seu desempenho pela troca evidente que se estabelece entre a cena e a plateia. $O$ espectador é ativo em sua própria forma de assimilar o que acontece no palco, influenciando a forma de ser e de fazer dos performers pelos estímulos que envia a partir de sua recepção e percepção da cena.

A luz performativa, então, só acontece efetivamente no contato com o espectador, pois é na mente, na percepção e no entendimento que ele possa vir a ter do que observa e sente que ela se realiza. Desde as primeiras pesquisas, o potencial performativo enquanto ato perlocutório revela estar diretamente relacionado à recepção: "este seria o caráter primordial de uma luz considerada performativa, uma iluminação que "acontece" em consonância com a ação cênica, ambas dadas à percepção e experiência do espectador" (LUCIANI, 2012, p. 92). Ele resulta da luz como ato performativo que advém do conjunto e interage com os demais componentes da cena dentro dos parâmetros da presença, ou seja, sua habilidade ou capacidade para atrair a atenção do espectador para a cena e mantê-lo conectado e em relação perceptiva com a ação cênica.

Para assimilar o conceito de performatividade da luz defendido nesta pesquisa, é importante entender como todos os conceitos analisados e apresentados se articulam nas diferentes perspectivas postas, resultando em uma nova interpretação do fenômeno da luz no teatro contemporâneo. Foi somente a partir da investigação de uma vasta multiplicidade de noções distintas é que foi possível ampliar, finalmente, o entendimento das funções da luz no teatro contemporâneo fazendo emergir os argumentos que possibilitaram a apresentação e defesa do conceito proposto. Existem certas características que permitem conceber / perceber / compreender uma luz como performativa na cena, desde o seu processo de criação até a apresentação ao público. São condições, circunstâncias e contextos indispensáveis para que o fenômeno da luz ativa ocorra. 
A luz que transforma a cena e age sobre a percepção do espectador, alterando-a, também reage e responde às suas reações, sempre que possível ou necessário. Da mesma forma que o ator, que percebe e responde às reações do público, o operador da luz também deve se colocar atento e reativo a ela, bem como aos tempos e intenções do ator. Essa luz performativa também pode ter a função de integrar palco e plateia, a exemplo do realizado e descrito pelo iluminador carioca Paulo Cesar Medeiros ${ }^{192}$ :

A percepção da luz pelo público muitas vezes se dá de forma muito
sutil. Algo bom que eles sentem. Um efeito, uma "mágica". Nosso
trabalho é feito da poética dos sonhos. Damos acesso ao invisível.
Deixamos as energias à mostra. Uma vez fiz uma luz com uma única
lâmpada. Na Solidão dos Campos de Algodão. Ela unia palco e plateia.
Só ela. Todos se sentiam um só. Ouvi isso de muita gente que assistiu
(MEDEIROS, anexos, p. 183).

Mesmo que com ambientes diferentes para cada um deles, a luz performativa considera a experiência do espectador desde sua chegada ao teatro até o final do espetáculo, por vezes ambientando a plateia ou o palco no momento da entrada e/ou saída do público.

Tão importante quando destacar o que pode ou não caracterizar uma luz performativa, é detectar as características favoráveis a uma performatividade da luz, mas cuja ausência não se revela como impeditiva para sua atuação como tal. A atuação do operador de luz, ou seja, sua performance como potencial performer da luz, é um exemplo disso. A operação da luz performativa, realizada em interação e interdependência com a cena, com seus riscos, interatividade e possibilidade de improvisação ou atuação propositora da luz, nas apresentações ou nos ensaios, pode ser um indicativo de ação performativa, mas não é condição para a manifestação do conceito da performatividade da luz. Desta forma, entende-se com isso que uma luz pode ser considerada performativa mesmo que não apresente tais características.

Além disso, é importante relembrar que, neste conceito, a luz performativa independe do teatro performativo, da performance ou de algumas das

\footnotetext{
192 Em entrevista realizada como parte desta pesquisa, disponível nos anexos, p 181-183.
} 
características pós dramáticas do espetáculo, podendo se manifestar em montagens teatrais tradicionais, clássicas, narrativas ou dramáticas, bem como em outros tipos de manifestação cênica ou artística, como instalações, desfiles ou exposições, desde que presentes e ativas na relação com o observador. No entanto, é importante destacar que a luz performativa no teatro acontece principalmente quando se trata da luz para a cena, no conceito apresentado por Tudella, ou seja, com a luz que interage com a ação cênica e é concebida especialmente para tal. A luz que ambienta também comunica e informa, mas, em princípio, não atua, não age como elemento transformador da cena, como elemento estrutural e estruturante do espetáculo.

Neste sentido, a luz performativa depende do processo colaborativo de criação e só pode ser concebida e atuar conjuntamente com os demais elementos constitutivos da cena. Apoiado filosoficamente em Deleuze, Badiou apresenta a performance como puro "devir imanente, oposto à representação ou à reflexão" (BADIOU; DURING, 2007, p. 24). Apesar da clara alusão ao trabalho do ator, bailarino ou artista em presença corporal, não posso deixar de relacionar esse conceito ao trabalho de improvisação em processos de criação de luz para espetáculo musicais, de dança ou teatro, cuja construção processual e coletiva permitem total integração entre cena e luz, performance corporal, textual ou musical e operação das luzes articuladas em um devir previsto ou, muitas vezes, imprevisível e improvisado coletivamente, mas cuja realização se opera, sempre, no momento da ação.

A iluminadora Marisa Bentivegna ${ }^{193}$ relatou um episódio marcante de sua carreira no qual identificou uma atuação potencialmente performativa da luz criada para o espetáculo de dança Aldeotas, da Companhia Nova Dança, com texto de Gero Camilo e direção de Cristiane Paoli Quito. Seu relato demonstrou a maneira como a luz interferiu na cena por meio do que chamou de luz aberta, que acontece quando a ação integrada do operador com a cena interfere e altera a atuação dos performers. A iluminadora descreveu ainda a forma como o jogo presente no trabalho de improvisação da diretora e a estrutura dramatúrgica,

193 Em entrevista realizada como parte desta pesquisa, disponível nos anexos, p. 151-163. 
criada a partir do texto proposto, permitia que as cenas acontecessem em ordens "aleatórias", mas de uma forma que "fizesse sentido para os atores, ou seja, poderia começar o espetáculo pela última cena e não tinha nenhuma marca espacial, então a luz tinha que dançar junto com o que estava acontecendo" (BENTIVEGNA, anexos, p. 158), propondo e permitindo que os performers entrassem no jogo ou não, instaurando um risco, uma tensão e uma imprevisibilidade à operação da luz.

O mais interessante, segundo seu relato, é que a luz também podia fazer proposições aos atores, a exemplo de uma determinada cena, cujo código estabelecido pela luz, poderia atrasá-la ou antecipá-la na ordem do espetáculo. Ela também descreveu a forma como, em um outro espetáculo com a mesma companhia e com bailarinos absolutamente treinados para o improviso, acontecia um jogo vivo entre a luz e a cena, no qual sua atuação atrás da mesa de luz era tão intensa que chegava à exaustão física. Ela declarou, sobre esta operação, que "não conseguia nem olhar para a mesa, eu ficava o tempo todo de olho no palco, propondo, recebendo e propondo. Às vezes, eu é quem dava o final do espetáculo, quando eu percebia que já tinham se esgotado todos os recursos e a história já tinha sido contada" (BENTIVEGNA, anexos, p. 159). Para ela, essa experiência com a Quito representou uma profunda relação iluminadora/intérpretes além de, inclusive, uma profunda relação iluminadora/plateia.

\subsection{1 lluminação e gravidade relativas (a luz e a maçã)}

Em uma conversa que antecedeu a entrevista realizada com Christine Richier ${ }^{194}$, ela questionou, depois de ouvir um pouco do contexto e da hipótese levantada nesta pesquisa sobre a performatividade da luz, como tantos outros já haviam feito antes, aliás, se não havia sido sempre assim, se a luz não havia tido sempre uma participação ativa na cena. Em resposta, eu expus, novamente, o

194 Entrevista realizada em Lyon em março de 2020, com a iluminadora e professora da ENSATT - École National Supérieur de Arts et Techniques du Spectacle. 
que tenho chamado de "teorias da gravidade e da relatividade aplicadas à performatividade da luz". Ela pareceu convencida, como tantos outros antes dela, o que incentivou a defesa da hipótese da luz performativa e conclusões realizadas a partir dela.

No entanto, a partir dessa conversa e de outras, parece importante expressar, também aqui neste documento de tese, mesmo que talvez um pouco tardiamente na ordem dos argumentos apresentados, alguns esclarecimentos. O primeiro, relativo ao próprio conceito de performatividade empregado, que refere-se mais ao entendimento anglo-saxão do termo do que ao francófono. Para os franceses, o termo performatif, fortemente ligado à representação e ao improviso, refere-se quase que exclusivamente (salvo outras percepções às quais eu possa não ter tido acesso) a algo efêmero, que ocorre uma só vez, conceito próximo ao de happening americano. O emprego adotado, no entanto, na intuição que deu origem à elaboração da hipótese investigada e aos argumentos apresentado ao logo desta tese, refere-se ao entendimento do termo como atuação, performance e desempenho, mesmo que como ato repetido, mas cuja realização ao vivo, no tempo e espaço da ação, implica na efemeridade, busca da superação e risco inerentes à ação viva (acte vivant), ou, como se diz mais frequentemente em língua portuguesa, ao vivo.

Umberto Eco afirma que "toda obra científica deve ser uma espécie de thriller, o relato de uma busca por algum Santo Graal" (ECO, 2013b, p. 12), então foi nesse sentido que eu empreendi esta busca, na intenção de encontrar os argumentos e explorar os conceitos necessários ao suporte da proposição original. Em seu texto, Eco destaca a importância do fascínio do pesquisador pela investigação e pela procura da "verdade oculta" por trás de teorias, argumentos e hipóteses, alegando que uma investigação científica deve ser movida pelo entusiasmo e pelo desejo de alcançar um resultado, além do prazer de empreender essa jornada no sentido da comprovação de ideias intuitivas e probabilidades oriundas da experiência, do trabalho e da paixão, no meu caso, a paixão pelo teatro, o trabalho com o ensino da iluminação cênica e as experiências com a criação. 
Nesta busca, eu descobri que a performatividade da luz seria como a gravidade, que não passou a existir nem foi inventada por Isaac Newton. Ele tão somente empreendeu a investigação e identificação de suas características e comportamento físico por meio de estudos científicos aplicados, a fim de que fosse possível, a partir deles, compreender seu funcionamento e explorar seu potencial em favor das atividades humanas, em favor da ciência, da arte e da tecnologia. Da mesma forma, a performatividade da luz pode ser considerada, de forma bastante simplista, como relativa, tanto à sua atuação conjunta com os demais componentes da cena quanto com a recepção, percepção e dedicação do espectador, e nunca como absoluta ou definitiva em seu desempenho ou atuação cênica.

Além disso, assim como a gravidade, que sofre a influência de diversos fatores físicos e metafísicos, a luz também é relativa, visto que, considerando sua natureza e comportamento, pode ser considerada tanto como onda quanto corpúsculo conforme o contexto em que se apresenta ou o contexto no qual é analisada. O mesmo acontece com a iluminação cênica que, susceptível e reagente a todo tipo de interação pode ser analisada em relação à relatividade que, de uma certa maneira, também não foi descoberta, mas que, ao ser estudada e explicada em termos científicos por Albert Einstein, demostrou como as circunstâncias e a maneira como o ser humano se relaciona com o tempo e o espaço podem modificar a forma de perceber e se relacionar com as coisas à sua volta. A luz performativa, então, considerada como ação e feito relacional, pode favorecer e facilitar a comunicação e a comunhão, no teatro, entre performer e espectador, entre cena e público. Por isso é importante conhecê-la, compreendê-la e entender como ela acontece, funciona e age nos palcos ou em outros espaços, nas mais diversas formas de expressão artística, dramática ou performativa, para estabelecer a relação entendido performatividade da luz no teatro. 


\subsection{A performatividade da luz ainda por investigar}

Tendo chegado ao final da pesquisa e percorrido o longo caminho da ideia original até as conclusões apresentadas nesta tese, não há como considerar o estudo da performatividade da luz completo ou definitivo. Assim como na física, na ciência ou nas artes tampouco é possível assumir um tema como estanque ou concluído. Como se diz na física quântica, não existe uma epistemologia universal nem verdades absolutas, mas pertinências, que merecem ser sempre investigadas e comprovadas, para serem substituídas por outros experimentos e pressupostos que dão origem a novas pertinências, e assim sucessivamente. Da mesma forma, fica evidente supor que possam existir outros aspectos da performatividade da luz, brechas, hipóteses em aberto e investigações ainda por fazer a respeito do mesmo conceito. Algumas delas podem ser capazes de confirmar e outras de contestar o que foi apresentado até aqui, cujo enfoque principal foi dado ao seu aspecto fenomenológico e material. Sem esgotar o assunto nem preencher todas as lacunas, este estudo deixa espaço para outras proposições sobre a performatividade da luz, surgidas ao longo da pesquisa e que ficam em aberto para eventuais e prováveis investigações futuras:

- A luz performativa como elemento fundamentalmente vinculado, quando não constituinte, ela mesma, de uma performance ou de um ato performativo independente;

- A presença e a atuação de um possível performer da luz, na figura do iluminador (lighting designer, créateur lumière), pela luz concebida, ou do operador de luz, pela luz executada (operada, performada);

- O tempo, o ritmo e o movimento como ação fundante da performatividade da luz na cena;

- A performatividade da cor;

- A comprovação da experiência do espectador face à recepção da luz performativa e de sua atuação sobre ele;

- A performatividade do blecaute, que, talvez, ainda mais do que a própria luz, interfere, interage e atua sobre a percepção do observador. 


\subsubsection{A luz como performance}

Um dos primeiros aspectos levantado na pesquisa, até mesmo antes de definir o foco que ela teria, foi relativo à relação de dependência entre a luz performativa e a performance ou o espetáculo performativo, propriamente dito. Foi um longo percurso de indagações e questionamentos, além do esforço para enquadrar o conceito de performatividade da luz ao do teatro performativo, visto que, na sua grande maioria, a identificação da atuação performativa da luz era verificada, também, em espetáculos e acontecimentos não necessariamente performativos, como ficava evidente em exemplos e casos de criações de luz analisadas ao longo da pesquisa, muitas delas de autoria própria.

Finalmente, a pesquisa se encaminhou para o estudo da luz-matéria e da materialidade poética da luz em sua ação sobre a percepção do espectador ativo no ato da recepção. Esse caminho descartou a necessidade da análise da luz específica do teatro performativo, mesmo que alguns dos estudos de caso realizados tenham se concentrado em exemplos desta natureza, como os espetáculos do Teatro Oficina e do Teatro da Vertigem. No entanto, o fato de desvincular os dois conceitos não excluiu a possibilidade de que, nestes casos, ela possa ter uma configuração ou comportamento específicos e determinados. Uma outra opção é que essa vertente da luz performativa possa ser analisada não só como efeito sobre o espectador, mas também, ela mesma, como performance. Alguns exemplos de instalação ou criação plástica de artistas como Alessandra Domingues ou James Turrell permitem vislumbrar a forma como a luz, desde que destituída de funções práticas e semânticas como instrumento de visibilidade e linguagem ou efeito material sobre a cena e o espectador, possa constituir ou se configurar como objeto estético independente e autônomo, como obra de arte não necessariamente teatral.

Como exemplo dessa possível plasticidade da luz, cito três experiências pessoais, a primeira em 2012/2013, a segunda em 2015 e a terceira em 2018. Mas duas primeiras, um projeto de iluminação cênica se tornou instalação artística, transformando a luz teatral performativa em performance (LUCIANI, 
2013), e na terceira, foi realizada uma instalação cuja luz, especialmente criada para tal, dialogava com a temática e proposição da obra. No primeiro caso, a luz do espetáculo Disparis, montado em Curitiba em 2010, foi selecionado para participar da exposição internacional WSD2013 em Cardiff, no Reino Unido ${ }^{195}$, cuja instalação foi elaborada e apresentada antes, em 2012, na mostra Performeios, em Curitiba. Para estas exposições, foi criada

\begin{abstract}
uma instalação na qual a interação e a interferência do público espectador da encenação original foi substituída, de forma amplificada, pela interação real proporcionada ao visitante da exposição. A instalação foi concebida a partir da criação de um filme com a montagem de cenas representativas da iluminação da peça que seria projetado em uma persiana suspensa. Ao atravessar essa persiana, a imagem projetada era entrecortada pela sombra da persiana, tornando-se mais ou menos nítida pelo posicionamento da pás que, conforme o grau de abertura, permitiam maior ou menor visibilidade das cenas que, por sua vez, também podiam estar filtradas pela persiana da peça real ou não e apresentavam maior ou menor grau de ação, dramaticidade ou erotismo (LUCIANI, 2013).
\end{abstract}

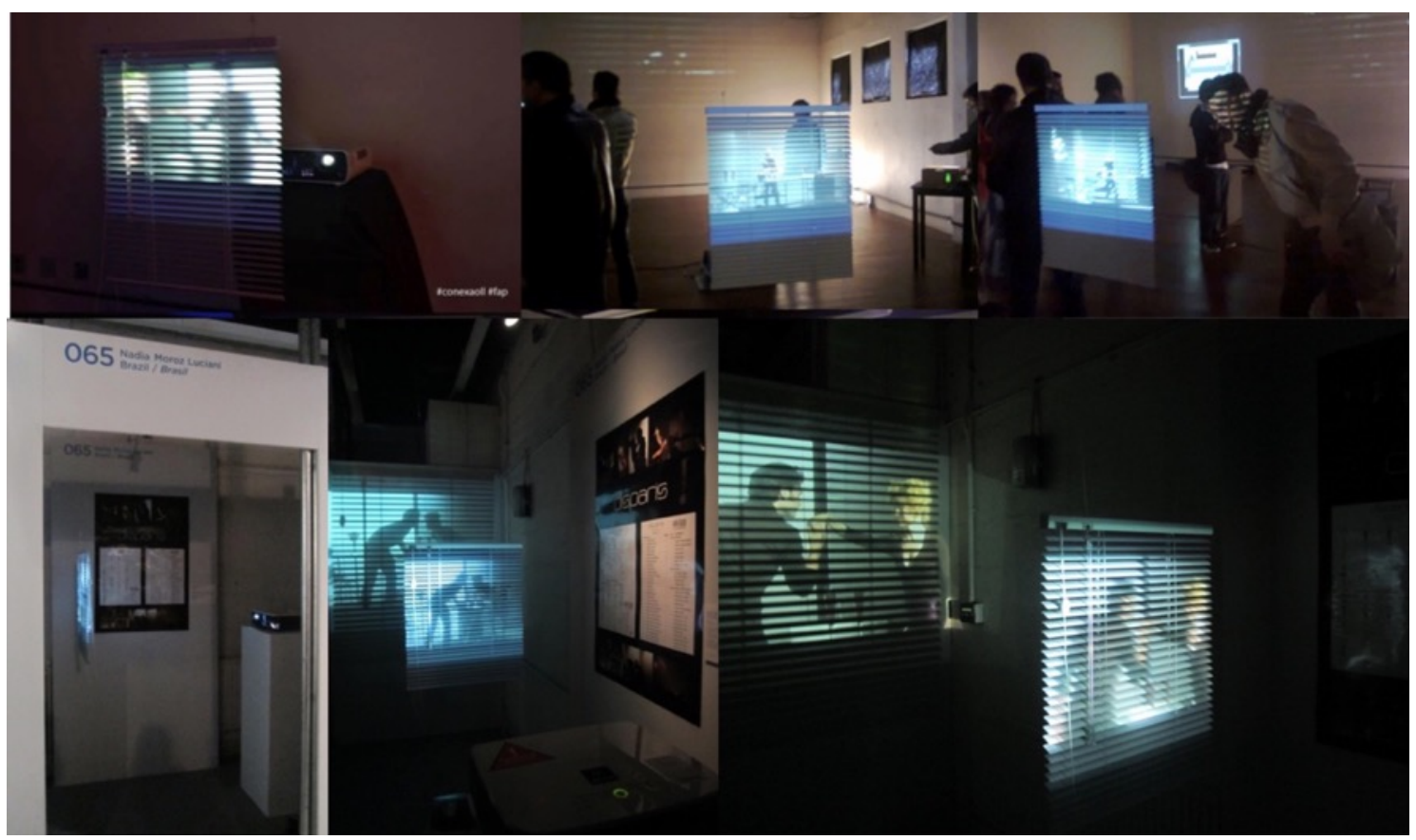

Figura 50 - Instalação da Exposição Multimeios, realizada na UNESPAR-FAP em Curitiba em 2012 e montagem feita no WSD2009 em Cardiff - UK em 2013. Fotos Nadia Luciani.

A interação do visitante da exposição com a projeção ocorria desde sua ação direta sobre a abertura da persiana e o ajuste do foco da imagem projetada até a interposição de sua própria imagem à frente da projeção, interferindo ou obstruindo-a completamente. Essas ações repetiam parcialmente a experiência

195 Disponível em http://www.wsd2013.com/nadia-moroz-luciani/ , visitado em janeiro de 2020. 
do espectador da peça original como voyeur, e abriam novas possibilidades de atuação de uma luz, originalmente cênica, tornada performance.

A segunda experiência se deu quando da seleção da luz do espetáculo $O$ Inoportuno, criada em 2013, para participar da Mostra Nacional Brasileira da Quadrienal de Praga de 2015 196 . A proposta, feita pelo curador geral da mostra, o artista plástico carioca Ronald Teixeira, para 30 artistas brasileiros, entre iluminadores, cenógrafos, sonoplastas e figurinistas, era a de representar o projeto de criação selecionado dentro de uma esfera metálica de $30 \mathrm{~cm}$ de diâmetro.

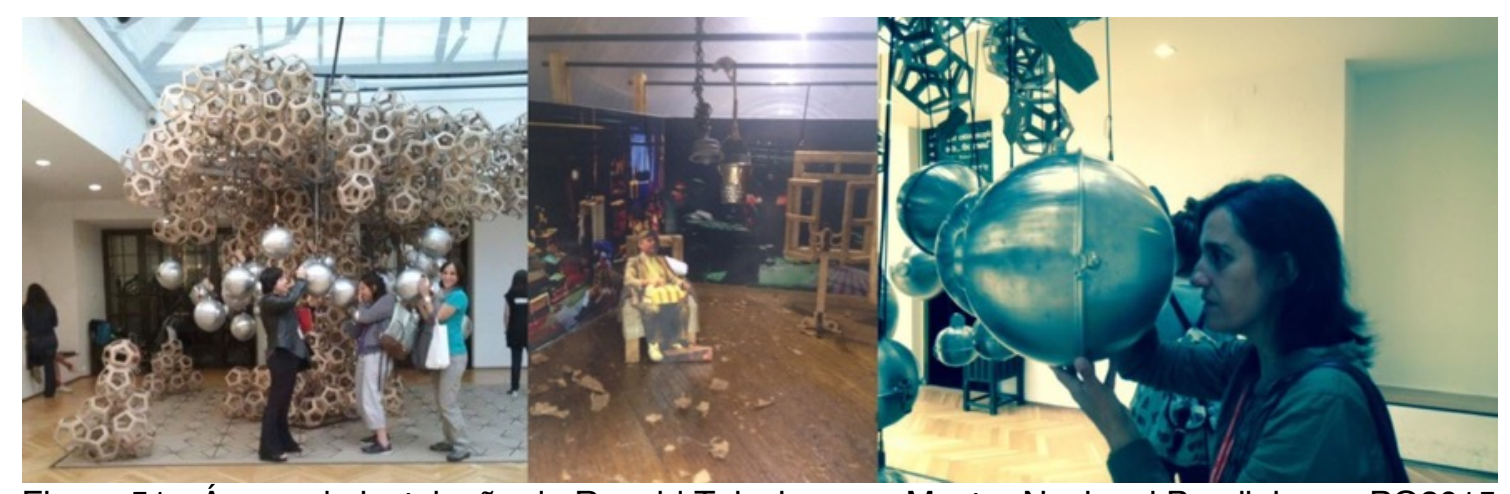

Figura 51 - Árvore da instalação de Ronald Teixeira para Mostra Nacional Brasileira na PQ2015 - interior e exterior da esfera. Fotos Claudia de Bem.

O desafio se tornou, então, imaginar uma forma de representar, gráfica e artisticamente, num espaço tridimensional limitado, um projeto de criação em iluminação. Com o uso de pequenas lâmpadas de LED para representar o conceito de luz quente e fria usado na peça, foi criado um mini cenário com imagens do espetáculo e a variação da luz emitida por cópias, em miniatura, dos dois lustres, feitos com sucata, especialmente criados para a peça. O resultado não foi exatamente performativo ou performático, apesar da exposição trazer algumas dessas características, mas a experiência de revisitar a concepção de uma luz bastante interativa permitiu uma análise mais profunda de sua atuação e relação com o observador no espetáculo e na exposição.

A exposição Intersecção foi realizada a partir de uma residência artística como parte da programação do MiTSP 2018 Festival entre 28 de fevereiro e 09

196 Disponível em https://pqbrasil.org/2015, visitado em janeiro de 2020. 
de março de 2018 no Memorial da Resistência em São Paulo. A equipe do trabalho era formada por artistas de diferentes áreas, principalmente cenógrafos e artistas plásticos. Um sonoplasta e eu complementamos o grupo de cenógrafos na criação, cuja intervenção luminosa e sonora sobre a peça principal da obra escultural acontecia ao vivo como uma performance. A mostra realizada em São Paulo foi exposta como representação brasileira na Mostra de Países e Regiões da Quadrienal de Praga - PQ2019.

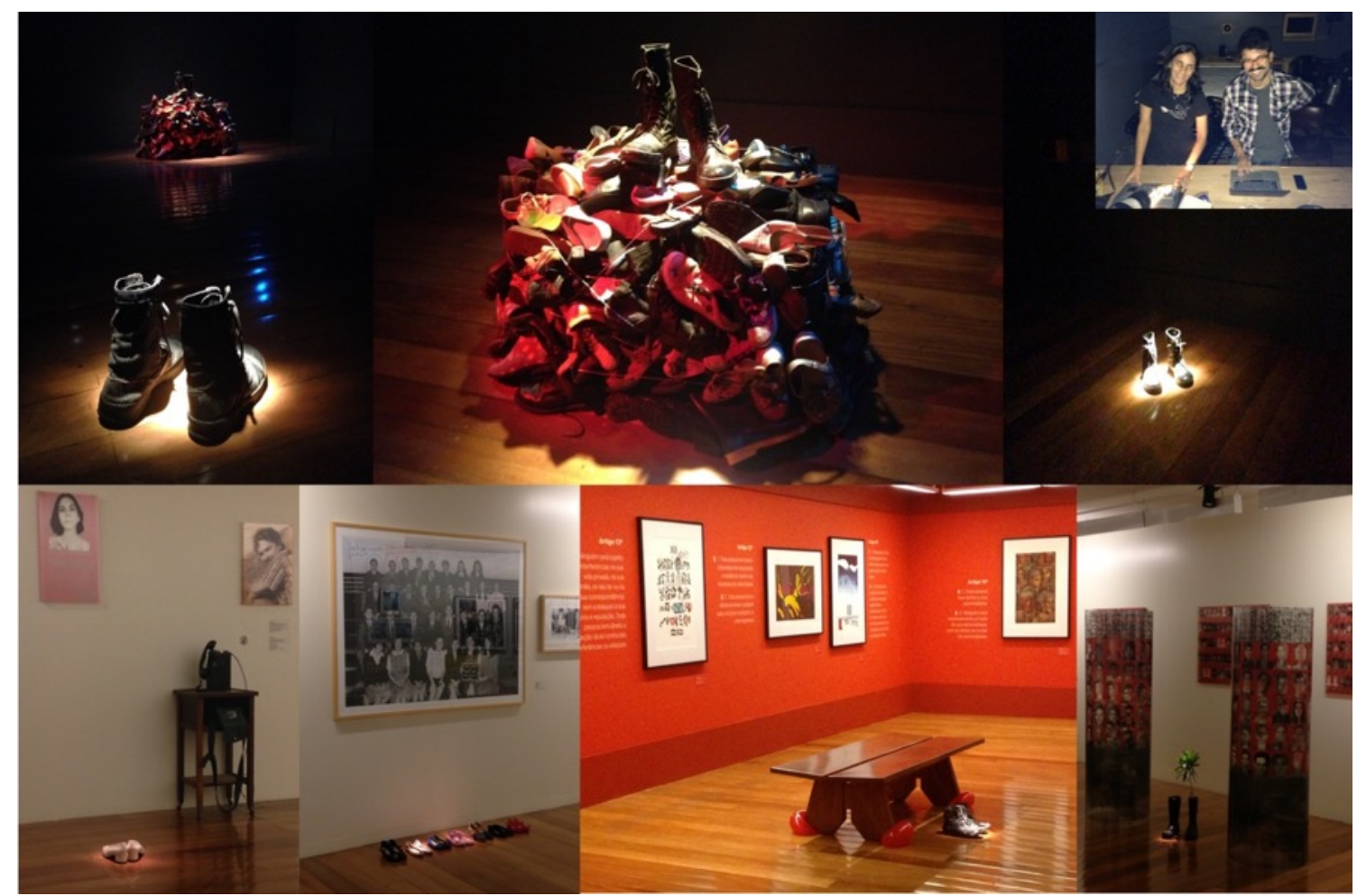

Figura 52 - Intersecções 2018 - Instalação, performance luminosa e sonora e intervenções na exposição permanente do Memorial da Resistência em São Paulo - MITsp2018. No alto à direita a cabine de luz e som improvisada para a performance. Fotos Nadia Luciani.

Alguns profissionais e designer cênicos relatam a forte relação existente entre cenografia, iluminação e artes plásticas, sendo que, como resultado desta forte intersecção, cenógrafos atuam também como iluminadores, a exemplo do tcheco Josef Svoboda (RICHIER, 2019, p. 384) e iluminadoras tornam-se também cenógrafas, como foi o caso de Marisa Bentivegna (anexos, p. 161). Em outros casos ainda, artistas com formação em artes visuais se deixam cativar pela luz do teatro, como Alessandra Domingues ${ }^{197}$, que diz realizar um trabalho de iluminadora no qual "posso dizer que exerço mais o meu lado artista plástica,

197 Em entrevista realizada como parte desta pesquisa, disponível nos anexos, p. 28-36. 
quando eu realmente uso as fontes de luz enquanto matéria, enquanto objeto escultural, como uma instalação... ou mesmo a luz para instaurar algo, ou provocar algo a nível da sensação das pessoas" (DOMINGUES, anexos, p. 31) e iluminadoras que se aventuram pelas artes visuais, como a pesquisa de Claudia de Bem ${ }^{198}$ sobre fontes naturais de luz como o sol, o fogo e os reflexos da luz na água ou outros materiais. Há uma linha, originalmente tênue, mas que se esfumaça gradativa e progressivamente, entre as artes cênicas, a performance e as artes visuais. É inegável a ocupação, pela luz performativa, deste interstício entre fronteiras cada vez mais difusas e intangíveis, invadindo todos os campos e avizinhando-se de todas as linguagens.

\subsubsection{A luz concebida e a luz performada - os performers da luz}

A luz concebida considera os parâmetros da criação e da concepção da luz performativa durante o processo colaborativo, com total interação do iluminador com a encenação e as proposições criativas dos demais membros da equipe de criação do espetáculo. A luz performada, por outro lado, considera a ação humana do operador de luz em sintonia com a ação dos demais performers e seus efeitos, em total interação, igualmente, com a cena e as ações previstas dos demais elementos componentes do espetáculo. Esta segunda noção pode considerar, ainda, a manipulação de objetos e equipamentos luminosos em cena, a exemplo da operação de luz às vistas do público ou a utilização de fontes luminosas diretamente operadas ou manuseadas por atores, bonequeiros ou outros performers da cena.

No início da pesquisa, antes de focar na performatividade da própria materialidade da luz, lugar das derradeiras investigações, havia, ainda, a impressão de ser preciso existir um agente performativo, um performer da luz, cuja atuação foi ponderada por dois parâmetros. Primeiro no contexto da criação, como ação performativa de quem concebe a luz, pelo conjunto dialético da

198 Doutoranda do PPGAC-ECA-USP com pesquisa sobre luz e espaço. 
presença/ausência (LEAL, 2018) que consideraria que o criador se faz presente pela obra criada. Em seguida, o segundo parâmetro seria a do operador ou manipulador da luz ou de seus instrumentos luminosos ou de controle da iluminação.

A performatividade da luz poderia ser observada, então, no primeiro caso, no trabalho do iluminador, assim como acontece com o trabalho do ator que, em consonância com a expressividade e dispondo de recursos próprios à sua linguagem, se expressa em cena e cativa um público disponível e atento. Ela está neste modo de fazer, de expressar a vocação das artes performativas, cuja revelação encontra-se na experiência que proporciona e sensações que provoca, para muito além do mostrar ou representar. Se até então, as funções da luz consideradas eram a visibilidade e representação, ela passa a ser, nesse contexto, uma expressão estética e poética desse artista, cuja atuação exprime intenções e ideias a partir de sua arte para favorecer a ação crítica e participativa da luz na concepção e construção da cena.

Nos dois casos, é possível imaginar que a produção de visualidades possa permitir que o iluminador criador da luz ou seu operador se façam presentes em cena por meio da materialidade ótica das projeções luminosas na cena. Considerando a teoria da relatividade de Einstein em uma nova interpretação proposta por Dodi Leal (2018, p. 56), um mesmo corpo ocuparia dois espaços diferentes num mesmo momento, na cabine e no palco, pela presença visual da intenção criativa ou da ação cênica realizada através da operação da luz. Ao executar um movimento na mesa de luz, o agente é colocado em cena, ele se mostra, se expõe ao risco e se expressa por meio da linguagem visual em forma de luz que materializa.

Visto que é seu contexto, sua condição de imprevisibilidade e seu processo marcado pelo princípio da ação que conferem sua existência como ato ficcional de construção da realidade, ela pode se tornar, assim, condição para a performatividade da luz concebida por um criador. A enunciação performativa envolve uma ação real, como a do criador/operador que executa a luz, presencialmente, de maneira visível para o público ou não, mas sempre no ato 
efetivo do "fazer" teatral, sua efemeridade representa a incerteza da realização e revela o valor de risco. Para Derrida, a ação contida na enunciação performativa pode, ou não, ser eficaz, e esta possibilidade do fracasso não constitui um erro, mas um direito, e o risco passa a ser norma desta ação (FÉRAL, 2009, p. 72). Isso poderia conferir à iluminação a possibilidade de um caráter performativo efêmero, atuante, contíguo e imprevisível, susceptível às consequências da própria ação e seu desenrolar cênico.

Josette Féral (2015), entende que o fazer, no teatro performativo, toma a frente do representar e a ação cênica centraliza-se no seu agente, no seu executor, no performer que lança mão dos recursos de que dispõe ou na própria configuração estrutural da cena para inscrever uma performatividade da qual a ação se torna pressuposto fundamental. Desta forma, é plausível pressupor que uma possível performatividade da luz só pudesse ser expressa pela atuação performativa de um agente humano, ou seja, de um operador da luz, por cuja ação se realizaria essa tal performance da luz.

No caso da operação da luz pelo operador ou manipulador da luz, o segundo caso proposto aqui de performer da luz, é possível citar alguns bons exemplos deste tipo de atuação da luz pela ação de um agente humano. Tanto a ação de atores manipulando equipamentos luminosos, como Moa Leal e Sidy Correa no espetáculo Duas Criaturas Gritando no Palco de Manoel Carlos Karam com direção de Gabriel Gorosito (BRUEL, anexos, p. 58-59), quanto a operação de luz em cena, a exemplo do ator Eduardo Moscovis na peça O Livro da diretora Christiane Jatahy (LUCIANI, 2012a, p. 97-98), de Cibele Forjaz como assistente de direção e iluminadora no espetáculo Para dar um Fim no Juízo de Deus, do Teatro Oficina (FORJAZ, anexos, p. 79), ou da iluminadora e atriz Nadja Naira em Suíte 1 da companhia brasileira com direção de Marcio Abreu (LUCIANI, 2012a, p. 95), são todos representativos deste tipo de performatividade da luz ou, talvez, do performer da luz.

Neste último exemplo, a iluminadora Nadja Naira atuava e executava a iluminação do espetáculo simultaneamente no palco, às vistas do público. A intenção da operação de luz aparente, neste caso, ia de encontro à crença da 
companhia de que não é preciso esconder o teatro e seus truques do público para que ele se envolva, participe e se comova com a história contada. Tendo tanto a iluminadora quanto a mesa de luz em cena, ficava explícita a fusão entre ficção e realidade quando Nadja intercalava a atuação, falas e ações de sua personagem com idas até a mesa de luz para executar uma troca de luz, com objetivos poéticos e estéticos precisos de interação com a cena e com o espectador.

Cibele Forjaz ${ }^{199}$ relatou sua experiência, além de assistente de direção de Zé Celso, como criadora e operadora de luz em todos os espetáculos que iluminou no Teatro Oficina, especialmente na peça Para dar um Fim no Juízo de Deus: "eu estava em cena com figurino, tinha falas e operava luz ao mesmo tempo, tinha um foco em mim" (FORJAZ, anexos, p. 79). Esse é um exemplo emblemático, mas não foi diferente em outros espetáculos da companhia, no quais havia, além da Cibele, que operava a mesa de luz, os operadores de pinbeams, pequenos canhões espalhados pelo teatro que iluminavam vezes os atores, vezes o próprio público:

\begin{abstract}
... o fato de que, nos dez anos do Oficina, eu operei, e a operação fazia parte da atuação ao vivo da luz e, muitas vezes, alguns espetáculos me levavam a entrar em cena [...] Em Bacantes, eram sete horas de espetáculo nas quais eu realmente improvisava e sabia o número de cada refletor, cantava junto... Eu estava em cena, e isso me permitia um tipo de atuação ao vivo que a peça me pedia. Ham-Let, ao contrário, embora a luz fosse muito simples e o teatro ainda não estivesse acabado, nós improvisamos [...] o roteiro, principalmente os pin-beams, e a relação entre geral e contra, focos muito precisos... Nós tínhamos um roteiro de cinquenta páginas, de quatro fileiras. Toda a movimentação de focos era muito precisa, enquanto outras eram improvisadas, mas sempre pensando sobre a presença da luz e da plateia, que estava sempre em contracenação profunda com os atores, junto com eles. Uma luz ativa e atuante" (FORJAZ, anexos, p. 78).
\end{abstract}

Na peça O Livro, cuja criação da luz ficou ao encargo do iluminador Paulo Cesar Medeiros, a relação entre ficção e realidade se dava pela interação simultânea da luz com a dramaturgia do espetáculo, com o público e com o intérprete, Eduardo Moscovis, cujo personagem narrava sua própria história à medida em que perdia gradativamente a visão e, operando uma mesa de luz

199 Em entrevista realizada como parte desta pesquisa, disponível nos anexos, p. 75-83. 
instalada no palco, às vistas do público, diminua a intensidade da luz no palco até o blecaute, privando também os espectadores da visibilidade da cena. $A$ performatividade da luz, neste caso, pode ser observada na "execução da luz às vistas do público, que poderia perceber com isso o controle do ator/narrador sobre o acender ou apagar das luzes, ou seja, a possibilidade de clarear ou escurecer a cena, ampliando ou diminuindo voluntariamente sua capacidade de ver e exercendo a opção entre enxergar ou não (LUCIANI, 2012a, p. 98).

Finalmente, o primeiro exemplo citado demonstra a maneira como os intérpretes podem apropriar-se performativamente, em cena, de instrumentos luminosos, criando uma relação direta com a linguagem poética da luz. Essa situação é muito comum no teatro de formas animadas, com a manipulação de objetos, luminosos ou não, confrontados com luz, sombra ou projeções. No caso da luz desta peça, no entanto, mesmo sendo originalmente operada por um operador de luz externo à cena, as luminárias começaram a ser exploradas, nos ensaios, pelos dois atores que perceberam a potencialidade daquele recurso como elemento de interação cênica entre eles. Beto Bruel200 explica que a motivação original do efeito foi financeira, pois não havia verba para realizar a luz do espetáculo. Foram criadas, inicialmente, quatro refletores de chão (PAR 38) fixos, cuja luz, passando através do tampo de vidro da mesa, elemento único que constituía o cenário, iluminaria os dois atores, cada um posicionado em uma das duas suas extremidades.

Mais tarde, duas dessas luzes foram trazidas para cima e, pelo fato das PAR 38 esquentarem muito e queimarem os atores, foram substituídas por luminárias de mesa com LED e tornadas móveis, passando a ser usadas por eles para iluminar um ao outro. Seus fachos eram projetados de diferentes ângulos, criando uma maneira dinâmica de interação, ao ponto de, num determinado momento, permitir uma batalha entre os personagens por meio dos fachos de luz direcionados por eles contra o outro, como espadas. Bruel sentiu necessidade de um terceiro equipamento e foi instalada uma luminária pendente (do tipo usado para iluminar mesas de sinuca), localizada em cima da mesa, ao

200 Em entrevista realizada como parte desta pesquisa, disponível nos anexos, p. 48-59. 
alcance e igualmente explorada pelos atores. Finalmente, o acender e apagar das três fontes luminosas passaram a ser realizados também por eles, que iluminavam, com as três luminárias, tanto um ao outro quanto a si mesmos. Segundo Beto, "ficou uma coisa muito simples, e ao mesmo tempo funcionou bem, tanto é que acabou sendo indicado até para o prêmio, [...] foi uma situação criada por necessidade e acabou ficando uma coisa muito interessante" (BRUEL, anexos, p. 54).

Mais especificamente relacionada à atuação do operador, que também pode ser chamado de performer da luz como aquele que, de uma certa forma, performa, atua e executa, colocando e instituindo a luz, como ação, em cena. A atuação do iluminador como operador de luz em espetáculos de improviso, considerando sua capacidade para acompanhar a cena é analisada por Marisa Bentivegna (2012) como uma potente possibilidade de expressão e atuação da luz na cena. Esse tipo de participação, que ela chama de operação "aberta" é...

\begin{abstract}
... aquela em que não existe um roteiro pré-determinado de cenas, com deixas definidas de acordo com o texto ou com a movimentação de intérpretes. É uma utilização de efeitos de iluminação acontecendo em tempo real. Com a tomada de decisão de qual luz, movimento de luz ou tempo de fusão é o mais adequado para aquele momento. É essencialmente um exercício de escuta entre operador e intérprete. $\mathrm{E}$ diferentemente do que se pode imaginar, não é um trabalho no qual o operador/criador segue os intérpretes em seu livre uso do espaço. $O$ operador/criador é proponente também, seja no posicionamento de uma cena no espaço, seja editando as imagens, seja provocando um ritmo ou mesmo definindo com a luz o final do espetáculo" (BENTIVEGNA, 2012, p. 40).
\end{abstract}

Ao executar a luz, esse performer integra-se à ação cênica, dramática ou performática, segundo um plano possivelmente, mas não necessariamente, préestabelecido, porém totalmente suscetível às ações simultâneas e dinâmicas dos demais performers e do público. A relação estabelecida entre o performer da luz e os demais performers em cena, sejam atores, bailarinos, músicos ou artistas de qualquer natureza, envolvidos com o espetáculo, pode se dar tanto na atividade criadora, durante os ensaios, quanto nas apresentações do espetáculo, diante do público espectador. Nesses casos, situações de risco, tensão, exposição, improviso e envolvimento entre a luz e os demais agentes cênicos são realidades que se apresentam como forma de atuação e interação 
performativa com a cena. A estudante Kaoana Cruz (2019) relatou, na pesquisa teórica sobre criação de luz ${ }^{201}$, a sua experiência como atriz e iluminadora do espetáculo Pétalo Vojo, montagem realizada com colegas do curso na universidade, do qual participava como atriz e para o qual criou a iluminação. $\mathrm{Na}$ estreia do espetáculo, acontecerem diversos problemas técnicos que abalaram sua atuação: "Eu me surpreendi diversas vezes, no palco, pensando em quantos segundos faltavam para a próxima mudança de luz, se ela iria entrar no momento certo, se todos os refletores funcionariam corretamente, entre outros pensamentos sobre a luz". Este fato, além de fazê-la rever a opção de acumular as duas funções, fez avaliar também a forma como "estar no palco, mais do que atrapalhar o trabalho de iluminadora, me proporcionou um outro ponto de vista e ideias a partir das quais eu pude conduzir a criação da luz". Considerando a situação, no geral, como uma "condição impar e privilegiada de estar em dois lugares ao mesmo tempo" (CRUZ, 2019, p. 48-51), ela percebeu a relação intrínseca entre a cena e a luz, tanto num papel quanto no outro.

Numa outra perspectiva, Miriam Rinaldi destaca como, do ponto de vista do ator, um risco real imposto pelo espaço ou outro fator, como o risco de um acidente físico, por exemplo, pode impor aos performers e à plateia a vivência de uma experiência radical. Num relato da atriz Luciana Schwinden à pesquisadora, ela expos como a tensão e o medo provocados por um risco real ao qual o ator Joelson Medeiros se expunha numa cena de Apocalipse 1,11 interferiam em sua atuação, dando à sua personagem uma emoção favorável à atmosfera e intenções propostas pelo espetáculo (RINALDI, 2018, p. 39), o que certamente afetava, igualmente, a percepção do público.

Uma iluminação performativa apresenta, como característica essencial, em qualquer um de seus aspectos ou formas de atuação, a intenção de tornar real o que seria antes ficcional, gerar consciência ao realizar e compartilhar a ação cênica, dando a perceber a realidade do que é performado. Mostaço (2009, 
p. 42-44) cita a busca da desnaturalização da representação ou da intenção de provocar algum tipo de conscientização ou arregimentação através de atos performáticos. A operação ou manipulação dos recursos de iluminação de maneira visível ao público é uma forma de alcançar este tipo de resultado, pois permite o distanciamento e o estranhamento que denotam esta consciência do fazer teatral ao expor a presença do agente que a executa e a imprevisibilidade e o risco inerentes à esta ação. Ao operar a mesa de luz ou manipular uma fonte luminosa em cena, essa atuação torna-se concreta e real, desnudando o truque e demonstrando a face real da cena como situação real, presencial e intencional. O público adquire, forçosamente, consciência da existência deste manipulador e não resta indícios de naturalidade ou de previsibilidade, fazendo com que o aqui/agora da cena transpasse o nível ficcional no sentido do real.

Por outro lado, a performatividade da luz também pode estar ligada ao virtuosismo da operação da luz em completa "sincronia com a marcação das cenas, as intenções dramáticas, a sonoplastia e a movimentação e gestos dos atores, garantindo o envolvimento e a implicação do espectador nos acontecimentos cênicos (LUCIANI, 2013, p. 3). A interação com a cena, sua imprevisibilidade, a maneira de atingir, dispor, e transformar a cena, bem como afetar e sensibilizar o espectador durante a atuação podem ser indícios de uma luz que pode prescindir da presença física do operador em cena, mas não da sua atuação performativa em tempo real, interferindo no espaço ficcional da cena e na expressão poética dos recursos visuais propostos por um tipo de iluminação igualmente performativa.

\subsubsection{A luz, o tempo, o ritmo e o movimento}

Para Svoboda, "a luz permite dar certo ritmo ao espaço"202 (RICHIER, anexo 1, p. 2), tornando o espaço da representação um ambiente rítmico que só é possível pelo movimento, por sua ação no tempo com duração e intensidade

202 « La lumière permet de donner un certain rythme à l'espace » (tradução da autora). 
determinadas. O movimento da luz revelou-se, com o advento da luz elétrica no teatro, um dos seus aspectos mais expressivos, associado, segundo o conceito investigado de performatividade da luz, à atuação do operador e à precisão necessária, na interação entre luz e cena, para afetar a percepção do espectador. Segundo Dominique Bruguière, a iluminação cênica cria o tempo, inventa as durações e instaura um ritmo no centro de uma narrativa. Segundo ela, "um efeito luminoso tem um começo e um fim, sua aparição no palco se faz através de uma temporalidade que pode ir de zero segundo a um tipo de infinito que será a duração da representação. Da mesma forma, o seu desaparecimento pode ser brusco, "seco", ou atuar, ao contrário, na lentidão"203 (BRUGUIÈRE, 2017 , p. 107-108). Isso tudo significa que há movimento, e que esse movimento interfere no ritmo e no tempo de duração da cena e do espetáculo. Este conjunto de luz, ritmo, tempo e movimento gerado no palco provoca e promove efeitos subjetivos na percepção do espectador pelo que dão a ver e, justamente, pela maneira como dão a ver. Christine Richier (2015) fala da importância do tempo e do ritmo na percepção geral do visual cênico:

... essa questão do ritmo, de uma escritura no tempo, coloca para a luz a questão de saber se ela se dará a ver (passagem brusca de um sentido ou uma cor a outra), ou se ela se desenvolverá sem que o espectador perceba. O movimento da luz não tem necessidade de ser levado a um nível de consciência para agir com potência204 (RICHIER, 2015, p. 96).

O movimento é, talvez, uma das propriedades mais importantes e mais negligenciadas da luz, pois, assim como a cor, é um de seus aspectos mais especialmente expressivos, sendo, muito possivelmente, o que mais revela as suas potencialidades performativas. Mais importante do que a luz que acende

\footnotetext{
203 "Un effet lumineux a un début et une fin, son apparition sur scène se fait à travers une temporalité qui peut aller de zéro seconde à une sorte d'infini qui serait celui de la durée de la représentation. De même, la disparition de l'effet peut être brutale, 'sèche', ou jouer au contraire de la lenteur » (tradução da autora).

204 «Cette question du rythme, d'une écriture dans le temps, pose à la lumière la question de savoir si elle se donnera à voir (passage brutal d'une direction ou d'une couleur à une autre), ou si elle déroulera son fil à l'insu du spectateur. Le mouvement de la lumière n'a pas besoin d'être hissé à un niveau de conscience pour agir puissamment » (tradução da autora).
} 
ou apaga em um projeto é a maneira como isso é feito. A lluminadora Nadja

Naira205, relatou a importância do movimento no seu processo criativo:

\begin{abstract}
Eu sempre penso assim: eu tenho que construir para mim mesma e para o espaço, uma cartelinha de pincéis. [...] Então, o que eu faço, quando vou ao teatro, é montar uma contraluz, lateral, pino, frente... Eu tento iluminar o espaço primeiro e depois eu penso como eu vou compor com esses pincéis. Então, o que eu tenho são pincéis mais fortes, pincéis mais fracos, mais estreitinhos, mais potentes, alguns mais coloridos. Eu penso sempre assim: vou me dar opções e depois fazer as opções trabalharem para mim, porque eu acho que o que constitui a luz é o movimento e não o desenho dela. Vai gerar desenho, claro, mas não é o desenho. Não é o efeito, apesar de gerar efeito. Para mim, o mais importante é o movimento entre um desenho e outro, entre uma situação e outra (NAIRA, anexos, p. 169).
\end{abstract}

O diretor de fotografia italiano Pasquale Mari206 reafirmou, com base em sua experiência cinematográfica, que "a luz é o movimento contínuo da visibilidade de corpos e objetos no espaço que nossos olhos espectadores interceptam" (MARI, anexos, p. 180). Já para o iluminador francês Christophe Forey ${ }^{207}$, a luz no teatro participa do ritmo, da passagem do tempo, e é somente pelo movimento que ela o faz. Segundo ele,

\begin{abstract}
Uma das grandes diferenças entre a luz no cinema e no teatro é que, no cinema, ela atua apenas na imagem, de uma maneira muito, muito importante, mas não age com o tempo, porque é a edição no cinema que faz o tempo. Assim, no teatro, na coreografia, a montagem do cinema é substituída pela operação da luz e pelo ritmo dos efeitos, o tempo. Se um efeito dura três minutos até acender uma luz, não é nem de longe o mesmo que se houver cinquenta efeitos que durem três segundos cada, é claro. Porque, de repente, isso cria uma edição fracionada, acelera as coisas, como se pode ver em um musical, onde tem vários efeitos por minuto e, de repente, a luz segue cada movimento da sobrancelha do ator. Em um teatro mais diferente, que eu faço com mais frequência, o tempo da luz vai ser longo, enquanto que a atuação do ator vai ser rápida e, então, essa atuação lenta é valorizada porque a luz é longa, como na música, pelo contraste (FOREY, anexos, p. 65-66).
\end{abstract}

Segundo Arnheim, "o movimento é a atração visual mais intensa da atenção" (ARNHEIM, 2012, p. 365), sendo impossível evitar que os olhos se voltem para o local de início de um movimento qualquer e o acompanhem por todo o seu curso, em uma resposta tão intensa quanto automática. O autor ainda

\footnotetext{
205 Em entrevista realizada como parte desta pesquisa, disponível nos anexos, p. 164-178.

206 Em entrevista realizada como parte desta pesquisa, disponível nos anexos, p. 179-180.

${ }^{207} \mathrm{Em}$ entrevista realizada como parte desta pesquisa, disponível nos anexos, p. 61-68.
} 
discorre sobre duas de suas principais características, a sequencia e simultaneidade, ambas de extrema relevância na análise do movimento da luz no teatro. Uma sequência de efeitos de luz determina o ritmo e a intensidade com que o espetáculo poderá afetar o público, de maneira mais ou menos eficaz de acordo com a simultaneidade entre os diferentes estímulos propostos e provocados no espectador. A distinção, na cena, entre as coisas imóveis e a luz, que as transforma e movimenta, evidencia o potencial performativo da luz. Apesar da importância e relevância do movimento para a performatividade da luz no teatro, este aspecto não foi suficientemente contemplado nesta pesquisa, merecendo uma análise futura mais aprofundada dos seus efeitos, resultados e potencialidades.

\title{
3.3.4 A performatividade da cor
}

Max Keller (2010), um dos mais influentes iluminadores da atualidade e um estudioso entusiasta do uso da cor na iluminação cênica, cujas reflexões podem ser apreciadas no vídeo A Journey into Light ${ }^{208}$, escreveu, a respeito da relação entre luz e cor:

\begin{abstract}
Luz e cor sempre apresentaram um desafio para pesquisadores e pintores. No renascimento, o arquiteto e teórico Leon Battista Alberti e Leonardo da Vinci, como pintor e multiartista, realizaram experiências com misturas de cores particularmente em suas pinturas. Leonardo da Vinci não apenas se interessava pela luz, como a investigava intensamente em relação com a sombra e a reflexão da luz, especialmente do ponto de vista de um pintor. Ele foi o primeiro a descrever o fenômeno das sombras coloridas e escreveu sobre suas descobertas na relação entre o tamanho da sombra projetada por objetos iluminados e a sua distância da fonte luminosa - e todo o contexto da perspectiva da cor, da luz e da escuridão. Luz e sombra não eram, então, consideradas como elementos isolados - inclusive considerando $o$ efeito que tinham sobre 0 olho humano e a pupila209 (KELLER, 2010, p. 17).
\end{abstract}

208 DVD disponível para compra pelo site http://maxkeller.net/reise-ins-licht-dvd.html

209 « Light and colour have always presented a challenge to researchers and painters. In the Renaissance, the architect and theoretician Leon Battista Alberti (1404 - 1372 [sic]) and Leonardo da Vinci $(1452$ - 1519), as a painter and all-round artist, experimented with mixing colours in particular and in their painting. Leonardo da Vinci not only interested in light, but examined light intensively in connection with shadow and related light reflections, especially from a painter's point of view. He was the first to describe the phenomenon of coloured shadows and 
O aspecto da cor foi, certamente, o mais negligenciado em toda a investigação a respeito da luz, não porque não seja importante ou porque eu não Ihe dê a devida importância, muito pelo contrário. A cor é um dos atributos mais relevantes no meu trabalho como iluminadora, considerando ainda eu já ter sido professora de Teoria e Prática da Cor no curso de Comunicação Visual da UFPR e ser, ainda hoje, uma aficionada pelo estudo dos sistemas cromáticos e pela psicologia das cores em seu uso no design gráfico e cênico. No entanto, por questões práticas de definição de tema e foco de estudo, esta pesquisa doutoral se concentrou, principalmente, no fenômeno luminoso e sua relação perceptiva com o espectador, sem dedicar-se ou ater-se ao importante aspecto da cor.

Como exemplo do potencial performativo da cor, o iluminador Renato Machado210 relata o que considerou com uma experiência performativa com luz e cor no espetáculo Deve haver algum sentido em mim que baste, da companhia de teatro Autônomo, que:

... propunha uma interação que interfere diretamente na percepção do
espectador. [...] A ideia da luz dessa peça é que não houvesse
nenhuma fonte de luz de dentro do espaço. As luzes viriam de fora e
dentro, os atores iriam compartilhar o espaço com sessenta
espectadores. A ideia era conseguir transformar esse lugar num
espaço completamente cromático, podia virar um espaço azul,
vermelho, verde... [...] Então você, de repente, estava em um espaço
completamente vermelho, ou completamente verde, ou azul.
Acreditávamos que essa percepção cromática alterava a maneira
como aquele espectador via a cena... a sensorialidade cromática era
uma ferramenta muito poderosa, porque ela previa que nós íamos
atingir diretamente o sensível do espectador e, a partir disso, mudar a
maneira como ele ia apreender o que estava vendo (MACHADO,
anexos, p. 193).

Existem diferentes teorias das cores, das mais científicas, como demonstram as hipóteses e experiências de Newton a respeito da decomposição das luz branca nas cores do espectro, às mais artísticas, como as proposições contrárias de Goethe, para quem a cor nada mais é do que um estímulo sensorial, ou fisiológicas, como a teoria de Young e Helmholtz, que afirmam que

wrote his findings on the relation of the size of shadows cast by illuminated objects to their distance from the source of light - and all within the context of the perspective of colour and light and dark. Light and shade were, therefore, not considered as isolated elements - even the effect they had on the human eye, the pupil, was analysed. » (tradução da autora)

210 Em entrevista realizada como parte desta pesquisa, disponível nos anexos, p. 184-195. 
a cor só se realiza, efetivamente, quando chega no cérebro do observador, depois de passar por seu sistema ótico. Seja qual for a teoria adotada, das cores existentes às inexistentes (PEDROSA, 1989), com seus contrastes, harmonias, simbologias, sensações e efeitos sobre o olho, a mente e a subjetividade humanas, o mais relevante a ser considerado, numa investigação futura, é seu potencial cênico e performativo sobre a percepção do espectador teatral. Em diferentes matizes, cromas ou temperaturas de cor, a cor influencia fortemente a percepção do público e altera, assim como a luz, ou até de forma ainda mais intensa e subconsciente, tudo o que lhe é dado a perceber.

A busca da cor ideal para um efeito, cena ou espetáculo é preocupação recorrente no processo de criação de diversos iluminadores, como relatado por Aurélio, "porque eu entendi, num dia que eu olhei para uma lâmpada mista num poste e vi que a temperatura de cor era semelhante à temperatura de cor da superfície lunar da lua cheia" (DE SIMONI, anexos, p. 44), por Guilherme, que mesmo admitindo não ter profundos conhecimentos teóricos a respeito, contou que "No Filho teve todo um processo de descoberta do uso da cor [...] Partimos da relação quente e fria para criar situações com contraste e, pela negação de âmbar e azul, fomos para sódio e bluegreen, que [...] juntas formavam um branco um pouco sujo e sombras coloridas" (BONFANTI, anexos, p. 132) ou ainda quando Marisa relaciona as cores e a percepção das crianças nos espetáculos infantis: "Eu gosto muito de trabalhar com cor e tenho muita facilidade com mistura de cores. Eu sempre saí dessa palheta básica de gelatinas, busquei cores diferentes e eu fico completamente livre, nesse sentido, para misturar gelatinas no universo infantil” (BENTIVEGNA, anexos, 155).

Apesar da luz e da cor serem fenômenos inseparáveis e de terem efeitos tão relevantes, tanto uma quanto a outra, sobre a percepção, seu estudo não foi realizado, a um só tempo, nesta pesquisa. Por permitirem abordagens distintas de investigação, foi dado, aqui, um enfoque mais específico ao fenômeno da luz em detrimento ao da cor. Apesar do interesse e relevância de tantas indagações e aspectos ainda sem resposta, a presente pesquisa abdicou de investigá-las individualmente para se concentrar em outros caminhos, seguindo os rastros e 
as possibilidades que se apresentavam como mais coerentes para 0 desenvolvimento de uma única linha investigativa. A luz-matéria performativa, que apesar de trazer em si todos estes diferentes aspectos, foi abordada de forma mais objetiva para que fosse possível chegar aos conceitos apresentados, mas sem, no entanto, descartar nenhum deles ou afirmar que não fossem caminhos interessantes passíveis de uma investigação mais aprofundada.

\subsubsection{A comprovação da experiência do espectador}

Essa hipótese foi levantada a partir da realização da disciplina sobre a experiência do espectador, ministrada pelo professor Leonel Carneiro (2016), na ECA durante o doutorado. O pesquisador apresentou, tanto em sua própria pesquisa doutoral quando na condução da disciplina, a entrevista como ferramenta estratégica para avaliar e analisar a experiência do espectador com o teatro, o que parece bastante pertinente, mas que eu tive dificuldade em transportar para o universo da luz. A maioria dos iluminadores, dos mais conceituados, como Jean Rosenthal (1972), que afirmou que a melhor luz é aquela que não é vista nem notada (ROSENTHAL, 1972, p. 3), aos mais jovens, como Elsa Revol211, que declarou, a respeito de sua luz, "eu penso que, de uma maneira muito direta, eu gosto que a luz que eu faço não seja vista" (REVOL, anexos, p. 96), optam por que sua luz não seja percebida racionalmente pelo público, o que se revela como um obstáculo para a avaliação dos seus efeitos sobre o espectador por meio de entrevistas.

Seria um contrassenso solicitar a um espectador que relate, após ter visto um espetáculo, que determinada sensação ou sentimento que possa ter tido em relação a uma determinada cena, seja resultado de sua percepção da luz. Parece ser consenso entre iluminadores que o sucesso de uma projeto de iluminação deva estar mais pautado, justamente, no fato de seus efeitos não serem percebidos racionalmente pelo público, mas que a luz colabore, contribua

211 Em entrevista realizada como parte desta pesquisa, disponível nos anexos, p. 92-108. 
e participe da percepção geral do espetáculo, de preferência sem ser notada isoladamente, como elemento atrativo ou preponderante sobre a cena e a percepção do espectador. De modo que este ainda é um tema em aberto, suscetível de ter sua forma ou estratégia de análise e avalição ainda por descobrir e aplicar.

\subsubsection{A performatividade do blecaute}

O vislumbre e o interesse em estudar performatividade do blecaute, definido como "na cena, escuridão esteticamente deliberada, definida pela retirada de toda luz artificial" (TUDELLA, 2017, p. 79) de um ambiente blindado à luz natural, surgiu a partir do contato com a professora e pesquisadora Véronique Perruchon (2016), autora de uma pesquisa inteiramente voltada ao blecaute em uma trajetória histórica e estética. $\mathrm{O}$ contato com a Véronique e seus estudos a respeito do blecaute instigaram a curiosidade e a oportunidade para a investigação do potencial performativo do blecaute, a exemplo, mas revelando-se muito mais potente, da potencialidade performativa da luz.

Os efeitos do blecaute sobre a percepção do espectador foram relatados em diferentes pesquisas, desde os estudos sobre a sombra até o uso da escuridão para fins artísticos em espetáculos de magia ou ilusionismo e de encantamento. A primeira manifestação do efeito do blecaute sobre os espectadores na história da iluminação se deu quando, pela primeira vez, a luz de plateia foi completamente apagada durante uma representação teatral, um acontecimento ocorrido por acaso e por engano, segundo o relato de Christine Richier:

É a Richard Wagner, em 1876, que se atribui o mérito do primeiro blecaute completo imposto à plateia, por ocasião da inauguração da Festpielhaus em Beyreuth, iluminada a gás. Esse blecaute total foi imputado por um erro de operação: Wagner teria pedido ao seu chefe gazeiro de reduzir a iluminação da plateia no início da representação come era de costume, mas com a correria dos preparativos da estreia, este último teria pesado a mão, apagando completamente a luz de plateia. Wagner, encantado, ordenou que ela não fosse acendida no intervalo: esse incidente favorecia plenamente ao estado de 
receptividade que ele desejava provocar no espectador, adotando o principio a partir de então212 (RICHIER, 2015, p. 90).

Em seu estudo, que permite entrever o blecaute como efeito luminoso entre os componentes da cena, Perruchon associa o blecaute (ausência de luz) ao silêncio (ausência de som) destacando a maneira como, em cena, ele pode ser favorável à escuta e à atenção por parte do espectador (PERRUCHON, 2016, p. 237). Ela apresenta Claude Régy como o representante incontestável na cena contemporânea francesa em cuja estética estão associados o blecaute e toda sua gama de variações. O silêncio e a lentidão extrema de movimentos no espaço se tornaram, segundo ela, a marca de seus espetáculos, comprovando que "se o silêncio se escuta, o blecaute se vê"213 (PERRUCHON, 2016, p. 238).

Entre outros depoimentos sobre experiências e usos expressivos do blecaute, está o relato de Nadja Naira ${ }^{214}$ sobre a exploração da potencialidade performativa do blecaute no espetáculo Vida, da companhia brasileira de teatro, quando uma cena compartilhada entre os atores e os espectadores uniu palco e plateia numa mesma situação perceptiva:

... os personagens estão numa sala de ensaio preparando uma apresentação de música. Então eles ensaiam, eles falam da vida, brigam, alguém chega, alguém sai e eles estão confinados em uma situação muito própria dos artistas, que é preparar algo para apresentar para alguém. $E$ chega um determinado momento em que essa apresentação acontece. [...] A luz deixa de ser uma luz ambiente e passa a ser uma luz teatral, [...] Tem luz na plateia, que se percebe como plateia, bate palma e reage como plateia. [...] Quando eles começam a tocar, cai a energia geral do teatro. Cai toda a luz e o som, e esse é o assunto da nossa situação, que dura dez minutos. Durante dez minutos, a plateia e o palco ficam no breu falando sobre o breu, sobre a impossibilidade de fazer algumas coisas sem energia. Por exemplo, um dos atores pergunta "Você me ouve? No escuro você me ouve?". É simples assim, mas extremamente imagético. Não tem nenhuma luz, mas é, pelos relatos dos espectadores, o momento mais

212 "C'est à Richard Wagner en 1876 que l'on attribue le coup de force du premier noir complet imposé dans la salle, à l'occasion de l'inauguration de la Festspielhaus à Bayreuth, éclairée au gaz. Ce noir total est imputé à une erreur de régie : Wagner aurait demandé à son chef gazier de réduire l'éclairage de la salle au début de la représentation comme il était d'usage, mais dans l'empressement des préparatifs de la première, ce dernier aurait eu la main lourde, éteignant complètement la salle. Wagner, ravi, ordonna qu'on ne la rallume pas à l'entracte : cet incident contribuait pleinement à l'état de réceptivité qu'il souhaitait provoquer chez le spectateur, il en adopta dès lors le principe " (tradução da autora).

213 " Si le silence s'écoute, le noir se regarde » (tradução da autora).

${ }^{214} \mathrm{Em}$ entrevista realizada como parte desta pesquisa, disponível nos anexos, p. 164-178. 
cheio de imagens do espetáculo. Porque eles conseguem imaginar tudo, eles têm um histórico de imagens na cabeça deles, de como a gente estava vestido, por onde a gente se desloca pelas nossas vozes... Eles sabem quem está falando apesar de não nos verem. [...] E como eles sabem disso? Porque a gente construiu todo um histórico juntos durante quarenta ou cinquenta minutos e por eles terem material para trabalhar. Então, o que não é visto, é estimulado, extremamente estimulado na cabeça do espectador. E quando a luz volta, é um choque para todo mundo, ficamos praticamente pelados, tanto a plateia quanto a gente, porque é constrangedor. A gente já está tão confortável nesses dez minutos, a gente já está tão íntimo, já está falando tão baixo, já estamos tão tranquilos, a gente já se acalmou, depois de ficar histéricos, está super bem, contando coisas bonitas... E, de repente, a luz volta, do nada. Isso é uma situação real. É claro que o público sabe que aquilo é falso, que aquilo é teatro, mas não importa. É onde se dá o máximo do teatro, onde ele se revela extremamente teatral. É real, porque a circunstância é real, ela está acontecendo e estamos todos ativos nessa situação (NAIRA, anexos, p. 175).

A pesquisadora Maria Clara Ferrer dedicou boa parte de sua pesquisa sobre a iluminação à obra de Eric Soyer junto à Companhia Louis Brouillard, de Joël Pommerat. Segundo ela, a presença da escuridão e a utilização sistemática do blecaute na estrutura fragmentada de seus espetáculos constituem uma forte identidade e uma constante em sua escrita cênica (FERRER, 2015, p. 56). Ao se questionar sobre a maneira como a escuridão atua na composição e, consequentemente, na percepção dos espetáculos, a pesquisadora acaba por concluir que existe um potencial performativo no uso do blecaute feito por Soyer. Ferrer explica que, ao sistematizar o uso do blecaute pelas diferentes durações e nuances da escuridão, Pommerat e Soyer fazem com que ele assuma, no espetáculo, um papel estruturante da escrita cênica. $O$ acender e apagar das cenas fazem com que elas não sejam percebidas pelo espectador como se tivessem um começo e um fim, mas como se fossem reminiscências que surgem e escapam ao pensamento, reflexos de memória, alterando sua expectativa a cada blecaute. No espetáculo Cercles/Fictions, o blecaute "não é só um utensílio técnico da obra, mas ele atua, age sobre o espectador, produzindo sensações e percepções que ficarão profundamente marcadas na memória do público" (FERRER, 2015, p. 69), revelando seu potencial performativo.

Além destes exemplos, muitos outros estimulam a curiosidade e o desejo de investigar, na sequencia do estudo da performatividade da luz, a vocação performativa da sua ausência. Nas são poucos os iluminadores que exploram o 
blecaute como potente recurso da iluminação cênica como recurso da não luz, que pode ser associado, no universo teatral sonoro ao silêncio, como ausência de som. A iluminadora e diretora Cibele Forjaz, criou uma interação poética e sensorial com o público que ela chama de "blecaute em cor" (FORJAZ, anexos, p. 76); Elsa Revol declarou a importância fundamental do blecaute em alguns de seus espetáculos (REVOL, anexos, pp. 96, 99 e 106); Alessandra Domingues falou do blecaute criado com uma explosão de luz, no qual faz desaparecer um ator em cena (DOMINGUES, anexos, p. 34), que lembra um efeito semelhante feito por Guilherme Bonfanti no final da peça O Livro de Jó (FORJAZ, 2008b, p. 161) ou a cena descrita por Lucas Amado ${ }^{215}$ na qual um ator desaparece num contraluz azul a menos de um metro e meio do público (AMADO, anexos, p. 149); Beto Bruel216 declarou o potencial expressivo do blecaute para estabelecer um ponto zero na percepção do espectador, a partir do qual tudo pode ser feito ou dito (BRUEL, anexos, p. 48), assim como Aurélio de Simoni217: "Para iluminar, você tem que ter a fonte luminosa ou a ausência dela, porque você também ilumina ausentando a luz [...] Quando você ausenta a noção, a percepção da luz, você está criando um efeito de luz, a ausência dela" (DE SIMONI, anexos, p. 38).

Peter Gasper, um importante iluminador alemão, radicado no Brasil nos anos 50, declarou que "iluminar é também apagar a luz"218 e Nadja Naira219 declarou ainda, a respeito do blecaute, que a ausência de luz é um estímulo para a imaginação, a exemplo da peça Krum, outro espetáculo da companhia brasileira no qual "a luz e a não luz [...] ativam o espectador para imaginar as situações, propor os espaços, completar as imagens [...] o público se compromete" (NAIRA, anexos, p. 175-176). Fica evidente, nos relatos de vários iluminadores, que o uso do blecaute como ato performativo não se restringe a códigos ou aplicações óbvias, como o início ou final de cenas ou do próprio

\footnotetext{
215 Em entrevista realizada como parte desta pesquisa, disponível nos anexos, p. 142-150.

216 Em entrevista realizada como parte desta pesquisa, disponível nos anexos, p. 48-59.

$217 \mathrm{Em}$ entrevista realizada como parte desta pesquisa, disponível nos anexos, p. 37-47.

${ }^{218} \mathrm{Na}$ palestra de encerramento do $1^{\circ}$ Congresso Brasileiro de lluminação Cênica realizado pelo GEPHIC, que deu origem à ABrIC - Associação Brasileira de lluminação Cênica, fundada na mesma ocasião, em São Caetano do Sul - São Paulo, em Setembro de 2005.

219 Em entrevista realizada como parte desta pesquisa, disponível nos anexos, p. 159-173.
} 
espetáculo. Nadja chega a sugerir, com suas experiências, uma desconstrução do blecaute como linguagem:

As pessoas vão dizer "blecaute é para começar uma cena e para terminar" e sim, eu também uso como borda, como porta de entrada e saída, uso para separar uma cena da outra, mas eu uso errado, fora da expectativa das pessoas. Elas pensam, "mas porque agora apagou a luz se não era para apagar a luz? Não acabou a cena, o ator ainda está falando, apagou a luz no meio da cena do ator... erraram! Calma, ainda não era para acender, eu vi o ator pelado saindo de cena, porque eu vi o ator pelado? Errei!" Esse momento que parece que há um erro e que parece que eu estou distraindo o espectador. Na verdade, eu não estou distraindo, eu só não estou dando para ele, didaticamente, a coisa, e isso faz com que ele estranhe, e nesse estranhamento, ele se ativa (NAIRA, anexos, p. 176).

Segundo Ferrer, "a escuridão ativa a imaginação do olhar" (FERRER, 2015, p. 61) e é essa imaginação ativa que interessa, particularmente, como resultado da ação performativa do blecaute sobre a percepção do espectador, muito provavelmente um dos temas mais fecundos e instigantes dos que permaneceram por investigar após a conclusão desta pesquisa. 


\section{CONSIDERAÇÕES FINAIS}

La lumière au théâtre ne se dit pas, elle se fond dans le paysage, agit en douce. ${ }^{220}$

Christine Richier

"A luz é tão evidente que não a vemos, é como o ar que respiramos, nós sentimos quando ela falta ou quando muda bruscamente, mas raramente a percebemos em um nível de consciência”. A afirmação de Christine Richier expressa a natureza e os efeitos que a luz, de uma forma geral, e a luz cênica, em especial, pode causar. Richier afirma, ainda, ser impossível dissociá-la dos demais componentes da cena, destacando a importância, para o acontecimento cênico, do movimento da luz e das condições de percepção do espectador em sua entrega ao espetáculo (RICHIER, 2015, p. 13). Fabrizio Crisafulli relembra duas ideias pré-concebidas, comuns nos meios teatrais, de que a iluminação cênica pertença a uma esfera eminentemente técnica, por um lado, e a um visual, por outro. Ele admite que essas visões são parcialmente aceitáveis, pois é incontestável que a iluminação pertence às duas dimensões, mas é preciso acrescentar a elas o fato "de que as qualidade fundamentais da iluminação teatral residem em sua capacidade de produzir sentido e modelar o espaço e o tempo pelo seu poder de ação e construção dramática" (CRISAFULLI, 2019, p. 209). Essas reflexões e percepções revelam a complexidade e a profundidade do estudo da iluminação cênica e de seus efeitos sobre o indivíduo.

Os aspectos investigados e apresentados nesta pesquisa demonstram de que forma a linguagem da luz, componente fundamental da cena, está presente nos diferentes palcos e espaços cênicos para constituir a estruturar os espetáculos e apresentações cênicas de maneira ativa e presente. Sua atuação integrada à cena é tão indissociável do conjunto que se torna comparável à atuação do performer (ator, músico ou dançarino), como agente igualmente performativo. Sua presença cênica é confirmada por sua constituição material

220 A luz no teatro não se explica, ela se funde na paisagem, age suavemente (tradução da autora). 
como fenômeno físico e imaterial como fenômeno perceptivo. Ela revela a capacidade para atrair e manter a atenção do espectador, ajudando a envolvêlo na realidade ficcional criada pela composição do visual cênico elaborado especialmente para ele. Naquele tempo/espaço da ação, o ato performativo possibilitado pela materialidade poética da luz instaura o devir no qual é estabelecida a comunhão e a cumplicidade da relação com o público. Além dele, o performer em cena é igualmente afetado pela presença da luz e pela resposta do espectador ativo e comprometido com a cena, numa ação mútua, conjunta e permanente.

O conceito de performatividade da luz, que de início existia apenas na observação da atuação da luz sobre o que ela ilumina, representa e revela, bem como sua ação sobre a percepção dos performers, instigou uma investigação mais profunda desse fenômeno entre físico e psicológico, material e imaterial, perceptivo e sensorial. Em seguida, surgiram questões e variáveis, como a presença imperativa de um performer da luz, a importância da operação, do movimento e da atuação do operador da luz e, principalmente, entre a natureza performativa da luz e a do espetáculo em si, entendimento essencial para se definir os contornos da investigação. Cada um desses questionamentos abria distintas possibilidades para o estudo da luz performativa e afastava o foco da pesquisa.

O escopo definitivo do trabalho foi encontrado nas hipóteses a respeito da recepção e da percepção da cena por parte do espectador e os resultados deste suposto "efeito" da luz sobre o público e cada espectador individualmente. Enfim, relacionando luz e iluminação, teatro e cenografia, participação e colaboração, ficção e realidade, física e percepção, presença e materialidade, recepção e cocriação, foi possível assimilar novos conceitos e constatar uma nova maneira de ver e entender o teatro e a iluminação. Esses conceitos e suas inter-relações permitiram verificar a importância da luz performativa no espetáculo, a interferência que ela pode exercer sobre a percepção de quem está em cena e fora dela, a maneira como interage e transforma as coisas sobre as quais incide direta e indiretamente e o forma como media e estabelece a conexão do público 
com o espetáculo. Ao associar essa percepção à ação da luz observada em trabalhos de criação próprios e de outros artistas, o conceito foi se estruturando e ficou evidente que é a luz, por si só, autônoma e independente em sua relação direta com o que ou quem ilumina e o olho de quem observa é o que, efetivamente, apresenta o potencial performativo identificado desde o início.

A performatividade da luz revela-se possível, então, a partir da presença cênica da luz como materialidade poética que, ao reunir arte e técnica, design, criação e tecnologia, permite à iluminação atuar, plástica e esteticamente, sobre a cena e a percepção do espectador. A partir da criação colaborativa entre todos os componentes do espetáculo, aliada a noções de composição, cor, forma, comunicação e percepção, entre outros, a materialidade poética da luz adquire a habilidade de transitar pelo espaço/tempo da ação performativa, emanando da obra teatral em direção ao espectador para estabelecer a relação fruitiva entre ambos e estimular sua entrega, envolvimento e percepção sensorial.

Ao final da investigação, já na fase da redação da tese, a realização das entrevistas permitiu verificar, junto a iluminadores, professores e pesquisadores brasileiros, franceses e italianos, a hipótese da performatividade da luz. Associada a outras perguntas relacionadas ao processo criativo de cada profissional, o questionamento a respeito das noções expostas revelou uma interessante concordância com os termos apresentados, principalmente no que concerne a atuação da luz na cena, que eu exponho, representativamente ${ }^{221}$, pelo relato da professora, diretora e iluminadora Cibele Forjaz ${ }^{222}$ :

Eu acho que com o mundo cada vez mais digital, a presença se tornou a coisa mais importante do teatro. A presença, o fórum, as práticas ritualísticas... Eu acho que é na presença viva em frente ao artista e nos corpos, vibrações, sons produzidos junto e ao vivo e com a participação ativa da plateia, que, no meu trabalho, tem sido cada vez mais sobre isso: "estar com" e não "mostrar para". Acho que a luz é esse elemento ligador de relação e de transformação muito rápida dessa relação do espectador com a cena... colocando-o dentro de cena ou tirando, indo de uma geral para um foco e então para uma luz de serviço que diz estamos aqui e agora (FORJAZ, anexos, p. 82).

221 As opiniões dos demais entrevistados podem ser verificadas nas respostas à pergunta número três das entrevistas realizadas para esta tese, disponíveis nos anexos, p. 28-233.

222 Em entrevista realizada como parte desta pesquisa, disponível nos anexos, p. 75-83. 
Alinhada ao pensamento do antropólogo argentino Jorge Kulemeyer, para quem "mais do que o que permite ver, o importante da iluminação cênica são as sensações que consegue provocar" complementado, citando Saint-Exupéry, que "o essencial é invisível para os olhos"223, esta pesquisa pretendeu analisar os efeitos da luz sobre a percepção humana e demonstrar como uma luz cênica performativa pode ir além de instrumento de visibilidade ou apoio da escritura dramatúrgica de um espetáculo. Ela buscou demonstrar que a iluminação pode, efetivamente, atuar como elo sensorial entre a cena e o espectador, valorizando as reações, emoções, sentimentos e sensações que é capaz de provocar, tanto como meio de acesso do público à cena e à ação dos artistas/performers quanto como estímulo no processo de criação e realização da obra cênica.

Essa luz é finalmente identificada como um agente performativo que afeta, não somente tudo sobre o que incide, mas também sobre a percepção de performers e espectadores. Como luz-matéria, ela é capaz de resultar, por meio de sua presença e materialidade poética, no efeito estruturante e transformador do espetáculo e do público espectador que a percebe ativamente em sua expressão imaterial. A luz que, como ato performativo, busca e conquista o comprometimento e a dedicação da plateia pela relação que estabelece entre o espetáculo e o espectador. Ao final deste longo percurso investigativo foi possível, finalmente, chegar ao entendimento dos conceitos apresentados nesta tese: o de luz performativa como o elemento que age sobre a cena e a percepção do público para estabelecer o elo entre a cena e o espectador, entendido como a performatividade da luz. 


\section{ÍNDICE DE FOTOS}

Figura 1 - Foto com Carlos Kur durante a Oficina de lluminação Cênica do LABIC realizada excepcionalmente no Mini Auditório do Teatro Guaíra em 2019. Foto acervo pessoal

1

Figura 2 - Entre meus dois mestres, Aurélio de Simoni e Beto Bruel, em abril de 2017 no Espaço das Artes em São Luiz do Purunã no Paraná - Foto: Kraw Penas. 5

Figura 3 - Encontro com equipe de criação do espetáculo Contes et Légendes, de Joël Pommerat, no Teatro Nacional Naterre-Amandiers em Janeiro de 2020. Fotos Nadia Luciani. 43

Figura 4 - Condução da atenção e do olhar do espectador pela luz no espetáculo A Menina que Pisou no Pão, no Mini auditório do Teatro Guaíra em Curitiba em 1993. Texto e direção de Eugenio Guielow. Luz Nadia Luciani. Fotos Chico Nogueira. 91

Figura 5 - Uso de cores quentes e frias na peça Otelo, as faces do ciúme, no Teatro Barracão EnCena em Curitiba em 2009. Texto de William Shakespeare, adaptação e direção de Silvia Monteiro. Luz Nadia Luciani. Foto Nicole Zattoni.

Figura 6 - Uso simbólico das cores âmbar, lavanda, vermelho, azul e amarelo na peça teatral Um Trágico Acidente, no Espaço Dois em Curitiba em 2008. Texto de Carlos Queiroz Telles e direção de George Sada. Luz Nadia Luciani. Fotos Daniel Sorentino.. 94

Figura 7 - Luz densa e material usada na peça Devorateme, apresentada na Casa Vermelha em Curitiba em 2002. Concepção e direção de Sueli Araújo. Luz Nadja Naira e Nadia Luciani. Foto Roberto Reitenbach. 95

Figura 8 - Dois momentos da luz de plateia como elemento de integração no Espetáculo Huis Clos - Representando Sartre, no Espaço FALEC em Curitiba em 2017. Texto de Jean Paul Sartre, adaptação e direção de Ênio Carvalho. Luz e Fotos Nadia Luciani. 98

Figura 9 - Quatro momentos da luz do balé-concerto Águas de Éden e do Hades no Teatro José Maria Santos em Curitiba em 2018. Concepção geral e direção artística de Maurício Dottore. Luz Nadia Luciani. Fotos Gabriel Stocchero. .... 99

Figura 10 - Cena do espetáculo $\mathrm{O}$ Voo do Poeta em que a projeção é usada como única fonte luminosa no Auditório Salvador de Ferrante do Teatro Guaíra em 2003. Coreografias e direção de Pedro Pires. Luz Nadia Luciani. Foto Sérgio Vieira. 
Figura 11 - Uso da projeção na peça Darwin, apresentada no TEUNI em Curitiba em 2012. Texto e direção de Fábio Salvatti. Luz Nadia Luciani. Fotos Rosana Roberta da Silva. 121

Figura 12 - Imagem projetada sobre cenário, músicos e bailarinos no espetáculo Águas do Éden e do Hades, apresentada no Teatro José Maria Santos em Curitiba em 2018. Concepção geral e direção artística de Maurício Dottore. Luz Nadia Luciani. Foto Gabriel Stocchero. 122

Figura 13 - Imagens externa e interna do Teatro Paiol em Curitiba nas quais é possível visualizar as janelas superiores que iluminavam o palco. Fotos Zig Koch e Eliane Costa. 128

Figura 14 - Representação de Witelo (1535) que retrata diversos fenômenos de reflexão e refração que podem conduzir a uma teoria da luz. (MAITTE, 2015. p.55) 142

Figura 15 - Efeito de luz surround na plateia para o espetáculo A Loucura de Bispo apresentado no Teatro Londrina em Curitiba em 2014. Direção geral de Octávio Nassur. Luz e Foto Nadia Luciani. 196

Figura 16 - Cartaz do Simpósio e conferência performativa de encerramento com Zé Celso no Teatro Oficina em São Paulo em 2016. Foto Marcos Bulhões. . 222

Figura 17 - Configuração do espaço cênico, relação cena/plateia e posição da cabine principal de operação de luz no Teatro Oficina. À esquerda cena de Cacilda. Texto e direção Zé Celso Martinez Corrêa. À direita cena de Bacantes. Texto de Eurípedes e direção de Zé Celso Martinez Corrêa. Luz Cibele Forjaz. Fotos Lenise Pinheiro. 225

Figura 18 - O vídeomaker Igor Marotti durante o Simpósio Teatro Oficina: seis décadas da cena radical brasileira no Teatro Oficina em São Paulo. Foto Marcos Bulhões. 227

Figura 19 - Zé Celso em cena no espetáculo Bacantes. Texto de Eurípedes e direção de Zé Celso Martinez Corrêa. Luz Cibele Forjaz. Foto Lenise Pinheiro. 230

Figura 20 - Cenas do Espetáculo Cacilda!, à esquerda cena da chegada de Godot e à direita cena da invocação. Texto e direção Zé Celso Martinez Corrêa. Luz Cibele Forjaz. Fotos Lenise Pinheiro. 236

Figura 21 - Cenas da missa no Espetáculo Cacilda! Texto e direção Zé Celso Martinez Corrêa. Luz Cibele Forjaz. Fotos Lenise Pinheiro. 237

Figura 22 - Ambientação quente criada com fumaça e baixas intensidades da luz branca na Igreja Santa Ifigênia para o espetáculo O Paraíso Perdido. Roteiro de Antônio Araújo e Sérgio de Carvalho. Concepção e direção geral de Antônio Araújo. Luz Guilherme Bonfanti. Foto Otávio Valle. 248 
Figura 23 - Exploração da arquitetura e configuração do espaço para efeito de silhueta em cena do espetáculo O Livro de Jó. Dramaturgia de Luís Alberto de Abreu. Concepção e direção geral de Antônio Araújo. Luz Guilherme Bonfanti. Foto Claudia Calabri. 252

Figura 24 - Uso de equipamentos luminosos hospitalares para iluminar e ambientar as cenas de O Livro de Jó. Dramaturgia de Luís Alberto de Abreu. Concepção e direção geral de Antônio Araújo. Luz Guilherme Bonfanti. Foto Eduardo Knapp. 254

Figura 25 - Uso do negatoscópio nas laterais da maca e de radiografias reais iluminadas pela contraluz na cena da condenação em O Livro de Jó. Dramaturgia de Luís Alberto de Abreu. Concepção e direção geral de Antônio Araújo. Luz Guilherme Bonfanti. Fotos de Guto Muniz e Lenise Pinheiro. 255

Figura 26 - Relação próxima entre a cena e o público favorece a interação e a atuação performativa da luz no espetáculo Apocalipse 1,11. Dramaturgia de Fernando Bonassi. Concepção e direção de Antônio Araújo. Luz Guilherme Bonfanti. Foto Edouard Fraipont. 257

Figura 27 - Interação da cena com o entorno na remontagem da peça BR-3 no Rio de Janeiro durante o Festiva RioEncena, lâmpadas de vapor metálico e destaque dos personagens em movimento. Dramaturgia de Bernardo de Carvalho. Concepção e direção geral de Antônio Araújo. Luz Guilherme Bonfanti. Foto RioEncena. 263

Figura 28 - Cena do desfile de moda na José Paulino da peça Bom Retiro 958 metros. Dramaturgia de Joca Reiners Terron. Concepção e direção geral de Antônio Araújo. Luz Guilherme Bonfanti. Foto Flavio Morbach Portella..... 266

Figura 29 - Instalação e uso da traquitana para controle da iluminação dos postes de iluminação pública na peça Bom Retiro, 958 metros. Dramaturgia de Joca Reiners Terron. Concepção e direção geral de Antônio Araújo. Luz Guilherme Bonfanti. Fotos Guilherme Bonfanti e João Maria. 268

Figura 30 - Cena em deslocamento pelas ruas do bairro paulistano na peça Bom Retiro, 958 metros. Dramaturgia de Joca Reiners Terron. Concepção e direção geral de Antônio Araújo. Luz Guilherme Bonfanti. Foto Nelson Kao. 271

Figura 31 - Cartaz e equipe do espetáculo Um Ricardo III, apresentado no Teatro Ênio Carvalho em Curitiba em 2018. Cartaz Álvaro Gusso. Foto Chico Nogueira. 274

Figura 32 - Elemento principal do cenário, o trono de Ricardo III, ainda não finalizado, e os quatro atores do espetáculo na peça Um Ricardo III, texto de William Shakespeare. Adaptação e direção de Rafael Camargo. Luz Nadia Luciani.. Fotos Nadia Luciani e Chico Nogueira. 274 
Figura 33 - Atores iluminados como narradores da peça Um Ricardo III. Texto de William Shakespeare. Adaptação e direção de Rafael Camargo. Luz e Foto Nadia Luciani. 276

Figura 34 - Espaço cênico com as luzes dos elementos do cenário e a configuração da plateia com a luz de entrada do público na sala. Fotos Nadia Luciani e Chico Nogueira. 277

Figura 35 - Os quatro atores do espetáculo no papel de Ricardo III. Fotos Chico Nogueira. 278

Figura 36 - À esquerda vemos a mesa de luz localizada na plateia, ainda durante a montagem e os ensaios, e à direita a posição final do operador de luz, no primeiro balcão do teatro, não utilizado para este espetáculo. Cenas de Um Ricardo III. Texto de William Shakespeare. Adaptação e direção de Rafael Camargo. Luz e Fotos Nadia Luciani. 281

Figura 37 - Bruno Rodrigues e Zeca Cenovicz na cena dos fantasmas do Príncipe Eduardo e de Buckingham, respectivamente. Um Ricardo III. Texto de William Shakespeare. Adaptação coletiva e direção de Rafael Camargo. Luz Nadia Luciani. Fotos Chico Nogueira. 284

Figura 38 - Pagú Leal, em seu deslocamento como Ricardo III até o centro do palco e depois que a luz se fecha sobre ela. Um Ricardo III. Texto de William Shakespeare. Adaptação coletiva e direção de Rafael Camargo. Luz Nadia Luciani. Fotos Chico Nogueira. 285

Figura 39 - Cena em que Ricardo, num interessante jogo cênico, mesmo de costas, seduz e convence a viúva de Henrique VI a desposá-lo. Um Ricardo III. Texto de William Shakespeare. Adaptação coletiva e direção de Rafael Camargo. Luz Nadia Luciani. Foto Chico Nogueira. 288

Figura 40 - Cena que que Ricardo anuncia a morte do irmão Clarence para o Rei Eduardo IV e sua corte. Um Ricardo III. Texto de William Shakespeare. Adaptação coletiva e direção de Rafael Camargo. Luz Nadia Luciani. Foto Chico Nogueira. 290

Figura 41 - O Rei Ricardo III em sua batalha final, enquanto os atores ao fundo tocam os instrumentos que ambientam a cena. Um Ricardo III. Texto de William Shakespeare. Adaptação coletiva e direção de Rafael Camargo. Luz Nadia Luciani. Foto Chico Nogueira. 294

Figura 42 - Sequencia de movimentos de luz até o texto de Richmond, ao fundo, e o último suspiro de Ricardo III, vencido em uma sanguinária batalha. Um Ricardo III. Texto de William Shakespeare. Adaptação coletiva e direção de Rafael Camargo. Luz Nadia Luciani. Fotos Chico Nogueira. 295

Figura 43 - A materialidade poética da luz no final do espetáculo Um Ricardo III, Um Ricardo III. texto de William Shakespeare. Adaptação coletiva e direção de Rafael Camargo. Luz Nadia Luciani. Fotos Nadia Luciani e Chico Nogueira. 296 
Figura 44 - Performers distribuídos pelo espaço ao início do espetáculo Multitud, coreografia de Tamara Cubas. Luz Leticia Skrycky e Sebastián Alíes. Foto Nadia Luciani. 302

Figura 45 - Massa de corpos iluminados pela luz randômica das lâmpadas florescentes verticais ao redor do palco no final da cena da corrida do espetáculo Multitud, coreografia de Tamara Cubas. Luz Leticia Skrycky e Sebastián Alíes. Foto Nadia Luciani. 308

Figura 46 - Cena invadida pela luz intensa dos dois maxibrutes laterais sobre os corpos exaustos ao final da cena enérgica da corrida em torno do palco no espetáculo Multitud, coreografia de Tamara Cubas. Luz Leticia Skrycky e Sebastián Alíes. Foto Nadia Luciani. 309

Figura 47 - Troca-troca de acessórios, roupas e emoções entre os performers num dos momentos intensos do espetáculo Multitud, coreografia de Tamara Cubas. Luz Leticia Skrycky e Sebastián Alíes. Foto Nadia Luciani.... 310

Figura 48 - Movimentação do corpos à luz das lâmpadas PAR que cegavam o público e atribuíam uma atmosfera imprecisa e mágica à cena no espetáculo Multitud, coreografia de Tamara Cubas. Luz Leticia Skrycky e Sebastián Alíes. Foto Nadia Luciani. 311

Figura 49 - Final do espetáculo Multitud, quando o elenco de 64 pessoas se alinha na boca de cena para confrontar o público aturdido e tão exausto quanto ele próprio. Coreografia de Tamara Cubas. Luz Leticia Skrycky e Sebastián Alíes. Foto Nadia Luciani. 312

Figura 50 - Instalação da Exposição Multimeios, realizada na UNESPAR-FAP em Curitiba em 2012 e montagem feita no WSD2009 em Cardiff - UK em 2013. Fotos Nadia Luciani. 347

Figura 51 - Árvore da instalação de Ronald Teixeira para Mostra Nacional Brasileira na PQ2015 - interior e exterior da esfera. Fotos Claudia de Bem. 348

Figura 52 - Intersecções 2018 - Instalação, performance luminosa e sonora e intervenções na exposição permanente do Memorial da Resistência em São Paulo - MITsp2018. No alto à direita a cabine de luz e som improvisada para a performance. Fotos Nadia Luciani. 349 


\section{REFERÊNCIAS BIBLIOGRÁFICAS}

ALMAFI, Marcello. A macro-harmonia da música no teatro. São Paulo: Giostri, 2015.

APPIA, Adolphe, L'œuvre d'art vivant. 1923.

- La mise en scène du drame wagnérien. In Oeuvres complètes. Lausanne: Societé Suisse du Théâtre, 1983.

ARAÚJO, Antônio. A encenação performativa. In Sala Preta, v. 8, p. 253258. São Paulo: USP, 2008.

. O processo colaborativo como modo de criação. In Olhar: Revista da Escola Superior de Artes Célia Helena. n.1, p. 49-51. São Paulo: ESCH, 2009.

ARAÚJO, Antônio (et al.); FERNANDES, Silvia (Org.). Teatro da Vertigem. Rio de Janeiro: Cobogó, 2018.

ARAÚJO, José Sávio. A Cena Ensina: uma proposta pedagógica para formação de professores de teatro. Tese (Doutorado em Educação) - Centro de Ciências Sociais Aplicadas. Natal: UFRN, 2005.

ARNHEIM, Rudolf. Arte \& percepção visual: uma psicologia da visão criadora. Nova versão. São Paulo: Cengage Learning, 2012.

AUMONT, Jacques. A imagem. Campinas: Papirus, 2012.

BADIOU, Alain; DURING, Elie. Um Teatro da Operação: uma conversa entre Alain Badiou e Elie During. In: Um teatro sem teatro. Catálogo da exposição organizada pelo Museu d'Art Contemporani de Barcelona e coproduzida com o Museu Colecção Berardo - Arte Moderna e Contemporânea de Lisboa, 2007.

BAKHTIN, Mikhail M. Para uma filosofia do ato responsável. São Carlos: Pedro \& João, 2010.

BARONE, Luciana Paula Castilho. O uso da imagem tecnológica na narrativa cênica contemporânea. Dissertação (Mestrado em Multimeios) Instituto de Artes. Campinas: UNICAMP, 2002.

BARROS, Anna. A arte da percepção: um namoro entre a luz e o espaço. $2^{a}$ edição. São Paulo: Annablume, 2010.

BARTHES, Roland. Escritos sobre teatro: textos reunidos e apresentados por Jean-Loup Rivière. São Paulo: Martins Fontes, 2007.

BAURRIAUD, Nicolas. Estética Relacional. São Paulo: Martins Fontes, 2009. 
BENEDETTO, Stephen Di. An introduction to theatre design. Londres: Routledge, 2012.

BENJAMIN, Walter. A obra de arte na época de sua reprodutibilidade técnica. Porto Alegre: Zouk, 2014.

BENTIVEGNA, Marisa. Luz e improvisação na cena: o criador em estado de libertação. In Revista A(I)berto, \#3, p. 39-46. São Paulo: SP Escola de Teatro, 2012.

BERTHOLD, Margot. História mundial do teatro. São Paulo: Perspectiva, 2008.

BIANCALANA, Gisela Reis. A Presença Performativa nas Artes da Cena e a Improvisação. In Revista Brasileira de Estudos da Presença, v.1, $n^{\circ} .1$, p.121-148. Porto Alegre: URGS, 2011.

BONFANTI, Guilherme. Relato de uma experiência: luz em processo. In Revista A(I)berto, \#1, p. 110-121. São Paulo: SP Escola de Teatro, 2011.

. Desenho de luz: traquitanas. In Sala Preta, v. 12, n. 2, p. 256-259. Dossiê Bom Retiro 958 metros - O processo de criação e a recepção. São Paulo: PPGAC, 2012.

. Relatos da Luz do Bom Retiro. Teatro da Vertigem. Disponível em http://guilhermebonfanti.com.br/vertigem/. São Paulo: Bonfanti, 2013.

. A luz no Teatro da Vertigem: processo de criação e pedagogia. In Sala Preta, v. 14, n. 2, p. 5-16. Cadernos de Luz. São Paulo: PPGAC, 2015.

. A visão de um projeto aberto. In ARAÚJO, Antônio (et al.); FERNANDES, Silvia (Org.). Teatro da Vertigem, p. 24-28. Rio de Janeiro: Cobogó, 2018.

BOONE, Mary Callahan. Jean Rosenthal's light: making visible the magician. In Theatre Topics., v.7, $n^{\circ} .1$, p. 77-92. (March 1997). Baltimore: Johns Hopkins University Press, 1997.

BOURRIAUD, Nicolas. Estética Relacional. São Paulo: Martins Fontes, 2009.

BUENO, Luciana. Muito além da caixa cênica: a realização cenográfica contemporânea na cidade de São Paulo. Dissertação (Mestrado em Artes) - Escola de Comunicação e Artes. São Paulo: USP, 2007.

BROOK, Peter. O teatro e seu espaço. Petrópolis: Vozes, 1970.

A porta aberta: reflexões sobre a interpretação e o teatro. São Paulo: Civilização Brasileira, 2000.

BRUGUIÈRE, Dominique. Penser la Lumière. França: Actes Sud, 2017.

CAMARGO, Roberto Gill. Função estética da luz. São Paulo: Perspectiva, 2012. 
CARLSON, Marvin. Teorias do teatro. São Paulo: UNESP, 1997.

. Performance: uma introdução crítica. Belo Horizonte: Humanitas, 2009.

CARNEIRO, Leonel Martins. A Experiência do Espectador Contemporâneo: memória, invenção e narrativa. Tese (Doutorado em Artes Cênicas) Escola de Comunicação e Artes. São Paulo: USP, 2016.

CARREIRA, André (Org.). Teatro da Vertigem: processos contemporâneos. São Paulo: Escola Célia Helena. 2009.

CARVALHO, Nadiana Assis de. Por uma Estética da Recepção Criativa e da Comunicação Performativa. In: Revista Arte da Cena, v. 1, n. 1, p. 7078. Goiânia: UFG, 2014.

CHAOUCHE, Sabine e VIALLETON, Jean-Yves. L'éclairage au théâtre (XVIIe $X X I^{e}$ siècles. Introduction. In Revue d'Histoire du Théâtre. $\mathrm{n}^{\circ} .273$, Trimestre 1. Paris: SHT, 2017.

CHAUÍ, Marilena. Merleau-Ponty: a obra fecunda. In: Revista Cult, edição 123. São Paulo: Bregantini, 2011.

COELHO NETTO, J. Teixeira. Semiótica, Informação e Comunicação. São Paulo: Perspectiva, 2010.

Colóquio Internacional Lumière-Matière. Comunicações de Yanna Kor e Flavia Dalila D’Amico. Veneza: Giorgio Cini, 2020.

Colóquio Internacional Lumière-Matière. Comunicações de Bernard Maitte, Pasquale Mari e Victor Inisan. Lille: UdL, 2019.

COSTA, Felisberto Sabino da. A Poética do Ser e Não Ser: procedimentos dramatúrgicos do teatro de animação. São Paulo: USP, 2016.

CRAIG, Edward Gordon. Da Arte do Teatro. Lisboa: Arcádia, 1963.

CRISAFULLI, Fabrizio. Lumière Active: Poétiques de la lumière dans le théatre contemporain. Tradução de Marc Scialom. Dublin: Artdigiland, 2019.

CRUZ, Kaoana Pereira da. Iluminação Cênica: o estudo da linguagem da iluminação a partir da sua contribuição para o processo criativo. TCC (Bacharelado em Artes Cênicas). UNESPAR - Campus de Curitiba II. Curitiba: FAP, 2019.

DE MARINIS, Marco. Para Comprender el Teatro. Buenos Aires: Galerna, 1997.

DERRIDA, Jacques. Marges de la Philosophie. Paris: Minuit, 1972. Sauf le nom. Paris: Galilée, 1993.

DESGRANGES, Flávio. A interferência dos processos de criação nos modos de recepção artística: percursos de um pretérito imperfeito. in 
DESGRANGES, Flávio \& SIMÕES, Giuliana (Orgs.). 0 ato do espectador: perspectivas artísticas e pedagógicas, p. 21 a 52. São Paulo: Hucitec; Florianópolis: iNerTE, 2017.

DIDI-HUBERMAN, Georges. L'Image ouverte, motif de l'incarnation dans les arts visuels. Paris: Gallimard, 2007.

DONDIS, Donis A. Sintaxe da Linguagem Visual. São Paulo: Martins Fontes, 2007.

DUFRENNE, Mikel. Estética e Filosofia. São Paulo: Perspectiva, 2015.

DURAN, Antonio. Dramaturgismo e Vertigem. In ARAÚJO, Antônio (et al.); FERNANDES, Silvia (Org.). Teatro da Vertigem, p. 43-46. Rio de Janeiro: Cobogó, 2018.

ECO, Umberto. Obra Aberta. São Paulo: Perspectiva, 2013.

. Confissões de um jovem Romancista. São Paulo: Cosac Naify, 2013b. . Como se faz uma Tese. São Paulo: Perspectiva, 2014.

FÉRAL, Josette. Entre performance et théâtralité: le théâtre performatif. Théâtre /Public, (190), September 2008. Tradução em Português como "Por uma poética da performatividade: o teatro performativo" In Sala Preta, São Paulo (Brasil), 2008.

. Performance e performatividade: o que são os estudos performáticos. In: Sobre Performatividade. Florianópolis: Letras Contemporâneas, 2009.

. De la Performance à la Performativité, Communications, v. 92, $\mathrm{n}^{\circ} .1, \mathrm{p}$ 205-218. Paris: Seuil, 2013.

. Além dos Limites: teoria e prática do teatro. São Paulo: Perspectiva, 2015.

. O flâneur e o cidadão: percurso em site specific. In ARAÚJO, Antônio (et al.); FERNANDES, Silvia (Org.). Teatro da Vertigem, p. 133-139. Rio de Janeiro: Cobogó, 2018.

FERNANDES, Silvia. Teatralidades Contemporâneas. São Paulo. Perspectiva, 2010.

. Experiências de performatividade na cena brasileira. in DESGRANGES, Flávio \& SIMÕES, Giuliana (Orgs.). $O$ ato do espectador: perspectivas artísticas e pedagógicas, p. 213 a 226. São Paulo: Hucitec; Florianópolis: iNerTE, 2017.

FERRER, Maria Clara. O desempenho da escuridão: análise do valor dramatúrgico do black-out em Cercles/Fictions de Joël Pommerat. In Sala Preta, v. 14, nº. 2, p. 54-74. Cadernos de Luz. São Paulo: PPGAC, 2015. 
FIGURELLI, Roberto. Estética e Crítica. Curitiba: UFPR, 2007.

FLUSSER, Vilém. O Mundo Codificado: por uma filosofia do design e da comunicação. São Paulo: Cosac Naify, 2007.

FORJAZ, Cibele. À luz da Linguagem. A lluminação Cênica: de Instrumento da visibilidade à 'Scriptura do visível' (Primeiro recorte: do fogo à Revolução Teatral). Dissertação (Mestrado em Artes Cênicas) - Escola de Comunicação e Artes. São Paulo: USP, 2008a.

- A linguagem da luz: a partir do conceito de pós-dramático desenvolvido por Hans-Thies Lehmann. In 0 Pós-Dramático: Um conceito operativo?, p. 151-171. São Paulo: Perspectiva, 2008b.

- À luz da Linguagem. A lluminação Cênica: de Instrumento da visibilidade à 'Scriptura do visível' \& outras poéticas da luz. Tese (Doutorado em Artes Cênicas) - Escola de Comunicação e Artes. São Paulo: USP, 2013a.

A Linguagem da Luz Encenadora no Teatro Oficina Uzyna Uzona: estudos de caso da luz em Ham-Let e Cacilda!. In Livro de Ouro do Teatro Oficina: a revista A Bigorna Extraordinária. Anexo, p. 13-16. São Paulo, 2013b.

- O Papel do Encenador: das vanguardas modernas ao processo colaborativo: notas rápidas sobre a função do diretor no teatro. In Revista Subtexto: Revista de Teatro do Galpão Cine Horto. v. 12, n. 11, p. 2032. Belo Horizonte: CPMT, 2015.

. A eletricidade entra em cena. In Urdimento - Revista de Estudos em Artes Cênicas, v. 1, n. 31, p. 63-77. Florianópolis: UDESC, 2018.

GABRIELI, Osvaldo. Um Teatro de Luz e Sombra. in Disegno. Desenho. Desígnio, p. 187-194. São Paulo: Senac, 2007.

GIBSON, James Jerome. The ecological approach to visual perception. Nova Jersey: Lawrence Erlbaum, 1986,

GOETHE, Johan Wolfgang. Doutrina das Cores. São Paulo: Nova Alexandria, 2011.

GRAZIOLI, Cristina. Luce e ombra: Storia, teorie e pratiche dell'illuminazione teatrale. Bari: Laterza, 2008.

GUINSBURG, Jacó; FERNANDES, Silvia (Orgs.). O Pós-dramático: um conceito operativo? São Paulo: Perspectiva, 2008.

GUINSBURG. J; COELHO NETTO, J. T.; CARDOSO, R. C. (Orgs.). Semiologia do Teatro. São Paulo: Perspectiva, 2006. 
GUMBRECHT, Hans Ulrich. Produção de Presença: o que o sentido não consegue transmitir. Rio de Janeiro: Contraponto - PUC-Rio, 2010.

HANNAH, Dorita. Performance Design. Harsløf Olav, 2008.

HACKING, lan. Representing and intervening: introductory topics in the philosophy of natural science. Cambridge: Cambridge University Press, 1983.

HILU, Luciane. Metodologia de Projeto com Abordagem em Design Thinking: uma proposta metodológica de aprendizagem colaborativa. Tese (Doutorado em Educação) - Programa de Pós Graduação em Educação. Curitiba: PUC-PR, 2016.

HOWARD, Pamela. O que é Cenografia? São Paulo: SESC, 2015.

ISER, Wolfgang. How to do theory. Victoria: Blackwell, 2007.

JAUSS, Hans Robert. Pour une esthétique de la réception. Tradução de Claude Maillard. Paris: Gallimard, 1978.

KELLER, Max. Light Fantastic: the art and design of stage lighting. Munique: Prestel Verlag, 2010.

KOR, Yanna. Les Théâtres d'Alfred Jarry: l'invention de la scène pataphysique. Tese (Doutorado em Estudos Teatrais) - Université Paul Valéry 3. Montpellier: UPVM, 2019.

LATOUR, Bruno. The Powers of Association. In The Sociological Revue, 32, 1984.

LEAL, Dodi. Luzvesti: iluminação cênica, corpomídia e desobediências de gênero. Salvador: Devires, 2018.

LEHMANN, Hans-Thies. Teatro Pós-dramático. São Paulo: Cosac Naify, 2007.

LECAT, Jean-Guy. Un spectacle, un public, un seul espace. Praga: OISTAT, 2007.

LUCIANI, Nadia Moroz. Sobre a Performatividade da Luz. in O Mosaico Revista Científica de Pesquisa em Artes, n. 8, (Julho/Dezembro) Faculdade de Artes do Paraná, p. 87-101. Curitiba: FAP, 2012a.

. A Performatividade da Luz em Otelo. In: Anais do VII Congresso da ABRACE - Tempos de Memórias: vestígios, ressonâncias, mutações. Porto Alegre: ABRACE, 2012b.

. Da Luz Performativa à Performance da Luz. ABRACE: Anais da VII Reunião Científica de Pesquisa e Pós-Graduação em Artes Cênicas. Processos de Criação e Expressão Cênicas. v. 14, n. 1. Belo Horizonte: UFMG, 2013. 
- Iluminação Cênica: uma experiência de ensino fundamentada nos princípios do design. Dissertação (Mestrado em Teatro) - Programa de Pós-Graduação em Teatro, Centro de Artes. Florianópolis: UDESC, 2014. . Notas sobre a luz performativa em Darwin. In Urdimento - Revista de Estudos em Artes Cênicas, v. 1, $\mathrm{n}^{\circ}$. 31, p. 162-177. Florianópolis: UDESC, 2018.

. A atuação da luz performativa na peça Huis Clos, Revisitando Sartre. In Urdimento - Revista de Estudos em Artes Cênicas, v. 2, $n^{\circ} .35$ (Ago/Set 2019), p. 404-429. Florianópolis: UDESC, 2019.

MAITTE, Bernard. Une histoire de la lumière: de Platon au photon. Paris: Seuil, 2015.

MASSA, Clóvis. Redefinições nos Estudos de Recepção/Relação Teatral In: Sala Preta, v. 8, nº. 6, p. 49-54. São Paulo: ECA-USP, 2008.

. Teatro e Recepção. In Para uma História Cultural do Teatro. Florianópolis/Jaraguá do Sul: Design, 2010.

MERLEAU-PONTY, Maurice. Fenomenologia da Percepção. Tradução Carlos Alberto Ribeiro de Moura. São Paulo: Martins Fontes, 1994.

MERLEAU-PONTY, Maurice. O Visível e o Invisível. São Paulo: Perspectiva, 2009.

MILNER, Max. L'Envers du visible, essai sur l'ombre. Paris: Seuil, 2005.

MOSTAÇO, Edélcio; OROFINO, Isabel; BAUMGÄRTEL, Stephan; COLLAÇO, Vera (Orgs.). Sobre Performatividade. Florianópolis: Letras Contemporâneas, 2009.

MOSTAÇO, Edélcio (Org.). Para uma história cultural do teatro. Florianópolis/ Jaraguá do Sul: Design, 2010.

. Kátharsis, a adesão. in DESGRANGES, Flávio \& SIMÕES, Giuliana (Orgs.). $\mathbf{O}$ ato do espectador: perspectivas artísticas e pedagógicas, $p$. 100 a 120. São Paulo: Hucitec; Florianópolis: iNerTE, 2017.

MOURA, Edgar Peixoto de. 50 anos luz, câmera e ação. São Paulo: Senac, 1999.

OIDA, Yoshi. El Actor Invisible. Barcelona: Alba, 2015.

OSTROWER, Fayga. Criatividade e Processos de Criação. Rio de Janeiro: Vozes, 1991.

PALMER, Scott. Light: readings in theatre practice. Hampshire: Palgrave Macmillan, 2013. 
PAREYSON, Luigi. Os Problemas da Estética. São Paulo: Martins Fontes, 2001.

PASSOS, Angelo Marcelo Adams dos. Adolphe Appia e seu olhar sobre a atuação teatral: cruzamentos e contaminações entre espaço, música e corpo. Tese (Doutorado em Teatro) - Programa de Pós-Graduação em Teatro, Centro de Artes. Florianópolis: UDESC, 2018.

PAVIS, Patrice. Dicionário de Teatro. São Paulo: Perspectiva, 1999

. A Análise dos Espetáculos. São Paulo: Perspectiva, 2005.

. A Encenação Contemporânea. São Paulo: Perspectiva, 2010.

PEDROSA, Israel. Da Cor à Cor Inexistente. Rio de Janeiro: Léo Christiano, 1989.

. O Universo da Cor. Rio de Janeiro: Senac, 2012.

PERRUCHON, Véronique. Noir: Lumière et Théatralité. Villeneuve D'Ascq: Septentrion, 2016.

PERRUCHON, Véronique. André Engel: CEuvre Théâtrale. Villeneuve D'Ascq: Septentrion, 2018.

PEREZ, Valmir. Linguagem e Alfabetismo Visual: A pesquisa no campo da estética aplicada a projetos de iluminação cênica. In Revista A(I)berto, \#3, p. 25 a 33. São Paulo: SP Escola de Teatro, 2012a.

. Luz e Arte. São Paulo: De Maio, 2012b.

PICON-VALLIN, Beatrice. A Cena em Ensaios. São Paulo: Perspectiva, 2008.

. A Arte do Teatro: entre tradição e vanguarda. Rio de Janeiro: Letras, Teatro do Pequeno Gesto, 2013.

PILBROW, Richard. Stage Lighting Design. London: Nick Hern, 2008.

RAMOS, Lúcia Galvão Gomes dos Reis. A Performance da Luz no contexto de Intervenções Urbanas. Dissertação (Mestrado em Artes Cênicas) Escola de Comunicação e Artes, Universidade de São Paulo. São Paulo: USP, 2019.

RAMOS, Luiz Fernando. Pós-dramático ou Poética da Cena? In GUINSBURG, Jacó (Org.). O Pós-dramático: um conceito operativo?. p. 59-70 São Paulo: Perspectiva, 2008.

. Mimesis performativa: a margem da invenção possível. São Paulo: Annablume, 2015.

A Recepção na Mimesis Performativa. in DESGRANGES, Flávio \& SIMÕES, Giuliana (Orgs.). $\mathbf{O}$ ato do espectador: perspectivas artísticas 
e pedagógicas. São Paulo: Hucitec; Florianópolis: iNerTE, 2017. p. 342 a 360.

RANCIÈRE, Jacques. O Espectador Emancipado. São Paulo: Martins Fontes, 2012.

RATTO, Gianni. Anti-tratado de Cenografia. São Paulo: Senac, 1999.

RICHIER, Christine. Petit nuancier de l'oeil du spectateur. In Revue des Sciences Sociales. Voie/Savoir. $n^{\circ}$. 54, p. 90-97. Disponível em https://journals.openedition.org/revss/2331.Strasbourg: UNISTRA, 2015.

. Josef Svoboda, poète de l'immatériel. Tese (Doutorado em Letras e Artes) École Doctorale. Lyon: Université Lumière Lyon 2, 2019.

RINALDI, Miriam. O ator do Teatro da Vertigem. In ARAÚJO, Antônio (et al.); FERNANDES, Silvia (Org.). Teatro da Vertigem, p. 29-42. Rio de Janeiro: Cobogó, 2018.

RIZZI, Maria Christina de Souza. Caminhos Metodológicos. in Inquietações e Mudanças no Ensino da Arte. São Paulo: Cortez, 2012.

ROHENKOHL, Raquel Andressa Stefeni. Criatividade e Design: uma análise da habilidade criativa no processo projetual. Unoesc \& Ciência - ACSA, vol. 3, no 1, p. 45-54. Joaçaba, 2012.

ROSENTHAL, Jean; WERTENBAKER, Lael. The magic of light. Boston: Lilltle, Brown \& Co, 1972.

ROUBINE, Jean-Jacques. A Linguagem da Encenação Teatral: 1880-1980. Rio de Janeiro: Zahar, 1998. . Introdução às Grandes Teorias do Teatro. Rio de Janeiro: Zahar, 2003.

SANTAELLA, Lucia. Percepção: fenomenologia, ecologia, semiótica. São Paulo: Cengage Learning, 2012.

SARAIVA, Hamilton Figueiredo. Iluminação Teatral: história, estética e técnica. Dissertação (Mestrado em Artes Cênicas) - Escola de Comunicação e Artes, Universidade de São Paulo. São Paulo, 1990.

. Interações Físicas e Psíquicas Geradas pelas Cores na lluminação Teatral. Tese (Doutorado em Artes Cênicas) - Escola de Comunicação e Artes, Universidade de São Paulo. São Paulo: USP, 1999.

Simpósio Teatro Oficina: seis décadas de cena radical brasileira. Depoimentos de Cibele Forjaz, Zé Celso Martinez Corrêa, Marcelo Drummond e Osvaldo Gabrielli. São Paulo: PPGAC, 2016.

SHEFFLER, Ismael. Teorias da Cena: teatro e visualidades. Curitiba: InterSaberes, 2019. 
SCHECHNER, Richard. Performance Studies: an introduction. London/New York: Routledge, 2007.

SILVA, Íris Fátima da. Formatividade e Interpretaçã: a filosofia estética de Luigi Pareyson. Tese (Doutorado em Filosofia) Centro de Ciência Humanas, letras e Artes - UFPB/UFPE/UFRN. Natal: UFRN, 2013.

SIMÕES, Giuliana. O espectador em processo: tensão entre arte e vida. in DESGRANGES, Flávio \& SIMÕES, Giuliana (Orgs.). $\mathbf{0}$ ato do espectador: perspectivas artísticas e pedagógicas, p. 361 a 378 . São Paulo: Hucitec; Florianópolis: iNerTE, 2017.

BONFANTI, Guilherme. Relato de uma experiência: luz em processo. In Revista A(I)berto, \#1, p. 110-121. São Paulo: SP Escola de Teatro, 2011.

TUDELLA, Eduardo. Design, cena e luz: anotações. In Revista A[I]berto, \#3, p. 11-24. São Paulo: SP Escola de Teatro, 2012.

. A Luz na Gênese do Espetáculo. Salvador: EDUFBA, 2017.

TURBIANI, Francisco Moreira. Uso de equipamentos luminosos não teatrais na iluminação cênica contemporânea em São Paulo. Monografia (Bolsa de Iniciação Tecnológica - PIC/USP) ECA. São Paulo: USP, 2012.

VALDEZ, Carmen. O espectador como bricoleur na cena contemporânea: uma nova estrutura de comunicação. In Cadernos Virtuais de Pesquisa em Artes Cênicas. Rio de Janeiro: UNIRIO, 2009.

WIENS, Birgit. Luz Criativa - O legado de Appia e as cenografias intermidiáticas de Hotel Pro Forma. Tradução Stephan Baumgärtel. In Urdimento Revista de Estudos em Artes Cênicas, v. 2, n. 23 (Dezembro 2014), p. 219-245. Florianópolis: UDESC, 2014.

WEST, Martha Ullmann. The Light Fantastic - Fuller, Rosenthal \& Tripton: beginning with Loïe Fuller in the $19^{\text {th }}$ century, dance has pioneered the development of $20^{\text {th }}$ century stage lighting. In Dance Magazine 70. $\mathrm{n}^{\circ} .2$ (Fevereiro 1996) p. 88-93. New York: DMF, 1996.

ZUMTHOR, Paul. Performance, Recepção, Leitura. São Paulo: Cosac Naify, 2007. 


\section{ANEXOS}

\section{Entrevistas}

A ideia de entrevistar alguns iluminadores surgiu, principalmente, pelo desejo de entender se as intuições, suposições e investigações teóricas a respeito da performatividade da luz teriam alguma procedência na prática dos iluminadores e nos seus trabalhos criativos. Era importante entender se essas proposições, na grande maioria não mais do que intuições oriundas da minha própria experiência artística, faziam sentido para outros profissionais da iluminação cênica. Buscando objetivar, mas sem direcionar suas respostas ou reflexões, o que poderia muito facilmente acontecer, foram elaboradas, então, questões abertas e gerais sobre a aplicação prática do conceito investigado e, de maneira complementar, a relação particular de cada iluminador entrevistado com a luz e o processo criativo.

Visto que no período de realização das entrevistas eu estava cumprindo meu doutorado sanduiche na França e também, com o objetivo de não exercer influência das minhas próprias opiniões sobre os entrevistados, considerando a minha proximidade com a maioria deles, e permitir uma maior imparcialidade na respostas, outra decisão importante foi solicitar que as entrevistas fossem feitas pela estudante Gabriela Valcanaia ${ }^{224}$. Esse trabalho, além de colaborar para minha pesquisa doutoral, faria também parte de suas próprias pesquisas acadêmicas sobre iluminação cênica, tema recorrente em seus estudos, interesses e recente prática profissional. Na qualidade de pesquisadora, a bolsista também transcreveu as respostas dos entrevistados, cujo material é apresentado nos anexos e em alguns trechos do conteúdo desta tese.

As perguntas para as entrevistas foram elaboradas com o objetivo de abordar os principais conceitos estruturantes da proposta conceitual de

224 Bolsista do PIC - Programa de Iniciação Científica e colaboradora do Projeto de Extensão LABIC - Laboratório de lluminação Cênica na UNESPAR - Campus de Curitiba II - Faculdade de Artes do Paraná. 
performatividade da luz apresentada nesta tese, a saber, a materialidade e imaterialidade da luz, o processo colaborativo de criação do espetáculo teatral, a relação com o espectador e a equipe de criação e, finalmente, a percepção que cada entrevistado tem sobre o tema proposto, a hipótese da ação performativa da luz no teatro contemporâneo.

A seleção dos iluminadores a serem entrevistados foi feita tanto pela relevância quanto pela disponibilidade dos profissionais contatados, o que resultou num panorama bastante amplo, nacionalmente, e um pouco menos no âmbito internacional, mas igualmente muito significativo. As entrevistas foram realizadas por mim e pela Gabriela Valcanaia já ao final do processo de pesquisa da tese, entre os meses de janeiro e abril de 2020, presencial ou virtualmente, por diferentes canais (E-mail, Skype, FaceTime, WhatsApp), conforme a disponibilidade, escolha e preferência das entrevistadoras, das entrevistadas e dos entrevistados.

Além da contribuição, mesmo que ao final do processo de pesquisa e redação da tese, para os conceitos e formulações apresentados e defendidos nesse processo doutoral, o resultado das entrevistas certamente não foi explorado em toda sua potencialidade. Depois da conclusão e defesa do doutorado, o material, muito provavelmente subutilizado neste contexto, certamente ainda poderá ser explorado e utilizado em outros estudos, pesquisas e investigações. 


\subsection{Questionário em Português}

\section{Sobre a Luz}

Como conceito, sem reflexões técnicas ou científicas, você considera que a luz seja material ou imaterial? Você saberia explicar a sua resposta?

\section{Sobre o processo criativo}

Você costuma trabalhar mais com a mesma companhia e o mesmo diretor ou varia? O que você pensa a respeito disso, você acha importante estabelecer uma relação mais próxima com o dramaturgo e encenador do espetáculo que vai iluminar ou até mesmo com todo o grupo e equipe de criação para criar a luz? Faz diferença no processo criativo trabalhar sempre com a mesma pessoa ou com pessoas diferentes a cada vez?

Qual a tua maior preocupação no momento de criação, a quem você dá mais atenção, o diretor ou dramaturgo, o ator em cena ou o espectador?

\section{Performatividade da Luz}

A pesquisadora deste trabalho defende, como resultado de suas pesquisas práticas como iluminadora e reflexivas como pesquisadora, que a iluminação cênica tem uma participação ativa na cena teatral, assim como em outras formas das artes cênicas como a música, a dança, entre outras. Com isso ela afirma que a luz atua, age em cena e interage com os demais componentes do espetáculo e também com o público, tendo a importante função de estabelecer e favorecer a relação entre o palco e plateia. Você concorda ou discorda dessa afirmação?

\section{Por quê?}

Você saberia dar alguns exemplos dessa atuação da luz no seu próprio trabalho? Pode ser um projeto inteiro ou alguns efeitos específicos. 


\subsection{Questionário em Francês}

1. À propos de la lumière et de l'éclairage, considérez-vous que la lumière scénique soit matérielle ou immatérielle?

Pourriez-vous expliquer votre réponse?

2. À propos de votre processus créatif, travaillez-vous généralement avec la même compagnie ou metteur-en-scène ?

Quelle est l'aspect le plus importante à considérer, à ton avis, pour la création lumière : les désirs du réalisateur, metteur-en-scène ou dramaturge, les besoins de l'acteur ou de la scène, ou le point de vue du spectateur?

3. La chercheuse de ce travail soutient, à la suite de ses recherches pratiques comme créatrice lumière et réflexives en tant que chercheuse, que l'éclairage scénique participe activement à la scène théâtrale et également à d'autres formes d'arts du spectacle comme la performance, la musique, la danse, entre autres. Dans ce sens-là, elle propose que la lumière performe, agit sur la scène et interagit avec les autres composants du spectacle ainsi qu'avec le public, ayant la fonction importante d'établir et favoriser la relation entre la scène et le spectateur.

Êtes-vous d'accord avec cette opinion ? Pourquoi ?

Pourriez-vous donner un ou plusieurs exemples de cette performance de la lumière dans votre travail créatif ? Cela peut être un projet ou réalisation lumière entière pour une pièce ou spectacle ou des effets spécifiques, des scènes isolées. 


\subsection{Questionário em Italiano}

1. Quando si tratta di luce e illuminazione, lei considera la luce di scena come materiale o immateriale?

Perché?

2. Per quanto riguarda il suo processo creativo, di solito lavora con la stessa compagnia o con lo stesso direttore?

A chi è diretta la sua luce? Alla volontà del regista, alle esigenze degli interpreti o allo sguardo dello spettatore?

3. La ricercatrice Nadia Luciani sostiene, come risultato della sua pratica e dei suoi studi, che l'illuminazione del palcoscenico ha un ruolo attivo nella scena teatrale (cosi come nelle altre forme di arti performative come la musica, la danza, tra le altre). Con questo afferma che la luce agisce, agisce sul palcoscenico e interagisce con le altre componenti dello spettacolo e con il pubblico, avendo l'importante funzione di stabilire e favorire il rapporto tra il palcoscenico e il pubblico.

Lei è d'accordo con questa opinione? Perché?

Potrebbe fare uno o alcuni esempi di questa performance della luce nel suo lavoro creativo? Può essere un intero progetto o uno o più effetti specifici. 


\section{Iluminadores Entrevistados - Biografias 225}

\section{Alessandra Domingues (São Paulo)}

lluminadora e Artista Visual, Alessandra realiza instalações site specific, nas quais se apropria da luz como linguagem. Em paralelo, cria projetos de luz para espetáculos de teatro, dança, shows de música e exposições. É artista cofundadora, com Cibele Forjaz, da Cia. Livre de Teatro e colaboradora da SP Escola de Teatro desde 2010. Realizou diversas exposições individuais e coletivas no Brasil e no exterior. Recebeu vários prêmios por suas criações teatrais. Fez residências artísticas no Experiência 2012 (Itaú Cultural, São Paulo, 2012) e no Red Bull Station (São Paulo, 2013-2014). Atualmente é mestranda em Artes Cênicas no PPGAC da Escola de Comunicação em Artes da USP com pesquisa voltada para a iluminação no teatro e nas artes visuais.

\section{Aurélio de Simoni (Rio de Janeiro)}

lluminador da primeira geração que firma o crédito de iluminador nas fichas técnicas dos espetáculos profissionais, realizou uma centena de projetos de iluminação para diretores brasileiros representativos. Atuando inicialmente como operador de luz, fez assistências de iluminação com Jorginho de Carvalho e assina seu primeiro trabalho em 1979, em Ponto de Partida, de Gianfrancesco Guarnieri e, em seguida, As Preciosas Ridículas, de Molière. A partir de 1980, estabelece uma parceria com Luiz Paulo Nenen, com quem cria e realiza a iluminação de uma média de oito espetáculos por ano até 1984, entre eles: Poleiro dos Anjos, de Buza Ferraz, 1981; Serafim Ponte Grande, de Oswald de Andrade (1890 - 1954), As Lágrimas Amargas de Petra von Kant, de Fassbinder, em 1982; Viúva, porém Honesta, de Nelson Rodrigues e A Terra dos Meninos iluminadores entrevistados foram consultados a respeito de seus conteúdos. 
Pelados, adaptação da obra de Graciliano Ramos, em 1983; Ensaio $n^{\circ} 1$ e $A$ Tragédia Brasileira, de Sérgio Sant'Anna, 1984, ambas direções de Bia Lessa. Em 1982, a dupla de iluminadores recebe o Troféu Mambembe pelo conjunto de trabalhos.

A partir de 1984, passa a trabalhar sozinho, realizando a iluminação para os espetáculos Emily com direção de Miguel Falabella em 1984; Galileu Galilei, de Bertolt Brecht, direção de Celso Nunes em 1987; A Caravana da llusão com direção de Luiz Arthur Nunes em 1993; Sermão da Quarta-Feira de Cinzas com direção de Moacir Chaves em 1994; Lima Barreto ao Terceiro Dia com direção de Aderbal Freire Filho em 1995; Noite de Reis com direção de Amir Haddad, 1997; entre outros. Em 2001 retoma a parceria com Luiz Paulo Nenen em Cócegas, de Ingrid Guimarães e Heloisa Périssé. Com diversos prêmios em teatro adulto e infantil, inclusive o Prêmio Shell por diversos espetáculos adultos, entre eles por Don Juan, de Molière, com direção de Moacir Chaves, com quem estabelece parcerias constantes a exemplo de Inutilezas, textos do poeta Manoel de Barros e Por Mares Nunca Dantes, de Geraldo Carneiro, ambas em 2002 e, no ano seguinte, Fausto, de Goethe, e Violência da Cidade. Em 2003, faz a luz para o grupo Intrépida Trupe, em Sonhos de Einstein.

\section{Beto Bruel - Sutil Companhia de Teatro / Felipe Hirsh (Curitiba)}

Luiz Roberto Bruel nasceu em 1950 na cidade paranaense da Lapa e iniciou sua carreira de iluminador por acaso, em 1971, quando foi convocado pelos colegas do Colégio Estadual do Paraná, em Curitiba, para fazer a iluminação de uma peça teatral. Passou a integrar o Grupo Margem de Teatro Experimental, dirigido por Manoel Carlos Karam em 1973 no Teatro de Bolso. Seu primeiro trabalho profissional foi com o Grupo Momento, na peça Marat Sade, sob a direção de Oraci Gemba. Com uma carreira proeminente na iluminação teatral, tendo iluminado vários atores renomados como Fernanda Montenegro, Paulo Autran, Marco Nanini, Caetano Veloso e Roberto Carlos, Bruel revela-se um verdadeiro artista da luz, com trabalhos com os mais 
importantes diretores, artistas e companhias de teatro e dança brasileiras. Depois de trabalhar por muito tempo pelos teatros paranaenses, Bruel finalmente extrapolou as fronteiras do estado e passou a iluminar peças de teatro, shows, óperas e espetáculos de dança também em São Paulo e no Rio. Em parcerias duradoras com diretores como Marcelo Marchioro, Edson Bueno, Fatima Ortiz e Felipe Hirsch, realizou projetos para 128 diretores diferentes e acumulou mais de 30 prêmios, entre eles o Prêmio Gralha Azul, do teatro paranaense, o Prêmio Shell, a nível Nacional e o Prêmio mundial do WSD - World Stage Design de melhor iluminação, conquistado em 2009. Com incontáveis projetos realizados, entre peças, shows, óperas, desfiles, concertos, balés e exposições, seus trabalhos recentes mais representativos são as peças $O$ Homem que amava a literatura com direção de Edson Bueno, Mãe Coragem com direção de Daniela Thomas, A pequena abelha e a árvore alta com direção de Ana Rosa Tezza e Antes que a derradeira noite se espalhe em Latino America de Felipe Hirsch, todas em 2019, os shows de Tributo à Legião Urbana com Wagner Moura, Beijo AA Força e Dafalia e Grupo Fato e as óperas Fidélio, com direção de Christiane Jathay e Orphée, com direção de Felipe Hirsch.

\section{Christine Richier - ENSATT (França)}

Co-diretora, com Thierry Fratissier, do Departamento do Curso de lluminação Cênica da ENSATT - École Supérieur des Arts et Tecniques du Spectacle, onde ensina História da Dramatargia da Luz, Christine Richier é membro da Unité de Recherche Passages XX-XXI, onde desenvolve pesquisas no campo da história e estética do teatro e da iluminação. É autora do livro Le Temps des Flammes: unes histoire de l'éclairage scénique avant I alampe à incandescence, publicado em 2011; do filme Josef Svoboda, Récit d'une Liberté, de 1992, e da Tese de Doutorado, defendida em 2019 na Université Lumière Lyon 2, Josef Svoboda, poète de l'immatériel, e acompanhou o trabalho e a obra de Josef Svoboda de 1986 a 1996, sendo a maior divulgadora de sua obra e pensamento a respeito do teatro, da cenografia e da iluminação, como Coordenadora da Associação Josef Svoboda, pela realizou, na França e em 
outros países, o Svoboda Day, já em sua segunda edição. Christine também é iluminadora e operadora de luz em turnê, profissões que exerceu, principalmente, entre 1980 e 2011, quando passou a dedicar-se integralmente à carreira acadêmica.

\section{Christophe Forey (França)}

lluminador de teatro, dança e ópera. Depois de uma formação na Escola do TNS de Strasbourg nos anos 80 , ele fez a criação de projetos de iluminação para Robert Gironès, Bruno Boëglin, Lucinda Childs, Sylvie Blocher, Moshe Leiser e Patrice Caurier, Lulla Chourlin, Benjamin Dupé, Cédric Dorier, JeanMarc Bourg no Grand Théâtre de Genève, no Scala de Milan, no Festival de Salzbourg, no ROH Covent Garden em Londres, no Théâtre Marinsky de SaintPétersbourg, no Metropolitan Opera de New York e em diversos teatros e óperas em Paris e no Festival d'Avignon.

\section{Claudia de Bem - (Porto Alegre)}

Radicada em São Paulo, iluminadora, artista multimídia, pesquisadora, mestre em artes cênicas e doutoranda na ECA-USP - Universidade de São Paulo desde 2016. Professora no Master BIM: Ferramentas de Gestão e Projeto do Instituto de Pós-graduação - IPOG, professora no Pós Graduação de Design Cenográfico na UFRGS. A sua trajetória artística se configura pela utilização da luz como potência desencadeadora de processos criativos que compartilham o espaço e interpenetram-se de poéticas que dialogam com a luz, assim como com a teatralidade e a performatividade da visualidade.

Desde 2008 têm se dedicado ao estudo da luz nas suas manifestações fenomenológicas estabelecendo um discurso das conexões da luz com o corpo, o cotidiano, a matéria e a natureza. No seu trabalho é notório a revelação de um 
olhar singular onde o ato de criar com luz é contemplar, ver, experimentar e sentir sua presença. Neste contexto, a artista desenha percursos imagéticos.

Durante sua carreira foi agraciada com 10 prêmios nas artes e recebeu 0 Prêmio Destaque Braskem-RS em luz e cenografia em 2015. Artista selecionada para representar o Brasil na Mostra de Países e Regiões nas Edições de 2015 e 2019 da Quadrienal de Praga, na República Tcheca. Como pesquisadora, acompanhou algumas produções do encenador americano Robert Wilson no Brasil (São Paulo e Porto Alegre) e na Argentina (Buenos Aires).

O ineditismo do seu trabalho é um mérito e carrega possibilidades do exercício da criatividade e construção de abordagens estéticas alternativas para os processos artísticos que implicam na visualidade. Atua preferencialmente na área de artes cênicas, visuais e da performance desde 1995.

\section{Cibele Forjaz - Teatro Oficina / Zé Celso Martinez Corrêa (São Paulo)}

Diretora e iluminadora teatral, Cibele Forjaz é graduada em artes cênicas com habilitação em direção teatral (1989) mestre em artes (2008) e doutora em artes cênicas (2013) pela ECA/USP. É docente e pesquisadora do departamento de artes cênicas da ECA/USP desde 2006, onde leciona iluminação e direção teatral, e do PPGAC/ECA/USP desde 2014. Em 30 anos de teatro profissional, participou ativamente de quatro coletivos de teatro: A Barca de Dionísio (1985/91); Teatro Oficina Uzyna Uzona (1992/01); Cia. Livre (desde 1999) e mundana companhia (desde 2008).

No grupo A Barca de Dionísio iluminou Leonce e Lena, de Büchner (1987) e dirigiu, principalmente, O Homem da Flor na Boca, de Pirandello (1988); Noite, de Harold Pinter (1988); e Woyzeck (1991). No Teatro Oficina, foi assistente de direção de Zé Celso e iluminadora (1993/00) tendo feito Ham-Let, Mistérios Gozozos; Bacantes; Pra Dar uma Fim no Juízo de Deus; Ella; Cacilda! e Os Sertões/O Homem 1. É diretora artística do grupo de teatro Cia. Livre, onde dirigiu, entre outros: Toda Nudez Será Castigada, de Nelson Rodrigues (2000/01); Um 
Bonde Chamado Desejo, de Tenesse Williams (2002); Cia. Livre Conta Kaná Kawã (2014/15) e Dostoiévski-Trip (2017), mais alguns espetáculo em parceria criativa entre a Cia. Livre e outras companhias. Com a mundana companhia, dirigiu: O Idiota - Uma Novela Teatral, releitura do romance de Dostoievski (2010/12) e Na Selva das Cidades, de Bertolt Brecht (2014/18).

Ganhou vários prêmios, entre eles, APCA (1989, 1998, 2004 e 2010), Mambembe (1996), Qualidade Brasil (2002), Shell (2004 e 2007) e Prêmio Governador de Estado - teatro (2015). Tem experiência na área de artes, com ênfase em teatro, história, estética e pedagogia da iluminação cênica; direção e encenação teatral; dramaturgia e cena em processo colaborativo; cruzamentos de linguagens do teatro com a dança e as artes plásticas e relações entre as artes cênicas e a antropologia. Realizou um pós-doutorado em Antropologia, na USP, com estudo de campo no Rio Xingu (2018/19).

\section{Eduardo Tudella - UFBA (Salvador)}

Começou seus estudos na Escola de Teatro da Universidade Federal da Bahia (UFBA) em 1976, cursando Direção Teatral. Depois da graduação, seguiu para a Universidade Federal do Rio de Janeiro (UFRJ) onde iniciou, em 1980, o Bacharelado em Artes Cênicas, habilitação em Cenografia, retornando a Salvador depois da sua conclusão em 1983. Em 1990 transferiu-se para os EUA a fim de cursar o mestrado na Tish School of the Arts, da New York University, recebendo o grau de Mestre das Belas Artes em MFA/Theatre Lighting Design em 1993. Retornando ao Brasil no mesmo ano, ingressou como docente na Escola de Teatro da UFBA. Defendeu sua tese de doutorado em 2013, tendo sido laureado no ano seguinte com o Prêmio Capes de Tese. Sua carreira acadêmica vem sendo acompanhada de extenso trabalho como designer, tendo atuado em dezenas de espetáculos. Recebeu o Prêmio Braskem em 2013 pelo projeto de luz para Longa Jornada Noite Adentro, direção de Harildo Déda e o Prêmio Cenym em 2014 pelo projeto de luz para Quarteto, direção de Gil Vicente Tavares. 


\section{Elsa Revol - Théâtre du Soleil (França)}

Elsa Revol cria luzes para teatro, ópera, circo, magia, campos tão diversos que enriquecem suas colaborações e encontros artísticos. No teatro, seus principais encontros foram com Ariane Mnouchkine, Galin Stoev e, recentemente, Wajdi Mouawad. Foi em 2007 que Elsa Revol se juntou ao Théâtre du Soleil para suas criações e turnês internacionais. Ela assinoiu as luzes de Os Náufragos de Fol Espoir, uma criação coletiva (2010) e Macbeth de Shakespeare, dirigida por Ariane Mnouchkine (2014). Por fim, acompanha a criação da iluminação de Une Chambre en Inde (2016). Com Galin Stoev, ela trabalhará pela primeira vez com a Comédie-Française em 2011, criando as luzes do Jeu de l'amour et du hasard de Marivaux. Com o mesmo diretor faz Tartuffe de Molière (2014). Em seguida ilumina Othello de Shakespeare para Léonie Simaga (2014) e Faust, dirigido por Valentine Losseau e Raphaël Navarro (2018) no Théâtre du Vieux-Colombier. Sua colaboração artística com Galin Stoev continua com outra peça de Marivaux, Le Triomphe de l'Amour (TGP 2013) e, em seguida, com a ópera Le Nozze di Figaro de Mozart (2015), Les Gens d'Oz de Yana Borissova, espetáculo para o qual ela também assina o vídeo (Théâtre National de la Colline, 2016) e Insoutenables Longues Etreintes de Yvan Viripaev criado no Théâtre de la Cité em Toulouse (2018). Elsa conhece Wajdi Mouawad durante a criação de Fauves (2019).

Desde 2009, Elsa Revol desenvolve uma pesquisa sobre a iluminação para espetáculos de Magie Nouvelle. Nesta linguagem, ela iluminou dois espetáculos de Etienne Saglio, Le Soir des Monstres (2009) e Les Limbes (2014), bem como Le Syndrome de Cassandre por Yann Frisch (2015) e, recentemente, Wade in the water para a companhia 14:20 (2016), bem como Der Freischutz, uma ópera encenada pela companhia 14h20 e dirigida por Laurence Equilbey. Essas várias colaborações e pesquisas são realizadas por meio de intervenções no CNAC (Centro Nacional de Artes do Circo) e na ENSATT (Escola Nacional de Artes e Técnicas do Espetáculo). Ela faz frequentes consultorias para o Cirque du Soleil sobre iluminação de efeitos de 
magia usados em seus espetáculos. As relações entre o visível e o invisível, os limites do perceptível, a temporalidade luminosa, são tanto aspectos de trabalho para Elsa Revol em suas criações de luz quanto o são para o teatro, o circo, a ópera, a magia ou as performances.

\section{Eric Soyer - Compagnie Louis Brouillard - Joël Pommerat (França)}

Eric Soyer compartilha processos de escritas cênicas com diversos criadores, diretores, coreógrafos e compositores nos palcos internacionais como Théo Mercier, Thierry Thieu Niang, Nacera Belaza, Ondrej Adameck, Sulayman Al Bassam, Angelin Preljocaj, Maud Le Pladec, Philippe Saire, Sylvain Maurice, Amir Koohestani reza, Jeanne Added, Jean Paul Gaultier, Zhao Miao, Phia Ménard, Joss De Paw, Abderrahmane Sissakom entre outros.

Em 1997 deu início a uma colaboração com o escritor e diretor Joel Pommerat em torno da criação de um repertório de vinte espetáculos da Compagnie Louis Brouillard e quatro óperas contemporâneas para o Festival de Aix, o teatro de La Monnaie e a Ópera Cômica. Recebeu o prêmio da crítica jornalística francesa pelo seu trabalho em 2008 e em 2012 e o Prêmio Molière pelo espetáculo Cendrillon (Cinderela) em 2017.

\section{Fabrizio Crisafulli - Companhia II Pudore Bene in Vista (Itália)}

Fabrizio Crisafulli é diretor de teatro e artista visual. Ele dirige a companhia II Pudore Bene in Vista, que ele fundou em 1991. Os aspectos particulares do seu trabalho são a utilização da luz como sujeito autônomo de construção poética e o teatro de lugar (considerando o lugar como "texto" e matriz da obra). Ele é também professor no DAMS de Roma e recebeu recentemente os seguintes prêmios: Doutorado Honoris Causa em Performance Design na Universidade de Roskilde, na Dinamarca (2015), Prêmio da Crítica da Association Nationale des Critiques de Théâtre da Italia (2016). 
Monografias consagradas à sua obra: S. Lux ((editado por), Lingua Stellare. II teatro di Fabrizio Crisafulli 1991-2002; un teatro dell'essere, Editoria \& Spettacolo, Roma, 2010; N. Tomasevic (editado por), Place, Body, Light. The Theatre of Fabrizio Crisafulli, Artdigiland, Dublin, 2013. Entre suas publicações estão: Luce attiva. Questioni della luce nel teatro contemporaneo, Titivillus, Corazzano (PI), 2007; Lumière Active. Poétiques de la lumière dans le théatre contemporain, Art Digilan, 2019; Il teatro dei luoghi. Lo spettacolo generato dalla realtà, Artdigiland, Dublin, 2015.

\section{Gianni Staropoli (Itália)}

Em 1997 depois da formação ENAIP como técnico de iluminação, colaborou com o poeta, diretor e ator Marcello Sambati - Dark Camera Companhia protagonista da vanguarda em Roma nos anos 70. Até 2002 trabalhou no Teatro Furio Camillo de Roma. Em 2003 iniciou um novo percurso de estudo e pesquisa sobre a luz e o espaço enquanto elementos coessenciais e construtivos da linguagem teatral, colaborando com diferentes grupos, diretores e coreógrafos: Marcello Sambati, Silvia Rampelli, Veronica Cruciani, Alessandra Cristiani, Lucia Calamaro, M. Belani, C. Baglioni, Biancofango, Deflorian/Tegliarini, Massimiliano Civica, Cristina Rizzo, Enzo Cosimi, Jacopo Gassman, Ascanio Celestini, Roberto Paci Dalò, Roberto Latini, Maurizio Smidht e Micrologus Ensamble, Filippo Timi, Yoko Muronoi, Companhia Caracalla Dance Theatre - Orchestra Sinfonica del Libano, Francesca Comencini, entre outros. Em 2013, na equipe do projeto My Day May Day realizou a instalação luminosa Flash Back na área subterrânea do Teatro Argentina em Roma.

Colabora atualmente de forma contínua com diversos diretores e coreógrafos, em produções italianas e internacionais, e mantém laboratórios universitários e para profissionais sobre a luz em sua relação com o espaço no teatro contemporâneo. A partis de março de 2020 estará encarregado de dar aulas na Accademia Nazionale Silvio D'Amico em Roma. Foi contemplado recentemente com os prêmios Ubu de melhor iluminação pelos espetáculos II 
Cielo non è Fondale em 2017 e Casi Niente em 2019, ambos com a direção de Deflorian/Tegliarini.

\section{Guilherme Bonfanti - Teatro da Vertigem (São Paulo)}

Guilherme Bonfanti Piedade, de nome artístico Guilherme Bonfanti, nasce em Leme - SP, em 11 de novembro de 1956. Light Designer, é com Antonio Araújo um dos fundadores do Teatro da Vertigem e coordenador e um dos fundadores do curso de lluminação da SP Escola de Teatro. Atua, desde 1987, em diversos projetos de artes visuais, arquitetura, mostras e exposições, moda, eventos profissionais e corporativos. Iniciou a carreira como técnico de luz no Espaço Off, casa noturna de Celso Curi, em São Paulo, centro difusor de arte experimental do período, atuando em dezenas de realizações.

Em 1990, faz o desenho de luz para Oberöstesseich e Hiperbórea, dois espetáculos de Antônio Araújo e, em 1992, fundam o Teatro da Vertigem com Paraíso Perdido, uma parceria duradoura que ainda hoje rende bons frutos artísticos. Além de luz para teatro, dança, shows e musicais, fez projetos de iluminação para a XXIII, XXIV, XXV, XXVI Bienais Internacionais de São Paulo e a Mostra dos 500 anos, projetando e coordenando todo o projeto técnico das exposições.

\section{Jorginho de Carvalho (Rio de Janeiro)}

Jorge Carvalho Moreira, em artes Jorginho de Carvalho, iniciou seus estudos do "fazer teatral" em 1960 no teatro amador "O Tablado" por conta da Bolsa de Estudos integral que Maria Clara Machado, tornando-se contrarregra em 1962 e começando a trabalhar com iluminação em seguida. Seu primeiro desenho de luz para o texto inédito "Androcles e o Leão" que Maria Clara Machado entregou para uma turma de alunos em 1966. Hoje Jorginho é um iluminador reconhecido com um currículo com mais de 600 "desenhos de luz" realizados nos últimos 50 anos para espetáculos de teatro, ópera, dança, shows, 
desfiles de moda e exposições. É também responsável pela criação e execução de diversos projetos de iluminação cênica para teatros e museus no Brasil. Segundo lan Michalski226, Jorginho "é o indiscutível pioneiro da iluminação moderna no Brasil [...] Ao impor sua autonomia, [...] ele engrandeceu o papel da luz na encenação e enriqueceu substancialmente a linguagem cênica do teatro nacional".

Participou da criação dos estatutos da Lei que Regulamentou a Profissão do Artista no Brasil como responsável pela área de lluminação Cênica quando fez parte da Diretoria do SATED cujo Presidente era o Ator Otávio Augusto. Em 1987 recebeu o título de Notório Saber em lluminação Cênica e foi nomeado professor no departamento de cenografia da UNIRIO. Em 1996, criou uma disciplina na qual os alunos são responsáveis pela criação de luz das Práticas de Montagens. Refez as ementas, os objetivos e atualizou a bibliografia das três disciplinas de Iluminação Cênica e, por fim, desenvolveu novos conteúdos programáticos elaborando também as apostilas usadas.

Foi agraciado com vários prêmios, tais como Troféu Mambembe, APCA e Molière (teatro adulto) e Coca-Cola, Maria Clara Machado e Zilka Sallaberry (teatro infanto-juvenil), além de outros prêmios em Belo Horizonte (MG), Porto Alegre e Pelotas (RS) e Salvador (BA). Em 1977, ganhou o primeiro Molière, específico para lluminação. A partir daí, a categoria de lluminação passou a ter um vencedor todo ano. Nos anos 2009 e 2010 foi um dos cinco jurados do Prêmio Shell de Teatro do Rio de Janeiro.

Em 2012, foi homenageado na Exposição Iluminando o futuro - 50 anos de Jorginho de Carvalho e fez o desenho de luz de vários espetáculos, dentre eles Três Noites a Caminho do Mar, que Hamilton Vaz Pereira criou para a reinauguração do Teatro Ipanema. Fez também a ópera Rigoletto, de Giuseppe Verdi, no Teatro Municipal do Rio de Janeiro com Direção de Pier Maestrini.

226 Pequena Enciclopédia do Teatro Brasileiro contemporâneo, elaborada em projeto para o CNPq. Rio de Janeiro, 1989. 
Iniciou 2013 fazendo o desenho de luz para o espetáculo Ary Barroso do princípio ao fim, musical de Diogo Vilela, no Teatro Carlos Gomes. Na comemoração de 20 anos da Cia de Dança Deborah Colker, fez o desenho de luz para Velox-2013 e para Nó. Terminou o ano com o desenho de luz para Sonhos de um Sedutor, com Luana Piovani, no Teatro Ipanema. Em 2014 fez o desenho de luz de Belle, novo espetáculo de dança de Deborah Colker. Em março de 2015, foi escolhido para ser o artista homenageado do ano do Prêmio Shell pelos relevantes serviços prestados ao Teatro do Rio de Janeiro por mais de 4 décadas. Em dezembro do mesmo ano fez o desenho de luz da ópera Menino Maluquinho, de Ziraldo, com direção de Sura Berditchevsky.

\section{Lucas Amado (Curitiba)}

Lucas Amado começou sua carreira no teatro em 1998, como ator da Cia Luiz Carlos Arutim em Barretos. Logo foi para São José do Rio Preto, para fazer parte de o grupo de teatro itinerante Fábrica de Sonhos, na qual desempenhou, entre 2004 a 2007, diversas funções, dentre elas, a iluminação. Em 2008 mudouse para Curitiba e começou a trabalhar como iluminador com alguns grupos da cidade como o Grupo Obragem, Antropofocus, Cia do Abração, Companhia Bife Seco, Setra Cia de Teatro e Tecer Teatro, com os quais ainda mantém vínculos de trabalho.

Em dança, criou a iluminação de vários espetáculos, trabalhando em parceria com Michele Moura, Marila Velloso, Luciana Navarro, Rosemeri Rocha, Loa Campos, e também com a DesCompanhia de Dança e o Coletivo Batton. É também iluminador de algumas bandas e grupos musicais, dentre eles Siricutico, Lemoskine, Trombone de Frutas, Trio Quintina, Melina Mulazani, Janaina Fellini, Sofia Oliveira, Mariá Sallum, Machete Bomb, Central Sistema de Som, Tuyo, Mulamba, Mumbai.

Nos últimos oito anos foi iluminador do palco principal do Festival Psicodália, iluminando shows de artistas brasileiros como Tom Zé, Hermeto 
Pascoal, Mutantes, Moraes Moreira, Cidadão Instigado, Metá Metá, e internacionais como Going, John Kay e Steppenwolf, além de fazer as produções técnicas para os festivais Som do Arame, FIMS, Mostra Espetacular e Novos Repertórios de Curitiba. Criou o escritório Espaço Criação Luz, onde desenvolve pesquisas voltadas para iluminação cênica, tanto para o teatro e a dança, como para shows e performances. Em 2012 recebeu o prêmio Gralha Azul pela iluminação do espetáculo As Tramóias de José na Cidade Labiríntica, do grupo Obragem. Em 2018 foi indicado para o prêmio Gralha Azul pelos espetáculos Criânsia e Airbag da Processo Multiartes, recebendo o prêmio por Airbag.

\section{Marisa Bentivegna (São Paulo)}

lluminadora e cenógrafa paulistana, estreou no Teatro profissional em 1990. Formada na Fundação Armando Alvares Penteado - FAAP - em Publicidade e Propaganda e na Escola de Belas Artes de São Paulo no curso de Desenho Industrial. Atualmente é integrante da Companhia Hiato, dirigida por Leonardo Moreira, como cenógrafa e iluminadora, e no ano de 2015 teve um cenário criado para esta companhia para o espetáculo 0 Jardim, selecionado para representar o Brasil na Quadrienal de Praga na República Tcheca. Também é integrante da Banda Mirim como diretora técnica, cenógrafa e iluminadora desde 2004, coletivo premiado em 2015 com o Prêmio Governador do Estado na categoria Arte para Crianças. Tem ainda como parceiros de criação os diretores Cristiane Paoli Quito, Nelson Baskerville, Marcelo Romagnoli e Kiko Marques, entre outros.

Em 2019 foi uma das dez artistas a representar o Brasil na Quadrienal de Praga com o cenário do espetáculo Enquanto Ela Dormia. Atua em teatro, dança, exposições e shows musicais, tendo trabalhado em mais de 20 países nas últimas décadas. Recebeu os seguintes prêmios individuais: Shell 1992 e APCA 1992 pela iluminação de O Paraíso Perdido, do Teatro da Vertigem; APCA 2007 e Coca-Cola FEMSA 2008 pelo cenário de O Menino Teresa, da Banda Mirim; Coca-Cola FEMSA 2007 pela iluminação de O Tesouro de Balacobaco, da 
Bendita Trupe; Shell 2010 pelo cenário de Escuro, da companhia Hiato; FITA 2011 - Festa Internacional de Teatro de Angra - pela iluminação de Música para Cortar os Pulsos, de Rafael Gomes; Shell 2011 pelo cenário de O Jardim, da Companhia Hiato; APCA 2017 pelo conjunto dos trabalhos criados para teatro infanto-juvenil naquele ano; Prêmio São Paulo de Incentivo ao Teatro Infantil e Jovem 2017 pelos cenários dos espetáculos Buda, Gagá e Skellig; Shell 2018 pela cenografia do espetáculo Os Três Mundos.

\section{Nadja Naira - companhia brasileira / Marcio Abreu (Curitiba)}

Iluminadora, diretora teatral e atriz, formada pelo Curso Superior de Artes Cênicas - PUC/PR e Centro Cultural Teatro Guaíra em 1993. Integra a companhia brasileira de teatro desde 2002, tendo participado todas as suas produções. Trabalha há mais de 25 anos com importantes diretores de teatro e com companhias de dança e tem diversos trabalhos em música, como óperas, shows de MPB e concertos. Recebeu diversas indicações a prêmios e em 2015 recebeu o Prêmio APTR e o Prêmio Questão de Crítica de melhor iluminação pelo espetáculo Krum. Em 2012 recebeu o Prêmio Shell RJ de melhor iluminação pelo espetáculo Esta Criança. Recebeu o Prêmio Governador do Estado PR Troféu Gralha Azul de melhor iluminação em 2000, 1999 e 1998 e o Prêmio Café do Teatro Curitiba PR- Troféu Poty Lazarotto em 1999 e 2001. Em 2015, participou da equipe da representação brasileira para a Seção dos Países e Regiões da Quadrienal de Praga (Espaço e Design da Performance) com trabalhos sobre as peças Nômades e Esta Criança.

Como diretora realizou: Bem-vindos à espécie humana (2019), Mesmas coisas (2017), A cidade sem mar (2016), com textos de Manoel Carlos Karam e A Viagem (2009), ambas em co-direção com Giovana Soar; Mar Paraguayo (2015) de Wilson Bueno; Bolacha Maria (2008), com textos de Manoel Carlos Karam; Os Leões (2006), de Pablo Miguel de la Vega y Mendoza. Dirigiu e adaptou textos para leituras dramáticas: Sabor Brasilis Cena HQ (2014), Mar Paraguayo (2008) de Wilson Bueno, Encrenca (2007) e outros textos de Manoel 
Carlos Karam. Como atriz, participou recentemente dos trabalhos da companhia brasileira de teatro em: Preto (2017), Projeto Brasil (2015), Nus ferozes e antropófagos (2014), Isso te interessa? (2011), Vida (2010), Distraits Nous Vaincrons (2010), Descartes Com Lentes (2009), Polifonias, (2006), Suíte 1 (2004). E ainda tem em seu histórico: A Volta ao Lar (2001), de Harold Pinter, direção de Sílvia Monteiro; Trecentina 500 (1999), texto de Mário Schoemberger e Enéas Lour, direção de João Luiz Fiani; A menina que pisou no pão (1999), texto e direção de Eugenio Gielow; O Dedo Volúvel do Destino (1995), texto e direção de Cleide Piasecki; O Vampiro e a Polaquinha (1995), de Dalton Trevisan, direção de Ademar Guerra.

Em 2010 participou do Projeto Ciclo de Obras Completas da FCC, lendo a obra do escritor Manoel Carlos Karam. Em 2012 no mesmo projeto leu a obra de Helena Kolody. Desde 2014, em parceria com a companhia brasileira de teatro, desenvolve projetos de leitura de autores brasileiros.

\section{Pasquale Mari (Itália)}

As pesquisas de Pasquale Mari dedicadas à imagem se situam na fronteira entre o cinema e o teatro desde a fundação, em Nápoles, em 1979 e em 1986 das companhias Falso Movimento e Teatri Uniti, respectivamente. Entre as obras líricas mais recentes, é possível citar o díptico Sancta Susanna / Cavalleria Rusticana na Opéra de la Bastille de Paris em novembro de 2016, a inauguração em 2017 da temporada do Teatro Scala di Milano com Andrea Chénier, o Falstaff du Staatsoper Berlin dirigido por Daniel Barenboim em 2018, Kovanchina no Teatro Scala di Milano, dirigido por Valeri Gergev em 2019. Entre suas obras cinematográficas mais importantes estão /l verificatore (1995) de Stefano Incerti (David di Donatello opera prima), Hammam (1996), HaremSuare (1998 - Globo de Ouro de Melhor Fotografia), Le Fate Ignoranti (2001) de Ferzan Ozpetek, Teatro di Guerra (1999) de Mario Martone, L'uomo in più (2001) de Paolo Sorrentino, L'Ora di religione (Cannes 2002), Buongiorno, Notte (Venise 
2005) e Il regista di matrimoni (Cannes 2006) de Marco Bellocchio (Globo de Ouro de Melhor Fotografia).

\section{Paulo Cesar Medeiros (Rio de Janeiro)}

Iluminador carioca com 35 anos de carreira, 101 indicações para Prêmios de Teatro e 21 prêmios recebidos. Entre eles, cinco Prêmios Shell, três APTRs, um Bibi Ferreira, um Aplauso, dois CEBETIJ, um Zilka Salaberry, um Reverência, um Sated, um Femsa, dois Coca Cola de Teatro Infanto-Juvenil, entre outros. Trabalhou ao lado de importantes diretores como Bibi Ferreira, Marília Pera, Sérgio Britto, Ítalo Rossi, Miguel Falabella, Charles Moeller e Cláudio Botelho, Gilberto Gawronski, Flávio Marinho, Marco Nanini, Hector Babenco, Amir Haddad, Fauzi Arap, Aderbal Freire Filho, Domingos de Oliveira, José Possi Neto, João Falcão, Rodrigo Portela, Ivan Sugahara e muitos outros. Esteve ao lado de coreógrafos como Luiz Arrieta, Dani Lima, Márcia Háiddé, Dalal Aschcar, Renato Vieira, Márcia Rubim, André Mesquita, Ana Vitória, entre outros. Com algo em torno de 1200 projetos de luz realizados, é sócio fundador da empresa de luz Art Light. Sua formação acadêmica inclui a graduação em Comunicação pela Universidade Gama Filho e Licenciatura em Artes Cênicas pela UniRio. Como formação técnica fez Cursos de Direção de Fotografia com Jorge Monclar e Cursos de Elétrica do Sesi/Senai.

Alguns dos espetáculos que iluminou são: O Futuro Dura Muito Tempo, com direção de Márcio Vianna; O Despertar da Primavera, com direção de Charles Moeller e Cláudio Botelho; A Partilha, com direção de Miguel Falabella; Cabaret, com direção de José Possi Neto; O Jornal, com direção de Kiko Mascarenhas e Lázaro Ramos; Mania de Explicação, com direção de Gabriel Vilela; Show de Maria Bethânia, com direção de Fauzi Arap; A Santa Joana dos Matadouros, com direção de Marina Vianna e Diogo Liberano; Auto de Anjicos, com direção de Amir Haddad; Tim Maia, com direção de João Fonseca; Makurú, com direção de José Mauro Brandt; As Aventuras do Menino Yogi, com direção de Arlindo Lopes e Juliana Terra e Tim Maia, com direção de João Fonseca. 


\section{Renato Machado (Rio de Janeiro)}

Renato Bandeira de Gouvêa Machado possui graduação em Cinema pela Universidade Estácio de Sá (2007), mestrado (2011) e doutorado (2019) em Artes Cênicas pela UNIRIO. Atualmente é professor agregado da Pontifícia Universidade Católica do Rio de Janeiro e da Universidade de Évora (Portugal). Tem experiência na área de Artes, com ênfase em lluminação, atuando principalmente nos seguintes temas: teatro, iluminação.

Como lluminador, trabalha com diversas companhias de teatro, como o Grupo Sobrevento, a Companhia Teatro Autônomo e a Cia. PeQuod de Teatro de Animação, com iluminações cujo estilo se molda ao tema e à linguagem do espetáculo. Faz sua formação técnica como assistente de Aurélio de Simoni e inicia a carreira com a peça Alheamento, ganhando projeção com Os meninos da Rua Paulo, sob a direção de Ricardo Kosovski. No Grupo Sobrevento ilumina Mozart Moments, 1991; Beckett, 1992; O Theatro de Brinquedo, 1993; Ubu, de Alfred Jarry, 1996; Cadê o Meu Herói?, de Horácio Tignanelli, 1998 entre outros.

Em 1992, faz seu primeiro trabalho com o diretor Jefferson Miranda, em Mann na Praia, da Companhia Teatro Autônomo, cujos espetáculos passa a iluminar. O Cemitério dos Vivos, da Luiz Fernando Lobo, em 1993, e A Incrível História do Homem que Bebia Xixi, em 1994, marcam o início de seu vínculo com a Companhia Ensaio Aberto e com a Companhia Dramática de Comédia. Em 1996, a iluminação do espetáculo Tempo de Infância, dirigido por Alice Koenow, Ihe vale o Prêmio Coca-Cola de Teatro Jovem. Entre 1994 e 2002 teve 13 indicações para prêmios de iluminação e, em 2002, recebeu o Prêmio Shell de Teatro por Tereza d'Ávila, a Santa Descalça, de Fidélis Fraga com direção de Luiz Arthur Nunes. Em 2004, recebeu o Prêmio Shell de Teatro por Filme Noir, da Companhia PeQuod, e a avaliação positiva da crítica Barbara Heliodora no jornal $O$ Globo: "Renato Machado também acerta ao iluminar a cena inteira apenas com luz de velas que criam uma atmosfera ao mesmo tempo original e déjà-vu, cheia de referências pop do cinema ou dos quadrinhos". 


\section{Roberto Gill Camargo (São Paulo)}

Nascido Roberto Abdelnur Camargo em Itapetininga, interior de São Paulo, foi para Sorocaba para realizar seus estudos. Interessado na linguagem como sistema de comunicação e produção de signo, fez mestrado em Linguística na PUC de Campinas. Mais tarde, desejando investigar o estudo dos signos em relação com as artes cênicas, concluiu o doutorado em Comunicação e Semiótica na PUC-SP sob a orientação de Helena Katz. Suas experiências com iluminação cênica tiveram início na década de 1980, primeiramente em teatro e dança, se ampliando aos poucos para outras áreas artísticas. Desenvolveu importantes estudos teóricos sobre as funções da iluminação, provenientes da abordagem de uma ampla bibliografia e diferentes autores nacionais e internacionais. Como autor e diretor teatral, iniciou seus trabalhos no final da década de 1960, em companhia de alguns nomes que mais tarde despontariam no teatro e na televisão como Paulo Betti, Eliane Giardini e Neusa Maria Faro. Entre suas publicações recentes estão os livros Função Estética da Luz, publicado pela editora Perspectiva; Conceito de lluminação Cênica; Palco e plateia: um estudo sobre a proxêmica teatral; Sonoplastia no Teatro; e Som e Cena, entre diversos artigos em importantes revistas científicas brasileiras.

\section{Rodrigo Ziolkowski (Curitiba)}

Iniciou sua carreira profissional como iluminador em $1991 \mathrm{com}$ seu primeiro desenho de luz para o espetáculo Valsa do Minuto a convite da atriz Guta Stresser. Depois deste, já assinou mais de 200 projetos. Nesses 29 anos, Rodrigo trabalhou com os principais profissionais de teatro e dança paranaenses e teve importantes intercâmbios com profissionais do cenário nacional como Antônio Abujamra, Ary Fontoura, Charles Möeller, Felipe Hirsch, Gabriel Vilella, Maneco Quinderé, Beto Bruel, Mario Bortoloto e Jean-Jacques Lemêtre. 
Seus principais trabalhos de criação foram Baal Babilônia de Felipe Hirsch em 1993, O Casamento de André Abujamra em 1997, Coincidência de Maurício Vogue em 2003, O Grande Show de Mágica com Maicon Clenk em 2007, Nada a Dizer de Laercio Ruffa em 2012, Circo Urbano de Rafael Camargo em 2015 e os espetáculos O Malefício da Mariposa em 2012, Tchekhov em 2013, Nuon em 2016 e A Pequena Abelha e a Árvore Alta em 2018 para a Ave Lola Produções com direção de Ana Rosa Tezza. Realizou também o projeto de iluminação para a $14^{\mathrm{a}}$ Bienal de Curitiba.

Recebeu o Troféu Gralha Azul em 1993 por Baal Babilônia, em 1997 por O Longo Caminho que vai de Zero a Ene, em 2014 por Tchekhov, em 2016 por Nuon e em 2019 por A Pequena Abelha e a Árvore Alta. Recebeu também o prêmio de melhor iluminação no Festival Isnard Azevedo por Baal Babilônia em 1003 e no Festival Lages por Romeu o Julieta em 2000. Em 2009 o trabalho The Sun is Up foi selecionado para figurar no catálogo World Stage Design e em 2018 foi indicado ao Prêmio Shell com Beto Bruel pela luz do espetáculo Nuon.

\section{Thierry Fratissier - ENSATT (França)}

Thierry Fratissier trabalha há 20 anos como iluminador, primeiro no teatro, depois na ópera e na dança. Suas criações mais recentes são a ópera Mort à Venise, de Vincent Vittoz (2005) e as peças de teatro Push Up de Roland Schimmelpfennig com direção de Gabriel Dufay (2009), Hetero de Denis Lauchaud com direção de Thomas Condemine (2012), Ylajali a partir da obra de Bob Fosse com direção de Gabriel Dufay (2013) e Mickey le Rouge de Tom Robbins com direção de Thomas Condemina (2015). Trabalhou como assistente de Dominique Brouguière e Jean Kalman. Com Dominique Brouguière realizou óperas de Jorge Lavelli e Dominique Pitoiset e diversos espetáculos da Claude Régy, Ypussef Chahine, Patrice Chéreau e a dupla Jérôme Deschamps e Macha Makeieff. Com Jean Kalman trabalhou com Hans Peter Klaus, Peter Brook e a dupla de diretoras Sonia Wieder-Atherton e Sarah Koné. 
O entendimento da iluminação cênica como responsável por unir atores, texto, espaço, música e figurinos em uma arte de intimidade o levou ao estudo de uma "luz e ser vivida" e a um trabalho relacionado com a arquitetura em colaboração com Nathalie Goldberg, cujo trabalho é elaborado pela matéria sensível. Além do seu trabalho artístico, ele atualmente coordena, junto com Christine Richier, o Programa Conception Lumière da ENSATT - École National Supérieur des Arts et Techniques du Spectacle na França.

\section{Wagner Corrêa (Curitiba)}

Wagner Corrêa trabalhar na área da iluminação cênica desde 1998. A partir de 2004, desenvolveu projetos para vários grupos e companhias de Curitiba, entre elas: Cia. do Ator Cômico, Pip Pesquisa em Dança, Selvática Ações Artísticas, Figurino e Cena, Grupo Antropofocus, Cia. Senhas e Vigor Mortis Vídeo, Stage \& Words. Em 2005 e 2006 foi também responsável técnico do Teatro HSBC de Curitiba, concebendo e/ou executando a luz para diversos shows, entre eles, os de Hermeto Pascoal, Duofel, Monica Salmaso, João Bosco e Martnália. Participou, com projetos de iluminação, do Festival de Curitiba (Mostra Oficial e Fringe), Filo - Festival Internacional de Londrina, Festival de Teatro de Recife, Porto Alegre em Cena, Festival do Teatro Brasileiro e FIDAE Festival Internacional de Artes Escenicas do Uruguai.

Indicado oito vezes ao Prêmio Gralha Azul do Teatro Paranaense, foi contemplado com o prêmio em 2011 por Av. Independência 161 - Trilha Sonora para Coisas Irreversíveis da Vigor Mortis em Parceria com a MKF Produções, em 2013 por Dorotéia - Uma Farsa Irresponsável da Santa Produção, em 2014 por Marlon Brando, Whisky, Zumbis e Outros Apocalipses da Vigor Mortis.

Participou do Palco Giratório do Sesc com criações e oficinas de luz em 2015 e 2017. Seus trabalhos mais recentes foram a criação de luz para os espetáculos Hoje é dia de Rock, direção de Gabriel Vilella para o TCP do Teatro Guaira; Viejos de Mi, de Sergio Mercúrio; El Titiretero de Banfield, na Argentina; 
Vigor Mortis Jukebox Vol 1, 2 e 3, da Vigor Mortis; O Massacre dos Anjos, da Cia. Rabiscos; Oco no TUT - UTFPR; Eva - Sem Costelas Frágeis, da Lapso Cia. Cênica. De 2011 a 2019 foi sócio da Trio, empresa de criação e execução de projetos, bem como de ações de formação em iluminação cênica.

\section{Wagner Pinto - Cia de Ópera Seca / Gerald Thomas (São Paulo)}

Lighting designer de refinamento estilístico e aguda precisão no manejo do instrumental, iniciou sua carreira em 1982, no Teatro dos Quatro, no Rio de Janeiro, como assistente de Aurélio de Simoni e Luiz Paulo Nenen. Assinou seu primeiro trabalho em 1984 para o espetáculo Imaculada, de Franco Scaglia, pelo qual recebeu sua primeira indicação como melhor iluminador. Participou das realizações iniciais do Grupo Tapa, Casa de Orestes e O Alienista. Em 1986, fez assistência de luz para o diretor Gerald Thomas e ajudou a fundar a Cia de Ópera Seca. Desta fase se destacam os Prêmios Shell, APETESP, APTA e Mambembe por Trilogia Kafka e o Prêmio Molière por Quatro Vezes Beckett e Quartett. Fez ainda a luz dos prestigiados espetáculos Eletra Com Creta, Navio Fantasma, Uma Metamorfose, Praga, Um Processo, Carmem com Filtro 2 e Meio, Mattogrosso, M.O.R.T.E e The Flash and Crash Days.

Estagiou no Teatro La MaMa e no Metropolitan Ópera House, em NY, entre 1988 e 1990, onde aprimorou suas técnicas de iluminação para Ópera. Trabalhou com Carlota Portella e Milton Dobbin no espetáculo Vacilou Dançou, no Teatro Nelson Rodrigues no Rio de Janeiro. lluminou Orlando para Bia Lessa em 1994 e, neste mesmo ano, ganhou o Prêmio Shell de Iluminação por Penteseléias, com direção Daniela Thomas e Bete Coelho. Em 1997, assinou o desenho de luz do espetáculo $A$ Breve Interrupção do Fim com o Grupo de Dança Primeiro Ato e concepção de Gerald Thomas e Sueli Machado. Entre 1997 e 1998, criou as luzes dos espetáculos Ensaio para Danton, Ensaio Sobre o Latão e Santa Joana dos Matadouros para a Companhia do Latão.

Venceu o prêmio FEMSA de Teatro Infantil e Jovem em 2010 por Quem Tem Medo de Curupira?, de Zeca Baleiro e Débora Dubois. Em 2012 recebeu o 
XV Prêmio Carlos Gomes de Ópera e Música Erudita, por L'Efant et les Sortilèges, do Theatro Municipal de São Paulo com direção cênica de Lívia Sabag. A partir de então assinou o desenho de luz de várias Óperas: Salomé, As Bodas de Figaro, Ifigênia em Táuris, The Turn of the Screw (A Volta do Parafuso), O Rouxinol e A Flauta Mágica para o Theatro Municipal de São Paulo e o Theatro São Pedro; Lohengrin, Debussy L'après-midi avec Mallarm para o Theatro da Paz, em Belém; Madama Butterfly e MacBeth para a Fundação Clóvis Salgado, em Belo Horizonte e Tristão e Isolda para o Theatro Municipal do Rio de Janeiro. Foi vencedor do Prêmio Shell de lluminação pelo espetáculo $A$ Máquina Tchekhov, de Matei Visniec, da Cia A Máquina com direção Denise Winberg e Clara Carvalho em 2016 e pelo espetáculo Dilúvio, de Gerald Thomas em 2018. Criou ainda a iluminação para prestigiadas obras teatrais como $A$ Casa dos Budas Ditosos, No Retrovisor, À Margem da Vida, Renato Russo, o Musical, Jardim das Cerejeiras, Os Imortais e Ponto Morto. Recebeu várias indicações na categoria melhor iluminador nos mais prestigiados prêmios do teatro brasileiro. 


\section{Conteúdo das Entrevistas}

As entrevistas foram realizadas em momentos, locais e formatos diferentes, dada a dificuldade de encontrar presencialmente todos os entrevistados bem como pela escolha particular de alguns deles por determinada forma ou meio, o que resulta em conteúdos diferenciados na configuração, mas todos com o mesmo teor e de igual relevância para a pesquisa.

3.1 Alessandra Domingues - lluminadora Paulistana ${ }^{227}$

1. Como conceito, você considera que a luz seja material ou imaterial? Você saberia explicar a sua resposta?

A.D. - Eu acho que a luz é uma forma de expressão, então ela tem essa particularidade da propriedade de ser as duas coisas, tanto matéria quanto imatéria. Ela é impalpável, ao mesmo tempo que pode ser partícula e pode ser fragmentada e aprisionada. Sobretudo, eu acho que ela é uma forma de expressão. Fico em duvida, às vezes, se ela é uma forma de expressão, porque não é só uma questão de comunicação e a linguagem, às vezes, está restrita à comunicação. Por isso, eu acho que, além de uma linguagem, ela é uma forma de expressão e ela é as duas coisas, matéria e imatéria.

\section{Você costuma trabalhar mais com a mesma companhia ou um} mesmo diretor ou varia?

A.D. - Isso varia. Eu fundei uma companhia, chamada Cia. Livre, na qual eu trabalhei desde o inicio e fiquei por 10 anos. No início, na Cia. Livre, tinha também uma circulação de diretores, a maioria dos projetos foi com a Cibele Forjaz, mas não se restringiu só a ela. Nos últimos anos, eu trabalhei com a Mundana Companhia, que também tem essa fluidez. Eu acho que, sobretudo,

${ }^{227}$ Entrevista realizada por Gabriela Valcanaia via Skype no dia 06 de fevereiro de 2020. 
as pessoas me chamam para um tipo de... meu trabalho é muito ligado ao processo, sou uma iluminadora pesquisadora in loco. Eu acho que essa particularidade de trabalhar em processo.... eu sou uma pessoa que gosto de acompanhar o processo de criação, interfiro no processo de criação e acabo quebrando um pouco as hierarquias. Acho que tem uma coisa ao analisar meu currículo, a maioria dos meus trabalhos não está conformado em palco-plateia, em palco italiano ou elisabetano. Na maioria das vezes em que usamos essa estrutura formal, foi para ser quebrada. Então, também tem também esse knowhow de trabalhar com espaços não convencionais e teatro fora do muro, posso dizer assim. Nos últimos anos, eu tenho trabalhado muito com teatro fora dos muros, fora da caixa cênica.

\section{G.V. - Esses teus trabalhos na Cia. Livre e na Companhia Mundana,} nas quais você ficou mais tempo... Como você sentiu que isso interferia na tua liberdade de propor e no modo como a tua luz se construía coletivamente? Como isso interferia no teu processo criativo?

A.D. - Eu acho que tem uma particularidade dessas duas companhias que, como as criações dos espetáculos, dos projetos, aconteciam com todos os criadores juntos, não existiu muita separação nos momentos de criação. Eu acho que no campo da criação, nessas duas companhias... ...no campo das ideias, todo mundo interfere muito no trabalho um do outro e acaba expandindo da própria coisa em si. Claro que a responsabilidade de fazer a luz era sempre minha, as decisões finais sobre qual tipo de equipamento, como essa luz ia acontecer, sempre foi minha. Claro que em conjunção e acordo com toda a equipe. O que eu sinto, principalmente na Mundana, é que existe essa quebra de hierarquia em todo projeto, então, apesar de eu ter a responsabilidade com a luz, as pessoas têm essa liberdade de propor coisas, assim como eu tenho de propor coisas. Isso é uma prática que me acompanha muito na minha carreira como iluminadora... Na minha trajetória, eu criei projetos ou mesmo luzes que eram lidas pelas pessoas como cenografia e não como iluminação. Acho que essas companhias, sobretudo, me permitem exercer um pensamento de luz, onde nem sempre o resultado formal é uma fonte de luz em si, mas, por exemplo, 
eu penso no objeto que vai receber essa luz, porque eu desejo que aconteçam $x$ coisas em relação à luz que vai bater ali, então o fato de eu sugerir um material, é um pensamento de luz, que não resulta necessariamente em fonte de luz. Então, eu acho que essas companhias têm essa coisa em comum, cada uma com as suas particularidades. A Mundana, nos últimos anos, foi muito mais hibrida nesse sentido. Nós fizemos um projeto que se chama Máquinas, no qual não existe a figura do diretor-encenador... É só a equipe de arte com os atores e todo o suporte que um espetáculo precisa, mas, realmente, as coisas iam se dando em razão das propostas. São companhias onde eu posso exercer um pensamento de luz, não me restringindo somente a um tipo de luz que vai acontecer. Por exemplo, eu usei fumaça vermelha, que não é luz, mas eu usei durante o dia porque eu queria um ambiente vermelho. Um objeto que solta fumaça vermelha na mão de um ator, como você nomeia isso? Isso é luz? Isso é cenografia? Isso é um objeto? Isso é direção de arte? O que é isso? E isso veio de um pensamento de luz, está no meu rider de luz. Então, esse privilégio de trabalhar com companhias, com esse tipo de projeto, não só essas duas companhias, mas, como eu já disse, eu acabo sendo chamada para projetos que permitem e que querem esse tipo de contribuição, ou melhor dizendo, de construir juntos. Acho que é isso.

\section{G.V. - Você disse que tem sido chamada para um tipo de trabalho que tem a ver com o teu histórico de projetos e portfólio... Você sente diferença de trabalhar em companhias com esse tipo de processo que você acabou de me contar e em outros projetos? Você sente que consegue exercer esse pensamento de luz mesmo fora desses contextos?}

A.D. - Sim, eu acho que isso me acompanha, ele faz parte do meu processo pessoal enquanto artista. Nós vamos carregando as nossas memórias, as nossas experiências para os nossos próximos projetos, então não é anulado. Talvez o jeito de eu me comunicar, de me portar e de eu propor tem certas diferenças em razão do como é gerido cada projeto, e isso é independente da permissividade ou da possibilidade de construir coletivamente... É sempre uma construção coletiva, não é? Raramente eu estive em projetos em que eu 
executei, ou estive ali para articular um único desejo. Normalmente esses desejos são fluídos. Por exemplo, estamos focando no teatro, mas eu tenho outras atividades que vão além do teatro. Eu trabalho com música e na música, por exemplo, existe mais essa possibilidade de construir junto. É uma construção que eu faço junto com a música que eu escuto e junto com os artistas que estão ali, no palco, mas ela se dá na hora do fazer, porque raramente temos a oportunidade de experimentar, como o teatro permite com os ensaios e tudo mais. E ali, ela tem uma função objetiva, eu estou ali numa configuração de palco e plateia, na maioria das vezes, então ela já foge do meu know-how teatral. Mas, ao mesmo tempo, ela conversa com tudo isso porque é aí que eu tenho essa possibilidade de liberdade formal, eu não preciso ficar conformada, ou ter um entendimento de criação de uma cena... A criação de ambiente é muito possível. Eu acabei de fazer um show com o Lucas Santana, no qual várias vezes só se via a silhueta dele, com contraluz... com um refletor atrás dele inclusive. São coisas que o teatro traz para os shows e coisas que os shows levam para o teatro. São processos diferentes. Eu também tenho um trabalho, no qual eu posso dizer que exerço mais o meu lado artista plástica, quando eu realmente uso as fontes de luz enquanto matéria, enquanto objeto escultural, como uma instalação... ou mesmo a luz para instaurar algo, ou provocar algo a nível da sensação das pessoas. Isso também é um processo no qual eu fico sozinha, que é mais solitário do que a música, porque nela eu ainda tenho com quem fazer a interlocução. Então, eu acho que são, sobretudo, as diferenças de onde eu estou... O teatro tem essa coisa em comum, que é essa construção coletiva, às vezes mais hierárquica, às vezes menos hierárquica, e que eu levo toda essa experiência a cada passagem, toda essa carga que está no meu corpo e, assim, em todos os ambientes em que eu trabalho. Quando eu vou fazer um trabalho de projeto de exposição, que é super objetivo, arquitetural, no qual eu tenho um diálogo com o espaço e com as obras, também um pensamento de luz, também é uma relação com o que eu vou iluminar. Ontem eu fui ver uma exposição do Soulages (La lumière viens du noir), que é um pintor que trabalha o preto, mas estava tão mal iluminada que foi a primeira vez que eu não me emocionei com uma tela dele, um pintor de quem eu gosto muito. A luz era tão, tão errada, mas 
tão errada, que quebrou qualquer possibilidade de entrar dentro do trabalho, pelo menos para mim. Então, tudo isso eu levo junto... Quando eu vou fazer os trabalhos, mesmo que sejam mais técnicos. Eu fiz o projeto da galeria da Cláudia Andujar, em Inhotim, não só da exposição, mas do pavilhão inteiro e, para mim, era muito importante que quando você entrasse no pavilhão... Porque você está ali fora, ao ar livre, com uma quantidade de luz grande, você vê tudo e daí você entra dentro de um pavilhão para ver fotos de natureza, então, de alguma forma, eu quis que, no corredor que entra dentro pavilhão... eu fiz uma linha de luz no chão, que ilumina a parede bem de leve, é luz de arquitetura, mas é tão leve que te faz, nem que por três segundos dessa passagem, o teu olho se acomodar e quando você entra de novo na sala e se depara com as fotos de natureza, é como se você estivesse entrando de novo dentro da floresta. Você acabou de sair da mata e entrou dentro de um edifício que tem fotos da mata, mas que tem essa transição. E ali, nessa passagem, a luz é muito baixinha, é uma sensação, é só uma pausa para entrar de novo numa sala bem iluminada, mas sem excesso de luz. Tem luz suficiente para você ver as obras e ficar confortável... Depois, você vai para uma outra sala onde tem luz natural junto, então é todo um percurso que foi pensado para que a obra dialogue com o entorno, mas se você entra direto de fora com a sua pupila super fechada por conta da claridade, já não vai ter esse impacto. Então, esse pensamento, desse percurso da luz, ele vai comigo para todos os lugares. Aí, eu também já comecei a pensar o que o espectador vê quando entra, qual a primeira luz da cena. Como o público senta ali, como recebemos o público dentro, para já prepará-lo para entrar dentro da história através dos seus estímulos fisiológicos do olho. Ou mesmo no Máquinas, por exemplo, eu fazia um corredor de minibrut que queimava o corpo da plateia, ou seja, as pessoas sentiam não só a luz forte, como também o calor dessa luz. Isso te obrigava a parar, a andar, se afastar... Isso também colocava as pessoas num estado físico, de corpo, para entrar dentro de um espetáculo de teatro. Eles já entravam de uma outra forma. Isso tem a ver com o meu lado artista visual, ou artista plástica.

\section{G.V. - Qual a tua maior preocupação no momento de criação, a quem} você dá mais atenção? 
A.D. - Isso depende muito do projeto, não é? De onde vai estar o projeto... essa pergunta é bem difícil. Eu estou, agora, no meio de um processo de mestrado, no qual eu falo um pouco sobre o meu processo de criação de $\mathrm{Na}$ Selva das Cidades e Máquinas do Mundo. Esses são dois projetos que eu fiz com a Companhia Mundana e que são bem diferentes enquanto processos de criação, mas parentes. Eu acho que vou falar deles porque acredito que eles estão mais frescos na minha memória. O Na Selva das Cidades teve um primeiro momento em que a preocupação era uma pesquisa de material, de relação com o espaço, porque o fizemos em espaços não convencionais mesmo, desde uma quadra na favela, até a própria favela em si, um salão paroquial, dentro do CEAJESP, dentro do LobStore. Ali, tínhamos um movimento de descobrir o texto, descobrir cada história... a cada quadro, descobrir quais eram as atmosferas, as sensações... Eu acho que eu posso dizer que o que tem em comum, em todos os processos, é uma preocupação: como eu traduzo as minhas primeiras impressões, que vêm das leituras, das primeiras interpretações, primeiros workshops, primeiras experimentações, em resultados formais. Eu acho que isso é uma coisa que liga todos eles e cada projeto me dá ferramentas diferentes para poder acessar esse tipo de coisa. Tem horas que a minha relação é: como eu acesso esse espaço arquitetônico, para construir essas sensações que eu tive, que são muito subjetivas, mas que, ao mesmo tempo, tem uma objetividade, porque tem uma história a ser contada, um jeito ou proposta estética $\mathrm{x}, \mathrm{y}$ ou $\mathrm{z}$, dependendo de cada projeto. Tem horas que essa preocupação está em como provocar o público, a partir de guiar o olho do público para ver o espetáculo. Tem horas que a minha preocupação está em criar uma fruição estética... Máquinas tinha várias coisas que mexiam com as sensações físicas, fisiológicas do olho, da estética, dos objetos... Eu acho que tem uma preocupação de que a luz seja componente. Não consigo muito objetivar, porque não tem uma ordem de preocupação. A última coisa que vem para mim, por exemplo, é o mapa de luz, o rider. Eu fico muito irritada quando eu acabei de começar um projeto e a pessoa já me pede o rider. Eu nem sei que tipo de equipamento eu vou usar, se vai ser uma vela ou um refletor de 5.000 Watts, até porque eu nem sei as sensações que me provocam para eu traduzir isso. 


\section{G.V. - Como o espectador entra no teu trabalho? Você se preocupa} com ele no momento em que você está organizando as tuas sensações, ou ele só chega depois?

A.D. - Eu me preocupo com ele, me preocupo bastante com ele porque é ele quem vai receber. Eu me preocupo tanto com quem está em cena quanto com quem vai receber... Por que eu acho que essa transmissão de sensações precisa estar para os dois, se eu consigo construir uma coisa que ajuda os atores a trazer as sensações e vice-versa, o público vai sentir isso. Para mim, o jogo é duplo e eu me preocupo muito com o espectador. Como eu estava te dizendo, para entrar no pavilhão da Claudia, eu me preocupei com esse percurso que ele faz, então eu me preocupo. Tem propostas de luz que eu fiz... por exemplo, tem o Só, um espetáculo que eu fiz com o João Miguel, com direção do Alvise Camozzi, no qual ele desaparece no fim. No fim do texto tinha uma rubrica na qual ele desparece e ao invés de fazer um blecaute, eu fiz um paredão de 12 minibruts na sala do teatro, na altura do olho do público. Eu fui acendendo esse paredão até que ele fosse obrigado a fechar os olhos, até queimar a sua retina e ele não enxergar mais nada. Isso é um exemplo, eu criei uma desaparição sem que ele simplesmente sumisse num blecaute, porque não era um corte que nós queríamos, mas uma continuidade... Era de outra forma, um encerramento de outra forma. Acho que esse é um exemplo de como eu tenho sempre o espectador em vista em todos os meus trabalhos e em todas as áreas que eu atuo.

\section{G.V. - Você pode repetir o nome desse espetáculo em que você causou o ofuscamento no público?}

A.D. - Só, chama-se Só. Um monólogo do João Miguel, com direção do Alvise Camozzi no Sesc Paulista antes da reforma.

G.V. - Eu não conheci o espaço do Sesc, o fato de ter sido antes da reforma é uma informação importante? 
A.D. - É importante porque, como eu falei, a relação arquitetônica diz muito... Qual a arquitetura, com qual teatro eu estou dialogando. Isso é uma coisa que me move muito, qual a relação... Você tinha me perguntado quais as preocupações que eu tinha, não é? Acho que uma delas é o lugar onde estou, tanto o espaço físico, arquitetônico, quanto o social. Ele é muito parceiro.

3. A pesquisadora deste trabalho defende, como resultado de suas pesquisas práticas como iluminadora e reflexivas como pesquisadora, que a iluminação cênica tem uma participação ativa na cena teatral, assim como em outras formas das artes cênicas como a música, a dança, entre outras. Com isso ela afirma que a luz atua, age em cena e interage com os demais componentes do espetáculo e também com o público, tendo a importante função de estabelecer e favorecer a relação entre o palco e plateia. Você concorda ou discorda dessa afirmação e por quê?

A.D. - Eu acho que, como eu disse, a luz é uma forma de expressão, então claro que ela é ativa em todos os níveis. Acho que o que acontece é que, às vezes, não temos consciência dessa atividade. Como ela é matéria e nãomatéria, então não percebemos a sua existência. Por exemplo, num show de música, como já me aconteceu, em um momento $\mathrm{x}$ da música, a luz explode e a plateia inteira faz "Uau!" e depois você vai perguntar para as pessoas sobre as sensações e elas não lembram da luz. Mas aí, se você vai nesse mesmo show e não acontece essa luz, tem só a musica, não é a mesma coisa... Eu fiz esse teste em um show que eu fiz, porque eu falei com uma amiga e ela disse: "Foi incrivel a luz!", mas as pessoas não tinham percebido, então, no dia seguinte eu não fiz o movimento e não foi "Uau!" A música foi tão bem executada quanto no dia anterior e não foi "Uau!" Então, eu acho que ela é um movimento ativo, mas ela também pode ser usada... É difícil dizer que ela é usada sem essa intenção, mas acho que como a luz também é uma forma de expressão, ela se vale das intenções. É como dizer que a pintura é ativa e não é ativa... Uma pintura de uma casa pode ser branca e querer dizer uma coisa e o azul diz outra, mas se você está efetivamente pensando sobre isso, ela está ali numa outra função... 
Mas como estamos falando de teatro e estamos falando de um meio de expressão, eu acho que sim, ela é ativa, ela é resultado. Não existe opção sem luz, existe a opção completamente no escuro, o que também é uma expressão, também é um jeito de apresentar as coisas, então ela pode ser muito pouco elaborada ou muito elaborada, depende de cada desejo, de cada projeto..., mas ela é presente, anyway!

G.V. - Você saberia dar alguns exemplos dessa atuação da luz no seu próprio trabalho? Pode ser um projeto inteiro ou um, ou mais, efeitos específicos. Você fez isso várias vezes na conversa, mas eu queria saber se tem mais algumas.

A.D. - Acho que o Máquinas do Mundo é projeto no qual a luz é muito ativa, ela está ali para provocar sensações estéticas e físicas. O público entra por um corredor de minibrut que acende e apaga, as pessoas andam, correm, quando tem luz, e ao mesmo tempo se afastam. Quando dá o blecaute, elas são obrigadas a parar... isso para chegar na cadeira. No meio do espetáculo, acontecem várias ações, vários fenômenos junto com música... A luz não está sozinha, mas ela é um bom exemplo de uma luz conscientemente ativa e como opção enquanto linguagem. É uma opção ela ser ativa... ora mais calma, ora mais agitada, mas o tempo inteiro ela é ativa junto com os corpos dos atores. Acho que Máquinas do Mundo é um bom exemplo disso.

\section{G.V. - Muito obrigada pelas respostas e pela atenção!}


3.2 Aurélio de Simoni - Iluminador Carioca 228

1. Sobre a luz, como conceito, como elemento físico e cênico, você acha que ela é material ou imaterial?

A.S. - Para mim, a luz é material e imaterial ao mesmo tempo, pois ela está no palco como algo material e ao mesmo tempo, quando é percebida pelo público, é imaterial, num espetáculo que, plasticamente e cenicamente, esteja de acordo com aquele mentor que nós temos que é a direção do espetáculo. Então, ela tem esses dois aspectos, o aspecto material, quando você a realiza, mas o sentimento, a percepção é imaterial. O raciocínio pode ser entendido assim: coloque cinco pessoas responsáveis pela iluminação de uma cena e você vai ter cinco projetos de luz distintos, criadas por esses criadores. Daí eu digo que ela não é material porque ela não é matemática e não podemos ter o conceito de que uma está certa e as outras erradas, são formas de ver e de se mostrar e de entender. Eu estou fazendo uma peça agora com a Clarice Niskier, que me fez gostar muito do Zeca Baleiro, eu já gostava das músicas dele, mas ele é um poeta... Nossa senhora!

\section{N.L. - Eu já fiz luz com ele!}

A.S. - Bom, Clarice Niskier, que não é a mesma Clarice de A Alma Imoral, porque ela está só há quatorze anos fazendo essa peça..., mas, então, Nadia, esse conceito da peça me fez entender que eu quero que me compreendam e não que me aceitem, entendeu? Então, esse é o conceito de quem cria alguma coisa. Eu costumo fazer uma brincadeira, mas é uma brincadeira muito séria... Você, quando cria, se não for presunçoso... porque quando eu digo, as pessoas que fazem teatro são presunçosas, porque elas acreditam que o público, o leitor, seja visual ou audiovisual, que ele esteja entendendo todas as suas propostas, coisa que não é verdade, mas se assim não fosse, nós não faríamos. Porque nós temos que acreditar naquilo, na nossa obra, na nossa feitura. Então, é isso,

${ }^{228}$ Entrevista realizada pela autora via Skype no dia 18 de março de 2020. 
é entender que luz, aquilo que você já me ouviu falar, nada mais é do que mostrar o trabalho dos outros. Isso é iluminar, e aí prende-se a esse conceito do material. Para iluminar, você tem que ter a fonte luminosa ou a ausência dela.

\section{N.L. - Ausência dela você quer dizer... o escuro?}

A.S. - Porque você também ilumina ausentando a luz. Quando você tem, no seu roteiro de luz, uma coisa que colocamos, aquele famoso BO é uma memória da mesa, é um efeito de luz. Quando você ausenta a noção, a percepção da luz, você está criando um efeito de luz, a ausência dela. Então essa pergunta que você me fez do material ou imaterial, ela é muito vasta, porque o material vai depender do que você entendeu, mostrar como essência, plasticamente falando, a essência da cena que está sendo feita. Ela é somada entre ator, diretor, cenógrafo, aderecista, diretor musical, coreógrafo... tudo informa luz. Eu costumo dizer que o iluminador é um privilegiado, porque tudo informa luz. Talvez por isso, quando me disseram: "hoje não vai ter espetáculo por conta do decreto do nosso governador" (sobre o coronavírus), eu disse, "caramba, eu gosto dessa merda, eu acho que o teatro realmente vale a pena". Eu gosto muito do que eu faço. Agora, se eu faço bem ou faço mal, isso é uma outra história que vai depender de quem está me vendo, de quem está me seguindo. Esse conceito de certo ou errado não existe, mas bem e mal, o bom e o ruim, isso existe e vai depender das pessoas. De quem lê o teu trabalho.

2. A segunda pergunta é sobre o processo criativo. Eu queria saber se você costuma trabalhar sempre com a mesma companhia ou o mesmo diretor, ou se você trabalha com vários diretores e várias companhias diferentes e como isso afeta o teu trabalho?

A.S. - Olha, querida, eu acho que eu já trabalhei com todo o mundo teatral brasileiro.

N.L. - Eu também acho (risos). 
A.S. - Tem algumas pessoas que eu trabalho mais, não vou dizer diuturnamente, mas eu trabalho mais constantemente, que é a companhia Atores de Laura, os trabalhos de Moacir Chaves e mil outros diretores, graças a deus. Eu estava tão feliz antes dessa história do coronavírus, porque dois diretores chegaram para mim e falaram: "Aurélio, eu tenho uma falha na minha carreira, você nunca fez uma luz para mim. O próximo espetáculo que eu fizer você vai fazer a luz". Isso abriu o meu coração..., mas trabalhar com um mesmo diretor pode ser um perigo, porque você pode ter uma tendência a criar vícios criativos. Ou seja, de você colocar uma coisa que eu digo que é tão inerente ao nosso trabalho, que esquecemos dele às vezes, que é o ponto de vista. Aonde está quem está nos vendo? Isso é tão importante, é nessa pedra fundamental da criação que eu digo sempre, que quando você cria a luz, contraluz, lateral, no chão, no alto, isso tudo vai depender de onde você está, esses conceitos de angulações de luz que você usa no seu espetáculo vão depender de onde está quem nos olha. $E$ trabalhar com um diretor que você não conhece, isso estimula. Não que o outro não estimule, porque tem uma coisa que é uma base do meu raciocínio, Nadia... Quando me chamam para fazer um trabalho, a primeira coisa que me vem à cabeça é uma pré-ocupação mesmo, que é "Eu vou estar à altura dessa expectativa? Vou estar à altura, com o meu trabalho, do entendimento do espetáculo que está sendo feito, que vai ser feito?" O nosso trabalho não é matemático. Eu já vi muita gente boa que fechou portas de teatro duas ou três semanas depois e disse: "Olha, não dá, e vamos fazer outra coisa, porque o público não aceitou." Trabalhar com um diretor que você está acostumado, tem uma expectativa, tem sempre os dois lados da tal moeda, não é? Por um lado, tem uma facilidade de expressão, de interlocução com essa pessoa, porque você já está acostumado, você já sabe se naquele dia ele está aborrecido ou não está, o que ele quer quando ele monta uma cena, você já tem o modus operandi e conduz a tua criação dentro dessa proposta, haja visto que ele é o maestro da história. Com um diretor que você nunca trabalhou, tem uma outra expectativa, que estimula você a trabalhar, mas não é uma expectativa que vai te deixar parado, você não pode deixar a novidade te travar, entendeu? E tem uma outra coisa, um terceiro ponto de vista, que é o espetáculo. É isso, o que está sendo 
feito, é que você vai tentar, junto do teu entendimento do que é fazer teatro, dentro da tua atividade, que você vai fazer ou não fazer um espetáculo que pode ser mais ou menos pirotécnico. Os musicais, já que eles estão agora tão em evidência, eles exigem toda uma paramentação, porque o conceito de musical é um conceito de efeitos luminosos. Muito embora eu confesse a você que eu fiz a luz do show da Leila Pinheiro e o menino riu quando eu falei que eu não uso moving light, eu uso stop light... (risos). Porque com Leila Pinheiro e um teclado, você ficar passeando com o moving, mudando luz para lá e para cá, desculpa, eu acho que é demais. Vamos ver a dona Leila cantar e a interpretação dela, e não ficar viajando no éter da sua luz! (risos) Mas é verdade! É engraçado que quando eu fiz a luz da Leila Pinheiro, eu me lembrei muito de você, daquele espetáculo dos franceses, com um piano, era um francês e um brasileiro, lembra? Eu me lembrei porque eu estava lá com a Dona Leila no teclado, ela dizendo: "Aurélio, o show vai ser esse: eu e o teclado." E teve, graças a deus, um menino, que toca um cavaquinho de cinco cordas e que faz aquele cavaquinho virar uma guitarra portuguesa, o garoto era excepcional. $O$ espetáculo tinha um up quando ele entrava, foram quatro ou cinco músicas junto com a Leila. É um somatório, não é? Você vai trabalhar com Moacir Chaves em um espetáculo e você vai fazer um segundo espetáculo com ele, ou posterior, que no meu caso já não é mais o segundo, já estamos com mais de trinta espetáculos feitos juntos, mas eu não sei, eu não tenho a certeza se vou atender a todas as necessidades dele e se vamos chegar a um entendimento. Temos um caminho, talvez um pouco mais fácil pelo respeito, pela forma de raciocinar que nós temos, já encontramos uma forma de trabalhar. Porque um novo diretor estimula, no fundo queremos que esse diretor seja uma pessoa que se agrade do nosso trabalho e isso é muito importante no nosso dia a dia. O teatro me deu essa possibilidade de ter uma... caramba, eu acredito que eu já conheci mais de mil personagens nesses quarenta e quatro anos, não sei quantas peças eu já fiz, mas são mais de mil personagens que eu visualizei como pensa, como raciocina, como agem aqueles personagens, como age um diretor, um contrarregra, uma atriz estrela. Uma atriz como Fernanda (Montenegro), que te 
ensina a cada segundo que você trabalha com ela. E vamos assimilando..., mas tem uma coisa: não existe regra na criação.

N.L. - Isso vai um pouco de encontro com a segunda parte da pergunta que é: quando você cria uma luz, qual é a tua maior preocupação? Com quem você se preocupa mais? Com o que o diretor, ou o dramaturgo, ou o próprio texto diz, com as necessidades do ator e da cena ou você pensa no espectador?

A.S. - Olha, desculpa... pega todas essas minhoquinhas que você colocou para eu botar no meu anzol e pense o seguinte: todas elas vão para um anzol na boca do espectador. Por que a mim, o que me interessa, já que eu faço parte de uma equipe... porque teatro é uma atividade coletiva por excelência, não é o exercício da individualidade e não podemos nos colocar nesse aspecto. Quando você cria um espetáculo, você está atendendo às necessidades do diretor. Quantas vezes nós, quando fazemos a nossa luz, temos que atender à cenografia do espetáculo. Como a cenografia determina algumas luzes! Algumas angulações são determinadas pela cenografia. Um figurino, você pode querer fazer um grande efeito, mas se você não vai mostrar um figurino na essência da criação dele... Você pode ter uma alteração durante o percorrer, nos efeitos que você faz, mas a essência de criação de um figurinista tem de ser mostrada. E o espectador, ele não me determina, não. Costumamos dizer que quando se fazemos a luz, ficamos cutucando o espectador para dizer, presta atenção agora nisso, dessa forma. Até quando começamos a subtrair luz, estimulamos o espectador a desencostar da cadeira e querer ver melhor. Às vezes, ele até reclama que não está vendo direito, mas o subconsciente dele está buscando ver a cena de uma melhor forma, ele quer ver de uma outra forma. Quando eu trabalho com um ator... gente, ator brasileiro às vezes dá pano para a manga, mas o fato é que temos... Com atores que eu tenho mais intimidade, eu chego e digo: "se você fizer essa cena numa contraluz, sem luz no seu rosto, o espectador vai entender melhor esse texto que você está falando". É uma conjugação, é um coletivo de preocupações que você tem que ter, sem esquecer que se você absorve, se você elimina uma informação do coletivo, você está 
quebrando aquele dentinho da engrenagem, aquele símbolo, e naquele ponto, a engrenagem não vai funcionar a contento. Então tudo, tudo é importante, tudo informa luz. E no seu trabalho, como responsável, nunca como dono, mas como responsável pela criação, você tem que ter esse entendimento do todo que está envolvido nessa criação.

\section{N.L. - Inclusive o expectador?}

A.S. - Ô! (risos) Nadia, nas minhas oficinas... você já me ouviu falar disso, eu digo que nós fazemos teatro no palco, mas a razão do teatro não está no palco. A razão do teatro está lá na plateia. Inclusive, quando eu fiz essa peça agora da Clarice Niskier, eu pensei, caramba, que bom, como é a ação transformadora do teatro... Porque, é lógico e evidente que você pode ir tomar a sua cerveja, tomar seu uísque ou sua caipirinha ou qualquer coisa para diluir um pouco o fígado, mas a ação transformadora do teatro está sendo um pouco relegada. Se está fazendo muito divertissement. Ou então, tem atores na nossa atividade que querem "Eu! Eu sou! Eu faço! O público está aqui por minha causa!" Desculpa, mas ele está fazendo um teatro errado.

3. Essa pesquisa defende, como resultado da minha investigação prática como iluminadora e teórica como pesquisadora, que a iluminação cênica tem uma participação ativa na cena teatral e que, como fenômeno físico, como matéria, ela age tanto na cena teatral quanto em outras formas de atuação, ela interage com os outros componentes do espetáculo e, principalmente, com o público, tendo a importante função de estabelecer e favorecer a relação entre o palco e a plateia. 0 que você acha dessa afirmação, dessa ação prática e performática da luz e se você pode dar exemplos, no teu trabalho, de um espetáculo ou de um efeito que você lembre que haja uma ação performática da luz?

A.S. - Olha, Nadia, isso que você falou da visão da iluminação e dessa função, que nós somos os vetores, nós que eu digo, nós os criadores, nós somos 
os vetores dessa materialização dessa proposta. E essa proposta é fazer com que o público entenda o porquê da cena e para isso, eu disse aqui já, várias vezes, existem naus que compõem essa frota para chegar num porto seguro, que são todas as atividades que compõem o fazer teatral. Isso é muito importante, não é uma ação individual. Agora, como a luz tem essa coisa... Para exemplificar, como você pediu para dar um exemplo, eu fiz um trabalho com o Antônio Pedro Borges, o baixinho. Lembre-se que eu sou velho, então minhas referências são de atores velhos. (risos) Mas eu fiz um trabalho, há muitos anos, que Antônio, na irreverência dele, do trabalho dele, ele botou o nome de Tá Russo no Açougue. O que era isso, meu deus? Era Santa Joana dos Matadouros de Brecht e ele botou o nome de Tá Russo no Açougue. Eu cheguei para ele e falei assim: "Antônio, eu...", eu gosto muito do Antônio, admiro muito o trabalho dele, e eu já tinha uma certa intimidade com ele e falei: "olha, eu não vou usar cor. Eu vou obedecer, por que disseram que tem umas novas pesquisas teatrais, o mundo sabe disso, que Brecht não gostava de cor". Amir Haddad fez a supervisão do espetáculo da Clarice, eu fiz dois espetáculos agora esse mês com ele, e ele diz que ele não quer mais teatro adjetivo, ele quer teatro substantivo. Com a peça da Clarice, tem cinquenta e poucos efeitos, movimentos de luz. Eu fiz uma outra com cinco movimentos de luz, contando a entrada e saída de plateia. Ou seja, uma, o ator entra, senta num banco e não levanta mais. Ele fica só falando... É o Riobaldo, o personagem do Guimarães Rosa, em uma adaptação do livro, contando a história de Grande Sertão Veredas e o Amir falou, eu não quero movimento. E o que que eu fiz? Gente, o que que eu vou fazer, isso aí qualquer criança faz. Mas aí ele falou: "Aurélio, porque você botou aqueles refletores no chão?" Eu disse: "é para te dar uma angulação e te dar uma leitura quando você vira" ... Ou seja, eu encontrei uma forma de eu não me sentir ausente do trabalho, eu me perguntei como eu poderia contribuir para esse trabalho. Um outro exemplo prático, é aquilo que eu te falei que saiu lá na Coréia, que me disseram que saiu na capa de uma revista técnica de iluminação teatral, é a história do meu pirex. Que a Claudinha de Bem me ligou uma vez pedindo autorização para usar o meu pirex e eu falei: "você está é maluca de me pedir autorização, eu hein, o que eu digo é use e abuse! Eu não quero nem saber, se 
você acha que funciona" ... Quando eu usei pela primeira vez o pirex, eu fiquei... eu digo, caramba, tem que ter um porquê de criarmos esses efeitos... Como o Renato Machado, um iluminador aqui do Rio, que adora criar, fazer as luzes dele, que têm sempre uma lampadinha pendurada... Ele adora a luz não formal, que não é só com a luz dos refletores. É muito interessante, o trabalho dele. A história dos pirex veio se repetindo até que um alemão disse que eu era multifacetado nas minhas criações, entendeu? O Renatinho (Machado), que viajou com a Companhia Aérea de Dança, quando chegou lá, e alemão falou que a luz era multifacetada (risos). E o produtor não queria levar os pirex, quando o Renato explicou, mostrou para ele a razão pela qual os pirex tinham que ir, venceu a resistência do produtor e ele concordou: "não, o moving não faz isso". Porque ele tinha dito que lá tem moving e que o moving fazia... Isso que o pirex faz, o moving não faz, não, entendeu? Isso é uma coisa que eu até posso te dizer que é meio autoral. A lua que eu fiz em Os Impagáveis, que aliás, diga-se de passagem, está estreando lá em Portugal... O Henry Panocelli e a Teresa Frota estão lá, eles se evadiram, foram para lá. E o Henry dirigiu Os Impagáveis, que tinha uma lua, e a lua foi feita com um queijo redondo de um metro e vinte de diâmetro com um material plástico, que naquela época era chamado de lisolene, ou seja, cortina de banheiro vagabunda. E eu botei duas lâmpadas mistas, porque eu entendi, num dia que eu olhei para uma lâmpada mista num poste e vi que a temperatura de cor era semelhante à temperatura de cor da superfície lunar da lua cheia. Então, é quando você coloca mesmo a coisa como bem autoral. O grupo de dança Primeiro Ato, que eu fiz a luz quando o Jorginho não pode fazer, e ele falou: "chama o Aurélio", e eu fui para lá... Pense, substituir Jorginho de Carvalho! Meu deus do céu..., mas eu fui lá e tinha uma cena que era Os Navegantes... eram os navegadores, toda uma coreografia, e era sobre navegação... eu nem conversei. Na primeira vez que eu usei, tinham dois pirex, nesse tinham quatro, porque tinha que pegar todo o palco para poder ter toda a cena iluminada. Então, a criação, ela não está sujeita a nada, sabe... são fatos que, quando trabalhamos, e você sabe disso, você é uma pessoa que cria as tuas luzes, você sabe que não existe fórmula, não existe matemática. Um dia eu cheguei para a Fernanda Montenegro, eu já te contei essa história, e falei para 
ela... Lágrimas Amargas, mesmo texto, mesmo cenário, mesma luz, mesmo figurino, mesmo elenco, mesmo teatro, um ano e meio em cartaz... E eu cheguei para ele e disse: "Fernanda, me diz uma coisa, tudo isso é igual...", mas eu, da cabine, como naquela época eu já não tinha mais roteiro, eu já sabia a luz de cor e salteado... Ah, sim, a mesa era uma analógica, não era mesa digital... Como eu estava dizendo, eu sabia tudo, então eu ficava vendo muito o espetáculo e eu falei para ela: "tem umas nuances que são diferentes no dia a dia". E ela, com a sapiência dela, me disse: "Meu amigo, se eu venho subindo a escada rolante desse shopping e machuco o meu dedão do pé, eu vou fazer esse espetáculo com o meu dedão doendo, e de alguma forma essa dor vai me provocar a fazer diferente o espetáculo". Entendeu? Então essa é a nossa criação. Tem uma coisa de grande importância. As pessoas dizem que a luz é uma coisa que edita e eu brigo, para que não seja solidificada, que a luz é fundamental no espetáculo, mas eu digo que a luz é tão importante quanto. Agora, para você ter essa tranquilidade de falar isso sem desmerecer o seu trabalho, é porque quando você entende o porque da criação de toda essa equipe reunida, o seu trabalho vai somar e ele vai aparecer como um trabalho de luz. Tem muita gente que chega para mim e diz: "Aurélio, eu adorei a luz", e eu digo: "Ah, que maravilha, que bom, mas você ouviu o texto? Você viu o cenário? Você viu que ator maravilhoso?" Então, quando o teatro tem o seu coletivo, o teatro se faz na essência. E não é muito difícil de conseguir isso, mas ter esse uníssono no coletivo, nas suas contribuições ao espetáculo.

\section{N.L. - Eu vou retomar um pouquinho a pergunta. Você disse que tudo} informa luz, tudo inspira a luz. De que forma você entende... a luz compõe com tudo o que acontece no espetáculo. Em alguns momentos da minha tese, eu falo que a luz contracena com o ator, com o cenário...

A.S. - Olha não fala isso, não fala isso não, porque... Teve um espetáculo, acho que ele esteve aí, O Filho Eterno, com Charles Fricks, direção do Daniel Herz. Era um monólogo, do Cristóvão Tezza, do argentino, O Filho Eterno. Ele teve um filho, excepcional e ficou reclamando com deus que o filho dele tinha nascido defeituoso, mas depois ele entendeu, ele foi corajoso, ele botou essa 
saga de um pai de uma criança excepcional na peça. O Charles ganhou o prêmio Shell, mas teve uma pessoa que foi assistir a estreia do espetáculo, eu ainda estava na mesa, não tinha passado a luz para o operador, que aliás era Marcelo, meu filho, que foi quem operou a luz. Eu desci da cabine, no Oi Futuro do Flamengo, e essa pessoa, que é uma pessoa que eu admiro muito, como atriz, como ser humano, chegou e disse: "Aurélio, que luz de mestre que você fez! Você criou um outro personagem, não é? Não é um monólogo, é um diálogo do ator com a tua luz". Aí é a luz materializando os porquês da situação. É quando você consegue isso... Enquanto o Charles estava falando de ir a um hospital, o que estava iluminado era uma cadeira. Ele estava conversando com uma cadeira. O visual era isso: uma cadeira iluminada e o ator iluminado. Mas, como tinha todo o desenvolvimento das atividades teatrais, entendia-se que ele estava no hospital e que ele estava vendo o filho... quando o médico fala para ele que ele tinha tido um filho excepcional, com síndrome de down, entendeu? Quando o médico vai falando para ele, eu coloquei... eu pedi ao Charles: "amigo, pelo amor de deus, usa protetor solar, que eu vou te sacrificar um pouco" ... eu coloquei quatro lâmpadas PAR a menos de dois metros de distância dele, foco dois, concentradas em cima dele. Ele começava a falar o que o médico estava falando e ia diminuindo a voz, como se fosse diminuindo o botão de volume, e a luz ia crescendo em cima dele e ele terminava a cena com toda aquela luz estourada em branco e ele só mexendo com a boca. Então, as pessoas disseram: "Aurélio, você fez tudo ali, aquela cadeira era, a gente via o outro personagem, o interlocutor estava personalizado na sua luz." Eu acho que é isso, é você entender, a luz tem o seu porquê, sim, mas tanto quanto as outras atividades. Não se coloque numa projeção onde só ela tenha luz. Deixa a tua luz iluminar todos os outros pedestais para que você, como espectador, você possa optar para qual situação você vai dar importância naquele momento.

N.L. - Ela não acontece sozinha, nunca, mas no momento em que ela está junto com os outros elementos, ela age junto com eles. Tão importante quanto todo o resto, como você disse, e interagindo e compondo a cena? 
A.S. - Ela tem uma materialidade sim, e você vê, isso é material. Agora, como você vê é o imaterial, e aí vai variar de uma pessoa sentada na A1 e a pessoa que está na A2 vai ver de uma forma diferente.

N.L. - E aí está a imaterialidade dela...

A.S. - Entendeu?

N.L. - Entendi... Então é isso, Sr. Aurélio de Simoni! Muito obrigada pela entrevista! 
3.3 Beto Bruel - lluminador Paranaense 229

\section{Como conceito, sobre a luz, a iluminação cênica e o fenômeno} físico da luz, você considera que a luz seja material ou imaterial?

B.B. - Eu acho que é material, já que ela está presente no palco tanto quanto o cenário e o figurino. A única diferença é que nós temos um sistema, que a luz, diferente do cenário e do figurino, apaga, você consegue apagar a luz, você tira a luz de cena, mas, com certeza, ela tem uma presença fortíssima, ela está lá, com certeza.

\section{N.L. - E o que você poderia falar sobre essa presença da luz?}

B.B. - Eu acho que, pela maneiro como eu ilumino as coisas, eu tenho que tentar ajudar o diretor a contar a história que ele quer contar, eu tenho que ajudar o cenógrafo a mostrar o cenário que ele quer mostrar, o figurino que o figurinista quer mostrar e os atores, principalmente os atores, ajudar a contar a história, então eu acho que a luz está muito presente dessa maneira. Em ser um elemento com o qual você rege. É praticamente parecido com o cinema, onde a câmera faz o zoom, eu faço e zoom com a luz, não é? Então, eu posso isolar uma cena... isso sempre conversando com o diretor, afinal, o que você está vendo no palco é o que o diretor quer mostrar, além da minha luz, em parceria com ele, com o cenário, o figurino. Mas com certeza, a função da luz é ajudar a contar a história.

\section{N.L. - E ela se materializa para isso?}

B.B. - Sim, sim, aliás, é um termo interessante, materializar. É uma coisa engraçada, por que a luz está quieta lá dentro do rack, dentro da mesa, e daí você liga, e olha a dimensão que a luz toma! Você veja, o que é um blecaute? A hora que termina um blecaute, o que você consegue fazer com luz, você mostra o que quiser. Na verdade, é até ruim falar isso, mas o teatro deve muito para os

229 Entrevista realizada pela autora via FaceTime no dia 20 de março de 2020. 
iluminadores, não é? Porque se não fossem os iluminadores, teria que ser só como os gregos, durante o dia, de acordo com a luz do sol, então eu acho que a luz elétrica ajudou muito e arranjou uma profissão para milhares de pessoas no mundo. A luz elétrica ajudou muito e com ela, através da luz, nós podemos mostrar, fazer uma criação. Você pega um refletor, um refletor não é nada, o refletor é uma coisa de lata que sai luz pela frente, e você consegue fazer muitas coisas maravilhosas com um jogo de cem refletores, cinco, duzentos. Eu sempre digo, o refletor é como um pincel, com ele vamos pintando a cena, então dentro dessa prática, quando você consegue fazer isso, a luz se torna uma arma poderosíssima, junto com aliados, o figurino e o cenário. E o som, também. Aliás, eu sempre digo, quando entra som em algum lugar, a luz tem que mexer. $\mathrm{O}$ som é um bom gancho para a luz mexer.

N.L. - E apesar de toda essa materialização da luz, você acha que ela tem, também, um lado imaterial?

B.B. - Engraçado, depois de... o que seria um lado imaterial da luz? É engraçado, um lado imaterial... Eu acho que se ela consegue se materializar, porque vai ser imaterial? Eu acho que não...

\section{N.L. - Não?}

B.B. - Eu estou na dúvida, mas eu acho que não... engraçado...

N.L. - Bom, então vamos para a segunda pergunta e depois voltamos para a imaterialidade da luz, se for o caso...

2. Agora, sobre o teu processo criativo, eu vou fazer uma pergunta meio óbvia, porque eu conheço o teu trabalho, mas mais para trazer uma reflexão, mesmo. Você costuma trabalhar sempre com uma mesma companhia, com um mesmo diretor, existe uma frequência, ou você varia bastante e trabalha com companhias e diretores diferentes a cada vez? 
B.B. - Eu trabalho muito com os mesmos diretores, mas, ao mesmo tempo, eu tenho uma variedade muito grande. Mas também trabalho com pessoas que eu nunca trabalhei, como nesse ano, no qual eu trabalhei com dois diretores que eu nunca tinha trabalhado antes e, ao mesmo tempo, eu trabalhei de novo com o Felipe (Hirsch), com quem eu já fiz quase 40 peças, com o Edson Bueno, que eu fiz quase esse número também. Eu acho muito interessante você trabalhar com um diretor novo, quando os dois estão se conhecendo, pensar “como é que esse diretor quer contar essa história?", e ele também deve pensar, "como é que o Beto está tentando fazer essa luz?" Eu estava falando do Rodrigo Portela nessa peça do TCP e a do Dom Correia, que eu fiz no Novelas. Então são duas peças, uma é bem grande, e são dois diretores que eu nunca tinha trabalhando e foram dois métodos diferentes, foi muito legal de fazer. Ao mesmo tempo, eu estava lá em São Paulo fazendo a próxima peça com o Felipe, com a Daniela Thomas, a mesma equipe de criação, então é muito mais fácil, tem esse trânsito já, você pode falar tal coisa, existe um caminho melhor para a montagem da luz. Uma equipe de criação, com certeza, é algo muito bom, ajuda muito o processo de uma peça. Mas, ao mesmo tempo, é muito instigante, também, você pegar um diretor novo, um cenógrafo novo. A outra peça que eu estava fazendo em São Paulo, com a direção da Bel Teixeira, era um musical com uma cenógrafa que eu nunca tinha trabalhado, então foi muito interessante, também. Eu acho, com certeza, que é muito bom trabalhar com pessoas novas. Eu faço, também, muitas parcerias. Eu trabalhei, por exemplo, com o Lucas (Amado) e com o Rodrigo Ziolkowski, fazer parceria com o pessoal é muito bom, você criar uma iluminação a dois, ajuda muito, é uma coisa que eu não fazia e que agora, hoje em dia, está acontecendo algumas vezes. É muito bom.

N.L. - E no resultado, você sente que trabalhar com um diretor que você trabalha há muito tempo ou com um diretor novo interfere no resultado do teu trabalho? Você falou que faz diferença e que é bom, nos dois casos, durante o processo criativo, mas e no resultado, na luz que você põe em cena, você acha que faz diferença, uma situação é melhor que a outra, ou não afeta? 
B.B. - Com certeza, o fato de conhecer o diretor ajuda muito a equipe, mas quanto ao resultado, é muito interessante você trabalhar com um diretor que você nunca trabalhou, porque você vai apresentar surpresas, soluções que ele nunca imaginava, e isso é visível, quando você apresenta a luz para um diretor que você nunca trabalhou, a surpresa. E é muito interessante, uma coisa que eu gosto é de acompanhar o método, como nesse caso do Rodrigo Portela. Quando ele apresentou a peça, uma peça muito complexa, conversamos muito, sobre aonde a peça ia chegar, esse processo foi muito interessante. Se o diretor chega e você sabe o caminho que ele vai pegar para chegar onde ele quer, você já conhece mais ou menos o método, mas quando você não conhece o diretor, é muito interessante de ver como ele consegue... e é tudo graças ao diretor e à equipe dele. O que é uma peça de teatro com trinta ou quarenta páginas? É uma pilha de papel, que se transforma numa obra. Eu acho muito interessante um diretor novo, quando você apresenta as soluções do que está criando, é esse tipo de coisa, às vezes ele instiga você a criar alguma coisa que ele está querendo fazer e às vezes é você que mostra alguma coisa diferente. Eu acho que a iluminação ajuda mais, até. O cenário ajuda também, mas a iluminação... Como o iluminador fica mais junto com o diretor, mais junto com a equipe, porque às vezes, o cenógrafo apresenta o projeto para o diretor, monta o cenário e vai embora. Algumas mudanças de cenário, até, partem da equipe, do diretor, do iluminador, do figurinista... E com o figurino também, ele chega, apronta... É muito difícil você mudar o cenário inteiro, o figurino inteiro de uma peça, coisa que com a luz, podemos fazer, não é? Você pode mudar a posição do refletor, você pode mudar toda a programação da luz... Essa última peça do Felipe, que ia estrear agora no dia 19, nós montamos cinco luzes para a primeira cena. A mesma posição, nós montamos cinco intensidades... nós tínhamos dúvida sobre para que lado ia a luz, então é muito interessante isso, você não faz cinco figurinos para a primeira cena, cinco cenários para a primeira cena, e a luz te dá essa condição. E eu acho isso muito bom, essa parceria, tanto com o diretor que você já trabalha quanto com o diretor novo, sempre tem coisa nova, coisa boa para acrescentar.

\section{N.L. - Você falou dessa peça, que peça é essa que vocês iam estrear?}


B.B. - A do Felipe, que não estreou, que foi transferida? É A Língua Brasileira, a história da língua, que tem texto em celta, tem texto em árabe, tem texto em tupi, é muito interessante, os atores estão loucos para decorar... Tem língua da África, foi feito um trabalho gigantesco para fazer todo esse levantamento para chegar na língua portuguesa. É um trabalho muito interessante que vai estrear daqui uns meses. E a outra coisa que eu estava dizendo sobre ela, é que nós montamos a primeira cena, que o Felipe dirigiu, e aconteceu uma coisa que... eu não sei o que vai ser daqui para a frente, mas visivelmente, o Felipe e eu achamos que a luz não funcionou, que o cenário está grande demais dentro da peça, que o figurino não está bom e que a sonoplastia não está boa. Ou seja, nós temos aí um caso muito grande para resolver pela frente, vamos ver como é que nós vamos resolver isso. E isso é muito bom, nesse caso, de acontecer o que está acontecendo com essa peça, porque provavelmente, se fosse um diretor que nós não tivéssemos contato, ele ia estar muito desesperado, já que achamos estranho o que aconteceu na primeira cena, mas eu acho que quando tem essa parceria, então, com certeza, vai ser mais fácil de resolver.

N.L. - Você está falando bastante do diretor, da tua relação com os diretores e com o cenógrafo também, como é o caso da Daniela, mas, de uma forma geral, quando você cria uma luz, qual a tua maior preocupação? É realmente só a opinião do diretor que te interessa, aquilo que o diretor e o cenógrafo querem passar, mas você se preocupa com o ator, com as necessidades do ator, as necessidades da cena, ou você pensa no espectador também?

B.B. - Ah, eu acho que é um conjunto, mas a minha maior preocupação, realmente, é que eu acho que eu tenho que criar o conforto do ator para ele fazer a peça, eu não posso ficar fazendo um festival de efeitos em cima de um ator, quando ele tem que contar uma história simples, então eu acho que eu tenho que ter esse cuidado básico, porque afinal, o que é o teatro? $O$ teatro é o ator, então qual é a minha função? Eu sempre digo isso, a minha função é iluminar o ator para ele contar a história da melhor maneira. Mas, ao mesmo tempo, eu 
acho que eu tenho a grande responsabilidade de ajudar o diretor a contar a história. Um bom exemplo é aquela peça Eu não vejo Moscou da janela do meu quarto, na qual eu ajudo a contar a história... Então, a peça é sobre uma família cujo espaço, inexplicavelmente, começa a diminuir, e no texto, sabe, não tem referência nenhuma para a luz, ou seja, eles vão mudando para um outro espaço levando cada vez menos objetos. E o que que eu imaginei? Eu imaginei cinco elipsos recortados, quatro elipsos recortados, três elipsos, dois elipsos e no final eles estão encurralados em um elipso. Então, foi muito interessante, a peca foi apresentada lá na SP Escola de Teatro, onde tem um teatro muito pequeno, e eu acabei ganhando o Shell com uma luz que era simples, que tinha elipso. Uma coisa assim, simples, aonde a luz foi fundamental. Aliás, do jeito que a peça ficou, sem a luz você acabava não entendendo nada. Quando eles passavam a peça sem a luz, você não entendia, e quando entrava a luz, você tinha uma noção exata da coisa, então nesse caso, a luz contava a história cem por cento. Dentro dessa pergunta, então, ela é fundamental, às vezes a luz tem a função de mostrar a peça. A luz sempre está lá, mas tem alguns momentos em que ajuda muito a cena, para ajudar a contar o que está acontecendo, mostrar alguma parte do cenário, com certeza. Essa luz, além de ajudar o diretor, eu também tenho que fazer a minha parte, não é, iluminar tudo o que precisa.

\section{N.L. - E no espectador, você pensa às vezes?}

B.B. - Aliás, o tempo todo! (risos) Porque não adianta nada eu fazer uma peça só com contraluz, só para mim, uma luz maravilhosa é para o ator dando o texto. E o espectador, dentro de tudo isso, a iluminação é fundamental para o espectador. Mas dentro desse teatro contemporâneo agora, tem diretor para quem fazemos luz, que na peça você não enxerga quem está falando, então é complicado, eu acho. Eu acho ruim o espectador não ver o rosto do ator. Eu, aliás, eu fico perseguindo o rosto do ator para ver se está bom, para mim é isso. Não é luz chapada, é luz lateral, qualquer luz, mas você tem que enxergar quem está falando.

N.L. - Mas você não iluminar o ator também pode ser uma forma de pensar no espectador, você não querer que ele veja o ator... 
B.B. - É... Então, eu acho o seguinte, tem casos, é claro, em que às vezes você não ilumina o ator, que é quando ele dá o texto no escuro, que tem a ver, mas não é toda peça que acontece isso, então... Aliás, com certeza, às vezes você ilumina o objeto em cena, e o ator fala o texto do lado, quando tem a ver dentro da história, mas isso é difícil de acontecer, não é? Não é uma coisa que acontece em toda peça, que é obrigatório. Eu acho que o que é obrigatório é a plateia sentar e ver quem está falando. É o mínimo, não é? (risos)

N.L. - Entendi... Você falou do teatro contemporâneo, existem alguns exemplos mais ou menos, mas tem-se falado muito do teatro colaborativo, onde existe uma colaboração maior da equipe. Você começou a trabalhar num teatro que é conhecido como o teatro do diretor, na qual só o diretor falava, onde só o diretor tinha voz. E hoje tem esse teatro dito colaborativo, você teve alguma experiência desse tipo? Como isso funciona com a criação da luz?

B.B. - Eu acho que... aliás, esse termo novo eu acho que não tem nada de novo, porque se o teatro não é colaborativo não sai a peça. (risos) Por mais que o diretor seja um ditador, como era nos anos setenta. Aliás, eu acho lamentável, o diretor achar que ele pode falar alto com alguém dentro de um ensaio. O teatro é contra tudo, e aí aparece um ditadorzinho achando que é um diretor, é um absurdo isso, mas vamos lá... Ou seja, por mais que o diretor ache que é ele que manda, ele depende de todo mundo, está todo mundo ali, ou seja, o teatro sempre foi coletivo, é isso muito bom, por isso que é bom fazer teatro, porque é a arte de todo mundo. Ainda mais, assim, vamos supor, como no caso com o Felipe, que tem uma equipe de criação, então, com certeza, é muito mais colaborativo... Nossa, é uma coisa super... Mas você falou um negócio, ali, com relação ao cenário, ao processo colaborativo... Eu acho que tem uma coisa que foi fundamental na minha vida... Eu nunca me afinei muito com cenógrafo, sabe, eu sempre achei cenógrafo meio egoísta, eu acho o cenógrafo egoísta, ele não participa tanto do teatro quanto o resto das pessoas. Então, quando eu comecei a trabalhar com a Daniela Thomas... Na verdade foi antes que eu comecei a notar cenário, foi em Praga em 2011... Em 2007 e 2011, quando fui para a 
Quadrienal de Praga, que realmente me abriu os olhos para o cenário. Eu nunca tinha prestado muita atenção em cenário, eu ia lá e iluminava: "Olha, monta o cenário lá que eu ilumino". Mas a partir dali, quando eu vi aquela massa de cenários e aquelas coisas... e depois, trabalhando com a Daniela... mudou muito a minha visão de cenário. Eu acho que hoje eu dia, eu sou quase... eu não sou cenógrafo, mas mudou muito a minha visão dentro da cenografia.

N.L. - Você acha que hoje você tem uma colaboração maior com o cenógrafo do que você tinha antigamente?

B.B. - Ah, com certeza! Eu acho que a partir da Daniela, minha relação com o cenógrafo mudou.

\section{N.L. - Mas só com ela? Ou mudou com todo os cenógrafos?}

B.B. - Sim, com todos os cenógrafos, porque antes eu não dava bola, realmente, eu acho que eu aprendi a conversar com o cenógrafo.

N.L. - Entendi. Mas e com o resto da equipe? Porque quando você fala equipe de criação, você está falando diretor, cenógrafo, figurinista, iluminador e sonoplasta, ou você incluindo o elenco também nessa equipe de criação?

B.B. - Com certeza, é todo mundo. Às vezes, a mulher do cafezinho dá uma ideia e fica boa na peça, então eu acho, sim, que o teatro é de todo mundo. É impressionante, o elenco, que participa de meses de ensaio, eles propõem muita coisa dentro do processo, eu acho que é muito interessante. Não existe o teatro do eu sozinho. Tem uns diretores que acham que é dele, mas não é.

N.L. - E na tua criação da luz, você é aberto para todas essas sugestões, para todas essas colaborações?

B.B. - É engraçado, porque geralmente eu vou lá e monto a luz, e aí a luz já está pronta, e dificilmente... Conversamos muito, em termos de intensidade, de alguma coisa assim, mas de mudar a cena, coisas assim, é difícil. Não lembro, eu acho que... eu aceito colaboração, é claro (risos) mas é difícil de acontecer, 
assim, de a pessoa falar "vamos mudar", mas, numa boa, claro... se eu achar, se eu concordar, eu mudo...

N.L. - Mas e você, você se mete muito no trabalho dos outros?

B.B. - Ah, eu acho que, hoje em dia, eu dou muito palpite. (risos) Principalmente, assim, quando eu conheço o pessoal e o diretor, como no caso do Felipe, com a equipe de criação, é quase obrigatório todo mundo falar o que pensa da peça, e isso ajuda muito, ele escuta tudo e se ele achar bom e quiser usar, usa, e se não achar bom, também, não usa. Então, realmente, eu acho que a liberdade que tem nisso, é muito legal. E tem diretor que fica na dele dirigindo e eu acho isso uma pena, porque ele fica sozinho e às vezes você pode ajudar. E dentro da pergunta que você fez, se hoje em dia eu dou muito palpite, com certeza, eu acho que, também, pela experiência... Eu acho que, às vezes, você ajuda muito, dentro da cenografia, até da marcação, você dá algum toque, e geralmente, quando eu falo isso, é em função de melhorar a iluminação, sabe, o ator entrar de uma lado, entrar do outro, onde eu possa entrar com a luz para conduzir melhor a cena. Então, com certeza, você pode ajudar muito, principalmente em emenda de cena, que às vezes o diretor tem dúvida e onde a iluminação é fundamental, como na emenda de cena, então, geralmente, eu dou muito palpite.

3. Agora, então, a última pergunta, que é sobre a performatividade da luz. É a minha pesquisa de doutorado, que é tanto uma pesquisa prática no meu trabalho como iluminadora quanto uma pesquisa teórica com base em outros autores, na qual eu defendo a participação ativa da iluminação na cena teatral, o que quer dizer que a luz não é só uma forma de permitir que o espectador veja o que está acontecendo em cena, mas ela tem uma voz ativa, uma participação autônoma na cena, podendo ser como um personagem, contracenar com os outros elementos da cena. A questão maior é que a luz age, tanto sobre a cena, numa atuação, uma performance, e sobre a percepção do espectador, a percepção que o espectador tem do 
espetáculo. Você concorda com isso, com essa atuação, essa função ativa na cena? E você poderia dar exemplos de algum espetáculo ou de alguns efeitos onde você sente essa atuação da luz?

B.B. - Bom, eu acho que sim, como eu já falei da Não vejo Moscou da janela do meu quarto, que é uma peça onde a luz era um personagem, realmente, eram três atores e a luz era o quarto personagem. Com certeza...

\section{N.L. - Quem dirigiu essa peça, Beto?}

B.B. - A Silvana Garcia. Tanto é que eu ganhei o Shell em São Paulo como iluminador e ela ganhou como diretora. Era uma peça muito simples na qual, realmente, tanto a direção quanto a luz eram fundamentais para contar a história. E eu acho, além de tudo o que nós já falamos aqui, que a luz, eu sempre digo isso, a luz que eu crio é para conversar com o ator e para conversar com a plateia. De uma certa maneira, eu converso com o ator por meio da luz, que é como eu induzo a emoção, eu levo o ator para onde ele quer, quer dizer, eu tenho aquela minha teoria de que o corpo do ator leva a luz, não é? Eu sempre eu uso o movimento do ator para mexer a luz, e eu acho que, com certeza, dentro de tudo isso que eu estou fazendo em relação ao ator, eu estou fazendo também para ajudar o espectador a se emocionar. Se eu levo um ator a chorar em cena, com certeza, a intensidade de luz que eu estou colocando, tudo lá, isso aí automaticamente vai passar para o espectador. Eu acho, como eu falei lá no início, que a cenografia, o figurino, não têm esse poder de fazer a plateia rir e chorar. Porque que a plateia ri? Porque ela enxergou, porque ela está vendo o ator, então é muito por causa da luz. De toda essa coisa, o que é engraçado, é que quando você ilumina um objeto na cena e a plateia saca, todo mundo ri. O que é aquilo ali? é a luz, ou seja, a luz é que fez aquele objeto falar. Então, com certeza, é a luz... E da mesma forma, quando você vai para um lado de suspense, a luz é fundamental numa peça de suspense. Se você faz uma geral branca, é uma coisa, mas se você muda a luz de um ambiente para outro, por exemplo, você tem uma geral branca no palco, o palco vazio, de repente, entra um som de suspense, a luz baixa, abre uma porta, você coloca uma contraluz, entra uma réstia da luz que está instalada lá fora, dentro do cenário, não precisa 
entrar ninguém em cena, só tendo uma sonoplastia e uma contraluz entrando pela porta e diminuindo a intensidade, num simples toque, você muda toda a ambientação, todo o clima do palco, e você já tem o clima de suspense. Então é isso a luz, porque se você fizer essa mesma cena, com as mesmas coisas, mas não mudasse a luz e não criasse essa luz externa, você não teria expectativa nenhuma, não teria o suspense. Eu posso dar outros exemplos, tem muitos exemplos de como você transforma a cena com a luz.

\section{N.L. - Eu lembro de te assistido uma peça com o Moa Leal e o Sidy} Correia no Mini na qual eles manipulavam duas luminárias, qual foi a ideia daquela peça?

B.B. - Bom, a ideia do (Gabriel) Gorosito, o Sidy (Correa) e o Moa (Leal) era montar uma peça, que os três pudessem viajar, colocar o cenário no carro, montar e apresentar a peça em qualquer lugar. Mas como eles não tinham projeto, então, não tinha dinheiro para montar a peça, a ideia era fazer um projeto super barato. Então eu quebrei a cabeça, fiquei pensando, pensando, pensando, e vendo os ensaios, eu pensei de que maneira eu podia fazer... A única ideia do cenário era uma mesa com um tampo de vidro, então a primeira ideia foi de colocar quatro PAR 38 no chão, para iluminar de baixo, sem muita mudança de luz, e nos ensaios eles iam usando os ângulos que tinha, colocando o rosto na luz. Depois, eu tive a ideia de deixar duas no chão e usar duas hastes de leitura, dois abajures, que subiram para cima da mesa e duas ficaram em baixo. Depois eliminamos as de baixo e eles começaram a usar a luz, eles manipularem a luz. Só que como era PAR 38, esquentava muito, queimando os dedos deles, então, fomos pesquisando, fomos para o LED e conseguimos um tom interessante. $O$ que no princípio era uma coisa fixa, os dois abajures em cima da mesa, começou a mexer e, de repente, deu uma dinâmica muito interessante. Então ao longo dos ensaios, as cenas já eram feitas da maneira que eles iluminavam, então, junto com a direção do Gorosito, já fazíamos a posição da luz que um ia iluminar o outro. Às vezes um iluminava o outro, às vezes o próprio ator iluminava ele mesmo, ele virava o refletor para ele mesmo para falar para o outro, então ele dizia um texto e depois virava para o outro responder. Como eles podiam 
acender e apagar as luminárias, ficou uma coisa muito dinâmica. No final, até tinha uma batalha, em cima da mesa, como se as luminárias virassem espadas, iluminado por baixo, por cima, pelo lado... E depois eu senti a necessidade de ter mais um ponto de luz, uma luz de apoio em cena, e coloquei uma luz dessas de sinuca em cima, que ficou muito interessante, então, às vezes, em alguns momentos, eles apagavam a luz deles e ficava só essa luz de sinuca, esse prato, que ajudava muito, ficou com um resultado muito bom. Então, era uma coisa muito simples, e ao mesmo tempo funcionou bem, tanto é que acabou sendo indicado até para o prêmio, uma peça que custou 800 reais. Foi uma situação criada por necessidade que acabou se tornando uma coisa muito interessante.

\section{N.L. - Muito bom. E você consegue pensar em mais algum exemplo?}

B.B. - Tem uma outra peça, $A$ morte do cacheiro viajante, com direção do Felipe (Hirsch) com o (Marco) Nanini. Isso foi em 2001, 2002, 2003, na qual a luz era toda baseada na movimentação do Nanini, do corpo do Nanini. Então todo o deslocamento, toda luz era junto com o Nanini, contracenava com ele, não existia... Era impressionante, o Nanini girava para um lado, para o outro, era muito sutil... A gravação da luz que foi feita, foi uma coisa demoradíssima, porque era o Nanini, sabe, era ele que conduzia a luz, o corpo do Nanini que conduzia. Era uma maneira especial... não era uma luz qualquer, ou seja, era uma luz que estava junto com o ator.
N.L. - Acho que é isso, obrigada pelo teu tempo e pelas respostas.
B.B. - Foi um prazer. 
3.4 Christine Richier - Iluminadora Francesa ${ }^{230}$

Por uma infelicidade e desajustes nos aparelhos de captação de som e imagem (normalmente faço os dois), a entrevista presencial realizada com a iluminadora, professora e pesquisadora Christine Richier na ENSATT, em Lyon, no dia 04 de março de 2020 não foi

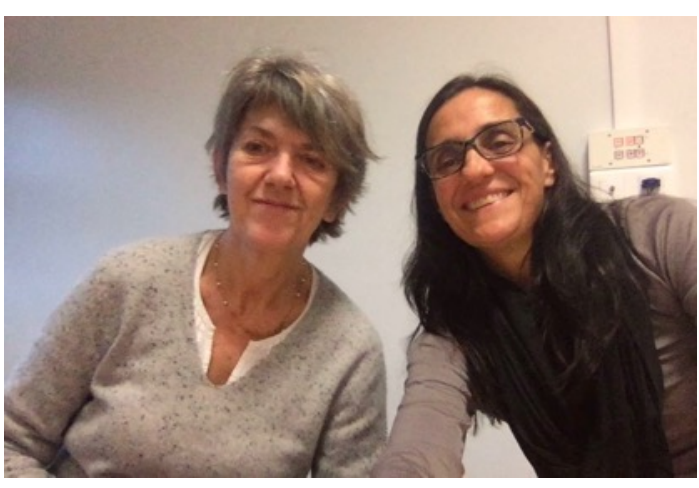
adequadamente gravada e salva, tendo sido perdida. Uma grande perda, considerando a riqueza dos mais de 50 minutos de conversa e das informações e opiniões concedidas. Infelizmente, dada a dificuldade de conciliar as agendas e do difícil momento por que passou toda a humanidade na primeira metade de 2020 devido à pandemia do coronavírus, causada pela propagação mundial da Covid-19, não foi possível refazer a entrevista.

No entanto, é importante ressaltar que muitas das ideias e conceitos da Christine Richier estão impressas em suas publicações e, principalmente, em sua tese de doutorado, à qual eu tive acesso na íntegra, inclusive aos originais da entrevista feita com o cenógrafo e iluminador por ela em Paris em março de 1993, anexos à tese. Além disso, alguns extratos da conversa com ela ainda guardados na memórias estão expressos em uma ou outra passagem do texto, direta ou indiretamente citados, além de diversas passagens de sua rica pesquisa doutoral. Fica registrado aqui, no entanto, o imenso agradecimento ao tempo e à atenção dedicados pela Christine tanto durante a entrevista quanto na visita feita à ENSATT nos dias 3 e 4 de março de 2020, dias passados na cidade de Lyon ao final do período do Doutorado Sanduiche realizado na França no final do ano de 2019 e início de 2020, logo antes do retorno ao Brasil.

230 Entrevista realizada pela autora na ENSATT - École Nacionalle Supérieur des Arts et Technique du Spectacle, em Lyon na França no dia 04 de março de 2020 (tradução da autora). 
3.5 Christophe Forey - Iluminador Francês ${ }^{231}$

1. Em relação à luz e à iluminação cênica, você considera que a luz é material ou imaterial? Que ela age no palco de forma material ou imaterial, quando os feixes de luz estão lá, presentes, ou seja, para você, trata-se da presença de luz no palco?

C.F. - De fato, eu diria que a luz é material e imaterial de acordo com o uso que se faz dela e de acordo com o seu funcionamento. Depois, se eu vou falar apenas da luz cênica e da iluminação de espetáculos, não voltando à física e coisas assim, que explicam muitas outras coisas, para mim ela é antes de tudo imaterial, isto é, ela ilumina coisas materiais, mas é imaterial e por sua imaterialidade pode transformar coisas materiais, isto é, os atores, os cenários, os tecidos, as matérias tangíveis que temos, que iluminamos. E esta é a relação desta imaterialidade e desta matéria com a qual você trabalha.

N.L. - Este é o lado imaterial, então? Você considera que a luz é imaterial, mas que ela materializa as coisas, digamos?

C.F. - Sim, ela pode transformar as coisas, mas ela em si é imaterial. Depois, as luzes que poderíamos dizer que se concretizam como matéria, como você disse, são as luzes que podemos ver nos shows, materializadas pela fumaça, por coisas assim com os fachos, quando a luz se torna ela mesma o cenário. E é isso, como você disse, nós a vemos, o que pode ser muito bom, mas não é exatamente o tipo de luz que eu faço. Eu posso fazer, em uma situação excepcional, eventualmente, porque depende de cada projeto, é claro.

N.L. - E você acha que essa luz material também poderia ser usada em uma peça, em um espetáculo que não seja um show, por exemplo?

C.F. - Sim, acontece em encenações recentes como montagens recentes de peças de Shakespeare, que é uma luz de concertos que é usada, como é

${ }^{231}$ Entrevista realizada pela autora em Paris no dia 20 de janeiro de 2020 (tradução da autora). 
feita. Ou na dança, isso é feito muito desde os anos 80 . Isso surgiu com os moving lights cuja luz se move e, de repente, se assumimos seu lado mutante e móvel, são parceiros, totalmente. Mas depois, a luz imaterial, ela intervém completamente na narração e na sua narrativa. Só porque é imaterial, não significa que não exista, imaterial significa que você não pode pegá-la com a mão, mas ela existe.

2. Sobre o processo criativo, quando você cria as luzes para os espetáculos com os quais trabalha, você tem o hábito de trabalhar com as mesmas companhias de teatro e o mesmo diretor ou você varia muito e qual é a influência dessa constância ou dessa variação no seu trabalho?

C.F. - Então, eu trabalho regularmente com os mesmos, mas tenho muitas pessoas com quem trabalho regularmente, então, além disso, depende da época. Como não sou mais tão jovem, tem muitos períodos que se seguem, pessoas com quem eu trabalho há 20 anos, outras com quem trabalhei e não trabalho mais porque não são mais deste mundo, mas com quem trabalhei durante 10 ou 15 anos. Mas em paralelo, eu trabalho também com várias equipes, e depois, efetivamente, o fato de trabalhar em equipe, primeiro traz certa confiança, uma confiança mútua, de ambos os lados, enquanto que quando trabalho só uma vez, o que também pode acontecer, quando me comprometo a administrar novas circunstâncias e quando me envolvo com alguém que não me conhece e que eu não conheço, em geral isso significa um desafio. Bem, é preciso que concordemos, que eu tente entender como ele trabalha, o que eu não sei no começo, e que ele, ou ela, da mesma maneira, procure entender ou peça que as coisas cheguem a um resultado que... Tem, então, um lado de jogo que é divertido, do qual eu gosto, mas que é diferente do processo quando se trata de pessoas com quem eu trabalho regularmente. Mesmo com pessoas com quem trabalho regularmente, com quem já existe uma confiança, com quem já há tudo isso, cada novo espetáculo é uma nova aventura e não sabemos como ele vai ser. E mesmo se nos conhecemos, eu não sei o que vou fazer antes e não sei com o que vai se parecer antes de começar. 
N.L. - Claro. E nesses dois tipos de realidade, quando você conhece a pessoa, sabe como ela trabalha, mesmo sem conhecer o espetáculo, mas existe essa confiança e, por outro lado, quando você não conhece, há uma interferência no resultado? Para você é melhor de uma maneira ou da outra?

C.F. - Não, de fato, no geral é melhor quando já nos conhecemos, tanto para o resultado quanto para o processo. Eu adoro quando não nos conhecemos, mas geralmente vamos mais longe quando já nos conhecemos.

N.L. - Ainda sobre a criação, qual é o aspecto mais importante no qual você pensa quando cria a luz: é o diretor e o que ele quer, o que ele deseja, o que ele pede, as necessidades dos que estão no palco ou se você pensa no espectador, no que eles precisam saber ou conhecer, enfim, do espetáculo?

C.F. - Eu começo a participar muito cedo do processo de criação, o que significa participar relativamente cedo da concepção do cenário, o que faz com que eu tenha muitas informações a respeito, então meu trabalho é focado em... primeiro eu ouço o que o diretor quer, basicamente, que história vamos contar e como ela será contada, porque, na verdade, é isso, antes de tudo saber o que estamos contando e depois como vamos fazer, qual será o estilo... se for teatro, se vai ser naturalista, vai ser abstrato, vai ser expressionista, ou se vamos fazer um patchwork de tudo isso, mas inevitavelmente o diretor saberá dizer qual será o estilo, então, se for noite em uma cena naturalista, eu não posso começar a colocar quadrados para todo lado, porque seria absurdo, mesmo que seja... Nós vamos contar uma história e temos que usar mais ou menos os mesmos meios para isso. Então, de fato, essa é minha primeira prioridade e depois, no ensaio, é o espetáculo, os atores e a presença dos atores para dar vida. A luz vive com os atores e dá vida à atuação dos atores... ou não. E o ator está em contato com um espaço, com um cenário, com uma mesa, com cadeiras, com paredes ou um céu... A luz deve criar o elo entre essas coisas inertes e as coisas vivas que são o ator e a atriz. E é isso, meu olhar está lá dentro, eu não penso nem por um segundo no olhar do espectador. 
N.L. - (Risos) Nem mesmo fisicamente, onde ele está, o lugar, ou seja, o ponto de vista que ele tem na cena...?

C.F. - Basicamente, o ponto de vista em geral, eu sei que ele não muda muito na plateia porque, caso contrário, seria necessário refazer tudo o tempo todo e, em uma primeira vista, é principalmente o centro da plateia, um ponto de vista comum. É o ideal e depois, os pontos de vista laterais dos espectadores, só se existem lugares infernais, problemas de reflexão, mas esses são casos muito pontuais, muito do tipo, aqui têm um espelho e a luz que bate nele, aí não é possível, mas isso é técnico, muito preciso e buscamos a solução para essas coisas, que não fazem parte da criação, mas que, efetivamente, levamos em consideração se acontece de cegar metade da plateia durante todo o espetáculo, isso não é interessante, mas esse é um segundo momento. Quer dizer, não é exatamente um segundo momento, pois se houver janelas para todo lado, é necessário levar isso em consideração primeiro, porque, caso contrário, não funcionará, mas é mais uma questão técnica. É isso.

3. E, finalmente, chegamos no tema de minha pesquisa, que é a performatividade da luz. Este trabalho sustenta, com base na minha pesquisa prática como iluminadora e teórica como pesquisadora, que a iluminação cênica participa ativamente da cena teatral e também de outras formas de artes cênicas, como a performance, a música, a dança, entre outras. Nesse sentido, eu proponho que a luz performa, atua no palco e interage com os demais componentes do espetáculo e com o público, tendo a importante função de estabelecer e promover a relação entre a cena e o espectador, ou seja, se o espectador entra em cena, se ele entra no espetáculo, se ele o acompanha, se ele está lá, isso acontece em relação à luz, de fato. É a luz que permite que seja estabelecida a relação entre o palco e o espectador. Você concorda com esta proposta e por quê?

C.F. - Sim, sim, claro que sim. Digamos que a luz, em princípio, é uma das linguagens... O teatro, a dança, existem vários tipos de atividade que 
trabalham juntos para criar uma obra de arte e em seguida cada uma delas tem sua própria linguagem para alcançar uma emoção, para transmitir algo porque 0 que é o teatro? É isso... tem quem escuta e assiste e tem quem fala e se mostra e é isso, é sobre como criar uma relação entre esses dois mundos, que é um relacionamento totalmente artificial e voluntário e o que é específico do teatro comparado à vida cotidiana, quando nós passeamos e olhamos as coisas na rua, é que existem pessoas que organizam o que é visto e, portanto, como criamos, ou melhor, tentamos criar uma obra de arte com isso, organizando esse tempo de uma hora ou duas horas ou três horas ou quatro horas que, nesse tempo, as coisas são organizadas para serem observadas e se tornarem uma outra coisa real, viva, mas que é organizada, ao contrário da vida real, que pode ser tão bonita quanto ou ainda mais, mas cuja organização nos escapa.

\section{N.L. - Sobre a qual não temos controle...}

C.F. - Isso. O que é bom, mas mesmo assim... Bem, vou voltar para a terra, então, sim, eu disse, cada um tem seu meio, de fato, então o cenário também vai contar algo, o ator vai dizer que cortamos as árvores, o figurino vai contar uma época, vai passar uma emoção do personagem, dizer se é um personagem vulgar ou chique, e isso faz parte do que o ator representará, então a luz, da mesma forma, vai contar uma história, vai criar um ambiente, trágico, triste, alegre, mais escuro, mais brilhante, com mais contraste, mais quente, mais frio e ela também participa do ritmo, da passagem do tempo. Uma das grandes diferenças entre a luz no cinema e no teatro é que, no cinema, ela atua apenas na imagem, de uma maneira muito, muito importante, mas não age com o tempo, porque é a edição no cinema que faz o tempo. Assim, no teatro, na coreografia, a montagem do cinema é substituída pela operação da luz e pelo ritmo dos efeitos, o tempo. Se um efeito dura três minutos até acender uma luz, não é nem de longe o mesmo que se houver cinquenta efeitos que durem três segundos cada, é claro. Porque, de repente, isso cria uma edição fracionada, acelera as coisas, como se pode ver em um musical, onde tem vários efeitos por minuto e, de repente, a luz segue cada movimento da sobrancelha do ator. Em um teatro mais diferente, que eu faço com mais frequência, o tempo da luz vai ser longo, 
enquanto que a atuação do ator vai ser rápida e, então, essa atuação lenta é valorizada porque a luz é longa, como na música, pelo contraste. Ah, sim, eu esqueci de falar da música, mas tudo bem. Porque, no que diz respeito ao tempo, o trabalho sobre o tempo da luz é o mesmo, ele colabora com a música ou com o sonoplasta, porque é principalmente o som e a luz que dão esse ritmo da montagem no teatro. Portanto, há uma parceria muito, muito importante entre música e luz. Sim, então existe essa história, existe ao mesmo tempo a criação de atmosferas, de ambientes, de sons etc. e de dar um ritmo.

\section{N.L. - Então é tanto imagem quanto ritmo? \\ C.F. - Isso. E, de repente, dessa maneira, a luz participa, ela conta uma} história.

N.L. - E então, quando eu digo que a luz atua no palco, isso significa, digamos, uma ação visual e narrativa, na sua opinião?

C.F. - Ou subjetiva, não é necessariamente narrativa, ela conta de certa forma ... é como a música, ela conta uma história, mas sem palavras.

\section{N.L. - Pela emoção?}

C.F. - Sim, pela emoção. Depois, em um ponto de vista prático, em relação..., mas depende, cada espetáculo é diferente, mas mesmo assim existem tipos de espetáculos. Quando eu posso, eu também participo desde o início dos ensaios, e se eu disponho de equipamentos de luz no estúdio de ensaios, o que aconteceu diversas vezes (já aconteceu também de fazer espetáculos de improvisação, mas isso é outra coisa), de trabalhar durante a primeira ou as duas primeiras semanas enquanto o diretor trabalhava com improvisação sobre o tema do espetáculo, sobre o tema das cenas, de eu trabalhar com a improvisação da luz e, nesse caso, eu não dizia para os atores o que eu ia fazer, eu só fazia. Eu coloquei uma luz que criou um limite entre dois espaços e eu pude notar, mesmo que às vezes não dê resultado nenhum, que a luz construiu um espaço e que os atores criaram em relação com ele, sendo que quando um deles se colocava na sombra e o outro em plena luz, inevitavelmente, 
a relação entre os dois se tornava diferente e, em seguida, o que estava na sombra podia, com um gesto, em um momento específico, entrar na luz, criando uma dinâmica muito forte e, de repente, interagindo assim com a improvisação. Depois, em geral, essas luzes se tornavam a minha base para a criação final da luz do espetáculo. Depois, então, de forma ideal, o que acontece comigo às vezes, foi que eu pude ensaiar, desde o primeiro dia, com luz no palco e no cenário. Esse fato aconteceu comigo há alguns anos atrás, na montagem do espetáculo O Nariz, de Chostakovitch, no caso uma ópera sensacional cujo cenário tinha uma estrutura dupla, giratória e com muitos elementos móveis, painéis em carrinhos, com uma porta, uma janela, o que permitia montar diferentes espaços. Tudo era neutro e essas duas estruturas faziam com que tudo fosse móvel e pelo fato de termos todo o cenário pronto e disponível, desde o início dos ensaios do espetáculo, o diretor, que chegava sempre meia hora antes do ensaio, olhava a maquete, e, finalmente, tendo pensado antes, me olhava. As meninas já tinham montado a luz, os maquinistas o cenário e eu, que tinha uma base da luz pronta, experimentei alguns efeitos de luz diretamente nas cenas, durante os ensaios, de acordo como espaço criado, que de repente era acentuado ou suavizado, criando essas áreas de jogo, ambientes mais escuros e assim a marcação da cena foi realizada diretamente neste espeço e com essa luz.

\section{N.L. - E isso durante os ensaios?}

Sim, durante os ensaios. E depois do ensaio, efetivamente, no dia seguinte ou no próximo dia, eu via o ensaio e mudava algumas coisas com base no que tinha visto, mudava a direção ou eliminava alguns efeitos que não eram mais necessários e no próximo ensaio fazia a mesma coisa para uma próxima etapa. O importante é que os ensaios aconteciam com uma proposta de espaço e de luz e o diretor levava a luz em consideração, necessariamente. Na verdade, se você coloca uma luz para um diretor, ele trabalha com essa luz, se você não coloca nada, bem, ele trabalha com o que tem.

N.L. - Sim, é isso, muito interessante. E finalmente, você acabou de dar um exemplo de um espetáculo, mas você tem outros exemplos, ou esse 
mesmo, no qual você pode dizer que a luz transformou as coisas, como você diz?

C.F. - Na verdade, eu não diria nesses termos, eu diria que a luz participa da escritura do espetáculo, que o espetáculo não existiria sem a luz, eu não transformo as coisas, eu as faço. Antes não havia nada, é como quando não há cenário, não há cenário, podemos dizer que o cenário transforma o espaço, mas não dizemos isso, dizemos que ele é instalado, com a luz é a mesma coisa, a instalamos. E a cada vez... enfim, o ideal é quando a luz encontra a atuação do ator e acontece algo mágico que funciona, e isso às vezes acontece e às vezes não.

N.L. - E você se lembra de um exemplo em que isso aconteceu?

C.F. - Sim, sim, sim, sim, mas eu teria que mostrar com fotos ...

N.L. - Ah, tudo bem, podemos fazer mais tarde. Mas está bom, acho que é isso, muito obrigada.

C.F. - Vamos fazer uma pausa?

N.L. - Vamos fazer uma pausa... (risos). Obrigada. 
3.6 Claudia de Bem - Iluminadora Gaúcha ${ }^{232}$

\section{Como conceito, você considera que a luz seja material ou imaterial? Você saberia explicar a sua resposta?}

C.B. - Eu considero a luz as duas coisas. Tenho uma relação da luz com o olhar, essa é a minha maior relação. Eu acho que a luz me conduz e me ensina a olhar as coisas. Acho que é uma dialética entre o que eu estou vendo e o que eu não estou vendo. Essa duplicidade está sempre junto. O primeiro conceito de luz é que ela torna as coisas visíveis. Aprendemos assim, mas ao mesmo tempo, para mim, luz é muito mais do que isso. É a maneira como eu vejo o mundo e como eu vejo as coisas. Como eu torno as coisas visíveis.

\section{Você costuma trabalhar mais com a mesma companhia e diretor} ou varia? O que você pensa a respeito disso?

C.B. - Eu vario bastante, mas quando eu morava no Sul, trabalhei um tempo com uma companhia ( 6 anos) e com dois diretores durante muitos anos. Foram experiências diferenciadas. Na companhia Incomode-te (RS), foi uma experiência mais coletiva, portanto eu tive maior liberdade criação, tanto que começamos a construir uma estética mais elaborada, uma linguagem visual. Também, nesta companhia não havia um diretor, somente. Os processos eram colaborativos, inclusive na concepção da encenação, o que torna tudo muito mais rico, com o que eu me identifico mais. Outra experiência foi com um diretor (dez anos) que produzia seus espetáculos e já tinha uma ideia fechada sobre a encenação. No tempo que trabalhamos juntos, eu estabeleci uma relação mais estética com a luz, mas havia uma relação aberta e muitas vezes eu sugeria algumas alternativas de luz para a encenação, mas creio que era menos desafiador, em termos de concepção e dramaturgia. $\mathrm{O}$ meu processo criativo

${ }^{232}$ Entrevista realizada por Gabriela Valcanaia em São Paulo no dia 27 de janeiro de 2020. 
com a luz, é uma coisa que eu tenho estudado bastante, então posso responder com bastante certeza. Eu sou uma pessoa nada pragmática e gosto deste meu traço, de ver o processo e de não ver sempre igual, de não ter cartas na manga, de entrar zerada a cada novo desafio. De pensar como se eu nunca tivesse realizado uma contraluz que funcionou, uma lateral ou uma diagonal. Sempre que eu penso luz para qualquer ação artística, seja o que for, eu crio uma narrativa. Não sei se porque venho do teatro, mas eu sempre crio narrativas e construo imagens dessas. Desde criança, eu aprecio muito desenhar e pintar, e utilizo muito isso quando entro num processo de criação de luz. Gosto do termo desenho de luz. Nos ensaios, levo comigo papel e lápis colorido. Este tipo de representação me auxilia na composição das cenas. Quando o processo tem texto, eu nunca gosto de ler antecipadamente. Às vezes me limita, então, a não ser que eu dirija o processo, eu prefiro não ler. Acho que o primeiro contato deva ser com a leitura do encenador sobre a obra.

\section{G.V. - Você acha importante estabelecer uma relação mais próxima} com o dramaturgo e encenador do espetáculo que vai iluminar ou até mesmo com todo o grupo e equipe de criação para criar a luz? Faz diferença trabalhar sempre com a mesma pessoa?

C.B. - Eu sempre trabalhei com muita gente, mas acho importante ter um diálogo estético mais desafiador e uma identidade com o diretor ou o grupo, é muito ruim quando só você está enxergando. É um sinalizador de que algo está errado comigo, na forma que estou no processo. Eu sou uma pessoa extremamente primorosa com estética no meu trabalho e tenho TOC com acabamento, mas nem sempre é assim. Quando eu trabalhei com o diretor Biño Sauitzvy, isso foi bem no início da minha carreira, eu tive uma empatia com a forma como entendíamos o espaço de encenação. Fizemos várias obras do Beckett. Me sinto privilegiada por ter tido, cedo, uma experiência tão profunda com o teatro. Apesar da minha inexperiência, eu conseguia criar num ambiente de afinidade cênica. Aprendi, ali, sobre a qualidade e a dramaturgia da luz. Já na companhia Incomode-te, com o tempo e a experiência, começamos a trabalhar com o espaço, a luz e a cena numa relação mais orgânica, criando uma 
identidade estética. Como eu era a pessoa que criava o espaço e a luz, começamos a ter encenações onde estas linguagens eram incorporadas a cena. Por questões econômicas, o espetáculo não poderia circular em teatros menores ou projetos com menos verba, porque quando você trabalha assim, você não pode abortar a concepção, faz parte de linguagem e não só da iluminação. Eu tinha questões que eram incompreendidas, apesar de eles gostarem muito do resultado, mas quando eu fazia avaliações técnicas sobre a incompatibilidade de alguns espaços, causava situações delicadas e eu me desgastei com isso. Por causa disso. Eu projetava cenários luminosos, com partes que acendiam e criavam a própria ação para a cena e eu não podia tirar. $E$ isto não era compreendido. É muito delicado quando não existe a compreensão de que, no teatro, é um conjunto de linguagens e todas precisam ser respeitadas. E não é uma questão de fazer valer um desenho de luz, o que estou falando, é de uma linguagem de encenação onde tudo dialoga. Então, para trabalhar numa mesma companhia, precisa ter uma identidade ou uma afinidade com o diálogo estético. É preciso ouvir todos os profissionais envolvidos e confiar neles.

\section{G.V. - Qual a tua maior preocupação no momento de criação, a quem} você dá mais atenção?

C.B. - Eu dou mais atenção ao desejo de quem me contrata, quem criou o conceito. Se for um diretor de cena, é ele, mas numa exposição é a obra. No teatro, temos mais essa discussão conceitual. Quando é música, atendo ao artista, mesmo que ele, a princípio, não me peça nada. Eu atendo a quem eu estou iluminando e o que vou iluminar, seja um espetáculo, um show, uma obra, uma casa ou uma fachada. Claro que cada profissional envolvido deve interpretar e abstrair com a sua ferramenta para trazer a sua colaboração com a obra.

G.V. - Como o espectador entra no teu processo criativo? Ele entra ou chega só na apresentação?

C.B. - O espectador sempre entra no meu processo criativo. Eu nunca pensei sobre esse aspecto de forma tão reflexiva, mas a recepção é 
fundamental. Nos aspectos visuais, tenho sempre alguns cuidados quanto a ofuscamento e desconfortos inapropriados. Quanto a propor um efeito visual pensando na reação do espectador, já utilizei isso em dois espetáculos, acho interessante trabalhar com essa possibilidade de interferência no olhar ou utilizar de conhecimentos óticos para criar efeitos. Claro que isso deve se adequar à proposta de encenação. Na verdade, estamos sempre pensando no espectador, e para fazermos proposições neste sentido, precisa compreender o sistema ótico. Saber como as pessoas enxergam.

3. A pesquisadora deste trabalho defende, como resultado de suas pesquisas práticas como iluminadora e reflexivas como pesquisadora, que a iluminação cênica tem uma participação ativa na cena teatral, assim como em outras formas das artes cênicas como a música, a dança, entre outras. Com isso ela afirma que a luz atua, age em cena e interage com os demais componentes do espetáculo e também com o público, tendo a importante função de estabelecer e favorecer a relação entre o palco e plateia. Você concorda ou discorda dessa afirmação? Por quê? Você saberia dar alguns exemplos dessa atuação da luz no seu próprio trabalho? Pode ser um projeto inteiro ou um, ou mais, efeitos específicos.

C.B. - Eu concordo e acredito nisso. A luz é essa ferramenta que faz com que as pessoas enxerguem mundos diferentes, se emocionem, reflitam, etc. Apesar de, às vezes, não termos esse lugar para ela, como nós iluminadores gostaríamos, por inúmeras questões. Nos comprometemos com que isso aconteça e sabemos que isso acontece e por isso é tão importante acreditarmos nessa potência. A dimensão que a luz pode alcançar numa obra e no espectador é infinita.

G.V. - Você saberia dar alguns exemplos dessa atuação da luz no seu próprio trabalho? Pode ser um projeto inteiro ou um, ou mais, efeitos específicos. 
C.B. - Eu fiz uma trilogia do Paul Auster e tinham várias interferências com o público. Um dos espetáculos, Dentro Fora, foi bem importante e determinante para um novo processo de pesquisa artística no qual me debruço até hoje. Era um texto em que os dois atores ficavam o tempo todo dentro de uma caixa de paredes de acrílico de 2 metros de altura. Eu propus uma instalação de luz dentro das caixas e nenhuma refletor foi instalado fora deste espaço. A imagem final era como se tivessem duas vitrines. O que o público via era apenas o espaço interno, um efeito bem interessante. Os atores relataram uma experiência perceptiva com a luz. A incidência da luz na parede acrílica, causava um espelhamento, eles viam a própria imagem refletida e não viam o público. Tinham que atuar sem a referência do espectador. Isso exigiu uma presença cênica muito maior do que a que eles costumavam ter e também acessar a outra sensorialidade. Teve ainda outro fator, eu utilizei temperaturas de cor para diferenciar as emoções contidas na narrativa. Instalei seis circuitos com lâmpadas e luminárias residenciais. O texto abordava o estado de imobilidade da humanidade contemporânea, gerado pelo caos da vida cotidiana. Uma metáfora sobre a condição inanimada da humanidade no tempo atual. A escolha foi trazer uma luz fria para os momentos em que dialogavam sobre 0 nada e uma luz mais quente para as memórias afetivas trazidas pelos personagens. Na ocasião, os atores relataram sua percepção com relação a estas atmosferas. Talvez pelo confinamento e a proximidade das fontes, eles conseguiam se conectar e se emocionar com isso. Outro momento, em que eles discursavam no vazio total sobre a cor azul, era lindo. Neste momento, propus uma inversão de foco para o espectador. Quando eles divagavam sobre o azul, criamos uma pausa poética com luz e som. A luz saía das caixas e o público era ofuscado e banhado com uma bateria de lâmpadas PAR 64 com filtro cromático azul 79. Apenas nesse momento os atores viam o público imerso neste azul e o público não via os atores. Não tinha quem não sentisse o azul e se emocionasse com ele. Nesse exemplo, a luz tinha uma performance. Ela atuava. O que identifico na minha estética hoje, é a forma que entendo a luz. Para mim, ela tem sempre uma escrita imagética e está relacionada às minhas referências luminosas, mas principalmente com minha interpretação daquilo que estou 
vendo. Identifico no desenho uma simetria, mesmo quando opto pelo assimétrico. Com relação à cor, eu também opto geralmente pelos corretivos, sou quase monocromática. A pigmentação, quando vem, tem um propósito muito bem pensado.

G.V. - Muito obrigada pelas respostas e pela atenção! 
3.7 Cibele Forjaz - Iluminadora Paulistana ${ }^{233}$

\section{Como conceito, você considera que a luz seja material ou imaterial? Você saberia explicar a sua resposta?}

C.F. - Então, eu acho que a luz tem uma existência material, concreta, que atua sobre os corpos, ela é vibração, atinge o olho e cria impulsos elétricos, frequência de ondas que viram imagem no cérebro e tem toda uma interação com o material e o concreto, mas na cena ela também pode ser um canal de comunicação entre o que é material e o que é imaterial. Isso ocorre principalmente na medida em que a luz atua no visível, não necessariamente de modo conceitual, mas pode provocar a imaginação e a participação ativa da plateia e, nesse sentido, ela é imaterial... É relação e propicia a projeção da subjetividade da plateia, da imaginação, da abertura para o que não é dito e é sentido, mas que não poderia ser explicado.

\section{A segunda pergunta é sobre processo criativo. Você costuma} trabalhar sempre com uma mesma companhia, tem relações mais longas com alguns diretores?

C.F. - São trinta e três anos de profissão, então, quando eu estava aprendendo, eu não fui assistente de nenhum iluminador, porque, naquele momento, eu comecei a fazer luz no meu grupo, que se chamava Barca de Dionísio, e rapidamente comecei a fazer luz de muitos que eram da minha geração, que estavam começando, e alguns já mais antigos. Eu fui aprendendo a fazer fazendo e, nesse momento, trabalhei muito com muita gente e comecei a fazer espetáculo de gerações muito distintas. O que me formou como uma mulher de teatro... A minha formação é em direção e eu acho que eu aprendi muito no teatro, nos grandes teatros diferentes e nas experiências na luz... Acho

${ }^{233}$ Entrevista realizada por Gabriela Valcanaia via Skype no dia 20 de abril de 2020. 
que eu posso dizer que a luz me ensinou a dirigir e a direção orientou meu foco de olhar para a luz encenadora. Eu acho que isso é uma primeira fase em que eu trabalhei muito.... fiz show, ópera, espetáculos pelo Brasil todo, além da minha companhia. Uma segunda fase, depois de ter trabalhado muito, foi entrar no Teatro Oficina, onde eu passei dez anos trabalhando só com o Zé Celso e com o Oficina, abrindo o teatro junto. Eu estava lá como um elemento do grupo para o que fosse necessário e, também, como assistente de direção. Por muito tempo, eu fiquei nas duas funções e foi onde eu realmente pude ver um trabalho com continuidade, com pesquisa, uma pesquisa específica e para um tipo de linguagem que eu estava criando junto. Ali, no Oficina, eu atingi um trabalho mais maduro e que estabelecia uma articulação estruturante de tempo e espaço, porque as cenas, todas, têm muitos planos, e que se misturam, e cabe à luz separar esses planos sincrônicos, colocá-los em realidades diferentes e relacioná-los. Fora que o foco do olhar precisa ser muito direto e apolíneo, mas sempre com o improviso.... Daí a criação de quatro pessoas que participavam ativamente, cantavam as músicas e operam os pin-beams, que depois viraram loko lights... Sempre tínhamos um roteiro muito preciso desse plano, focado para que fosse possível jogar com os outros e improvisar, colocando a plateia em cena, tirando a plateia, entrando na cabeça da personagem ou explicitando o teatro e mostrando tudo. O Oficina tem uma relação muito direta com o público, é um rito presente e muito aberto. Nesse sentido, a operação... e eu sempre operei a luz, é sobre estar junto e ter esse aprofundamento da linguagem da luz como uma atuante na cena e na relação direta com a plateia. Eram cinco ou seis luzes diferentes na plateia dependendo do tipo de interação e relação com o espaço naquele momento. Eu consegui fazer umas pesquisas bem específicas, com todo um plano de iluminação pública gelatinada, porque ela tem outra densidade... Lâmpadas industriais como os HQIs, as lâmpadas mistas e de sódio... Isso tudo com cor! Então, eu usava sódio com vermelho, HQI com verde, lâmpadas mistas com azuis e algumas HQls sem cor para dar um aspecto de luz de estádio. Existia também o blecaute em cor, uma interação mais poética e sensorial. Haviam muitos planos: um cria a história, outro conduz pelo espaço, outro que cria diferentes realidades. Eu fiquei 10 anos ensaiando junto e isso é 
muito importante, porque um aprofundamento como esse, é feito junto com os atores, nos ensaios, e refletindo sobre cada elemento da cena em conjunto, principalmente a partir do trabalho com os atores. Eu acho que a luz é um trabalho diário com os atores. E depois veio a docência e, como professora de luz, eu vi um tipo de pesquisa mais histórica, quando fiz meu mestrado e doutorado sobre a constituição da luz como linguagem na virada do século XIX para o $\mathrm{XX}$, as vanguardas.... Acho que é um momento fundamental e, por isso mesmo, a noção de uma luz encenadora, estruturante das linguagens do espetáculo, que articula tempo e espaço junto com todas, mas que é muito determinante da visibilidade, do que é visível, o que é invisível, o que é imaginário, como é invisível, as mudanças de tempo e espaço, a fusão. Eu acho que tem uma escrita da visualidade na qual a luz é muito ativa e isso desde o Appia. Falando da luz ativa, isso é uma coisa que tem história, que tem tradição, e eu acho que eu entre nessa tradição, tanto estudando quanto ensinando e sendo encenadora, pensando a luz como essa articuladora de visibilidade na cena.

\section{G.V. - Eu queria ouvir um pouco sobre o teu processo criativo e entender a que ou a quem você dá mais atenção no momento de criação.}

C.F. - Ele (o processo criativo) é feito em sala de ensaio e tem um processo de construção, criação e experimentação, porque eu acho que a luz tem que experimentar, ela não se faz só no mapa, só na cabeça e eu gosto de ensaiar com luz. Eu fico operando luz de parede, com lanterninha... porque eu gosto de ensaiar junto, ir criando junto e essa é a minha lida com o dia a dia do ensaio e é nessa friç̧ão que a luz vai se entendendo como um elemento fundador dessa relação com a plateia, já que muitas vezes a plateia é colocada em cena pela luz. Ela une ou separa o tempo e os espaços muito rapidamente e transita muito rapidamente entre esses vários planos. A luz é, então, fundamental na relação com a plateia e com esse trânsito entre ilusão e realidade, uma espécie de reflexão com a qual o teatro brinca o tempo inteiro. Acho que são milhões de possibilidades da luz como articuladora e encenadora. Eu acho que é do ensaio mesmo, do dia a dia e, se possível, já experimentando, 
como foi a minha experiência de 10 anos no Oficina, onde a luz era feita durante o ensaio. Às vezes, no meio do ensaio, porque os ensaios são longos e nas seis ou oito horas de ensaio dava para montar, experimentar... Espetáculos longos, mas ensaios lentos e que voltam muito. Essa é uma experiência muito específica de criação de uma linguagem, mas há outros muito importantes, como é o caso do Guilherme (Bonfanti) com o Vertigem, a Alessandra (Domingues) com a Cia. Livre, onde eu dirijo, que são possibilidades de desenvolvimento de uma linguagem e de uma poética comum entre todos os elementos da cena e todas as pessoas que compartilham a criação.

\section{G.V. - Você poderia falar um pouco da tua experiência como diretora} da Cia. Livre e como você continua pensando sobre luz, mesmo tendo outra pessoa responsável pelo projeto de luz?

C.F. - Eu sempre dirigi e a luz veio junto. O que acontece é que gosto muito do processo de criação no bate bola, na reflexão conjunta e eu faço tudo em coletivo, não sou muito da solidão, de pré-planejar, fazer só na minha cabeça e tudo para mim vem da vibração conjunta da criação teatral. Então, quando eu dirijo, essa relação é fundamental, porque é lógico que eu não deixo de ser uma pessoa que sente ou que vê através da luz, mas a liberdade da Alessandra e a pesquisa dela, como tem sido desenvolvida, me atravessa completamente, então eu acho que é mais o como você conversa, fala... Mas para mim é sempre importante, às vezes, até agora eu gosto de iluminar junto com os alunos, ou com jovens iluminadores que foram meus alunos ou alunas... Eu gosto de trabalhar em coletivo, experimentar junto e isso me provoca.

\section{G.V. - Como é a tua relação com assistentes? Você poderia falar um pouco sobre isso?}

C.F. - Ela é tão profunda que, em geral, começa como meu assistente e acaba assinando junto, porque chega uma hora que você não sabe, porque não tem propriedade privada sobre a criação quando você bate bola. Lógico, as relações vão se fazendo, a atuação da pessoa mais comum, receptiva ou mais como propositiva. Depende da maturidade e do desenvolvimento da experiência 
de cada um ou cada uma, mas, normalmente, vira uma parceria e é uma via de mão dupla, em que se aprende dos dois lados. E também, o fato de que, nos dez anos do Oficina, eu operei, e a operação fazia parte da atuação ao vivo da luz e, muitas vezes, alguns espetáculos me levavam a entrar em cena, como é o caso de Para dar um Fim no Juízo de Deus. Em Bacantes, eram sete horas de espetáculo nas quais eu realmente improvisava e sabia o número de cada refletor, cantava junto... Eu estava em cena, e isso me permitia um tipo de atuação ao vivo que a peça me pedia. Ham-Let, ao contrário, embora a luz fosse muito simples e o teatro ainda não estivesse acabado, nós improvisamos porque podíamos chegar a vinte mil quilowatts, só, pela amperagem que tínhamos e que era muito restrita. Mas o roteiro, principalmente os pin-beams e a relação entre geral e contra, focos muito precisos... Nós tínhamos um roteiro de cinquenta páginas, de quatro fileiras. Toda a movimentação de focos era muito precisa, enquanto outras coisas eram improvisadas, mas sempre pensando sobre a presença da luz no palco e na plateia, que estava sempre em contracenação profunda com os atores, junto com eles. Uma luz ativa e atuante.

\section{G.V. - Você se coloca, no momento da apresentação e como operadora, como uma co-atuante e/ou no lugar de espectadora?}

C.F. - Eu acho que a luz participa da ação, quer seja com a interação da sua materialidade, vibração, foco e sua escrita, mas também na experiência de entrar em cena com lanternas ou pin-beams e ser uma parceira presencial na atuação e de maneira corpórea. Em Para Dar um Fim no Juízo de Deus, eu estava em cena com figurino, tinha falas e operava luz ao mesmo tempo, tinha um foco sobre mim. Então, tem muitas formas de explicitar e atuar ao vivo, e faz parte da pesquisa do Oficina uma atuação que não é representativa ou que simboliza, mas que presentifica, atua junto e é ao vivo. Eram várias pesquisas, mas que tinham espaço para serem aprofundadas e terem continuidade. Foram dez anos em grupo, num teatro que é o mesmo espaço, ensaiando seis ou oito horas por dia, lendo e estudando junto. É uma outra possibilidade de aprofundamento da atuação da luz na cena. 
G.V. - Você pode falar um pouco sobre a relação que tem com o espectador e com a comunicação, que é tão importante na sua fala.

C.F. - Depende muito de cada espetáculo, se é uma comunicação, mais de uma história, sensação... Isso varia muito, se é uma dança e aonde você comunica e como você comunica. Eu acho que não é exatamente só para o espectador, mas é com o espectador, tentando uma comunicação muito explícita da presença da luz como uma linguagem que atua junto e que está aberta a improvisos, que está aberta ao improviso, que cria as viradas da narrativa... É muito comum tudo mudar por uma transformação no espaço, então eu me sinto muito em cena.... o ritmo da cena e o pulsar... eu estou junto. É o Hamlet e a luz, juntos, atuando e contando a história, refletindo, parando, interrompendo, fazendo fórum. A presença da luz em cada momento está nessa tensão com tempo e espaço, então é uma escrita fundamental. Se a peça propõe uma escrita e uma criação ao vivo, a luz também tem que ser.

G.V. - Você falou sobre o aspecto material e imaterial da luz e de ela se colocar como linguagem quando você está contracenando com o ator ou a atriz. As tuas necessidades de explicação ou de compartilhar, por exemplo, dizendo "estou colocando esse foco e ele vai te seguir", é o mesmo canal de comunicação que há entre dois atores em cena? Ou ela é mais sensível, mais racional?

C.F. - Acho que muda bem e vai desde o exemplo do Ham-Let, em que ele é o motor condutor da peça e a luz, ao vir junto, é um pouco o narrador de Ham-Let. Outras vezes ela vem de fora e é uma escrita de orquestração do espetáculo. Em outras, é muito no feeling com o ator ou o dançarino, mas em espetáculos de improviso e em dança, acontece muito de você contracenar e estar em dueto. Eu acho que depende muito de cada espetáculo, porque quando você constrói uma criação, é muito importante experimentar, mesmo! Ultimamente, eu tenho tido vontade de entrar em cena com lanternas, luzinhas, estar em cena, cada vez mais junto, tudo muito simples, mas atuando ao vivo e com o meu próprio corpo em cena mesmo. 
3. A pesquisadora deste trabalho defende, como resultado de suas pesquisas práticas como iluminadora e reflexivas como pesquisadora, que a iluminação cênica tem uma participação ativa na cena teatral, assim como em outras formas das artes cênicas como a música, a dança, entre outras. Com isso ela afirma que a luz atua, age em cena e interage com os demais componentes do espetáculo e também com o público, tendo a importante função de estabelecer e favorecer a relação entre o palco e plateia. Você concorda ou discorda dessa afirmação? Por quê?

C.F. - Eu acho que eu iluminei, no Oficina, mais plateia do que cena (risos). Eu vou contar uma historinha do meu primeiro contato trabalhando com o Oficina. Eu recebi um recado na secretária eletrônica de que eu iria entrar no segundo dia do processo de Ham-Let e que já ia ter uma leitura aberta em um auditório do SESC, que eu não lembro qual era. Eu não sabia como ia ser, mas entrei no ônibus e fui. Eu me preparei para improvisar, mas fiz um contra, uma luz de frente e assim que começou, o Zé (Celso) começou a correr pela plateia gritando "LUZ! LUZ NA PLATEIA!" e eu corri pegar um refletor e saí atrás dele iluminando, ele, as pessoas e a relação com a plateia. Nesse sentido, a luz atuava sobre a subjetividade da plateia junto... do indizível. Eu concordo completamente e acho que a luz é, ela mesma, um atuador estrutural e estruturante para o espetáculo de teatro, mesmo que seja um espelhinho.

G.V. - Você entende que a relação da luz sobre a subjetividade da plateia é diferente da maneira como ela age sobre a subjetividade do ator ou da atriz?

C.F. - Com o ator é uma contracenação de quem leva a peça, discussão, história junto, mas no caso da plateia, tem a surpresa da atuação direta. Se eu jogo uma luz no seu rosto, acendo a luz, e você está no teatro, foco no ator, ou se está quase no escuro e você precisa imaginar o que está havendo e, de repente, acende uma geral de dez HQls e te coloca em um estádio... Fora a vibração que toca no teu corpo, o calor... Fecha a cena, ou coloca todo mundo 
dentro do teatro no aqui e agora. É uma atuação em tudo, desde a criação de atmosfera até a construção de muitos espaços e muitos tempos compartilhados com a plateia. Então, quer seja como no Oficina, que era explícito ao ter cinco gerais diferentes para a plateia, uma de cima, uma de baixo... até espetáculo que tem mais uma atuação sobre a imaginação, mas eu acho que sempre a luz interage bastante com o olhar da plateia. No cinema, isso está presente em muitos recortes, planos e trabalhos de edição, mas no teatro, isso está ao vivo com a plateia, então você leva e um tanto é o olhar que vai (risos), você sugere, mas o que a pessoa vai imaginar, se ela vai ver um monstro naquele escuro ou se vai ver a sombra, é um trabalho junto com a plateia. Eu acho que tinha falado disso, mas desde a criação do cinema, os vídeos, as milhares de fotos e a sociedade do espetáculo... Às vezes eu brinco que as pessoas vão ter o seu foco de luz móvel para andar pelas ruas (risos). Eu acho que com o mundo cada vez mais digital, a presença se tornou a coisa mais importante do teatro. A presença, o fórum, as práticas ritualísticas... Eu acho que é na presença viva em frente ao artista e nos corpos, vibrações, sons produzidos junto e ao vivo e com a participação ativa da plateia, que, no meu trabalho, tem sido cada vez mais sobre isso: "estar com" e não "mostrar para". Acho que a luz é esse elemento ligador de relação e de transformação muito rápida dessa relação do espectador com a cena... colocando-o dentro de cena ou tirando, indo de uma geral para um foco e então para uma luz de serviço que diz: "estamos aqui e agora". Acho que esse é o tipo de criação e de escrita compartilhada.

\section{G.V. - Você pode me dar algum exemplo dessa atuação da luz no teu} trabalho e que tenha sido significativo para ti?

C.F. - Acho que os focos móveis no Oficina e o como eles articulam, já que focos móveis já existem antes das lâmpadas de filamento... Mas o como ele articula os planos e permite o improviso e o jogo entre a ficção e a realidade. Acho que a experiência em Mistérios Gozosos e Bacantes com as lâmpadas de iluminação pública, que eu acho bem significativo mostrar outra densidade da luz, outra forma de contracenar com eles de diferentes pontos, tanto em temperatura de cor, mas também do tipo de fonte, do fogo ao moving-light ou a 
projeção. Essa pesquisa dos panelões de iluminação pública criando esse fundo em cor e que você, também, se tem uma linha de luz sobre um ator, a plateia também vê que ele ainda está lá, mas que está em um fundo azul, o que difere completamente o que é escrito ou iluminado com luzes quentes, que também é estética e poética. É uma delícia ser iluminadora, por isso é uma gama de possibilidades de processos criativos e de experimentação com fontes diversas e formas de atuações... os atores. Eu lembro de ter visto Hamletmachine, do Marcio Aurélio com a Marilena Ansaldi, que operava alguns refletores em umas torres que tinha um dimmer para cada refletor e ela ia lá, subia, ligava e mudava de lugar. Isso era uma utilização explícita de um elemento de linguagem e que também é poética, porque ela fazia isso dançando e integrava tudo.

\section{G.V. - Para você, existe uma escrita da luz dissociável da cena?}

\section{Como um elemento próprio?}

C.F. - Não, eu acho que é uma relação conjunta, porque ela não existe sem um corpo que a reflete, uma fumaça, um corpo humano ou a plateia, o espaço... não acho que existe nenhuma escrita própria na linguagem do teatro e todas vão de encontro à construção conjunta. Quando é meu cenário, minha luz, minha cena, isso não tem nada a ver. São planos que se articulam, falam juntos, se enredam, e é uma teia que precisa de organicidade e harmonia, ou um contraste explícito desejado, mas a escrita é em conjunto e polifônica. Não penso e não faço nada sozinha e por isso precisa vir do ensaio, mas tem uma articulação visível muito forte e uma orquestração de como os vários planos do que é visível se enredam. A luz, nunca sozinha, mas sempre junto dos outros elementos e por isso que não é só estrutural como também estruturante da cena. É nessa articulação na verdade.

\section{G.V. - Acho que é isso. Muito obrigada!}


3.8 Eduardo Tudella - lluminador Baiano 234

\section{Como conceito, sem reflexões técnicas ou científicas, você considera que a luz seja material ou imaterial? Você saberia explicar a sua resposta?}

E.T. - Eu considero difícil dar uma resposta para essa pergunta sem levar em consideração abordagens técnicas ou científicas. Do meu ponto de vista é impossível pensar nessa reposta quando relacionamos os conceitos de material, ou negando isso, e imaterial. É muito difícil, para mim, não levar em conta os aspectos técnicos e científicos. A minha resposta é justamente a dificuldade de pensar nisso sem aspectos técnicos ou científicos. O primeiro ponto é que, para o ser humano poder fazer esse tipo de pergunta, ele precisa da luz no seu aspecto material, afinal de contas, nós só estamos aqui, eu e você e a vida, de modo geral, no planeta, por causa da fusão nuclear, só porque o sol está transformando hidrogênio em hélio. Eu não consigo me desvincular disso. A minha resposta é que a luz é tanto material quanto imaterial. Afinal de contas, é a luz que nos elabora aqui e a nossa presença só é possível por causa da luz ou da sua condição científica. Por outro lado, a natureza humana e o como ela se constitui, inclui essa abordagem imaterial, filosófica, subjetiva. Hoje, vivemos na era da subjetividade e as questões mentais definem tudo ou grande parte das coisas para determinada categoria de pessoas. Então, a minha resposta, simplificando, seria: a luz é tanto material, uma vez que agora o sol está transformando hidrogênio em hélio e nos faz existir aqui e esse existir inclui os aspectos humanos de subjetividade e de ordem psicológica, então o homem opera com a luz nas instâncias material e imaterial. Aliás, na minha pesquisa de doutorado eu evitei, por estratégia, usar analogias entre luz e conhecimento, luz e sabedoria, exatamente para mostrar que é possível tratar a luz sem esse viés, mas que o ser humano não consegue. É impressionante como na área das artes cênicas, da performance, muita gente usa, como em outras áreas, a luz como

${ }^{234}$ Entrevista realizada por Gabriela Valcanaia via Skype no dia 22 de janeiro de 2020. 
um sinônimo de sabedoria, engrandecimento divino, superior ou de perfeição, e a sombra como o mal, o negativo. Esse movimento subjetivo de ver a luz e sombra como opostos é ocidental, desde Platão e o mito da caverna, ainda que se olharmos a história da Grécia Antiga, em Plínio, haja a desconstrução da sombra como o mal. A construção dessa abordagem cristã, neoplatônica de sombra e luz, bem e mal é uma abordagem subjetiva do que é apenas a fusão nuclear.

2. A segunda pergunta é sobre processo criativo. Eu sei que, no teu currículo, você participou de várias montagens na universidade, mas você trabalha com alguma companhia ou com um diretor a mais tempo? Isso varia?

E.T. - Varia sim, mas aqui em Salvador, nós temos uma relação especial entre a universidade e o teatro de modo geral, porque é muito difícil você encontrar um profissional com relevância no mercado baiano que não tenha contato com a universidade. Nós temos um mercado amador muito forte, temos no Teatro Vila Velha, bastante importante para a cidade, uma linha de teatro experimental onde se poderia pensar em uma distância com a universidade, que eles chamam de universidade livre, mas impressiona a quantidade de pessoas que lá estão e que têm trânsito na universidade. Então, na Bahia, em Salvador, não se pode trazer esse modelo que temos em outros lugares com o teatro universitário e o teatro profissional. Temos um ambiente muito mixado com essas duas vertentes. Então, eu trabalho há muito tempo para uma companhia que se chama O Teatro Nu, cujo diretor se chama Gil Vicente Tavares, que foi meu aluno e orientando. Eu fiz o projeto de luz e de cenário para o espetáculo de formatura dele e trabalhamos juntos há quase duas décadas. Acabamos de fazer uma ópera completamente distanciado da universidade. Então, eu trabalho tanto com esse grupo e outros, que não estão necessariamente vinculados com a universidade, e vez por outra sou convidado por diretores que não têm trajetórias acadêmicas, mas que passaram pela universidade. Aqui na Bahia, é muito difícil fazer uma fronteira. Se você me chamar para fazer um projeto de um 
leilão de cavalos, um desfile de modas, para um enterro, eu vou e faço. Quando você começa a trabalhar com iluminação, você faz todo tipo de projeto, ou, pelo menos, na minha formação, o que eu penso é como tratar a luz para determinada natureza de evento. Eu me sinto disposto, não sei se tenho capacidade, mas de fazer uma iluminação para uma luta de MMA, porque eu compreendo desse modo.

G.V. - Você acha importante estabelecer uma relação mais próxima com o dramaturgo e encenador do espetáculo que vai iluminar ou até mesmo com todo o grupo e equipe de criação, para criar a luz? Faz diferença trabalhar a tanto tempo com o Teatro Novo?

E.T. - É claro que faz diferença, como eu disse para você, o diretor do Teatro Novo foi meu aluno e na peça que eu fiz cenário e figurino ele ganhou o prêmio revelação do ano. É uma pessoa com quem eu trabalho há duas décadas e ele era muito jovem quando nos conhecemos e agora é uma personalidade do teatro baiano, com muitos louros. Eu continuo sendo apenas o técnico que trabalha ali na iluminação, em que eu entendo que cada evento que eu vou me envolver eu me coloco aberto e, para mim, a palavra-chave é flexibilidade. É importante que eu esteja aberto para compreender a proposta de qualquer projeto e tentar descobrir de que modo eu posso contribuir. Quando você fala um dramaturgo, eu entendo como o autor do texto dramático e literário formal. $\mathrm{O}$ autor de uma peça, caso esteja vivo e a sua disposição, você pode conversar com ele, mas a maioria dos autores dos textos que montamos não estão nessa condição, então nós precisamos nos abrir para o texto, que, em minha opinião, se for um texto de qualidade, pode fornecer material suficiente para que alguém que trabalhe com iluminação faça o seu projeto para a cena. Às vezes, tem diretores que, ao conversar comigo, estranham o fato de me pedirem um ponto de vista e eu pergunto se já tem elenco, porque eu gosto de ouvir os atores. Muitas vezes, o registro da voz, o timbre, a maneira como um ator empresta a sua voz na elaboração de uma personagem, na sua relação com a outra e em contrates que me geram imagens. Tudo o que acontece na cena me provoca, porque na minha abordagem, o teatro, dança, performance, cena... são tantos 
nomes, mas que têm a sua origem do termo latino compósita, ou seja, se você tirar um elemento daquilo ali, aquilo se transforma em outra coisa. Quando você tira um elemento e coloca outro, essa natureza que chamamos de espetáculo, de cena, será então uma arte compósita, criando uma outra realidade, uma nova natureza. Em um espetáculo, a cor de um figurino, a textura de um cenário, a música que você vai usar, tudo tem uma contribuição que só aquele aspecto pode dar. Para mim, essa é a natureza importante da nossa atividade. Os aspectos que compõe a nossa atividade, têm outras questões particulares que os compõe.

\section{G.V. - Qual a tua maior preocupação no momento de criação, a quem} você dá mais atenção?

E.T. - Como eu the disse anteriormente, eu não dou atenção a uma questão em especial, mas ao conjunto. Quando um diretor me convida para trabalhar com um texto especifico, a primeira coisa que eu faço é, se eu não conheço o texto, ler o texto. Um lighting designer, como é a minha formação, se ele tem algum tipo de contribuição que servirá de base na música, no texto, a primeira coisa que eu vou fazer é criar o meu próprio ponto de vista sobre ele. Vou dar um exemplo objetivo para você: eu fiz uma peça de Brecht, que na minha opinião Brecht escreveu para que o espectador saísse do teatro vomitando, com náusea do tamanho da monstruosidade que é o ser humano. Essa é a minha leitura da peça, mas quando eu vi, a concepção do diretor era totalmente romântica. Eu estava numa situação institucional, na qual eu era obrigada a fazer a peça, então o que eu fiz com a minha abordagem daquela peça foi guardá-la em uma gaveta da minha alma e fiz a peça seguindo as indicações do diretor. A peça foi indicada a prêmios, mas em minha opinião, não era a abordagem que eu faço da peça. Então, eu procuro me concentrar em tudo que constitui o espetáculo e, caso haja texto, começo a partir do texto. Quando esse texto começa a ser tratado pelo diretor, pode vir e ter uma outra cara, como nessa história que eu te contei, ou quando o ator começa a construir a personagem e começam a aparecer, entre as personagens, algum tipo de provocação para mim, e eu procuro ficar atento o tempo inteiro para cada um dos detalhes. 
G.V. - Nesse sentindo o espectador é levado em conta ou ele só chega quando o espetáculo é finalizado?

E.T. - A questão do espectador é importante para mim e para se encenar, porque enquanto não há espectador, não há cena. Você pode ensaiar três anos, enquanto você não fizer aquilo para alguém, não há cena, porque ela só existe nesse contato. Quando você é autora de pecas teatrais e começa a escrever uma peça, quando você escrever a primeira letra, por exemplo a peça se chama A Casa de Maria... quando você escreve "a", o espectador já está presente, mesmo que seja para por numa gaveta. Uma peça ou a ideia de um espetáculo é concebida para o público e o espetáculo não ocorre enquanto o público não estiver presente. Tudo o que você constrói ou elabora em uma peça não existe antes que haja o espectador e, nesse sentido, nada do que concebemos nos pertence, isso vale para todos nós. Por isso que em minha opinião, o que eu crio para a cena, que é a elaboração da imagem, em minha opinião, a imagem na cena desconstrói qualquer noção de propriedade. Você pode elaborar um figurino, usar um brinco que você usa para construir a personagem, mas enquanto o público não estiver lá, esse figurino não existe. Um foco de luz ou um elemento de cenário não existem enquanto o público não estiver lá, e quando ele estiver, isso já não te pertence, porque você está entrando em contato com o público, expondo o público, e só a resposta dele constrói o espetáculo.

3. A pesquisadora deste trabalho defende, como resultado de suas pesquisas práticas como iluminadora e reflexivas como pesquisadora, que a iluminação cênica tem uma participação ativa na cena teatral, assim como em outras formas das artes cênicas como a música, a dança, entre outras. Com isso ela afirma que a luz atua, age em cena e interage com os demais componentes do espetáculo e também com o público, tendo a importante função de estabelecer e favorecer a relação entre o palco e plateia. Você concorda ou discorda dessa afirmação? Por quê? 
E.T. - Eu concordo absolutamente, não há nada nessa elaboração de Nadia que eu possa discordar, nem teria fundamentação. Primeiro, porque de um ponto de vista, o que chamamos de cena, espetáculo, teatro, dança, dançateatro, todas essas coisas, como eu já disse, só acontecem efetivamente com o público. Então, sem a presença da luz, o espetáculo cênico seria muito raro, porque eu me pergunto, e faço essa pergunta aos meus alunos: quando, no último ano, você assistiu a um espetáculo em que não se visse nada? É muito raro, eu assisti em toda a minha vida apenas dois espetáculos nas trevas, no escuro, onde entrávamos de venda para assistir ou se apagava a luz. Então, sem luz não há cena, do ponto de vista da cena, com as convenções que conhecemos. Então, é impossível negar a contribuição da luz, uma vez que, no espetáculo, se inclui a natureza da imagem visual fisicalizada. Você, para mim, agora, é uma imagem fisicalizada, e isso só é possível por conta da luz.

\section{G.V. - Então, a contribuição da luz para o espetáculo é definitiva e só} a luz pode contribuir da maneira como ela contribui. Você pode me dar algum exemplo, já que você concorda, dessa característica da luz no teu trabalho?

E.T. - Em minha opinião, qualquer espetáculo meu que você tenha assistido tem essa contribuição. Não só meu, mas de qualquer iluminador, ou seja, não é possível iluminar um espetáculo sem a ação da luz. Em um espetáculo que as pessoas foram lá e assistiram à imagem fisicalizada. Eu quero chamar atenção para a questão da imagem, porque no teatro, há pessoas que só concebem a imagem em duas vertentes: a imagem como algo que você grava e reproduz, como uma foto ou um vídeo, ou uma pintura, um desenho, ou então essa coisa subjetiva. Lembre que eu disse que estamos na era da subjetividade... Eu trago a imagem em várias vertentes: do ponto de vista da neurociência, percepção e sensação... Então, em um espetáculo meu, agora entramos em um tópico que eu considero muito difícil, que é fazer relato sobre um espetáculo. Se eu pegar um espetáculo como Quartet...

\section{G.V. - Que você apresentou na Quadrienal de Praga, não é?}


E.T. - Isso. No espetáculo, há muitos momentos em que as pessoas estão elaborando convencimentos, uma personagem tentando convencer a outra usando mentiras. Como no meu processo de projetos, eu sempre parto de uma imagem, que geralmente eu chamo de uma imagem verbalmente articulada no texto, ou seja, há algo que o dramaturgo escreveu e que está na boca de um personagem, aqui ou acolá, que me provoca, porque na fala existem provocações de textura, cor, forma, e isso me leva para um caminho de elaboração do meu projeto. Os meus processos sempre partem de uma imagem, assim, ou de uma espécie de metáfora. Nessa peça, o personagem masculino pergunta para a personagem feminina de onde ela tira as cores com as quais pinta os vícios dele. Daí eu parti para construir a minha abordagem visual da peça. Eu me coloquei a pensar, "quem tem algum vício?", "o que é um vício?” O vício é uma coisa tão enraizada em você, que se torna até primitivo, e que dele você não consegue se desvincular, é intenso e profundo. Do ponto de vista visual, não há nada tão intenso, profundo e único, mas eu pensei nas cores primárias, porque delas ou nelas se origina tudo o que vemos. Sem as cores primárias, você não efetiva a sensação e a percepção visual. Então, eu decidi fazer esse espetáculo só com cores primárias, para mergulhar nos vícios dessa personagem. Em muitos momentos, quando uma personagem ia mentir para tentar convencer a outra, eu usava o magenta porque ele é uma cor que não se percebe no espaço, mas nas coisas, e o magenta só consegue ser encontrado artificialmente, ele não existe na natureza. Então, do ponto de vista da cor eu usei o magenta para trabalhar essa falsidade. O magenta era o highlight, o ponto de maior luminosidade, do ponto de vista cromático, e do brilho mesmo, era o magenta. Quando as personagens se abriam, estavam fragilizadas, e eu usava um azul com vermelho e ficava um violeta bem suave... Você acha que eu vou explicar isso para o diretor? Ele já tem tanta coisa para se preocupar: dois atores enlouquecidos em cena, cenógrafo, figurinista. Eu construo isso e mostro o resultado para o diretor. Tem um momento, na peça, em que uma personagem descreve a outra num momento de carinho e diz "meu amado câncer". Aí alguém que viu o ensaio disse "agora vem um vermelho" e eu usei uma cor enverdecida, como algo purulento... eu faço essas associações. Então, houve o meu conceito, 
que estava lá quando a personagem perguntou sobre as cores dos vícios, que eu já te falei, e a partir dela eu criei imagens mentais. Eu trabalhei para transformar essas imagens mentais em efetivas na cena e visualizáveis para o público. Quando o público entrou em contato com o espetáculo, cada um dos espectadores visualizava a partir de suas próprias interpretações, afinal, nós temos a sensação, ao ver, e depois a percepção, que chamamos na psicologia de imaginário, onde você congrega a tua experiência de vida como um todo para compreender o que você viu. Eu agora estou descrevendo isso para você, então eu tenho a imagem que está na minha memória, a imagem do texto, a imagem que eu elaborei, a imagem que eu criei no espetáculo, essa que eu descrevi para você e essa que você criou... são seis coisas. Por isso, em minha opinião, é impossível gravar um vídeo ou fotografar, ou descrever um espetáculo, porque ele só existe no momento em que ele está acontecendo. Se eu descrever um efeito para você, ele vai ser essas seis imagens, e o efeito é sempre um movimento. Então, eu posso fazer uma peça inteira sem efeito, mas o efeito é um elemento necessário para construir esse discurso da cena. Imagine se eu for descrever para você: quando eu fiz Mestre Aroldo e Os Meninos, a transição de dia para noite durava 40 minutos... e como eu vou descrever isso? O espetáculo é superimportante para o ser humano porque é o único evento que você precisa do artista e do observador ali, presentes, para acontecer. Por isso que, há muito tempo, se diz que o teatro vai acabar e nunca acaba. Eu acho isso importantíssimo. Minha resposta fica assim porque ela toca em muitos aspectos da minha pesquisa, que hoje não é mais em iluminação, mas é em imagem.

\section{G.V. - Muito obrigada!}


3.9 Elsa Revol - lluminadora Francesa ${ }^{235}$

1. Eu estou fazendo minha pesquisa de doutorado sobre a performatividade da luz, então tenho três perguntas para poder basear a pesquisa também no trabalho e na experiência profissional e prática dos iluminadores. A primeira pergunta é, portanto, sobre a materialidade ou a imaterialidade da luz, o que você pensa a respeito?

E.R. - Eu diria, em princípio, que a luz só pode existir se houver algo para receber a luz. A questão é sobretudo o fato de que a própria luz não existe, nós só a vemos quando ela atinge um corpo, um objeto ou um espaço. Então, de alguma forma, eu percebo particularmente o seu lado imaterial porque enquanto não há nada, não podemos vê-la. E ela não ganha vida, a luz só se torna matéria quando há um corpo ou um objeto a atravessa. Então, quando não há nada, ela é imaterial e, quando há algo, ela se torna matéria.

N.L. - Podemos dizer, então, que ela é material quando associada a outra coisa?

E.R. - Sim, quando algo a atravessa, é isso, ou quando ela própria atinge algo, quando há uma interação com outra coisa. É isso.

N.L. - E essa interação é uma interação mais informativa, semiótica, ela representa algo ou não necessariamente?

E.R. - Não, não, não necessariamente, sobre isso podemos dizer que a dramaturgia da luz é, pode ser simbólica, pode ser factual, pode haver muitas coisas, isso é ainda mais um dado, é, em termos de escrita, a luz é uma outra ... sim, ela pode ter uma gama muito ampla nesse sentido.

235 Entrevista realizada pela autora em Paris no dia 06 de fevereiro de 2020 (tradução da autora, original ao final dos anexos). 
2. Passemos à segunda pergunta, então, que é sobre o processo de criação. Você costuma trabalhar habitualmente com as mesmas companhias ou o mesmo diretor ou isso varia?

E.R. - Varia muito, mas tenho grandes afinidades e há pessoas com quem trabalho há muito tempo. Eu trabalho em várias áreas, digamos, no teatro, no circo, na magia, e nesses grupos eu tenho minhas companhias ou meus diretores aos quais sou bastante fiel.

N.L. - E você acha que isso influencia o trabalho como criadora, ou seja, qual é a diferença de ser convidada para fazer uma iluminação para uma dessas companhias ou quando alguém que você não conhece, de quem você não sabe nada, afinal, te convida, como isso afeta a criação?

E.R. - Bem, o último exemplo de processo novo que eu tive foi no ano passado, quando fiz a criação da luz de Fauves para Wajdi Mouawade, Essa foi a primeira vez que trabalhei para ele, eu não tinha visto nenhum espetáculo dele e ele não tinha visto nenhum espetáculo do qual eu tivesse feito a luz. Então, foi realmente uma descoberta dupla e o que posso dizer é que foi preciso de um tempo longo para nos conhecermos, pois ... é sempre muito difícil falar sobre luz, de repente todo mundo usa palavras diferentes, um vocabulário diferente e, portanto, só entender a linguagem do outro, saber quando ele diz: "não sei, não gosto de luz dura", por exemplo, o que isso significa, luz dura para essa pessoa? Ou depois, Wajdi me conduziu a um lugar de cores que era bastante incomum para mim, e, de repente, eu também tive que buscar em mim coisas novas e coisas completamente desconhecidas, completamente diferentes, é isso. Nesse caso, isso te obriga a fazer um pouco o trabalho de um tradutor, de um intérprete, para entender o vocabulário do outro e, em seguida, procurar em si mesmo como responder, como estar presente e que lugar da criação ativar, por assim dizer, então é super enriquecedor, porque me mostrou lugares muito potentes, foi realmente uma colaboração e um encontro muito, muito, muito forte, mas extremamente cansativo porque nessa situação, nós não temos nenhum ponto de apoio, por assim dizer, é um lado totalmente novo, de repente, como por exemplo, com Galin Stoev, com quem já fiz quase uma dúzia de criações, devo 
ter feito perto de sete ou oito, já não é preciso nem conversar, as coisas fluem, rolam, são muito mais fluidas e, de repente, há um lugar de tranquilidade que permite que você se coloque em um estado de pesquisa, por assim dizer, mais fluido, mais seguro. Às vezes, isso pode ter a desvantagem de te acomodar; você não pode se deixar levar demais, por assim dizer, enquanto que, quando é tudo mais novo, isso faz com que você esteja em constante atividade, é isso.

\section{N.L. - E tudo correu bem no seu trabalho com Wajdi?}

E.R. - Sim, correu muito bem, foi muito, muito, muito desafiador. Muito, muito, muito desafiador, mas correu tudo muito, muito, muito bem, mas por outro lado foi de uma intensidade fenomenal, sabe, foi muito... é isso. Mas sim, sim, correu tudo muito bem. Eu revi o espetáculo depois, pois ele ficou em cartaz mais de um mês no Colline (Théatre National de la Colline), então eu pude vê-lo depois de dar um bom tempo para as coisas se estabilizarem antes de rever o espetáculo e, ah sim, foi ótimo. Mas, mesmo assim, tinha uma sensação de não ter concluído o processo, porque todo o tempo que passamos nos conhecendo, descobrindo e entendendo um ao outro, foi um tempo que não foi completamente dedicado para a luz do espetáculo propriamente dita. Durante esse tempo de reconhecimento tinha também o espetáculo que estava sendo construído, então de repente, eu acho que acabamos correndo muito contra o tempo, porque tínhamos que fazer as duas coisas ao mesmo tempo, se conhecer e fazer o espetáculo, o que acabava sendo uma tarefa dupla, é isso.

\section{N.L. - E nesse caso, por exemplo, se você tivesse a oportunidade de} trabalhar com ele novamente, seria mais tranquilo?

E.R. - Ah, sim, é claro, porque já existe uma linguagem comum que foi construída em conjunto e, desta forma, já começaremos de algo instituído enquanto que, na primeira vez, começamos do nada.

N.L. - E artisticamente, qual tipo de situação você acha que te provoca mais, que te cativa? Esse tatear, essa incerteza, artisticamente falando, ajuda ou atrapalha? Você sente alguma diferença? 
E.R. - Sim, sim, há uma diferença muito grande, mas é uma diferença emocional, na verdade. É que eu realmente tive a impressão de estar indo para um lugar estrangeiro, de estar constantemente estimulada por cheiros, gostos, ver coisas, uma língua que eu não conhecia e, de repente, quando estamos assim, num lugar estrangeiro, nós somos super estimulados e de repente nos encontramos em um estado criativo muito forte, que é quase, por assim dizer, instintivo e com uma reação muito reativa, digamos, enquanto que quando trabalho seja com o Galin ou seja com o Vasil, com quem eu estive ontem à noite na estreia, que são pessoas muito mais conhecidas, então com eles eu tenho a impressão de estar em casa, de poder assentar as coisas, de poder ser eu mesma em um lugar de tranquilidade e, de repente, de buscar profundamente coisas que são... que vêm com calma e serenidade, enquanto que do contrário, são coisas que vêm de muito fundo, mas muito mais subconscientemente, eu não sei como explicar, muito mais reativamente, como uma reação. Assim, eu diria que eu acho muito bom encadear os dois, e não estar apenas em um tipo de trabalho ou no outro, porque isso permite que você experimente diferentes situações da criação, é isso.
N.L. - E é possível se alimentar mutuamente...
E.R. - Sim, claro, ah, bem, sim, isso é óbvio.

N.L. - E você estava falando sobre esse envolvimento com o diretor e cada espetáculo, porque eu imagino que, mesmo quando você trabalha com o mesmo diretor em diferentes espetáculos, cada espetáculo é um espetáculo diferente, então há também questões específicas e ainda os atores. Tem companhias que têm seus próprios atores e bailarinos fixos e outras que mudam o tempo todo, o diretor, mas que também podem mudar os performers. E também há o espectador, então a continuação da pergunta sobre o processo de criação é precisamente sobre com o que você se preocupa ou o que chama mais a tua atenção no momento da criação: os desejos do realizador, diretor ou dramaturgo, as necessidades do ator ou da cena, ou o ponto de vista do espectador? 
E.R. - No circo, há uma dimensão de perigo na qual a luz tem uma enorme parcela de responsabilidade, portanto, quando eu trabalho no circo, onde há atrações e demandas específicas das coisas que são possíveis ou não possíveis, como por exemplo, um malabarista que não pode ser ofuscado quando olha para cima e joga suas bolas porque precisa vê-las, então, mesmo que não haja perigo físico para ele, resulta na incapacidade para fazer o que tem que fazer, um equilibrista que precisa ver a corda... alguns precisam ver a corda, outros precisam ver o chão. Existem demandas como essas para o trapézio, quando os artistas precisam absolutamente ver o teto da tenda ou as paredes. Cada atração e cada artista circense tem as necessidades específicas de cada performance técnica, portanto, quando eu trabalho no circo, primeiro me preocupo com essas demandas, por assim dizer. E com isso eu posso saber em que lacuna eu vou poder delimitar as coisas, de certa forma, para descobrir como vou ser capaz de criar. Em seguida, com a magia, também há um grande espaço para demandas específicas. Existem companhias de magia com as quais eu trabalho e para quem eu tenho que levar em conta essas demandas como ponto de partida para a criação e outras para as quais eu também trabalho, mas cujo ponto de partida já é o propósito e a dramaturgia do espetáculo e cujas demandas técnicas de magia chegam em um segundo momento. Então, realmente tudo depende da maneira como você trabalha, como aprende as coisas. No teatro, há o texto, que está lá, então ele é o começo, exceto no Théâtre du Soleil, onde são feitas criações colaborativas, então lá as coisas são construídas pouco a pouco e, sendo assim, acontecem em outra temporalidade. Pode-se dizer que, durante o período de ensaios, eu não penso imediatamente no espectador, isso é algo que vem depois. Eu realmente penso no conjunto do trabalho do diretor, em relação ao que eu realmente me dei conta, desde que comecei a fazer luz, de que o tempo de trabalho nos ensaios é um tempo realmente específico e um tempo muito diferenciado, quer dizer, uma cena que vai durar 30 segundos, pode levar seis horas para ser criada. E de repente, se eu colocar a luz definitiva do espetáculo para esses 30 segundos, se eu colocar essa luz por 6 horas para a equipe trabalhar, não vai dar certo, não é possível. Então, eu tenho muito cuidado para que a luz de trabalho, a luz de ensaio seja 
uma luz que forneça ao diretor e aos atores o ambiente necessário para eles poderem criar. Então, para mim, este é um ponto de partida muito forte. No Théâtre du Soleil, especificamente, nós ficamos em criação por 9 meses, então não podemos usar uma luz de espetáculo por 9 meses, isso não é possível, então tem que haver realmente uma adequação à medida que as cenas vão sendo criadas, à medida que o trabalho avança, à medida que nos aproximamos cada vez mais do espetáculo. Depois, também existem os casos nos quais eu chego realmente no último minuto, para uma criação que já está pronta e onde a equipe já ensaiou com luz de serviço e eu chego para iluminar algo que já existe, isto é muito diferente. Mas é isso. Depois disso, eu penso no espectador no sentido de eu sempre pensar sobre de onde vem o olhar do espectador para receber o que vou oferecer. Nesse caso, as coisas são construídas quase numa temporalidade invertida, na qual, quando eu quero que haja um espaço com um efeito ou sensação particular ou uma recepção específica de luz, eu presto atenção ao que vem antes para colocar no estado de receber o que quero que as pessoas percebam. Isso significa que essa é uma construção que acontece um pouco mais tarde, é uma construção muito temporal, muito ligada à temporalidade do espetáculo, de modo que deve acontecer quando o espetáculo já estiver num estágio muito mais avançado.

\section{N.L. - Sim, eu entendo, seria como se você primeiro criasse o efeito e depois pensasse se ele vai funcionar, se vai chegar ou não no espectador...}

E.R. - Sim, é um pouco isso, é um pouco assim, é isso, é... é antes de eu... é pensar se esse efeito, eu o faço acontecer de maneira imperceptível ou se faço o contrário, criando uma grande ruptura e, de repente, coloco antes uma luz que não tem nada a ver e acontece uma ruptura ou então será que eu preferiria que esse efeito acontecesse realmente de uma maneira sutil... sim, é isso. 
3. E agora passamos finalmente para a última pergunta, que é específica da minha pesquisa de doutorado, a performatividade da luz, ou seja, que a luz performa, que atua sobre o palco e sobre a percepção do espectador, quer dizer, um pouco como eu falei, em ação com os outros componentes da cena. E então, se você concorda com isso, com esta ação da luz, eu diria até como uma ação autônoma, mesmo que ela atue apenas em conjunto com os outros componentes, mas isto é, sua ação como elemento autônomo e independente, mas em conjunto com os outros e não que ela só exista em função dos outros elementos, como acreditamos por muito tempo, que a luz existia para mostrar o trabalho dos outros criadores. Eu digo mais o contrário, digo que ela tem um papel a desempenhar. $O$ que você pensa disso?

E.R. - Bem, eu penso que, de uma maneira muito direta, eu gosto que a luz que eu faço não seja vista, de repente é isso, que não seja vista, ou seja, que o espectador não desligue do espetáculo que ele está vendo e recebendo porque há algo na luz que o distrai sem motivo, digamos, é isso. Não é por esse motivo que a luz não existe, e não é por isso que a luz tem que ser muito discreta ou muito invisível, mas sim estar num lugar justo, pois existem vários componentes que fazem o espetáculo e, obviamente, existem as pessoas no palco, mas há também a cenografia, há também o som, pode haver vídeo, e a luz, de modo que todos esses componentes devem se encarregar de certas funções e não estarem apenas em acumulo uns dos outros, se sobrepondo, por assim dizer. E é verdade que aconteceu comigo diversas vezes de eu fazer espetáculos nos quais, de repente, nos encontrávamos a pessoa do som, eu, e a do vídeo para nos darmos conta que, puxa, nós estávamos dizendo, os três, a mesma coisa, então será que não poderíamos mudar isso, porque é demais, de repente os atores que estão no palco, finalmente, estão sufocados pelo peso do som, do vídeo e da luz, então tentamos reajustar coisas para que isso se equilibre também. Depois, um lado que eu diria ser um pouco mais performativo, aconteceu em um espetáculo que eu fiz há dois anos chamado Je suis la Bête de Julie Dellile, no qual a luz teve uma participação muito, muito, muito importante na própria escrita do espetáculo. Eu acho que existe realmente uma 
dimensão performativa na própria escrita da luz e no que a luz diz, no que assume como função... na atmosfera que cria... é realmente um espetáculo que começa no blecaute completo e aos poucos as coisas começam a acontecer, a tomar forma, as coisas surgem realmente da penumbra e o espaço é, então, habitado pela luz, acontecem realmente efeitos de luz, de tempestade, de flashes, de presença da luz com fumaça, de tudo o que é visível no espaço. Há também um jogo de reflexos móveis e em fluxo da luz no corpo da atriz e, ao mesmo tempo, é sempre algo que acontece em acompanhamento do que está acontecendo, que permanece a serviço do espetáculo, não necessariamente da atriz, mas do espetáculo, e acho que isso é algo que Wajdi Mouawade diz muito, que apesar de que seja ele quem escreve o texto, ele quem faz a direção, o espetáculo é algo que está fora dele e ele diz que todo mundo participa desse espetáculo, é isso mesmo e, de repente, eu penso que, sim, a luz se torna realmente performativa quando está a serviço de espetáculo, sim, é isso.

N.L. - Poderíamos dizer que, na verdade, não apenas a luz, mas todos os componentes, por exemplo...

E.R. - Sim, claro.

N.L. - Isso não significa, quando eu falo da performatividade da luz, que eu estou defendendo um protagonismo da luz, mas que não há mais protagonista. É uma ação conjunta. É um pouco isso, ela fica equilibrado com o resto.

E.R. - Sim, ela certamente tem a dizer sobre o espetáculo e para o espetáculo, e ela tem seu lugar verdadeiro, digamos, que não é apenas fazer o espectador ver o que está acontecendo no palco, efetivamente há uma dimensão de escrita, uma dimensão de dramaturgia, de noção de tomada da palavra também da luz, no ritmo também, no ambiente, na cor, sim, em tudo isso.

N.L. - Você falou um pouco sobre o ritmo, não sei se você tem o hábito de operar a luz dos teus projetos, mas qual é o seu relacionamento 


\section{com o operador de luz, qual é o papel dele? Se a luz realiza uma performance, é preciso pensar que ela deva ser bem-feita...}

E.R. - Ah, sim, é muito importante, sim, há, digamos, dois espetáculos nos quais eu faço, eu mesma, a operação da luz e todos os outros espetáculos para os quais eu fiz a luz, não sou eu quem faz a operação e dependendo do operador de luz, se sou eu quem o escolhe, se não sou eu quem o escolhe, se ele é alguém que me acompanha desde o início da criação, se é alguém que chega pouco antes da estreia, modifico a expectativa que eu posso ter sobre a performatividade da luz, quando, de repente, eu me adapto para ter certeza de que tudo vai acontecer, a cada vez, com qualidade, eu me adapto à pessoa que tenho ao meu lado. Se eu sinto que é alguém que é muito sensível, muito atento e muito à vontade para atuar em partes com um pouco de improvisação, eu me permito ter um pouco mais de liberdade no sentido de fazer coisas para a atmosfera do palco, se é também um espetáculo que não vai circular muito, então, e que preserva esse lado de novidade a cada apresentação, eu me permito isso. Se é um espetáculo que é apresentado todas as noites durante dois meses ou é algo que possa se tornar uma rotina ou rotineiro ou algo parecido, eu tento formatar as coisas informaticamente o máximo possível para que, se eu tiver efeitos um pouco mais complexos no que diz respeito ao tempo, eu tente programá-los o máximo possível para que fique o mais próximo possível do que eu gostaria, é isso. Além disso, é verdade que eu gosto de voltar de vez em quando, porque a efemeridade do espetáculo ao vivo necessariamente se modifica, então eu tento readequar um pouco as coisas, mudar ou... é isso. Às vezes não é possível, às vezes é até impossível mesmo, mas quando é possível, é verdade que é muito bom poder transformar um pouco as coisas também.

\section{N.L. - Você tem operadores de luz ou assistentes que te} acompanham durante todo o processo criativo?

E.R. - Eu tenho operadores de luz, como eu trabalho com as mesmas companhias, muitas vezes os operadores de luz estão associados às companhias, então são pessoas que eu conheço. Além disso, não é exatamente um assistente, seria mais alguém presente na época dos ensaios, na verdade, 
de criação, alguém que não necessariamente será o operador da luz, ele pode ser simplesmente um elo entre o operador da luz e eu. Isso também existe. Afinal, tudo depende do tamanho da criação e da produção. Também existem muitos, muitos espetáculos nos quais eu estou sozinha, sou eu quem opera a luz durante os ensaios, sou eu quem está por trás da mesa de luz e, no final, vamos dizer, nas últimas duas semanas, há alguém que chega e eu o ensino a fazer o que fiz durante toda a criação. Isso também é muito comum.

\section{N.L. - E em que tipo situação você se sente mais à vontade, mais confortável ou mais segura?}

E.R. - Isso varia tanto, é mais confortável quando é alguém com quem eu já trabalhei, quando de repente existe um lugar de linguagem comum, assim, que é rápida. É confortável também quando eu sinto que a pessoa realmente não entende o que eu quero e essa pessoa me permite mexer na mesa e eu posso fazer eu mesma. Há lugares onde isso não é possível e é quando eu preciso conseguir colocar em palavras o que quero da luz e que isso possa ser passada para o operador de luz. Então, isso é complicado, mas, é isso, é muito difícil porque, de repente, isso bloqueia toda a espontaneidade nos ensaios, você precisa conseguir antecipar muito as coisas e isso exige colocar as coisas em palavras, enquanto que às vezes é instintivo, eu sinto que devo acender isso e aquilo, mas só o tempo de explicar e a cena já passou, todo o momento se foi e às vezes me irrita ter que dizer para a pessoa, aí eu prefiro não dizer nada e não fazer o efeito, mantendo a ideia em mente para tentar fora do palco, mais tarde, fazer o que eu queria. É verdade que é difícil desta forma. E é muito comum. Depois depende, eu acho que isso depende das afinidades, depende dos hábitos de trabalho, depende de muitas coisas, é muito variável.

\section{N.L. - E neste lado informatizado da iluminação, você prefere gravar} as coisas ou gosta de fazer manualmente? Como foi ontem?

E.R. - Então ontem, ontem foi a estreia de I Woke up in Motion de Vasil Tasevski, alguém com quem eu trabalho há seis anos nesse mesmo espetáculo. Faz seis anos que nós trabalhamos nesse espetáculo, nós fizemos muitas 
residências e em seis anos eu nunca gravei uma única memória. Eu sempre fiz as coisas de uma maneira muito performativa, de repente, no sentido de arte contemporânea e de performance cênica e com a aproximação da estreia, eu disse a mim mesma que eu precisava ter pelo menos ter um roteiro estruturado com estados luminosos gravados, então eu gravei alguns estados luminosos, algumas cenas de roteiro, mas deixando muitos momentos no quais eu podia improvisar com os refletores direto nos masters para usar desta forma.

N.L. - Sim, eu senti vários momentos do espetáculo nos quais a luz realmente respirava com o performer, era algo muito sensível e, por isso, não imaginei que fossem gravados.

E.R. - Não, isso não era possível, eu gosto mesmo de conseguir fazer isso em um espetáculo, o que eu estava dizendo, por exemplo, no Je Suis la Bête, podemos dizer que tem $90 \%$ da luz gravada nas memórias, mas eu mantive mesmo assim momentos, pequenos intervalos de tempo com uma luz mais improvisada, mais acompanhando o que está acontecia no palco, etc. E isso eu penso que é algo, quando o operador de luz tem essa sensibilidade, ele pode curtir muito estar dentro e se colocar num lugar de diálogo com o palco. Depois, existem operadores de luz que não se sentem nem um pouco à vontade com isso e que preferem participar de um trabalho mais mecânico, porque isso é melhor para eles. Mas dessa vez, de repente, eu tinha um operador de luz para esse espetáculo que estava realmente em sintonia com isso, também com essa vontade de acompanhar, sim, de estar em diálogo realmente com o palco, era isso.

N.L. - Não sei se pode ser dito assim, mas isso significa que, dependendo do operador de luz que você tem disponível, isso pode limitar um pouco a tua criação?

E.R. - Sim, claro. 


\section{N.L. - Que difícil! E é comum que você não possa escolhê-lo? Me} parece muito complicado não poder escolher o operador de luz, eu nem consigo imaginar.

E.R. - Sim, é muito complicado, completamente, isso limita e, ao mesmo tempo, exige um exercício mental no momento da criação forte o suficiente para se dizer ok, aqui eu sinto, realmente, que para o espetáculo eu devo conseguir para fazer isso, e a luz que é solicitada para este momento para este espetáculo, finalmente, tem que ser assim e, de repente, eu sei que é isso, eu sei que é isso, que se fosse eu quem fosse fazer, eu poderia fazer dessa maneira, dessa maneira, dessa maneira, e aí, como é outra pessoa terá que fazer, como conseguir passar para ela o essencial, o próprio sentido dessa coisa com os meios que tenho? E com os recursos humanos que eu tenho também? De repente, acho que isso faz com que nos coloquemos questões muito específicas. Isso limita mas, ao mesmo tempo, traz para um lugar do essencial que também é muito interessante... Na primeira criação de luz que eu fiz, o operador de luz me disse: "mas você sabe, eu não gosto do que é gravado, eu realmente gosto de acompanhar as pessoas no palco, etc.", e eu disse "ah, que incrível, ótimo, ouça, tudo bem, então, de repente, vamos trabalhar juntos para isso". Eu voltei para ver o espetáculo e, foi catastrófico, mas catastrófico mesmo, porque bom, não tinha mais nada a ver com o que eu tinha como ideia da iluminação, etc. Então, de alguma forma, a gravação também é um jeito para preservar também, ter uma base segura, digamos. É isso, existe esse lado que é bom. Enfim, limita, mas, assim como às vezes não temos dimmers suficiente e isso limita ou como não temos todos os refletores que queremos, isso limita, bem, mas é isso, isso é uma limitação que devemos aceitar como uma limitação a mais além de todas as outras limitações, para que isso não seja um problema em si, entende? Teve ainda uma vez em que eu pedi para mudar o operador de luz, porque eu realmente senti que ele ia prejudicar o espetáculo, que seria realmente demais, sim, muito mal ajustado ao que o espetáculo precisava. Não era nem mesmo o que a luz iria precisar, era o que o espetáculo precisava. E, naquele momento, a diretora entendeu muito bem, discutimos e então aí as coisas foram feitas de 
maneira muito simples, mas é verdade que eu tive que reagir muito rápido, de qualquer forma, para alertar para o fato.

\section{N.L. - E com relação aos performers, você acha que existem companhias ou performers com quem você pode contar mais para o resultado da luz?}

E.R. - Ah, bem, isso é óbvio, claro, claro. Há pessoas que se colocam na luz e há pessoas que não se colocam na luz, tem tipos de sensibilidade muito, muito diferentes, isso é claro. Há pessoas que têm uma estabilidade nas marcações, por exemplo, ou no ritmo, o que é muito agradável, porque, de repente, a luz será capaz de ser construída de uma maneira muito simples, e há outras que são muito mais imprevisíveis e que estão sempre no lugar errado, seja no que diz respeito ao tempo ou à posição no palco, o que é bem complicado, então.

\section{N.L. - Mas há também um lado improvisacional que também pode ser positivo?}

E.R. - Depois que a criação é feita, eu diria que se o objetivo do espetáculo não é o de estar em uma improvisação, o objetivo do espetáculo ainda está ligado a alguma coisa que está mais escrita e que estamos em uma representação, por assim dizer, então é bom ter pessoas um pouco mais estáveis, porque é mais simples, entende? Eu fiz uma ópera no ano passado, na qual havia solistas que se posicionavam perfeitamente, o tempo todo, no mesmo lugar, na mesma nota e então havia outros que, realmente, eram incontroláveis, sabe. E é complicado, é complicado, porque de repente é preciso ser capaz de ajustar as coisas ao longo do caminho e isso exige uma adaptação que não é necessariamente bem-vinda naquele momento. É isso. Quando as coisas não estão dentro de uma estrutura da improvisação, eu acho que ainda é mais simples ser mais correto, entende? 
N.L. - Ainda sobre o espetáculo de ontem, sobre os músicos no palco, eu vi que você os iluminava raramente, ou quase nunca. Essa foi uma opção tua ou do Vasil?

E.R. - Então, eles eram muito menos iluminados do que isso e decidimos que, como eu também estava no palco e que tinha uma luz saindo da mesa de controle e, de repente, eu estava um pouco visível, havia uma necessidade, talvez, de reequilibrar um pouco isso tudo, então eu fiz o ajuste colocando luzes de serviço falsas que eles não usavam, mas que serviam apenas para fazer pequenas luminosidades para percebê-los em alguns momentos. Eles não precisavam se ver ou ver as partituras, era realmente uma improvisação, eles estavam juntos, só isso. Eles se conheciam tanto e nós trabalhamos tanto juntos, por seis anos, que de repente havia uma sensação de conforto, de conhecimento e confiança que fazia com que não houvesse essa necessidade. E o Vasil queria realmente que houvesse momentos muito escuros, momentos em que a música emanava do blecaute, então essa foi uma decisão que tomamos juntos.

\section{N.L. - E a projeção foi criada por ele mesmo?}

E.R. - Sim, foi o Vasil quem fez o vídeo todo. Ele frequentou uma escola de circo em Charlon-en-Champagne, e depois ele foi para Fresnoy (Le Fresnoy Studio National des Arts Contemporains), perto de Lille, uma verdadeira escola de arte contemporânea para efetivamente desenvolver todo o seu aspecto visual com a fotografia e com o cinema. Ele tem uma relação muito forte com a imagem, muito forte, com a matéria da imagem.

N.L. - E eu vi que havia momentos no espetáculo em que a luz se apagava quase completamente para deixar só a projeção...

E.R. - Sim, absolutamente. Sim, sim, a projeção é uma fonte de luz tanto quanto um refletor, por assim dizer. Sim, nós realmente trabalhamos juntos nisso juntos, mesmo.

N.L. - E então uma última pergunta, talvez, sobre essa escolha de estar no palco. Você acha que, para que a luz performe, é preciso estar no 
palco e qual é a importância, nesse espetáculo, de estar no palco, mudaria alguma coisa se você estivesse na cabine?

E.R. - Bom, fui eu quem pediu para estar no palco. Nós fizemos muitas residências onde éramos só nós dois e não havia mais ninguém, nem mesmo os músicos. Nós dois tivemos muitos momentos de trabalho só entre os dois, então eu estava com a mesa na primeira fila da plateia e ele estava no palco, o que fazia com que eu estivesse muito perto dele, de frente, mas muito perto. E nós logo percebemos que precisávamos dessa proximidade. Além disso, havia a questão do vídeo, do computador que gerenciava o vídeo. No começo, era ele quem operava os vídeos e, desta forma, ele ficava indo e vindo entre o computador e o palco. Pouco a pouco eu fui assumindo essa operação da cabine, por assim dizer, e de repente havia uma central de controle técnico no palco em relação ao uso do vídeo e, no início do trabalho, eu não tinha gravado absolutamente nenhuma memória e fazia tudo, tudo, tudo, tudo manual e de repente a distância de estar na cabine com a separação do público, ou seja, havia o palco, toda a distância do público e só depois eu, o que me limitou muito. Eu tive dificuldade para estar num bom estado de abertura, de escuta, de disponibilidade para poder estar com ele, para poder estar junto. Além disso, desequilibrava muito as coisas o fato de os músicos estarem no palco, então logo pareceu muito lógico que eu estivesse perto também.

\section{N.L. - E você não pensou em manter esse lugar na primeira fila, por exemplo?}

E.R. - Sim, nós pensamos nisso, mas isso incomodava muito o público, houve um momento em que eu fiquei na primeira fila da frente, mas na lateral e depois disso eu fui diretamente para o palco, para ficar realmente junto, porque é verdade que após seis anos de trabalho, nós queríamos mostrar algo juntos, entende? Éramos realmente os cinco, entende, os três músicos, Vasil e eu, realmente um lugar de... é isso. Depois, é verdade que não me parece nada impossível que a luz seja performativa com uma operação fora do palco, Tem vezes em que queremos fazer com que a luz seja performativa colocando a operação no palco e isso não funciona de jeito nenhum também, então eu acho 
que não existe relação entre a performatividade da luz e a operação de luz no palco, mas nesse caso específico eu não poderia estar em outro lugar.

N.L. - No caso foi mais pela proximidade do que para estar visível.

E.R. - Ah, sim, sim, completamente, exatamente, eu poderia estar escondida sem problemas, mas era para estar perto. Vejo que ele me vê, que seja alguma coisa juntos nas duas situações. Mas para o público, não é necessário que ele veja essa relação, e é também por isso que eu tentei esconder o máximo possível as luzes de serviço da mesa, para que as pessoas me vissem o mínimo possível. Eu mantive a luz necessária, o mínimo para poder trabalhar e, se fosse o contrário, eu teria reforçado essa posição da cabine e a minha posição no palco, mas não, não, não era esse o caso, não, não, era realmente para termos uma proximidade, os dois, para trabalhar e que, em caso de necessidade, também houvesse a possibilidade de ele vir até mim, o que aconteceu às vezes, não ontem, mas houve momentos em que houve necessidade, é isso, é mais isso.

N.L. - E para terminar, no espetáculo de ontem ou, se preferir, em outros espetáculos, você consegue me dar exemplos da performatividade da luz em que você sente que a luz realmente tinha, em conjunto com a cena, um papel performativo.

E.R. - Eu diria que posso pensar imediatamente em outro trabalho que fiz com dançarinos, o trabalho se chama Ondes et Fréquences e trabalhamos com situações bastante interessantes no sentido de que chegávamos nos teatros nos quais tinham espetáculos que se apresentavam à noite e nós não podíamos pendurar refletores e, de repente, eu tinha que fazer a luz dessa performance Ondes et Fréquences com a geral de outro espetáculo e de outra pessoa que eu não sabia o que era, não sabia de antemão e nós começávamos a improvisar enquanto eu descobria, pouco a pouco, o que ia ser a luz. Desta forma, havia um tipo, assim, de trabalho que tinha realmente uma abertura enorme para acatar as coisas como elas são, como elas aconteciam, sem planejar nada com antecedência. Há no trabalho com Vasil, no Woke up in Motion, um pouco desse 
tipo de coisa em que temos muito de improvisação, onde fazíamos coisas, tínhamos alguns espaços de criação, mas cuja escrita era feita assim, procurando juntos, então, de repente, a luz rapidamente adquiriu um lugar muito importante na dinâmica dessa escrita, então acho que tem isso, tem também momentos em que o ritmo da luz com efeitos de chaser, efeitos de cor, efeitos de mixagem com o vídeo, como esse, o reflexo do vídeo, a luz em si e elementos visuais fortes, nos quais os corpos também entram e que são também os pontos de partida das sequências, é isso.

\section{N.L. - Neste trabalho com Vasil, houve momentos em que a luz foi a proponente de ações, movimentos, marcações?}

E.R. - Tem aquele corredor (de luz) que foi realmente o ponto de partida da criação, onde de repente a luz no início estava realmente apenas nesse corredor, e toda a questão dos chases, também, na cena com a esfera que gira que foi também muito um ponto de partida para o trabalho. $O$ trabalho sobre a cor, a complementar, a complementaridade das cores para ir em direção ao branco, para ter zonas coloridas, também é algo que nós trabalhamos mais na performance do que tínhamos feito juntos em Fresnoy (Le Fresnoy Studio National des Arts Contemporains) no final dos seus estudos, portanto, sim, houve realmente momentos de pesquisa, completamente sobre a luz e depois 0 movimento que se seguiu a ela.
N.L. - Bom, ok, muito obrigado.
E.R. - Ah, eu que agradeço.

N.L. - Obrigado pelo seu tempo, pela disponibilidade logo após uma estreia.

E.R. - Foi um prazer. 
3.10 Eric Soyer - Cenógrafo e lluminador Francês ${ }^{236}$

1. A respeito da luz e da iluminação, você considera que a iluminação cênica é material ou imaterial? Você poderia explicar a tua resposta?

E.S. - Para mim, a luz do palco é profundamente imaterial no sentido de que é uma onda, mas, apesar disso, o que é um paradoxo, é que é ela que desenha, revela ou oculta. Nesse sentido, podemos dizer que ela é profundamente material, então é isso, estamos diante de um paradoxo, visto que é ela quem esculpe, é ela quem revela os materiais, no sentido de que os materiais a absorvem ou refratam, então, na verdade, podemos dizer que, em todo caso, ela é reveladora e é uma onda, como o som, mas que se destina aos olhos enquanto que o som se destina aos ouvidos. Mas em ambos os casos, nós apenas percebemos o comprimento de onda que nos é possível perceber, ou seja, relativamente pouco comparado a todo o espectro.

2. No que diz respeito ao seu processo criativo, você costuma trabalhar com a mesma companhia ou com o mesmo diretor? Qual é o aspecto mais importante, na tua opinião, para a criação da luz: as vontades do diretor ou do dramaturgo, as necessidades do ator ou da cena ou o ponto de vista do espectador?

E.S. - Sobre o meu processo criativo, na verdade, eu trabalho com várias pessoas em diferentes áreas, quer seja teatro, dança, coreografia, ópera contemporânea ou música, digamos, eletrônica, por exemplo, que são experiências bem diferentes, necessidades muito diferentes umas das outras, entre uma ópera e um espetáculo teatral, e eu trabalho com pessoas que escrevem, então sempre começamos a partir de uma página em branco e é claro que os desejos do diretor, do encenador, do dramaturgo são fundamentais,

${ }^{236}$ Entrevista realizada por WhatsApp por Maria Clara Ferrer, recebida no dia 18 de junho de 2020 (tradução da autora, original ao final dos anexos). 
especialmente em sua capacidade de despertar ou desencadear outros desejos nas pessoas ao seu redor, nos colaboradores. Depois, não se trata de responder aos seus desejos, mas de criar um diálogo com eles, de poder, pelo desejo, estimular a criatividade e isso, isso também passa por zonas de atrito. Finalmente, as necessidades do ator, do dançarino ou do cantor obviamente devem ser levadas em consideração, não necessariamente para seu conforto, mas pelos seus imperativos, que são todos imperativos diferentes, um dançarino às vezes deve ser capaz de ver o chão dependendo do tipo de coreografia, um ator em algum momento terá necessidade de ser ofuscado pela luz, enfim, tudo isso são pequenas coisas que devemos obviamente levar em conta, um cantor em algum momento precisará ver um monitor ou o maestro para que você possa saber o compasso da música, o que significa que nesse momento ele não pode estar ofuscado. Bem, essas são pequenas coisas, tudo isso é um pouco de detalhes, mas mesmo assim é importante e o ponto de vista do espectador, em geral, com frequência, de qualquer maneira, trabalhamos do ponto de vista do espectador, com certeza nos posicionamos, eu me posiciono, quando crio uma luz, no ponto de vista do espectador, então na verdade nós consideramos todo o conjunto de informações e o próprio iluminador, ou melhor, eu mesmo sou, de fato, o receptor dessas informações e a primeira cobaia sensível em relação ao que acontece em cena.

3. A pesquisadora deste trabalho afirma, como resultado de sua prática e estudos, que a iluminação cênica participa ativamente da cena teatral, assim como de outras formas de artes cênicas como a performance, a música, a dança, entre outras. Nesse sentido, ela propõe que a luz atua, age no palco e interage com os demais componentes do espetáculo, assim como com o público, tendo a importante função de estabelecer e promover a relação entre o palco e a plateia. Você concorda com esta opinião? Por quê? Você poderia dar um ou alguns exemplos desse desempenho da luz em seu trabalho criativo? Pode ser um projeto inteiro ou alguns efeitos específicos. 
E.S. - A iluminação cênica participa ativamente da cena teatral, assim como em outras formas de espetáculo, como a performance, a música, a dança, entre outras, obviamente sim, completamente, a luz, a iluminação se escreve no espaço-tempo como uma partitura e permite, de fato, além das atmosferas e das arquiteturas, desenhar uma partitura, digamos, espaço-temporal. Ela é, portanto, um elemento fundamental que tem uma parte muito, muito ativa na relação entre a cena e o espectador. No meu trabalho, na verdade, a luz vai, acima de tudo, assim como na cozinha, vamos definir um sabor, definir as texturas de luz que vão nos ajudar. Em seguida, vamos definir uma palheta e, a partir desta palheta, vamos escrever uma partitura e cada espetáculo, de alguma forma, tem seu sabor, sua própria essência. Obviamente que na minha maneira de abordar as coisas, tem uma coisa que podemos encontrar por meio da totalidade do espetáculo e que chamamos de uma linguagem com as coisas reconhecíveis pela maneira que eu tenho de ver e também de dar a ver. Assim, cada espetáculo é, por assim dizer, uma experiência entre o que chamamos de dispositivo cênico e cenográfico e a composição da luz, a partitura. E depois, de acordo com meu trabalho a longo prazo, com diferentes famílias artísticas, obviamente também há uma noção de repertório, de laboratório que se desenvolve e que fará com que haja especificidades que permitem crescer e criar uma continuidade de umas para as outras.

Apenas um exemplo dos últimos trabalhos que poderão ser vistos na primavera, Both Sides with Jeanne Added, um palco muito grande de 9 metros por 4 metros no qual ela se desloca por um dispositivo bi frontal, com o público, então, circundando os dois lados da cena e um trabalho sobre uma plataforma branca, ou seja, também um suporte, assim, de reflexão da luz e um trabalho no qual, de fato, essa plataforma se torna uma espécie de massa viva com muita luz estroboscópica que acaba por desmaterializar, de repente, o corpo da intérprete, de Jeanne Added. E essa plataforma, aos poucos... na verdade, vamos no sentido inverso de um movimento, de um show no qual começamos lentamente e acabamos no topo. Nesse show, de fato, começamos no topo, o público entra, estamos em um grande clube, então em 30 minutos, ela começa, ela está sozinha no palco, o microfone, a música é difundida e estamos em um 
nível muito, como dizer, um nível muito alto de movimento da luz, uma luz muito dinâmica, estroboscópica, alto contraste, ondas de luz, pulsação, etc. Depois, então, ao final de 30 minutos a cena é desmontada às vistas do público e acabamos em um quadrado branco no qual ela canta com uma voz grave, apenas voz grave, então estamos em uma outra coisa muito mais crua, 20 minutos, uma luz que se torna um pouco mais colocada e muito mais focada na artista. Ainda com um pouco de movimento, mas com menos movimento na luz, então a cena é ainda mais desmontada, chegamos a um quadrado de 1 por 1 que sobe um pouco e aí no final, acabamos na maior sobriedade luminosa. Esse é, então, por exemplo, um exemplo de um dos últimos trabalhos que eu fiz. 
3.11 Fabrizio Crisafulli - lluminador e Diretor de Teatro Italiano 237

\section{Quando se trata de luz e iluminação, você considera a luz do palco} como material ou imaterial? Por quê?

F.C. - Embora, do ponto de vista físico, possamos dizer que a luz é um elemento imaterial, do ponto de vista artístico, eu tendo a considerá-la como matéria. É como algo que tem sua própria substância, que pode ser modelado e que pode receber formas e configurações, capazes de fazer a própria luz se tornar um elemento "concreto", capaz de "presença". Eu nasci nas encostas do Etna e, desde criança, observando os fluxos de lava à noite, tive essa percepção da luz como matéria e forma, e isso acho que me influenciou bastante no desenvolvimento dessa ideia.

Comparado à dualidade material-imaterial, há outro aspecto que me interessa, que diz respeito à relação da luz com a cena, objetos, atores: é sua capacidade de dar a esses elementos materialidade ou imaterialidade, dependendo de como ela é usada. Em particular, dependendo se é luz difusa ou concentrada e como sua energia é regulada. É evidente que uma luz direta e dura, que cria sombras claras, torna a coisa iluminada mais "material" do que uma luz suave e difusa; e que existe um nível de intensidade de luz abaixo do qual tudo parece diáfano, imaterial e que, ao elevar a intensidade, tudo adquire concretude e materialidade. Costumo usar essas diferenças em sentido dramatúrgico e poético. Algumas vezes, por exemplo, usei variações muito lentas da intensidade da luz, apenas para explorar os diferentes graus da relação material-imaterial, que podem ser experimentados como tais no nível perceptivo, mas que também podem se tornar significativos no nível dramatúrgico.

\section{No que diz respeito ao seu processo criativo, você costuma} trabalhar com a mesma companhia ou com o mesmo diretor? Para quem a

\footnotetext{
237 Entrevista realizada pela autora por e-mail, enviado no dia 20 de janeiro de 2020 e recebido no dia $1^{\circ}$ de março de 2020 (tradução da autora com revisão de Antônio Palermo, original ao final dos anexos).
} 
luz é direcionada? À vontade do diretor, às necessidades dos artistas ou ao olhar do espectador?

F.C. - Na verdade, sou diretor e normalmente também desenho o espaço e a luz dos meus espetáculos. Não desenho luz para os outros. Eu fiz isso no passado, mas em algum momento eu parei de fazer isso porque não estava indo bem. Na minha concepção, a luz teatral é um elemento primário e gerador comparado a tudo o mais, exatamente como a luz é no mundo real. No meu trabalho teatral, isso significa que a luz é colocada no início, já no estágio de concepção do espetáculo. Ela participa, junto com os demais elementos expressivos, na definição do espírito, do sentido, do caráter poético e da dramaturgia da obra. Possui autonomia própria de ação e, portanto, um peso muito importante em relação à direção.

Nas colaborações que eu aceitei fazer ao longo do tempo, quase sempre por ser amigo do diretor ou do coreógrafo (tudo antes de 2004), verifiquei que manter minha concepção de luz envolvia uma colaboração significativa em relação à concepção da peça e da direção, e isso criou dificuldades no trabalho e, às vezes, também nos relacionamentos. Por isso, inevitavelmente, tive que "voltar" e me limitar a tentar fazer "luzes bonitas", o que não é realmente o que me interessa. Em vez disso, estou interessado em que a luz seja um elemento estrutural do trabalho. Um elemento original e sugestivo.

Quanto à pergunta "a quem a luz é direcionada", eu diria que considero a luz relevante e incisiva em relação a todos os aspectos aos quais você mencionou: a direção, como eu disse; assim como o artista e o espectador. É assim que eu faço.

3. A pesquisadora Nadia Luciani afirma, como resultado de sua prática e estudos, que a iluminação de palco tem um papel ativo na cena do teatro, assim como em outras formas de artes cênicas, como música, dança, entre outras. Com isso, ela afirma que a luz atua, age no palco e interage com os demais componentes do espetáculo e com o público, tendo a importante função de estabelecer e promover a relação entre o 


\section{palco e o público. Você concorda com esta opinião? Por quê? Você poderia} dar um ou alguns exemplos desse desempenho da luz em seu trabalho criativo? Pode ser um projeto inteiro ou alguns efeitos específicos.

F.C. - Eu concordo perfeitamente com sua ideia de luz teatral como luz ativa, tanto que em 2007 escrevi um livro sobre o assunto chamado "Luz ativa", tirando essa definição de Adolphe Appia, a quem o volume é dedicado. No livro, analiso como essa ideia evoluiu do final do século XIX para os dias atuais, na obra de muitos protagonistas da cena ocidental do teatro, e também expus a declinação que ela assume em minha própria busca como diretor.

No meu trabalho, o caráter ativo e interativo da luz está sempre presente, sem exceção. Se eu quiser dar um exemplo, voltaria ao primeiro programa que fiz como autor e diretor, II pudore bene in vista, de 1991. Esse trabalho nasceu de uma longa experiência de oficinas que conduzi na Sicília desde meados dos anos oitenta, com a qual realizei uma pesquisa (que continuo fazendo com meus alunos, até hoje) sobre a linguagem autônoma da luz no teatro. Minha referência foi a música. A luz pode desenvolver seu próprio caminho autônomo no teatro como o som pode fazer? Isso pode ser feito, como a música, o ritmo, a fala, o significado, a poesia? Os laboratórios também nasceram da ideia de devolver à luz, no palco, um papel compatível com o que é na realidade. Um papel enérgico e ativo. E estender o conceito de luz teatral para além dos domínios aos quais geralmente se faz ela pertencer, que são técnicos e visuais. Até então, os laboratórios produziam cerca de dez cenas sem texto e sem atores, inteiramente baseados em luz, objetos e som. Elas eram, portanto, desprovidos dos elementos nos quais o sentido e a dramaturgia de uma performance teatral geralmente se baseiam. E eles foram fundamentais para eu elaborar, de fato, uma linguagem autônoma da luz no teatro e entender como a luz pode se tornar estrutura, significado, dramaturgia. Na /l pudore bene in vista, que foi concebida naqueles laboratórios, mas que contava com a presença de artistas de carne e osso pela primeira vez, a luz teve um papel norteador no momento em que as ações foram inseridas no espaço em relação ao qual se organizaram e, por sua vez, na ação com a qual as atrizes se relacionavam. De certo modo, tudo, até 
gestos e palavras, "nasceu" da luz, que marcou as posições, condicionou os movimentos, indicou o que fazer. A relação usual ator-luz foi completamente revertida. Essa qualidade de interação que, naquela experiência, tinha formas extremas em favor da luz, nos projetos subsequentes assumiu formas mais equilibradas, nas quais a força das ações do ator e a das ações da luz tenderam a se compensar. Mas, naquele momento, a suposição dessas formas extremas me interessava muito precisamente na compreensão da capacidade autônoma da luz como linguagem e como substância dramática. 
3.12 Gianni Staropoli - Iluminador Italiano ${ }^{238}$

\section{Quando se trata de luz e iluminação, você considera a luz do palco} como material ou imaterial? Por quê?

G.S. - Luz e iluminação, em linguagem universal, são dois termos de grande significado e beleza. Duas definições que convergem por natureza no mesmo ponto, que é um ponto de origem. A conjunção "e" dentro de sua pergunta, instintivamente - eu não saberia como explicar - me leva de alguma maneira a imaginar essa origem; as infinitas variações e sugestões, que surgem toda vez que me vejo fazendo reflexões íntimas sobre a luz. Um simples "e" pode tornar-se uma chave para acessar novos mundos. Luz e sombra, perto e longe, real e irreal. Infinitos outros "e" que podem eliminar distâncias siderais.

A luz cênica é sem dúvida uma luz projetada e construída, que se torna concreta. No momento em que a construímos, nós a tornamos viva e ativa, esquecendo, por sorte, a sua natureza artificial e efêmera. E é também por essa simples razão, na minha opinião, que ela pode se tornar material e imaterial ao mesmo tempo. Deixa-se moldar precisamente por ser matéria metamórfica da construção do espaço cênico.

Quando começo um novo trabalho, seja em teatro ou dança, depois de uma primeira fase - necessária - às margens e na observação de tudo e de todos, quando eu entro no centro do trabalho e dos relacionamentos, vejo surgirem os códigos que caracterizarão o sentido e a estética do espetáculo. Com isso, quero dizer quando os códigos e as intenções da direção surgem, quando aparecem, inevitavelmente, até aquelas que serão as características substanciais da luz que vai ser construída. Para mim, o espaço sempre determina a luz e vice-versa. É a natureza do espaço cênico - quando é bemfeita - que transforma a luz em material ou imaterial, depende do que a luz

\footnotetext{
238 Entrevista realizada pela autora por e-mail, enviado no dia 17 de janeiro de 2020 e recebido no dia 08 de abril de 2020 (tradução da autora com revisão de Antônio Palermo, original ao final dos anexos).
} 
encontra. Depende de como eu percebo e interpreto esse todo. Eu posso afirmar, com certeza, pela minha percepção, de que, quando penso e crio luz, eu crio e sinto o imaterial - a substância mais preciosa da luz - e que quando ilumino para só para clarear, sinto o material - a possibilidade mais concreta da luz - a força tangível mesmo. Não é uma equação superficial, mas um conjunto de percepções subjetivas. Pessoalmente, eu sempre prefiro tentar construir uma luz que seja imaterial no conjunto - no sentido metafísico - tento dar à luz um sentido amplo e que seja o mais leve e elegante possível. A partir daí, procuro todas as variações e modulações necessárias para um trabalho dramaturgicamente profundo e preciso.

2. No que diz respeito ao seu processo criativo, você costuma trabalhar sempre com a mesma empresa ou com o mesmo diretor? Para quem a luz é direcionada? À vontade do diretor, às necessidades dos artistas ou ao olhar do espectador?

G.S. - Eu sou um profissional autônomo e trabalho principalmente com o teatro e a dança contemporânea. Gosto muito de experimentar a dramaturgia contemporânea e, no que diz respeito à dança, adoro a coreografia contemporânea que utiliza o espaço do palco em sua nudez. Tenho a sorte de colaborar com vários diretores e coreógrafos e essa riqueza me permite amadurecer profundamente meu olhar e ampliar minha experiência. $O$ espetáculo ao vivo acontece no olhar de quem também está vivo.

Gostaria de dizer que, quando eu trabalho, estou sempre imerso no pensamento da luz: o pensamento que alimenta o trabalho é o meu caminho pessoal, mas o espetáculo é obviamente o único meio para finalizar meu pensamento pessoal - mesmo trabalhando na escuta e em sinergia com todos - sem o espaço cênico, não creio haver como alimentar meu pensamento sobre a luz e o espaço. Eu trabalho para contribuir com a criação do espetáculo e o público é parte integrante do espetáculo. Muitas vezes sinto o desejo de atingir o público na plateia diretamente com a luz e, quando posso fazê-lo, fico feliz em 
poder me comunicar e me expressar dessa maneira. Pode acontecer que durante os ensaios e as montagens, eu sinta vontade de fazer algo específico que envolva os espectadores. Além disso, não acredito que o espetáculo ao vivo deva ocorrer em um quadro, mas "expandir-se" para o espaço e o espaço dos espectadores também ser uma parte ativa do espetáculo.

3. A pesquisadora Nadia Luciani afirma, como resultado de sua prática e estudos, que a iluminação cênica tem um papel ativo na cena do teatro (assim como em outras formas de artes cênicas, como a música, a dança, entre outras). Com isso, ela afirma que a luz atua, age no palco e interage com os demais componentes do espetáculo e com o público, tendo a importante função de estabelecer e promover a relação entre o palco e a plateia. Você concorda com esta opinião? Por quê? Você poderia dar um ou alguns exemplos desse desempenho da luz em seu trabalho criativo? Pode ser um projeto inteiro ou efeitos específicos.

G.S. - Eu concordo plenamente com as questões colocadas em sua pergunta. A luz atua no palco e o transforma ativamente. Mas a luz é transformadora - seja livre no céu ou no espaço cênico construído - e é ativada graças à relação e à interação com todos os outros componentes criativos. Voltando ao conceito de iluminação, acredito que um palco não deve ser "iluminado", mas totalmente agitado e movimentado com a luz. Os corpos no espaço cênico sem uma relação com a luz, seriam bonecos de pau no espaço vazio.

A luz é a base que favorece a relação entre o palco e o público. A luz é uma matéria viva e ativa, necessária tanto na vida cotidiana quanto em todas as artes cênicas. E o público na sala sempre reconhece e se reconhece com a luz da cena, porque lá fora ele vive na luz. No ocidente, isso tem um valor, enquanto em outras áreas acontece de forma indubitavelmente diferente. Espaço e luz são a minha realidade. 
Alguns anos atrás, para um espetáculo, eu fiz construir um grande espelho giratório - operado na mesa de comando - que ficava posicionado do lado direito do palco, às vistas do público. Durante uma cena "dramática", junto com a música, eu acionava o espelho, que começava a girar muito lentamente e, desta forma, ofuscava o público na plateia com uma luz muito forte. À medida que a cena crescia, eu aumentava gradualmente a velocidade chegando ao máximo, de modo que cada passagem provocava um brilho muito intenso e quase violento sobre o ator e o público. Na minha opinião, funcionou muito bem. Deu à cena, em total concretude, uma luz tangível, dramática e violenta.

Na minha opinião, ao construir um projeto de iluminação, nunca se deve tratar a luz como um material para produzir efeitos, mas tentar comunicar algo que possa dar a ênfase certa ao espaço e aos corpos. 
3.13 Guilherme Bonfanti - Iluminador Paulista239

1. Como conceito, você considera que a luz seja material ou imaterial? Você saberia explicar a sua resposta?

G.B. - É bem complicado (risos) porque eu acho que transita nos dois lugares. A materialidade dela existe porque ela está colocada na cena, agora ela não é palpável e se você pensa matéria como algo que você toca e que você pega... Você sai da luz e toca nela. Se pensar na atmosfera e na luz, vai entender que a luz se torna física e concreta por conta da atmosfera. Se você pensar nas partículas, você sabe onde há e não há luz. Eu acho que não existe uma resposta "ou é ou não é". Eu acho que a questão atmosférica é do campo imaterial e a presença dela na cena para mim tem a ver com a materialidade, enquanto ideia ou conceito. Eu não penso nisso isolado, estou pensando em atrito com as outras áreas da cena e como alguém que cria e eu acho que é desse lugar que eu preciso pensar: ela transita por esses dois aspectos.

\section{A segunda pergunta é sobre o processo criativo. Você costuma trabalhar sempre com uma mesma companhia ou diretor?}

G.B. - Eu acho que existem duas instâncias do meu trabalho. Uma é com o Vertigem, que foi o que me formou como artista e pensador da luz, porque o trabalho autoral está aqui (no Vertigem), assim como as minhas pesquisas e o meu trabalho pedagógico começou aqui e acho que ele expande para a SP (Escola de Teatro), mas o que foi para lá é o que eu descobri aqui e, lógico que depois, sair daqui e fazer outras coisas é como um complemento do meu trabalho aqui. $\mathrm{O}$ Vertigem trabalha com site specific e com uma relação com a arquitetura e o espaço. Quando eu fui fazer experimentos em arquitetura, me ajudou aqui porque se eu sou um pesquisador de luz, me interessa conhecer

239 Entrevista realizada por Gabriela Valcanaia via Skype no dia 20 de março de 2020. 
todas as possibilidades que eu tenho como fonte de luz, e na arquitetura eu vou descobrir um monte de equipamento que não é comum no teatro. Quando eu vou fazer um desfile, eu descubro uma lógica que pode vir em alguma situação... a distribuição, a maneira como usa, o tipo de lâmpada... Eu acho que técnica e a estética andam juntas e não dá para separar, então eu estou falando de técnica agora, mas eu estou pensando na estética. Aí a questão do show, onde eu conheci os LEDs e os moving-lights, que acabaram entrando no Vertigem como proposta minha de querer ver o LED ou os moving-lights dentro da cena de teatro. Eu diria que eu saio do Vertigem para ver outras coisas e entrar em contato com outras possibilidades e tudo isso volta para cá. É muito importante, para mim, que eu saia e veja outras coisas. Isso reverberou na escola (SP Escola de Teatro), em levar artistas da luz para falar para os alunos e que eles tenham uma visão mais ampla do que é luz, que não fiquem com uma visão única e exclusiva do que é luz. Isso é bastante presente no meu trabalho, estar muito aberto para dialogar com outras linguagens. Tento levar um pouco disso para os alunos. Claro que se olharmos do ponto de vista acadêmico ou do desenvolvimento da linguagem, o trabalho do Vertigem é muito mais rico e me possibilita muito mais coisas, porque me coloca em situações que me obrigam a dar saltos para poder conseguir vencer essas situações que aparecem. Nos outros trabalhos, é um ou outro que me coloca em uma situação como essa, mas a maioria não, são trabalhos com soluções mais simples e mais óbvias, no sentido de não ter grandes invenções.

\section{G.V. - Você agora fez um trabalho junto com o Zé Celso no Oficina,} não é? Conta como foi...

G.B. - Fiz o Roda Viva e foi muito interessante. Foi uma loucura, como não poderia deixar de ser (risos). No Cadernos de Luz, tanto no meu site quanto no da escola, eu tenho um relato sobre o meu processo e lá você vai ter acesso a tudo o que eu penso e pensei (risos), mas eu também dou voz para as pessoas que trabalharam comigo colocando textos delas. Em primeiro lugar, é um grande prazer trabalhar com uma pessoa como ele, que representa tudo o que ele representa para o teatro brasileiro e eu acho que isso é uma condição que está 
assim de qualquer questão. Ele está com oitenta e poucos anos, indo para o final da vida dele, e quando essa oportunidade surgiu eu não deixei passar. É engraçado, porque o convite surgiu para que eu fizesse a luz junto com o Beto Bruel e eu me neguei a fazer junto com ele, mas não por eu ter algum problema com o Beto, até porque ele é uma figura que não tem como ter problema, é um ser humano supergeneroso. Ele queria fazer comigo (risos) e insistiu comigo, mas eu entendia que aquela experiência tinha que ser única e não podia ser compartilhada... Eu teria que administrar uma outra coisa, que é estar desenhando com alguém, e eu queria estar inteiro naquela experiência. Não tem a ver com autoria, era pela experiência. O Beto também não ia conseguir estar aqui no tempo que eu estaria e isso seria complicado.

Então, o que aconteceu quando eu cheguei, foi o encontro com uma estrutura muito blocada, enquanto luz na cena. Existia um fantasma que me rondava lá dentro que era a Cibele Forjaz (risos). Ela ficou muitos anos ali dentro e o que se faz hoje no Oficina é o que ela descobriu e isso foi continuado... O sistema RGB, o vapor, a luz que ilumina o todo e não distingue palco e plateia... O Zé (Celso) tem essa relação e a presença da plateia é muito forte o tempo todo. O que eu encontrei foram duas pessoas que trabalhavam na equipe, com uma série de demandas para mim, às quais eu tinha que cumprir. Tinha um check list: plateia tem que ser iluminada, a árvore tem que ser iluminada, o coreto tem que ser iluminado, o fundo tem que ser iluminado, a arquitetura tem que ser iluminada. Eu fiquei louco com isso, porque isso significava que eu, como criador, tinha que atender uma série de questões que já estavam postas ali e eu entrei achando que aquilo era o terreno da liberdade e da transgressão. Tinha um paradoxo ali e uma vez eu brinquei com o Zé, porque quando eu trouxe a ideia do LED e do moving, e mesmo antes de entrar, eu li o que a Lina Bo Bardi e o (Edson) Elito escreveram e o que a Cibele escreveu, mas na verdade, é porque o Chico Turbiani, que trabalha comigo na SP fez uma pesquisa sobre a luz do Oficina que eu li também. Eu entrei ali, então, entendendo um pouco do que era o espaço e um pouco do que tinha sido feito de luz lá, e quando eu cheguei para trabalhar, queria levar um novo olhar sobre aquilo tudo. O espetáculo já era uma profusão de planos ficcionais, que era uma loucura, e mais mil planos para dar 
conta, o que fazia com que o meu trabalho fosse meio de guarda de trânsito porque eu ficava organizando "agora esse plano... agora aquele" e a primeira coisa que eu falei para o Zé quando eu vi um ensaio, foi isso, de que eu preciso organizar isso tudo, porque tem horas que o público olha o todo, mas tem horas que não, e eu preciso saber o que é e quando. Ele concordou que era isso mesmo, mas quando eu trouxe o LED e os movings, que até então, para ele, era uma coisa horrorosa e que não era luz de teatro... Com o Beto, eu tenho boas conversas sobre isso, porque a visão dele tem mudado muito ultimamente e às vezes ele me manda fotos de trabalhos e diz "olha, compadre, fiz um evento cheio de moving e cheio de LED" (risos). Mas no Oficina, quando eu trouxe o LED, eu vi aquele preconceito básico e falei para o Zé: "você é muito conservador e está preso numa luz que não existe mais. A Lina fala do terreiro tecnológico, do bárbaro tecnizado, porque você tira a tecnologia daqui? Você continua trabalhando em cima de direção, dramaturgia e atuação, mas estamos em 2020 e todas as áreas são parte da cena”. Isso, ele ficava repetindo para mim ao longo do processo: "eu sei que você me acha conservador". Para mim foi um grande choque o que foi o Oficina por fora, como esse lugar de transgressão, resistência e, lá dentro, uma coisa um pouco formatada e engessada com toda a loucura que existe. Até minha filha Maria fez uma monografia que se chamava Revolução Estética e ela pegou o Roda Viva como estudo de caso e chega uma hora que ela questiona o quanto o Roda Viva de 1964 modificou paradigmas e o de hoje já não consegue mais, porque agora a plateia que vai ali já sabe o que vai ver e eles estão um pouco presos nisso. Eu senti que a luz foi um pouco difícil nesse sentido, mas foi ok para mim porque eu acho que é um embate um tanto salutar. Era uma estrutura do grande Zé Celso Martinez Corrêa, que senta e ouve todo mundo, mas que sabemos que diretores que trabalham em colaborativo são muito espertos em ouvir todo mundo e conduzir para onde acham mais importante. Tem uma coisa, um pouco centralizadora dele que eu achei um pouco difícil, e outra coisa, foi que eu trabalhava com uma mesa Live onde não tem cue, não tem roteiro e onde o ator pisa, uma luz acende, ele vai para lá, a luz acende. Aí eu pensei: "Como assim? A luz não tem projeto? Não tem desenho? A luz não é proposta?" Aos poucos fomos conseguindo fazer tudo 
estar pré-gravado e só ajustar tempos com a luz abrindo e fechando, mudando planos. O Zé não conhecia o meu processo e eu entrei ali numa precariedade técnica absoluta para um teatro gigantesco com uma pista imensa que tem que ser iluminada. O que eu fiz foi zerar a casa e depois fazer uma montagem para poder começar a ensaiar. Eu tenho um pouco dessa ideia de que essa primeira luz não precisa ter nada a ver com a peça, mas eu com ela, que eu vou descobrir a dinâmica, a cor, o que eu tenho que fechar e o que precisa abrir... Eu estou ali fazendo uma atmosfera para o ator trabalhar. Eu fazia aquilo e o Zé olhava como se fosse luz e era infernal, porque ele fica com o microfone ligado e falando durante os ensaios e as peças, dirigindo o que está acontecendo na peça e ele ficava pedindo luz aqui, luz lá. Um dia, no final de um ensaio ele falou que estava tudo muito aberto e era óbvio "concordo com você, mas a cena começa com um ator a cinquenta centímetros um do outro e acabam com um cara a vinte metros do outro, então eu abro e eles ficam no lugar ou eu vou abrir a luz" e ele dizia "não, ele tem que ficar na luz, porque a pista precisa ter várias leituras". No próximo ensaio ele grita "luz" e eu grito "você quer que abra, ou eu mantenho fechado e eles ficam na luz?" e ele "deixa fechado!"

Eu fui começando a reparar que essa autoridade é porque, no campo da luz, não tem contestação nunca, o que com os atores é comum e eles tem vários embates, mas a luz tinha uma coisa de subserviência. Então, a questão da autoria, de ter alguém pensando a luz para ele... Eu não sei como foi a experiência dele com o Beto, não falamos sobre isso, mas foi bastante difícil levar uma ideia de luz que fosse diferente da dele, mas eu consegui levar minha pesquisa com os movings, com os LEDs e consegui levar uma ideia de luz préorganizada e também que é uma pessoa só que opera e não duas ou três. Consegui fazer com que tivesse um desenho e que ele fizesse parte da encenação, como mais um elemento de comunicação com quem está na plateia e que atendia todas as demandas de iluminar a plateia, iluminar árvore, isso e aquilo. Na plateia, como eu sabia que era algo importante para eles, eu tentei dar dois tratamentos, porque ele me pedia sempre isso. Foi uma experiência muito bacana, mas não sei o quanto a minha contribuição se mantém, porque eu soube que eles fizeram o Municipal agora, e eles já fizeram com a mesa sem 
gravar e com duas pessoas operando ao mesmo tempo. Para mim é como se não houvesse uma ideia de processo, como se a luz do primeiro ensaio já fosse definitiva e o tempo todo eu ficava explicando o que era o processo e como era o processo. Foi uma experiência absolutamente rica, mas para não repetir. Eu me sinto muito feliz de ter feito parte desse projeto, foi muito bacana ver aquele grupo de cinquenta anos de idade trabalhando e o motor daquilo ali é o cara de oitenta e poucos anos, é ele que faz aquilo girar. Tem pessoas superimportantes lá dentro como o Marcelo Drummond, a Camila (Mota), e Sylvia (Prado) e um monte de gente nova que mantém aquela energia pulsante e foi bem bacana. No relato eu conto mais detalhes, se um dia você tiver paciência, leia.

G.V. - Lerei sim! Eu queria entender como que vocês estabelecem as relações entre as áreas criativas no Vertigem? Como estabelecem a linguagem de comunicação entre vocês?

G.B. - Nós trabalhamos com teatro colaborativo, fomos experimentando e chegamos a essa maneira de nos relacionarmos. Em princípio, tem essa questão horizontal de fato e não existe um pré-projeto de nada, enquanto em um modelo mais tradicional o diretor e o cenógrafo se encontrariam antes, chegam a uma proposta de cenografia e quando começa o processo isso já está concebido. Aqui, nós temos uma porosidade muito grande, e eu incluo nisso os atores. Acho que quem menos interfere é a dramaturgia, que se preocupa mesmo com a palavra. Depois, sempre fazemos um texto do que foi encenado. O (Antônio) Duran, que é o nosso dramaturge, vem depois que a peça está em cartaz com um gravador e reescreve o texto como foi dito, isso foi feito no Bom Retiro. Nesse momento, entram rubricas inventadas por todas as áreas, que não estavam no texto original, coisas de luz aparecem e viram rubrica. Tudo passa pela sala, sempre. Temos um percurso que é uma pesquisa teórica, que uma hora se mistura com uma pesquisa de campo, que gera material para a sala de ensaio. Entramos numa série de workshops, mas claro que não é sempre exatamente assim... Nós já fizemos textos prontos, mas nunca deixa de ter uma pesquisa teórica e uma sequência de workshops, mesmo com o texto pronto, os atores às vezes trazem outras possibilidades. Quando fomos para Bruxelas com 
Dizer aquilo que não pensamos em línguas que não falamos, o texto era do Bernardo (Carvalho) e um dos personagens surgiu lá, pela necessidade de conexões entre as cenas. As ideias vão surgindo porque um ator faz um workshop, e nele ele traz uma ideia de luz, de espaço, de figurino e todo mundo que está na sala olha aquilo e vai reelaborando a partir daquilo. Às vezes, se joga uma coisa fora e se propõe algo novo. Quando marcamos de levar proposições para a cena do hotel no Apocalipse, por exemplo, eu trouxe proposições e a cenografia, o figurino e tudo isso se vê na hora, na sala de ensaio. Entra uma luz sem que o ator saiba, uma atmosfera que ele não pensou e não estava acostumado, mas aí fazemos essa experimentação algumas vezes no mesmo dia e, de uma para a outra, nós conversamos e vamos ajustando as coisas... É uma criação que se dá em processo e não temos grandes atritos e dificuldades de lidar com essas instabilidades, nunca foi uma questão. É um trabalho que vai sendo construído junto e com um invadindo o trabalho do outro, claro, com respeito. Temos o que o Tó (Antônio Araújo) chama de hierarquias flutuantes e, em dados momentos, cada um de nós tem a palavra, digamos que a direção da coisa, então isso aqui está mais consolidado. Agora, não temos mais atores, então eu não sei como isso vai se dar. Estamos com um projeto novo, que devemos fazer duas etapas aqui no Brasil e depois apresentar em Berlim, que é uma performance que iremos criar juntos, com atores que ainda serão chamados, não sei exatamente como vai ser isso, mas é bastante normal nós interferimos na vida dos outros de maneira positiva (risos).

G.V. - Quando você elabora uma proposta de luz, concebendo uma ideia para os workshops, ou mesmo para ajustar as propostas junto com o restante da equipe criativa, o que você tem em mente? Para quem você dá mais atenção?

G.B. - Em fazer uma proposta (risos)? Às vezes eu direciono para o Tó (Antônio Araújo), porque por vezes o olhar dele é muito no ator e na palavra, ele está preocupado em ouvir aquele texto. Vejo isso em mim, também, quando eu vou assistir uma peça de um aluno na escola, e estou lá para ver a luz dele, eu saio dali sem saber sobre o que era aquilo e não fixo na narrativa, porque nossa 
atenção é direcionada e por isso eu o chamo para olhar. Em geral eu estou preocupado com o processo, com a proposição, com a cena e é raro eu estar preocupado com o ator, por exemplo, não por um descaso, mas às vezes eu acho que eles viram centro demais. Às vezes eu converso com o cenógrafo "vou fazer isso, veja se é legal para você", ou "naquela parede que você fez e estou pensando em fazer uma textura, veja se está ok". Quando tem uma direção entrando pela primeira vez, estou mais focado naquilo que eu estou propondo e vendo se aquilo tem a ver com a cena. Eu, no primeiro momento, estou um pouco olhando a relação da luz com os elementos e entendendo como isso vai acontecer. A cena, para mim, é a coisa mais importante. Eu vejo a Alessandra Domingues, que migrou um pouco para as artes visuais, e eu sempre tive muita dificuldade com o abstrato, mas acho que é porque eu sempre parti para uma pesquisa antes de qualquer coisa, então é muito contraditório... O tema, os espaços me motivam para alguma coisa. Eu odeio os workshops e nunca faço workshop por conta disso. Eu fico "mas o que eu vou fazer?" E na escola eu fico forçando os alunos para isso de desenvolver a autonomia com essa instalação da luz como matéria e como colocar. Eu sempre tive dificuldade, porque a cena sempre me instigou e me movimentou muito, mas eu sempre chego na sala de ensaio com alguma coisa em andamento, porque eu tenho uma visão e uma leitura sobre aquilo ali, mas não é abstrato, porque eu já penso em onde irá ser, que conexões o material que estou pensando em colocar pode ter com o espaço e tudo isso me leva a uma pesquisa de materiais, porque eu preciso da concretude da cena. Eu me sinto um pouco limitado no campo abstrato (risos).

\section{G.V. - Como o espectador entra no teu processo criativo?}

G.B. - Eu nunca pensei exatamente nisso. Quando eu faço exposições ou eventos, eu fico no lugar até ver o público entrar, eu gostava de ver as pessoas nos contrastes que eu tinha provocado no espaço e como os corpos se colocavam na relação com a luz. Eu sempre estou conectado com essa coisa do contraste e é uma coisa que me pega muito, apesar de que, às vezes, se faça necessário uma coisa chapada. O público, em geral, e quando fomos para a Bélgica, que o público estava no meio da luz, eu achava interessante ver aqueles 
corpos modificados pela cor, as formas ganhando outras formas por conta de projeções ou ângulos de incidência de luz, mas nunca foi uma preocupação. Eu nunca pensei sobre o campo fisiológico de que a cor tal gera determinada sensação, nem sei como faz isso. Até o básico de começar com pouca luz para daí ganhar muita luz nunca foi muito um parâmetro para mim, porque isso normalmente me conecta a uma ideia do efeito pelo efeito. Se a cena, o texto, o trabalho, estivessem nesse lugar, talvez eu fosse para esse campo, mas, em geral, é mais uma curiosidade de ver os corpos sendo modificados por aquelas atmosferas. Eu tenho trabalhado muito com saturação e tenho achado interessante ver as pessoas verdes, azuis, vermelhas (risos).

\section{G.V. - Você acha que o espectador não entra no processo? Nem nos} workshops?

G.B. - Nesse sentido, de como o público vai receber, isso eu nunca penso. Acho que o Vertigem me deu uma certa liberdade de criar. A teleologia da obra, de que o êxito de uma obra está nela mesma, acho que o (Luigi) Pareyson que fala isso. Aliás, eu estudei esse texto algumas vezes com os alunos porque, para mim, faz muito sentido: a minha conexão é com a obra, com o sentido e eu tenho que atender ou atritar com ela, a minha relação é ali. O que o público vai achar, se ele vai gostar... por exemplo eu fiz um trabalho no (Teatro) Municipal onde eu criei uma estrutura simétrica no teto, mas absolutamente simétrica... Às vezes eu extrapolo a questão da estética para coisas assim, principalmente quando o teto é visível. Como eu sou muito assimétrico, o que vem de luz para baixo é completamente assimétrico. Eu fico inventando algumas coisas, assim, que eu acho que a plateia nunca vai perceber. Para mim a relação é disso atritando com o que é visto pelo público.

G.V. - A pesquisadora deste trabalho defende, como resultado de suas pesquisas práticas como iluminadora e reflexivas como pesquisadora, que a iluminação cênica tem uma participação ativa na cena teatral e também em outras formas das artes cênicas como a música, a dança, entre outras. Com isso, ela afirma que a luz atua, age em cena e interage com os demais componentes do espetáculo e também com o 
público, tendo a importante função de estabelecer e favorecer a relação entre o palco e plateia. Você concorda ou discorda dessa afirmação? Pelo que você estava me dizendo antes, parece que, na relação com o espectador, vocês discordam.

G.B. - Acho que, no final, sim, porque para mim é questionável. A luz pode complicar, atritar, dificultar, trazer uma camada que, às vezes, pode te levar para outra compreensão. Claro que a luz não pode ir para um lado e a cena para o outro, não é disso que eu estou falando. Eu fico um pouco em dúvida quando eu ouço alguém dizendo o que a luz tem que fazer, porque eu acho que ela já tem tanto para fazer que eu acho que precisamos de uma certa liberdade no resto. Nesse lugar, eu fico um pouco em dúvida com o que ela fala, mas o restante eu concordo, é óbvio. O Beto me disse uma vez, e eu nunca esqueci de quando ele foi ver um o Apocalipse, na época em que apresentamos em Curitiba, e no final ele me encontra e diz "é compadre, a luz ilumina a cena, né?" Na época não éramos amigos, então eu não disse nada e claro que, talvez, a luz no presídio de Curitiba não tenha ficado como era no espaço original aqui em São Paulo, mas é um presídio e tem um elemento ficcional acontecendo, a luz cria uma atmosfera e é óbvio que ela não está só iluminando a cena, mas ressignificando o espaço também, porque a função dele muda. Mas eu acredito que, no Vertigem, eu não penso em aparecer, não acho que a minha luz precise ser uma camada de significado na cena, eu preciso ser autônomo... O que eu penso é no que eu estou vendo e como que eu vou me envolver com o que eu estou vendo. No Bom Retiro tem um dado performativo muito forte porque os operadores estão muito visíveis aí e tem uma autoria muito grande. A rua, para mim, foi o dado mais difícil e não sei se vai de encontro ou contra o que ela fala, mas a primeira coisa que veio à minha a cabeça, quando eu vi aquelas cenas na rua, era que... O Tó falava muito do teatro em atrito com a cidade e aquilo ficava reverberando na minha cabeça. Tudo o que eu vi, junto com duas assistentes de iluminação foi... assistentes são um problema, porque eles ficam querendo mostrar trabalho e trazem várias coisas para o chefe (risos)... Eu acho um pouco chato. Tinha uma narradora que circulava e conduzia o público e as meninas todas com lanternas, iluminando a cara da atriz, e eu explicando que não queria 
um seguidor e nem nada do que a Cibele descobriu dentro do Oficina porque é muito teatral. Eu não queria aquilo, mas eu também não tinha nada para por no lugar, e eu sabia que não podia criar um espaço com tripés porque eu ia estar criando um outro plano dentro da cidade, que era o do teatro acontecendo, e a minha questão estava mais em encontrar uma coerência dentro do meu próprio trabalho com os elementos que são visíveis, feitos para que o público veja. É algo que tem conexão direta com isso que estamos discutindo ou com a arquitetura do lugar. Eu nunca vou entrar num shopping e ir colocando refletor, como acontecia, sem nenhum sentido. Eu fazia uma luz na estrutura da arquitetura, mas vou iluminar a cena com aquelas lâmpadas, elas estarão a serviço da cena. Ficamos oito meses ensaiando e eu fiquei quatro meses sem saber o que fazer, até eu perceber que o que eu tinha que fazer era usar os postes, a luz da rua. Eu fui, então, discutir com a Isadora Giuntini, que era a estagiária de arquitetura que estava no projeto. Pensamos juntos e ela fez o desenho técnico de um mecanismo com o qual eu poderia manipular a luz do próprio poste. Eu tentei apagar, mas vi logo que não rolava, então criamos uma máscara, e quando ela começou a funcionar, eu fui desenvolvendo outras possibilidades de usar isso na narrativa. Fomos criando usos para mudar a luz, fazer blecautes, mudar a iluminação da rua. Aquilo estava a serviço da cena, mas tinha uma presença muito forte na cena, porque quando as pessoas saíam do shopping, estava tudo completamente escuro e um poste aceso com uma cena acontecendo lá, então o público ia imediatamente para lá, porque é um código. Acontece a cena e quando o Beto diz uma coisa, o operador vai manipulando ali e todo mundo vê o blecaute vindo. Nessa situação, pode parecer que luz esteja tendo um papel na narrativa, que seja superior à cena, mas aquilo é uma resposta inusitada para aquilo que você viu na cena. O Tó tinha muita necessidade de foco de atenção na rua, porque a cidade inteira está em movimento o tempo inteiro, e quando entrou a solução dos postes, isso estava totalmente a serviço dessa organização da cena, porque o público entendia, ajudava na dinâmica... Era como com um dimmer, só que manual. Todo mundo via aqueles caras manipulando os postes e isso deslocava da cena, mas ao 
mesmo tempo isso era completamente conectado com a própria cena. Acho que é isso, não sei se fica tão longe do que ela afirma.

G.V. - Acho que não, mas é a tua resposta, uma percepção tua. Você consegue me contar alguns outros exemplos de trabalhos que você ache que a sua luz construiu dramaturgia interferindo na cena?

G.B. - Acho que no Filho acontecia isso também. É um processo que eu sempre gostei bastante, a cor sempre foi uma coisa muito intuitiva para mim e eu não entendo nada de cor. Eu coloco e às vezes dá certo, às vezes eu finjo que deu certo e às vezes eu assumo que não deu certo e preciso assumir isso e mudar. Com os aparelhos digitais, isso de testar as cores é muito mais fácil, mas comprar gelatina e não ser aquela cor é um problema (risos). No Filho teve todo um processo de descoberta do uso da cor que foi muito rico. Partimos da relação quente e fria para criar situações com contraste e, pela negação de âmbar e azul, fomos para sódio e bluegreen, que são opostos no espectro RGB e que juntas formavam um branco um pouco sujo e sombras coloridas... Isso era o que eu via, mas provavelmente nem todos repararam. O espetáculo tinha várias dificuldades, porque o ator às vezes fazia uma cena interna, subjetiva, dialógica, era ele numa reflexão sobre si e com o público e dele com a cena. No Filho, eu acho que o que mais se destaca são os movings, que se colocam quando alguém tinha um monólogo interno. O cenário era um depósito de objetos domésticos com uma passarela em cima e o público ficava todo sentado sem ver tudo, porque estavam no meio desse lugar. Eu fazia um jogo, que era de montar quadros, e quando o ator se movia, tudo se movia com ele e não havia um contorno circular em torno do ator. A convenção teatral de seguidores estava ali, mas a qualidade dessa seguida era diferente. Para mim, tem um dado performativo e autoral que era: tínhamos a luz difusa na qual se via a cor mudando, os recortes mudando e assim eu construía e desconstruía os ambientes na frente do público. Eu não deixava de criar atmosfera, mas eu não criava uma ilusão do como ela acontece... na minha cabeça de autor, eu estou desmistificando a atmosfera, rompendo uma norma teatral e criando um novo jogo ali. Acho que Jó (a peça O Livro de Jó) também é um exemplo muito bom, 
dos elementos hospitalares, quando ele está no hospital e se entende doente, se olha no espelho e o que o ilumina é um olho cirúrgico, e a partir daí tudo o que você vê é um jogo teatral construindo uma atmosfera com um objeto de hospital e não um refletor, e eu acho que isso cria um atrito na cena e desloca a atmosfera que está sendo guiada. Acho que esses são os exemplos, acha que é suficiente?

\section{G.V. - É sim! Queria te fazer uma outra pergunta: como surge essa} demanda de criar novas fontes luminosas, como você lida com ela?

G.B. - Veja, precisamos ter um carinho com as coisas e com quem somos. Me chamavam para fazer trabalhos porque os produtores ou diretores julgam que a peça precisa de formas diferentes de iluminar e quando você vai assistir a um ensaio você percebe que não cabe ali. Eu acho que essa demanda é completamente do Vertigem e tem um pé no acaso, porque quando chegamos para fazer $O$ Paraíso Perdido, eu não tinha a menor ideia do que estava acontecendo. Eu e o Tó conversávamos muito, porque fazia três projetos que eu tinha começado e eu não sabia muito bem o que era luz, as propriedades, não sabia articular uma ideia com a luz, mas eu tinhas as situações... A igreja me colocou algumas questões e eu fui obrigado a resolver. Talvez, olhando de fora, você tenha uma visão menos direta que a minha, o Chico está fazendo o mestrado dele sobre o meu trabalho e eu tenho muita curiosidade de saber o que ele vai falar. Eu acho que tem uma coisa do criador, desse campo da intuição que é muito forte em mim. Eu não sou muito da academia e não me preocupo muito com referência, é muito difícil eu ir procurar referências para resolver os meus problemas, mas aí eu não sei se eu confio demais na minha criatividade (risos), eu fico achando que preciso inventar as coisas. Lógico que as referências estão em você, eu não vou atrás. No Paraíso eu escondi os refletores porque algo me dizia que aquilo não era bom, que a experiência do público precisava ser total e ele não podia ficar vendo coisas acontecendo, a luz teatral tinha que desaparecer. Depois é que eu comecei a entender isso, na hora era apenas intuitivo. Tem uma hora que o Tó faz uma cena, que é o castigo com os pais ou mães deitados e os filhos ficam batendo, e essa cena é a punição e isso está 
praticamente alinhado com o confessionário, aí eu olhei aquele confessionário e sabia que a luz precisava vir de dentro do confessionário. Eu não percebo de cara o que é, mas com o tempo vou entendendo que aquela luz de dentro do confessionário tinha tudo a ver com o resto. Acho que o Paraíso foi me abrindo e quando fomos para a Catedral de Curitiba já tínhamos feito um tempo em cartaz em São Paulo e eu tinha entendido as deficiências, porque eu tenho uma facilidade e aprendo rápido, a não ser as MAs (risos), isso não entra na minha cabeça. Quando chega o Jó (O Livro de Jó), vamos andar por todo o espaço, ver tudo e conhecer o lugar, a energia do lugar... Foi em um passeio desses que encontramos uma sala cheia de equipamentos de luz hospitalar e móveis e eu imediatamente fui tirando as luminárias e separando... O Jó é o grande salto dessa pesquisa de materiais e é quando eu tomo consciência que esse é o caminho que vou desenvolver com o Vertigem. Essa relação conceitual do que está no campo visível do público, com aquela arquitetura e espaço, também são muito importantes. A Cibele tinha uma pesquisa com lâmpadas de descarga, trabalhei um pouco com ela e foi como eu fui me afastando mais dos refletores, que, se pensarmos bem, eu ainda nem conhecia (risos). Ir para esses equipamentos foi fundamental para mim. A quantidade de coisas que eu vou juntando e acumulando, você não tem ideia (risos). Eu ia nos ferros-velhos procurar objetos que não tivessem uma cara definida ou que eu podia transformar pela função dos objetos na cena. Estar nesses lugares resolvia uma questão estética e conceitual, mas também a situação precária que vivíamos financeiramente e a minha falta de conhecimento para colocar equipamentos outros dentro do Vertigem, então eu ia inventando. O meu desconhecimento me levou para esse campo, mas também, no trabalho do Vertigem, para as questões que o site specific vai te trazendo. Isso vai ficando mais consciente e no Apocalipse começamos a visitar delegacias, bordéis, hotéis e começamos a trabalhar objetos de um lugar com um trato de lâmpada diferente... Eu fui radicalizando um pouco a minha relação com a matéria. Eu não vou só reproduzir a imagem que esses lugares têm, mas eu vou trazer materiais e colocar aqui. A plateia nem sabe disso, mas ela está em um lugar que não tem só a atmosfera, mas os materiais que vieram desses lugares. Chegou uma hora que eu me 
cansei disso, foi quando entraram os LEDs e os movings. Eu comecei a querer colocar as tecnologias em atrito e, para mim, existe uma questão conceitual nas escolhas dos materiais que vamos usar. Quando eu montei O Duelo, com direção de Georgette Fadel, eu usei equipamentos muito novos e muito antigos e ela me perguntou "só com isso vai dar para iluminar a peça toda?" e isso era um disparador para mim. Isso tem a ver, para mim, com o rompimento de alguns dogmas e de romper as possibilidades para iluminar a cena.

\section{G.V. - Você ou seus assistentes não fazem um projeto antes de a} peça estar pronta?

G.B. - Fazemos, testamos o ângulo no 3D, mas isso tem hora para acontecer. Na hora que eu sei o que eu quero, é hora da tecnologia entrar e me dizer como fazer isso dar certo, mas no campo da criação, eu estou absolutamente aberto e sem pensar em programa 3D. No Vertigem, as coisas se dão muito no processo, então não tem muito como fazer pré-projetos ou preparações. Normalmente, tem um grupo de pessoas que vem estagiar, desses eu já escolho um que vai ficar como operador e que segue comigo. No Filho, aconteceu uma coisa super legal, porque uma pessoa que vinha da arquitetura ficou com as plantas, desenhos técnicos e procuração, outro foi para o campo da elétrica e fomos fazendo um procedimento interessante: o espaço estava definido no piso, cada um ganhou uma folha e desenhou a sua planta e tivemos cinco projetos diferentes, mas olhamos o que era comum e o que era diferente e discutimos se entrava ou não. A planta toda foi feita nesse procedimento... eu sabia o que eu queria, então eu já fiz a primeira, mas o processo deles mexendo foi muito legal. Depois isso vai para a fase dos desenhos, vemos se dá certo ou não. Eu gosto de deixar a escolha dos equipamentos e os desenhos técnicos mais para a frente, acho que o legal é mergulhar na cena e nos experimentos.

\section{G.V. - Acho que é isso. Muito obrigada pela entrevista e por poder} conhecer o espaço de trabalho de vocês!

G.B. - De nada! 
3.14 Jorginho de Carvalho - Iluminador Carioca ${ }^{240}$

\section{Como conceito, você considera que a luz seja material ou} imaterial?

J.C. - Agora descansado, acho que entendi melhor sua pergunta. Você queria saber sobre LUZ e não lluminação, não é isso? Então, você gostaria de saber se considero que a luz seja material ou imaterial? Minha resposta é imaterial.

\section{G.V. - Você saberia explicar a sua resposta?}

J.C. - Vou tentar! Para mim, ela é imaterial por não se poder tocar na luz, somente ver. Assim como não se pode tocar no som, somente ouvir. Por isso, a explicação de que eu não consigo separar numa peça a parte da luz que é material e imaterial, tudo o que eu faço numa peça tem conceito material e imaterial. Para realizar uma iluminação de conceito imaterial, eu precisaria fazer um evento de luz e som, duas artes que eu considero imateriais e que juntas podem realizar um espetáculo que dê prazer de assistir e onde mesmo se vendo materialidades reveladas pela luz ou se ouvindo melodias conhecidas, pois não passam do segundo plano, já que as duas artes materiais são os protagonistas em primeiro plano. Somente assim acredito que ficaria interessante de se assistir.

Já existem muitos e belos espetáculos imateriais de som e luz. Porém, o vídeo ${ }^{241}$ que também está no WhatsApp mostra o que considero conceito de iluminação do espetáculo. Quando digo que o conceito geral vem dos debates do início da realização do espetáculo, já que um diretor pega o texto que deseja realizar e ambos, texto e direção, se juntam aos atores para lerem esse texto e

240 Entrevista realizada por Gabriela Valcanaia e Nadia Luciani por um e-mail enviado no dia 22 de abril e respostas recebidas por e-mail e WhatsApp entre os dias 11 e 23 de maio de 2020.

241 Vídeo do espetáculo Belle, da Cia Deborah Colker com iluminação de Jorginho de Carvalho, cujo link foi enviados por ele pelo WhatsApp e está disponível no YouTube no endereço https://www.youtube.com/watch?v=NdAcz03j3bk\&list=PLEtxQQNXnPZs rP5TIwIBprSAGf5GIm UL. 
debaterem o conceito geral que será realizado, seus motivos, desejos, intrigâncias, etc. Tudo que possa fortalecer o conhecimento de todos para uma realização que será levada na direção escolhida em consenso. Para terminar, voltando aos vídeos ${ }^{242}$, eles são espetáculos que têm um conceito geral bem definido, já que foram originados por dois grandes textos, Belle, de Joseph Kessel e Cão sem Plumas, de João Cabral de Melo Neto. Em ambos, tem vários momentos de conceitos que se afastam do conceito geral, por conta de licenças poéticas enfatizadas pela dramaturgia da luz que torna visível o Invisível, mas sempre somando essas variações ao conceito geral. Em Belle, que trata de um casal com relação aparentemente definida. Porém Belle sofre de um problema de grande insatisfação com desejos não satisfeitos pelo marido, que a levam a ter uma vida dupla. Em Cão sem Plumas, tem a situação de fome sendo enfatizada pela dramaturgia da luz quando os atores são coreografados pela direção, transformando-os em uma enorme pilha de caranguejos, e outras tantas licenças poéticas. Porém, sempre retornando ao conceito geral de realizar uma grande denúncia do drama social proposto na poesia de João Cabral de Melo Neto.

2. Você costuma trabalhar mais com a mesma companhia/diretor ou varia? Você pode citar alguns nomes e contar sobre como se sente em relação a esses trabalhos?

J.C. - A minha resposta é sim sobre ter o costume de trabalhar com a mesma direção e sim para trabalhar com vários diretores. O motivo é que em 1960 fui abduzido pelo teatro amador O Tablado e seu fazer teatral, e aos poucos fui compreendendo que a palavra 'amador' para os Tabladianos significava "Amar fazer um bom teatro". Então, em 1966, eu me tornei um Tabladiano, ou seja, passei a ser um ativista do fazer teatral, com o compromisso de dar o meu

\footnotetext{
242 Jorginho também enviou o link do vídeo do ballet Cão sem Plumas, mais uma realização da Cia Deborah Colker com iluminação de Jorginho de Carvalho, disponível no YouTube https://www.youtube.com/watch?v=9WjDsa C2Bw\&list=PLEtxQQNXnPZs rP5TIwIBprSAGf5GI $\underline{\mathrm{mUL} \& \text { index }=2}$
} 
melhor, e hoje, em 2020, tenho certeza que vou continuar sendo tanto um ativista Tabladiano quanto um Flamenguista, ambos até morrer! Em 1967, sendo aprovado para o emprego de Escriturário na Secretaria de Cultura da Guanabara, fui transferido para atender a requisição de Napoleão Muniz Freire, diretor do Teatro Gláucio Gil desde 63, para compor seu quadro técnico como Auxiliar de Eletricista do teatro, que só tinha um técnico, o Sr. José de Mattos. Ele, após minha contratação foi promovido à Chefe dos Eletricistas do Teatro. Eu fiquei feliz pelo primeiro emprego como profissional de lluminação, mas tanto pela função de Auxiliar de Eletricista de Teatro, quanto por uma Carteira Profissional assinada pela Secretaria de Cultura da Guanabara. Em fins de 1968, Napoleão conseguiu que Roberto de Cleto aceitasse substituí-lo na direção do Teatro, o que para mim não mudaria nada, já que tive com ambos uma boa relação em suas épocas de Tablado.

Então, se de 1960 à 1967, só trabalhei com a direção de Maria Clara Machado, a partir de 1967 até 1970, além de trabalhar como profissional no Teatro Gláucio Gil, continuei fazendo luz para Maria Clara no Tablado e, como já tinha ensinado o operador de luz nos ensaios, primeiro sob minha égide e, depois, nas apresentações da peça sob a égide de Clara ou seu assistente. Mas neste período, também atendendo minha necessidade de conhecer os teatros pelo Brasil, consegui ir a Porto Alegre com Luiz de Lima com O Preço, espetáculo que havia estreado no Teatro Princesa Isabel no Rio de Janeiro. Depois, eu consegui viajar com a Cia Tônia Carreiro por três semanas pelo interior de São Paulo sob a égide do técnico de luz responsável pela iluminação da Cia Tônia Carreiro, Sr. Jerônimo Cruz. Em fins de 1970, aceitei o convite de João Bittencourt para viajar com Frank Sinatra 4815, e sabendo que Roberto de Cleto não aceitaria mais uma licença para sair do teatro, ao ir falar com ele, comecei dizendo que poderia me demitir. Quando voltasse, uns 13 ou 15 dias depois, se ele quisesse, eu poderia ensinar meu substituto o tempo que fosse necessário.

Então de 1960 à 1970, ou seja, em meus apenas dez anos luz, comprovo que tenho razão em responder com dois sim (à pergunta feita), pois se de 1960 à 1967 com certeza só trabalhei com Maria Clara Machado, de 1967 à 1970, 
além de continuar fazendo os desenhos de luz do Tablado sob a direção de Maria Clara, fiz todas as montagens de luz das peças que se apresentaram no Teatro Gláucio Gil, não como lluminador, mas como auxiliar de eletricista. Neste período eu também fiz três trabalhos avulsos, ou seja, com outros diretores: viajei para Porto Alegre com o diretor Luiz de Lima como responsável técnico da peça O Preço; depois viajei com a Cia Tônia Carreiro durante três semanas pelo interior de São Paulo com o espetáculo Falando de Rosas, com direção de Cecil Thiré e sob a égide de Jerônimo Cruz, responsável técnico da Cia Tônia Carreiro. Por fim, precisei me demitir do Gláucio Gil para poder viajar para Porto Alegre com o espetáculo Frank Sinatra 4815, como responsável técnico pela lluminação, sob a égide do diretor João Bittencourt.

Para terminar essa segunda resposta, informo que a síntese de trabalhos que fiz com seus distintos diretores e com trabalhos fixos com uma direção foram Hamilton Vaz Pereira de 1975 até o início do governo atual. Assim como com Deborah Colker desde 1995 com o espetáculo Velox até outubro de 2019, com o espetáculo Clássico que ela dirigiu para o Circo Crescer e Viver, e ainda com alguns outros diretores estrangeiros.

3. A pesquisadora deste trabalho defende, como resultado de suas pesquisas práticas como iluminadora e reflexivas como pesquisadora, que a iluminação cênica tem uma participação ativa na cena teatral, assim como em outras formas das artes cênicas como a música, a dança, entre outras. Com isso ela afirma que a luz atua, age em cena e interage com os demais componentes do espetáculo e também com o público, tendo a importante função de estabelecer e favorecer a relação entre o palco e plateia. Você concorda ou discorda dessa afirmação? Por quê?

J.C. - Querida, me sinto até suspeito em falar, pois essa terceira pergunta está mais do que explicada nas respostas anteriores, pois nós que fazemos teatro sabemos que $\mathrm{o}$ ator se completa quando interage com a plateia, ou quando ele percebe o resultado do seu trabalho na resposta do público, que 
quando entende e se apaixona, reage espontaneamente e não se incomoda até em interromper a cena que se apaixonou aplaudindo no meio dela.

$\mathrm{Na}$ verdade, (foi) quando disse que entendia lluminação e me identifiquei totalmente com ela por significar, para mim, que a lluminação interpretava a ação que estava sendo realizada em cada momento. Que a lluminação precisava ser entendida como intérprete, tendo conceito e dramaturgia. Só assim, ela ia somar de forma diferenciada para cada espetáculo. Quando eu comecei a desenhar luz, não tinha ideia que ia ser por toda a minha vida por opção e não por falta (de opção). Pouco tempo depois, tive que refrear minha avidez em difundir essa ideia de luz como intérprete que, na época, era só um sentimento e não tinha muita gente interessada em debater essa ideia comigo.

Então, percebi que precisava primeiro formar uma equipe de técnicos que me acompanhassem nos trabalhos, daí as oficinas de luz que me convidavam pra fazer, ou o governo me enviava, pois a notícia, assim como dizia José Wilker "Ela, quando é boa, espeta você, tira você da cadeira, agiliza sua difusão". Pois bem, as peças que eu viajava como responsável, eu trocava um bom pagamento por uma grande quantidade de técnicos para ajudar, e meu cérebro contabilizava a quantidade de técnicos que eu ia seduzir para mais um conhecimento que começava pelo título que ao invés de ser "Oficina de Luz 20 horas", eu intitulava "Oficina de lluminação Cênica, Metodologia e Compreensão", e não tenho ideia de quantas oficinas eu fiz por esse Brasil afora. E é claro que no Rio eu tinha a possibilidade de fazer várias equipes, porque eu montava muita luz. Assim, eu driblei a primeira barreira, que eram os técnicos que discutiam o porquê de ter que montar mais refletores que o normal, formas diferentes de fazê-lo, principalmente para acabar a montagem mais rápido, se iam ficar ganhando sempre a mesma coisa.

Minha resposta sempre era que iria possibilitar aos donos do teatro alugálo para mais companhias, já que os trabalhos de montagem acabariam mais cedo, e com isso o trabalho dos técnicos teria mais visibilidade e assim poderiam ter recebimentos diferenciados e que iriam descobrir que, de acordo com o trabalho de cada um, seu nome ia ser comentado a quilômetros dali por pessoas 
que ele nem conheciam e elas também não, mas que, se por acaso se encontrassem, iam ter imenso prazer somente por estarem se conhecendo. Essa é a magia do teatro, pelo menos para os Tabladianos é assim.

Nem preciso dizer que, com isso, o canal para difundir novas metodologias para se montar uma luz e realizar uma lluminação de maneira diferenciada, entendendo a luz como intérprete de um espetáculo, estava aberto. Bastava ocupar e difundir. Em suma, como poderia ter uma opinião diferente da sua hoje, quando me entendo ter sido um bandeirante da minha época pesquisando a descoberta das entranhas da lluminação nos teatros do Brasil. Minha resposta já foi sim à essa terceira pergunta, por todas as respostas das outras perguntas. E desculpe a minha prolixidade. Essa palavra existe? (risos) Eu sei que a empreguei por ter consciência de ser um prolixo exagerado. Então, sobre a parte de dar exemplos de alguns espetáculos, os dois vídeos que Ihes enviei são bastante ricos a respeito da interação com o público e interagindo com sua atuação no espetáculo. 
3.15 Lucas Amado - lluminador Paranaense ${ }^{243}$

1. Como conceito, você considera que a luz seja material ou imaterial? Você saberia explicar a sua resposta?

L.A. - Eu não penso a luz como o refletor que acende, até porque eu vejo a escuridão como luz também. Talvez o meu pensamento seja imaterial, porque a luz para mim é mais uma sensação, mas é material porque eu preciso estudar o material, a fisicalidade e a geometria. Então o meu processo é o estudo de referências. Tem uma citação do Waldo León que era fotógrafo, iluminador e artista visual, que fala sobre como eu vejo a luz hoje: "A luz é a influência mais importante em nossa percepção visual do mundo". Eu olho o mundo como geometria. Quando eu entro em qualquer lugar eu olho a luz, mas antes eu olho a porta retangular que compõe com a parede e a luminária redonda e a distância da mesa ao chão e faço tudo isso em segundos. Então, sempre que me chamam para dar consultoria em algum lugar, eu sempre começo vendo a dimensão do lugar, seja para fazer a luz de um bar ou de uma ópera. Eu vejo a dimensão e isso sempre foi natural para mim, mas agora, estudando isso, eu compreendo que é assim. Então para mim é imaterial.

2. Sobre o teu processo criativo, eu queria entender se você costuma trabalhar mais com a mesma companhia e diretor ou se varia?

L.A. - Eu trabalho com alguns grupos ou diretores, o que eu gosto muito. $\mathrm{Na}$ verdade, eu sinto muita falta desse trabalho de grupo, de viajar dentro de processos. Mas eu sou muito versátil e trabalho com muitas tangentes da iluminação e linguagens completamente diferentes. Mas tem alguns grupos que eu trabalho e faço uma pesquisa, com o Obragem, por exemplo. Eu estou há onze anos direto com eles e ganhamos vários prêmios.

${ }^{243}$ Entrevista realizada por Gabriela Valcanaia em Curitiba no dia 07 de março de 2020. 


\section{G.V. - Você vê esse reconhecimento como reflexo do trabalho} aprofundado e de estar dentro do grupo há mais tempo?

L.A. - Antes de falar de grupo eu prefiro falar do teatro. Eu trabalho com todas as linguagens artísticas, mas considero que o teatro é a que mais me fala, porque pode conter todas as outras artes e porque a comunicação nele é mais profunda. Nele eu encontro mais pesquisa, embasamento e aprofundamento. Eu sou chamado para fazer luz em shows por ser iluminador de teatro. Mas respondendo a sua pergunta sobre grupos, com certeza, o reconhecimento vem também desses grupos, principalmente do Obragem. O que eu gosto, de trabalhar com eles, é que eu aprendi a ter um processo, desenvolvi o meu processo e hoje, mais maduro, eu estou levando o meu processo para dentro do grupo. Hoje em dia, quando eu vou fazer direção de shows, dança, teatro, qualquer coisa, eu levo exercícios, levo tarefas. Eu procuro, quando tem tempo de processo, levar uma aula ou um exercício e conversar sobre posicionamento na luz dentro da espacialidade.

G.V. - Você acha importante estabelecer uma relação mais próxima com o dramaturgo e encenador do espetáculo que vai iluminar ou até mesmo com todo o grupo e equipe de criação para criar a luz? Você falou dessa prática de levar exercícios e eu gostaria de ouvir mais sobre o teu processo criativo nos grupos.

L.A. - Eu acho fundamental essa conexão. Quando eu começo a fazer luz, eu não penso em equipamento, de início. Eu sempre começo pela observação do processo e como ele acontece e quando falo com alguém sobre isso, falo sobre a respiração, sobre estar aberto. Eu sempre vou para o trabalho dos artistas, beber das referências. Eu sou meio polêmico na cidade por que eu me digo um artista da luz, e levanto essa bandeira mesmo, justamente porque eu vejo a dificuldade que as pessoas têm de entender a importância da luz e a importância de um profissional, ou uma profissional dentro desse processo. Nós, como grupo de artistas, precisamos estar conectados para passar uma verdade. Eu trabalho e estudo, mas gostaria de chegar ainda mais nesse resultado que é o de trabalhar a sinestesia. Não é sempre que eu consigo colocar isso, mas isso 
tem ficado mais orgânico para mim na escolha de equipamento, de equipe. Para mim tudo influência. O meu contato com a obra está em primeiro lugar.

\section{G.V. - A obra...?}

L.A. - A obra física, a obra artística no geral, o projeto da montagem, encenação, trabalho de ator, texto. Quando você pega o trabalho para fazer, para mim, aquilo é uma obra. Até para o meu corpo e a minha cabeça acreditarem nela, eu tento entender o conjunto todo como obra, para que o meu corpo assimile isso. Para mim, o trabalho em grupo é, além de maravilhoso, indispensável para o crescimento. Se estudarmos a história da humanidade, vamos perceber que o ser humano precisa de grupos. O teatro tem várias tangentes, mas ele é a arte do trabalho em equipe. Eu nunca gosto quando alguém elogia uma luz minha e eu percebo que ela está indo além da obra.

\section{G.V. - Qual a tua maior preocupação no momento de criação, a quem} você dá mais atenção? O que ou quem você tem em mente?

L.A. - Eu luto contra a ideia de ter cartas na manga. Depende de onde começa, se começar numa reunião, onde a obra ainda não está exposta, a primeira coisa que eu penso é se eu vou gostar. Por que se eu vou gostar eu já vou muito mais aberto. Se eu não vou gostar, mas eu preciso ou é importante, eu faço um trabalho interno de entender o que, no trabalho, eu gosto, ou posso gostar, e o que nele pode me transformar. Já aconteceu de eu não aceitar trabalhos porque não ia rolar. Eu preciso me divertir. Aí eu conheço o texto, penso onde vai ser, qual a verba, na empresa que vou locar, na equipe que vou chamar. Eu tento não deixar que tudo isso aconteça cedo demais, mas na maioria das vezes, o signo da luz se imprime no primeiro ensaio. Muitas coisas acontecem, e então eu fico olhando a sombra da janela no chão... Às vezes o espaço onde vai ser apresentado não tem nada a ver com o espaço onde estamos ensaiando, mas eu quero imprimir isso de algum jeito. Já aconteceu de eu propor geometrias, quadrados, claro que a obra pedia, mas também porque estava ligado ao que tinha acontecido na sala de ensaio. 


\section{G.V. - O espectador está, de alguma maneira, no teu processo criativo?}

L.A. - Eu penso no espectador a todo o momento, e em todos os trabalhos que eu faço. A obra não precisa explicar, mas ela precisa tocar. Se ela não me toca, que trabalho há anos com isso, como vai tocar alguém que vai assistir? A pessoa, quando paga o ingresso, precisa ter a experiência. Em todos os shows que eu faço, eu me preocupo e converso com o fotógrafo, cinegrafista, o dono ou a dona do evento ou festival, com a pessoa que tá assistindo. Eu sou o cara que programa a posição de um moving heade desce na plateia para ver se pega nos olhos da plateia. Às vezes eu coloco coisas para incomodar os olhos da plateia, lógico que com moderação, mas porque a linguagem ou o espetáculo pede. Eu penso nas cadeiras que as pessoas estão sentadas, ou sobre como preparar o espaço para que elas não sentem. Não só com a plateia, mas com os atores também, coloco fitas no chão, afino a intensidade da luz, coloco o artista na frente e pergunto se dói os olhos, se machuca. A coisa, para mim, é um planeta, cheio de funções. Mas é difícil porque nem todo mundo está aberto para isso.

\section{G.V. - Qual a tua relação com o diretor e com o texto?}

L.A. - Eu tenho um respeito e gosto de ter uma relação profunda e amigável com a direção, porque eu acho que o diretor ou a diretora é que faze a amarração de uma ideia muito grande, que envolve muita gente e tem muita coisa envolvida. Já o texto, eu acho que é o coração, ou o cérebro, se é que eles são órgãos separados. Mas acho que vou dizer que é o cérebro, para dizer que o coração é mais sensorial, sensível e almático. Então o texto, como cérebro, é que vai ser o fio condutor, que vai levar a ideia do início ao fim, mas tem um corpo que faz a conexão, e eu não vou nem dizer que ele faz amarração, por que eu acho que quem faz isso é a direção. Então, essas duas figuras são importantíssimas e que eu sempre respeitei e admirei, inclusive já tive até medo de algumas, de longe, e que hoje tenho como amigas mesmo, como a Olga Nenevê, do Obragem ou o Adriano Esturilho do Cinema. Eu acabei de fazer um trabalho em São Francisco do Sul, que eu considero um dos grandes trabalhos 
da minha vida. Chama-se $A$ casa. Foram oito meses de processo à distância, comigo indo lá uma vez por mês. Eu fiz a luz com o cálculo da energia do poste, tivemos que comprar esse poste por que era numa casa centenária, que não podia pregar um prego na parede. Eu fiz uma luz completamente baseada em Edward Hopper e, claro, pensando no texto, na obra e na direção. Então ressignifiquei várias coisas da casa. Por exemplo, trabalhei com abajures, luminárias e lustres. Eu refiz e mudei alguns lustres da casa, que estavam quebrados. A única coisa de refletores de teatro que eu coloquei, que, na verdade, eram de arquitetura, eram externos. Eu estudei o sol e a lua naquela casa, por causa das cenas que aconteciam em seis cômodos da casa, com cenário super-realista, e que, ao mesmo tempo, não era. Eu misturei algumas linguagens ali dentro, trabalhei com LED também. Foi muito interessante. $O$ texto, na minha vida ali, foi a primeira conexão. As janelas da casa todas acendiam, era uma loucura. Foi interessante porque eu fiz um trabalho com os artistas, com a diretora, primeiro, e depois com o elenco, para que eles operassem a luz de cada cômodo. Isso porque nós não tínhamos tanta grana para ter um sistema que, dentro de um lugar, tivesse alguém assistindo, com uns televisores, para poder saber a hora que ele ia operar. O que eu fiz foi colocar dimmer em tudo, nos lustres, e o que acontecia é que a pessoa abria a cortina e aí, na próxima cena, entrava a luz que já estava acesa e que batia nas grades da janela, fazendo um desenho em quem estava na frente, com um bafinho de tal refletor e o lustre a tantos por cento. A conexão com o texto foi muito importante, ele é uma cápsula do tempo que te leva para aquele lugar e começa a significar coisas para você, que é um artista visual. $O$ texto é onde eu decupo e encontro tudo. Confesso que, na realidade do Brasil, trabalhando com a realidade dos editais do estado, é tão difícil...! O texto te oferece tantas coisas, tantos sonhos, tantos lugares, coisas que a falta de grana não nos deixa alcançar. Isso também é importante, você aprende a lidar com as coisas e a criar. 
3. A pesquisadora deste trabalho defende, como resultado de suas pesquisas práticas como iluminadora e reflexivas como pesquisadora, que a iluminação cênica tem uma participação ativa na cena teatral, assim como em outras formas das artes cênicas como a música, a dança, entre outras. Com isso ela afirma que a luz atua, age em cena e interage com os demais componentes do espetáculo e também com o público, tendo a importante função de estabelecer e favorecer a relação entre o palco e plateia. Você concorda ou discorda dessa afirmação? Por quê? Você saberia dar alguns exemplos dessa atuação da luz no seu próprio trabalho? Pode ser um projeto inteiro ou um ou mais efeitos específicos.

L.A. - Concordo plenamente, mas entendo pelo jeito que ela escreveu que nós não supervalorizamos a luz dentro de um processo. São vários sentidos. Ela pode ajudar, pode compor, pode ser o objeto de estudo, ser a obra, estar dentro e estar fora. Eu concordo muito! E é muito interessante fazermos um estudo básico e objetivo do surgimento da iluminação no mundo, do surgimento da iluminação no Brasil, do surgimento dos refletores e do caminho todo da luz. De como veio desde o uso do óleo de baleia até a energia elétrica e os refletores no mundo. Daí, de repente, começam a chegar outros refletores. Por exemplo, o elipso mudou a história da iluminação no mundo. Ele começou a trazer muitos significados. A luz não era mais igual. O dia é âmbar, a noite é azul, a floresta é verde. Ele começou a fazer recortes, focar, desfocar, fazer triângulos, formas geométricas, colocar gobo na frente. Estou falando disso para dizer que a história da iluminação é paralela, mas que ela é arte e um movimento artístico que é muito complexo, bom e ruim, bonito e feio. A luz é isso também. Não tem como separar, é intrínseco. A história nos mostra o quanto ela é ressignificada. As pessoas lutaram muito para mostrar a importância do trabalho. $E$ hoje ainda, eu luto para mostrar a importância do meu trabalho. Quando eu chego num grupo, principalmente de música, eu vejo que a galera da música, a não ser os famosos que já tem uma equipe que trabalha com isso e mostra a importância, a maioria não entende e acha que é um pisca-pisca, só uma geral que acende. E não é! Quando você encontra alguém que não é famoso e te diz "eu estou fazendo um show, estou com pouca grana, mas estou escolhendo algumas 
pessoas para trabalhar. O cara do som é tal pessoa e eu queria trabalhar alguém da luz, meu show é sensível e eu gostaria de ter esse cuidado da luz." Quando você percebe que alguém viu isso, eu faço até de graça, às vezes, porque a pessoa viu que a luz faz parte da obra. Eu acho que essa pesquisa é fundamental e que precisamos fomentar essas pesquisas. Eu tenho esse texto da Cibele Forjaz, e adoraria conhecer ela, e carrego isso daqui para todo lugar por que 0 nosso mundo é muito machista e o homem é muito burro e ele leva essa burrice para todo lugar. Daí, quando você olha para uma mulher que estuda você olha e diz: "Luz é isso! Não é um 'negócio que acende', é um pensamento, sensação". Essas pesquisas precisam estar no FaceBook, no Instagram. As pessoas precisam ler isso e entender isso. Inclusive essas perguntas, todo mundo devia estar recebendo essas perguntas, ou lendo as respostas de outras pessoas. Eu acho a pesquisa inteligente.

\section{G.V. - Tem algum outro trabalho, além de $A$ casa, no qual você veja} esse conceito de luz ativa?

L.A. - Todos os meus trabalhos! Eu tenho uma formatura para iluminar na segunda-feira, eu coloco a minha assinatura. Hoje eu chamo assim e acho até um pouco arrogante, mas precisamos nos valorizar um pouco. Tem um trabalho específico que eu fui premiado, com o grupo Obragem, que construímos na estrada. Se chama As Tramóias de José na Cidade Labiríntica. Estávamos a cinco meses na estrada com um outro espetáculo, em temporada. Ele foi inteiro construído na estrada, inclusive o material gráfico, porque a Elenize (Dezgeniski), que é fotógrafa, estava viajando conosco como atriz. Eu amo falar desse processo, esse trabalho foi feito em uma casa pequena, não é onde hoje é a sede do Obragem, mas foi o primeiro espaço do Obragem. Era uma sala de dois metros e meio de altura e quatro metros de largura, com uma plateia de quarenta lugares. Eu estou te explicando tudo isso para você entender como foi. Então, a plateia ficava a dois metros e meio do Eduardo Giacomini, que fazia o monólogo sob a direção da Olga (Nenevê), que fez a dramaturgia também e com trilha da Edith (de Camargo). Ele ficava em cima de uma plataforma quadrada de $2 \times 2$, que tinha uns quarenta centímetros de altura com um eixo no meio e 
molas esticadas, que faziam com que a plataforma andasse para todos os lados. Ela estava no lugar, mas ela se mexia para cima e para baixo quando ele andava. O interessante desse cenário, é que ele foi feito baseado na obra de um alemão que trabalhava com essa pira de sensações na arquitetura. Era um cenário de ferro e uma hora de texto, texto, texto e ele ali, parado. Eu pensei "o que eu vou fazer?" Então eu fiz tudo com luz de jardim, PAR 38 e PAR 36, que chamamos de pin-beam, e uma mesa analógica de doze canais, porque não tínhamos grana. E tem um efeito específico, tem vários, projeção..., mas tem um que era muito foda. Eu estudei muito para fazer, mas foi meio no grito. $O$ ator estava no meio dessa estrutura, falando o texto, e o texto falava de pessoas que somem. Por exemplo, pessoas que moram na rua e que se misturam com o lixo, chega uma hora que elas somem e você não vê mais elas. Elas somem. Estão ali, mas ninguém mais vê, porque a sociedade começa a ignorar o que é feio, não é? Ele falava isso, "as pessoas somem" e eu sentia necessidade de colocar uma coisa óbvia, eu odeio trabalhar com o óbvio, mas coloquei o óbvio. Então ele ia falando e ia sumindo, por que eu coloquei uma luz, um contra reto que passava em cima da cabeça dele, mas não batia nele, num azul anil, 274 da Rosco, porque é uma cor plástica e com fumaça ela fica forte e robusta, então realmente ele some. $E$ tinha uma PAR 36 em cima, no rosto dele e enquanto ele ia andando bem devagar para trás, uma trilha ia entrando e ele ia falando e não dava para ver que ele estava andando por que eu ia tirando esse pin-beam e colocando esse contra e ele sumia. Ele sumia, a um metro e meio das pessoas, e todo mundo ficava chocado. Fizemos umas duzentas apresentações no Brasil e todo mundo vinha falar comigo, não entendendo esse efeito. E tem outra peça, que se chama Air Bag, que eu fiquei muito orgulhoso e que dá para entender o quanto a luz é importante. Ela foi feita num galpão retangular aberto que só tinha duas paredes e gente morando lá, merda no chão... A luz não entrou em mim na leitura do texto, mas entrou em mim quando eu cheguei no lugar, na visita técnica, já. A hora que eu cheguei e olhei a Guenia (Lemos), que é a cenógrafa e estava apresentando o espaço, eu falei que se estávamos saindo de um palco italiano, não tinha porque fazermos a peça de frente para a plateia, então sugeri fazer em diagonal e me fodi, porque não tinha eletricidade no lugar. Eu comprei um poste, 
metragem de cabo, bitola, calcular a altura. Tive que chamar um cara que entendia de arquitetura para descobrir se as tesouras de aço iriam aguentar, porque tinham partes enferrujadas, então eu tive que criar barras, descer canos de seis metros e todos angulados... Geral, centro, contra. E nesse trabalho, eu usei três linguagens: luz arquitetural, porque todas as paredes ascenderam de cinco em cinco metros com aquelas tartaruguinhas, para criar uma linha reta. Foi feito grafite e o cenário era um monte de carro velho, amassado e eu falei, tem muita poluição, porque, além disso, tinha a iluminação de teatro. Então tinha a arquitetural, depois a de teatro, uma coisa bem clean, limpa. Eu desci luminárias retas para criar simetria no espaço. E levei Moving e Par LED, que ninguém leva para o teatro, é difícil. Então todo mundo ficou de cara comigo, porque era esse ambiente aberto com um monte de equipamento, e máquina de fumaça no chão, era uma loucura. E com esses dois trabalhos, eu ganhei prêmios.

\section{G.V. - Que legal! Muito obrigada pelas respostas e pela atenção!}


3.16 Marisa Bentivegna - Iluminadora e Cenógrafa Paulista244

1. Como conceito, você considera que a luz seja material ou imaterial? Você saberia explicar a sua resposta?

M.B. - Estamos falando de teatro, não é? Porque eu acho que é a área em que conseguimos ter um pouco mais de clareza nas construções. Eu atuo muito em música, mas o processo é tão diferente que eu teria que responder para cada área e não conseguiria pensar num todo. Então, eu acho que é as duas coisas, eu penso nas duas coisas. Para mim, faz sentido ser as duas coisas... Material no sentido mesmo da concretude. Você está me perguntando de conceito, não é?

G.V. - Sim, mas acho que você não precisa se prender nas discussões da física. A pergunta é também sobre a sensorialidade.

M.B. - Se eu for pensar num projeto meu, eu acho que tem um lado do resultado do meu trabalho, que quando você me pergunta isso eu fico pensando um pouco em concretude e subjetividade, penso um pouco por aí. Acho que a minha luz, e qualquer luz, tem um lado material, concreto, óbvio, que é daquilo que enxergamos e que deciframos, como a cor... E tem o lado da sensação, daquilo que muitas vezes o público não consegue identificar, mas toca em algum lugar que, talvez, até eu, como criadora, não consiga dimensionar, porque acho que depende muito da referência pessoal de quem assiste. Mas eu acho que nós, como criadores de um universo visual, eu acho que nós atuamos no visível e no decifrável, e também no indecifrável, fazendo um trabalho mais subjetivo. Eu trabalho muito com o concreto, com o material, quando estou projetando as coisas técnicas, que são muito concretas. Tem que lidar com equipamentos, com as especificações de cada espaço, de cada espetáculo, mas, não raro, o resultado de um projeto, para mim, depois que ele já está montado e afinado, e que eu já estou trabalhando nele, por mais que eu planeje tudo, sempre tem algo

${ }^{244}$ Entrevista realizada por Gabriela Valcanaia em São Paulo no dia 27 de janeiro de 2020. 
que acontece e que eu não previa, não esperava e que, às vezes, vai para o positivo e às vezes para o negativo. Então, tem também um dado, você acha que controla tudo e domina tudo, mas tem, no fazer da luz, algo que só se dá quando ela está ali, montada de fato. Não tem 3D que simule. Então, eu acho que tem também um fator surpresa, sempre.

\section{Você costuma trabalhar mais com a mesma companhia e diretor}

\section{ou varia?}

M.B. - Eu trabalho com várias companhias. Eu trabalho, basicamente, de três maneiras: companhias estáveis, nas quais eu sou parte do núcleo criativo e atuo em todos os seus projetos desde a fundação, que são a Cia Hiato, que já tem 10 anos e a Banda Mirim, que fez 15 anos; eu trabalho com alguns diretores que não são de companhia, mas que são parcerias constantes, tipo a Cristiane Paoli Quito, Nelson Baskerville e Marcelo Romagnoli, fora da Banda Mirim também, porque ele é o diretor da Banda. Eu teria uma lista para te falar, mas são diretores que são convidados por grupos ou que têm seus próprios projetos e que sempre me chamam para mantermos essa parceria criativa e tem os diretores que me chamam eventualmente. Tem alguns com quem eu trabalhei uma única vez, alguns que, depois dessa primeira vez, acabam virando parceiros, ou esses trabalhos um pouco mais comerciais, por assim dizer, que a produção chama um grupo de criadores para fazer um projeto, e quando acaba, ninguém mais se vê. Mas eu gosto muito de ter parceiros, de trabalhar em companhias e eu acho fundamental, para o meu desenvolvimento artístico, ter essa referência, de onde você veio, para onde você vai e onde está artisticamente. E esse tipo de entendimento sobre o meu trabalho, eu só consigo dentro de grupos e companhias, porque daí, é uma percepção de um amadurecimento geral, de todo mundo, ou uma mudança de linguagem geral, em todo mundo. Então, para mim, esse é o meu grande alimento, é onde eu me fortaleço para conseguir criar esporadicamente, aqui ou ali, com outras pessoas. Eu acho que eu ficaria muito em dúvida se eu não tivesse essas referências bem sólidas. 


\section{G.V. - O que efetivamente muda quando você está trabalhando com} esses grupos e quando você é chamada para um trabalho esporádico?

M.B. - Acho que a primeira coisa que eu posso te responder é que você não tem medo de errar quando está dentro de um grupo onde todo mundo se conhece. O processo ali é muito mais importante do que o resultado, então, se o resultado não for tão bom, do ponto de vista estético, com certeza o processo foi. Porque, às vezes, o processo é tão profundo que ele vai te conduzindo para coisas que nem sempre serão o espetáculo como objeto final. Então, várias vezes, é o processo que vale a pena. Você chega num resultado, que é o resultado do processo. Quando uma pessoa te chama para fazer um trabalho a um mês da estreia, você conseguindo assistir três ou quatro ensaios, com um dia de montagem e estreia no dia seguinte, você não pode errar. Então, muitas vezes, você nem faz aquilo que você acha que é o ideal, mas você faz aquilo com o que você não vai correr risco. Você não vai experimentar umas coisas que não fez ainda. Eu estou exagerando, para ficar claro esse lugar. Vivemos uma situação bastante cruel aqui, de estreias. Temos muito pouco tempo no palco. É diferente de um figurino, que você consegue, em sala de ensaio, cortar, mexer, subir, descer... Na luz, você só consegue quando vai efetivamente para o teatro, ninguém tem um espaço onde você consegue reproduzir, com todo o equipamento, o que seria o ideal. Eu não me lembro de nenhuma companhia que tenha um teatro como sede, em que você possa ficar ensaiando e no qual você vai estrear, no qual você fique montando a luz ao longo do processo... Isso não existe. Tem essa crueldade de você ter que ser muito assertivo. E eu sou cenógrafa, não só iluminadora, então, o tempo todo, eu estou virando a chave de uma coisa para a outra. Na luz, eu acho mais cruel, de todas as áreas criativas. Então, acho que isso de não ter medo do erro é uma coisa que só é possível no lugar do trabalho em grupo. Outra coisa interessante de trabalhar em grupo é que todas as pessoas conhecem o teu trabalho, então eu posso contar, por exemplo, se eu fizer um cenário (desculpe falar de cenário), mas que vá ser manipulado pelos atores, que não vamos usar contrarregra. É muito difícil, 
para mim, propor isso em um elenco comercial, dizer "vocês vão virar essa parede, girar isso aqui". Num trabalho de grupo isso faz absolutamente parte, sabemos que podemos contar um com o outro e podemos mesmo.

\section{G.V. - Não é um problema você falar sobre a cenografia, mas eu} queria saber qual a tua maior preocupação no momento de criação da luz, a quem você dá mais atenção? O que ou quem você tem em mente?

M.B. - Eu passo por muitos momentos e tenho processos muito diferentes. Tem vezes muito rápidas, em que a solução de um encaminhamento vem rápida, e tenho processos muito truncados e difíceis, de chegar perto do momento de ter que montar e não saber ainda direito o que fazer. Eu assisto muito ensaio, fico muito na sala de ensaio. Atualmente, eu tenho ficado menos tempo do que eu gostaria e precisaria, por questão de tempo, mesmo, mas para mim é fundamental assistir ensaio, entrar em contato com o material pesquisado. Às vezes tem muito disso, não é...? Os atores, dramaturgos e diretores se fecham um pouco nessa parte da pesquisa e chamam os outros criadores mais para a frente, e só então dizem o que pesquisam. Eu sinto que é fundamental que todo mundo caminhe junto... Então, tem esse momento da pesquisa, que para mim é bem importante. E tem processos que são insights, ou com referências estéticas tão claras, dependendo do tema ou do projeto, que fica fácil de resolver... E às vezes, eu só vou conseguir resolver no palco. De chegar, olhar os materiais que tem e experimentar, porque não sei o que fazer e esse estalo não vêm. E não acho que ter um insight ou resolver na última hora faz de um projeto ou outro ser melhor. Claro que eu prefiro chegar ao teatro e ter tudo organizado, sabendo o que vou fazer. Não gosto de montar e remontar de novo, porque você está experimentando usando a mão de obra dos técnicos, então mesmo quando eu não tenho certeza, eu prefiro fazer uma montagem e me virar com aquilo.

\section{G.V. - Como você vê o espectador no teu processo criativo?}

M.B. - Normalmente, eu não o tenho em mente. Eu acho que com a Banda Mirim, sim. Dizemos que fazemos espetáculos infanto-senis, de crianças 
até a terceira idade, mas tem um recorte mais forte na infância e na juventude. Eu acho que quando eu faço teatro para criança, eu levo muito mais em consideração o público do que quando eu faço teatro para adulto. Em vários sentidos, até nisso de, antes de começar o espetáculo, não poder dar um blecaute total na casa, porque a criança pode começar a chorar e vários diretores me pedem isso. E eu digo: "azar da criança, ela precisa se acostumar". Porque a gente vai levando em consideração a criança... E eu adoro quando, por exemplo, você faz um arco-íris e as crianças gritam "UM ARCO-IRIS!". Eles embarcam e acreditam muito mais. E é gostoso fazer uma luz lúdica, saber que vai rolar uma identificação e um entendimento daquilo. Então, talvez, nesse sentido, eu me preocupe mais, ou leve mais em consideração um público mais jovem e que me divirta mais, também, fique mais livre para provocar e para brincar do que com um público adulto, que você não pode jogar uma luz na cara, que ele já se sente ofuscado e tampa o olho, e incomoda, porque o que eles querem é ficar ali, confortáveis nas suas cadeiras.

\section{G.V. - O que é essa ludicidade que você diz ter nas luzes que faz para} espetáculos infantis?

M.B. - Eu gosto muito de trabalhar com cor e tenho muita facilidade com mistura de cores. Eu sempre saí dessa palheta básica de gelatinas, busquei cores diferentes e eu fico completamente livre, nesse sentido, para misturar gelatinas no universo infantil. Um pouco pelas temáticas, ou pela facilidade mesmo. Você não precisa estar dentro de um desenho estético muito definido, eu sinto que tenho muita liberdade em relação às cores. Eu sinto que as crianças recebem muito bem a cor e reagem muito. No último espetáculo que eu fiz com a Banda Mirim, que se chama Buda, eu uso moving-lights e é uma delícia, porque qualquer movimento... Por exemplo, tem uma hora que a atriz diz que quando Buda nasceu, uma luz atravessou a floresta, e ela faz um movimento com o braço, e daí tem um moving que anda junto com ela. Não há sessão em que as crianças não reajam a isso e é uma bobagem, do ponto de vista do desenho de luz, mas acaba sendo tudo mais fantástico mesmo. É uma liberdade que se tem ao criar para criança que nem sempre conseguimos ter no teatro adulto, por que 
temos que estar em uma estética, usar só temperatura de cor, ou ter desenhos mais marcados, luzes mais paradas. Eu acho que o teatro infantil ganhou uma importância, nos últimos quinze anos, ou ele começou a ser mais compreendido. Quando eu comecei a trabalhar com luz, em qualquer teatro que você chegasse para trabalhar, setenta por cento do equipamento do teatro era para o adulto e 0 resto do infantil. O tempo para a montagem também, sempre uma coisa bizarra para o infantil, era chegar e fazer com uma geral. "Tem uma geral azul, uma branca e uma âmbar, se vira aí..." Eu peguei isso, e hoje em dia é muito de igual para igual e, muitas vezes, o infantil tem até mais espaço, porque tem mais público e, às vezes, mais dinheiro envolvido. E eu acho que nos últimos quinze anos, na cidade de São Paulo, que é onde eu trabalho mesmo, a produção de teatro infantil é impressionante e tem espetáculos muito, muito legais. Só falta as pessoas entenderem que, na verdade, fazer bom teatro para crianças é garantir público jovem e público adulto para o teatro. Público jovem ainda é um problema, mas, de uns oito anos para cá, começaram a ter espetáculos mais específicos para o público jovem. É muito difícil ter espetáculos legais para adolescentes. E tem cenógrafos, figurinistas, dramaturgos, diretores e grupos maravilhosos de teatro infantil. Eu acho muito legal para todo mundo, não só para o iluminador. É um lugar de liberdade mesmo. E tem isso de você estar formando o público do futuro, com qualidade. Eu me lembro de, quando jovem, ir assistir alguns espetáculos infantis muito ruins. Eu já era bailarina, na época, então já tinha uma noção de palco, uma noção estética e pensava que era muito ruim. E hoje, ainda, eu tenho memória desses espetáculos e penso "Meu deus do céu...!".

G.V. - No momento de criação, o que você tem mais em mente? São as necessidades do ator/atriz/performer, o que o diretor pede ou as ideias originais do dramaturgo?

M.B. - Eu levo tudo em consideração, não crio isoladamente. Eu acho que tem uma coisa que vem primeiro, que é a ideia da encenação, do que é que estamos falando...

\section{G.V. - Essa ideia é a do diretor ou é a tua primeira impressão?}


M.B. - Normalmente vem do diretor, mas eu tenho um diálogo muito próximo, talvez até por eu ser cenógrafa, com os cenógrafos, figurinistas e até com a área do visagismo. São áreas que precisam andar juntas, não adianta cada um fazer o seu, chegar na hora e ser aquele Frankenstein. Então, eu tenho esse diálogo muito próximo, sempre, mas não tem como eu passar por cima de um direcionamento. Eu sou muito respeitosa com diretores, talvez até, algumas vezes, eu achasse que poderia ter feito diferente e não fiz porque eu estava respeitando o direcionamento geral do projeto. Estou pensando em todas as áreas e acho que o texto é o que menos me influencia. Muitas vezes eu não leio o texto em casa antes, eu prefiro mais escutar o ator falando na sala de ensaio do que ler e criar uma ideia na minha cabeça.

3. A pesquisadora deste trabalho defende, como resultado de suas pesquisas práticas como iluminadora e reflexivas como pesquisadora, que a iluminação cênica tem uma participação ativa na cena teatral, assim como em outras formas das artes cênicas como a música, a dança, entre outras. Com isso ela afirma que a luz atua, age em cena e interage com os demais componentes do espetáculo e também com o público, tendo a importante função de estabelecer e favorecer a relação entre o palco e plateia. Você concorda ou discorda dessa afirmação? Por quê?

M.B. - Eu concordo e acho que se eu não concordasse, eu não seria mais iluminadora, porque eu acho que, quando você cria um trabalho, você quer atingir alguém. Porque se você fica criando só para você mesma, chega uma hora em que você não aguenta mais, então eu concordo. Com você lendo essa definição da Nadia (Luciani), eu me lembrei um pouco da minha relação com a Cristiane Paoli Quito, que é uma diretora com quem eu trabalho há quase vinte anos. Nós nos conhecemos fazendo um show juntas, que ela foi chamada para dirigir. Era da Ceumar e nós estreamos esse show no Itaú Cultural. Esse show é também, um pouco, o meu pontapé inicial para a cenografia, por causa da Quito. Teve um determinado momento em que um refletor de chão saiu da afinação e eu fiquei super angustiada na cabine, porque eu queria usar aquela 
luz, para que ela incidisse sobre a Ceumar e projetasse uma sombra no fundo. E o sentido dessa luz só era aquela sombra e não ia dar certo. A Quito me viu meio estabanada na mesa, perguntou o que estava acontecendo e eu falei "Desafinou o refletor...". Ela me disse: “Ué, vai lá e afina!". E eu "Mas agora? No meio do show...?" E ela me disse: "Se você precisa dessa luz, vai lá e afina, está ali, na beirinha do palco, você não precisa nem subir". Essa coisa super besta fez com que eu quebrasse completamente a minha quarta parede, ali, de técnica. E assim, não existe essa barreira entre o palco e a cabine. Ninguém ali na plateia está achando que está acontecendo mágica, todo mundo sabe que tem alguém por trás. Claro, ela não me falou isso, mas eu entendi tudo isso naquele momento. E deu tudo certo, resolvemos e o show foi ótimo. E agora, quando eu paro para pensar, nem era tão essencial assim, dava para ter resolvido de outra maneira.

A Quito é diretora de uma companhia que se chama Cia Nova Dança e que é uma companhia de dança que trabalha com improvisação em cena. Ela me chamou para fazer o trabalho do Aldeotas, em 2003 ou 2004, com o Gero Camilo e o Marat Descartes. É um texto do Gero no qual ela estava começando a experimentar essa coisa do improviso no teatro, então tinha uma estrutura dramatúrgica que era o texto, mas as cenas podiam acontecer em ordens "aleatórias". Nem tão aleatórias, mas dentro de algo que fizesse sentido para os atores, ou seja, o espetáculo poderia começar pela última cena e não tinha nenhuma marca espacial, então a luz tinha que dançar junto com o que estava acontecendo ali. O mais interessante é que a luz não teria que correr atrás das proposições dos atores, ela poderia propor. Então, por exemplo, tinha uma determinada cena que eles deveriam nadar em um açude e tinha uma determinada luz, que era um código para esse momento. E eu poderia propor essa cena e eles poderiam embarcar ou não, mas normalmente embarcavam, porque nós trabalhávamos com esse princípio da escuta, todos os intérpretes jogando juntos ali.

G.V. - Nessa montagem você era a iluminadora e também operava a luz do espetáculo? 
M.B. - Sim, eu operei grande parte da vida do espetáculo, mas a medida que foram vindo outras temporadas, eu fui passando, mas é isso...

\section{G.V. - Porque é jogo, não é?...}

M.B. - É jogo e aí não tem operador, por melhor que seja, que tenha essa escuta. É um treino e uma coragem. Você precisa ter determinadas características para conseguir estar ali, em tempo real. Até o aquecimento era meio junto, íamos aquecendo os corpos e os refletores e abríamos para o público, o negócio começava e era um sucesso. A partir dessa experiência com a Quito, eu nunca mais consegui operar um espetáculo de teatro com prazer, virou uma coisa muito chata, ainda mais depois das mesas computadorizadas, que você só aperta o go. Foi ficando, para mim, uma coisa muito, muito robotizada. E aí, depois desse espetáculo, eu fui trabalhar no Nova Dança. Daí sim, com os bailarinos absolutamente treinados para o improviso, então, era um jogo super vivo, era um espetáculo que eu saía suando da mesa de luz. Eu não conseguia nem olhar para a mesa, eu ficava o tempo todo de olho no palco e propondo, recebendo, propondo e propondo. E, às vezes, eu é quem dava o final do espetáculo, quando eu percebia que já tinham se esgotado todos os recursos e a história já tinha sido contada. Essa experiência com a Quito, para mim, foi a mais profunda da relação iluminadora/intérpretes e, talvez, também, da minha relação iluminadora/plateia. O público do Nova Dança sabia que os espetáculos eram sempre diferentes e voltavam. E aí começaram a perceber que a luz também era sempre diferente. Foi uma fase em que eu vi que nós estávamos formando um público que ia prestando atenção na luz. Então, eu ouvia de pessoas, que não eram críticos de teatro, mas pessoas amigas ou do público em geral: "Nossa, eu nunca tinha visto isso, nunca imaginei que tinha uma pessoa por trás” ... Eu não entendo como (risos), eu fui sentindo uma alegria de perceber os meus novos amigos percebendo qual a minha importância dentro do meu trabalho, é legal isso. E com a Quito tinha isso mesmo, de o público ver, rever e interagir, dizendo “...ontem foi melhor”, “...hoje não teve aquela cena” e perceber que é realmente diferente a cada dia. Só que ficou muito difícil fazer qualquer coisa depois disso, que fosse roteirizada, fechadinha. Então, hoje em dia, eu 
consigo operar muito show, porque ali tem essa liberdade. Claro que tem um roteiro, mas para a luz é muito livre. E consigo operar os espetáculos das minhas companhias, que daí o vinculo é outro, está além do jogo de cena, mas está ali, mantendo a qualidade, estando junto do grupo... Eu nunca mais consegui operar uma luz que não fosse aberta.

\section{G.V. - Você continua trabalhando com a Quito?}

M.B. - Com a Quito sim, o Nova Dança tirou um ano sabático que já dura quatro anos, mas agora está com algumas ideias para voltar. Mas continuo trabalhando com a Quito, sim, e no ano passado fizemos um espetáculo super legal, que é o Skellig, um espetáculo para crianças, dentro dessa linha de improviso, em que todo mundo faz todos os personagens e tem um jogo bem aberto, porque a Quito também acabou ficando um pouco desse jeito. Não dá para ficar sem jogo cênico, não dá mais para fazer teatro tradicional na forma. Então, por exemplo, eu dei, várias vezes, na SP (Escola de Teatro do Governo de São Paulo), exercícios de improvisação na luz, porque é um traquejo que os iluminadores e os operadores precisam ter, não só da coisa de resolver tecnicamente com rapidez, mas de pensar e respirar junto com quem está no palco. Não dá para você ficar jogando no celular porque a próxima cena é em cinco minutos e você só vai dar um go, você precisa estar respirando junto porque senão, não tem porque você estar lá. Agora eu sinto dessa maneira e escolher um operador para operar as minhas luzes também se tornou uma questão importante. Que tipo de envolvimento essa pessoa vai ter, e um pouco pelo temperamento do espetáculo também.

\section{G.V. - Posso te pedir mais exemplos de trabalhos nos quais a tua luz} agiu na construção dramatúrgica do espetáculo?

M.B. - Tem um espetáculo que eu gosto muito e acho muito forte, mas não sei se tem vídeo dele. É um monólogo da Roberta Estrela D'Alva que se chama Vai te Catar e que conta umas coisas da vida dela. É um Spokenword, uma técnica americana onde o texto é dado de uma maneira na qual a palavra tem uma força poética, quase musical. Então, tem esse jogo, não só do que está 
sendo dito, mas do como está sendo dito. E a luz desse espetáculo... Eu fui ver uma leitura do texto e o desenho veio inteiro para mim. E era muito movimento! $\mathrm{O}$ espetáculo de uma hora tinha uns trezentos e cinquenta movimentos. Ele era muito pautado na palavra e na imagem da palavra. E eu tive a sorte de ter uma operadora que entendeu tudo e que operava super bem, porque se não operasse super bem, ficaria uma porcaria. Esse espetáculo era um reloginho do texto, trilha e luz. Mesmo o público mais leigo e distraído não tinha como negar a luz. Era muito impactante e foi muito importante para mim.

\section{G.V. - Você se importaria de me contar um pouco da tua relação com} a cenografia e a espacialidade?

M.B. - Eu comecei a fazer cenário por acaso, quando eu vi, eu era cenógrafa. Nunca tive essa pretensão. Eu identifico que comecei a fazer cenário nesse projeto da Ceumar em que eu fiz umas luminárias, que eram uns buquês de flores pendurados e que, para mim, tinham a ver com o projeto de luz, mas, de repente, a Quito virou para mim e disse: "Você fez um cenário!". Eu neguei e disse: "Não, isso são só luminárias." O que aconteceu, então, é que quando eu fui fazer Aldeotas com a Quito, a peça se passava no interior no Ceará e se falava muito do céu e da terra. E eu estava pensando em resolver essas imagens pelo ponto de vista da iluminação. Estreamos no SESC Belenzinho, numa época em que ele não era o que é hoje, uma unidade padrão. Mas quando o SESC comprou (o lugar), era uma grande fábrica, com vários galpões onde aconteciam as atividades. Quando fomos fazer a visita técnica, a uns quinze dias da estreia, chegamos onde seria apresentado e era uma sala adaptada num pedaço do galpão. Então tinha um teto de fábrica, que era inclinado e reto, formando um monte de triângulos no telhado, uma arquibancada super alta, da qual a última fileira ficava praticamente na altura dos refletores, e eu fiquei desesperada, porque tudo o que eu tinha pensado, de iluminar o teto e tentar criar essa espacialidade com a luz, porque não ia ter cenário nem nada, era caixa preta, eu falei para a Quito que não ia rolar, com toda a interferência do telhado e que era impossível acreditar que aquilo era um céu estrelado, por mais que eu tentasse resolver isso com luz. Aí eu pensei que se conseguíssemos neutralizar 
e fazer um piso e teto brancos, isso rebateria uma coisa na outra... Mas o pé direito era baixo e teria que iluminar de baixo para cima e de cima para baixo. Fui olhando o espaço, meio desesperada e meio pensando em soluções. Saí de lá e disse que tudo o que eu tinha planejado não daria certo, a não ser que eu fizesse tal coisa. Ela me disse: "Faça!". E assim foi meu pontapé inicial e na hora de assinar o programa, ela disse que iria me colocar como cenário e iluminação. Eu neguei, disse que "Não, não sou cenógrafa." e ela me disse: "Mas existe uma construção aqui e as pessoas vão querer saber quem fez." Então eu pedi para colocar que eu assinava o espaço cênico, porque era mais abstrato e menos legível. Discutimos um pouco mais os materiais, ela me pediu coisas mais orgânicas, disse que não queria tela plastificada... e essa discussão era uma novidade para mim. E funcionou muito. Eram dois grandes rebatedores horizontais e deu super certo. A Quito é que foi me dando essa liberdade para criar.

A partir daí, eu comecei a fazer e assinar cenário, mas eu percebi que a questão do espaço nunca foi desvinculada, porque o espaço sempre foi muito importante para mim. Você, quando vai fazer um projeto de luz, mesmo numa caixa preta, não dá para não saber se é fundo de veludo, um piso de linóleo, se é uma perna esticada ou franzida. Tudo isso para mim é importante e saber do espaço é uma coisa absolutamente natural. O que eu observo, de uns anos para cá, é que a dupla cenário e figurino era assinada pela mesma pessoa de maneira muito comum, e hoje em dia, para mim, faz muito mais sentido ser uma cenógrafa-iluminadora, do que fazer cenário e figurino. Eu acho que a luz também ganhou um pouco mais de espaço e respeito. A luz sempre foi meio coadjuvante, durante muito tempo vivemos isso de a luz ser apenas para enxergar o que estava acontecendo no palco. Uma boa geral branca, no máximo um foco aqui ou ali. Não faz tanto tempo que a luz teve essa liberdade de contar a história junto. Para mim, agora, é muito difícil ir fazer só a luz de um espetáculo e não dar palpite. Mas eu tento ser sempre muito ética e tenho várias discussões, buscando solucionar o projeto como um todo e menos como palpites, mas é inevitável. Para mim, o espaço é superimportante e, em noventa por cento dos casos, a criação do espaço vem antes do que a criação da luz. 
G.V. - Com espaço, você quer dizer atmosfera, ou espaço concreto?

M.B. - Concreto. Falo de desenho de cenário, escolha de materiais. Mas eu não tenho formação de arquiteta, estou fazendo e aprendendo, e não sou nada sem bons parceiros. Eu não sou nada sem uma boa cenotécnica para solucionar.

G.V. - Muito obrigada pelas respostas e pela atenção! 
3.17 Nadja Naira - lluminadora Curitibana ${ }^{245}$

\section{Como conceito, você considera que a luz seja material ou imaterial? Você saberia explicar a sua resposta?}

N.N. - Eu considero material e imaterial, e eu consigo, sim, explicar a minha resposta. Vamos pensar assim, como é que ela acontece como fenômeno físico? Ela me permite ver coisas, como primeira questão da luz. Então, o que ela faz na cena, é uma questão de visibilidade: vou entender o que eu vou ver e eu vou ver o espaço. Então, eu acho que a primeira questão da materialidade da luz está com a definição da espacialidade. Da relação que eu tenho entre o que é cena e o que não é cena. Por exemplo, as distâncias entre um ator e outro, um espaço da cena e outro, entre o palco e o espectador. Então, para mim, a primeira questão da luz é o espaço, não só da visibilidade, mas da sensação do espaço. E aí que entra a questão da imaterialidade, imediatamente. Ela é material porque é construtora de uma coisa física, mas é também construtora de uma sensação, que posso chamar de imaterial. Então, para mim, ela é as duas coisas e eu sempre vou partir desse lugar, do espaço.

\section{Você costuma trabalhar mais com a mesma companhia e diretor} ou varia?

N.N. - Eu sempre trabalhei com muitos diretores, muitas companhias e muitas formas de trabalho na cena. Eu nunca trabalhei só com teatro ou só com dança ou só com música. Eu trabalho com muitas linguagens diferentes, como a performance, e um pouco de luz para fotografia e para filmagem também. Nunca fiz só iluminação ou pensei nela isolada das artes cênicas. Talvez por eu ter começado a trabalhar no teatro como atriz, lá na origem. Eu comecei fazendo curso de teatro, para me formar como atriz e, logo na sequencia, eu conheci a

245 Entrevista realizada por Gabriela Valcanaia em São Paulo no dia 27 de fevereiro de 2020. 
luz e a técnica e me apaixonei pela técnica. Entender tudo o que eu precisava para ser atriz, eu precisava conhecer da técnica, não só da luz, mas do texto, da cenografia, do figurino e mesmo da produção. Eu tive a sorte de, muito rapidamente, ser absorvida pela luz. A Nadia (Luciani) foi a pessoa que me fez essa ponte. Eu entrei na faculdade, a turma do quarto ano estava precisando de elenco e a Marília Gomes Pereira me convidou para participar, como atriz, desse espetáculo de formatura. Eu fui convidada para fazer uma pontinha, uma personagem pequena. Fui e a Nadia estava fazendo o TCC dela em Design e a proposta dela era fazer a luz e o cenário de uma peça de teatro com a Luciane (Hilu). Quando a Nadia chegou, eu pensei "Nossa, essa mulher tem o mesmo nome que eu... que interessante", aí eu fiquei interessada, rolou uma identificação, normal, e aí ela fazia uma coisa que eu não sabia o que era, luz. Quando você começa a fazer teatro, você sabe que precisa do ator, do texto, da cena, dos objetos de cena, mas luz era uma coisa um pouco abstrata para mim. Eu sabia que podíamos por música, construir objetos, adereços... Mas luz, era muito novo e uma tecnologia completamente esquisita. E ela foi extremamente generosa e didática. Levou-me para a cabine e disse: "luz é isso aqui, é todo um sistema que escolhemos o que acende e o que apaga, separamos os espaços, iluminamos um ator, colocamos uma cor, iluminamos o cenário." Ela me deu uma aula, que é a característica principal dessa criatura, e ela fez eu me encantar pela ideia da luz. E aí, imediatamente, eu comecei a fazer. Ela me apresentou o Beto (Bruel) na sequencia e ele tinha acabado de sofrer o acidente do incêndio no SESI, então ele não podia pegar as coisas. Ele só podia falar, então foi um curso muito interessante, porque o meu professor só falava, ele não fazia nada. Ele não afinava um refletor, não escrevia um roteiro, não desenhava uma planta, o Beto só dizia o que fazer. Isso foi bem interessante e rapidamente eu fui absorvida e já estava operando luz, cortando gelatina, desenhando mapa, dirigindo carro e indo buscar comida para os meninos. E foi muito rápido. Acontece que o Beto sempre foi uma pessoa que trabalhou para todo mundo, todo mundo mesmo. Então eu, imediatamente, comecei a trabalhar para todo mundo. E comecei a operar luz para alguém e fazer assistência de direção para outro alguém, substituir atrizes. $\mathrm{O}$ meu primeiro trabalho profissional como atriz 
foi uma substituição na peça $O$ vampiro e a Polaquinha, eu substituí a Guta Stresser. Eu demorei para me reconhecer como criadora, atriz, iluminadora. Aí, o que aconteceu foi que quando eu estava me formando na faculdade como atriz, eu já era profissional de luz, já tinha carteira profissional, DRT de operação. Eu operava muita luz e conclui a faculdade com o desespero dos professores de não me verem nunca na sala, porque de terça a domingo eu estava no teatro. Então eu conheci todo mundo, porque eu me formei em 94, ano no qual Marcelo Marchioro e Edson Bueno estavam no auge das carreiras deles, produzindo e dirigindo muita coisa no Teatro Guaíra. Na época, tínhamos muita produção institucional, com uma grana grande só da instituição e o resto das companhias eram todas meio amadoras, fazendo seus espetáculos meio na raça, com um patrocínio pequeno. Quem tinha patrocínio para montar peças eram a Fundação Cultural de Curitiba, que montava uma ou duas peças grandes por ano, e o Teatro Guaíra, que também montava de uma a duas peças por ano. Então, ao lado do Beto, eu pude conhecer o Oraci Gemba, a Lala Schneider e ele me apresentou para a galera toda do teatro. E imediatamente eu comecei a frequentar a galera da música, porque eu tinha um professor, o Zeca Wachelke, que era da música e que me carregou para um coro cênico, então eu comecei a fazer luz do coro cênico dele. Conheci muita gente da música e comecei a fazer luz para shows de música, de MPB, do Conservatório de Música Popular Brasileira. Quando o CMPB abriu em Curitiba, eu fui a primeira iluminadora da Orquestra de Cordas, dos coros cênicos, eu fiz, com o Roberto Gnattali, todos os eventos. E hoje eu tenho a companhia brasileira de teatro, que eu trabalho há 18 anos, prioritariamente, mas eu trabalho com bastante gente bem diferente, gente do Rio, São Paulo, Belo Horizonte, Manaus, Recife e Porto Alegre, nos últimos 10 anos. Eu não me considero mais iluminadora, não que eu tenha deixado de fazer luz, mas não me considero iluminadora profissional, não é essa a minha carreira. Eu também faço luz, mas eu sou outra coisa, porque eu também sou atriz, sou diretora, sou assistente de direção, sou produtora de teatro, mexo com texto e dramaturgia. A luz ainda é a minha referência, mas não é meu ponto de partida, de como eu penso o teatro. Eu penso o teatro numa relação com o espectador e não com a cena, com a imagem da cena, ou com o 
efeito que a luz vai ter lá. Não é meu material de trabalho. Acho que a minha palavra ainda é a luz, apesar de eu gostar muito das palavras e usar muito as palavras. Eu também uso o meu corpo, as palavras, a luz, a cena. Mas eu não sou uma profissional de luz e não me considero uma iluminadora. Eu parei de estudar, de pesquisar luz e de me dedicar só ao exercício de iluminação. Eu sei que quando eu vou para um projeto hoje, as pessoas me chamam porque eu tenho um negócio diferente dos iluminadores. Eu vou lá perturbar o processo, cutucar, perguntar outras coisas e, por acaso, também fazer a luz. Mas é mais comum que as pessoas me chamem por outros motivos que não a iluminação.

\section{G.V. - Como você entende que essa pluralidade de linguagens e} áreas que você trabalha, e mesmo as pessoas, elas influenciam na maneira como você constrói a luz?

N.N. - Eu tenho um pouco de dificuldade de entender qual o meu perfil, porque eu não entendo muito como eu penso. Como você vai se jogando nas propostas dos outros, propostas estéticas, plásticas, ou nas escolhas, até filosóficas, dos outros. Quando você entra em um processo, normalmente você entra para ajudar alguém a construir algo que ele quer. Eu acho que eu tenho uma escuta boa, que eu consigo escutar bastante as pessoas e o que elas querem e ajudar a executar o que elas querem. Então, eu acho que eu fiquei meio sem personalidade nesse sentido. Eu vejo a minha luz e reconheço que, às vezes, eu puxo um pouco para o meu lado, me defendo um pouco nas minhas técnicas, nos meus procedimentos e escolhas estéticas. Sei que influencio muitos trabalhos pelas minhas opções e que, como eu proponho certos movimentos, eu sei que eu acabo pesando a mão, mas eu acho que essa multiplicidade, ao mesmo tempo em que me dá liberdade, segurança para dizer coisas, ela me deixa, num outro sentido, extremamente exposta à abertura de não saber qual a minha pesquisa ou de não saber o que eu penso mesmo. É meio contraditório e um pouco confuso, mas é um pouco como eu me sinto. Às vezes, eu me sinto extremamente insegura de dar uma ideia, um palpite ou de propor um efeito de luz mesmo... Às vezes, eu fico pensando "podia ser um contra luz agora, mas será?" Umas coisas bem bobas, assim, "podia ser um 
movimento mais rápido", "podia ser um movimento mais lento", "quem sabe se tivesse uma cor...”. Mas, por exemplo, eu posso falar de um período em que a minha luz perdeu a cor. Isso é bem interessante e tem a ver com o Marcio Abreu, com crueza, com mostrar o que esta acontecendo na real, sem deixar de ser mágico, misterioso, mas, ao mesmo tempo, buscávamos uma forma de fazer teatro e de construir a cena que não fosse excessivamente romântica ou psicologizada, falsa ou antiga. Buscávamos uma contemporaneidade nos assuntos, na forma de se relacionar com o espaço e com a plateia. Tinha muito a ver com "quem são essas pessoas?" e com o como colocamos o público e o ator, "que espaço é esse?". O que foi acontecendo com a minha luz é que ela foi perdendo um ângulo dramático e foi perdendo a cor. Eu fui percebendo que a minha luz deixou de ser desenho e começou a ser volume. E tem uma questão no uso da cor, eu comecei a usar luz nos objetos e cor nos objetos, e não cor nos refletores. Então eu não usava um filtro colorido, mas eu interferia muito na cenografia e no figurino, porque eu comecei a entender que a cor não estava na luz. Eu só podia mexer um pouco na temperatura da cor: se era frio e, portanto, mais seco, ou se era mais quente e doce, suave. A luz foi ficando sem cor, soft e volumosa, enquanto a cenografia tinha volume, muita cor e era recortada.

\section{G.V. - Você tem algum espetáculo que possa ilustrar esse período?}

N.N. - Muitos! Um deles é o Esta Criança, que talvez seja a luz que resume essa fase em que eu não trabalho mais com espaços isolados, com foco, efeito nenhum, apesar de a cenografia ser cheia de efeitos. Paredes se moviam, a luz entrava por frestas, eu deixava e sempre deixo que a cenografia faça a luz, não que a luz faça a cenografia. É a cenografia do (Fernando) Marés que compõe o espaço, a luz entre por ela, como se a luz viesse sempre de outro lugar que não aquele que está ali. Isso talvez seja uma característica minha e do Marcio (Abreu) que, claro, é a referência de como eu mexi na forma de pensar conceitualmente a luz. São as demandas dele que me construíram também, esteticamente, que limparam algumas ideias e que, literalmente, esclareceram algumas coisas. É a minha relação com o Marcio (Abreu), porque pensamos a 
direção de um espetáculo... É legal, porque eu estou falando no plural de propósito, porque nós dirigimos tudo junto nos últimos anos.

\section{G.V. - Mesmo quando você estava em cena?}

N.N. - Mesmo quando eu estava em cena. No sentido de entender para onde vai. Eu não tenho domínio sobre técnicas de atuação, de como os atores podem falar ou dizer as coisas. Posso ajudá-los aqui ou ali, mas eu não tenho esses conhecimentos técnicos. Mas o como a coisa se dá e acontece no palco, na cena, é muito a minha pira. Eu gosto das maquetes, dos desenhos de deslocamento... Por exemplo, como você pensa a altura do palco, onde fica a plateia em relação ao palco, se ela está em cima ou embaixo, como é a arquitetura do espaço, porque tudo isso interfere muito no trabalho. O ator está olhando a plateia de cima para baixo ou o contrário? A plateia vê o ator de cima ou no mesmo nível? Na real, essa é a minha grande pira (risos)...

\section{G.V. - E a luz?}

N.N. - A luz vem e ela se faz sozinha! Muitas pessoas me perguntam "O que você pensou para propor essa luz?" e eu digo "Eu não sei! A luz vai acontecer..." Por exemplo, como eu penso um projeto de luz? Não sei se te interessa, mas eu vou dizer, porque é interessante para a tua pergunta. Eu sempre penso assim: eu tenho que construir para mim mesma e para o espaço, uma cartelinha de pincéis. Eu tenho que abrir uma caixinha com opções. Então, o que eu faço, quando vou ao teatro, é montar uma contraluz, lateral, pino, frente... Eu tento iluminar o espaço primeiro e depois eu penso como eu vou compor com esses pincéis. Então, o que eu tenho são pincéis mais fortes, pincéis mais fracos, mais estreitinhos, mais potentes, alguns mais coloridos. Eu penso sempre assim: vou me dar opções e depois fazer as opções trabalharem para mim, porque eu acho que o que constitui a luz é o movimento e não o desenho dela. Vai gerar desenho, claro, mas não é o desenho. Não é o efeito, apesar de gerar efeito. Para mim, o mais importante é o movimento entre um desenho e outro, entre uma situação e outra. Talvez aí esteja a questão: são as situações e as circunstancias que me dão o parâmetro, digamos. O primeiro ato de Porque 
não vivemos? é uma festa... o que tem na luz de uma festa e que festa é essa? Eu preciso iluminar essa festa, mas não pode ser uma festa porque seria uma hora e meia de festa. Às vezes é uma festa e em outras não é. Às vezes a luz mostra que é uma festa, às vezes não. O segundo ato de Porque não vivemos? é um delírio, um sonho, uma coisa que eu vejo aos pedaços, aos poucos, eu escuto partes de conversas, eu vejo partes de corpos. É outra coisa. São linguagens diferentes e situações diferentes e não pode ser uma luz semelhante, porque é de outra natureza, é de outro gênero. Como faz tecnicamente? Eu não sei explicar.

\section{G.V. - Como que você entende essa mudança de natureza da luz? No que está mudado?}

N.N. - Eu não sei, eu me sinto, atualmente, extremamente presa, porque você entra em um teatro e o que você tem? Umas varas que estão a pino, algumas que você pode por na lateral ou no chão, uma ou duas frontais e os refletores, que são basicamente os mesmos. São umas latas pretas, com um foco lá dentro, que pode ser LED ou lâmpada, não faz diferença, mas tem um espelho e uma lente que faz sair a luz para um lado especifico. Alguns refletores andam sozinhos, alguns dá para por cor, alguns que pode por desenhos, alguns com pouca luz, outros com muita luz, mas no fundo é tudo igual. Chato, chatice! Mas ao mesmo tempo são o nosso material de trabalho, de todos os dias, os nossos pinceizinhos. Claro que hoje em dia é muito mais amplo e nós podemos fazer muito mais coisas, os LEDs estão aí e nós podemos fazer muita coisa com eles, a cenografia está muito mais luminosa do que era e é um reflexo bem interessante dos nossos tempos, em que a visualidade é desesperadora e nós ficamos exaustos de tantas imagens que vemos. Eu acho, inclusive, um desafio ir para o teatro, escurecer a sala e colocar um foquinho de luz na mão de um ator. Eu acho uma doideira nos propormos a uma coisa dessas. Somos bastante limitado e estamos bem presinhos. Eu estou falando nós, todos os iluminadores e as pessoas que trabalham no palco. Tentamos sair do formato e o formato tem muito a ver com a arquitetura, a limitação tem muito a ver com essa plateia que está estabelecida na frente de um palco que é frontal. Eu não vou ficar negando 
isso a vida toda também e ficar trabalhando em galpões alternativos. Ou vou para a rua porque o teatro não me satisfaz. Se o teatro não me satisfaz, eu vou fazer com ele algo que me satisfaça. Eu desmonto a lógica dele, fico brigando com ele. Vejo eu e Marcio (Abreu), e ele muito, muito, muito nesse sentido, porque vamos ao teatro e ele fica doente, porque ele quer desfazer a lógica (do teatro), quer tirar o público da passividade, quer estimular o público a agir e reagir, pensar porque que as pessoas estão sentadas ali, porque elas estão há tanto tempo ali e que elas precisam se deslocar de um espaço para o outro, que elas são plateia e que devem reagir como plateia, que elas não são passivas e que não precisam aceitar essa forma. Claro, isso é objeto de criação, também, e nesse sentido a luz é potente pra caralho! Porque ela pode abrir esse espaço, fechar esse espaço, borrar esse espaço. Somos nós, luz, que conseguimos separar palco e plateia, somos nós que conseguimos juntar palco e plateia. A cenografia também consegue, se você traz um tapete vermelho que começa na plateia e avança no palco, você borra uma fronteira. Acho que essa ideia de abrir, borrar fronteira, perder a limitação, não criar muros... é o que fazemos na companhia. Lugar de criação máxima, é claro. É muito bom ter uma parceria de tantos anos, eu posso fazer e continuar desenvolvendo isso. Só eu e Márcio (Abreu) talvez saibamos o que é isso, ou alguém que acompanha o nosso trabalho há muito tempo. Porque quando alguém vê um trabalho muito pontual, consegue entender uma coisa de uma peça, uma questão estética de linguagem de uma peça ou de outra, mas é importante olhar para todas as peças ao mesmo tempo e tentar entender o que tem de característico, de semelhante na linguagem de todas elas. Você sempre vai encontrar essa questão do espaço, da relação com a plateia, quem é a plateia e o que ela esta fazendo aqui, qual o papel dela nessa peça, se ela é juíza, ou cúmplice, minha amiga no meio da ação ou não. Mas essa é a nossa pergunta principal: que fronteira é essa que nós temos que vencer?

\section{G.V. - Vocês inventam fronteiras ou trabalham com as que}

\section{aparecem?}


N.N. - Tentamos desfazer as fronteiras. Reconhecê-las e desfazê-las. Não gostamos das fronteiras. Às vezes, precisa determinar para poder desfazer. Eu me sinto sempre borrando, sempre desfocando refletor, sempre usando o refletor ao contrário do que ele foi feito para usar, usar o refletor errado... Isso é bem divertido (risos). E eu carrego isso para os outros trabalhos que eu faço, eu me vejo fazendo isso em shows, em outras peças de teatro, quando eu estou fazendo a luz. Pergunto para os diretores "E aí, onde o teu público vai sentar, como ele senta, como levanta, como vai embora?" Às vezes, é preciso fazer o convencional e está tudo bem, as pessoas entendem as hierarquias, as lógicas... Mas as fronteiras, nós procuramos desfazê-las. Às vezes construímos, sem perceber, mas pensamos sempre em desfazer as fronteiras entre o palco e a plateia, entre o autor e o ator... Tem muita gente que vê uma fronteira muito grande entre o autor do texto e o ator, procuramos borrar essa margem e dar as palavras para o ator dizer, evitar essas sacralizações dos espaços, das pessoas e essas hierarquias bizarras.

\section{G.V. - Em quem você pensa, ou qual a tua maior preocupação} quando está criando? Você falou um pouco disso, mas eu queria saber como o espectador entra no teu processo de criação de luz. Você pensa nele?

N.N. - É só o espectador que me interessa. Pense o que são o ator, o texto, a cenografia, a iluminação, a marcação, os efeitos, senão uma situação que está sendo criada naquele momento, por todos esses elementos, para que alguém se relacione com aquilo. Quem é esse alguém? Não é o ator, não é o técnico... É também, mas é principalmente aquela pessoa que está ali, que veio até esse lugar para ver, ouvir e estar nesse lugar. Então, o que eu penso quando eu crio é em como a pessoa que veio aqui vai ser afetada por isso, vai perceber isso e vai ver isso. É nela que eu penso, mas não é ceder também. Porque se você só pensa no espectador, você cria tudo para o deleite do espectador? Não! Você cria tudo porque o espectador vai entender? Não! Você cria tudo porque a demanda do espectador vai...? Não! Porque pode virar uma facilitação. Você faz tudo para agradar, para que seja bonito para o espectador, para que seja fácil 
ou didático? Não, não e não! Essas respostas são todas não. Não é para ele, é com ele. Talvez seja essa a questão, são essas as palavras: "Como eu consigo criar um espaço com ele, para que ele se sinta lá, vivo ativo, pertencente?" Não é só pertencente num sentido bom, ele pode se sentir incomodado, querer sair, não estar confortável em assistir a uma peça de três horas, a cadeira pode ser desconfortável, a temperatura pode incomodar, as palavras podem ser difíceis e ele precisa correr atrás de outras dramaturgias que não a das palavras, essas coisas... Mas se não for o espectador é o que? Eu, minha vaidade ou o meu desejo de fazer uma cena bonita para guardar numa foto? Tem peças que não são fotografáveis, com efeitos belíssimos que nunca serão registráveis sonora ou visualmente. São impossíveis de serem registrados porque dependem de uma situação de relação. Então, em quem eu penso? No espectador. Talvez não em cem por cento do tempo, mas cento e cinquenta por cento do tempo! Mas eu não sou criadora de luz, entende?

3. Para essa próxima pergunta, eu vou contextualizar a pesquisa da Nadia, tudo bem? Então, ela defende, como resultado de suas pesquisas práticas como iluminadora e reflexivas como pesquisadora, que a iluminação cênica tem uma participação ativa na cena teatral, assim como em outras formas das artes cênicas como a música, a dança, entre outras. Com isso ela afirma que a luz atua, age em cena e interage com os demais componentes do espetáculo e também com o público, tendo a importante função de estabelecer e favorecer a relação entre o palco e plateia. Você concorda ou discorda dessa afirmação? Por quê? Você saberia dar alguns exemplos dessa atuação da luz no seu próprio trabalho? Pode ser um projeto inteiro ou um, ou mais, efeitos específicos.

N.N. - Concordo absolutamente, acho que é exatamente do que se trata a luz. Não tenho nenhuma ressalva com relação a isso. Se eu tiver que dar exemplos mais práticos de como a luz efetivamente aparece nos meus trabalhos, posso começar falando não da luz, mas do blecaute. Ele é bem importante. Além do período em que a minha luz perdeu cor e foco, que é o período do Esta 
Criança, ao mesmo tempo e paralelo, fui percebendo, junto com o Marcio, e é sempre com o Marcio que essas coisas vão aparecendo, fui percebendo que a luz tinha uma função dramatúrgica dentro do espetáculo. Ela tem o mesmo peso e a mesma medida que uma palavra, que o corpo de um ator. Às vezes, ela é até mais potente, porque ela carrega a informação do que vai ser visto. Então eu vou direcionar o olho do espectador. Ele vai ver uma coisa e não vai ver outra, esse não ver é tão importante quanto o que é visto, ou mais, talvez. Eu vou pegar uma peça específica que se chama Vida, com direção do Marcio (Abreu) e cenografia do (Fernando) Marés, na qual temos uma situação que é: os personagens estão numa sala de ensaio preparando uma apresentação de música. Então eles ensaiam, eles falam da vida, brigam, alguém chega, alguém sai e eles estão confinados em uma situação muito própria dos artistas, que é preparar algo para apresentar para alguém. E chega um determinado momento em que essa apresentação acontece. O palco vira a cena da apresentação, a cenografia muda, os atores pegam seus instrumentos, trocam de roupa, fechase uma cortina, abre-se uma cortina. A luz deixa de ser uma luz ambiente e passa a ser uma luz teatral, ganha cor, fumaça, canhão de luz seguidor, contra luz azul, globo de espelhos que gira. Tem luz na plateia, que se percebe como plateia, bate palma e reage como plateia. Eu estabeleço, então, um espaço diferente do que eu tinha com a luz, eu consigo compor um outro espaço. Quando eles começam a tocar, cai a energia geral do teatro. Cai toda a luz e o som, e esse é o assunto da nossa situação, que dura dez minutos. Durante dez minutos, a plateia e o palco ficam no breu falando sobre o breu, sobre a impossibilidade de fazer algumas coisas sem energia. Por exemplo, um dos atores pergunta "Você me ouve? No escuro você me ouve?". É simples assim, mas extremamente imagético. Não tem nenhuma luz, mas é, pelos relatos dos espectadores, o momento mais cheio de imagens do espetáculo. Porque eles conseguem imaginar tudo, eles têm um histórico de imagens na cabeça deles, de como a gente estava vestido, por onde a gente se desloca pelas nossas vozes... Eles sabem quem está falando apesar de não nos verem. Eu por exemplo, atuo nesse espetáculo e me desloco muito no espaço, entro, saio, vou para a plateia, volto, desloco objetos. Eles sabem onde eu estou, sabem que é 
a Giovana (Soar), sabem que é o Ranieri (Gonzalez), que é o Rodrigo (Ferrarini). E como eles sabem disso? Porque a gente construiu todo um histórico juntos durante quarenta ou cinquenta minutos e por eles terem material para trabalhar. Então, o que não é visto, é estimulado, extremamente estimulado na cabeça do espectador. E quando a luz volta, é um choque para todo mundo, ficamos praticamente pelados, tanto a plateia quanto a gente, porque é constrangedor. A gente já está tão confortável nesses dez minutos, a gente já está tão íntimo, já está falando tão baixo, já estamos tão tranquilos, a gente já se acalmou, depois de ficar histéricos, está super bem, contando coisas bonitas... E, de repente, a luz volta, do nada. Isso é uma situação real. É claro que o público sabe que aquilo é falso, que aquilo é teatro, mas não importa. É onde se dá o máximo do teatro, onde ele se revela extremamente teatral. É real, porque a circunstância é real, ela está acontecendo e estamos todos ativos nessa situação. Ok, esse é o grande exemplo do blecaute, onde a luz fez grande parte do trabalho. É a luz, a ausência de luz. Vou continuar no blecaute, porque tem outro trabalho nosso que se chama Krum e é a história de um cara que, muito jovem, vai morar longe da família, num outro país bem distante. Quando ele volta, não está feliz ou cheio de coisas incríveis que ele fez, ele volta sem nada para contar, arrasado e fracassado. Um anti-herói, um cara que tinha tudo para ter dado certo, mas que volta e não deu nada certo. Ele está paralisado e não consegue fazer nada. A cidadezinha que ele deixou também está paralisada no tempo, nas mesmas relações. E na primeira parte do texto, quando é a parte da apresentação dos personagens, na qual a plateia não sabe muito bem quem são as figuras, e para a qual usamos os blecautes para permitir ao público completar as figuras por si mesmo. Decidimos, então, mostrar pequenos flashes das cenas. O texto continua, ele se repete às vezes, a situação está lá, mas só vemos flashes de alguns gestos dessa relação, em espaços muito exíguos, muito fechados. Os blecautes são irregulares e longos e a luz, quando volta, é sempre praticamente a mesma, a plateia vê dois ou três segundos de um flash de uma situação. Só que isso estimula muito o espectador, porque ele completa tudo o que ele não vê, porque ele sabe que aquela mãe tem um vestido vermelho, que aquele filho tem uma mochila... O espectador vê a mãe de costas e não de frente. Ouve a 
mãe dizer que está esperando pelo filho e não tem cenografia, são só os corpos dos atores. Boa parte da cenografia do Krum é feita pelos corpos dos atores e não pelos objetos, pela cenografia física, que foi concebida pelo (Fernando) Marés. Usamos bastante isso também. E a luz e a não luz, nesse caso do Krum, são fundadoras da relação, elas começam a peça assim, então elas ativam o espectador, de cara, para imaginar as situações, propor os espaços, completar as imagens. Claro, com o que ele tem, mas o evento teatral fica muito mais rico e mais comprometido, o público se compromete. Estimulamos ou proporcionamos uma cumplicidade, uma convivência. É difícil que ele não se alie a essa situação. O cara já veio ao teatro, já saiu da casa dele, leu o release da peça, já está lá e quando ele se vê estimulado a correr atrás da imagem, atrás de tentar entender onde é que está, de pensar "o que eu posso colocar aqui?", quando ele se percebe usando as memórias dele mesmo para completar as imagens, é bem interessante. O Krum é bem legal para esse estudo de blecaute, tem muita quebra de cena, eu uso muito. As pessoas vão dizer "blecaute é para começar uma cena e para terminar" e sim, eu também uso como borda, como porta de entrada e saída, uso para separar uma cena da outra, mas eu uso errado, fora da expectativa das pessoas. Elas pensam, "mas porque agora apagou a luz se não era para apagar a luz? Não acabou a cena, o ator ainda está falando, apagou a luz no meio da cena do ator... erraram! Calma, ainda não era para acender, eu vi o ator pelado saindo de cena, porque eu vi o ator pelado? Errei!" Esse momento que parece que há um erro e que parece que eu estou distraindo o espectador. Na verdade, eu não estou distraindo, eu só não estou dando para ele, didaticamente, a coisa, e isso faz com que ele estranhe, e nesse estranhamento, ele se ativa. Isso também vai ter no Nós, que é um espetáculo do Grupo Galpão, de Belo Horizonte, que eu e o Marcio trabalhamos juntos, assim como no Outros, tinha bastante isso também.

Além do blecaute eu tenho outra característica nos meus desenhos de luz, que é o que eu chamo de "muita luz". Sempre tem um momento em que eu vou acender, como diz o Beto Bruel "até a bilheteria", porque eu vejo necessidade, na curva do espetáculo, sendo ele mais épico ou mais dramático, não importa, eu sempre acho um momento e procuro esse momento, em que eu 
possa desnudar tudo e dizer "Olha, estamos todos aqui e é todo mundo da mesma cor, do mesmo tamanho, respira no mesmo espaço, tem a mesma roupa, os mesmos olhos, os mesmo sentidos, estamos aqui, é hoje, quinta-feira, três da tarde!" Isso, eu faço um pouco de questão de fazer sempre, mas aí é um pouco impositivo meu, mas eu gosto de usar essa situação. Às vezes eu me questiono sobre o blecaute de começo e final, entrada do público com luz ou entrada do público sem luz. É claro que eu me pergunto sobre essas coisas e que às vezes eu as uso, da maneira mais óbvia possível, da cartilha mesmo, uso. Acho que tudo bem, são os códigos que as pessoas entendem. Apaga-se a luz acabou o espetáculo... Às vezes sim, às vezes não. Às vezes ajuda a simplesmente acomodar as pessoas, tranquiliza. Então, se eu apagar a imagem e diminuir o som as pessoas vão entender que acabou ótimo, tudo bem, eu também uso esse recurso e não vou fugir dele só por estilo, para fazer uma modinha.

\section{G.V. - Você consegue me descrever um efeito específico, que não} um projeto inteiro, como em Vida, Krum ou Esta Criança?

N.N. - Consigo, é um pouco sobre cenografia, mas tudo bem. Quando fomos montar o Outros, do Galpão, a ideia mais profunda do trabalho era a impossibilidade de dizer as coisas. Não há mais o que ser dito, as palavras não bastam, as relações estão desgastadas, é um grupo que há muito tempo trabalha junto. Desde o Nós, a gente trabalhava sobre essa questão, então no Outros, a questão da idade, da pessoa mais velha, que já está no fim de alguma coisa... Tinha sempre esse abismo, essa coisa que acaba uma tentativa de continuar e de se manter. Então, eu tinha sempre essa vontade de que a estética do espetáculo... tínhamos esse desejo sempre, com a cenografia, de que fosse tudo mais moderno, mais contemporâneo, que tivesse uma roupa mais nova. Que não fosse uma roupa de brechó ou uma cadeira velha, que fossem coisas modernas, atuais, com tecnologia, um corte de roupa bonita, uma luz contemporânea. Então, não eram só lâmpadas convencionais, que eu usasse LED, que eu usasse cor, bastante movimento. Então tem um palco! Os cenários das peças do Galpão que eu fiz são todos do Marcelo Alvarenga, cenógrafo do 
grupo. A peça Outros começa com um show, tem muito movimento, eu uso strobo, uso cor, faço um show bem movimentado. Mas daí tinha um momento, que era um momento saudosista, eles montam um baile e uma das mulheres ensina as outras pessoas a dançar uma valsa. Aí você fala, "que coisa cheia de mofo, que cena mofada." Como que transformar essa cena mofada numa cena contemporânea? Nós dividimos, mudamos a marcação dela, atrapalhamos a lógica da cena, ao invés de ajudar, fazemos repetições que fiquem interessantes e contem outras histórias através da aula da dança. E fomos mexendo nela dramaturgicamente, repetindo a cena e tem um momento que eles param de ensaiar e vão se apresentar, então, digamos que a mesma lógica que tínhamos no Vida, temos na dança do Outros. Eu queria muito que tivesse um lustre. $O$ que compõe a cena? O que precisamos de cenografia nesse momento da valsa? Íamos mudar o figurino de todo mundo, era um figurino de gala, bonito..., mas tinha uma questão espacial, eu queria e precisava mudar o espaço. Como eu faço isso? O espaço é branco, a cenografia é branca, tem uma parede de fundo, mas não tem nada para as coxias, então não iam entrar objetos. Então eu propus um lustre, porque para mim, um salão de baile tem um lustre. Mas não podia ser um lustre antigo, um lustre de cristal, tinha que ser um lustre mais contemporâneo. Aí nós ficamos, com o cenógrafo (Marcelo Alvarenga), pesquisando e chegamos ao neonflex e construímos a luminária que é uma linha de luz. Tudo bem, uma linha de luz... Só que essa linha de luz dança! E ela dança muito, porque ela se mexe fisicamente, porque nós a mexemos, mas porque eu uso strobo. Então eu crio uma imagem, sobre outra imagem, porque são duas linhas de luz que dançam e a luz dança junto com eles. Eu consigo fazer o espaço dançar com eles, porque eu movimento o teto com as linhas, projeto a sombra deles sobre a parede branca, multiplicando a quantidade de dançantes. Tecnicamente e plasticamente é um efeito, onde a luz consegue ajudar a encenação.

\section{G.V. - Muito obrigada pelas respostas e pela atenção!}


3.18 Pasquale Mari - Iluminador e Diretor de Fotografia Italiano246

1. A respeito da luz e da iluminação cênica, você considera que a luz cênica é material ou imaterial? Você poderia explicar a tua resposta?

P.M. - Acredito que a resposta para a questão de saber se a luz do palco é material ou imaterial deveria ser: nem uma nem a outra, como tentei argumentar em minha comunicação ao colóquio de Lille intitulado Le Voyage de la lumière. A luz é o movimento contínuo da visibilidade de corpos e objetos no espaço que nossos olhos espectadores interceptam. Mas também acredito que, se não considerarmos a luz, entre outras coisas, na construção do fato cênico, se não lhe dermos o status de material, quantificável, manipulável, com um peso físico na composição da imagem, se torna impossível analisar sua dinâmica na criação de nossa experiência como espectador.

2. A respeito do teu processo criativo, você trabalha normalmente com a mesma companhia e os mesmos diretores ou isso varia? Esse fato tem alguma interferência na criação? Qual o aspecto mais importante a ser considerado, na tua opinião, durante a criação da luz: o desejo e as demandas do diretor ou do dramaturgo, as necessidades do ator ou da cena ou ainda o ponto de vista do espectador?

P.M. - Meu processo criativo, convocado pelo gesto do diretor, visa os espectadores, com os quais me identifico antes de qualquer coisa em qualquer contexto em que me encontre operando. Tento programar e estruturar a rede de pontos de vista a que a criação cênica será submetida, na tentativa de formar um olhar crítico e seletivo em mim e nas pessoas ao meu lado no desenrolar dos eventos e implicações emocionais do que vemos.

\footnotetext{
246 Entrevista realizada pela autora por e-mail, enviado no dia 20 de janeiro de 2020 e recebido no dia $1^{\circ}$ de março de 2020 (tradução da autora com revisão de Antônio Palermo, original ao final dos anexos).
} 
3. A pesquisadora deste trabalho sustenta, com base em suas pesquisas práticas como iluminadora e teóricas como professora e pesquisadora, que a iluminação cênica participa ativamente da cena teatral e também em outras formas de artes cênicas como a performance, a música, a dança, entre outras. Neste sentido, ela propõe que a luz performa, que age sobre a cena $\mathrm{e}$ interage com os demais componentes do espetáculo bem como com o público, tendo a importante função de estabelecer e favorizar a relação entre a cena e o espectador. Você concorda com esta opinião? Porque? Você poderia dar um ou mais exemplos dessa performance da luz no teu trabalho criativo? Pode ser com um projeto inteiro ou cenas e efeitos isolados.

P.M. - Quem manipula a luz do espetáculo deve se encarregar do volume geral do edifício ou de toda a área do local onde ocorre o encontro entre atores e público, considerando-se parte de uma comunidade e habitante de um lugar que, até onde temporário, pode ser experimentado pelos presentes como um mundo cuja luz é uma das condições da existência (o som é igualmente). Nesse sentido, a responsabilidade é muito alta e a missão daqueles que lidam com as fontes de iluminação é muito exigente, em vista da criação de relações entre os seres humanos que decidiram se unir para compartilhar uma experiência artística, o que se aplica ao teatro e ao cinema, como para instalações de artes visuais interativas e performáticas em museus. 
3.19 Paulo Cesar Medeiros - Iluminador Carioca ${ }^{247}$

1. Como conceito, você considera que a luz seja material ou imaterial? Você saberia explicar a sua resposta?

P.C.M. - A cada dia que passa, tendo a luz como meu principal elemento de comunicação, percebo sua materialidade absoluta, sua forma, sua falta de forma, seu constante estado de mutação por ser um elemento de percepção sensorial. A ideia de que há uma luz pré-existente em cada corpo, em cada cena, em cada relação humana, me atrai demais. Parto sempre da ideia de que nossa tarefa mais nobre é a de dar materialidade a uma luz que já existe. Como cada um de nós sempre verá a mesma cena ou as mesmas situações de maneira distinta e peculiar, nunca haverá a "luz certa" ou a "luz perfeita". Haverá sim, a luz "que vemos". A luz que cada artista percebe ao se relacionar com o objeto ou ser humano a ser iluminado. Esse é um processo único, insubstituível e sagrado. A materialidade da luz se dá no campo semântico, perceptivo e emocional, mas se faz concreta se entendermos que para nós "ela está lá". A luz que nós vemos (e só nós vemos) está ali, esperando para ser vista.

\section{Você costuma trabalhar mais com a mesma companhia e o mesmo} diretor ou varia? $\mathrm{O}$ que você pensa a respeito disso?

P.C.M. - Trabalhei com muitas companhias de teatro e com todo tipo de produção. Desenvolvi relações de amizade e trabalho com diretores de estilos muito diferentes entre si. Aprendi a ver através dos seus olhares, através de, junto com eles, descobrir a luz de cada cena, de cada espetáculo. O trabalho em companhia permite um desenvolvimento mais calmo e cuidadoso na criação, mas temos sempre que estar alertas para que o padrão e a linguagem criativa de cada companhia não se transformem numa prisão criativa. A linguagem de

247 Entrevista realizada por Gabriela Valcanaia por e-mail enviado no dia 17 de fevereiro e recebido no dia 17 de março de 2020. 
cada espetáculo tem de vir de dentro da cena, de cada processo. Não há linguagem mais importante do que a vida sendo vivida naquele instante. Naquela época e com aqueles atores envolvidos naquele exato momento da criação. Por isso, acho que é preciso estar em permanente estado de alerta contra a cristalização de imagens e métodos. O palco é o campo de sonhos no qual vivemos e descobrimos a vida. Podemos reinventar a vida em cada ensaio, mas é preciso estarmos disponíveis e atentos. A luz é feita de tudo que pulsa, que se move, que vive. Para perceber uma luz é preciso estar vivo e em conexão permanente.

G.V. - Você acha importante estabelecer uma relação mais próxima com o dramaturgo e encenador do espetáculo que vai iluminar ou até mesmo com todo o grupo e equipe de criação para criar a luz? Faz diferença trabalhar sempre com a mesma pessoa?

P.C.M. - É essencial a relação permanente com todos da equipe. Todos. O iluminador não é um artista plástico que cria uma obra a ser exibida. Ele é um braço da direção. A luz me parece ser o elemento da cena mais próximo das características dos atores. A luz respira, tem texturas, tem quentes e frios, muda de estado, de intensidade, direciona o olhar, dá valor a esse ou aquele elemento... A luz para mim é um ator. Eu sempre me coloco para a direção como um ator. Experimento coisas, mudo e mudo e mudo de novo. Escuto todos da equipe. Às vezes, o comentário de alguém totalmente leigo tecnicamente te diz mais sobre o que você está fazendo do que o de um outro iluminador. Trabalhar sempre com a mesma pessoa me parece como um casamento de muito tempo. Se os dois não se reinventarem constantemente, fica chato e repetitivo. Esse é o fim da maioria dos casamentos. Sou a favor de parcerias, mas com muita atenção e sempre se desafiando. Sempre.

\section{G.V. - Qual a tua maior preocupação no momento de criação, a quem} você dá mais atenção?

P.C.M. - A tudo. Tudo me influencia, mas, com o tempo me fixei no olhar dos atores. Para onde olham? Por que olham? Como se relacionam? Acho que 
o público tem uma hierarquia do olhar. Começa nos olhos dos atores, depois seus rostos, seus corpos, seu espaço, o cenário e depois os detalhes. Acho que quando reaprendemos a ver com o olhar dos espectadores nosso olhar muda definitivamente. Minha maior preocupação no momento de criação é de estar em conexão com o espetáculo. Isso acontecendo, tudo flui naturalmente.

\section{G.V. - Como o espectador entra no teu processo criativo?}

P.C.M. - Eu entrei no teatro através do olhar de dois espectadores. Meus pais, que não são de teatro, sempre foram público de teatro. Eu ficava em casa esperando a chegada deles e minha mãe me contava sobre as peças através dos programas. Para mim, só há sentido em fazer teatro se for para pensar no público.

3. A pesquisadora deste trabalho defende, como resultado de suas pesquisas práticas como iluminadora e reflexivas como pesquisadora, que a iluminação cênica tem uma participação ativa na cena teatral, assim como em outras formas das artes cênicas como a música, a dança, entre outras. Com isso ela afirma que a luz atua, age em cena e interage com os demais componentes do espetáculo e também com o público, tendo a importante função de estabelecer e favorecer a relação entre o palco e plateia. Você concorda ou discorda dessa afirmação? Por quê? Você saberia dar alguns exemplos dessa atuação da luz no seu próprio trabalho? Pode ser um projeto inteiro ou um, ou mais, efeitos específicos.

P.C.M. - Concordo totalmente. A percepção da luz pelo público muitas vezes se dá de forma muito sutil. Algo bom que eles sentem. Um efeito, uma "mágica". Nosso trabalho é feito da poética dos sonhos. Damos acesso ao invisível. Deixamos as energias à mostra. Uma vez fiz uma luz com uma única lâmpada. Na Solidão dos Campos de Algodão. Ela unia palco e plateia. Só ela. Todos se sentiam um só. Ouvi isso de muita gente que assistiu. 
3.20 Renato Machado - lluminador Carioca ${ }^{248}$

1. Como conceito, sem reflexões técnicas ou científicas, você considera que a luz seja material ou imaterial? Você saberia explicar a sua resposta?

R.M. - Sem reflexões científicas, não é? (risos). Eu acho que, na verdade do ponto de vista científico mesmo, ela pode ser entendida como partícula e como onda eletromagnética e essas são duas maneiras possíveis de compreensão. Eu acho que nessa pergunta, mais do que entender se ela é material ou imaterial, acho que importa para quem trabalha com isso, entender o poder que ela tem como construção narrativa. Acho isso mais importante do que a materialidade dela. Desse ponto de vista, podemos inferir que ela é material, porque ela tem uma interferência poderosa na construção narrativa. $\mathrm{Na}$ verdade, eu costumo dizer nas minhas aulas o seguinte: se pensarmos num veículo de expressão como o teatro, as duas únicas coisas que são capazes de mudar, dentro de uma peça teatral, de maneira quase indefinida, e que podem mudar quantas vezes você quiser, são a luz e o trabalho do ator. E pela luz ter uma interferência tão significativa, eu só consigo pensar nela como sendo material, uma coisa concreta.

\section{Você costuma trabalhar mais com as mesmas companhias e os} mesmos diretores ou varia?

R.M. - Vou te responder isso de duas maneiras diferentes. A primeira é uma coisa que eu também falo em sala de aula. Quando alguém te liga para te convidar para criar a luz de um espetáculo, eu costumo dizer, mas isso não é um verdade concreta e nem sempre nós agimos dessa maneira, mas eu costumo dizer que a primeira pergunta que você faz para essa pessoa que está te ligando

248 Entrevista realizada por Gabriela Valcanaia via Skype no dia 26 de janeiro de 2020. 
é "quanto eu vou ganhar?" Essa é a pergunta número um e indica coisas. A primeira coisa indicada é que você vive disso e que você precisa, através do seu trabalho fazer uma arrecadação financeira que provenha o seu sustento. Diz, por isso, que, dependendo do valor, você não vai fazer, mas tem outros fatores nesse caso, que é conhecer essa pessoa e o trabalho dela, se ela é a sua amiga, se você nunca a viu, se você não gosta dela... Dependendo dos valores acertados, você vai fazer e vai fazer da melhor maneira que você puder fazer. Isso é uma coisa, mas a outra, é que durante a sua vida profissional, você vai criando pares, que são pessoas com quem você tem afinidade, que gostam do seu trabalho, que gostam de trabalhar com você, que você gosta daquelas pessoas. Você desenvolve, na vida e na carreira de teatro e show, amizades com algumas pessoas. Eu tenho uma série delas e com as quais eu trabalho há muitos anos. Tem, por exemplo, algumas companhias de teatro cariocas, como é o caso do Aquela Cia de Teatro, do Marco André e do Pedro Kosovski, e da PeQuod, que é uma companhia de teatro de animação, das quais eu fiz todos os trabalhos e são companhias de 15 anos. Com o grupo Sobrevento, eu trabalho desde 1991. A companhia de teatro Autônomo, do Jefferson Miranda, eu só não fiz um espetáculo. Então é isso... você desenvolve amigos e parceiros artísticos. Eu acho que são duas coisas, uma são os seus pares, com quem você trabalha regularmente e que fazem um networking de contatos para você trabalhar e tem os convites que você aceita porque você precisa ganhar dinheiro (risos). Independente de você gostar da peça ou da pessoa ou não, porque isso não importa.

G.V. - É um trabalho, não é? (risos) Você começou a falar um pouco disso, mas eu queria ouvir mais sobre estabelecer relações mais próxima com o dramaturgo e o encenador do espetáculo que vai iluminar ou até mesmo com todo o grupo e equipe de criação para criar a luz? Nesse sentido, faz diferença trabalhar sempre com a mesma pessoa?

R.M. - As relações... Bom, eu costumo pensar que o iluminador, de forma geral e com raras exceções, pelo menos no processo de trabalho que eu vivencio no cotidiano, tem muito pouco contato com o dramaturgo. O dramaturgo é uma 
pessoa com quem não temos muito contato. A pessoa que escreve o texto não é alguém que a gente tenha muito contato. $O$ teatro, a partir do final do século $\mathrm{XIX}$ e início do século $\mathrm{XX}$, sofreu uma transformação muito grande que alça 0 diretor, o encenador, a ser o principal condutor da narrativa, então o contato com o encenador é absolutamente primordial. Eu digo, nas minhas aulas também, o seguinte: temos que ter na cabeça que trabalhamos para outra pessoa. Eu trabalho para um encenador. Por mais que eu trabalhe com uma ferramenta poderosa, por mais que ela possa ter um nível de prioridade que a coloque acima de outras ferramentas, eu trabalho para um encenador e devo satisfação a ele. A minha função é usar a minha imaginação para criar um projeto que atenda a expectativa e a imaginação dele. $\mathrm{O}$ contato com o diretor é primordial, assim como com os desejos dele. Eu costumo dizer que, se você teve uma ideia incrível, sensacional para resolver um projeto de iluminação, mas o seu diretor não gostar da sua ideia, você vai jogá-la fora. É simples assim. Você vai pegar a sua ideia incrível e vai jogá-la fora porque ele não curtiu a sua ideia. $E$ tem um outro contato, porque existe uma coisa importante que é a estrutura que o teatro tem em torno de uma equipe de criação. Esse contato e essas relações, eu acho que são superimportantes. Eu acho que, durante o processo de criação de uma peça, ter encontros regulares com os principais responsáveis por cada uma das disciplinas envolvidas na criação da peça, é fundamental. E para isso você faz uma reunião na qual está o diretor, o iluminador, o cenógrafo, figurinista, diretor musical, videografista, se for o caso, coreógrafa... Esses encontros, que definem efetivamente a estética que aquele espetáculo vai ter, são fundamentais. Nesses encontros, os atores normalmente não fazem parte e isso tem uma razão. Esses encontros são um espaço que temos para dialogar com o diretor, enquanto o ator tem esse espaço cotidianamente e não precisa desse espaço. Eu não costumo discutir muito a criação com os atores, não é muito comum, apesar de, às vezes, acontecer. Acho que, do ponto de vista das relações, eu posso ouvir mais ou menos isso.

G.V. - Você citou algumas companhias com as quais você trabalha há mais tempo, mas eu queria saber... e essa resposta é bem pessoal! 


\section{Como você sente a diferença de trabalhar nesses grupos e de trabalhar com outros grupos que te convidam para um trabalho esporádico?}

R.M. - Acho que tem uma diferença. Mesmo quando alguém te convida para um trabalho esporádico, que é, a princípio, um convite de alguém que você não conhece, a ideia, quando você vai fazer o trabalho, é que aquela pessoa chamou você pelo resto da vida dela (risos)... É estabelecer com ela uma relação que torne possível ela te chamar para trabalhar com ela pelo resto da vida dela. Eu entendo que tem diretores que não gostam disso, é um fato. Eu trabalhei com uma diretora que gosta de mudar a equipe toda a todo trabalho e a relação dela com o trabalho é essa: gosta de ter pessoas diferentes toda vez. Eu prefiro trabalhar sempre com a mesma pessoa. Como iluminador, eu acredito que criamos um vínculo que facilita muito as coisas. Primeiro, porque se você trabalha repetidamente com a mesma pessoa, você tem um entendimento da estética que aquela pessoa propõe e do tipo de trabalho que ela propõe. Isso é uma coisa e outra, que é a seguinte: você tem um entendimento emocional da relação que você tem com aquela pessoa e esse entendimento é muito importante. Eu vou te dar um exemplo prático: eu trabalho com um diretor, que é absolutamente querido e adorável, um ser humano que chega sempre para ensaiar de muito bom humor e que tem muito prazer em trabalhar e que não tem nenhum problema em delegar funções... Eu trabalho também com um diretor que é muito difícil e com quem eu trabalho há muitos anos, mas ele é um ser humano difícil e eu costumo dizer para ele que a relação dele com o trabalho é como a de uma criança de cinco anos com um brinquedo, e que alguém precisa chegar dizer para ele que o brinquedo dele não voa. $O$ entendimento emocional de você saber lidar com a pessoa faz você saber como chegar e dizer "seu brinquedo não voa e não vai voar". Tem vantagens de trabalhar sempre com a mesma pessoa: você tem um entendimento da estética, do emocional e no trato com a pessoa. E ela também com você, entendendo o que você procura no seu trabalho. Por exemplo, nos trabalhos que eu faço nas companhias, eu dificilmente proponho um projeto que não tenha nenhum tipo de risco envolvido. Eu acho que, sem o risco, não tem graça nenhuma, e isso, normalmente, quem está me contratando e trabalha comigo, sabe. É uma perda de tempo, ela sabe 
e tem noção disso. Sabe que vou propor para ela uma estrutura que não é muito comum, que ela não está acostumada a ver. Vamos tentar encontrar um equilíbrio para puxar a narrativa de um determinado lugar. Eu acho que o trabalho também impõe certas coisas a você. Eu fui convidado e fiz uma comédia dirigida por Bibi Ferreira. Era uma montagem de Tango, Bolero e Tchá Tchá Tchá. Eu entrei nesse trabalho a uma semana da estreia e quando você entra num trabalho nessas condições, você chega, vê um ensaio, faz a luz e acabou. Você faz isso, porque é o que dá para fazer e entende que o trabalho impõe limites. Nesse sentido, o trabalho de companhia é mais legal, porque ele impõe menos limites. Você está no processo há mais tempo, conhece aquelas pessoas. Eu vou estrear uma peça no início deste ano com a PeQuod, uma montagem de Pinóquio, da qual nós já estamos falando desde meados do ano passado. Então, você já está envolvido com aquilo há mais tempo, o que te permite fazer um trabalho mais preciso. Se você vê um ensaio a uma semana da estreia, é isso o que você tem e faz o que você consegue imaginar daquilo ali...

G.V. - Qual a tua maior preocupação no momento de criação? A quem você dá mais atenção? Posso explicar a pergunta apontando a tua relação com o diretor, ator, a concepção, que é algo que você já falou antes. Ou mesmo com as ideias originais do texto ou com o espectador...

R.M. - Eu vou te dizer que não é com nenhum desses (risos). Na verdade, o meu processo de criação é muito intuitivo, então a minha maior preocupação quando eu estou criando a luz do espetáculo, é eu me colocar no lugar da mais absoluta liberdade, de eu poder criar o que eu quiser. Eu dou um exemplo, que eu acho que é um exemplo divertido, que é, se eu estou vendo um ensaio, e acho que para aquela cena eu acho interessante que haja um refletor voando, eu escrevo "refletor voando" e se ele vai ou não voar e como, é um outro problema que eu vou resolver depois. Nesse momento, é legal que você possa imaginar e ponto. Minha maior preocupação é ter a mente aberta num espaço de liberdade, para que eu me permita ir para qualquer lugar. Se eu tivesse que responder dentro dessa lista que você me deu, eu acho que seria a narrativa e como eu posso fazer para ajudar aquela narrativa a chegar em quem está vendo, 
mesmo que ela não tenha texto ou seja abstrata. Como eu posso ajudar a pessoa a ter percepção daquilo de alguma maneira. Tem uma frase do Jorginho de Carvalho que eu adoro. Ele conta que estava trabalhando em uma peça e que nela havia um ator que dava um texto no escuro, e que o ator veio reclamar que estava dando o texto no escuro e o Jorginho disse "você está no escuro porque você deveria estar, se não fosse assim, você não estaria. Está escuro porque é o melhor para cena, para a narrativa, você estar no escuro". Então, dentro desses seus tópicos, é a narrativa, para estruturar a narrativa a fim de que ela chegue em quem está vendo e, por isso, não me importa muito o ator e se ele está no escuro ou não, mas importa como vai chegar e como estamos contando aquilo ali.

\section{G.V. - Para ti, qual a diferença de pensar na narrativa e no espectador?}

R.M. - Quando crio, eu não penso no espectador porque eu me coloco como espectador e tem que chegar em mim. Por isso, para mim, não há nenhuma diferença entre fazer teatro adulto ou teatro infantil. Eu me coloco no lugar do espectador, com a minha idade, aos 52 anos, e me pergunto como aquilo vai chegar em mim, então, não importa se eu sou criança, se eu sou adulto. Eu nunca penso em um espectador médio, mas me coloco como espectador. Eu faço uma coisa, que acho divertida: se eu puder, não converso com o diretor antes de ver um ensaio. Prefiro ver o ensaio primeiro, porque, na verdade, o fato de eu conseguir ver um ensaio primeiro faz com que eu consiga manter uma impressão sobre o trabalho que é a minha impressão daquele objeto e que ainda não está permeada pelas ideias daquele cara. Depois, eu começo um processo que é de troca, justamente por eu ter tido uma impressão pessoal antes. Isso nem sempre é verdade. Eu fiz um trabalho com um diretor iraniano no qual nós fizemos um trabalho de mesa de uma semana, debruçados sobre o texto, e quando eu fui assistir o primeiro ensaio, eu já sabia toda a luz. O processo criativo foi feito dentro de uma sala com o texto na frente, mas não é a maneira como eu gosto, eu realmente prefiro ver o ensaio como meu objeto principal de trabalho. 
3. A pesquisadora deste trabalho defende, como resultado de suas pesquisas práticas como iluminadora e reflexivas como pesquisadora, que a iluminação cênica tem uma participação ativa na cena teatral, assim como em outras formas das artes cênicas como a música, a dança, entre outras. Com isso ela afirma que a luz atua, age em cena e interage com os demais componentes do espetáculo e também com o público, tendo a importante função de estabelecer e favorecer a relação entre o palco e plateia. Você concorda ou discorda dessa afirmação? Por quê? Você saberia dar alguns exemplos dessa atuação da luz no seu próprio trabalho? Pode ser um projeto inteiro ou alguns efeitos específicos.

R.M. - Ela está fazendo o doutorado, não é? Eu pergunto porque acabei de defender o meu.

G.V. - Ela está sim! (Risos) Você ainda está atordoado com a tese? Ou já passou?

R.M. - Passou. Estamos em janeiro e eu defendi em abril do ano passado. Quando eu fiz o meu mestrado, eu propus um paralelo entre o teatro e o cinema. Eu defendi a seguinte ideia: as estruturas de iluminação cênica, se conseguirmos fazer uma transposição e pensar no cinema, a luz é um fundamento básico e alicerce básico, porque a fotografia só imprime a partir da existência de luz. No entanto, o que eu defendo no meu mestrado, é que a iluminação cênica, da obra ao vivo, ela se aproxima muito mais de mecanismos de edição do cinema do que da fotografia cinematográfica, em termos de montagem do cinema. Na verdade, o que o iluminador faz é manipular estruturas de tempo e espaço em cena em prol de uma narrativa. É quase como se pudéssemos imaginar que o iluminador é um editor da cena ao vivo, em tempo real, para quem está vendo. Desse ponto de vista, é óbvio que eu concordo completamente com a afirmação dela (risos)! A luz é um elemento absolutamente atuante. É tão atuante e tão importante, que realmente a mudança que acontece no teatro no século $X X$ se dá pela invenção da luz elétrica. A mudança que o teatro sofreu, e que alça o diretor a ser o principal condutor da narrativa, só é possível porque aconteceu um fato tecnológico que foi a inserção da luz elétrica na cena. O Roubine vai dizer isso, 
o Artaud disse isso, algumas pessoas além de mim disseram isso (risos). A luz permite uma manipulação da cena, por parte do diretor, que não existia, e isso muda completamente a perspectiva do teatro no século XX e é fundamental. Desse ponto de vista, eu concordo com ela, porque ela é um elemento cênico atuante.

Por outro lado, o meu doutorado... eu falei do mestrado e agora vou falar do doutorado (risos). Eu acho que como a luz elétrica foi uma grande revolução tecnológica e que proporcionou novos caminhos para o teatro, o meu doutorado defende que estamos diante de uma nova grande revolução tecnológica, e que ela vai criar novos caminho para o teatro e já está criando. E essa revolução tecnológica é a digitalização dos processos e o computador como ferramenta de trabalho. Isso está gerando uma nova forma de construção da narrativa no teatro. No meu doutorado, por exemplo, eu parto de uma peça que eu fiz e uma que eu vi. A segunda foi de uma companhia britânica chamada Punchdrunk e a peça se chama Sleep no More. É uma peça que se passa em um hotel de cinco andares com mais de cem cômodos coreografados e, quando você sai de lá, você pensa: "como esse cara controla e comanda isso tudo? Como ele controla cem cômodos com o público podendo ir livremente para onde quiser?" Não tinha um roteiro ou um guia para a plateia seguir e isso só era possível por conta da digitalização. Isso tem levado a um novo paradigma da construção teatral e, na verdade, estamos diante de uma coisa muito poderosa, porque a luz não só interfere, de fato, na construção da narrativa, mas, como a Nadia diz, ela é atuante na cena... A associação entre projeção, iluminação, sonoplastia, cenografia e figurino com estrutura de tecnologia e a utilização do computador como ferramenta, estão nos levando para um novo status, uma coisa completamente diferente. Eu acho que estamos caminhando para uma coisa divertida. E a peça que eu fiz tinha uma dimensão diferente: era uma casa com dez cômodos, o público andava por dentro da casa e o meu operador de luz andava por dentro da casa inteira junto com o público e operava tudo de um tablete, a luz e o vídeo. Cenografia e figurino também, mas chega em outro lugar e com uma certa perspectiva diferente, mas luz, som e vídeo são afetados muito 
rapidamente por um avanço tecnológico. Somos afetados muito diretamente e muito rapidamente. Você trabalha com luz? Conhece o protocolo DMX?

\section{G.V. - Sim!}

R.M. - O DMX é o nosso protocolo digital de comunicação e que conduz 512 informações. Cada cabo DMX é capaz de conduzir 512 informações dentro de uma matriz digital. Existem empresas desenvolvendo aparelhos usam um cabo DMX de controle para cada modo dele. O DMX vai ficar obsoleto e vai cair, então vão precisar existir outros protocolos que deem conta, porque ele virou um caminhãozinho para movimentar uma laje de concreto gigante e vão precisar existir outros protocolos que deem conta dessa laje de concreto gigante. Essas inovações entram no mercado e nos afetam muito rapidamente e muito ferozmente. Temos que estar atentos o tempo todo, porque estamos indo para outro lugar. Sobre a tua pergunta, eu concordo sim!

G.V. - Tem uma segunda parte na pergunta que é se você, já que concorda, conseguiria dar alguns exemplos dessa atuação da luz no seu próprio trabalho. Você falou desse exemplo que está na sua tese, mas você consegue pensar em outros exemplos, como um projeto inteiro ou um efeito específico. Ou você acha que todas as tuas luzes se encaixam nesse conceito de performatividade?

R.M. - Eu acho que criar narrativa, ela sempre cria, esse é o jogo. Eu vou te dar um exemplo que, dos trabalhos que eu fiz nos meus 30 anos de profissão, talvez seja o mais radical. Eu tenho um grande amigo que é coreógrafo e um dia ele me fez uma proposta ao contrário: que eu fizesse a luz e ele fizesse o balé depois. E eu falei para você antes que, para mim, o ensaio é o objeto mais importante de trabalho, de onde surge a coisa, então eu me perguntei: como eu vou criar sem ensaio? Como eu vou pensar em um foco num bailarino se ele não está lá? A primeira impressão que eu tive, foi de dizer que seria impossível, mas fui para casa e fiquei com a proposta dele na cabeça. Eu cheguei em um jeito que daria para fazer: propus uma estrutura em que a luz interage com os seus bailarinos através de algum tipo de jogo e seus bailarinos vão ter que jogar esse 
jogo. Eu tinha cinco jogos: Um piso, que eram quatro placas de 60x60 em "L", que quando o bailarino pisava ela acendia e quando saia ela apagava; Em volta do palco inteiro, haviam torres de um metro de altura que, na parte superior, ficava um elipsoidal que estava diametralmente opostos a eles e, quando os acendíamos com a fumaça, criava um linha no palco; E como nós tínhamos esse território iluminado, era um jogo da velha e foi então que eu disse para ele fazer os bailarinos dançarem sem encostar nessas linhas; Tínhamos quatro luminárias, que ficavam cada uma em uma estrutura metálica presa em uma vara americana vertical, com seu facho de luz podendo ser direcionado para cima ou para baixo. Um bailarino era suspenso por uma vara de luz, preso em um cinto de asa delta com um refletor amarrado em si, podendo iluminar o que ele quisesse e, por fim, algumas lanternas de corpo. Ele criou a coreografia a partir desses cinco jogos. Na verdade, nesse trabalho, podemos pensar que a narrativa surgiu de propostas de jogos de luz. Nesse sentido ela é completamente performativa.

\section{G.V. - Como é o nome dessa peça? Quando ela foi montada?}

R.M. - Claro Escuro, de uma companhia que hoje não existe mais, mas se chamava Tanz House. Foi antes dos anos dois mil, não lembro exatamente quando. Esse, talvez, seja o exemplo mais radical, onde fica clara essa interferência.

\section{G.V. - Com certeza fica (risos)! Você tem mais algum exemplo que gostaria de contar? Senão podemos encerrar.}

R.M. - Então, acho que, como eu te disse, ela sempre constrói narrativa e os exemplos são sempre os mais frescos ou mais recentes... Ou esse que é bem marcante. Eu acho que posso te dar mais dois exemplos que são significativos e grandes projetos: O primeiro é da companhia de teatro Autônomo e se chamava Deve haver algum sentido em mim que baste, de 2002, que propunha uma interação que interfere diretamente na percepção do espectador. Ele acontecia num espaço completamente fechado de $6 \mathrm{~m} \times 12 \mathrm{~m}$ e totalmente irregular como forma. As pessoas entravam, ele se fechava e tinha um teto que 
se fechava com um material que se chama pergaminho de abajur, que é um material que se usa para fazer a cúpula do abajur. A ideia da luz dessa peça é que não houvesse nenhuma fonte de luz de dentro do espaço. As luzes viriam de fora e dentro, os atores iriam compartilhar o espaço com sessenta espectadores. A ideia era conseguir transformar esse lugar num espaço completamente cromático, podia virar um espaço azul, vermelho, verde... Tínhamos três núcleos de cena que aconteciam em tempos diferentes na linha do tempo e cada uma dessas cenas era associada a uma dessas épocas. Então você, de repente, estava em um espaço completamente vermelho, ou completamente verde, ou azul. Acreditávamos que essa percepção cromática alterava a maneira como aquele espectador via a cena... a sensorialidade cromática era uma ferramenta muito poderosa, porque ela previa que nós íamos atingir diretamente o sensível do espectador e, a partir disso, mudar a maneira como ele ia apreender o que estava vendo. Um exemplo mais recente é que, no ano passado, eu fiz uma peça que se chama Agosto, um texto teatral que virou um filme August: Osage County. O filme se passa em uma casa em um lugar que se chamava Osage County em Oklahoma (EUA) e a casa é gigantesca. A personagem principal, que no filme era a Meryl Streep e na peça foi feita pela Guida Viana, está recebendo os filhos em casa para uma reunião familiar e o marido se suicida nos primeiros dias. Ela já está, há muito tempo, num processo depressivo e fecha todas as entradas de luz da casa. Ela quer que fique escuro em casa, mesmo durante o dia, mas nessa região, o calor é muito intenso e a luz do sol é muito poderosa. Fizemos essa peça no Teatro da Oi Futuro, cujo palco tem $5 \mathrm{~m} \times 5 \mathrm{~m}$, ou seja, é minúsculo! $\mathrm{E}$ a casa é um personagem da peça. Para ilustrar o que eu estou te dizendo, vou ter citar uma frase do Domingos de Oliveira, que é diretor de teatro e cinema que diz o seguinte: "uma das coisas legais do teatro é que nele pode tudo... então você está no teatro com a cortina fechada e um ator no proscênio se vira para a plateia e diz 'Estamos em Marte'. A partir desse momento, você está em Marte, enquanto no cinema tem que gastar vinte milhões para isso." (risos). É uma relação completamente diferente. Fizemos essa peça com a coisa da casa e tudo mais, onde o cenário eram cadeira e tapetes... E a brincadeira da luz era que a personagem cobre tudo de 
preto, então a casa está o tempo todo no escuro, com pano preto. Então, no fundo do palco, a uns quarenta centímetros do fundo, tinha uma tela preta feita de tela agrícola, que é uma variante nacional para a tela rosco. Atrás dessa tela preta, eu coloquei oito minibruts apontados para o público. A luz ficava o tempo todo numa intensidade muito baixa, como se a tela não estivesse deixando-a entrar ali, e de vez em quando, a gente estourava eles na cara da plateia, e eles não viam nada. Foi a maneira que nós encontramos para mostrar, no teatro, como é uma casa onde a mulher fecha todas as entradas de luz natural e, nesse sentido, é muito legal, porque entramos na história e construímos a narrativa, e isso que é importante, o como mostramos para o público, como performamos e como fazemos ele ver. Mas é isso, eu dou toda força para esse projeto da Nadia, estou a disposição!

\section{G.V. - Muito obrigada pelas respostas e pela atenção!}


3.21 Roberto Gill Camargo - lluminador Paulista 249

1. Como conceito, você considera que a luz seja material ou imaterial? Você saberia explicar a sua resposta?

R.G.C. - É preciso esclarecer o que se quer dizer com material ou imaterial. Claro que temos uma ideia do que é material como algo que tenha uma presença física e imaterial que não tenha uma presença física. Do ponto de vista da percepção, podemos dizer que a luz é um elemento imaterial, embora nós a vejamos, não conseguimos perceber as menores partículas que constituem a radiação. Ela é imaterial, pelo ponto de vista da percepção, por ser intangível, ou seja, que não podemos tocar, pegar. Se podemos chamar isso de imaterialidade, a esse perceptivo visual, vejo uma coisa, mas quando a toco eu não consigo pegá-la com as mãos. Os termos imaterial e intangível me parecem muito próximos e ambos dizem respeito ao ato de perceber a presença da luz seja por via dos olhos ou do toque, ou até mesmo do ponto de vista de outras sensações talvez. Do ponto de vista físico, mesmo eu não sendo físico, nem astrônomo, nem nada..., mas tenho a impressão que ela tem uma condição física sim, por meio de radiações. Isso é uma grande questão para a física moderna, que vai se dividir entre a física corpuscular e a ondulatória. Então seriam ondas ou seriam partículas? É uma questão complicada e eu não sou físico para diferenciar uma coisa da outra, estou apenas diferenciando que são momentos cruciais para a física. E vai haver os que dirão que uma hora ela é corpo e na outra é onda. Eu vejo das duas formas, mas tendo a descrevê-la como onda. Mas voltando para a pergunta inicial eu acho que ela é as duas coisas, que ela é material para os olhos, mas é imaterial quando está nas coisas e você não a dissocia das coisas. Ela se dá a ver nas coisas.

\section{Você costuma trabalhar mais com a mesma companhia e um} mesmo diretor ou varia?

249 Entrevista realizada por Gabriela Valcanaia em São Paulo no dia 15 de janeiro de 2020. 
R.G.C. - Eu sempre trabalhei mais com dança do que com teatro, por conta da minha esposa e filha, que são bailarinas. Na dança, o trabalho é mais livre, mas tenho feito também trabalhos com um grupo, estamos juntos há vinte anos e lá eu posso executar o meu pensamento sobre a luz e a cena. As artes da cena, a dança e o teatro têm uma relação diferente com a luz, comparando com pintura, cinema ou fotografia, que são imagens bidimensionais. As artes cênicas são tridimensionais e por isso a luz precisa ir além do quadro, do foco, além da visão apenas pictórica. As pessoas usam recursos geométricos em um fenômeno que não é geométrico. Eu entendo a luz como um sistema aglutinante, ou seja, que não consigo separar o fluxo da luz em pedacinhos, assim como acontece em relação à água. O teatro ao ar livre, sob luz natural, é exemplo de uso da luz enquanto sistema aglutinante. Nos palcos fechados, eu luto o tempo todo com a selvageria da luz, tentando domar essa selvageria com refletores, recortes, mesas de controle, botões. Esse controle obedece, também, a uma necessidade de seguir as demandas do público, cujo olhar está mais voltado para as experiências de sistemas artificiais de luz no seu cotidiano do que para os efeitos da luz natural. Assim você acaba sujeitando a arte e a expressão do artista a demandas do olhar externo e isso me parece um pouco complicado. Eu passo a desconfiar desse sistema de controlar o olhar. E nesse sentido eu proporia uma forma de ver a iluminação cênica como uma coisa mais... não sujeita ao espetáculo, à cena, porque assim, ela também poderia estar sujeita a outras formas de controle, mas que dialogue, que converse e que troque, democraticamente falando, com as instâncias, os acontecimentos estéticos, que são o processo da criação. A criação do cenário, do ator, do texto e a da luz estão todas dialogando em busca de uma autonomia e de não ser uma arte subjugada a demandas externas. Entendo que as artes cênicas têm três energias vivas: o ator, ou o dançarino que pode mover-se em cena; a luz, que depende da eletricidade, é uma energia viva, e finalmente o som, que também depende de energia elétrica e é uma matéria viva que está ali emanando de um instrumento musical, da voz do cantor. Então são o ator, a luz e o som as energias vivas. O restante não é que não sejam energias vivas, mas estão estagnadas. O cenário, por exemplo, se você deixar uma cadeira lá no palco 
durante um ano e ninguém resolva retirá-la, ela ainda vai estar lá. Penso que é a partir dessas três energias vivas em cena que precisamos repensar as coisas e repensar qual o estatuto da luz dentro da iluminação. Luz é uma coisa e iluminação é outra. Nós estamos falando de iluminação cênica, mas estamos falando de luz também, porque a luz é matéria prima da iluminação, mas a iluminação, a técnica, que é o uso da luz para determinados fins, ela segue uma história, os aparelhos que usamos, os tipos de lâmpada, tudo isso tem uma história e uma evolução técnica. Encher o palco de LED não quer dizer modernidade, você pode estar fazendo uma coisa muito antiga com um monte de coisa nova. Precisamos enxergar que viemos da vela, que inventamos o dimmer... precisamos sempre enxergar que, por trás dessa coisa, existe sempre um princípio teleológico, funcional, pragmático. Até que ponto vamos fazer da arte pragmática, ou seja arte para ser usada? Isso não é o sentido aristotélico, que diz que a arte é para ser fruída, para você curtir, para você viver... então, vem lá de trás, essa luta.

G.V. - O teu trabalho tem se concentrado nos trabalhos que você dirige e ilumina, você tem trabalhado com o mesmo elenco, com o mesmo grupo de trabalho, no geral?

R.G.C. - Sim, eles estão comigo há vinte anos.

\section{G.V. - E como você sente que esse tempo trabalhando junto interfere} no teu trabalho?

R.G.C. - Anda sozinho. É um princípio em que cada um traz uma coisa e já dialogamos, o que tem que ser descartado já vai sendo descartado. É bem esse princípio contemporâneo que muitos grupos têm e adotamos a mesma coisa. A minha linha, usando um termo emprestado da biologia, é um trabalho coevolutivo, ou seja, de codependência entre as partes envolvidas, e que só anda se tiver esse entendimento, essa negociação entre as partes. Você coloca um elemento, aí vem outro e coloca outra coisa e transforma o que veio antes. Isso é um ciclo, um processo possível pela transformabilidade, uma coevolução. $\mathrm{Na}$ verdade, são impactos e trocas, uma coisa vem e causa um impacto e 
promove uma resposta em troca, o que causa um novo impacto, e assim por diante.

\section{G.V. - Ainda sobre o teu processo criativo, qual é a tua maior preocupação no momento da criação, a quem que você dá mais atenção?}

R.G.C. - A primeira preocupação que eu tenho é não direcionar o olhar do espectador através da luz. Não estou preocupado com isso e nem passa pela minha cabeça, sinceramente. Quem pede para mim "Quero um foco aqui” eu digo "Eu não quero. Por que que você quer esse foco? O que que tem aí na sua cabecinha para querer esse foco?" Eu gosto que a gente se dê a ver e que haja uma conversa entre todos os elementos da cena. O que me preocupa é isso, não fazer uma luz que direcione o olhar do público. Eu proponho um direcionamento no começo e deixo esse direcionamento o tempo todo, como se a obra estivesse propondo essa leitura. Você vê a obra da maneira que você quiser. Eu não vou colocar um foco quando entra o ator $\mathrm{x}$ direcionando o olhar do público como se ele fosse um distraído e eu ficasse apontando para onde ele deve olhar. Eu acho isso um mal caminho a seguir, porque você direciona de tal forma que você limita o sentido e a interpretação dele. Quando você cria focos, cria círculos, você transforma a luz (que comparo com a fala) em escrita. A "escrita" é cheia de palavras atomizadas, de linhas isoladas, de pausas pensadas, que propõe uma leitura muito mais unívoca do que a fala. Quando eu faço um foco aqui, eu suprimo a pausa e deixo uma escrita enxuta. O foco silencia a fala, a pausa, o que não é dito, o que não é mostrado. Não tenho horror ao foco, apenas o estou usando como exemplo de luz estagnada. Isso, no teatro contemporâneo é um problema menor, mas em uma peça realista isso é bem problemático. Claro que a escrita da cena, como diz a Cibele Forjaz, é diferente da escrita de linguagem, mas toda linguagem pressupões um signo e um não signo, que é um signo também. Então você vê uma noite, numa avenida como a Paulista, um farol aceso, eu leio esse farol dentro da noite e não desvinculado, aquilo tem um sentido dentro da noite que pode ser um policial, por exemplo. A noite faz parte da existência e a iluminação excluiu a noite. A orientadora da Nadia na França diz isso. 


\section{G.V. - Véronique Perruchon?}

R.G.C. - Sim, o livro dela é sobre isso. Então, eu questiono esses foquinhos e essas coisas aí. Ainda bem que os refletores de foco existem porque fazemos iluminação com eles, mas tem formas de usar esses refletores sem necessariamente trabalhar com focos fechados e luzes muito chapadas, tipo "quero dizer isso com essa luz" ... O que eu tenho gostado de fazer é propor, no início, um tipo de luz, que alguns vão chamar de atmosférica, para aquele ponto ou para aquela coisa que vai acontecer e deixo que aconteça. Eu não quero encenar na luz, nesse sentido eu acredito que a pintura impressionista tem muito mais a oferecer para o estudo da iluminação do que os demais estilos que vieram antes, como o barroco... Porque a iluminação elétrica surge quase no início da fotografia e então os artistas plásticos começaram a produzir o que a fotografia não conseguia mostrar. Depois, surge o expressionismo, com a dramaticidade de países que estavam em guerra e com bombas... Esse contexto não poderia produzir uma obra que não fosse dramática. O que eu questiono é essa dramaticidade estar em um espetáculo brasileiro, em uma dança folclórica, por exemplo, ou no Auto da Compadecida com foco, quando no Nordeste tudo é muito claro, iluminado, não há guerra, campo de concentração. Não tem cabimento usar focos fechados dizendo este é o mal e este outro é o bem. Então me preocupa muito essa autoridade que assumimos ao empregar a luz. A pessoa diz "gostei da sua luz", ou "não gostei da luz", mas você não vai mexer nada? Eu não, não vou porque eu não quero isso. Eu vou ser ousado no que vou dizer, mas todos nós que fazemos luz estamos pesquisando muito, discutindo muito e dando passos muito avançados na estética teatral e da dança. Há outras áreas que não estão nessa mesma evolução. Talvez, o que nos faz estar mais à frente é o avanço da tecnologia, que nos últimos anos deitou e rolou no palco... E o figurino? E o cenário? Quantas pessoas estão efetivamente pensando sobre? Na luz, está cheio de gente e é uma tecnologia que exige que a gente reveja os conceitos, não é?

G.V. - Então, isso significa que os teus projetos de luz não tenham movimento? 
R.G.C. - Não, não necessariamente, mas até pode... Em estudos mais avançados eu tenho feito isso. Quando eu pego um bom teatro, como um Sesc, eu faço um processo minucioso, usando a mão, os dedos. Chega um cara e me pergunta: "como é para gravar?" e eu digo que não vai gravar nada, porque quem vai gravar é o meu espirito na hora em que eu estiver operando a luz. Para esse entendimento de luz que eu estou propondo, a operação de luz é tudo. Eu já fiz muito espetáculo em que o cara diz "teu espetáculo é à noite? Tem peça infantil à tarde e não pode mexer na luz deles", para mim está tudo bem. Eu acendo tudo o que tem e vou tirando, regulando a intensidade... Porque tanto faz estar vindo da direita ou da esquerda, claro que eu não vou atingir aquele objetivo que eu queria e que ele está atingindo na peça infantil que se apresenta antes, mas eu consigo fazer. Teve uma vez, também, que os técnicos não tinham tempo de montagem e eu pedi para todos descerem as varas até onde não batia na cabeça dos atores e fizemos o espetáculo com todas as varas aparentes. Para quê que eu vou perder a tarde inteira, se eu não tenho esse tempo, para colocar uma coisa aqui, outra ali e outra lá. A luz está... está estando, não há a necessidade de eu dizer "esteja aqui ou esteja ali".

3. A pesquisadora deste trabalho defende, como resultado de suas pesquisas práticas como iluminadora e reflexivas como pesquisadora, que a iluminação cênica tem uma participação ativa na cena teatral, assim como em outras formas das artes cênicas como a música, a dança, entre outras. Com isso ela afirma que a luz atua, age em cena e interage com os demais componentes do espetáculo e também com o público, tendo a importante função de estabelecer e favorecer a relação entre o palco e plateia. Você concorda ou discorda dessa afirmação? Por quê? Você saberia dar alguns exemplos dessa atuação da luz no seu próprio trabalho? Pode ser um projeto inteiro ou efeitos específicos. Você fez isso várias vezes na conversa, mas eu queria saber se tem mais algum exemplo.

R.G.C. - Eu concordo, claro, ela tem razão. A luz age, atua, interage com a cena e com o espectador. O espectador é um ser que está vivenciando aquela 
experiência e esse vivenciar depende das coisas que ele está vendo... Inclusive da luz. Aquele acordo que foi feito para um trabalho é um acordo inteiro e o espectador participa desse acordo, da orquestração de todos os elementos da cena e dos sentidos que expressam. São várias linguagens que estão trazendo uma ideia. Para mim, essa ideia é um sentido, no caso do teatro... no caso da dança é praticamente a mesma coisa, mas está estritamente ligado ao corpo. Dificilmente tem cenário ou, quando tem, não é um cenário que fique travando a movimentação do bailarino no palco. A dança resume um pouco o número de componentes visuais, mas ao mesmo tempo amplia o espaço cênico e as possibilidades desse corpo se expressar em todas as dimensões. Eu acho que a luz tem essa função de atuar, penetrar e entrar no elemento material da cena e dialogar com essa materialidade. Eu dou muita importância para essa relação física que existe entre a luz e a matéria. Aliás, isso é mais um capítulo da física: luz e matéria. A relação que existe entre a luz e as coisas, que você vê num descampado, mais luz aqui, menos ali, mais azul aqui, menos ali, mais verde, marrom, aqui entra luz solar, aqui é pedra... Todo tipo de materialidade que existe na natureza dialoga com esse trabalho e a melhor lição que temos é a luz solar. Essa característica eu levo para cena. Quando uma atriz chega para mim e diz que acha melhor um vermelho e eu digo não, é porque acredito que outra cor ou nenhuma cor pode ser mais integrada com o conjunto. Esses ajustes precisam ser feitos, porque tem coisas que são feitas, principalmente a cor, para chamar atenção. Agora, o poder da luz é tão forte e tão grande na cena e por isso é tão fácil manipular o olhar externo. Tem que tomar muito cuidado com essa manipulação. Existe sempre um fator ideológico por trás da construção das imagens que são apresentadas. Uma luz de uma festa é toda indireta e todo mundo fica lindo, aí chega no banheiro, que a luz é sempre horrível e pensa "eu estou mesmo assim?" E não está. Se a luz do banheiro estivesse na balada inteira ninguém ia dançar ou paquerar. A luz indireta distrai um pouco... Eu já fiz isso, coloquei a luz lateral, mais difusa, porque era uma cena de amor e eu achava que não podia usar uma luz bem de frente. A luz é manipuladora do olhar e eu sei disso, a Nádia sabe..., mas há aqueles que estão chegando para fazer luz $3 \times 4$, profissionalmente inclusive. Continuam levando para a eternidade esses 
preconceitos sobre como é uma boa luz no palco, sem saber porquê. Todo signo, inclusive o signo da luz, tem uma história e uma ideologia por trás. Ainda falando de manipulação, por exemplo, eu gosto muito do suspense como gênero, mas quando o suspense se dá como elemento de natureza como em Esperando Godot, do Beckett. Mas aquele suspense que a pessoa vai subindo degrau por degrau e a sonoplastia vai fazendo tãnranran, tãnranran... ah, me poupe. Ou na cena de amor que os dois correm e a música toca... Na vida, amamos sem ter musiquinha, queríamos que tivesse, mas não tem. É uma coisa irreal, feita para o mercado, para pegar o público como uma novela, mas não podemos nos basear nisso, principalmente quando falamos em uma cena contemporânea, que é muito aberta e que não se deixa levar por modismos, mas tenta firmar um posicionamento de mundo. Quem quiser seguir, que siga, mas quem não quiser... eu não vou tentar direcionar. O que eu vejo como importante na diferença do teatro e da performance é essa relação com o público. No teatro, se tem doze pessoas assistindo, influencia a atuação da equipe, deixa desmotivado, enquanto que na performance não, ela acontece aqui e quem quiser ver, fica, ela acontece mesmo assim. A visibilidade dela é ampla, aberta, não direcionada. Se você quiser, você olha, se não quiser, não olha. A liberdade que a performance tem não pode ser arranjada. Duas forças superimportantes no teatro e na dança contemporânea do século XX para cá são Brecht e a Performance. São muito importantes porque mudam o fazer e o ver o que está sendo feito. Uma participação do social, do político, da quebra da representação, como diria Brecht. Uma coisa é chegar e assistir a um espetáculo, outra é vivenciar uma performance e atuar com ela. A performatividade do espetáculo é uma coisa que está chegando devagarinho, mas tudo isso começou com Brecht. Mostra tudo, perfeitamente como precisa ser, e então desconstrói e diz que isso está sendo contado e o espectador fica em choque, como acontece no filme Bacurau (2019). É um filme, conta uma história e, de repente, acontecem umas coisas loucas que mexem com a nossa expectativa. É uma espera do inesperado.

G.V. - Quando você cria a luz de um espetáculo, a quem ou a que você dá mais atenção? Dramaturgia, proposta do diretor? Você falou 


\section{bastante da tua relação com o espectador, mas como é isso no momento em que você está criando?}

R.G.C. - Com certeza, não é para o público e se for é porque escapa. Não é para nenhuma dessas coisas, no geral é para o todo. Você quer que as pessoas curtam o seu trabalho, mas o teu trabalho é luz? Não, o trabalho é o todo. Existe uma força muito forte que guia a comunicação dos homens, que é mais forte que a força da gravidade. É o principal atrator: o sentido. Você olha um aglomerado de pessoas na rua e pensa "o que está acontecendo?" Você está querendo saber o sentido. E esse sentido, que eu chamo de todo, que o espectador tem que viver. Todos nós fazemos isso quando assistimos uma coisa que amamos. A plateia levanta, bate palma, quer pegar, abraçar, falar, por que houve aquele encontro. Isso vem lá de trás como uma cerimônia. Agora, quando fica a plateia aqui e o palco ali, isso não acontece... E não é a luz que precisa fazer acontecer, é o conjunto. Às vezes, termina o ensaio e eu penso "não rolou". Há algo em mim, nos atores, em um dos atores, entre todos nós como sociedade, que impede que a coisa aconteça, mas quando acontece não existe erro porque as coisas acontecem em conjunto. É essa integração que faz a arte.

\section{G.V. - Muito obrigada!}


3.22 Rodrigo Ziolkowski - lluminador Paranaense 250

1. Como conceito, você considera que a luz seja material ou imaterial? Você saberia explicar a sua resposta?

R.Z. - Para mim, a luz é material, material cênico. Ela se concretiza e se traduz no elemento cenográfico e também dramatúrgico de um espetáculo. A luz contribui para que se encaminhe o espectador para a intenção que o espetáculo necessita. Nesse momento, ela se concretiza visualmente. A luz não é palpável, mas ela é presente, é mais ou menos como o vento, não conseguimos pegar, mas sentimos. Ao mesmo tempo, a luz tem essa inconstância. Assim que o espetáculo encerra, você desliga o equipamento de iluminação e ela não existe mais. Talvez venha daí essa questão sobre a materialidade. Eu sempre faço uma analogia com outros trabalhos efêmeros, porque a luz é um trabalho efêmero, diferente da escultura ou da pintura, que conseguem permanecer séculos a fio. Ela tem essa efemeridade. Gosto de uma imagem, a dos monges tibetanos que fazem, na areia, uma mandala, que eles levam semanas para fazê-la perfeita e colorida. Essa é uma prática que eles têm de desapego. Assim que o trabalho é terminado, o próprio autor precisa se desapegar dele. Na luz, eu sinto que também precisamos ter um pouco de desapego, porque ela só dura o tempo do espetáculo.

2. Você costuma trabalhar mais com a mesma companhia e o mesmo diretor ou varia? O que você pensa a respeito disso, você acha importante estabelecer uma relação mais próxima com o dramaturgo e encenador do espetáculo que vai iluminar ou até mesmo com todo o grupo e equipe de criação? Faz diferença no processo criativo trabalhar sempre com a mesma pessoa ou com pessoas diferentes a cada vez?

\footnotetext{
250 Entrevista realizada por Gabriela Valcanaia por e-mail enviado no dia 30 de março e recebido no dia 20 de abril de 2020.
} 
R.Z. - Ao longo desses anos que eu tenho trabalhado com luz houve algumas parcerias mais duradouras. Com essas parcerias, vamos maturando uma cumplicidade, ela fica maior e com isso temos um entendimento maior sobre o trabalho. $\mathrm{O}$ trabalho com iluminação depende muito de interpretar o trabalho da direção, lógico que você contribui criativamente, mas o grande objetivo é você colaborar para que um projeto da mente de um idealizador se concretize, seja ele o diretor, produtor, ou quem teve a iniciativa desse trabalho. Lógico que quando você consegue integrar uma companhia por mais tempo você perde menos tempo para descobrir os caminhos, para enxergar os reais anseios que 0 criador tem para a sua obra e isso acaba facilitando e sobra mais tempo para criar, que é o que se economiza com esses anos de trabalhos trilhados ao invés de ter que descobrir a toda outra vez. Quando você trabalha com pessoas... tendo pouca experiência com aquele artista, você pode levar mais tempo para encontrar o melhor caminho.

\section{G.V. - Qual a tua maior preocupação no momento de criação, a quem você dá mais atenção?}

R.Z. - No momento da criação a minha maior preocupação é bastante básica: conseguir realizar o melhor trabalho possível ou um bom trabalho. Para que isso aconteça, eu começo participando desses encontros, assistindo os ensaios e a maior atenção que eu dou, até mais atenção do que eu dou para o diretor, é a que eu dou ao ensaio que está sendo realizado. Como aquela companhia está tentando contar essa história, desenvolver esse espetáculo... Com o passar do tempo, eu procuro não intervir muito na direção, deixo-os trabalharem bastante até eu conseguir entender o espetáculo... Nesse momento, eu começo a tirar dúvidas e a criar na minha mente e vamos delineando qual o processo criativo que vamos adotar. Vou me inteirando com a direção também, para que possamos tomar decisões juntos. No decorrer do tempo, vamos entrando em contato com o todo, com os demais criadores, o elenco e a equipe em geral. A partir daí, a partir desse material é que eu começo a minha criação, eu entendo mais como descobrir a luz do espetáculo... Lógico que vamos dando 
soluções criativas e as ideias que queremos acrescentar para enriquecer o espetáculo.

\section{G.V. - Como o espectador entra no teu processo criativo?}

R.Z. - Bom, o espectador entra no meu processo criativo de maneira completamente independente, porque quando o espectador entrar em contato com a obra, acabou, ela está pronta e ele não interfere. Claro que sempre pensamos em entregar o melhor trabalho para o espectador, o objetivo de uma peça de teatro é o outro, oferecer o melhor para o outro. O espectador contribui muito com os feedbacks, as impressões que ele deve. Às vezes, nessa conversa, você vai se sentir recompensado, porque o espectador conseguiu enxergar o que você queria. Às vezes ele mostra coisas que você não viu no teu próprio trabalho. Você pode crescer também ouvindo críticas e isso é muito importante. Apesar de ser difícil, nós crescemos muito com as situações mais adversas.

3. A pesquisadora deste trabalho defende, como resultado de suas pesquisas práticas como iluminadora e reflexivas como pesquisadora, que a iluminação cênica tem uma participação ativa na cena teatral, assim como em outras formas das artes cênicas como a música, a dança, entre outras. Com isso ela afirma que a luz atua, age em cena e interage com os demais componentes do espetáculo e também com o público, tendo a importante função de estabelecer e favorecer a relação entre o palco e plateia. Você concorda ou discorda dessa afirmação? Por quê? Você saberia dar alguns exemplos dessa atuação da luz no seu próprio trabalho? Pode ser um projeto inteiro ou alguns efeitos específicos.

R.Z. - Quanto à colocação da pesquisa, eu concordo plenamente. A luz é um organismo vivo dentro do espetáculo, no qual o espectador é muito sensível a toda intervenção do trabalho de iluminação. Você pode preparar o espectador para um clima de determinada cena o mesmo fazer com que ele se perca se você não fizer a luz adequada para a cena. Eu levei muito tempo para compreender essa função dentro do trabalho. Às vezes, no início da carreira o iluminador quer mostrar um trabalho diferente, quer forçar e aparecer... Ele quer 
marcar a própria assinatura no trabalho, mas com o tempo você vai percebendo que isso é menos relevante e que você passa a interpretar a luz de um espetáculo de maneira mais assertiva. Acho que a criação de luz tem dois momentos: o primeiro é a concepção de um plano de luz do espetáculo e o segundo é o momento quando o iluminador senta na frente da mesa de iluminação e começa a passar o roteiro, porque aí sim você começa a escrever uma dramaturgia com a luz, você vai pontuando, assim como as intervenções das músicas, do cenário ou do figurino, e a luz participa ativamente de todo esse processo. Nos últimos anos eu tenho tido o privilégio de trabalhar com a companhia Ave Lola. Em alguns espetáculos tivemos a presença do músico Jean-Jacques Lemêtre, do Théâtre du Soleil e nessa experiência eu pude aprender muito. Humildemente, eu considero que a luz vem em segundo plano com a sua participação no espetáculo, porque eu acho que antes dela vem a música, que tem essa capacidade de pontuar o espetáculo, quando a luz vem junto, reafirmando cada vírgula e cada ponto dessa narrativa. Então, a parte de roteirização de luz é muitíssimo importante nessa parte ativa que a iluminação pode corresponder, além da arte cenográfica, que seria estabelecer o contra luz azul, por exemplo, ou branco... Para mim, isso faz parte da concepção e depois a roteirização é que vai fazer com que essa luz pontue, respire, pause, acentue certos momentos do espetáculo. Gabriela, obrigada pela participação nesse projeto.

\section{G.V. - Eu é que agradeço!}


3.23 Thierry Fratissier - Iluminador Francês ${ }^{251}$

\section{Em relação à luz e à iluminação, você considera que a luz cênica é} material ou imaterial? Você poderia explicar sua resposta?

T.F. - Para mim, ela é, basicamente, material e imaterial. Material por que temos que compor com um feixe, com cores, com um projetor, etc. Mas o resultado e a ação da luz no palco são imateriais. Então, obviamente, temos que passar pelas duas concepções da luz. Isso, para entendê-la e, finalmente, o que mais nos interessa é o lado imaterial da luz, mais que o lado material, que ainda é uma passagem obrigatória. É um pouco a matéria com a qual trabalhamos e a dimensão imaterial da luz, é mais a ação da luz no espetáculo, se se trata de um espetáculo.

N.L. - E o que atinge o espectador, na sua opinião, é mais o lado material ou o lado imaterial?

T.F. - Ah, isso depende de com que espectador estamos lidando; se estamos lidando com iniciados da iluminação, eles analisarão o lado material da luz e, sem dúvida, serão sensíveis ao lado imaterial da luz. Na maioria das vezes, eu ouso esperar que não tenhamos que lidar com espectadores muito iniciados no trabalho de construção da luz; portanto, neste caso, é obviamente o lado imaterial da luz que eles percebem primeiramente.

2. Em relação ao seu processo de criação, você geralmente trabalha com uma única companhia de teatro e um único diretor ou é variável?

T.F. - Ah, é muito variável, o que é muito bom inclusive, para mim. Isso não nos impede de ter uma fidelidade com um diretor com quem temos

251 Entrevista realizada pela autora no dia 04 de março de 2020 na ENSATT - École National Supérieur de Arts et Techniques du Spectacle, em Lyon na França (tradução da autora, original ao final dos anexos). 
afinidades especiais e cujo trabalho é naturalmente mais profundo. Existe, necessariamente, fidelidades em nosso espetáculo, felizmente. Mas felizmente, também, que eu tenha a sorte de nem sempre trabalhar com as mesmas pessoas, o que me abre muitas perspectivas, visto que aprendemos tanto com os outros quanto, eu espero, os outros aprendem conosco, há trocas que são variadas se trabalharmos com pessoas diferentes.

N.L. - E isso interfere, portanto, trabalhar com alguém que você tem o hábito de trabalhar ou trabalhar com alguém que você não conhece, isso influencia no trabalho?

T.F. - Isso nos posiciona de maneira diferente, especialmente quando... Sim, quando trabalhamos pela primeira vez com um diretor, inevitavelmente ocorrem etapas de descoberta, é isso, mas, ao mesmo tempo, é muito empolgante. Quando você trabalha pela enésima vez com um diretor ou uma diretora, o que acontece com muita frequência, bem, nós nos apoiamos mais sobre a experiência em comum.

N.L. - Qual é o aspecto mais importante a considerar, na sua opinião, para a criação de luz: os desejos do realizador, diretor ou dramaturgo, as necessidades do ator ou da cena ou o ponto de vista do espectador?

T.F. - Já, para mim, o que mais me preocupa é a ideia que faço do trabalho da luz neste espetáculo, é principalmente isso. A partir do momento em que você é coerente consigo mesmo, que você propõe um trabalho coerente com o trabalho do palco, coletivo, você fica mais à vontade. Naturalmente, o ponto de vista do diretor é um ponto de vista essencial, pois é ele, em geral, quem nos conduziu a esse projeto, por isso é essencial prestar atenção ao que ele propõe, ir na direção que ele propõe, possivelmente não no mesmo sentido, mas que haja um debate relacionado a isso, pontualmente. Mas no geral, é importante irmos no sentido do trabalho do líder do projeto, de certa maneira. Então, obviamente, quando eu estou minimamente em acordo com minhas propostas, eu realmente espero que o diretor também esteja, o que nem sempre é o caso. Então, neste caso, acontecem algumas discussões e depois mudamos 
algumas coisas. Depois, do palco... então, do ator, eu ouso dizer que nunca, mas músico, bailarino, aí depende... Se existem realmente questões imperativas, por exemplo, um pianista que precise ver seu teclado para tocar ou que não queira que sua partitura seja iluminada na cor azul, o que acontece diversas vezes, então isso eu levo absolutamente em conta. No entanto, se um ator me disser que se sente ofuscado pela luz naquele momento, em geral, eu o ouço, mas não o levo necessariamente em consideração. (risos) Ou seja, para mim o que importa é o olhar de quem está na plateia, que pode ser o diretor, o meu olhar, obviamente, mas também o olhar do espectador, visto que essa é a última parte da questão. Então, o espectador, eu começo a pensar nele só quando já me sinto um tanto coerente em relação a tudo e aí sim, à força de constatar que eu percebo muitas coisas no dia em que assisto à estreia e que já não posso fazer mais nada, então isso significa que talvez eu não pense o suficiente no espectador, (risos) visto que quando eu me encontro na posição de espectador, percebo muitas revelações, tanto sobre o trabalho dos atores quanto sobre 0 trabalho da luz, inclusive. Mas é verdade que minha primeira preocupação não é com o espectador. Não é, enfim, porque eu espero que o trabalho que fazemos juntos quando montamos um espetáculo traga algo de novo para o espectador, algo que possa surpreendê-lo. De alguma forma, alimentá-lo com o que ele não tenha sido alimentado antes. Parece muito pretensioso, mas ao mesmo tempo é um pouco nossa ambição.

\section{N.L. - A luz seria complementar ao espetáculo, seria isso?}

T.F. - Eu não estou falando necessariamente do espetáculo, da luz, mas quer dizer que o espetáculo... Para mim, é importante que o espectador possa perceber coisas que ele não esperava. Então, se eu começar a the oferecer o que ele espera, é um pouco contraditório, é isso. Mas, por outro lado, existe um grande respeito pelo espectador, ao longo de toda a obra, ou seja, evidentemente que o espetáculo para o qual se trabalha é um espetáculo dirigido ao espectador, no fundo sabemos, não podemos fugir disso, mas minha preocupação é não me dizer "ah, o espectador", exceto quando descubro escapes, vazamentos de luz ou ofuscamentos indesejados, pensando no 
conforto, um pouco sobre não colocá-lo em uma situação desconfortável não desejada pelo espetáculo.

3. E agora, para explicar um pouco a minha pesquisa, este trabalho, como continuidade da minha pesquisa prática como criadora de luz e reflexiva como pesquisadora, afirma que a iluminação cênica participa ativamente da cena teatral e igualmente em outras formas das artes cênicas. Assim, nesse sentido, ele propõe que a luz age, ou seja, que ela atua no palco e interage com os demais componentes e também com o espectador. Você concorda com esta opinião? Porque? E, se puder, dê alguns exemplos que passem pela tua cabeça de criações nas quais isso aconteça.

T.F. - Eu tenho a sorte de ensinar na ENSATT, então essas são questões diárias de reflexão e que são naturalmente provocadas tanto pelas perguntas dos alunos quanto pelos trabalhos deles, que me inspiram certas reflexões. Assim, é claro que a luz não pode trabalhar sozinha, sendo que um ator sozinho pode produzir um espetáculo, assim como um cenógrafo pode produzir um objeto cenográfico, ou seja, podemos parar no momento em que a cenografia está pronta. Obviamente isso não vai representar um espetáculo, mas pelo menos há algo de tangível. E o mesmo acontece com o figurino, o mesmo acontece com o som. Isso não significa que elas são atividades independentes do resto, mas que, por si só, podem ser auto suficientes, de uma determinada forma, mas para a luz é impossível, ou seja, se não tivermos uma cenografia, quero dizer, um chão, ou até mais que isso, se não tivermos um ator, dançarino, cantor, ou outro personagem para iluminar, se não houver a encenação que o acompanha, nós não podemos fazer nada. Então, naturalmente, somos obrigados a fazer a luz com tudo o que compõe o próprio espetáculo. Isso me faz lembrar um pouco a primeira pergunta, é óbvio que o resultado da luz vai criar uma interação. Além disso, eu esqueci de dizer que a luz, na maioria das vezes no sistema de produção de hoje, só chega realmente no fim da criação, ou seja, já existe o cenário, os figurinos, e até, é claro, o ator, tudo chega antes 
que a luz possa ser montada no palco. E aí todo o trabalho é modificado, todo o trabalho dos outros é modificado e, principalmente, o do diretor que, se estiver atento à luz, também saberá usá-la para extrair dela informações que transmitirá ao espectador. E então o espectador, obviamente, vê apenas o todo e a luz é, de uma certa maneira, o elo entre ele e esse todo. O link entre tudo. É isso, eu quero dizer que se cortamos a luz, não há mais espetáculo, mas se iluminamos, tudo o que foi posto em cena desde o início pode aparecer e naturalmente que os atores, entre eles, se veem de forma diferente quando colocamos a luz, então atuam juntos de forma diferente, os figurinos vivem de forma diferente. E nós, naturalmente, os levamos em consideração para escolher tanto as direções quanto as cores das luzes que devem funcionar com o figurino e a cenografia, nem se fala, porque obviamente é ela quem esculpe a luz, é isso, nosso trabalho é um trabalho que naturalmente leva em conta todo o trabalho, o conjunto. Foi essa a pergunta?

N.L. - Sim, é um pouco isso, mas quando falamos sobre o vínculo entre esses diferentes componentes e que, como você diz, se não houver luz, ainda pode haver um espetáculo, essa luz que chega ao final, quando tudo já foi criado, para fazer esse tipo de camada final do espetáculo, isso não poderia acontecer de forma diferente, havendo uma participação da luz desde o início, por exemplo, quando propostas de luz possam mudar ou estimular a criação do cenário, dos figurinos ou mesmo da encenação, da movimentação dos atores, ou seja, que a luz possa ter um papel mais participativo no processo de criação?

T.F. - Sim, mas isso não impedirá que ela esteja pronta por último. Sim, quer dizer, foi isso que eu quis dizer, foi bom que você retomou a ideia que eu desenvolvi, porque ela não estava suficientemente precisa. A luz pode participar muito antes. $\mathrm{E}$, inclusive, a luz pode intervir desde as conversas de elaboração do espetáculo. O que eu quis dizer é que, por um lado, é cada vez mais raro ter o palco disponível por tempo suficiente para que a iluminação possa fazer propostas reais com antecedência. Bem, falando nisso, eu tive várias experiências, mas uma em particular que me marcou e sobre a qual podemos 
conversar daqui a pouco, se for o caso, mas cuja iluminação apareceu muito cedo, mas, em todo caso, a luz é a última coisa a acontecer (materialmente) antes da estreia. $O$ trabalho pode continuar depois, mas é raro vermos um cenário ser transformado pouco antes da estreia, é raro ver figurinos serem questionados no dia anterior à estreia, mas não é nada raro rever a iluminação na véspera estreia, se não toda ela, pelo menos algumas cenas, é isso. Então, o que quero dizer é que, de qualquer maneira, a luz, de uma ou outra forma, é flexível o suficiente para poder ser trabalhada por muito mais tempo durante o processo criativo.

\section{N.L. - E você falou sobre um exemplo que gostaria de dar...}

T.F. - Ah, sim, trabalhei muito com Claude Régy, que morreu há pouco tempo. Eu era o assistente de Dominique Bruguière na época e passei verões inteiros trabalhando a luz durante os ensaios, porque quando nós chegamos, os ensaios não haviam começado ainda, só o cenário estava montado, as luzes estavam prontas e começamos a trabalhar assim, com luz. Eu vivi essa experiência, gostei dela, mas percebo suas vantagens e também suas desvantagens. As vantagens sempre existirão, obviamente, pois a luz envolvida desde o início da criação é algo que valoriza a iluminação, de certa forma, mas há uma desvantagem, eu acho, que é o fato da luz ser alguma coisa que... cada passo da criação cria um evento que mobiliza a todos. Por exemplo, a chegada ao palco é um evento, a chegada do cenário, presumindo que o cenário não foi montado antes, é um evento, a chegada dos figurinos é um evento, a chegada da luz, do som etc., também são eventos essenciais, na minha opinião, para revitalizar a veia criativa. Se tudo estiver lá desde o início, falta algo que não acontece quando se chega perto da estreia, então é preciso lidar com esse tipo de coisa com cautela, na minha opinião.

N.L. - Entendo o que você quer dizer, é como quando uma peça é apresentada por muito tempo, em algum momento há um relaxamento, e isso também pode acontecer durante o processo de criação... 
T.F. - Sim, é isso, mas é claro, e acima de tudo no processo de criação, porque sempre há, e isso é inevitável, eu diria até que é bom, momentos em que percebemos que não estamos avançando, que estamos perdidos. E é quando estamos perdidos que nos nutrimos mais e eu acho que, para o diretor, são indispensáveis esses momentos em que ele precisa de alguma coisa e essa coisa acontece, por exemplo, com os figurinos, a luz, alguma coisa de novo. E os atores também, se lhes dermos os figurinos desde o primeiro dia, haverá um relaxamento. Eu acho que há a necessidade do novo, de novos elementos, durante o período da criação, para poder continuar criando.

N.L. - Mas existem iluminadores, por exemplo, que experimentam a luz durante os ensaios, como isolar algo, criar um clima na sala de ensaios, diminuir a luz, destacar algo durante os ensaios, ou seja, não é a luz do espetáculo, finalmente, mas são testes com os atores, os performers, então, pode ser...

T.F. - Isso depende das condições de trabalho, se as condições permitirem, é muito bom. Além disso, quando eu faço luz, não faço luz sem os atores junto e nunca peço que eles venham apenas por causa da luz. Eu faço a luz durante os ensaios, se possível, se houver tempo suficiente, porque é a única maneira, na minha opinião, de ser exato com a iluminação. Então, geralmente, à tarde e à noite, nós... eu aprendi a fazer assim com a ópera, de fato, porque o tempo na ópera é muito mais calculado e muito mais curto, na maior parte do tempo para realizar um trabalho normalmente muito importante. Você precisa, então, ser muito reativo e eu entendi toda a riqueza que essa mobilização poderia trazer à luz. Não há nada melhor, na minha opinião, do que os atores para ajudar a fazer a luz. E por isso é que você tem que aproveitar o tempo que temos juntos. E o tempo que temos juntos é quando eles ensaiam, e não de dizer: "venham, vamos fazer um ensaio de luz", eu odeio isso. Para mim é uma armadilha. $E$ isso não impede que, na manhã seguinte, trabalhemos a luz em detalhes, os tempos, sem os atores, se possível com dublês, isso ajuda muito, porque eu não imagino, a partir do momento que é um espetáculo com atores, eu não vejo como você pode fazer a luz sem os atores em cena... 
N.L. - Para a afinação, a gravação, tudo isso, você precisa ter alguém no palco, mas você tenta trabalhar na programação, na afinação, então, durante os ensaios?

T.F. - Ah, sim, isso é indispensável. Quero dizer, eu aprendi isso com a ópera, não saberia como fazer de outra forma. Acontece comigo, quando temos pouco tempo, e isso... Bem, as condições são um pouco excepcionais, mas esse não é o tipo de condição que eu procuro. Como encontrar... nós podemos preparar a luz o quanto quisermos, mas em um determinado momento é a verdade do palco que nos indica o caminho do trabalho, na minha opinião. Tratase de observar o que está acontecendo, saber capturar momentos importantes, as direções que são impostas de uma certa maneira aos nossos olhos de acordo com princípios lógicos e... é isso, os bons timings, é assim que eu gosto de trabalhar. E não vejo como podemos fazer diferente. É claro que isso pode ser feito de maneira diferente, mas acho que com isso se perde algo essencial.

N.L. - Mas, por exemplo, para o timing ou para gravar uma cena, isso é difícil de fazer durante uma passada, por exemplo.

T.F. - Ah, é mais difícil, mas depende de quantos efeitos você tem. Se você tiver um a cada dez segundos, é complicado, mas se tiver um que pode durar cinco minutos, é possível trabalhar nele. Isso depende, é verdade, mas é verdade que o ideal, e é por isso que aconselho os alunos, quando possível, a começar a operação da luz o mais rápido possível, mesmo que tudo não esteja pronto, etc., porque esse é o primordial do nosso trabalho.

N.L. - Ah, isso é interessante, visto que tem a ver com essa ação da luz, dá mais chance de ensaiar a operação, de coordenar, mesmo que não tenhamos tudo, tem efeitos chave que serão ajustados com os ensaios.

T.F. - Exatamente, é claro. Porque eu, durante os ensaios, aos quais assisto o máximo possível, na medida do possível, tomo notas, referências e depois, quando começo o trabalho, essas anotações são importantes porque fornecem pontos de referência. Na realidade, sempre fazemos a luz de uma cena 
em relação ao que aconteceu antes e ao que provavelmente acontecerá depois, é isso, e depois equalizamos tudo isso e deixamos de lado as anotações, em um determinado momento, porque elas já não servem mais. Mesmo assim, sempre existirão exemplos do contrário, mas na maioria das vezes percebo que eu me nutro antes e no momento de criar tudo acontece quase em tempo real. É isso.

\section{N.L. - Bem, muito obrigada.}

T.F. - Bem, com prazer.

N.L. - Foi um grande prazer, sim, obrigada pelas respostas. Bem, é isso.

T.F. - É isso.

N.L. - Obrigada. 
3.24 Wagner Corrêa - Iluminador Paranaense 252

1. Como conceito, sem reflexões técnicas ou científicas, você considera que a luz seja material ou imaterial? Você saberia explicar a sua resposta?

W.C. - As duas coisas, material e imaterial. Vou tentar explicar... a luz tem volume, muitas vezes tem forma, desenho, pode ser vista... nesse sentido é material. Por outro lado, a luz pode não apresentar uma forma especifica, um desenho. Digamos que se torna quase imperceptível. Mas, ela revela ou esconde algo ou alguém em cena. Nesse caso, se torna algo imaterial em função de algo material.

\section{Você costuma trabalhar mais com a mesma companhia e diretor} ou varia? O que você pensa a respeito disso?

W.C. - Trabalho com alguns grupos, companhias e diretores. Alguns há muito tempo, como a Vigor Mortis, por exemplo, há quinze anos, praticamente desde que comecei a criar. Com a Cia Senhas, há quase dez anos. Eu estou, nesse momento, iniciando uma parceria de criação com o Antropofocus, grupo que existe há vinte anos e fiz a primeira criação para o espetáculo Justo Hoje. Acho ótimo passear por diversas linguagens e pesquisas distintas, é muito enriquecedor. Acontece com frequência, também, de surgirem projetos específicos, onde se desenvolve um trabalho para um show ou evento. Tudo acaba trazendo aprendizado, mas o trabalho contínuo com um grupo ou diretor traz um resultado diferente, a relação é outra. Tanto o grupo quanto nós, criadores, nos aprofundamos na pesquisa de uma linguagem ou linha de trabalho.

252 Entrevista realizada por Gabriela Valcanaia por e-mail enviado no dia 30 de março e recebido no dia 02 de abril de 2020. 
G.V. - Você acha importante estabelecer uma relação mais próxima com o dramaturgo e o encenador do espetáculo que vai iluminar, ou até mesmo com todo o grupo e equipe de criação para criar a luz? Faz diferença trabalhar sempre com a mesma pessoa?

W.C. - Normalmente, a relação é mais próxima com o encenador, muitas vezes, este também é o dramaturgo. Mas, é importante também a relação com os demais criadores, a luz tem relação direta com cenário, figurino, maquiagem, trilha sonora. Além disso, tenho os atores, bailarinos ou músicos como parceiros. Muitas vezes, efeitos que criamos só funcionam com a colaboração de todos. Sobre a diferença de trabalhar sempre com a mesma, acho que respondi na questão anterior.

G.V. - Qual a tua maior preocupação no momento de criação, a quem você dá mais atenção?

W.C. - Talvez não seja a quem, mas a quê... criar a atmosfera, o clima necessário à cena. É muita coisa para dar atenção. A condução do olhar do público, ajudar dramaturgicamente a cena, dar ênfase a um ou outro elemento, um ou outro momento específico. No caso da dança, um ou outro movimento.

\section{G.V. - Como o espectador entra no teu processo criativo?}

W.C. - Eu tento, num primeiro momento, me ver como espectador, como gostaria de ver algo em cena, como gostaria de sentir determinada cena ou coreografia. Em alguns trabalhos pude "brincar" com tipos de luzes diferentes na plateia. As vezes na intenção de causar alguma sensação diferente no público, outras vezes tentando incluir o público na cena. Por fim, acho bacana quando se consegue surpreender o espectador. Existem diversas formas de se iluminar uma cena. Mas, nem sempre a mais usual é a melhor.

3. A pesquisadora deste trabalho defende, como resultado de suas pesquisas práticas como iluminadora e reflexivas como pesquisadora, que 
a iluminação cênica tem uma participação ativa na cena teatral, assim como em outras formas das artes cênicas como a música, a dança, entre outras. Com isso ela afirma que a luz atua, age em cena e interage com os demais componentes do espetáculo e também com o público, tendo a importante função de estabelecer e favorecer a relação entre o palco e plateia. Você concorda ou discorda dessa afirmação? Por quê? Você saberia dar alguns exemplos dessa atuação da luz no seu próprio trabalho? Pode ser um projeto inteiro ou um, ou mais, efeitos específicos.

W.C. - Eu concordo plenamente. Acredito, sim, que a luz está em cena tanto quanto os outros elementos visuais ou sensoriais. Em determinados projetos, com mais destaque, outros nem tanto, mas a luz sempre está ali... Para aparecer, por si só, ou para ajudar a contar uma estória, para causar uma sensação ou para que, simplesmente, algo seja visto ou deixe de ser visto. A luz existe, entre outras coisas, para que outros elementos possam existir ou se transformar. Como mencionei em respostas anteriores, trabalho há quinze anos com a Vigor Mortis, uma Companhia de Teatro e Cinema que tem, em sua pesquisa de linguagem, estudos sobre o humor, o horror, o cinema, os quadrinhos. É necessária uma experimentação continuada de possibilidades de efeitos, ângulos, recursos. Em muitos trabalhos utilizamos projeções em vídeo. Nesse caso, nossa busca é pelo ângulo correto para que a luz não interfira de maneira equivocada na projeção e vice-versa. Em outros trabalhos, utilizamos sangue falso e coreografias de luta, e também se pesquisa ângulos e intensidade de luz para mostrar esses efeitos. A luz tem que ser posicionada em um ângulo específico para mostrar o volume do sangue falso. Às vezes precisamos distrair o olhar do público para algo especifico enquanto um ator esconde uma bolsa de sangue na boca, por exemplo. Ou para que um golpe em uma luta funcione, iludindo o olhar do público. No caso da Cia Senhas, na maioria dos trabalhos os atores precisam ver o olhar do público, ou seja, há que se ter alguma luz na plateia. A busca, então, é por maneiras diferentes de iluminar a plateia, de forma que isso se encaixe com a dramaturgia do espetáculo e com os demais elementos visuais da cena. 
3.25 Wagner Pinto - lluminador Paulista253

1. Como conceito, você considera que a luz é material ou imaterial?

W.P. - Ela é matéria, com certeza... posso te responder mais para frente como eu penso?

2. Claro, como for melhor para você. Eu vou fazer algumas perguntas que dizem respeito ao seu processo criativo, ok? Você costuma trabalhar sempre com o mesmo diretor ou o mesmo grupo?

W.P. - De certa forma, eu acabo trabalhando com os mesmos diretores, por exemplo, a Denise Weinberg, a Clara Carvalho e com o Gerald Thomas, nem se fala, porque é a Cia de Ópera Seca. Eu acabo sendo chamado por diretores que tem um grupo, mas não pelo grupo. Tem também o Gustavo Kurlat, a Débora Dubois... Acabamos trabalhando juntos porque rola uma cumplicidade. Tem muito mais gente, mas se eu for ficar nomeando aqui nós vamos ficar só nessa pergunta (risos).

G.V. - Dessas pessoas que você citou, qual a diferença de trabalhar com eles e de quando é a primeira vez com um novo grupo ou diretor?

W.P. - Geralmente, quando eu trabalho para alguém, eu volto a trabalhar mais umas três ou cinco vezes, isso tem sido a frequência. A diferença é que os processos de criação começam truncados, no sentido de ninguém se conhecer, não saber lidar com certas situações, como falar para aquelas pessoas. Há diretores que não gostam dos atores no palco na marcação de luz, eu já prefiro, porque é uma forma de eles estarem percebendo como se trabalha com a luz. O que eu tenho percebido, é que tem chegado uma geração de atores e atrizes que não sabem se comportar na luz. Isso, em parte, eu acho que é por

253 Entrevista realizada por Gabriela Valcanaia via Skype no dia 29 de janeiro de 2020. 
gravarmos a luz sem que eles estejam presentes... Sempre gravamos com alguém, mas aí você não consegue ajustar a temperatura de cor e quando chega na hora de fazer um ensaio técnico demora mais tempo porque eles precisam descobrir onde está o foco... Tem coisas na formação dos atores que tem se perdido, essa relação de saber se colocar na luz pela própria sombra é essencial. Quando eu trabalhava na Cia de Ópera Seca, o processo sempre foi ter os atores no palco, porque é a forma de todos entendermos juntos os efeitos... Isso demanda um pouco mais de tempo e é cansativo para o ator que está há meses ensaiando a cena, mas é o tempo necessário para que tudo fique fechado. Quando a luz entra, ela chega para fazer o quadro final da história. Claro, você tem cenário, tem figurino, mas é a luz que determina a fotografia. Eu penso em fotografia o tempo inteiro, o meu processo criativo é em quadros, eu não tenho um processo que pensa "a cena se trata de noite e dia". Talvez eu inverta isso, claro, depende de como o texto me dá essa possibilidade, mas eu não tenho um fio condutor que pensa "começa amanhecendo e termina com a noite". O que eu tenho em mente é um quebra cabeça, que eu vou montando durante o processo de criação e que, quando se fecha, as pessoas leem como se tivesse um fio condutor, mas para mim não tem.

\section{G.V. - A primeira coisa que chega para ti é uma imagem, um quadro?}

W.P. - É um quadro vivo. Nos meus primeiros ensaios para um projeto novo, eu não anoto nada, porque quando eu começo a escrever, aquilo fica como uma primeira imagem e a cena vai sempre se desenrolando com o tempo de ensaio e ela já não faz sentido. Quando eu estou em um processo criativo, se eu anotar, a coisa fica comigo e eu comecei a adiantar os próximos quadros quando eles ainda nem chegaram. Dentro desse processo, ainda tem o que eu gosto de chamar de "a obra do acaso total", que é quando acontece, sem querer, um efeito que você não estava nem imaginando, mas está lá e deu certo. Eu começo a anotar depois de uma semana de ensaio, fazer alguns rabiscos e já ter algumas ideias. Tudo depende do espaço em que você entra, da técnica para montagem, do orçamento... hoje em dia, os meus projetos de luz variam mais do valor que eu tenho de cachê e equipamento do que dos processos criativos, mas isso é 
pelo tempo que eu tenho de trabalho, porque para quem está começando, é tudo descoberta. Eu continuo descobrindo coisas, aprendendo com os técnicos das casas, vendo espetáculos de amigos... Eu não acho que eu estou pronto e acho que, se eu me considero um artista, eu estou sempre em processo de transformação. Tem horas que você acerta e tem horas que você erra, é normal. O meu processo é um pouco esse também, porque, em um primeiro momento, eu observo, tento entender o que se quer. E eu trago a fotografia para o teatro, vou quadro a quadro, como se fosse o cinema construindo o frame, vou fazendo tudo acontecer. Meus assistentes dizem que existe um fio condutor, mas que eu o ignoro (risos). Eu faço as coisas um pouco de trás para frente, eu sei como terminar, mas não sei como abrir o espetáculo. Às vezes eu estou com tudo pronto e fico me batendo para resolver o início... Você precisa pegar o espectador em três momentos: no início, no meio e no fim. E tem umas coisas entre isso, porque é bom manter o espectador atento (risos). Quando você tem um projeto de luz que é maior, ou seja, que aparece mais que o espetáculo, alguma coisa está errada... na direção ou no seu processo de querer aparecer mais do que o espetáculo. Você tem que estar de acordo, porque você serve o espetáculo e não ele que te serve, entendeu? É o que acontece quando eu vejo muitos amigos querendo tornar as coisas show em cima de algo que eu imagino resolver com dez ou quinze refletores. Claro que se tiver quinhentos refletores, eu faço, mas quero ver fazer com quinze. Mesmo quando eu tenho vários refletores eu tento usar qualidades diferentes de lâmpada e fazer com que eles encaixem muito bem no espetáculo sem exagerar na dose. Talvez, em uma cena ou outra isso passe (risos) porque eu tenho uma parafernalha na minha mão e quando vejo já foi. Eu não vou agradar todo mundo, mas eu trabalho para que em alguma parte desse espetáculo eu pegue o espectador. Talvez eu não te pegue, mas daí é realmente "não gosto do trabalho dele, da linha de trabalho dele", porque geralmente eu pego a pessoa em alguma cena.

G.V. - Você sente que quando você está criando, você dá mais atenção para o texto, para o diretor ou para a sua concepção? 
W.P. - A primeira coisa é o texto, ele é que vai fazer você encontrar a trajetória. Às vezes, você tem um texto tão bom, que te dá tudo. Normalmente, eu recebo o texto antes, dou uma lida sem me aprofundar muito, porque isso também depende da concepção do diretor. Depois dessa primeira leitura eu vou para a direção, que é onde vai se organizar realmente o que ele quer, porque, na verdade, o diretor é a figura central da brincadeira e tudo parte dele e de como ele concebe a obra e eu só penso em mim por último. Eu também penso muito que eu posso não acertar, e isso é uma insegurança constante. Eu termino um trabalho e penso que, no próximo, eu posso não conseguir e todo mundo se pergunta como, já que eu tenho anos de carreira, mas não é bem assim, tem uma geração nova chegando e uma nova forma de ver... A internet facilitou a velocidade, mas eu venho de um tempo que nós nos comunicávamos por ficha de orelhão, fax e agora você faz tudo com o telefone, inclusive luz. Em alguns teatros, que eu já tenho as senhas de acesso, eu entro na mesa através do meu smartphone. Eu venho de um processo em que a lâmpada alógena era a que mandava e hoje são os LEDs e as digitais. É ótimo o desenvolvimento tecnológico, mas eu prefiro criar com lâmpada PAR 64. Com a boa e velha lâmpada PAR, elipsos e alguns fresnéis eu faço a brincadeira acontecer, porque é o que eu gosto de trabalhar. Óbvio que as mesas digitais facilitam... Você tem uma fila de dez LEDs e um universo de cor infinito, enquanto para cada cor que eu fizesse antes iria precisar de uma fila de dez dessa para cada cor, você precisava de trinta para ter o sistema RGB e poder fazer as misturas. Hoje em dia está tudo muito mais fácil, mas ainda existe uma dificuldade de se criar. Tem tudo na mão e não consegue fazer acontecer e, nesse sentido, eu acho que a experiência te dá um pouco de bagagem para você usar o equipamento de forma muito mais proveitosa do que quando você está começando. Eu sempre sinto que estou começando, por conta dessa insegurança e a dúvida de saber se eu vou acertar ou não. Quando você está inseguro, se mantém mais atento. No meu processo eu tento não perder o foco, que é você não ter a certeza se vai dar certo. Antes de ver a luz montada, algumas pessoas me perguntam se vai ficar bonito e eu digo que não sei e que também estou querendo ver... Claro que algumas coisas vão ficando mais óbvias, pela experiência de fazer efeitos 
repetidos, de trabalhar com processos repetidos ou mesmo de montagens em longas temporadas. A montagem sempre tem uma constância, uma repetição da tua forma de trabalho. Por exemplo, eu trabalho com as gerais cruzadas (duas cruzadas e uma central), mas tem pessoas que trabalham com elas mais cruzadas entre elas e eu não, porque o meu estilo é ter sempre um lado do seu rosto que não vai estar iluminado, áreas mais escuras que outras e esse é o propósito do meu trabalho: ter luz e sombra. Uma geral limpa e perfeita é o que a Globo precisa, porque hoje em dia, nem em óperas você tem mais essa geral cem por cento sem sombra. Como eu vim de uma escola de vanguarda, isso me trouxe essa possibilidade de não usar o padrão e criar o meu estilo, de mostrar o jeito como eu vejo e de dar a cara para bater. O Guilherme Bonfanti tem o dele, o Beto Bruel tem o dele, Caetano Vilela, Marisa Bentivegna, Claudia de Bem, Cibele Forjaz, Isabela Fantini... Mas se você pensar, nós todos vamos passar pelo mesmo processo: texto, direção, ensaio. Cada um tem um jeito de mostrar o seu trabalho de forma diferente e é aí que você consegue parcerias, que os trabalhos com eles se repetem e que vai criando identidade. Onde tem fumaça todo mundo sabe que a ali tem Wagner Pinto (risos). O difícil é quando o diretor já está acostumado a uma relação com o processo de trabalho do iluminador ou com o design, a estética, mas começar uma peça é como começar um namoro, tem um jogo de sedução, de espera, de paciência... Às vezes isso vira um casamento, às vezes não. Por isso que quando você me pergunta sobre como é trabalhar com os mesmos diretores e grupos, hoje em dia eu não sei se tenho tanta paciência como eu tinha no passado, principalmente com a Cia de Ópera Seca do Gerald Thomas, a Cia do Latão e o Grupo Tapa, que foram três companhias que eu passei e me fizeram pensar sobre o que eu gosto, da parte de criar em grupo, que é a constância e a criação de uma linguagem com os atores, que são sempre os mesmo e isso facilita as gravações e o modo deles se colocarem na luz e cria uma cumplicidade com os atores que não acontece quando você chega para fazer um trabalho e logo sai. O que eu acho que não teria, é a paciência para passar um tempo numa companhia, é a impaciência que o grupo tem com o que vai acontecer daqui a pouco gravando luz, o embate e as discussões. Claro que quando eu trabalho com grupos avulsos, tem essa 
conversa, pode ser que essa conversa seja no particular, mas no grupo isso toma outras proporções. E por processos mesmo, por exemplo, para mim tem que ter elenco no palco, e se o diretor quiser ensaiar, isso vai ter que ser um acordo, eu preciso respeitar. Existem dois planos de trabalhos: o primeiro é que você tem os atores e faz já com eles e o segundo é quando você não tem os atores e faz uma passada só para eles entenderem o que é e só depois a passagem para valer. No primeiro você faz o processo duas vezes e no segundo você faz isso três vezes e ainda não é o suficiente.

\section{G.V. - Você pensa no espectador quando está criando?}

W.P. - Eu só penso no espectador. E além disso, penso em como ter uma luz para cinema ao vivo, essa é a experiência que eu quero provocar. Que se você pegar um espetáculo meu e filmar, ou fotografar, você verá que tem ali princípios de cinema. Tem profundidade, não deixa o ator ficar chapado no fundo, tem primeiro plano, segundo plano e terceiro plano. E o tempo todo eu só penso no espectador quando eu estou criando. Os atores estão no palco e eu na plateia, eu vejo os ensaios pela perspectiva do espectador... Eu crio para quem está na plateia, mesmo!

G.V. - Eu vou contextualizar a pesquisa da Nadia e depois pedir a tua opinião sobre, tudo bem? A pesquisadora deste trabalho defende, como resultado de suas pesquisas práticas como iluminadora e reflexivas como pesquisadora, que a iluminação cênica tem uma participação ativa na cena teatral, assim como em outras formas das artes cênicas como a música, a dança, entre outras. Com isso ela afirma que a luz atua, age em cena e interage com os demais componentes do espetáculo e também com o público, tendo a importante função de estabelecer e favorecer a relação entre o palco e plateia. Você concorda ou discorda dessa afirmação? Pode me citar algum espetáculo que você iluminou no qual isso aconteceu? 
W.P. - Concordo, claro! (risos) Um espetáculo é Condomínio Visniec, com direção da Clara de Carvalho. Eu não sou só o responsável pela luz, como sou pelo cenário. São seis atores em cena e eu sou o sétimo elemento, com quem eles contracenam o tempo todo... Máquina Tchecov também, O Dilúvio do Gerald Thomas, Renato Russo - o musical, com direção de Mauro Mendonça Filho, Opera Navio Fantasma, com o Gerald, Carmen, com o Cleber Papa, Madame Butterfly, com a Bia Lessa.

\section{G.V. - Você pode me contar um pouco como a luz interagia nesses espetáculos? Pode ser com um deles apenas.}

W.P. - Eu vou falar de Condomínio que é o mais recente e está mais fresco. Ele é um espetáculo que acontece dentro de um nada, como se fosse um prédio com vários andares e cada um está no seu apartamento. Não temos um prédio, mas a luz interage como se cada um tivesse o seu andar, seu cantinho e ela consegue remeter a um outro contexto para além do prédio, que é uma linha de horizonte muito maior. O Condomínio é feito com poucos refletores e isso me deixa muito animado, porque nos acostumamos a trabalhar com uma quantidade de equipamento de trezentos, quatrocentos refletores e nesse tinha quarenta (risos). Atende super bem as necessidades do espetáculo e da direção de cena para o espetáculo, claro, mas é divertido.

G.V. - Você vê, em algum dos teus trabalhos, que alguma cena se fez a partir de uma proposta de luz?

W.P. - Não, em nenhum desses isso aconteceu porque geralmente quando estamos ensaiando, não temos os recursos de equipamentos de luz dentro da sala, então eu nunca posso propor... Claro, posso mencionar o que eu quero, posso falar o que pretendo, mas sem o equipamento as pessoas às vezes não enxergam o que você tem como ideia. Por exemplo, se eu digo "vamos fazer essa cena em uma contraluz e vai se transformar em uma silhueta", às vezes as pessoas não entendem que para isso, não vai ter luz nenhuma de frente, os termos se confundem. No Dilúvio do Gerald eu já consegui fazer isso, tínhamos, nos ensaios, alguns refletores que me davam uma noção do que eu 
teria no final. Eu trabalhei bastante com isso porque, com o Gerald, a construção era outra: primeiro, vinha a luz e depois a cena. Primeiro tínhamos a fotografia e depois a cena. Quando ele fez A Batalha, nos perguntamos o que fazer e eu propus um paredão no fundo cheio de furos e uma vara que ficava subindo e descendo, fazendo com que isso tivesse movimento e desse conta dos tiros e da coisa toda. Com o Gerald, aquilo que eu te falei de ter o final pronto antes do início cai por terra, porque com ele tudo vem através da luz. Ele tem as ideias sobre a cena e começa a trabalhá-la, mas já tem um pensamento sobre luz por trás. Com alguns diretores que eu citei no início poderia ser assim, mas nunca temos a verba para manter os equipamentos dentro da sala. Algumas vezes, eu fiz maquetes em papelão para tentar mostrar o que eu pensava, mas foi com o Gerald e as produções com o Sesc, eles abriram o cofre. Ter dinheiro facilita muito, mas não significa que você vai acertar. No caso, eu acertei e ganhei prêmios, com o Dilúvio eu ganhei o Shell, mas não é certeza. Eu fiz outros espetáculos que eu acho ainda mais bonito do que $O$ Dilúvio e nada aconteceu. Mas eu nunca sei mesmo como vai ser ou se vai funcionar e quando termina um espetáculo eu sou o primeiro a ir embora, não gosto de subir no palco para receber aplauso...

\section{G.V. - Você não foi retirar o Shell?}

W.P. - Não... Fui uma vez e é desesperador quando você não ganha, então decidi que esse processo eu não quero passar nunca mais. Eu deixei de ir e passei a ganhar. No único que eu fui eu não ganhei (risos). No momento que você não leva o prêmio a festa acaba... Isso poderia ser muito diferente se tivesse primeiro, segundo e terceiro lugar. Claro que o Oscar é um só e quem não ganha, que corra atrás para ganhar o seu, mas já que você está entre os três (indicados), você não sai da festa tão triste. Eu acho que é um problema um prêmio tão grande quanto o Shell dar um prêmio do oito mil... Se depois de um prêmio você fosse bombar trabalhando, mas as pessoas não te chamam para trabalhar quando você ganha o Shell, porque acham que você vai estar caro. Passa o ano e elas voltam a te ligar porque "agora dá pra negociar com ele", mal sabem elas que eu tenho uma cota de espetáculos que eu faço de graça, porque 
é uma forma de agradecer aos trabalhos que eu tenho, principalmente das produções grandes, porque eu acredito que é uma troca e já está tudo tão difícil de fazer. Tem trabalhos sem nada de verba, outros que eu participo e só tem o cachê do meu assistente.

\section{G.V. - Como as mesas digitais, os LEDs e a tecnologia de modo geral} estão presentes no teu trabalho?

W.P. - Se eu pudesse não ter os LEDs eu não teria, mas hoje isso é impossível. Um dos motivos de eu ter me afastado da Cia de Ópera Seca foi essa minha busca por querer sempre o mais tecnológico e o melhor para o espetáculo. Eu passei um tempo fora do país, morei em Nova lorque, na Suíça e na Alemanha e sempre me perguntam porque eu não fiquei, e a questão é que você vai ser sempre imigrante e por isso será o terceiro em quem eles vão pensar: o primeiro é quem ele quer, o segundo é que ele nem quer, mas é da terra, e você é o terceiro. Aí podem vir dizer, “... mas se você batalhar”, mas imagine que eu já tenho que batalhar no meu país, aí eu saio dele e vou pra Alemanha... Você imagine EU transitando em um complexo de dois quarteirões e meio, com quatro teatros e as máquinas mais incríveis que eu já vi na vida, com galpões para cenário e figurino com tudo do melhor e eu era o único negro ali. No primeiro dia, entrando na cantina do teatro, que é onde todos os técnicos comem e bebem, estava um burburinho e assim que eu entrei silenciou a cantina inteira. Aos poucos, você vai percebendo que isso vai sendo aceito até que eu eles entenderam que tínhamos feito um contrato de cinco anos para que o Gerald dirigisse a Companhia da Bavária, e que de seis em seis meses eles veriam a nossa cara lá dentro. Em quatro dias isso já se normalizou, as amizades que eu fiz e tudo o que eu aprendi valeram super a pena. Eu sou um dos caras que sempre fui a favor e sempre corri atrás de trazer a tecnologia para os espetáculos, mas hoje eu questiono um pouco o uso dos LEDs. Para você usar o LED como uma tecnologia de ponta, precisa de mesas que deem conta de abrir universos e universos. Agora, algo que é o mais interessante disso tudo é que eu sou um dos primeiros aqui em São Paulo a trabalhar com técnicas meninas no teatro. 


\section{G.V. - Mulher é realmente uma tecnologia nova na iluminação cênica} (risos)...

W.P. - Antigamente, quando eu comecei, principalmente, era muito foda para vocês meninas estarem na escada ou em uma posição de frente. Se estivessem, seria em uma função secundária, porque o machismo está em todos os meios. O que mudou a minha cabeça foi quando eu fui para Nova lorque montar Trilogia Kafka com o Gerald. Ficamos um mês e meio em temporada no La MaMa (La Mama Experimental Theatre Club) e eu tinha apenas o técnico geral da casa como homem na montagem, o resto eram quatro meninas, isso em 1988. Essa foi uma experiência muito bacana, eu fiquei mais tempo em Nova lorque trabalhando no La MaMa, mas nessa época eu ainda não falava inglês e fui ficando esperto e aprendendo como eram os nomes das coisas, até que eu ganhei o menor teatro para coordenar. E nisso eu fiquei cinco anos indo e voltando, indo para Munique e, assim, a Cia de Ópera Seca ficou girando, ou todos juntos, com o elenco, ou só eu, Gerald, Daniela. O Gerald me apresentou o mundo porque ele me levava junto. Quando eu voltei para o Brasil, eu decidi começar a trabalhar com meninas. A Aline Santini é um dos meus orgulhos e é alguém que sabe tudo o que eu sei.

\section{G.V. - Como você começou a trabalhar com o Gerald?}

W.P. - Eu comecei trabalhando no Teatro dos Quatro como assistente de contrarregra. Eu era atleta de remo, treinava para ser atleta de ponta até que um dia minha mãe me pediu para largar o remo e ajudar em casa. Eu me perguntei o que eu poderia fazer, porque eu só sabia remar e estudar. Minha mãe era camareira de teatro e me disse "você poderia trabalhar lá, nada lá te encanta?" Eu tinha interesse na luz, no som, mas a vaga era para assistente de contrarregra e a minha mãe insistiu dizendo que se eu ficasse no teatro o Aurélio (de Simoni) e o (Luiz Paulo) Neném iriam me ensinar. Eles eram os maiores iluminadores do Rio de Janeiro e ainda são. Eu comecei observando, um dia perguntei como funcionava a mesa e aí surgiu o convite de eu aprender a operar espetáculo (do Aurélio), que era tudo o que eu queria. Ele me ensinou durante dois meses e meio a operar a luz daquele espetáculo, eu aprendi efeito por 
efeito... Hoje em dia os espetáculos não tem nem temporada desse tamanho. Ele quis me ensinar direito, claro que podia ser mais rápido, mas com ele eu aprendi a organizar um agrupamento na mesa e hoje eu vejo a importância, porque uma boa luz começa na distribuição dos agrupamentos na mesa. Dentro desse tempo, ele ia me levando para as montagens, eu passei um bom tempo limpando refletor e limpando lente até subir na escada para ligar, tudo tinha tempo, mas hoje as escolas que estão formando... Eu vejo os profissionais no mercado e é difícil. Eu estava trabalhando no Teatro do Quatro e o Gerald foi convidado para dirigir o Quatro Vezes Beckett, que era um dos três espetáculos que a Shell estava produzindo lá quando começou os patrocínios das multinacionais. O Gerald tinha recém chegado no Brasil, era 1984 e eu fui apresentado a ele para trabalhar com ele e com Sérgio Britto, Rubens Corrêa, Ítalo Rossi e Richard Riguetti, que eram os famosos naquela época. Depois desse processo, foi bem complicado, porque ele voltou para o Brasil chutando o balde, falando mal do teatro nacional e da Globo, mas era o que tínhamos no Rio de Janeiro. Nós trabalhamos nessa peça juntos e quando terminou a temporada ele disse "ano que vem eu volto e quero trabalhar com você". Ele me fez ver a luz de um modo diferente, experimentar fazer luz sem gelatina em uma época em que tudo era gelatina. Eu fiz a geral mais limpa, perfeita e sem sombra e quando ele chegou, odiou e disse que queria sombra e luz. No ano seguinte montamos Quartett com Tônia Carrero e Sérgio Britto e no final de 1985 fundamos a Cia de Ópera Seca, que existe até hoje, agindo de outro modo. Ele me disse que eu teria que escolher entre Rio e São Paulo e que no início a grana não ia ser fixa... Nem precisou disso porque o Yacoff Sarkovas logo começou a produzir a companhia e tínhamos um salário. Eu larguei o Rio, minha família e vim para uma terra que é onde eu moro até hoje. Depois disso trabalhamos muito juntos e disso você deve saber um pouco através de livros, enfim...

\section{G.V. - Como é a tua relação com assistentes? Você teve muitos?}

W.P. - Não tive muitos, porque eu sempre crio um casamento, a não ser que a relação de trabalho seja difícil. A Aline trabalhou comigo por treze anos, depois veio o Gabriel e eu fiquei um tempo vagando sem um assistente até 
encontrar outro. É complicado estar na posição de assistência, eu sei porque passei por isso e com o Gerald foi um tempo até assinar os projetos. Eu via que, quanto mais eu queria, mais ele me dava e quanto menos eu queria, mais ele me tirava. Eu fui aprendendo muito dessa relação com ele. O quanto é preciso estar dentro, o quanto você entende a linguagem que você está fazendo. Uma coisa é dizer a linguagem do Guilherme, da Mariza, da Aline, que agora está chegando numa linguagem própria, e claro que isso vai da quantidade de oportunidade que ela tem para trabalhar, senão ela vai ficando para trás. A minha relação com os assistentes é de confiança e entrega total, eu delego total e quero mais dividir do que ficar mandando ou decidindo as coisas... Eu chamo e penso junto em, como podemos resolver aquilo. Com o Gabriel eu não faço mapa, eu chego e monto as varas, que é a minha terapia e o único tempo que eu realmente tenho para montagem, depois disso eu já não afino, não gravo e só fico pedindo. O Gabriel foi um achado, ele fazia os tempos das entradas intuitivamente e era do jeito que eu imaginava a luz acontecendo, com a mão leve e sem eu precisar falar nada. Foi paixão mesmo, ele é o cara (risos). E uma preocupação na hora do ensaio geral, com os detalhes de afinação e ele dizendo que ia arrumar e eu dizia "calma, eu sei, na hora do espetáculo vai dar certo" e ele entendeu muito bem e muito rápido esse meu processo de montagem, porque na hora do espetáculo a luz não entra, ela acontece e isso ele faz muito bem. Ele faz acontecer e é uma parceria que eu não troco. Hoje eu que ligo para ele e pergunto como está a agenda dele (risos) porque precisamos estar juntos. Eu tenho uma relação boa com assistente quando eu vejo que quer estar perto e aprendendo, mas quando não quer, eu também não me prendo. Eu não brigo com técnico, se for para bater boca, eu vou bater com gente grande, com a produção, que não está fazendo o trabalho, e não com a equipe. Eu fui um dos primeiros da nossa geração a ir para fora, eu fiz a minha carreira fora do país e não troco por nada, mas também não troco o meu país, porque eu acho que o legal é aprender lá fora e fazer aqui. Essa troca é muito importante... Por exemplo, o Bob Wilson veio para o Brasil e o que nós sabemos da luz dele? Quem pode falar com propriedade são os técnicos do Sesc que fizeram a montagem, mas o que seria legal? Fazer palestra, abrir mesmo, é importante 
fazer isso e é importante que quem vem seja pago para isso. Ficamos nesse bairrismo idiota e não trocamos, mas o que fazemos é arte! No último evento em Florianópolis (A Luz em Cena) me pediram para falar sobre a luz na pele negra... Eu ri porque o meu meio de convívio é completamente branco e eu sou o único negro de ponta na iluminação na cidade de São Paulo, então eu sou um ponto em uma folha branca. O que eu fiz foi chamar os outros negros que estavam ali comigo para falarmos juntos porque eles podiam falar sobre. No evento, quem poderia falar é o Eduardo Tudella, que mora e trabalha na Bahia e iluminou muito mais pessoas negras que eu. Eu iluminei uma pessoa negra, foi no ano passado o Rogério Brito, que foi inclusive indicado ao Shell e que fez o Ricardo III todo de preto e as pessoas começaram a questionar que o mal então é preto, mas gente, se ficarmos agora nessa coisa não vamos fazer NADA porque os atores negros não vão poder fazer nada que não sejam assuntos ancestrais... Nenhum negro pode fazer Shakespeare? Clara, a diretora, até me perguntou e eu disse que "estamos trabalhando em uma caixinha mágica e que aqui tudo pode se transformar, se começarmos com isso vai ficar chato e outra, ele me representa como um ator negro fazendo esse papel e fazendo BEM, deu show mesmo" para além do fato de que tinha um produtor, o iluminador e mais três pessoas da equipe que eram negras, enquanto tinham seis pessoas brancas, esse equilíbrio é maior do que na maioria das montagens. No teatro todo mundo tem voz ativa e é por isso que nós amamos fazer isso.

\section{G.V. - Muito obrigada, Wagner! \\ W.P. - De nada!}




\title{
4 Conteúdos originais das entrevistas em francês e italiano
}

\author{
Interview Christophe Forey - Éclairagiste Français
}

1. À propos de la lumière et de l'éclairage pour la scène, tu considères que la lumière scénique elle est matérielle ou elle est immatérielle ? Donc elle agit sur scène d'une façon immatérielle où le faisceau de lumière il est là, il est présent, donc c'est à propos de la présence de la lumière sur scène.

En fait, moi je dirais que la lumière est matérielle et immatérielle selon l'usage qu'on en fait et selon le fonctionnement. Après si je vais parler que de la lumière scénique et la lumière de spectacle, on ne va pas revenir sur la physique et des choses comme ça, qui expliquent bien d'autres choses, pour moi elle est plutôt d'abord immatérielle, c'est à dire, elle éclaire des choses matérielles, mais la lumière est immatérielle et par son immatérialité elle peut transformer les choses matérielles, c'est à dire, les acteurs, les décors, les tissus, les matières tangibles qu'on a, qu'on éclaire. Et c'est le rapport de cette immatérialité et de cette matière sur lequel tu travailles.

Ça c'est le côté immatériel, donc la lumière tu considères qu'elle est immatérielle mais elle matérialise les choses disons.

Oui, elle peut transformer les choses, mais elle-même elle est immatérielle. Après les lumières qu'on pourrait dire qui se concrétisent en matière, comme tu disais, c'est plutôt les lumières qu'on peut voir dans les concerts, matérialisées par les fumées, par des choses comme ça avec les faisceaux, où la lumière devient un décor elle-même. Et ça c'est, comme tu disais, on le voit, ça peut être très bien, mais ce n'est pas exactement ce que je pratique. Je peux le faire d'une façon exceptionnelle, éventuellement, parce que ça dépend de chaque projet, bien sûr. 
Et tu penses que cette lumière matérielle, elle pourrais être utilisée aussi dans une pièce de théâtre, dans un spectacle qui ne soit pas un concert, par exemple?

Oui, ça arrive dans des mises-en-scène récentes qu'on a pu voire des Shakespeares récents, que c'est la lumière de concert qui fait, où ça se fait. Ou en dance, ça se fait beaucoup depuis les années 80. C'est venu beaucoup avec les moving lights qui bougent et qui du coup, si on affirme le côté mouvant et mobile, ça c'est des partners, complétement. Mais après, la lumière immatérielle, elle intervient complètement dans la narration et dans leur récit. Ce n'est pas parce qu'elle est immatérielle qu'elle n'existe pas, immatérielle ça veut dire qu'on ne peut pas la prendre dans la main, mais elle existe.

2. À propos du processus de création, c'est à dire, quand tu créé les lumières avec les spectacles avec qui tu travailles, si tu as l'habitude de travailler souvent avec les mêmes compagnies de théâtre ou le même metteur-en-scène ou si tu varies beaucoup et quelle est l'influence de cette constance ou de cette variation dans ton travail ?

Alors, moi je travaille plutôt régulièrement avec les mêmes, mais j'ai pas mal de monde avec qui je travaille régulièrement, alors après ça dépends de périodes, comme je ne suis plus si jeune, il y a beaucoup de périodes successives, et donc il y a des gens avec qui je travaille depuis 20 ans, il y a des gens que j'ai travaillé et je ne travaille plus avec eux parce ils ne sont plus de ce monde, mais avec qui j'ai travaillée pendant 10 ans ou 15 ans, mais en parallèle avec plusieurs équipes, et donc, et après effectivement, le fait de travailler en équipe, d'abord ça amène une confiance, c'est une confiance réciproque, des deux côté, alors que quand je travaille ponctuellement, comme ça peut m'arriver également, où je suis engagé à contrôle de circonstances que je suis engagé avec quelqu'un qui ne me connais pas et que je ne connais pas, en général il y a un chalenge de, bah, il faut qu'on s'accorde, c'est que moi je cherche à comprendre comment il travaille, que je ne sais pas au départ, et lui de la même 
façon, ou elle de la même façon cherche à comprendre ou exige des choses pour avoir un résultat qui... donc il y a un côté jeu qui est rigolo, qui me plait, mais qui est différent du processus quand c'est un travail avec de personnes avec qui je travaille régulièrement. Même avec des gens avec qui je travaille régulièrement, donc avec qui a confiance, avec qui il y a tout ça, chaque nouveau spectacle c'est une nouvelle aventure et on ne sait pas comment elle va être. Et même si on se connaît, moi je ne sais pas ce que je vais faire avant et je ne sais pas à quoi ça va ressembler avant qu'on commence, même si on se connaît.

Bien sûr. Et dans ces deux sortes de réalité, quand tu connaît la personne, tu connaît comment elle travaille, même quand on connaît pas le spectacle, mais, quand il y a cette confiance et de l'autre côté, est-ce que ça a une interférence sur le résultat ? Est-ce que c'est mieux d'une façon que de l'autre?

Non, en fait, globalement c'est mieux quand on se connaît pour le résultat et pour le processus aussi. J'adore quand on se connaît pas, mais on va plus loin en général quand on se connaît déjà.

Encore sur la création, quelle est l'aspect le plus importante auquel tu penses quand tu créé la lumière : c'est le metteur-en-scène et ce qu'il veut, ce qu'il désire, ce qu'il te demande, les besoins de ceux qui sont sur scène ou si tu penses au spectateur, qu'est-ce qu'ils ont besoin de savoir, de connaître, enfin ?

Je suis assez tôt dans le processus de création, donc assez tôt au niveau de la conception de décor, donc j'ai déjà en amont pas mal d'info, donc mon travail se focalise sur... d'abord j'entends ce que le metteur-en-scène veux, en gros quelle histoire on raconte, et comment on va la raconter, parce qu'en fait c'est ça, c'est d'abord savoir qu'est qu'on raconte et en suite comment on va le faire, dans quel style est-ce qu'on va... si c'est du théâtre, est-ce qu'on va être naturaliste, est-ce qu'on va être abstrait, est-ce qu'on va être expressionniste, ou est-ce qu'on va faire un patchwork de tout ça, mais forcément le metteur-enscène il saura dire un style, alors s'il fait nuit dans une scène naturaliste je ne 
vais pas me mettre à mettre des carrés par tout parce que ce serait absurde, même si c'est... on raconte une histoire et on doit utiliser un peu les mêmes moyens pour les parvenir. Et donc en fait c'est ça ma priorité, d'abord, et en suite c'est, en répétition, c'est le spectacle, les acteurs et la présence des acteurs pour vivre. La lumière elle vie avec les acteurs et elle fait vivre le jeu des acteurs... ou pas. Et l'acteur il est en rapport avec un espace, avec un décor, avec une table, avec des chaises, avec des murs, ou un ciel... La lumière elle doit crées le lien entre ces choses inertes et la chose vivante qui est l'acteur et l'actrice. Et donc c'est ça, mon regard il est là-dedans, je ne pense pas une seconde au regard du spectateur.

(Rires) Même pas physiquement, où il est, la place, c'est à dire le point de vue qu'ils ont sur la scène... ?

En gros le point de vue en général je sais qu'il ne bouge pas trop dans la salle parce que sinon il faut tout refaire tout le temps et dans un premier des gros tissage c'est plutôt centre salle et un point de vue moyen et un peu idéal et après les points de vue sur les côtés des spectateurs c'est juste si vraiment il y a des places infernales, des problèmes de reflets, et là c'est des choses très ponctuelles, très, genre là à cette position-là ils ont un miroir et il y a la lumière qui arrive dedans, c'est pas possible, mais ça c'est un truc technique, précis et on trouve la solution à ces trucs-là, ça ne participe pas de la création, mais effectivement on y tiens compte s'il fait par éblouir la moitié de la salle pendant tout le spectacle ce n'est pas intéressant, mais ça c'est un deuxième temps. Attends, ce n'est pas exactement un deuxième temps, mais s'il y a des fenêtres par tout il faut en tenir compte dans un premier temps, parce que sinon ça ne marchera pas, mais c'est plutôt de l'ordre technique. Voilà.

3. Et puis finalement on rentre effectivement dans le thème de ma recherche qui est la performativité de la lumière. La chercheuse de ce travail soutient, à la suite de ses recherches pratiques comme créatrice lumière et réflexives en tant que chercheuse, que l'éclairage scénique 
participe activement à la scène théâtrale et également à d'autres formes d'arts du spectacle comme la performance, la musique, la danse, entre autres. Dans ce sens, elle propose que la lumière performe, agit sur la scène et interagit avec les autres composants du spectacle ainsi qu'avec le public, ayant la fonction importante d'établir et favoriser la relation entre la scène et le spectateur, c'est à dire, si le spectateur rentre dans la scène, s'il rentre dans le spectacle, s'il suit, s'il est là, c'est par rapport à la lumière, en fait. C'est la lumière qui permet que la relation soit établie entre la scène et le spectateur. Donc es-tu d'accord avec cette proposition et pourquoi ?

Oui, oui, plutôt oui. Disons, la lumière à la base c'est un des... c'est le théâtre, la danse, il y a plusieurs corps de métiers qui travaillent ensemble pour créer une œuvre d'art et en suite chaque corpos de métier a son propre langage pour aboutir à une émotion, à transmettre quelque chose parce qu'est-ce que c'est du théâtre, c'est... il y a des gens qui écoutent et regardent et il y a des gens qui parlent et se montrent et c'est là, c'est comment créer une relation entre ces deux mondes, qui est une relation totalement artificielle et volontaire et ce qui est particulier au théâtre par rapport à la vie courante quand on se promène et qu'on regarde dans la rue c'est qu'il y a des gens qui organisent ce qui est vu et donc comment on crée, enfin ou essaye de créer une œuvre d'art avec ça, en organisant ce temps de une heure ou deux heures ou trois heures ou quatre heures que pendant ce temps-là les choses sont organisées pour être regardés et réfute c'est une autre chose réel, vivant, mais qui est organisé, à la différence de la vie réelle qui peut être aussi belle, voire d'avantage, mais dont l'organisation nous échappe.

\section{Dont on n'a pas le contrôle...}

Voilà. Ce qui est bien, mais quand même... Bon, moi je vais revenir sur terre, donc, ah oui je disais, chacun a son medium, en fait, donc le décor il va raconter une datcha aussi, le comédien il va raconter qu'on coupe les arbres, les costumes vont raconter une époque, ils vont raconter une émotion du personnage, si c'est un personnage vulgaire ou un personnage rigong, et ça participe de ce que va jouer le comédien, donc la lumière au même titre elle 
raconte l'histoire, elle crée une ambiance, si c'est tragique, si c'est triste, si c'est gaie, si ce sera plus sombre, si ce sera plus lumineux, il y aura plus de contraste, si ce sera plus chaud, si sera plus froid et aussi elle participe du rythme, du temps qui passe. Une des grosses différences de la lumière au cinéma et au théâtre c'est qu'au cinéma elle ne travaille que sur l'image, d'une façon très, très importante, mais elle ne travaille pas sur le temps, parce que c'est le montage au cinéma qui fait le temps. Alors au théâtre, en chorégraphie, le montage du cinéma y est remplacé par la conduite lumière et le rythme des effets, le temps, si un effet dure trois minutes pour amener une lumière ce fait pas du tout pareil que si on a cinquante effets qui durent trois seconde, évidement. Parce que du coup ça fait un montage haché, ça accélère les choses, c'est comme on peut voir en comédie musicale où il y a plusieurs effets par minute et du coup la lumière elle suit chaque inflexion de sourcil de chaque comédien. Dans un théâtre plus différent que je pratique d'avantage le temps de la lumière va être long alors que le jeu de l'acteur va être rapide, et du coup de ce jeu de l'acteur rapide il est mis en valeur parce que le temps de la lumière est long, comme en musique, d'avoir des contrastes. Oui, j'ai oublié la musique là-dedans, ce n'est rien. Parce qu'au niveau du temps le travail sur le temps de la lumière c'est le même, il collabore avec la musique ou l'engeigner du son, parce que c'est beaucoup le son et la lumière qui donnent ce rythme de montage au théâtre. Donc il y a une parenté entre musique et lumière très, très importante. Oui, donc il y a cette histoire, il y a, à la fois, créer des atmosphères, des ambiances, des sons, etc. et de donner un rythme.

\section{Donc c'est tant l'image que le rythme?}

Voilà. Et donc du coup, de cette façon-là la lumière elle participe, elle raconte une histoire.

Et donc quand je dis que la lumière elle agit sur scène, c'est plutôt, disons, une action visuelle et narrative, à ton avis ?

Ou subjective, ce n'est pas forcément narrative, ça raconte d'une façon... c'est comme la musique, ça raconte une histoire mais sans les mots. Par les 
émotions, oui. Après dans un point de vue pratique par rapport... alors ça dépend, chaque spectacle est différent, mais il y a quand même des familles de spectacles. Quand je peux, moi également je suis là au début des répétitions, si je peux, en studio de répétition, disposer des lumières, ça m'est arrivé plusieurs fois (ça m'est arrivé de faire des spectacles d'improvisation, mais ça c'est encore autre chose) de travailler pour la première ou les deux premières semaines quand le metteur-en-scène travail en improvisation sur le thème du spectacle, sur le thème des scènes, de travailler en improvisation lumière et en fait moi je ne dis pas aux acteurs ce que je vais faire, je le fais. Je mets une lumière qui fait une frontière entre deux espaces et ce dont je me suis aperçu, des fois ça ne fait rien du tout, et des fois ça construit l'espace et ils fonctionnent par rapport à ça, ou alors il y en a un qui va se mettre dans l'ombre et l'autre va se mettre en pleine lumière et forcément le rapport des deux est différent et une fois celui qui est dans l'ombre sur un geste, sur un moment, et si il va entrer dans la lumière il crée une dynamique très forte et du coup ça interagit comme ça en improvisation et après en général c'est ma base de la lumière du spectacle final. Alors après dans l'idéal, ça m'arrive parfois, que je répète directement du jour zéro en lumière sur scène dans le décor. Oui, ça m'est arrivé, c'était il y a quelques années, c'était Le Nez de Chostakovitch, donc un opéra sensationnel et c'était un décor avec une double tournette et avec plein d'éléments mobiles, des panneaux sur charriots, une porte, une fenêtre, donc ça permettait de faire tous les espaces et tout été neutre et sur deux tournettes tout été mobile et en fait avant chaque, quand on a répété le spectacle on avait tout le décor dès le zéro, le metteur-enscène il arrivait une demi-heure avant la répète, il regardait la maquette, il me voyait, enfin, il avait réfléchi avant, mais, les filles plaçaient les choses, puis les machinistes plaçaient les décors et moi j'avais une base de lumière et je mettais directement une lumière pour la répétition en fonction de l'espace qu'il avait créé, mais du coup ça accentuait ou ça relativisait et ça créait forcément des zones de jeu, des zones plus sombres et directement la mise-en-scène était faite dans cet espace et dans cette lumière. Et ça pendent les répétitions ? Oui, pendant les répétitions. Et après la répétition, en fait, le lendemain ou le surlendemain, j'avais vu la répétition et moi j'améliorais les choses en fonction de ce que j'avais vu, je 
n'allais plus rendre une direction ou il y a une que je laissais tomber parce que ce n'était pas productive et la répétition suivante on avait la même chose à l'étape suivante, mais la répétition se passait avec une proposition d'espace et de lumière et le metteur-en-scène tient compte de la lumière, du coup, forcément. En fait tu mets de la lumière à un metteur-en-scène et il va jouer avec, tu ne mets pas de lumière, bah, il joue avec ce qu'il a.

Oui, c'est ça, très intéressant. Et puis finalement, tu viens de donner un exemple d'un spectacle, mais est-ce que tu as d'autres effectivement où tu puisses dire que la lumière ou alors dans ce spectacle même comment elle transformait les choses, comme tu dis ?

En fait moi je ne dirais pas dans ces termes-là, je dirais que la lumière elle participe à l'écriture du spectacle, ce spectacle-là n'existerais pas sans la lumière, je ne transforme pas les choses, je les fabrique. Avant il n'y a rien, c'est comme s'il n'y a pas de décor il n'y a pas de décor, le décor on peut dire qu'il transforme l'espace, mais on ne dis pas ça, on le pose, mais la lumière c'est pareil, on la pose. Et à chaque fois... enfin, l'idéal c'est quand la lumière elle rencontre le jeu de l'acteur et il y a un truc magique qui fonctionne, et des fois ça arrive et des fois pas.

\section{Et tu te souviens d'un exemple où ça arrive ?}

Oui, oui, oui, oui, mais il faut voir avec des photos...

Ah d'accord, ça peut se faire. C'est bien, c'est ça, merci beaucoup.

On fait une pause ?

On fait une pause... (rires). Merci. 
Interview Eric Soyer - Éclairagiste Français

1. À propos de la lumière et de l'éclairage, considérez-vous que la lumière scénique soit matérielle ou immatérielle ? Pourriez-vous expliquer votre réponse?

La lumière scénique est pour moi profondément immatérielle dans ce sens que c'est une onde, mais néanmoins ce qui est un paradoxe c'est que c'est elle qui dessine, dévoile ou cache. Dans ce sens-là on peut dire qu'elle est profondément matérielle, donc voilà, on est en face d'un paradoxe, puis que c'est elle qui sculpte, c'est elle qui dévoile les matériaux, dans ce sens que les matériaux l'absorbent ou la réfractent, donc en fait on peut dire que en tout cas c'est un révélateur et c'est une onde donc comme le son, sauf qu'elle s'adresse aux yeux et le son s'adresse aux oreilles, mais les deux, voilà, et nous on en aperçoit juste les longueur d'onde qu'on sait percevoir, c'est à dire, relativement peu par rapport à tout le spectre.

2. À propos de votre processus créatif, travaillez-vous généralement avec la même compagnie ou metteur-en-scène ? Quelle est l'aspect le plus importante à considérer, à ton avis, pour la création lumière : les désirs du réalisateur, metteur-en-scène ou dramaturge, les besoins de l'acteur ou de la scène, ou le point de vue du spectateur?

À propos de mon processus créatif, en fait je travaille avec multiple personnes dans de domaines différents, que ce soit le théâtre, la dance, la chorégraphie, l'opéra contemporain ou la musique on va dire electro, par exemple, et du coup voilà, c'est des expériences assez différentes, des impératifs assez différents les uns des autres entre un opéra et un spectacle de théâtre et je travaille avec des gens qui écrivent, donc on part toujours d'une page blanche et le désire du réalisateur, du metteur-en-scène, du dramaturge évidement est fondamentale, surtout dans sa capacité à susciter ou engendrer d'autres désires chez les gens qui l'environnent, chez les collaborateurs. Après il ne s'agit pas de 
répondre à ses désirs mais il s'agit de créer un dialogue avec, de pouvoir, par le désire, exciter la créativité et ça, ça passe aussi par les zones de frictions aussi. Finalement, les besoins de l'acteur, du danseur ou du chanteur évidemment sont à prendre en compte, pas forcément pour son confort mais pour ses impératifs, sont tous des impératifs différents, un danseur par fois doit pouvoir voire le sol selon le type de chorégraphie, un acteur a un certain moment aura besoin d'être ébloui, enfin voilà, tout ça c'est des petite choses dont on doit évidemment tenir compte, un chanteur à un moment donné devra pouvoir voire un moniteur ou le chef d'orchestre de manière à pouvoir prendre la battue, donc ça veut dire que à ce moment-là il ne doit pas être ébloui. Bon ça c'est des petites choses, tout ça c'est un peu du détail, mais c'est quand même important et le point de vue du spectateur, en général souvent quand même on travaille du point de vue du spectateur, certes on se positionne, je me positionne quand je crée une lumière du point de vue du spectateur, donc en fait on enrobe, on va dire, l'ensemble des données et soi-même, enfin, moi-même je suis en fait le réceptacle de ses données et le premier cobaye sensible par rapport à ce qui se passe.

3. La chercheuse de ce travail soutient, à la suite de ses recherches pratiques comme créatrice lumière et réflexives en tant que chercheuse, que l'éclairage scénique participe activement à la scène théâtrale et également à d'autres formes d'arts du spectacle comme la performance, la musique, la danse, entre autres. Dans ce sens-là, elle propose que la lumière performe, agit sur la scène et interagit avec les autres composants du spectacle ainsi qu'avec le public, ayant la fonction importante d'établir et favoriser la relation entre la scène et le spectateur. Êtes-vous d'accord avec cette opinion ? Pourquoi ? Pourriez-vous donner un ou plusieurs exemples de cette performance de la lumière dans votre travail créatif ? Cela peut être un projet ou réalisation lumière entière pour une pièce ou spectacle ou des effets spécifiques, des scènes isolées.

L'éclairage scénique participe activement à la scène théâtrale, également a d'autres formes de spectacle comme la performance, la musique, la danse, 
entre autres, évidemment oui, complètement, la lumière, donc l'éclairage s'écrit dans l'espace-temps tout comme une partition et permet en fait de pouvoir, audelà des atmosphères et des architectures, dessiner une partition on va dire spatio-temporelle, donc c'est un élément fondamentale qui a une part très, très active dans la relation entre la scène et le spectateur. Dans mon travail en fait la lumière avant tout va, tout comme dans la cuisine en fait, on va définir une saveur, donc moi je vais définir les textures, les textures de lumière qui vont nous aider en suite, on va définir une palette et de cette palette en suite on va écrire une partition et du coup chaque spectacle, en fait de toute façon, a sa saveur, son entité propre. En suite évidemment dans ma manière moi d'aborder les choses, il y a une chose qui fait qu'on peut retrouver à travers l'ensemble du spectacle ce qu'on appelle un langage avec des choses reconnaissables de la façon que j'ai de regarder et de donner aussi à voir. Donc chaque spectacle est, comment dire, une expérience, une expérience entre ce qu'on appelle le dispositif scénique et scénographique et la composition de la lumière, la partition. Et après, selon mon travail dans la durée, avec des familles artistiques, évidemment il y a aussi une notion de répertoire, de laboratoire qui se développe et que fera qu'il y aura des spécificités que vont pouvoir grandir et faire suite les unes aux autres.

Juste un exemple dans les derniers travaux qui seront visibles au printemps, Both Sides avec Jeanne Added, une très grande scène de 9 mètres par 4 mètres sur laquelle elle évolue dans un dispositif bi frontale donc le public entourant les deux côtés de la scène et un travail sur une plateforme blanche donc aussi un support comme ça de réflexion de la lumière et un travail où en fait cette plateforme devient une espèce de masse vivante avec pas mal de stroboscope qui viennent dématérialiser tout d'un coup le corps de l'interprète, de Jeanne Added. Et cette plateforme, au fur et à mesure, en fait, on va à l'envers d'un mouvement, d'un concert où on démarrait tout doucement et on finit au sommet. Là en fait on démarre au sommet, le public rentre, on est dans un grand club in, puis en 30 minutes en fait elle démarre, elle est seule en scène, le micro, la musique est diffusée et on est en très, très haut, très haut, comment dire, niveau de mouvement de la lumière, une lumière très dynamique, stroboscope, 
contraste élevé, vagues de lumière, pulsation, etc. Puis en fait, au bout de 30 minutes la scène est démontée à vue du public et on reste sur un carré blanc où là elle entame une basse voix, juste basse voix, donc on est sur une autre chose beaucoup plus brute, 20 minutes, une lumière qui devient un petit peu plus posée et beaucoup plus foccusée sur l'artiste. Encore un peu de mouvement, mais moins de mouvement dans la lumière, puis la scène est encore démontée, on arrive sur un carré de 1 par 1 qui s'élève un peu et là on finit dans la plus grande sobriété lumineuse. Voilà, donc ça par exemple, c'est un exemple d'un des derniers travaux que j'ai effectués. 
Interview Elsa Revol - Éclairagiste Française

1. Je fais ma recherche sur la performativité de la lumière, donc j'ai trois questions pour baser aussi la recherche aussi sur le travail et l'expérience professionnel et pratique des éclairagistes, effectivement. La première question est donc à propos de la matérialité ou l'immatérialité de la lumière, qu'en penses-tu ?

Je dirais déjà que la lumière ne peut exister que s'il y a quelque chose pour recevoir la lumière. C'est surtout que la lumière en elle-même elle n'existe pas, on la voit quand elle impacte sur un corps ou sur un objet ou sur un espace. Donc quelque part comme ça le côté immatériel me touche particulièrement parce que tant qu'il n'y a rien on ne la voit pas. Et elle ne prend vie, elle ne devient matière que quand il y a un corps ou un objet qui la traverse. Donc, quand il n'y a rien elle est immatérielle et quand il y a quelque chose elle devient matière.

On pourrait dire qu'elle est matérielle quand elle est associé à quelque chose d'autre?

Oui, quand quelque chose la traverse, voilà, ou quand elle même percute quelque chose, quand il y a une interaction avec autre chose. Voilà.

Et cette interaction c'est une interaction plutôt informative, sémiotique, elle représente quelque chose ou pas forcément ?

No, no, pas forcément, là dessous on va dire la dramaturgie de la lumière elle est, elle peut être symbolique, elle peut être factuelle, elle peut être beaucoup de choses, ça c'est encore une autre donnée, c'est, au niveau de l'écriture de la lumière c'est un autre... ouais elle peut avoir un éventail très large là-dessous. 


\section{On passe à la deuxième question alors, qui est sur le processus} de création, est-ce que tu travailles habituellement avec les mêmes compagnies ou metteur-en-scène ou ça varie ?

Ça varie beaucoup mais j'ai des grandes affinités et il y a des gens avec qui je travaille depuis longtemps. Je travaille dans plusieurs domaines, on va dire, dans le théâtre, dans le cirque, dans la magie, et dans ces familles là j'ai mes compagnies ou mes metteurs-en-scène que je suis assez fidèlement.

Et est-ce que tu penses que ça influence le travail comme créatrice, c'est à dire, quelle est la différence être invitée pour faire un éclairage pour une de ces compagnies ou alors quand quelqu'un t'invite que tu ne connais pas du tout, que tu ne sais pas du tout, commet ça réverbère sur la création?

Eh, bah, le dernier exemple de nouveauté que j'ai eu c'était l'année dernière, j'ai fait la création lumière de Fauves pour Wajdi Mouawade, donc c'est la première fois que j'ai travaillé pour lui, je n'avais vu aucun spectacle de lui et il n'avait vu aucun spectacle dont j'avais fait la lumière. Donc ça a été vraiment une double découverte et ce que je peux dire c'est qu'il y a un temps très long pour s'apprivoiser, pour... c'est toujours très difficile de parler de la lumière, du coup chacun utilise des mots différents, un vocabulaire différent et donc déjà comprendre le langage de l'autre, savoir quand il dit, je ne sais pas, je n'aime la lumière dure, par exemple, qu'est-ce que ça veut dire, la lumière dure pour cette personne-là ? Ou après Wajdi m'a emmené dans un endroit de couleur qui est un endroit assez inhabituel pour moi, et du coup j'ai eu du aussi aller chercher en moi des choses nouvelles et des choses assez inconnues, assez différentes, voilà. Donc ça nécessite d'être un peu dans un travail de traducteur, en interprète, de comprendre le vocabulaire de l'autre et en suite d'aller chercher en soi comment répondre, comment être là-dedans, et à quel endroit de création activer, on va dire, donc c'est hyper enrichissant, parce que moi ça m'a ouvert des endroits très forts, c'était vraiment une collaboration et une rencontre très, très, très forte, mais extrêmement épuisante parce que ça, on repose sur aucun acquis, on va dire, c'est tout un côté nouveau, du coup par exemple avec Galin 
Stoev avec qui j'ai fait maintenant presque une dizaine de création, j'en ai eu du en faire sept ou huit, on a presque plus besoin de se parler, c'est les choses coulent, roulent, sont beaucoup plus fluides, et du coup il y a un endroit de repos qui permet d'être dans un endroit de recherche, on va dire, plus fluide, plus sûr. Parfois ça peut avoir l'inconvénient d'aller vers l'endormissement, il ne faut pas se laisser un peu trop aller, on va dire, alors que quand c'est plutôt de la nouveauté, bah ça fait être en activité constante quoi, voilà.

\section{Et c'était bien passe ce travail avec Wajdi ?}

Oui, ça s'est très bien passé, c'était très, très, très éprouvant. Très, très, très éprouvant, ça s'est très, très, très bien passé mais du coup s'était d'une intensité phénoménale, quoi, c'était très, voilà, mais oui, oui, ça c'était très bien passé, J'ai revu le spectacle, il a joué plus d'un mois à la Colline (Théatre National de la Colline), du coup j'ai pu le voir après laissé un vrai temps pour que les choses se déposent et de revoir le spectacle, ah, oui, c'était super, oui c'était super. Mais il y avait quand même une sensation de pas fini parce que tout le temps qu'on a passé à se connaître, se découvrir et à se comprendre, tout c'était un temps qui n'a pas été complètement pour la lumière en elle-même du spectacle. Pendant ce temps il y avait le spectacle qui se construisait aussi, du coup j'ai trouvé qu'on a beaucoup couru après le pas, parce que, voilà, il y avait deux choses à faire ensemble, il y avait se découvrir et faire le spectacle, ça faisait double tache, voilà.

Et là par exemple si tu avais l'opportunité de retravailler avec lui ca pourrais être plus à l'aise ?

Ah, oui, bien sûr, parce qu'il y a déjà un langage commun qui se construit ensemble et du coup on partirait de quelque chose alors qu'on ne partait de rien.

Et artistiquement tu penses que quelle situation te provoque le plus, t'engage? Est-ce que ce 'marcher dans le vide', cette incertitude artistiquement ça rapporte plus ou moins, tu vois une différence ? 
Oui, oui, il y a une très grande différence, mais c'est une différence émotionnelle, en fait. C'est que moi j'ai vraiment une impression d'être partie à l'étranger, d'être constamment stimulée par des odeurs, des gouts, des visions des choses, une langue que je ne connaissais pas et du coup quand on est comme ça à l'étranger on est sur stimulé et du coup on est dans un état créatif très fort qui est presque, on va dire, instinctif et dans une réaction très réactive on va dire, alors que quand je travail soit avec Galin soit avec Vasil avec qui j'étais hier soir à la première, ce sont des gens beaucoup plus connus, là j'ai l'impression d'être à la maison, de pouvoir déposer les choses, de pouvoir être moi-même dans un endroit de détente et du coup d'aller chercher en profondeur des choses qui sont... qui arrivent avec de l'apaisement et de la sérénité, alors que sinon c'est des choses qui viennent de très profond, mais beaucoup plus inconsciemment, je ne sais pas comment dire, beaucoup plus réactivement, comme une réaction. Du coup, je dirais que je trouve ça très bien d'enchainer les deux, et de ne pas être que dans un ou que dans l'autre parce que ça permet d'être dans des différentes situations de création, voilà.

\section{On peut s'alimenter mutuellement...}

Oui, bien sûr, ah, bah oui, ça c'est évident.

Et tu parlais de cet engagement avec le metteur-en-scène et chaque spectacle, parce que j'imagine que même quand tu travailles avec le même metteur-en-scène pour plusieurs spectacles, chaque spectacle est un spectacle différent, donc il y a aussi des enjeux spécifiques et il y aussi les acteurs, donc il y a des compagnies qui ont les acteurs, les danseurs fixes et d'autres qui changent tout le temps, le metteur-en-scène mais qui peuvent aussi changer les performeurs. Et il y a aussi le spectateur, donc la suite de la question sur le processus de création est justement qu'est-ce que t'inquiète ou prends plus l'attention au moment de la création : les désirs du réalisateur, metteur-en-scène ou dramaturge, les besoins de l'acteur ou de la scène, ou le point de vue du spectateur? 
Dans le cirque il y a une dimension de danger où la lumière a une parte de responsabilité énorme, donc quand je travaille pour du cirque où il y des agrèges et demandes des spécificités des choses qui sont possibles ou pas possibles, par exemple, un jongleur ne peux pas être ébloui quand il regarde dans l'air et quand il lance ses balles parce qu'il doit voir ses balles, voilà, il n'y a pas de danger physique pour lui, mais c'est une incapacité pour lui de faire ce qu'il a à faire, un fil-de-fériste il doit voire son fil ou il doit voire... certains doivent voir leur fil d'autres doivent voir le sol. II y a des contraintes comme ça pour du trapèze, il faut qu'ils voient absolument la toile du chapiteau ou les mures, ou, voilà. Chaque agrès et chaque circacien a des besoins spécifiques à la performance technique, du coup quand je travaille pour le cirque je m'intéresse d'abord à ces contraintes-là, on va dire. Et du coup je sais dans quelle fenêtre je vais pouvoir, délimite un peu les choses pour pouvoir savoir comment je vais pouvoir créer. Après pour la magie, il y a aussi un endroit de contrainte très fort. II y a des compagnies avec qui je travaille en magie où je prends compte à ces contraintes comme point de départ de création et d'autres compagnies pour qui je travaille avec qui je prends le propos et la dramaturgie du spectacle comme point de départ et les contraintes technique de la magie arriveront dans un deuxième temps. Donc ça, ça dépend vraiment de la manière de travailler, d'apprendre les choses. En théâtre il y a le texte, qui est là, donc c'est le départ, à part au Théâtre du Soleil où c'est des créations collectives, donc là les choses se construisent au fur et à mesure et du coup sont dans une autre temporalité. On va dire que sur le temps des répétitions je ne pense pas au spectateur tout de suite, c'est quelque chose qui vient plus tard. Je pense vraiment au consort de travail du metteur-en-scène où je me suis vraiment rendue compte depuis que j'ai commencé à faire de la lumière que le temps de travail des répétitions est un temps vraiment spécifique et un temps vraiment à part, c'est à dire, une scène qui au final va durer 30 secondes, on peut passer six heures à la travailler quand même. Et du coup si je mets la lumière qu'il y aura dans le spectacle pour ces 30 secondes, si je mets cette lumière-là pendant 6 heures pour travailler, ça ne marche pas, ce n'est pas possible. Du coup je suis très attentive à ce que la lumière de travail, la lumière des répétitions soit une lumière qui permet au 
metteur-en-scène et qui permettent aux comédiens d'être dans l'état nécessaire pour pouvoir créer. Donc pour moi ça c'est un point de départ très fort. Notamment dans le Théâtre du Soleil on est pendant 9 mois en création, on ne peut pas être pendant 9 mois dans une lumière de spectacle, ce n'est pas possible, donc il y a vraiment un ajustement qui se fait au fur et à mesure des scènes, au fur et à mesure du travail, au fur et à mesure de quand on se rapproche de plus en plus du spectacle. Après il y a aussi des cas de figure où j'arrive vraiment au dernier minute, sur une création qui est faite et là ils ont déjà répété en lumière de service et je viens faire la lumière de quelque chose qui existe, ça c'est très différent. Mais, voilà. Après, le spectateur j'y pense dans le sens où je réfléchi toujours à d'où vient l'œil du spectateur pour recevoir ce que je vais lui donner, du coup les choses se construisent presque en temporalité inversée, où quand je veux qu'il y ait un endroit avec un effet ou sensation ou une réception particulière de la lumière, je fais attention à ce qui vient avant pour être dans l'état de recevoir ce que je veux que les gens reçoivent. Ça veut dire que c'est une construction un peu plus tard, c'est une construction très temporelle, très liée à la temporalité du spectacle, donc ça il faut que le spectacle soit déjà beaucoup plus avancé.

Ok je vois, ce serait comme si d'abord tu crées l'effet et puis tu réfléchis s'il va fonctionner, s'il va marcher ou pas auprès du spectateur...

Ouais, c'est un peu ça, c'est un peu ça, voilà, c'est... est-ce que avant je... est-ce que cet effet-là je le fait arriver de manière imperceptible ou est-ce que au contraire je crée une grosse rupture et du coup avant je mets une lumière qui n'a rien à voir et il y a une rupture qui se fait ou alors est-ce que cet effet-là j'aimerais qu'il arrive vraiment en subtilité... voilà, c'est ça.

3. Et là on passe finalement à la dernière question, qu'est par rapport à ma recherche, la performativité de la lumière, c'est à dire, que la lumière elle performe, elle agit sur scène et sur le spectateur, c'est à dire, un peu comme j'avais dit, en action avec les autres composants de la scène. Et 
donc si tu es d'accord avec ça, avec cette action de la lumière, je dirais même une action autonome, même si elle n'agit qu'en conjonction avec les autres composants, mais c'est à dire, son action comme élément autonome, indépendant en conjonction avec les autres et non pas qu'il existe en fonction des autres comme on a cru pendent longtemps, que la lumière existait pour montrer le travail des autres. Je dis plutôt le contraire, je dis qu'elle a rôle à jouer. Qu'est-ce que tu en penses ?

Bah, j'en pense que d'une manière bien directe j'aime bien que la lumière que je fais ne se voit pas, du coup que ne se voit pas c'est à dire que le spectateur ne décroche pas du spectacle qu'il est en train de voir et de recevoir parce qu'il y a quelque chose en lumière que le fait se décrocher sans raison, on va dire, voilà. Ce n'est pas pour ça que la lumière n'existe pas, et ce n'est pas pour ça que la lumière doit être très ?? ou très invisible, c'est d'être à un endroit juste parce que il y a plusieurs composants qui font le spectacle et il y a évidemment les personnes sur scène mais il y a aussi la scénographie, il y a aussi le son, il peut y avoir la vidéo, et la lumière donc tous ces composants-là doivent prendre en charge certaines choses et ne pas être que en addition les uns et les autres, en surcharge, on va dire. Et c'est vrai qu'il m'est arrivé plusieurs fois de faire des spectacles où d'un coup on se retrouve avec la personne du son, moi, la vidéo à se dire mais là on est en train de dire les trois la même chose, donc est-ce qu'on ne peut pas changer ça parce que c'est trop, du coup est comédiens sur scène, enfin, sont écrasé par le poids du son la vidéo et de la lumière, donc on essaye de réajuster les choses pour que ça s'équilibre aussi. Après le côté je dirais un peu plus performatif, il y a un spectacle que j'ai fait il y a deux ans qui s'appelle Je suis la Bête de Julie Dellile où la lumière a une part très, très, très importante dans l'écriture même du spectacle. Je pense que il y a vraiment une dimension performative là dans l'écriture même de la lumière et de ce que la lumière dit, prend en charge ce..., dans l'ambiance que sa..., c'est vraiment un spectacle qui démarre dans le noir complet et petit à petit les choses commencent à arriver, à se dessiner, de la pénombre vraiment les choses naissent et l'espace est ensuite habité par la lumière, il y a des effets vraiment de lumière, d'orage, de flashes, de présence de la lumière avec de la fumée, de tout qui est visible dans l'espace, 
il y a aussi tout un jeu de reflet mouvant et mobile de la lumière sur le corpos de la comédienne et en même temps c'est toujours quelque chose qui est en accompagnement de ce qui se passe, qui reste au service du spectacle, pas forcément de la comédienne mais du spectacle et je pense que ça c'est quelque chose que Wajdi Mouawade dit beaucoup, c'est que malgré que ce soit lui qui écrive le texte, lui qui fasse la mise-en-scène, le spectacle est une chose qui est en dehors de lui et qu'il dise que chacun participe à ce spectacle, c'est vraiment ça et du coup je pense que, ouais, la lumière devient vraiment performative quand elle est au service du spectacle, ouais, c'est ça.

On pourrait dire ça, effectivement pas que de la lumière, mais de tous les composants, par exemple...

Ouais, bien sûr.

Cela ne veut pas dire, quand je parle de la performativité de la lumière, que je cherche un protagonisme de la lumière, mais qu'il n'y a plus de protagoniste. C'est une action commune. C'est un peu ça, elle est équilibrée avec le reste.

Oui, elle a surement à dire du spectacle et pour le spectacle, et elle a sa place réelle, on va dire, que n'est pas juste de faire en sorte que le spectateur voit ce qui se passe sur scène, il y a vraiment une dimension d'écriture, une dimension de dramaturgie, de notion de prise de parole aussi de la lumière, dans le rythme aussi, dans l'ambiance, dans la couleur, ouais, dans tout ça quoi.

Tu as parlé un peu du rythme, je ne sais pas si tu as l'habitude de faire la régie dans tes éclairages, mais quelle est ta relation avec le régisseur lumière, quel est son rôle ? Si la lumière a une performance, il faut penser qu'elle soit bien faite...

Ah, oui, c'est très important, oui, il y a, on va dire, deux spectacles dont je fais, moi, la régie et tous les autres spectacles dont je fais la lumière c'est pas moi qui fait la régie et en fonction du régisseur lumière, si c'est moi qui le choisie, si c'est pas moi qui le choisie, si c'est quelqu'un qui m'accompagne dès le début 
de la création, si c'est quelqu'un qui arrive juste avant la première je modifie l'ambition que je peux avoir sur la performativité de la lumière, où du coup je m'adapte pour être sure que ça va être à chaque fois de qualité je m'adapte à la personne que j'ai à mes côtés. Si je sens que c'est quelqu'un qui est très sensible, très à l'écoute et qui est très à l'aise dans des parties un peu d'improvisation je me permet d'avoir une liberté un peu plus grande dans le sens des choses à faire dans l'ambiance du plateau, si c'est aussi un spectacle qui ne va pas trop tourner, voilà, et qui sa garde ce côté un peu de nouveauté à chaque fois, je me permets ça. Si c'est un spectacle qui va jouer tous les soirs pendant deux mois où c'est quelque chose qui va devenir une routine ou routinier ou tout ça j'essaye de cadre les choses informatiquement le plus possible pour que si j'ai des effets un peu complexes au niveau temporel j'essaye de les programmer vraiment au maximum pour que ça puisse être au plus proche de c'est que j'aurais souhaité, voilà. Après c'est vrai que j'aime bien revenir de temps en temps parce que le vivant du spectacle vivant bouge forcement donc essayer un peu de réajuster les choses, de modifier ou, voilà. Des fois ce n'est pas possible, des fois ce n'est pas possible du tout, mais quand c'est possible c'est vrai que c'est très agréable de pouvoir faire un peu évoluer les choses aussi, quoi.

\section{Est-ce que tu as des régisseurs ou des assistants qui} t'accompagnent dans tout le processus de création ?

J'ai des régisseurs lumière, comme je travaille avec les mêmes compagnies souvent les régisseurs lumière sont associés aux compagnies du coup c'est des gens que je retrouve, après ce n'est pas forcément le terme d'assistant, il est plutôt présent sur le temps des répétitions, en fait, de création où c'est quelqu'un qui ne vas pas forcément être le régisseur lumière, il peut être justement un lien entre le régisseur lumière et moi. Ça, ça existe aussi. Après tout dépends de l'échelle de la création et de la production. II y a aussi beaucoup, beaucoup de spectacle où je suis toute seule, c'est moi qui fais la régie pendent les répétitions, c'est moi qui suis derrière le jeu d'orgue et à la fin, on va dire, sur les deux dernières semaines il y a quelqu'un qui vient et je lui apprends à faire ce que j'ai fait pendant toute la création. Ça aussi c'est très courant. 


\section{Et dans quelle situation tu te sens plus à l'aise, plus confortable ou plus sûre?}

Ça varie tellement, c'est plus confortable quand c'est quelqu'un avec qui j'ai déjà travaillé où du coup il y a un endroit de langage commun, quoi, qui est rapide. C'est confortable aussi quand je sens que la personne ne comprend pas vraiment ce que je veux et que cette personne me laisse toucher au jeu d'orgue où je peux faire moi. II y a des endroits où ce n'est pas possible et où il faut que j'arrive à mettre des mots sur ce que je veux en lumière et que ça puisse être passé par le régisseur, quoi. Voilà, ça c'est compliqué, mais, voilà, ça c'est très difficile parce que du coup ça bloque toute spontanéité en répétition, il faut réussir à anticiper les choses beaucoup et ça demande de mettre les choses en mots, alors que des fois c'est instinctif, je sens qu'il faut monter ça et ça, mais juste le temps de l'expliquer la scène est passé, tout le moment est passé et des fois ça me gonfle d'avoir à lui dire, du coup je préfère ne pas lui dire et pas le faire et garder l'idée dans la tête et on essayera, en dehors du plateau plus tard, de faire ça, quoi. Comme ça c'est vrai que c'est difficile. Et c'est très courant. Après ça dépends, je pense que ça dépend des affinités, ça dépend des habitudes de travail, ça dépends de beaucoup de choses, c'est très variable.

Et dans ce côté numérique de l'éclairage, est-ce que tu préfères enregistrer les choses ou tu aimes plutôt faire manuellement ? C'était comment hier?

Alors hier, donc hier c'était la première de / Woke up in Motion de Vasil Tasevski qui est quelqu'un avec qui je travaille depuis six ans sur ce même spectacle. Ça fait six ans qu'on travaille sur ce spectacle et on a beaucoup fait de résidences avec des sorties des résidences et où du coup je n'avais en six ans jamais enregistré une seule mémoire. J'étais toujours à faire les choses d'une manière très performative pour le coup dans le sens art contemporain et performance scénique et là avec la première qu'arrivait je me suis dit que j'avais besoin d'avoir quand même une conduite structurée avec des états lumineux enregistrés, du coup j'ai enregistré certains états lumineux, certains pas de 
conduite mais il restait quand même beaucoup de moments où j'étais en directe avec les projecteurs sur les masters et à faire en directe comme ça, quoi.

Oui, je sentais à plusieurs moments où la lumière vraiment respirait avec le performer, c'était quelque chose de très sensitif et pour ça je n'imaginais pas de le faire enregistrer.

Non, ça ce n'était pas possible, j'aime bien réussir à mettre ça même dans un spectacle, ce que je disais dans, par exemple, dans Je Suis la Bête, on va dire qu'il y a $90 \%$ de la lumière enregistrée en mémoire, mais j'ai gardé quand même des endroits, de petites plages des moments avec une lumière plus improvisée, plus en accompagnement avec ce qui se passe au plateau, etc. Et ça je pense que c'est des choses, quand le régisseur lumière a cette sensibilitélà, il peut beaucoup apprécier être là-dedans et se mettre en état de dialogue avec le plateau. Après il y a des régisseurs lumière qui ne sont pas du tout à l'aise avec ça et qui préfère être dans une réalisation plus mécanique parce que ça leurs conviens mieux. Mais là pour le coup j'ai un régisseur lumière pour ce spectacle qui était vraiment en phase avec ça, avec aussi cette envie d'être dans un accompagnement, ouais, en dialogue vraiment avec le plateau, c'était ça.

Je ne sais pas si ça peut se dire comme ça, mais ça veut dire qu'en dépendant du régisseur lumière que tu as disponible ça peut te limiter un peu la création ?

Oui, bien sûr.

C'est dur. Et c'est fréquent que tu ne puisses pas le choisir ? Cela me semble très complique de ne pouvoir par choisir le régisseur lumière, je ne peux même pas imaginer.

Ouais, c'est très compliqué, complètement, ça limite et en même temps ça nécessite d'avoir une gymnastique cérébrale au moment de la création assez forte pour se dire ok, là je sens que vraiment pour le spectacle il faut que j'arrive à faire ça et la lumière qui est appelé pour ce moment pour ce spectacle, enfin, il faut que ce soit comme ça et du coup je sais que c'est ça, du coup, je sais que 
c'est ça, moi si c'était moi qui le faisait j'aurais pu le faire de cette manière, de cette manière, de cette manière, et là comme c'est quelqu'un d'autre qui va devoir le réaliser, comment réussir à faire passer l'essentiel, le sens même de cette chose avec les moyens que j'ai ? Et les moyens humains que j'ai aussi ? Du coup je trouve que ça fait poser des questions très justes, ça limite et en même temps ça ramène à un endroit d'essentiel qui est aussi très intéressant parce que j'ai fait la toute première création lumière que j'ai fait le régisseur lumière m'a dit oh, mais moi tu sais, je n'aime pas du tout ce qui est enregistré, j'aime beaucoup suivre les gens au plateau, etc., j'ai dit ah, bah génial, super, bah écoute très bien, du coup on va travailler ensemble pour ça. Je retourne voir le spectacle, c'était catastrophique, mais catastrophique, parce que bah, il n'y avait plus rien à voir avec ce que moi j'avais comme vision de la lumière etc. Du coup quelque part l'enregistrement est aussi un endroit pour préserver aussi, il y a une base sûre, on va dire, quoi. Et ça, il y a ce côté-là qui est bien. Non, enfin, ça limite mais, tout comme des fois on n'a pas assez de grada et ça limite ou comme on n'a pas les projos qu'on veut, ça limite, enfin, voilà, c'est des contraintes qui le prend comme une contrainte en plus de toutes les autres contraintes donc ce n'est pas un problème en soit, quoi. II y a eu quand même une fois où j'ai demandé est-ce qu'on change le régisseur lumière parce que vraiment je sentais que ça allait vraiment desservir le spectacle, que ça allait être vraiment trop, ouais, trop pas adapté à ce dont le spectacle avait besoin, c'était même pas ce dont la lumière allait avoir besoin, c'était ce dont le spectacle avait besoin, à ce moment-là la metteur-en-scène a très bien compris, on en a discuté et puis voilà les choses se sont faites très simplement, mais c'est vrai que j'ai eu du réagir quand même assez vite pour signaler ça, quoi.

\section{Et en ce qui concerne les performeurs, est-ce que tu sens qu'il y a} des compagnies ou des performeurs sur qui tu peux compter plus pour le résultat de la lumière?

Ah, bah, ça c'est clair, bien sûr, bien sûr. Il y a des gens qui se place dans la lumière et il y a des gens qui ne se place pas dans la lumière, il y a des endroits de sensibilité qui sont très, très différents, c'est clair. Il y a des personnes qui ont 
une stabilité dans les positions par exemple ou dans le rythme qui est très agréable parce que du coup la lumière elle va pouvoir se construire avec d'une manière simple et puis il y en a qui sont beaucoup plus imprévisibles et du coup qui sont toujours à côté de la plaque soit au niveau du temps soit au niveau de la place et c'est compliqué, quoi.

\section{Mais il y a aussi un côté improvisationel qui peut être positive aussi ?}

Une fois que la création est faite, je dirais que si le propos du spectacle n'est pas à être dans une improvisation, le propos du spectacle est quand même d'être dans une chose qui est plutôt écrite et qu'on est dans une représentation donc comme ça, d'avoir des gens un peu stables c'est bien, parce que c'est quand même plus simple, quoi. J'ai fait un opéra l'année dernière où il y avait des solistes qui se plaçaient parfaitement tout le temps au même endroit à la même note et puis il y en avait vraiment, ils étaient ingérables, quoi. Et c'est compliqué, c'est compliqué parce que du coup il faut pouvoir réajuster les choses en cours de route et ça nécessite d'être dans une adaptation qui n'est pas forcément bien venue à ce moment-là. Voilà. Quand les choses ne sont pas dans un cadre d'improvisation je trouve que c'est quand même plus simple d'être plus régulier, quoi.

Encore à propos du spectacle de hier, pour les musiciens sur scène, j'ai vu que tu les éclairais très rarement, voire presque jamais, c'était une option à toi ou du danseur?

Alors, ils étaient beaucoup moins éclairés que ça et on a décidé que comme moi j'étais sur scène et qui j'avais une lumière qui émanait de la régie et du coup que j'étais faiblement visible, il y avait besoin parfois de rééquilibrer un peu cette chose-là donc j'ai réajusté en leur mettant des fausses lampes de régie qui ne leurs servent pas, mais qui servait juste à faire des petites lueurs pour les percevoir à des moments. Déjà eux ils n'avaient absolument pas besoin de se voir ou de voir des partitions, c'était vraiment de l'improvisation, ils étaient ensemble quoi. Là ils se connaissent tellement et on a tellement travaillé ensemble, ça fait six ans quoi que du coup il y avait un endroit de confort, de 
connaissance et de confiance qu'a fait qu'il n'y avait pas ce besoin-là. Et Vasil avait vraiment envie qu'il y ait des moments vraiment de noir, des moments où la musique émane de l'obscurité, donc ça s'est fait ensemble.

\section{Et la projection c'était créé par lui-même?}

Oui, c'est Vasil qui a fait toute la vidéo. II a fait une école de cirque à Charlon-en-Champagne, et ensuite il était au Fresnoy à côté de Lille vraiment une école d'art contemporain pour vraiment développer tout son côté visuel de photographie et de film. II a un rapport à l'image très fort, la matière image très forte.

Et j'ai vu qu'il y avait des moments dans le spectacle où effectivement la lumière s'éteignait presque complètement pour laisser la projection...

Ouais, tout à fait. Ouais, ouais, la projection est autant source de lumière que la lumière des projecteurs, on va dire. Ouais, on a vraiment travaillé ensemble là-dessus conjointement, quoi.

Et puis une dernière question, peut-être, sur ce choix d'être sur scène. Est-ce que tu penses que pour que la lumière performe il faut y être et quel est l'importance dans ce spectacle d'être sur scène, ça changerait quelque chose si tu étais dans la régie?

Bah, c'est moi qui a demandé d'être au plateau. On a beaucoup fait des résidences où on était que tous les deux et il n'y avait personne d'autre, même pas les musiciens. On a fait beaucoup des moments de travail juste tous les deux, du coup j'avais le jeu d'orgue au premier rang des gradins et lui il était sur scène, donc j'étais très proche de lui mais en frontal, mais très proche. Et on s'est vite rendu compte qu'on avait besoin de cette proximité-là. Et en plus de ça il y avait la question de la vidéo, de l'ordinateur qui envoie la vidéo. Au début c'est lui qui envoyé les vidéos et du coup il faisait des aller-retours entre l'ordinateur et le plateau, petit à petit c'est moi qui a pris ça en charge dans la régie, on va dire, du coup il y avait un pôle de régie technique sur le plateau par rapport à la 
présence de la vidéo et puis au début du travail j'avais absolument enregistré aucune mémoire et je faisais tout, tout, tout, tout en directe et du coup la distance d'être en régie avec la séparation avec le publique, c'est à dire qu'il y avait le plateau, toute la masse du publique et ensuite moi, ça me coupait énormément, j'avais beaucoup de mal à être dans la bonne ouverture, écoute, disponibilité pour pouvoir être avec, pour pouvoir être ensemble. Et puis ça déséquilibrait beaucoup les choses le fait que les musiciens étaient au plateau, ça semblait tout de suite très logique que je sois aussi proche.

Et vous n'avez pas pensé à garder cet endroit au premier rang, par exemple?

Si, on y a pensé, mais ça gênait trop le publique, il y a eu un moment où j'étais au premier rang mais sur le côté et après j'étais directement comme ça au plateau pour être vraiment ensemble, parce que c'est vrai qu'au bout de six ans de travail on avait envie de montrer quelque chose ensemble, quoi. C'était vraiment tous les cinq, quoi, les trois musiciens, Vasil et moi, vraiment un endroit de... voilà. Après, c'est vrai que ça ne me semble pas du tout impossible que la lumière soit performative avec une régie pas au plateau et il y a des moments où on veut faire comme si la lumière était performative en mettant la régie sur le plateau et ça ne marche pas du tout non plus, enfin, je pense que ça n'as pas de lien entre la performativité de la lumière et la régie au plateau, mais pour ce cas précis-là je ne pouvais pas être ailleurs.

\section{Donc c'est plutôt la proximité que d'être visible.}

Ah oui, oui, complétement, exactement, j'aurais pu être cachée sans problème, mais c'était d'être proche. Je le vois qu'il me voit, que ce soit quelque chose ensemble dans les deux cas de figure. Mais pour le publique ce n'est pas nécessaire qu'il voit cette relation, et c'est pour ça aussi que j'ai essayé de masquer au maximum les lumières de la régie pour qu'on me voit le moins possible, j'ai gardé que la lumière utile, le minimum pour pouvoir travailler et sinon j'aurais mis-en-scène cette position de régie et ma position au plateau, mais là non, ce n'était pas le cas, non, non, c'est vraiment qu'on ait une proximité tous 
les deux de travail et que en cas de besoin aussi il y ai aussi une possibilité qu'il puisse venir me voir, ce qui est arrivé des fois, pas hier, mais il y a des fois où il y a eu des besoins, voilà, c'est plus ça.

Et pour finir, dans le spectacle de hier ou si tu préfères, dans d'autres spectacles, est-ce que tu arrives à me donner des exemples de la performativité de la lumière où tu sens que la lumière vraiment a eu, en conjointions avec la scène un rôle performatif.

Je dirais que je pense tout de suite à un autre travail que j'ai fait avec des danseurs, le travail s'appelle Ondes et Fréquences et on a travaillé avec des cas de figures assez agréables dans le sens où on arrivait dans des théâtres où il y avait des spectacles qui jouaient le soir et on ne pouvait pas accrocher des projecteurs et du coup je faisais la lumière de cette performance Ondes et Fréquences avec le plan de feu d'un autre spectacle et de quelqu'un d'autre où je ne savais pas ce que c'était, je ne savais pas à l'avance et on se lançait dans des improvisations où je découvrais au fur et à mesure ce qui était la lumière. Du coup il y avait un endroit comme ça de travail qui était vraiment dans une ouverture énorme de prendre les choses tels qu'elles sont, comme elles viennent sans rien prévoir à l'avance. II y a dans le travail avec Vasil là de I Woke Up in Motion il y a eu aussi un peu ce genre de chose où on a beaucoup était en improvisation où on faisais les choses, on avais un peu des endroits de canva, mais l'écriture s'est faite comme ça où on cherchait ensemble, du coup la lumière a eu très vite une place très importante dans la dynamique de cette écriture, donc je pense que il y a ça, il y a aussi des moments où le rythme de la lumière avec des effets de chasers, des effets de couleurs, des effets comme ça de mélange de la vidéo, le réflexe de la vidéo, la lumière en elle-même et des choses visuelles fortes dans lesquelles les corps entrent aussi et qui sont les points de départ des séquences aussi, voilà.

Est-ce que dans ce travail avec Vasil il y a eu des moments où la lumière a été propositeur des actions, mouvements, placements ? 
Il y a ce chemin qui était vraiment le point de départ de la création où du coup la lumière au départ était vraiment que dans ce chemin, et toute la question de chasers aussi avec son agrès de sphère qui tourne comme ça aussi ça a été aussi très un point départ de travail. Le travail sur la couleur, le complémentaire, la complémentarité des couleurs pour aller vers le blanc, avoir des zones colorées, ça c'est aussi quelque chose qu'n a aussi travaillé plus dans la performance qu'on a fait ensemble au Fresnoy pour sa fin d'étude donc oui, il y a eu des moments de recherche vraiment, complètement que sur la lumière et ensuite le mouvement en a décollé.

Bah ok, merci beaucoup.

Bah, je t'en prie

Merci de ton temps, de la disponibilité juste après une première.

Avec plaisir. 
Domande Fabrizio Crisafulli - Lighting Designer e Regista Teatrale

\section{Quando si tratta di luce e illuminazione, lei considera la luce di scena come materiale o immateriale? Perché?}

Per quanto, da un punto di vista fisico, si possa dire che la luce sia un elemento immateriale, dal punto di vista artistico tendo a considerarla una materia. Quindi qualcosa che ha una sua sostanza, che può essere modellata, e alla quale si possono dare forme e configurazioni capaci di far divenire la luce stessa un elemento "concreto", capace di "presenza".

Sono nato alle pendici dell'Etna, e fin da bambino, osservando le colate laviche di notte, ho avuto questa percezione della luce come materia e come forma, e questo credo mi abbia influenzato molto nello sviluppo di questa idea. Rispetto alla dualità materiale-immateriale c'è un ulteriore aspetto che mi interessa, che riguarda il rapporto della luce con la scena, gli oggetti, gli attori: è la sua capacità di conferire a questi elementi materialità $o$ immaterialità a seconda di come venga impiegata. In particolare, a seconda che si tratti di luce diffusa o concentrata e di come venga regolata la sua potenza. È evidente che una luce diretta, dura, che crea ombre nette, rende la cosa illuminata più "materiale" rispetto a quanto fa invece una luce soffice, diffusa; e che esiste un livello di intensità della luce al di sotto del quale tutto appare diafano, immateriale e che alzando la potenza tutto acquista invece concretezza e materialità. Spesso utilizzo queste differenze in senso drammaturgico e poetico. A volte, ad esempio, mi è capitato di utilizzare lentissime variazioni di intensità della luce, proprio per esplorare i tantissimi gradi del rapporto materiale-immateriale, esperibili come tali sul piano percettivo, ma che possono diventare significativi anche sul piano drammaturgico.

2. Per quanto riguarda il suo processo creativo, di solito lavora con la stessa compagnia o con lo stesso direttore? A chi è diretta la sua luce? Alla volontà del regista, alle esigenze degli interpreti o allo sguardo dello spettatore? 
In realtà, sono un regista e normalmente progetto anche lo spazio e la luce dei miei spettacoli. Non progetto la luce per altri. L'ho fatto in passato, ma a un certo punto ho smesso di farlo perché non andava bene. Nella mia concezione, la luce teatrale è un elemento primario e generativo rispetto a tutto il resto, esattamente come lo è la luce nel mondo reale.

Nel mio lavoro teatrale, questo implica che la luce si collochi in prima linea già nella fase di ideazione dello spettacolo. Partecipa, alla pari con gli altri elementi espressivi, alla definizione dello spirito, del senso, del carattere poetico e della drammaturgia del lavoro. Ha una propria autonomia di azione e quindi un peso rilevantissimo rispetto alla regia.

Nelle collaborazioni che nel corso del tempo ho accettato di fare, quasi sempre perché ero amico del regista o del coreografo (tutte anteriori al 2004), ho verificato che il mantenere la mia concezione della luce comportava una notevole incisività nei confronti dell'ideazione del pezzo e della regia, e questo creava difficoltà nel lavoro e, a volte, anche nei rapporti. Dovevo quindi inevitabilmente "retrocedere" e limitarmi a cercare di fare delle "belle luci", che non è proprio quello che mi interessa. Mi interessa invece che la luce sia un elemento strutturale del lavoro. Un elemento sorgivo e suscitatore.

Per quanto riguarda la questione "a chi è diretta la luce", direi che considero la luce rilevante ed incisiva rispetto a tutti gli aspetti ai quali ha accennato: la regia, come ho detto; così come il performer e lo spettatore. E come tale la uso.

3. La ricercatrice Nadia Luciani sostiene, come risultato della sua pratica e dei suoi studi, che l'illuminazione del palcoscenico ha un ruolo attivo nella scena teatrale (cosi come nelle altre forme di arti performative come la musica, la danza, tra le altre). Con questo afferma che la luce agisce, agisce sul palcoscenico e interagisce con le altre componenti dello spettacolo e con il pubblico, avendo l'importante funzione di stabilire e favorire il rapporto tra il palcoscenico e il pubblico. Lei è d'accordo con questa opinione? Perché? Potrebbe fare uno o alcuni esempi di questa 


\section{performance della luce nel suo lavoro creativo? Può essere un intero progetto o uno o più effetti specifici.}

Condivido perfettamente la sua idea della luce teatrale come luce attiva, tanto da aver scritto nel 2007 un libro sull'argomento che si chiama proprio "Luce attiva", traendo questa definizione da Adolphe Appia, cui il volume è dedicato. Nel libro analizzo come tale idea si sia evoluta dalla fine dell'Ottocento ad oggi nel lavoro di molti protagonisti della scena teatrale occidentale, ed espongo anche la declinazione che essa assume nella mia stessa ricerca di regista.

Nel mio lavoro il carattere attivo e interattivo della luce è sempre presente, senza eccezioni. Volendo fare comunque un esempio, risalirei al primo spettacolo che ho realizzato da autore e da regista, II pudore bene in vista, del 1991. Quel lavoro nasceva da una lunga esperienza di laboratori che avevo condotto in Sicilia dalla metà degli anni Ottanta, con la quale portavo avanti una ricerca (che ho sempre continuato a fare con i miei allievi, fino ad oggi) sul linguaggio autonomo della luce in teatro. II mio riferimento era la musica. La luce può sviluppare un proprio percorso autonomo in teatro, come può farlo il suono? Può farsi, come la musica, Tempo, discorso, senso, poesia? I laboratori erano nati inoltre dall'idea di restituire alla luce, in scena, un ruolo conforme a quello che essa è nella realtà. Un ruolo energetico e innervante. $E$ di estendere la concezione della luce teatrale oltre i domini ai quali in genere viene fatta appartenere, che sono quello tecnico e quello visivo. I laboratori avevano prodotto fino ad allora una decina di spettacoli senza testo e senza attori, interamente basati sulla luce, gli oggetti, il suono. Erano quindi privi di quegli elementi cui solitamente si affidano il senso e la drammaturgia di uno spettacolo teatrale. E sono stati fondamentali per me per elaborare, appunto, un linguaggio autonomo della luce in teatro e per comprendere come la luce possa farsi struttura, senso, drammaturgia. In II pudore bene in vista, che aveva avuto il proprio terreno di coltura in quei laboratori ma nel quale vi era per la prima volta la presenza di performer in carne e ossa, la luce svolgeva comunque un ruologuida. Era Tempo nel quale le azioni si inserivano, Spazio rispetto al quale si organizzavano, ed era a sua volta Azione con cui le attrici si relazionavano. In un 
certo senso, tutto, anche i gesti e le parole, "nasceva" dalla luce, la quale marcava le posizioni, condizionava i movimenti, indicava le cose da fare. Vi si ribaltava completamente il consueto rapporto attore-luce. Questa qualità dell'interazione che in quello spettacolo aveva forme estreme a favore della luce, in spettacoli successivi ha assunto forme più paritarie, nelle quali la forza delle azioni attoriali e quella delle azioni di luce tendono a bilanciarsi. Ma in quel momento l'assunzione di quelle forme estreme mi interessava molto proprio per comprendere la capacità autonome della luce come linguaggio e come sostanza drammatica. 


\section{Domande Gianni Staropoli - Lighting Designer}

\section{Quando si tratta di luce e illuminazione, lei considera la luce di scena come materiale o immateriale? Perché?}

Luce e illuminazione, nel linguaggio universale, sono due termini di grandissimo significato e bellezza. Due definizioni che convergono per natura nello stesso punto, che è un punto di origine.

La congiunzione "e" all'interno della sua domanda, istintivamente - non saprei spiegarlo - mi riporta in qualche modo a immaginare quell'origine; alle infinite declinazioni e suggestioni, che scaturiscono ogni volta che mi trovo a fare riflessioni intime sulla luce. Si inanellano mondi grazie ad una semplice "e" di congiunzione. Luce e ombra, vicino e lontano, reale e irreale. Infinite altre "e" che annullano siderali distanze.

La luce di scena, è senza dubbio una luce pensata e costruita, che si fa concreta. Nel momento in cui la si costruisce, la rendiamo viva e attiva, dimenticando per nostra fortuna la sua natura artificiale ed effimera. Ed è anche per questo semplice motivo, a mio parere, che può divenire materiale e immateriale allo stesso tempo. Si lascia plasmare proprio perché materia metamorfica di costruzione dello spazio scenico.

Quando mi approccio ad un nuovo lavoro, che sia prosa o danza, dopo una primissima fase - necessaria - di "soglia" e di orientamento nel tutto e tra tutti, successivamente, addentrandomi nel vivo del lavoro e delle relazioni, vedo affiorare i codici che caratterizzeranno il senso e l'estetica dello spettacolo. Con ciò, voglio dire che, affiorando i codici e le intenzioni registiche, affiorano inevitabilmente anche quelle che saranno le caratteristiche sostanziali della luce da costruire. Per me lo spazio determina sempre la luce e viceversa. E' la natura dello spazio scenico - lavorandoci bene - che trasforma la luce in materiale o immateriale; dipende cosa incontra la luce. Dipende come percepisco e interpreto quell'insieme. Posso dire con certezza di sensazione, che quando penso e creo la luce, creo e avverto l'immateriale - la sostanza più preziosa della 
luce - quando illumino per illuminare, avverto il materiale - la possibilità più concreta della luce - la forza tangibile anche. Non è un'equazione superficiale ma un insieme di percezioni soggettive. Personalmente preferisco sempre provare a costruire una luce che sia immateriale nell'insieme - nel senso metafisico - provo a conferire alla luce un senso alto e un segno il più possibile leggero e elegante. Poi da lì tutte le variazioni e modulazioni necessarie per un lavoro drammaturgicamente approfondito e misurato.

\section{Per quanto riguarda il suo processo creativo, di solito lavora con} la stessa compagnia o con lo stesso direttore? A chi è diretta la sua luce? Alla volontà del regista, alle esigenze degli interpreti o allo sguardo dello spettatore?

Sono un libero professionista e lavoro prevalentemente con la prosa e con la danza contemporanea. Mi piace molto cimentarmi con la drammaturgia contemporanea e per quanto riguarda la danza, amo la coreografia contemporanea che usa lo spazio scenico nella sua nudità. Ho la fortuna di collaborare con diversi registi e coreografi e questo spaziare mi permette di maturare profondamente il mio sguardo e la mia esperienza. Lo spettacolo dal vivo si fa nello sguardo anch'esso vivo.

Vorrei dire che quando lavoro, sono sempre immerso nel pensiero della luce: il pensiero che nutre il lavoro è un mio percorso personale ma lo spettacolo è ovviamente il mezzo unico per finalizzare il mio intimo pensiero - si lavora sempre in sinergia e in ascolto con tutti - e senza lo spazio scenico non credo avrei modo di alimentare il mio pensiero sulla luce e lo spazio.

Lavoro per contribuire alla creazione dello spettacolo e il pubblico è parte integrante dello spettacolo. Mi capita spesso di sentire il desiderio di arrivare a toccare direttamente con la luce il pubblico in sala e quando riesco a farlo, mi rende felice poter comunicare ed esprimermi in questo modo. Può capitare che durante le prove e gli allestimenti io avverta il desiderio di fare una cosa precisa 
che coinvolga gli spettatori. Inoltre non credo che lo spettacolo dal vivo debba farsi in una cornice ma "espandersi" nello spazio e lo spazio degli spettatori è pur sempre parte attiva dello spettacolo.

3. La ricercatrice Nadia Luciani sostiene, come risultato della sua pratica e dei suoi studi, che l'illuminazione del palcoscenico ha un ruolo attivo nella scena teatrale (cosi come nelle altre forme di arti performative come la musica, la danza, tra le altre). Con questo afferma che la luce agisce sul palcoscenico e interagisce con le altre componenti dello spettacolo e con il pubblico, avendo l'importante funzione di stabilire e favorire il rapporto tra il palcoscenico e il pubblico. Lei é d'accordo con questa opinione? Perché? Potrebbe fare uno o alcuni esempi di questa performance della luce nel suo lavoro creativo? Può essere un intero progetto $o$ uno o più effetti specifici.

Sono pienamente d'accordo sulle questioni che formano la sua domanda.

La luce agisce sul-il palcoscenico e lo trasforma attivamente. Ma la luce è trasformativa - che sia libera nel cielo o nello spazio scenico costruito - e si attiva grazie all'interazione-relazione con tutte le altre componenti creative. Ritornando al concetto d'illuminazione, credo che un palcoscenico non debba essere "illuminato" ma, pienamente agito e movimentato con la luce. I corpi nello spazio scenico senza una relazione con la luce, sarebbero burattini di legno nello spazio vuoto.

La luce è il cardine che favorisce sì il rapporto palcoscenico e pubblico. La luce è una materia viva e attiva necessaria tanto nella vita quotidiana quanto alle arti sceniche tutte. E il pubblico in sala riconosce e si riconosce sempre con la luce di scena, perché fuori vive nella luce. In occidente questo ha un valore mentre in altre aree del modo è indubbiamente diverso. Lo spazio e la luce sono la mia realtà. 
Qualche anno fa, per uno spettacolo, feci costruire un grande specchio girevole - azionato dalla consolle - era posizionato in scena a vista sul lato destro. Durante una scena "drammatica", insieme alla musica, azionavo lo specchio, che iniziava a girare su se stesso lentissimamente e quindi abbagliando il pubblico in sala con una fortissima luce. Col crescere della scena, aumentavo gradualmente la velocità fino al massimo, per cui ogni passaggio era un abbaglio intensissimo e quasi violento sull'attore e sul pubblico. A mio parere funzionava molto. Dava alla scena, nella totale concretezza, una tangibile luce drammatica e violenta.

Secondo me quando si costruisce un progetto luci, non bisognerebbe mai trattare la luce come materia per fare effetti, ma, provare a comunicare qualcosa, che possa dare la giusta evidenza allo spazio e ai corpi. 
Domande Pasquale Mari - Lighting Designer e Direttore della Fotografia

1. Quando si tratta di luce e illuminazione, lei considera la luce di scena come materiale o immateriale? Perché?

Credo che la risposta alla domanda se la luce di scena sia materiale o immateriale debba essere: né l'una né l'altra cosa, come ho cercato di argomentare nella mia comunicazione al colloque di Lille dal titolo Le Voyage de la lumière. La luce è il movimento continuo della visibilità di corpi e oggetti nello spazio che i nostri occhi di spettatori intercettano. Ma credo anche che se non consideriamo la luce come una materia tra le altre nella costruzione del fatto scenico, se non le diamo lo statuto di un materiale, quantificabile, manipolabile, con un peso fisico nella composizione dell'immagine, è impossibile poi analizzare la sua dinamica nella creazione della nostra esperienza di spettatori.

2. Per quanto riguarda il suo processo creativo, di solito lavora con la stessa compagnia o con lo stesso direttore? A chi è diretta la sua luce? Alla volontà del regista, alle esigenze degli interpreti o allo sguardo dello spettatore?

Il mio processo creativo, convocato dal gesto del regista, è rivolto agli spettatori, con i quali mi identifico prima di tutto in qualsiasi contesto mi trovi ad operare. Cerco di programmare e strutturare la rete dei punti di vista cui sarà sottoposta la creazione scenica, nel tentativo di formare in me stesso e nelle persone al mio fianco uno sguardo critico e selettivo sullo svolgersi degli accadimenti e delle implicazioni emotive di quello che vediamo.

3. La ricercatrice Nadia Luciani sostiene, come risultato della sua pratica e dei suoi studi, che l'illuminazione del palcoscenico ha un ruolo attivo nella scena teatrale (cosi come nelle altre forme di arti performative come la musica, la danza, tra le altre). Con questo afferma che la luce agisce, agisce sul palcoscenico e interagisce con le altre componenti dello spettacolo e con il pubblico, avendo l'importante funzione di stabilire e favorire il rapporto tra il palcoscenico e il pubblico. Lei è d'accordo con 
questa opinione? Perché? Potrebbe fare uno o alcuni esempi di questa performance della luce nel suo lavoro creativo? Può essere un intero progetto o uno o più effetti specifici.

Chi manipola la luce dello spettacolo deve prendere in carico il volume complessivo dell'edificio o l'intera area del sito in cui si realizza l'incontro tra attori e pubblico, considerandosi come parte di una comunità e abitante di un luogo che, per quanto temporaneo, possa essere vissuto dai presenti come un Mondo di cui la luce è una delle condizioni di esistenza (il suono lo è altrettanto). In questo senso è molto alta la responsabilità e molto impegnativa la missione di chi maneggia le fonti di illuminazione in vista della creazione di relazioni tra quegli esseri umani che hanno deciso di riunirsi per mettere in comune un'esperienza artistica e questo vale per il teatro e per il cinema, come per le installazioni di arte visiva sia museale che interattiva e performativa. 
Interview Thierry Fratissier - Éclairagiste Français

1. À propos de la lumière et de l'éclairage, considérez-vous que la lumière scénique soit matérielle ou immatérielle ? Pourriez-vous expliquer votre réponse?

T.F. - Pour moi elle est forcément matérielle et immatérielle, matérielle pourquoi on doit composer avec un faisceau, avec des couleurs, avec un projecteur, etc. Mais le rendu et l'action de la lumière sur le plateau est immatériel. Donc évidement on est obligé de passer par les deux conceptions de la lumière. Voilà, pour la comprendre et finalement ce qui nous intéresse d'avantage est le côté immatériel de la lumière plutôt que le côté matériel qui est malgré tout un passage obligé. C'est un peu, c'est la matière que l'on travaille et la dimension immatérielle de la lumière, c'est plus l'action de la lumière sur le spectacle, s'il s'agit d'un spectacle.

\section{N.L. - Et ce qui atteint le spectateur, à votre avis, c'est plutôt son côté matériel ou son côté immatériel ?}

T.F. - Ah, ça dépend à quel spectateur nous avons à faire, si on a à faire à des connaisseurs en lumière, ils vont analyser le côté matériel de la lumière et sans doute être sensible au côté immatériel de la lumière. La plupart du temps j'ose espérer que nous n'avons pas à faire à des spectateurs très initiés au travail de la construction de la lumière, donc eux évidement c'est le côté immatériel de la lumière qu'ils perçoivent tout de suite.

\section{2. À propos de votre processus créatif, travaillez-vous généralement} avec une seule compagnie théâtrale ou un seul metteur-en-scène ou c'est variable?

T.F. - Ah, c'est très variable, et c'est heureux d'ailleurs, pour moi, oui. Ça n'empêche pas que on peut avoir une fidélité à un metteur-en-scène avec lequel 
on a des affinités particulières et où le travail naturellement s'approfondi. II y a forcément de fidélités dans notre spectacle et heureusement. Mais heureusement aussi que je la chance de ne pas travailler toujours avec les mêmes personnes, ça m'ouvre beaucoup de perspectives, comme on apprends autant des autres que j'espère les autres apprennent de nous, il y a d'échanges qui sont variés si on travaille avec des personnes différentes.

N.L. - Et cela a une interférence donc, travailler avec une personne que vous avec l'habitude de travailler et travailler avec quelqu'un que vous ne connaissez pas du tout, ça influence?

T.F. - Ça nous positionne différemment surtout lors du, oui, quand on travaille pour la première fois avec un metteur-en-scène, forcément il y a des étapes de découverte, voilà, et en même temps c'est très excitant. Quand on travaille pour na énième fois avec un metteur-en-scène ou une metteur-enscène, ce qui arrive très-très souvent, bon, on s'appuie davantage sur l'expérience commune.

N.L. - Quelle est l'aspect le plus important à considérer, à votre avis, pour la création lumière : les désirs du réalisateur, metteur-en-scène ou dramaturge, les besoins de l'acteur ou de la scène, ou le point de vue du spectateur?

T.F. - Déjà, moi, ce qui m'occupe le plus c'est l'idée moi que je m'y fais du travail de la lumière sur ce spectacle, c'est surtout ça. À partir du moment où on est cohérent avec sois même, on est cohérent, on propose un travail cohérent avec le travail du plateau, collectif, déjà on est plus à l'aise. Naturellement, le point de vue du metteur-en-scène est un point de vue essentiel, puis que c'est lui, en général, qui nous a emmener sur ce projet, donc c'est indispensable pour nous d'avoir l'attention sur ce qu'il propose, d'aller dans le sens qu'il propose, éventuellement ne pas aller dans le sens, mais qu'il y ait un débat par rapport à ça ponctuellement, mais globalement il faut quand même qu'on aille dans le sens du travail du porteur du projet, d'une certaine manière. Donc, évidement, quand je suis à peu près d'accord avec mes propositions, j'espère vraiment que le 
metteur-en-scène va l'être aussi, ce qui n'est pas toujours le cas, donc dans ce cas-là il y a un échange et puis on modifie les choses. Après, de la scène... ou de l'acteur, de la scène... alors de l'acteur, j'ose dire jamais. Acteur, musicien, danseur... Alors, ça dépend, s'il y a vraiment des impératifs, par exemple un pianiste qui va vouloir voir son clavier pour jouer, ou qui ne veut pas que sa partition soit éclairée en bleu, ce qui arrive quand même très souvent, là, ça j'en tiens absolument compte. Après, si un acteur me dis qu'il est trop ébloui à ce moment-là, en général, je l'écoute, mais je n'en tiens pas forcément compte (rires). C'est à dire, pour moi ce qui compte c'est l'œil de celui qui est dans la salle, alors, ça peut être le metteur-en-scène, mon œil évidemment, mais aussi, l'œil du spectateur, puis que c'est la dernière proposition (de la question). Alors, du spectateur, moi je commence à y penser une fois que je suis un peu cohérent par rapport à tout et alors oui, force de constater que je découvre énormément de choses le jour où j'assiste à la première et que je n'ai plus rien à faire (rires), donc ça veut dire que je ne pense peut être pas suffisamment au spectateur parce que lorsque je me retrouve spectateur du spectacle il me vient plein de révélations aussi bien sur le travail des acteurs que sur le travail de la lumière d'ailleurs. Mais c'est vrai que mon premier souci ce n'est pas celui du spectateur. Non, non, parce que j'espère que le travail que nous faisons ensemble lorsque nous faisons un spectacle apporte quelque chose de nouveau au spectateur qui puisse le surprendre. En tout cas l'alimenter de ce qu'il n'a pas été alimenté jusqu'à présent. C'est quand même très prétentieux, mais en même temps c'est un peu notre ambition.

\section{N.L. - La lumière ce serait complémentaire au spectacle, c'est un peu} ça?

T.F. - Alors, je ne parle pas forcément du spectacle, de la lumière, mais c'est à dire que le spectacle, il faut que, selon moi, que le spectateur puisse puiser de choses qu'il n'attendait pas. Donc si je commence à lui servir ce qu'il attend, c'est un peu contradictoire, voilà. Mais par contre il y a un grand respect du spectateur, tout au long du travail, c'est à dire que, évidement, le spectacle pour lequel on travail c'est un spectacle qui, on s'adresse au spectateur, on 
arrière-plan on le sait, on ne peut pas s'affranchir de cela, mais ma préoccupation n'est-ce pas de me dire, oh le spectateur, sauf quand je regarde des découverte, de fuites de lumière ou des éblouissements non voulus, le confort, un peu de ne pas le mettre dans une situation inconfortable, une situation inconfortable qui n'est pas voulue par le spectacle.

3. La chercheuse de ce travail soutient, à la suite de ses recherches pratiques comme créatrice lumière et réflexives en tant que chercheuse, que l'éclairage scénique participe activement à la scène théâtrale et également à d'autres formes d'arts du spectacle. Donc, dans ce sens, elle propose que la lumière performe, c'est à dire, qu'elle agit sur la scène et interagit avec les autres composants et aussi avec le spectateur. Êtes-vous d'accord avec cette opinion ? Pourquoi ? Et si vous pouvez donner des exemples que vous viennent à la tête de création où ça se passe.

T.F. - Alors, donc moi j'ai la chance d'enseigner à l'ENSATT, donc ces sont des sujets de réflexion quotidiens et qui sont naturellement provoqués par soit les questions des étudiants soit leurs travails qui m'inspirent certaines réflexions. Alors, évidemment que la lumière ne peut pas travailler seule, autant un acteur seul peut produire un spectacle, autant un scénographe peut produire un objet scénographique, c'est à dire que on peut s'arrêter au moment où la scénographie est faite. Évidemment ça ne va pas faire un spectacle, mais au moins il y a quelque chose de tangible. Et c'est pareil pour le costume, même pareil pour le son. Ça ne veut pas dire que ce sont des activités qui sont indépendantes du reste, mais à elles-mêmes elles peuvent se suffire à un certain endroit, la lumière c'est impossible, c'est à dire, si on n'a pas une scénographie, je veux dire, un sol, voire plus, si on n'a pas un acteur, un danseur, un chanteur, autre, bah, un personnage à éclairer, s'il n'y a pas la mise-en-scène qui va avec, nous, on ne peut rien faire. Donc, naturellement, on est obligé d'utiliser la lumière avec tout ce qui compose le spectacle lui-même. Bon après, ça me rappelle un peu quand même la première question, évidemment que le résultat de la lumière va créer une interaction, en plus j'ai oublié de dire que la lumière la plupart du 
temps dans le système de production d'aujourd'hui elle n'arrive que vraiment en fin de création, c'est à dire que on a la scénographie, les costumes, avant ou même, naturellement, l'acteur, avant que la lumière ne puisse naitre sur le plateau. Et tout le travail en est modifié, tout le travail des autres en est modifié et principalement celui du metteur-en-scène qui, s'il est attentif à la lumière, il va savoir s'en servir aussi, pour pouvoir dégager des informations importantes qu'il va transmettre au spectateur. Et alors le spectateur lui évidemment ne voit qu'un ensemble et la lumière c'est le lien d'une certaine manière. Le lien entre tout. Voilà, c'est à dire, si on coupe la lumière, il n'y a plus de spectacle, si on éclaire, tout ce qui a été mis en branle depuis le début peut apparaître et naturellement que les acteurs, entre eux, se voient différemment dès qu'il y a la lumière, donc jouent ensemble différemment, les costumes vivent différemment et nous on en tiens compte naturellement pour choisir à la fois les directions mais des couleurs des lumières qui doivent travailler avec une costume, la scénographie, n'en parlons pas parce qu'évidemment c'est elle qui sculpte la lumière, donc voilà, notre travail c'est un travail qui tiens compte naturellement de tout travail, de l'ensemble. Est-ce que c'est la question?

N.L. - Oui, c'est un peu ça mais quand on parle de lien entre ces différents composants et que, comme vous dites, s'il n'y a pas la lumière, ça peut avoir un spectacle aussi, cette lumière qu'arrive à la fin quand tout a été déjà créé pour faire cette sorte de couche finale dans le spectacle, ça ne pourrait pas se passer différemment, c'est à dire, une participation de la lumière depuis le début, par exemple, que des propositions de la lumière puissent changer ou stimuler la création du décor, des costumes ou même de la mise-en-scène, des placement des acteurs, c'est à dire, que la lumière puisse avoir un rôle plus participatif dans le processus de création ?

T.F. - Si, mais ça n'empêchera pas d'être prête la dernière. Oui, c'est à dire que c'est surtout ça que je voulais dire, c'est bien que vous m'y est reprise sur l'idée que j'ai développée, car elle n'était pas suffisamment précise. La lumière peut intervenir beaucoup plus tôt. Et d'ailleurs dans des conversations de préparation du spectacle la lumière intervient. Ce que je voulais dire c'est que, 
d'une part, c'est de plus en plus rares d'avoir un plateau suffisamment long temps pour que la lumière fasse des propositions réelles suffisamment tôt. Bon, ceci dit, j'en ai eu plusieurs expériences, mais une particulièrement qui a marqué mon esprit et dont on peut parler tout à l'heure éventuellement, où la lumière arrive très vite, mais, de toute façon, la lumière, c'est elle qui, la dernière touche avant la première c'est la lumière. Le travail il peut continuer après, mais c'est rare quand on voit une scénographie qui est bouleversée un tout petit peu avant la première, c'est rare de voir des costumes remis en question la veille de la première, or ce n'est pas du tout rare de revoir des lumière la veille de la première, si ce n'est dans l'ensemble, au moins sur certaines scènes, voilà. Donc, ce que je veux dire c'est que de toute façon la lumière est aussi un moyen assez souple pour pouvoir continuer à travailler très longtemps dans le processus de création.

\section{N.L. - Et vous avez parlé d'un exemple que vous voulez donner...}

T.F. - Ah oui, j’ai beaucoup travaillé avec Claude Régy, qui est mort il y a peu de temps, et où j'ai passé des... alors j'étais l'assistent de Dominique Bruguière à l'époque et j'ai passé des étés complets à travailler, pendant les répétitions, la lumière, parce que on arrivait et personne n'avait encore répété, juste le décor était implanté, les lumières étaient implantées et on commençait a travailler comme ça, avec de la lumière. Donc cette expérience je l'ai vécu, je l'ai apprécié, je vois ses avantages et aussi ses inconvénients. Les avantages elles vont toujours être là, évidemment, du coup la lumière est partie prenante dès le début de la création, c'est valorisant, d'une certaine manière, et puis il y a quand même un inconvénient, je trouve, c'est que la lumière elle est quelque chose qui... chaque étape de la création crée un événement qui remobilise tout le monde. Par exemple, l'arrivée sur le haut du plateau, c'est un événement, l'arrivée du décor, à supposer que la scénographie ne soit pas implantée avant, c'est un événement, l'arrivée des costumes c'est un événement, l'arrivée de la lumière, du son, etc., ces sont aussi des événements qui sont indispensable, à mon avis, pour redynamiser la baie de création. Si toute est là depuis le départ, 
il y a quelque chose qui ne se fait pas quand on est proche de la première, donc il faut manier ce genre de chose avec précaution, à mon avis.

N.L. - Je comprends ce que vous dites, c'est comme quand une pièce se joue sur une très longue période, à un moment donné il y a un relâchement, et ça peut se passer aussi dans le processus de création...

T.F. - Oui, voilà, mais bien sûr, et surtout dans le processus de création parce qu'il y a toujours, c'est inévitable, je dirais même c'est heureux, des moments où on se dit on n'avance pas, où on est perdu. Et c'est quand on est perdu qu'on se nourrit le plus et je pense que pour le metteur-en-scène c'est indispensable ses moments où il a besoin de quelque chose et cette chose arrive, par exemple sur les costumes, la lumière, quelque chose de nouveau. Et les acteurs aussi, si on leur donne les costumes dès le premier jour, il va y avoir une lassitude, il y a besoin de nouveauté, d'éléments nouveaux, voilà, pour pouvoir continuer à créer lors de la période de création, je pense.

N.L. - Mais, là, par exemple, il y a des éclairagistes qui font des essais de lumière pendant les répétitions, du style essayer d'isoler, créer un climat dans la salle de répétition, diminuer la lumière, mettre en valeur quelque chose pendant les répétitions, c'est à dire, ce n'est pas la lumière du spectacle, finalement, mais c'est des essais avec les acteurs, les performeurs, donc, ça peut être...

T.F. - Ça dépend avec des conditions de travail, si les conditions permettent, c'est très bien, d'ailleurs, moi quand je fais des lumières je ne fais pas la lumière sans les acteurs dedans et jamais je ne leur demande de venir uniquement pour la lumière, les lumières je les fait pendant les répétitions, dans la mesure du possible, si on a suffisamment de temps, parce que c'est le seul moyen, à mon avis, d'être juste avec la lumière. Donc, globalement l'après-midi et le soir, on... j'ai beaucoup appris ça de l'opéra, en fait, parce que à l'opéra le temps est beaucoup plus métrisé, et beaucoup plus court, la plupart du temps, pour un travail souvent très important, donc il faut être très réactif et j'ai compris toute la richesse que pouvait apporter à la lumière cette mobilisation, et il n'y a 
pas mieux, selon moi, que les acteurs pour pouvoir nous aider à faire la lumière. Et donc il faut profiter du temps qu'on a ensemble. Et le temps qu'on a ensemble c'est pendant qu'ils répètent, eux, pas de se dire, tiens, on fait un séance lumière, voilà, je déteste ça. Pour moi c'est un échec. Et ça n'empêche pas que le lendemain matin on travaille la lumière dans le détail, les temps, sans les acteurs, si possible avec de doublures, ça c'est quand même très important car je n'imagine pas, à partir du moment où c'est un spectacle avec des acteurs, je ne vois pas comment on peut faire de la lumière sans les acteurs...

N.L. - Pour la mise au point, l'enregistrement, tout ça, il faut avoir quelqu'un sur scène, mais vous essayez de travailler alors pendent les répétitions, dans la programmation, dans la mise au point ?

T.F. - Ah, bah, c'est indispensable. Ça veut dire, j'ai appris ça de l'opéra, je ne saurais plus comment faire autrement. Ça m'arrive, lorsqu'on a peu de temps, et que, bon les conditions un peu exceptionnelles, mas ce n'est pas le type de condition que je recherche. Comment trouver... on peut préparer autant qu'on veut la lumière, à un moment donné c'est la vérité du plateau qui nous guident dans l'élaboration du travail à mon avis. Donc il s'agit, en regardant ce qui se passe, de savoir capter des moments importants, les directions qui s'imposent d'une certaine manière à nos yeux selon les principes logiques et voilà, les bons timings, voilà. Et je ne vois pas comment on peut faire autrement. Certes ça peut se faire autrement, mais je trouve qu'on passe à côté de quelque chose d'essentiel.

N.L. - Mais par exemple, pour le timing ou pour enregistrer une scène, quelque chose comme ça, c'est difficile de le faire pendent un filage, par exemple.

T.F. - Ah, c'est plus difficile, mais ça dépend de combien d'effets on a. Si on en a toutes les dix secondes, c'est compliqué. Si on en a qui peut durer cinq minutes on peut le travailler. Ça, ça dépend, c'est vrai, mais c'est vrai que l'idéal et c'est pour ça que je conseille aux étudiants, lorsque que c'est possible pour 
eux, de débuter la conduite le plus tôt possible, même si tout n'est pas réglé, etc., parce que c'est ça le cœur de notre travail.

N.L. - Ah, c'est intéressant ça, puisque ça a un rapport avec cette action de la lumière, ça donne plus de chance de répéter la régie, d'accorder, même si on n'a pas tout, il y a des effets clé qui seront mis au point avec les répétitions.

T.F. - Exactement, bien sûr. Parce que moi pendant les répétitions, auxquelles j'assiste le plus possible, dans la mesure du possible, on prend des notes, on a des références, et puis quand on commence le travail, ces notes sont importantes parce qu'elles nous donnent des points de repère. En réalité on ne fait jamais que la lumière d'une scène par rapport à ce qui s'est passé avant et ce qui risque de se passer après, voilà, après on équilibre tout ça et les notes à un moment on laisse tomber parce qu'on n'y est plus quoi. Alors, il y a toujours, toujours, toujours des exemples du contraire, mais moi la plupart du temps je m'aperçois que je me suis nourri avant et au moment de réaliser c'est en temps réel quasiment. Voilà.

N.L. - Bah, merci beaucoup.

T.F. - Bah, avec plaisir.

N.L. - C'était un super plaisir, oui, merci pour les réponses. Bah, voilà.

T.F. - Voilà.

N.L. - Merci. 


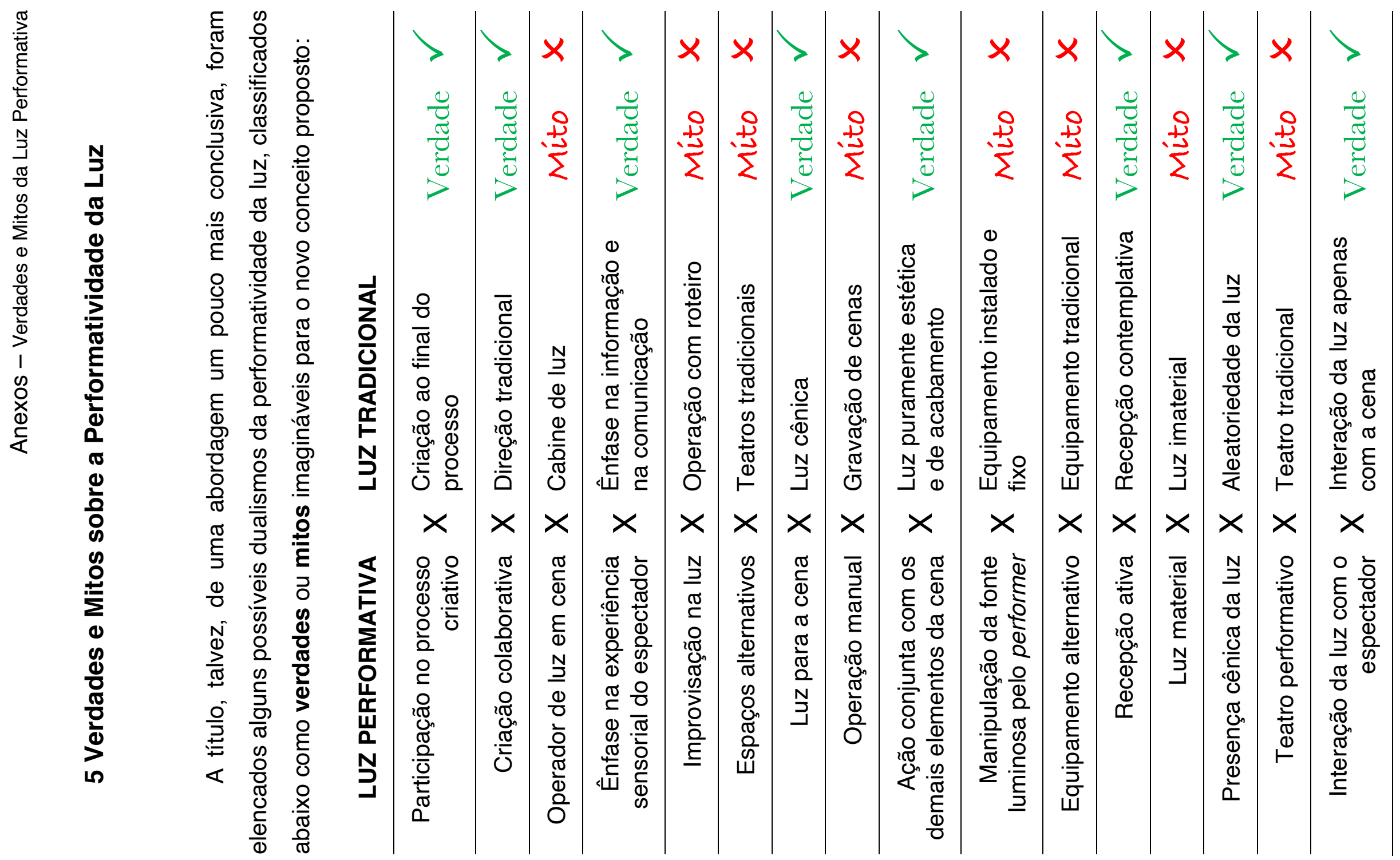

